\title{
EARLY BRYOLOGICAL LITERATURE
}

\author{
A DESCRIPTIVE BIBLIOGRAPHY OF SELECTED \\ PU'BLICATIONS TREATING MUSCI DURING THE FIRST \\ DECADES OF THE NINETEENTH CENTURY AND \\ ESPECIALLY OF THE YEARS 1825, 1826 AND 1827.
}

\section{PROEFSCHRIFT}

TER VERKRIJGING VAN DE GRAAD VAN DOCTOR IN DE WIS. KUNDE EN NATUURWETENSCHAPPEN AAN DE RIJKSUNIVER. SITEIT TE UTRECHT, OP GEZAG VAN DE RECTOR MAGNIFICUS, PROF. DR. A. C. DE VOOYS,

VOLGENS BESLUIT VAN DE SENAAT IN HET OPENBAAR TE VERDEDIGEN OP WOENSDAG 5 JUNI 1968

DES NAMIDDAGS OM 2.45 UUR.

DOOR

\section{WILLEM DANIËL MARGADANT}

GEBOREN OP 28 MEI 1916 TE WIJK AAN ZEE EN DUIN

1968

HUNT BOTANICAL LIBRARY

PITTSBURGH, PENNSYLVANIA

U.S.A. 
PROMOTOR: PROF. DR. F. A. STAFLEU 


\section{Aan Veroniaa}

Marjolein Robin 
Bij het afsluiten van dit proefschrift wil ik allen, die mij daarbij geholpen hebben, hartelijk bedanken.

In de allereerste plaats dank ik Prof. Dr. G.H.M. Lawrence, directeur van de Hunt Botanical Library, voor de gelegenheid, mij geboden, dit proefschrift in het kader van de Bibliographia Buntiana te bewerken. Bovendien betuig ik hem mijn warme dank voor zijn persoonlijke belangstelling en voor de wijze, waarop hij mij geheel vrij liet het onderwerp uit te werken.

In het bijzonder dank ik ook mijn promotor, Prof.Dr. F.A. Stafleu voor de hulp bij het concretiseren van de probleemsteliing van dit proefschrift, voor de vele waardevolle adviezen die hij me gegeven heeft zowel aan het begin van, als tijdens het onderzoek, en voor zijn hulp bij de afwerking van deze publicatie. Zijn rijke ervaring op het gebied van botanische nomenclatuur en preciese datering is van grote betekenis voor me geweest. Het spijt me enerzijds, dat ik in verband met de beschikbare tijd niet al zijn adviezen kon opvolgen, en anderzijds, dat ik mijn gegevens niet tot zijn beschikking kon stelien voor zijn samenvattende publicatie over exacte dateringen van botanische werken. Het verheugt mij. hem op deze manier de resultaten van mijn onderzoek te kunnen aanbieden.

Vervolgens, en zeker niet minder welgemeend, gaat mijn dank uit naar Prof. Dr. R. van der Wijk, voor het verwezenlijken van een reeds vroeg door ons gekoesterde wens, een Index Musoorum tot stand te brengen en het mogelijk maken van mijn aandeel in de voorbereiding. Ook voor alles wat hij voor me gedaan heeft tijdens deze periode ben ik hem zeer dankbaar. Ik stel het op prijs dat hij dit proefschrift door heeft willen lezen en mij critische opmerkingen heeft willen doen toekomen. Ik hoop, dat het hem een genoegen doet, dat een aantal problemen, die rezen bij het bewerken van de Index Muscorum, opgelost zijn.

Tevens wil ik op deze plaats mijn dank brengen voor de financisle steun, die de Nederlandse Organisatie voor Zuiver Wetenschappelijk Onderzoek verleend heeft ten behoeve van mijn werk te Groningen.

De velen, die mij in diverse instituten geholpen hebben met een of ander onderdeel van het werk, wil ik hier gezamenlijk bedanken, ook al doe ik het uitvoeriger in de "acknowledgements" in het Engelse deel. Een uitzondering wil ik echter maken voor I. MacPhail, die mij ingeleid heeft in de analytische bibliografie en die mij steeds vriendelijk behulpzaam is geweest met het oplossen van bibliografische moeilijkheden. Bovendien heeft hij de eerste versie van dit werk geheel doorgelezen en van opbouwende critiek voorzien, waarvoor ik hem zeer dankbaar ben. Vervolgens wil ik al degenen bedanken, die niet genoemd worden en toch bijgedragen hebben aan het totstandkomen van dit proefschrift. 


\section{PROBLEEMSTELLING.}

Verschillende protlemen, die cen nadere behandeling vereisten, rezer bij mijn werk aan de Index Muscorum. Deze index geeft een opsomming van alle Latijnse namen voor geslachten, soorten en variëteiten van bladmossen (Musoi) met toepassing van de moderne internationale nomenclatuurregels. In verhand met net fundarentele pricriteitsbeginsel hierin is het nodig, de juiste datum van publicatie te kennen van de boeken of artikelen, waarin nieuwe Latijnse namen voorkomen.

Enkele belangrijke froblemen betroffen publicaties uit de jaren 1825,1826 en 1827, waarvan de preciese datum niet was opgespoord, en ook de volgorde, de relatieve datum, onzeker was. Elk van deze drie Jaren kwam in aanmerking voor het artikel van G.A. Walker Amott: ilouveile diaposition mothodique des es dces de mousses. Het exemplaar van het tijdschrift dat voor de Index iluscorum geraadpleegd werd, had het jaartal 1827 op de titelfagina; er was evenwel aanleiding om te veronderstellen dat de betrokken aflevering in 1926 was gepub?iceerd, maar de literaturcitaten gaven 1825 op. Vervolgens was er twijfel betreffende de publicatie-data van de 2 delen van S. E. Bridel: Bryologia Europaea, waarvan het voorbericht gedagtekend was 16 Dec. $1826,20 d a t$ publikatie van deel 1 in 1826 twijfelachtig leek. Een belangrijke moeilijkheld was de relatieve datering ten opzichte van enige van de 11 afleveringen van C.F. Schwaegrichen: Species Musoorum ... Supplementum.

In verband met deze problemen werden de jaren 1825-1827 uitgekozen voor een nader onderzoek, toen zich in het kader van het botanisch-bibliografische project Bibliographia Buntiana van de Hunt Botanical Library te Pittsburgh, Pennsylvanie, de gelezenheid voordeed, een speciaal hoofdstuk te bewerken. Dit project beocgt een gedetailleerde biblicgrafie te geven van alles wat over botanie gepubliceerd werd in de periode van $1730-1840$.

Mijn onderzoek begon met het raadplegen van alle toegankelijke publicaties uit de genoemde drie jaren, waarvan het mogelijk geacht werd dat er mossen in behandeld waren. Boeken die inderdaad mossen noemer, werden vorder bestudeerd, ook al betrof het minder belangrijke werken, b.v. populariserende bocken. Het tijdschriftenmateriaal werd minder grondig bestudeerd in verband met de arbeidsverdeling in het gehele project. Gezien de ervaring verkregen door mifn werk voor de Index luscorum is de kans echter niet groot dat er nomenclatorisch belangrijke publicaties over het hoofd zijn gezien.

Van de werken die wel zijn behandeld, zijn in het algemeen ook andere delen of afleveringen opgenomen. Van enkele belangrijke auteurs zijn alle bryologische werken vanaf omstreeks 1800 bestudeerd. Enkele publicaties zijn beschreven in verband met andere boeken van dezelfde auteur, hoewel er geen Husci in genoemd zijn.

Bovendien is een aantal bryologische publicaties van de jaren 1822-1824 behandeld. Dr. G. Sayre bestudee de pericde $1801-1821$ in haar werk: Dates of publicatione treating lusci... 1801-1821, 1959, en een aansluiting was wel gewenst. Ik heb echter niet cestreefd naar volledigheid betreffende publicaties van deze periode; enkele werken warin nieuwe soorten zijn beschreven, zijn niet opgenomen.

\section{METHODE}

De behandelde publicaties zifn in de eerste plaats beschrever volfens de moderne methode van de descriptieve bibliografie, zoals deze vervolmaakt is door Sir velter Greg in Engeland en door F. Fowers in Amerika, en door A.lan Sitevenson aangepast werd aan de specifieke problemen van botanische hoeken. Zijn methode werd, in verband met de probleemstelling, niet vol.ledig gevolgd; zo werd b.v. het lettertype hier niet heschreven. Een belangrijk verschil met de methoden van de genoemde schrijuers is, dat de inhoudsbeschrijving niet verwijst naar katern-merken, maar naar bladzijden. Dit geeft minder kans op fouten en is veel gemakkelijk r te gebruiken. Tevens wordt echter een systeer voorgesteld om ondubbelzinnige bladzijde-verwijzingen mogelifk te maken in die gevallen, waarin verschillende nummeringen in één boek voorkomen, of verschillende stellen ongenumerde parina's. Voor de collatie-formule zelf worden enkele verfijningen voorgesteld.

Deze methode van boekbeschrijving is uitvoeric uiteengezet in het hoofdstuk Descriptive bibliography applied to botany. Ten behoeve van de juiste vermelding van het bihliografische format is een determineertabel van formaten voor boeken op handgeschept papier toegevoegd, waarin gegevens van Johnson: Typographie .... 1821, verwerkt zijn, en eigen waarnemingen en overwegingen.

Het gedetailleerde onderzoek van de structuur van de boeken en van enkele tijdschriftnn is de basis voor de vaststelling van de inhoud van delen en afleveringen en van eventuele 
Het gedetailleerde onderzoek van de structuur van de boeken en tijdschriften, die in afleveringen verschenen zijn, is de basis voor de vaststelling van de inhoud van delen en afleveringen en $v a n$ eventuele varjanten. Ook geeft het aanknopjingspunten voor de preciese datering.

Belangrijke gegevens voor de datering werden verkregen uit de aankondigingen en besprekingen in de contemporaine literatuur. Dank $2 j j$ de vriendelijke toestemming van de medewerkers van de Hunt Botanical Library: Dr. C. Weber. Mej.I.H.Vegter, en de Heer F. Schüt, kon een gedeelte van het door hen bijeengebrachte material benut worden. Ik heb getracht, die besprekingen en ankondigingen, die voon de datering van belang konden zijn, zelf te zien, maar dit is niet in alle gevallen mogelijk geweest. Bovendien is het aantal tijdschriften, waruit de gegevens geput zijn, beperkt en voorts konden enkele belangrijke bronnen niet geraadpleegd worden.

In diverse bibliotheken en archieven bestudeerde ik handschriften-collecties. Dit leverde belangrijke nieuwe informatie op. Ook in dit opzicht moesten er nog belangrijke collecties buiten beschouwing, blijuen.

\section{RESULTATEN.}

De boekbeschrijvingen van de behandelde boeken en tijdscrhiftartikelen zijn bijeengebracht in het hoofdstuk speoial bibliography. Zover ik weet is dit de eerste keer, dat deze beschrijvingsmethode is toegepast op alle publicaties over een botanische groep uit een bepaalde periode. De catalogus die door Allan Stevenson geschreven is, betreft alle boeken uit één bibliotheek. De data van deze publicaties jijn zo nauwkeurig mogelijk uitgewerkt als de
beschikbare bronnen toelieten. Een opsomming van an antal concrete punten volgt.

1. Het eerste artikel met een belangrijk dateringsprobleem, dat van Annott, bleek in niet ninder dan 5 verschillende vormen gepubliceerd te zijn. Zonder twijfel is de eerste hiervan het separaat in quarto-format met het jaartal 1825 op de titelpagina en de verkorte titel: Disposition methodique des espoes de mousess. Naar mijn mening is dit in januari 1826 verschenen; die is uitvoerig geargumenteerd, maar absolute zekerheid kon niet verkregen worden. De later gepubliceerde vormen zijn nomenclatorisch niet geheel zonder betekenis door enkele indirecte verwijzingen naar publicaties (Schwaegrichen en Gaudichaud), die in de tussenliggende periode verschenen.

2. De twee delen van Bridel, Bryologia univaroa, bleken inderdaad in 1826 en 1827 te zijn gepubliceerd, zoals de titelpagina vermeldt, met de beperking, dat het supplement op deel 1 alsmede het voorbericht en de classificatie-overzichten tegelifk met het t:veede deel verschenen zijn; dit verklaart de late datum van het voorbericht.

3. De verschillende stukken van de Supplementen van Schwaegrichen zijn voldoende nauwkeurig gedateerd cm de vclgorde ten ofzichte van de andere belangrijke werken te befalen. Een betere benadering is voor sommige stukken noc wel gewenst.

4. De relatieve datexing van verschillende andere nomenclatorisch belangrijke werken werd bepaald. Jo bleek Greville zijn Flora Edinenois te hebben gepubliceerd vEbr aflevering 20 van zijn scottioh cryptogamio flora inplaats van erna, zoals verondersteld werd tijdens de voorbereiding van Index Musoorum.

5. De inhoud van de afzonderlijke afleveringen van boeken en van enige tijdschriften, waarvan de details nog niet alle bekend waren, is met behulp van de bihliorrafische methode vastgesteld. Met name betreft dit twee wexken van W.J.Hooker: kusci exotioi en Exotic flora. Bij het laatste werk is onder meer gebmik gemaakt ven off-set afdrukken van verwijderde aflevering-titels op de eerste of laatste bladzijde van de afleveringen van een bepaald exemplaar.

6 . Enkele publicaties verden gevonden, waarvan de mossennamen tot nu toe over het hoofd gezien waren in de bryologische literatury (Casbessedes, Chevallier).

7 De eerste kleurendrukken van afbeeldingen van mossen, die mij bekend geworden zijn, vallen in de behandelde periode. Dit betreft mosprotonema in het artikel van T.F.L. Nees von Esenbeck, 1824 , en gehele mosplanten in de werken van Sommerfelt en Chevallier, beide in 1826.

8 . In verschillende werken werden cancellantia geconstateerd, warvan tot nu toe geen vermelding gevonden werd in de literatuur, b.v. in het nomenclatorisch belangrijke boek van Hedwig, Speoies Husoorum frondosorum. 
9. Het velijn-papier, dat oorspronkelijk in hoofdzaak gebruikt werd voor luxe-uitvoeringen van boeken, kwam blijkbaar in de behandelde periode in grotere hoeveelheden en tegen relatief lagere prijzen beschikbaar, aangezien in verschillende boeken een overgang gevonden werd van gevergeerd papier naar de nieuwe soort. Machinaal vervaardipd papier werd echter nog weinig voor het drukken van boeken gebruikt. Ik heb het alleen kunnen constateren in een deel van de TRANSACTIONS OF THE LIINEAN SOCIETY, namelijk dat van 1827 (zie Greville $n, 2$ ) , andere delen hiervan heb ik niet onderzocht.

Als algemeen resultaat van het onderzoek heb ik de historische ontwikkeling van de bryologie in de eerste drie decaden van de negentiende eeuw kunnen bespreken. Hieraan gaat een schets vooraf van de ontwikkeling in de periode v6రr 1800 . Ik heb hierbit aandacht geschonken aan het invoeren van een natuurlifke classificatie voor de bryophyten en aan de diverse opvattingen over de levenscyclus van de mossen. 
C O NTENTS

\begin{tabular}{|c|c|}
\hline INTRODUCTION & $I-V I I I$ \\
\hline Bryology before 1800 & $I-\quad$ II \\
\hline Bryology from $1800-1830$ & II- $\quad v$ \\
\hline Priority in botanical nomenclature & V-VII \\
\hline Sources & VII-VIII \\
\hline DESCRIPTIVE BIBLIOGRAPHY APPLIED TO BOTANY & $1-34$ \\
\hline Concept of descriptive and analytical bi & phy 1 \\
\hline Paper & 1- 3 \\
\hline Printing & $3-6$ \\
\hline Binding & 6 \\
\hline Edition, issue and state & 6- \\
\hline Title-description & 9 \\
\hline Bibliographical format & $10-14$ \\
\hline Key to bibliographical formats & $15-21$ \\
\hline Collational formula & $22-25$ \\
\hline Pagination & $25-.26$ \\
\hline Contents & $26-27$ \\
\hline Plates & $27-28$ \\
\hline Paper description & 28 \\
\hline Dates of publication & $28-29$ \\
\hline Reviews, announcements [etc.] & 29 \\
\hline Signs & 29 \\
\hline Abbreviations & $30-32$ \\
\hline Sources & $33-34$ \\
\hline SPECIAL BIBLIOGRAPHY & $36-238$ \\
\hline Corrections and additions & 230 \\
\hline SUMMARY & $240-241$ \\
\hline ACKNOWLEDGEMENTS & 241 \\
\hline CHRONOLOGY & $248-251$ \\
\hline INDEXES & $252-277$ \\
\hline Plant names & $252-255$ \\
\hline Artists & 255 \\
\hline Engraver: & 255 \\
\hline Botanists & $256-257$ \\
\hline Printers & 258 \\
\hline Publishers & 258 \\
\hline Subjects & $258-277$ \\
\hline Exsiccata & 277 \\
\hline
\end{tabular}


BRYOLOEY 3EFORE 1300.

Bryology, the study of mosses (liusoi) and liverworts or hefatics (Bepatioae) began with Dillenius (1687-1747), who wrote the first book explisitly devoted to this group of plants: Bistoria Huscorum, Oxford, 1741. Dillenius followed the general concept of his predecessors, including under "mosses" every low-growing plant which was not clearly a flowering plant, a fern or a fungus: Musoi (in the present-day sense), Hepaticae, Lichenes and Algae, plus some fern allies, Lycopodium and Isoetes, and even a flowering plant, Subularia. This concept still lingers in the popular ideas about "moss": when bryologists ask their correspondents for mosses they often receive lichens instead. The words used in various languages reflect the same concept, e.g. the word "korstmos" in Dutch, for lichen. Another use of the word in a more general sense is its application to the area where such plants grow, especially marshy areas: "moss" in Scotland, "mossa" (plural "mossar") in Sweden (moss being "mossa", plural "mossor"), and "Moos" in Southern Germany.

Dillenius considered the capsule of mosses to represent anthers, since the spores resemble pollen. P.A. Micheli (1679-1737), however, had already observed that spores of hepatics germinated and concluded that they were not equivalent to pollen. He took the cylindrical bodies in the star-like cups of the mosses for female organs and the paraphyses for male organs. Dillenius, on the other hand, was impressed by the stalked heads with gemmae of Auracomnium androgynum; he wrote that these probably were female (Appendix. Cat.plant.... Gissam ... 1719). He created a separate genus for this moss, using the name Mnium i). Later he added to the genus several other species, including a few hepatics, with similar heads of gemmae.

The significance of Linnaeus (1707-1778) for bryology should not be underestimated. He introduced the binary system of nomenclature for the names of species, and used it consistently in his Speoies plantarum, 1753. He moreover limited the Musci to the special group of plants for which the name is now in use. However, he included the genus Lyoopodium in this group, as well as some Bepatioae (the same ones as were included by Dillenius in his Mnium, plus the genus Porella which he knew only from the insufficient illustration and the erroneous description in the work of Dillenius). The other genere of Bepatioae were arranged under Algae by Linnaeus in his Species piantarum as well as in the sketch of a natural method, Eragmenta Methodi Maturalis, in his Philosophia botanioa of 1751 .

Linnaeus did not use microscopic characters. In his opinion a group based solely on such characters did not merit the rank of species. This attitude is comparable to the reluctance of some present-day taxonomists to use cytological or chemical characters in the delimitation of species.

The life history of the bryophytes interested Linnaeus in connection with his sexual system of plants. In the Hortus Cliffortianus he indicated the sexes correctly but in later works he adopted the opinion of Dillenius. In Semina Musoorum, the thesis of P.J. Bergius (1730-1790), a pupil of Linnaeus, the concepts were reviewed and the idea of spores representing polien was maintained, because of their similarity in burning: the propagula of Aulacomnium androgynum were considered to be seeds, and the "stars" of the mosses, already described by Micheli, were condidered to be female plants.

Adanson (1727-1806) described natural families of plants in his Famizles des plantes, knowing an unpublished outline of the natural classification by Bernard de Jussieu (1699-1777). Adanson accepted the Bepatiaas as an independent group, and, remarkably, removed them from the Musoi (which still included Lyoopodium). The Musoi were placed far from the other cryptogams at the end of his families, after the conifers. In his scheme the Musoi represented the group of plants closest to the minerals in the "chain of being". a concept amply discussed by Lovejoy (1936). In his manuscripts (collection at the Hunt Botanical Library) Adanson explicitly mentioned "dryness" as a criterion for this arrangement; possibly he also had in mind a resemblance to conifers on the one side and to dendrites in minerals on the other. However this may be, he certainly did not think in terms of a transition to minerals; this is clear from the same manuscript notes. Though Adanson used the microscope frequently for the study of infusoria, I have found nothing indicating that he used it for the taxonomical study of bryophytes.

1) The epeoies oonoerned. Mnium androgynum, wae plaoed by sahwaegriahen in the genue Aulacomnium. S.O. Lindberg (1835-1889) tried to reestablioh the woe of the name Mnium for thio genus, apparently oonoidering $M$. androgynum to be the historioal type. The name aulacomnium Sohwaegrichen, however, was well eetabliohed and was later placed on the list of nomina conservende. 
The founder of bryology undoubtedly is Johann Hedwig (1730-1799). He was the first to use the microscope intensively for the study of mosses. He discovered the male and female organs, now called antheridia and archegonia, and the spermatozoa; he studied the development of the sporophyte and of the calyptra as well as the structure of the peristome. He created several new genera based on the characters of the sporophyte in conbination with those of the male "flower" the group of leaves surrounding the antheridia. He illustrated his own books, and several of the drawings are still unsurpassed. His importance for taxonomy was recognized in 1910, when the International Botanical Congress selected his speoies luscorum as the starting-point for the nomenclature of Husoi (Sphagnum excepted).

The idea of sexual reproduction of mosses was opposed by N.J. de Necker (17301793) 2 ). He had experimented with small pieces of mosses and hepatics and had found that new plants could grow from any part. Horeover, he tried to hybridize Marohantia and Conocephalum, with the Dillenian concept in mind of spores as pollen and gemmae as seeds. The result of his experiments was negative, and he drew the correct conclusion that the gemmae represent a vegetative form of propagation. Other experiments to sow spores directly did not succeed either and this led him to the erroneous generalization that mosses did not reproduce sexually.

The natural classification of Bernard de Jussieu was developed and published by his nephew, Antoine Laurent de Jussieu (1748-1836). In his great work, Genera piantarum, 1789 , the Musci and Bepatioae were grouped together under Aootyledones. A very clear, conclse history of the various concepts on sexuality in mosses was added; this already mentioned Palisot de Beauvois, but not de Necker. The treatment of genera of bryophytes was conservative, and a natural classification within the group was not worked out.

\section{BRYOLOGY FROM $1800-1830$.}

The French Revolution and its aftermath, the Napoleonic wars, had a great influence on the political and economic situation in Europe and, indirectly, on the climate for scientific developments. It ended the era of royal patronage of science on the continent, especially in France, where the Aoademie des sciences was abolished in 1793 , it was revived in 1795 as the Inetitut de Franoe.

The wars, the blockade of the continent by the British and the French answer, an effort to make the continent self-supporting, made the economic conditions very difficult. Possibilities for travel and publication came to a minimum. Periodicals stopped publication, either completely or temporarily, especially during the most difficult years known as the Napoleonic pause $(1810-1813)$. Collecting was only possible locally, unless done by physicians or pharmacists in the army in their spare time. Shipping collections was dangerous, Palisot lost several collections in this manner. Nevertheless in the first years of the century some important publications were published. Hedwig's last work, Species Mrooorum, was published in 1801 by Schwaegrichen. Since this book later became the new starting-point for names of Musoi (Sphagnum excepted) the nomenclatural importance of this period increased, and even minor local floras may have to be cited as sources of valid publication of names.

of more than local importance are the books of Bridel and later the Schwaegrichen supplements to Hedwig's Speoise Muscorum; both authors adopted the Hedwigian classification and proposed new genera, either peculiar forms of exotic mosses or segregates of European genera. Bridel especially proposed several new genera, basing them on characters of the calyptra.

After the Napoleonic wars normal conditions were restored. Scientists traveled again, opportunities for publishing improved, and collecting was once again possible. $A$ lively exchange of specimens, publications and ideas followed, Another important factor in the development of bryology, and of the study of cryptogams in general, was tiat more and better microscopes became available. Hicroscopic details could be studied with greater precision and ease, and they began to play more important role in the delimitation of species and other taxa. Life history studies became more accurate. This motivated an intensification of the work begun hy Hedwig. Yet some botanists who worked with mosses, e.g. William Baxter and A.E. Sauter, never used a microscope.

2) The date of birth of N.J. de Necker is sometimes given as 1729. I oheoked the regiotration of baptiom in the book of the parish of saint-Etienne in Lille, France, of Natelis Martinu. Joseph, son of jaoob Deneokere and Anna Theresia Berthe; it was ciated 25 Dec. 7730 . Beoause of the second (Chriatian) name. Martinus. I feit there was some doubt that the baptismal certificate concerned the botaniot. cheoking the alphabatical regieters of the relevant pertod of all four parishes of Lille I found onily two other recietrations of ohildren of the oame parents, with different chrietian name. I therefore oan agree with the biography: Leclair, Fim.: Holl-HertinJoseph De Necker botaniste Lillois. Bull.Soc.Etudes Prov.Cambrai 10: 184-189. 1907. 
A further important trend in bryology was the change from ths Linnaean system to the natural classification. This was especially the case in the third decade. An example is Hooker's Flora Sootiaa, 1821. The bibliographic analysis shows that the authcr changed his plans during the printing of the work, which began with the phanerogams in the Linnaean classification. Coming to the cryptogams, he was not satisfied with this system; instead he treated them in a second part, using the natural classification. The genera of phanerogams were again enumerated, and arranged in natural "orders" which were described in collaboration wi.th J. Lindley (1799-1865) and others.

The generic concepts used by $W . J$. Hooker were rather broad. He did not accept several of Hedwig's genera; he united Fiosideno with Dioranum, Barbula and Tortula. In both sets the genera were distinguished in the Hedwigian system by the form of the organs surrounding the antheridi.e. Hooker united Blasia with Jungermannia in his British Jungermannias, because of the similarity in the sporophyte; the older authors had taken the vegetative gemmae for sexual structures. This conservative concept was important, since it founced a tradition in Great Britain which was difficult to break. Hooker certainly proposed sone new British genera (Tayloria, and with Taylor: Anomodon, Zygodon), but these apparently had striking differences in the peristome. The genus Drepanophyllum is another example of a new genus accepted by Hooker. Schwaegrichen founded the new species Fissiciens falaifolius in 1616 for vegetative specisens. This was in agreement with Hedwig's concept of Fisoidene, which was characterized by a bifid peristome and axillary antheridia, but of which the vegetative plants were mainly with leaves in two ranks. Hooker included this species in the genus Dioranum in 1818 . Soon afterwards L.C.H. Richard (1754-1821) sent him drawings of the sporophyte, showing a naked mouth, and the description of this species, with the proposal of a new genus, Drepanophy lium. This was published by Hooker. Possibly the peculiar vegetative strua ture of this moss, together with the absence of a peristome, played a role in the creation of the genus. Without this vegetative structure Hooker might have arranged the species in the genus Gymnostomum or Hymenostomum. Hooker's conservative attitude is evident from a comparison of the treatments in the two editions of the Muscologia Britannioa and in the izora scotioa.

In this connection it is aignificant that an early attempt to apply the natural method to British plants was ignored: S.F. Gray: A natural arrangement of British plante, 1821 (not treated in this thesis). The genus Jungermannia of Linnaeus was segregated by Gray into several smaller genera. One of the reasons for the neglect of this work was the use of the ending - us for the names of the new genera derived from the personal names of men, e.g. Ricoardius and Bassanius, now conserved with the ending -a: Riocardia, Bazzania. It is likely that Hooker did not appreciate this segregation in a group on which he had published a generic concept still broader than that of Linnaeus.

G.A. Walker Arnott is another British author who was interested in a natural classification of the mosses. He learned microscopic botany in Edinburgh, together with R.K. Greville, from John Stewart (d. 1820) 3). From the correspondence between Arnott and Ad. Brongniart it can be inferred that Arnott discussed the natural classification and its application to susoi with Brongniart during his first stay in Paris, in 1821. Though Arnott was not in a position to write synopsio Musoorum a plan discussed with Brongniart in 1821, he prepared his Nouvelle diaposition methodique des especes de mousses, an arrangement of species and genera in groups of which he did not indicate the rank; Kittel treated these groups as "tribus". The generic concept adopted by Arnott was mainly that of W.J. Hooker. In the monographs which Arnott published together with Greville long discussions and descriptions of $f e w$ genera were given, but only one new genus was proposed: Dissodon Grev. \& Arnott. In Arnott's own article of 1826 there was only one: Maarodon Arnott. Arnott did not accept many of the new species and genera of the German authors, sometimes on superficial grounds. Kittel criticized some of Arnott's opinions in his notes in the $8^{\circ}$ issues of the same article. Bridel reacted somewhat sharply to remarks of Arnott and Kittel in his preface to the Bryologia universa.

Greville concentrated more on the descriptions and drawings of scottish species, and especiaily on microscopic Fungi, a group to which he had contributed in Hooker's Piora scotica.

3) One is tempted to consider John stewart the moving force and the editor of the Edinburgh reprint of Dillenius: Historia Musorum, 7811. An indiaation might be that thio reprint lias publiohed by $C$. Stewart. In any oase a contemporaneous botanist with knowledge of oryptogams must have added the list of ourrent binomials for the plante iliustrated in the work. 
In France the natural classification was applied to the bryophytes (and other cryptogams) by A.P. de Candolle, in the third edition of the Flore Francaise (18051815); he proposed a number of new species and new combinations, but not a new classification of groups within lusoi.

The most important French bryologist of the period was Palisot de Beauvois, who proposed several new genera in 1804 and new species in 1805. His work luocologie, $1822[18237 j$. might have been more important had he lived to supervise the printing. In 1824 his pupil, N.A. Desvaux, indicated several corrections to that work.

Palisot de Beauvois proposed a different theory with regard to the sexuality of mosses (as was mentioned by A.L. de Jussieu, Genera plantarum, 1789). This was maintained in his later publications. He considered the capsule to be hermaphroditic, with the spores as male pollen and female cells in the columella. This probably was based on the observation of moving particles from crushed cells of the columella. The teeth of the peristome with their hygroscopic movements were supposed to have a fertilizing function. Desvaux did not accept the theory of Hedwig; but he could not support Palisot's view of the function of the columella, since he knew that the occurrence of moving particles after crushing cells was a general phenomenon, even though R. Brown had not yet published his researches on the Brownian movement.

The influence of Adolphe Brongniart $(1801-1876)$ on bryology is underestimated if only his original publications are taken into account. He was one of the first authors to describe fossil bryophytes (Biotoixe des vegetaux fossiles, 1828-1837, not treated in this thesis). He also descrited living representatives of plant groups, comparing vegetative details of living plants with fossil remains, and thereby opened the way for recognition of the importance of vegetative characters in plant taxonomy. It is likely that this had an influence on Wilhelm Philipp Schimper (1808-1880), also a palaeontologist and moreover the main author of the Bryologia Europaea, 1836-1855, by Bruch, Schimper and Gümbel, in which many segregated genera were proposed, especially of the old genus Hypnum.

In France a natural classification was also worked out by F.F. Chevallier, in his plore de envirore de Paris. He did not propose new genera, but changed circumscriptions of genera and of species, and included many varieties. His classification of Musci was not adopted, and the new combinations were overlooked by E.G. Paris (1827 -1911 ) and other indexers. The second edition, published in 1836, consists mainly of the old sheets, but with a number of cancels.

A most active development of the taxonomy of bryology took place in Germany. Schwaegrichen described new species received from various parts of the world and published fine drawings in the supplements to Hedwig's Species Buscorum. Bridel develcped a new classification, especially in his Bryologia univeroa, the culmination of his bryological studies. He was undoubtedly the kest bryologist of the period. He proposed numerous new species and a considerable number of new genera. The synonymy given in his last work is completes virtually every place where the name of a moss species was published was listed.

Most other German bryologists, e.8. Hornschuch, C.G. Nees von Esenbeck, Furnrohr and Bruch, supported the trend of generic segregation. Their works show a detailed knowledge of the plants, possible only with the aid of a microscope. A mild criticism of Bridel's segregation is found in the review of the Bryologia universa in Linnaea. This review, probably written by the editor, von Schlechtendal (1794-1866), questioned the number of new genera: "... oind deran jicht zuvieli" (are there not too many of them?). It is probable that the reviewer influenced the later bryologist, C. Muller (1818-1899), also of Halle, who advocated large genera and small species. The life history of the mosses was also thoroughly studied by German authors. T.F.L. Nees von Esenbeck cultivated mosses from gemmae and spores and described the early stages, publishing the first color prints of parts of mosses, to my knowledge. This protonema stage, which had previously been clearly described and illustrated by Hedwig, was the subject of philosophical considerations, since it resembles $A$ gae so closely that some authors claimed that 1 igas changed into lusoi.

This problem, as well as that of generatio epontanea, was studied by Cassebeer in experiments with the cultivation of mosses, e.g. of crushed sporophytes. He had the sound idea, long before Pasteur, to sterilize his vessels and culture-media in some way (boiling), but apparently he was unable to realize the role of microscopical contamination introduced with the plant material. His conclusion was that generatio epontanea was not correct, but generatio aequivooa was. Different moss species gave, in his opinion, different types of "Priestleyan green matter", which he considered to represent larvae of the moss. This was not the protonema, which he also observed and described from germinating spores. 
The works of the Swedish algologist C.A. Agardh (1785-1859) should be sturied in this connection, since he advocated similar ideas a development of species of $A$ gas into other species or into lusci. He included the moss protonema in his considerations. :icreover he expressed an early idea of the cell theory.

The German "Naturphilosophie" should also be mentioned. It was advocated by Cken, C,G. iiees von Esenheck and others. Oken constructed a system for biology and mineralogy in which nearly everywhere a division into 3 or 4 groups was present, more or less following the elements of the old philosophers: fire, air, water and earth.

An early reaction to this construction of systems on preconceived ideas can be found in Perleb: Lehrbuch cer Naturgeschichte dee Pfianzenreichs, 1826; he stressed the descriptive character of natural history and opposed to the "iaturphilosophie". Later the word "liaturphilosophie" even became in a way synonymous with speculative biolofical theory.

The dissemination of knowledge, a special chapter in the history of biology, is not extensively treated here. The handhooks and popular introductory books of the period 1825-1827 are included in the bibliography, but this period is too short to varrant a general outline. Exsiccata, however, are treated from a much longer period, since they can contain new names. Several interestirg series are described in this thesis. The long series of Funck and the impressive quarto publication of :!ougeot and Xestler were influential; several authors published exsiccata with a similar make-up.

\section{PRIORITY IN BOTAHICAL HONEHCLATURE.}

The principle of priority is of basic importance in biological nomerclature. When different latin names of the same rank exist for the same taxon (a systematical unit of any rank), in general only that nare which was published first is consicered correct. Fowever, the International Code of Botanical liomenclature (ICBii), published under the auspices of the International Rotanica: Congresses, contain a number of limitationa of the principle of priority.

A very important limitation is the freedom of the botanist to use his owr. scientific judgment as to the circumscription of genera, species end taxa of other ranks. For example, a binary name of a species does not have prior:ty over another name for that species in another genus. Instead, the principle is applied solely to the specific epithet; the earliest validly published epithet should be used in conbination with the name of the other genus, unless there is a legitimate reason preverting its use in that position. Such a reason is the existence of an earlier homonym in the zerus to which the species is trarsferred, that is the existence of the same name for another species; in such a case the next oldest validly published epithet has to ie used. The priority rule governs the use of epithets of taxa of lower rank than species (subspecies, varieties) in the same way, although this is linited to epithets in the same rank.

This rule of priority of epithets was not always accepted. Many authors in the aarly nineteenth century felt free to use a new epithet when transferring a species to another genus. Obviously one of their reasons was the avoidance of combinations of generic names and specific epithets which are contradictory, e.g. Bryum kryoides. Instead. These autnors countea priority for the complete name, the combination of generic name and specific epithet. W.J. Hooker and his son, J.D. Hooker, used this rule. It was therefore applied in the well-known index of names of phanerogans, Index keweneis; hence the name "Kew-rule".

Another limitation is the use of starting-points. Names published before the starting-poirt are considered not validly published, though they can have importance for the typification of the validly published one. For most eroups, including the Hepatioae and Sphagnum, the starting-point is the work of Linnaeus: Species plantarum, 1753. For Musoi (sphagnaceas excepted) it is Hedwig: Speoies Huscorum, 1801.

As consequence of the importance of priority it is necessary to estahlish dates of publication of many books in which new names are published. Effective publication is defined (ICBN Art.29) as follows: "Publication is effected... only by. distribution of printed metter (through ale, exchange, or gift) to the general public or at leas to botanical institutiono with libreries accesible to botaniete generally" Since the word "institutions" is an unqualified plural, the minimum of two different libraries would fulfill the requirement for effective publication, though this is certainjy not to be recommended for future usage. However, for proof of the existence of an article or book in the past it is a handy criterion. If two reviews were published, giving infependent opinions, it xay be taken for granted that the book was in existence at the time of the reviews. There is a possibility of pre-publication copies, having been sent tc the reviewing journals before the actual date of availibility to the 
public, but in general the writing of reviews took some time, and the reviews may be assumed to have come out after the actual date of publication of the book itself. Announcements should be differentiated in pre-gublication announcements, definitely stating that the book was not yet published, and post-publication announcements, citing pages of the book or in any other way making certain that the book existed at the day of writing or publishing the announcement. Other announcements should not be trusted fully.

The words "exchange, or gift" include methods often excluded from publication. When an author sends separates from articles in feriodicals to his correspondents, this constitutes effective publication, even if these separates have the same page numbers es the article and no additional title-page. If we apply the same minimum here, two correspondents would be sufficient for proof of effective publication. Letters from the author to botanists accompanying copies are important to establish the dates of publication of books in general and of these separates in particular. A modern compilation of the Latin names of Musci was authorized by the VIIIth International Botanical Congress (Paris, 1954). 4 volumes have so far been published: R. van der Wijk, H.D. Margadant P.A. Florschitz: Index thecorum, vols.1-4, 1959-1967 (the 5th volume is in preparation). The current rules of nomenclature are applied consistently in this work, such as the change of the etarting-point, the priority of efithets, and the requirements for valid publication. Moreover references are given to taxonomic synonyms as was done by Paris in his Index bryologicus, and in the Index Kewensis. A new feature is, however, the citation of the author who is responsible for the taxonomic opinion.

The exact dates of publication of many works were needed for this compilation. During the preparation Dr. G. Sayre published her Dates of publications desoribing Musci, 1807-1821, 1959. listing all publications containing names of Muci in the years mentioned, as well as the information concerning the exact dates of publication which she as embled during year of work in American and European libraries. Sayre's work proved to be very helpful for all those cases in which names were published more or less simultaneously in that period. For other periods the compilation published by Mrs. M.J. van Steenis-Kruseman in Plora Malesiana, 1954, was indispensable. Nevertheless many dates had to be ascertained from other sources, which proved to be a timeconsuming task. For several important works provisional dates were used. It was found that especially the period $1825-1827$ presented some important problems.

This concerned in the first place the article by G.A. Walker Arnott with the head-title Houvelle disposition mithodique des eopdoes de moksere. Several sources indicated the date 1825 for this publication, but the journal consulted during the preparation of Index Musoorum had title-page with the date 1827 . However, there was some reason to assume that the fascicle concerned was published in 1826.

Secondly the actual years of publication of the two volunes of S.E. Bridel: Bryologia univerea, were open to doubt: because the preface date is 16 Nec. 1826 it was difficult to accept 1826 for this part. Moreover a supplement to vol. 1 was clearly issued later than the main part of vol.1, but the date 1827 , used for this part in Index huecorum, was assigned to it on rather loose crounds.

In the third place the two foregoing publications had some connection with parts of Schwaegrichen: Species Auscorum... supplementum. Therefore, these parts too had to be dated correctly.

Having the opporturity to select a secial part in the preparation of the Bibliographia Buntiana, of the Hunt Botanical Library (HBL). Pittsburgh, Pennsylvania, I chose these problems. This large project aims at giving a detailed bibliographical description of all botanical books published in the period 1730-1840, using the method: of descriptive bibliography, as developed by Greg, llackerrow, Bowers and Alan Stevenson, and adapted to the special purpose.

I examined all botanical books and articles in periodicals that I could trace which were published during 1825,1826 and 1827 , and prepared detailed bibliographical description of those works which had some bryological contents. Works which had several parts or volumes were treated completely, including thcse published outside these three years. For this reason the starting-point book for Husi. Hedwig's Species husoorum, is included, since Schwaegrichen considered his supplements to belong to Hedwig's book. Of some authors I included earlier bryological works, e.g. W.J. Hooker, because their treatment elucidates some peculiarities of the preparation of the books useful for works within the three years mentioned. 
Besides works of these three years I also studied those published in the years 1822-1824, thus bridging the gap between 1825 and the last year studied by Dr. G. Sayre, 1821. For these years, however, I did not make an effort to trace everything which might have some bryology and $I$ only checked those works in which many names of Musci were present as well as some others which happered to come to my attention; some publications with new names are not included because the time did not permit to do so. The methods used for the bibliographical descriptions are explained at length in the chapter on general bibliography; it is sufficient to mention here that the methods aim at giving a description of the book as a physical object and to elucidate its history of printing and publication.

For the task of tracing reviews and announcements I had the valueble collaboration of the team of workers of the Hunt Botanical Library, who excerpted the periodicals of the period 1730-1840 for Bibliographia Buntiana: Dr. Claude Weber. Geneva (now Ithaca, N.Y.), Roman languages, Miss I.H. Vegter, Utrecht, the English language, and $\mathrm{Yr}$. C.F. Schutz, Utrecht, Germanic languages. They kindly consented to publish a few of their findings here, for which I wamly thank them. In many cases I checked these items myself, especially if the dating of the publication in question could depend on the wording of the revies or announcement, but it was not possible to do so for all references.

\section{SOURCES}

Agardh, C.A.: Disertatio de metamorphosi Algarum. Lund, 1820.

Adanson, M.: Families des plantes, 2 vols. Paris, 1763[-1764]. (Stafl, TL n.5)

Brongniart, Ad.T.: Bistoire des vegstaus foosiles. 2 vols. Paris-Ansterdam, 1828-1837. (Stafl. TL n.151)

Bruch, P., Schimper, W.P. \& Glimbel, W.T.: Bryologia Europaea.

6 vols. in 65 fasc. Stuttgart, $1836-1855$. (Stafl. TL n.167)

Dillenius, J.J.: Catalogus plantarum sponte oiroa Giseam nasoontium. Frankfurt am Main, 1718.

Dillenius, J.J.: [Re-issue of Catalogus, with added] Appendix. Frankfurt am İain, 1719.

Dillenius, J.J.: Historia Muscorum. Oxford, 1741. (Stafl. TL n.297)

Dillenius, J.J.: Historia Huscorum. [reprint] Edinburgh, 1811.

Gray, S.F.:

Hedwig, J.:

A natural arrangement of Britioh plants. 2 vols. London, 1821.

Vorlaufige Anseige seiner Beobaohtungen von den wahren Gesohiechtetheilen der Hoosen und ihre Fortpflanzung duroh Saamen. Lefpr. Samm1. Phyaik 1(3). 1778 .

Hedwig, J.:

Vom wahren Uroprunge der mannliohen Begattungstheile der Pflansen. Leipz. Magazin Math. Natunk. 1782 ( 3 ).

Hedwig, J.:

Hedwig, J.:

Pundamentum historiae naturali musoorum frondosorum iconibus iliustratum. 2 parts. Leipzig, 1782-1783.

Theoria generationis a fruatifiaationis piantarum oryptoganicarum Linnaei .... Petropol, 1784 [according to Meusel: Das gelehrte Teutschland ... 3: 149; this was published in 1785]. Ed.2. Leipzig, 1798 .

Hedwig, J.:

Desoriptio et adumbratio miorosoopioo-analytioa musoorum frondosomu. neo non aliorum vegetantium, olaspe oryptoganiou linnaei novorum dubiieque veratorum. 4 vols, in 16 fasc. Leipzig, [1784-]1797; original title on fasc.1: Stirpes oryptogamioae novae aut

dubiae ioonibus adumbratio additaque historia analytioa; issued with German title: Abbildungen neuer und sweifel-

hafter oryptogamioohen Gewaohoe. nebst ihrer analytischen Gesohiohte. Leipzig, 1875-11797?1. 
Indes Muscorum: see: Wijk, R, van der, Margadant, H.D, \& Florschütz, P.A. Jussieu. Bern. de 1 ordines naturazes in Ludovioi XV horto Trianonensi dispositi anno 1759. Manuscript (PMusBC), published in: A.L. de Jussieu: Genera plantarum p. Ixiii-ixx, 1789, and in Adanson, M.: Bamilies des plantos, ed.2:36.1847 [1864].

Jussieu, A.t. de: Genera plantarum. Paris, 1789.

Lamarck. J.B.A.P.M. de: Flore Frangoire.

2 vols. Paris, $1778,9779 j$. (Stafl. TL n.638)

Lamarck a de Candolle, A.P.: Flore Prangaies.

Ed.3.. 4 "tomes" in 5 vols. Paris, 1805. (Stafl. TL $\mathrm{n}, 641$ )

[Re-issue with new title and an additional vol.:j "tome" 5, vol.6. Paris. 1815. [Variant of this issue has a printed announcement on the verso of the title-leaf.]

Linnaeus, C.: Bortus Cliffortianue. Amsterdam, 1737. (Stafl. TL n.721)

Linnaeus, C.: Philoeophia botanioa ...

Stockholm, Amsterdam, 1751. (Stafl. TL n.729)

Linnaeus, C. (praeses), Bergius, P.J. (respondens): Semina Muscoxum deteota. Upsala, 1750. [Consulted: Amoen. Aced. (Holm.) 2: 284-306. 1751.]

Lovejoy, A.0.: The great ohain of being. Cambridge, Mass., 1936.

Micheli, P.A.: Hova piantarum genera juxta Tournefortit methodum dieposita ... Florentia, 1729. (Stafl. TL n.843)

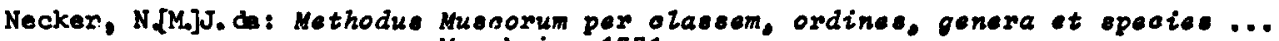
Mannheim, 1771 .

Necker, NdM]J. de: Physiologia husoorum ... Mannhein, 1774.

Necker. N\{M.jJ. de: Phytosoologie phizosophique ... Heuwied \& Strasburg. 1790.

Palisot de Beauvois, A.M.F.J.: Prodrome de l'asthogamie... Megesin Encjel. 5(19): 289-330. 1804 .

Palisot de Beauvois, A.M.F.J.: Prodrome des oinquidme t oixidme familles le i'acthogamie. Les mousses. Les iycopodes. Paris, 1804. (Stafl. TL n.939)

Paris, E.G.: Indew bryologious. Publ, in 5 parts in Act. Soc, Iinn, Bordeau, $1894-1898$, and issued in book form with separate pagination. Supplement, 1900 .

Paris, E.G.1 Indee bryologiaue. Ed.2. 2 vols. in 5 parts. Paris, 1903-1906.

Sayre, G.: Dates of publiaations decoribing Nusai, 1801-1821. Troy, N.Y., 1959.

Stafleu, F.A.: Introduotion to Juecieu'o Genera plantarum. In reprint ed. of A.L. de Jussieu: Genera plantarum. Weinheim, 1966.

Stefleu, F.A.: The great Prodromue. In reprint ed. of A.P. de Candolle: Prodromus oystematio naturalio regni vegetabilis. Lehre, 1966 .

Stafleu, F.A.: Brongniart' Histoire des vightaus foesize. Taxon 15(8): 320-330. 1966 Nov.

Steenis-Kruseman, M.J. van Stearn, W.T.: Date of publioation. Flore Malesiane ger.1, vol. 4(5): CLXIII-CCXIX. 1954.

Wijk, R. van der, Margadant, W.D. Florschatz, P.A.: Indes Nusoorum. 4 vols. Utrecht, 1959-1967 (vol.5 in preparation). Regnum vegetabile vol.17, $26,33,48$. 


\section{DE S C R I P T I V E B I B L I O G R A P H Y \\ APPLIED TO BOTANY}

\section{CONCEPT OF DESCRIPTIVE AIID AIALYTICAL BIBLIOGRAPHY}

Since a major part of this thesis is devoted to the bibliographical descriptions of books, an introduction to the methods of descriptive bibliography as described by Gree, lickerrow, Isdaile and Bowers is thought necessary.

The term bibliography is used in different senses. The usual meaning is a list of titles of books and articles on a particular subject, branch of knowledge, or of a particular author. Then given at the end of a scientific paper the purpose is to identify those books and papers referred to in the text. Usually only a minimum of information is Eiven, and sometimes even not enough for the identification. The words "Iiterature", "references", or "sources" are preferred by bibliographers for these lists.

An annotated catalogue of books on a particular subject, such as for botany Pritzel's Thesaurus literaturas botanicae, is usually included in the concept of a bibliography. In my opinion it will be difficult to change this use; nevertheless bibliographers of the analytical school prefer the word "catalogue", or "annotated catalogue", or "bibliographical catalogue" for this type.

The restricted concept of bibliography includes only those lists of which every book has been checked in a number of copies, so that a reasonable chance exists that variants have been traced; a technical condensed description of the book as a physical object is given, including the variants found.

For this descriptive bibliography and its companion, analytical bibliography, the thorough study of the book as a physical object in as many aspects as possible is the main point. The description resulting from this study is given in a condensed form, in the same way as a chemical formula represents in a very short form the resuit of the study of the chemist on a certain compound. With this description the trained bibliographer can compare other copies to detect variants. The reasons why variants came into existence can be understood when the processes of printing are known, and the history of the book can be deducted from the variants. In this way the descriptive bibliography becomes analytical bibliography: a number of copies have to be studied and critically compared.

The different bibliographical tems used and the method followed here will be discussed under the headings: Paper (p,1); Printing (p.3); Binding (p.6); Edition, issue and state $(p, 6)$; Title description ( $p .9$ ); Bibliographical format ( $p .10)$; Key to bibliographical formats (p.15); Collational formula (p.22); Pagination (p.25); Contents (p.26); Plates (p.27); Paper description (p.28); Dates of publication (p.28); Reviews, announcements etc. (p.29); Signs (p.29); Abbreviations $(p, 30)$; Sources $(p, 33)$.

\section{PAPER}

Originally all European paper was handmade from linen rags. Though Réaumur $(1683-1757)$ pointed to the wasps and their paper-like nests from wood pulp, it was scarcely before 1800 that paper was manufactured from wood. About the same time attempts were made to construct paper-machines, but they came into regular use much later. In the traditional paper mills, usually in a region with water power and clean water, the fibres are loosened by beating to form the pulp, a suspension of the fibres in water. The vatman, named after the vats containing the pulp, dipped his mould in the pulp. This mould was a rectangular frame, covered with two systems of copper wires. Those parallel to the shorter sides, the ohaino, were rather widely spaced, e.g. $2 \mathrm{~cm}$. Those parallel to the longer sides, supported by the former, were the wires, closely set, e.g. with distances of $1 \mathrm{~mm}$. This frame was covered by another upper frame, the deckle. This had an oblique inner side at one border along which the vatran could pour bacl: into the vat the superfluous pulp. This frame obviously determined the size of the sheet, allowing, of course, for shrinking during the drying process. The important task of the vatman was to ascertain an even thickness of the pulp over the whole frame with a fairly equal distribution of fibres lying in different directions. This was achieved by a shaking movement of the mould, a skill not acquired easily and occasionally lost overnight. This loss would be the end of the career of the vatman and it is the origin of the Dutch expression "de hussel kwijt zijn", probably identical with "de kluts kwijt zijn", now meaning "to be 
at a complete loss". The borders of the hand-made sheet, the deokle-edges, are irregular in outline and thickness, sirce the pulp could creep betweer. tic eckle and the frame, or fail to reach the deckle in some places. They play an important role in the identification of the format of books. These deckle-edges are different from torn edges, resulting from cutting a sheet with a paper knife, producing numerous small protruding fibres.

The chains and wires caused thinner places in the paper, the ohain- and wirelines. They are characteristic for this type of paper, laid paper. They can be seen when the paper is held against the light, or when the wet paper is placed on a dark background. Moreover, a watermark may be present, visible in the same way. It was produced by tying some design of bent copper wires to the chains and wires of the mould. Each vatman had at least two moulds to a vat, and several vats might have been in use in one mill. Therefore, though a mill had a certain general design in all moulds for paper of a certain size, the individual designs varied, occasionally even quite markedly. Paper parties from one mill contained these modifications at random, and so do the books printed from such a supply. This should be kept in mind when watermarks are used for dating purposes. Alan Stevenson, expert on watermarks, pointed to the results of the considerable wear of the copper designs, so that the same mould at different times gave marked differences in the watermark, e.g. distortions or even complete disappearance of certain parts. Afterwards scme attempt could be made to repair the fault. An able bibliographer may establish the relative age of certain paper, and therefore, of the printing of publications.

Originally the watermark was placed in the center of one half-sheet. Wany different designs have been used. Some designs became indications of certain paper sizes, e.g. pot, foolscap, crown, and in France grapes (raisin). The trademark of a papermaker or mill was also used as a design, e.g. a bee-hive for the papermaker Honig (Dutch for honey), or a whale after the name of a windmill. Initials of the papermaker were often added, or a device, e.g. Pro Patria. A watermark in the opposite half-sheet, named the countermark, consisted, especially in France, of the name of the papermaker, the place or region of the mill, an indication of the quality (in French papers $f i n$, weyen or bulle), and a year number. The watermark and its countermark are separated in the descriptions by a long equal-sign $=$. When nothing to the contrary is stated, it is placed in the centers of the half-sheets. The dates in the watermarks can be helpful for establishing dates of publication and it should be standard procedure for natural history bibliographers to check watermarks in critical cases. The dates, if correct, cannot be later than the dates of printing. Mistakes in watermarks are not rare, especially mirror positions of letters such as N. Mistakes in dates may occur, but I do not know of any case of post-dating. Certainly dates in the watermarks of plates can be found which are much later than the year on the title, but these copies of the plates were obviously printed after the original publication, when the number of plates originally printed was exhausted.

Normaliy paper for printing was consumed within a few years, and the dates do not differ too much from the dates of publiction. An obvious exception is a stock of paper set aside by a publisher or printer for a special book or serial in instalcents, which will show the same mark for a long tine. A rather anusing discrepancy was caused by a French decree of about 1742 , which prescribed papermakers to add their name, place, and the year in the watermark. It gave an explicit example, mentioning the year 1742. For about three decades onwards many French papernakers strictly adhered to the letter of the law, putting the date 1742 in the watermark throughout the years.

A new type of paper with a smooth surface was produced first in Encland about 1755, probably by the papermaker James Whatman (died 1757), and was used in Baskerville's Virgil, 1757. This paper, wove paper, was not much used before 1800, but became the most important paper several decaries later. It was made on a mould with a mesh of copper wires closely set in both directions. The resulting lines are sometimes visible in the early wove paper. A watermark could not be realized in the same way as in laid paper, since the mesh had no room for the tiny wires which held the watermark wires in place. Therefore early wove paper is as a rule without a watermark. However, another technique was developed: with a special tool a design was pressed into the wet paper. As a result the watermark in handmade wove paper is usually situated not far from the border of the sheet, e.s. the lower left part of the sheet. It may appear near the base of one of the first four leaves of an octavo 
Eatherir.5, or in the fold of a conjurate pair. Knowing this method I can explain excepticnal cases of a couble waternark in one sheet in wove paper, of which the large rajority had one watermark only (Hooker, Exotio flora, Greville, Scottish cruptogamio flora, and Cobbett, The American gardener; see Buntia 2: 71-73. 1965). ify explanation is that by error a few sheets were treated twice with the same tool in different places. This unusual phenomenon first seemed to be caused by cancellantia (irregularities in the watermarks are very helpful in detecting cancellantia), but conjugacy, deckle-edges and the study of other copies showed that in these few cases no cancellantia were involved.

A very important development was the paper machine. The closely woven mesh of wire was made endless by fastening the ends together to rotate over rollers. The connection of the two ends can occasionally be seen as a watermarklike seam in the paper. The pulp traveled continuously with this web and underwent necessary operations until the paper was strong enough to be lifted off. The great difficulty which had to be overcome was the correct shaking of the traveiling pulp. Still, the result was not equal to good handmade paper, since the fibres have a preference for a direction in connection with the traveling, which is clearly observable in the curling when two strips cut in different directions are pasted together. In this type of paper a watermark could be added by letting the still wet paper pass through a pair of rollers, the dandy-rolls, which embossed the desired design into the paper. This would give a repetition of the mark at certain distances. Chain-and wirelines could be faked in the same way.

An important stage in the paper making process is the drying. As a first measure the wet handmade sheets were often placed between felts, under pressure, so that noisture was pressed out. After that the sheets were dried by hanging in wellaired sheds. In some papers the impression of the felt fibres can clearly be seen under slanting light. In machine-made paper, the drying was still more critical. When the continuous band of paper was to be lifted from the wire-cloth, it had to be dry enough. This was achieved by passing the paper through several rolis and exposing it to a drying stream of air.

Finally the finished sheets were checked for faults, probably sorted into quality classes, and prepared for shipment. It is clear that the quality and especially the thickness of handmade paper cannot be standardized as j.t is in modern paper. There might be overlapping in classes of different thickness, as is sometimes seen in books with thicker paper for the plates.

The question of names of paper sizes can be mentioned here. In the course of time a considerable number of paper sizes have been made, and many names have been in use, These names had a different meaning in different regions. Labarre gives a selection in his Encyclopedia of paper-making, and Stevenson also compiled a list with their dimensions. However, I came across quite a number of books of which the paper size could not be classified satisfactorily with these classifications, even in uncut form, and stating a name of the nearest larger class without any certainty does not appeal to me. I preferred to drop these names except where other evidence was present, such as announcements of publishers. Instead the leaf height is stated of the largest copy measured, and in some cases the dimensions of the sheet from an uncut copy.

Paper colors are given only when other than white. The white papers may have a variety of brownish colors now, because of aging. No attempt has been made to describe the browning, unless there was some reason to mention differences.

\section{PRINTING}

Some main points will be discussed to give an idea of the necessary steps in the production of a book so that its physical make-up may be understood.

Before printing can begin, the format, the size of the printed part of the page, and the font-size and type must be decided upon. The format will be discussed later; the dimensions of the type-page are the result of the chosen format and paper, and the font is usually selected from those available in the printer's shop. It is a very rare occasion when a special type is bought or made for a book. Movable type so essential for printing, exists in a large variety of sizes and forms:. Some trained bibliographers are able to recognize fonts used by early printers, who usually cut their own types. With the division of labor special type-foundries came into 
existence. Their products becane available comercially, and in rare cases special fonts were made on order. With some experience it is not too difficult to guess the general period of the type-font. llot ruch critical work has been done on the recognition of the type-fonts of special printers in the 18 th and 19 th centuries. However, the type-font can easily be recopnized in special cases, e.E. the small horizontal line in the stalk of the letter " 1 " in the font of the Imprimerie Rcyale at the Louvre, Paris (this can be seen in the first edition of Lamarck's Flore Francoise, 1778). Bibliographers use general names or the fonts. Also accurate measurements of 20 (soretines 10) lines are often given; these lines should nct be leaded (viz. provided with thin strips inserted between the lines to rive rore space). The typeforts have not been described in tiris thesis.

The setting of the type is done by the compositor. Isire after line is set, and these are arranged into pages. At the top of the page is added the head-1ine, containing the page number and the running title. At the bottom is arded the directionline, which contains the signature, the catchword and the indication of title and volume number. Any of these three may be absent. The oignatures are the letters or numbers assigned to the gatherings and the individual leaves. A gathering is the set of leaves which are folled together as a unit in binding. Usually one gathering consists of one sheet, but in "quired" sheets two or more sheets are folded within each other; in smaller formats half-sheets or smaller parts are used for one gathering. Each gathering has a special mark, letter or number, and individual leaves are numbered within each gathering. If a gathering of 8 leaves has the indication A, its individual leave are $A_{1}-A_{8}$. These indications, the signatures, are printed on a part of the leaves (always on the rectos, or front sides), except for the omission of the cipher 1 on the first leaf. For a long time the number of leaves signed per gathering was half the total number per gathering plus one. liainly in the course of the 19 th century the number of signed leaves was Eradually reduced to one leaf, the first one only. In some formats another system was adopted: in gatherings of 6 or 12 leaves the part with cut leaves which was laid in the middle of the gathering, was proviced with a special signature, often an asterisk, or the letter of the gathering with the number "2", not indicating the leaf number as usual, but the cut part of the gathering. The catohword is the first word of the next page printed in advance as a check for the binder. The older custom was a catchword on every fage. This was cut down to having a catchword only on the last page of a gathering. The absence of a catchword in a place where it normally would be present may be an indication of a. break in fascicles and should therefore be recorded by the bibliographer. The title indication is rarely present in the direction-line; the volume indication is more usual. These indications can also have a meaning for the bibliographer, as I explained in a case of $18^{\circ}$ in $6 \mathrm{~s}$, where this was the only intrinsic clue for the format (Uuntia 2: 167. 1965: Aglae Adanon, La maioon de campagne, Paris, 1322).

When the compositor had set enough pages to fill one sheet (or in the case of quired sheets, one gathering), he arranged the set pages together in two frames, called the formes, one forme for each side of the sheet, as a preparation for printing. This is the imposing, and the arrangement is the imposition. The forme containing page 1, or the corresponding first (odd) page of a sheet, is referred to as the outer forme, and the other, containing page 2, cr the corresponding even page, as the inner forme. In a special imposition, referred to as half-oheet imposition,
both groups are arranged in different halves of the same forme: the complete blank sheets are printed at one side; following this the other side is printed with the same forme, in the reverse position, so that rectos and versos (back side leaf match. In this way eaci shect, after printing is comfleted, contains two identical half-sheets. Hatermark and countermark will appear at random in different halfsheets in the same copy of a book, and also in the same gathering in different copies; statistically the mean will be 50 for each mark. This method has the obvious advantage for the printer that the type-font can be reused sooner than with full-sheet printing. Smaller printing-shops will consequently have a preference for this method. It has also been used for plate-books appearing in fascicles and with a limited amount of text per fascicle. The results of the different types of inposition wiil be treated in the discussion of formats $(7,8)$.

After the imposition of a sheet is finished, a proof can be printed. The modern usage of printing proofs in long strips of paper, galley proofs, obviousiy was not possible in the time of hand-made paper. The proofs usually were (and are) read by 
the corrector, who compared them with the nanuscript, and indicated other possible corrections. liore important are the corrections of the author himself. often he will want to change what he mote in the original nanuscript; the high costs of this extra correction need not be stressed here. After these corrections have been rade and a second proof has been read, usually the fiat for printing is given. Accordingly the number of shests set by the publisher is struck off. Bibliographical problems result from changes during printing. Type-font could break or fall out, e.g. pagenurbers, or farts of the forme could be distorted. The printer, stopping the press, could try to repair the damage and inadvertently introduce errors. The author could visit the printer, discover a sentence not to his liking, and order a stop-prese correction, a practice abhorred by all printers. The sheets already printed hefore such alterations were not discaried but used for copies of the book. variants in different copies have to be studied thoroughly so that can be indicated which one was printed first. Analytical bibliography has been able to prove in several cases that guesses based on the text had been erroneous. Such first states are eagerly sought for by bibliophiles, and indeed, are valuable for tracing the history of printing of the book concerned. However, they do not necessarily represent the first published copies since in many cases the changed sheet will have been prepared for sale first, being on top of the pile of printed sheets.

Anotier method of making important corrections after the beginning of printing was to reprint complete new leaves with the changed text. The originai leaves with the mistakes should be discarded, canceled, to be replaced by the new leaves. The replaced leaf is known as the canoellandum (plural cancellanda) and the replacing leaf as the cancellano (Flural cancellantia). A cancellans pasted to the remaining stub of a cancellandum is easily recognized, provided the copy is not too tightly bound. It is more difficult to detect cancellantia which are tipped in (pasted along a narrow strip) to another leaf, or which consist of a pair of conjugate leaves. They show at once in unopened copies; uncut copies are helpful too, since the edges can be checked. The chain-lines and the watermarks give useful indications when they do not match in places where they should in intact gatherings. The bibliographer has to take it for granted that he will overlook conjugate pairs of cancellantia, especially in wove paper, unless chance brings an uncut copy or a copy with both cancellanda and cancellantia under his eyes. Of course, he helps chance by studying a number of copies.

Usually the cancellantia were printed together with the last parts of the book, as well as the index and preliminaries. Evidence in some books, as Bridel's Bryologia Universa, makes it likely that cancellantia were the result of making the index: in this case the author found that he had treated two sfecies each twice, in two different genera. Two leaves were canceled and one new leaf inserted instead. This was printed as part of one of the last sheets. The binder was supposed to cut this out, remove the cancellanda, and tip the cancelians in at the right place. In some copies this was not done, so that the original sheets could be traced: this cancellans was part of the book as it was published, and not an alteration after publishing. This vill be discussed in the chapter on editions, states and issues ( 5 ).

Because the preliminaries were printed later than the text, the compositor often signed the first sheet or gathering with the letter "B", taking for granted that the preliminaries (often shortened to 'prelims! in bibliographical usage) would take op one gathering. The consequences for the collational formula of the bibliographer will be discussed later. The preliminarios nearly always contain the title-page, often the dedication, the preface, and occasionaliy a list of contents. When a sheet was not completely filled with these leaves, the compositor added a half-titie, giving only a short title and the name of the author.

The titie-page is the authoritative source for the title and the date of a book. There may be other titles used for the book, but that of the title-page is decisive. The date, however, is often not correct, or not completely correct. In botanical nomenclature the date printed on the work must be considered correct unless other evidence proves the contrary. It is an important task for the bibliographer of botany to check the correctness of these dates. Strictly speaking, most of the methods of ascertaining dates of publication are outside the field of descriptive bibliography, since they use the collateral evidence of reviews and announcements of reviews in contemporaneous literature as well as of autograph letters of authors and others, or data from archives of publishers, and lists of book-acquisitions of academies and societie'. Internal evidence is the domain of the descriptive bibliographer, but for botanical work the other evidence is necessary. 
Book published ir. faccicles are interestir.g for the descriptive bibliographer. Publishers found that a market for expensive books could be created by publishing piecemeal a small number of sheets and plates. These were issued in wrafpers, often of colored, infericr paper, to be discarded when the final volume was bound. These wrappers were printed with a wrapper-title (exceptions are not known to me, but their absence is difficult to prove) This often bears the year or even month of publication, at least of planned publication, though not always the actual date. fiso, they can indicate the mode of publication and price. The back may have fublisher's anncuncements. These wrappers are, therefore, valuable for the botanical bibliographer, since these dates abviously have a preference over those of later published volume-titles, and in the absence of other evidence of actual publication dates, have to be accepted for purposes of botanical nomenclature.

Wrapper-titles are also important for dating instalnents of periodicals, published before the title-page to the complete volume is issued, usually with the last instalment, or the first of the next volume, together with the index. Again, the date on the wrapper is important.

In addition, the more complicated case exists, both in books and periodicals, that the wrapper had another title than the completed volume on its title-page, as the Memoires de la sooiet Linnesene de Parie, published in fascicles with the titie Annales de la sooists Linnesene de Paris on the wrappers.

\section{BINDING}

The subject of book-binding is an interesting topic, but it falls largely outsice the scope of this thesis. For the period treated the books were often scld unbound and the buyer could have his copy bound as he wanted. Therefore, the binding belongs to the individual copy, and the purpose here is to describe issues and editions, not individual copies.

Nevertheless, some points can be discussed. Firstly, the techniques of binding have an interaction with the folding of the sheets. Certain formats are preferred, because they facilitate normal binding, and other fomats necessitate a special kind of binding. This is clear in the case of a broadsheet, where the individual leaves have to be stitched together. At the other extreme there is a limit to the folding together of conjugate leaves. More than 10 pairs are rarely bound together in. a gathering, since it makes binding more difficult. This is further discussed under formats, quiring, and the imposition of $32^{\circ}$ format.

Secondly, though usually the copies were sold by the publisher in a wrapper without any printing, and of inferior paper, the cases where printed matter occur should be mentioned by the biblicgrapher whenever they come to his attention. This has been discussed extensively for fascicle-titles, where it is one of the inportant tasks of the botanical bibliographer to trace the exact text of the wrappers. In some cases books were published with lobels pasted on the front or or the spine. In one case this spine-label had another title than the title-page (Hooker, Musoi exotici, 1818-20); in another case, though ourside the period concerned, the spine-label had inportant information 0.7 the date of publication: the last digit of the year was filled out by hand and indicated one year later than that printed on the title-page. 'The bibliographer should be eware of such details and give a description in in appropriate place.

\section{EDITION, ISSUE and STATE}

Bibliographers writing in the English language have restricted the meaning of the word edition from the broad usage outside of bibliography. The words issue and state were defined as being within an edition, and therefore different from the normal usage outside of bibliography. The long discussions devoted to the problem of how to differentiate these three terms, and the many examples of which not enough details of the history are known for a certain classification, show the difficulties of this problem. Bowers writes: "No problem offers more traps for the bibliographer than the clasoification of books by edition, isaue and tare." (Bowers, P2inciples of bibliographical description, reissue 1962, Hew York, p.38). He begins the next paragraph with the following statement: "The fact that nothing which has ever been or ever will be written about edition, issue and tate will indicate the invariable line to take with amall number of abnormally complex books does not mean that an attemp at definition, and the working-out of general principles to implement the definition is a van task" 
Bowers offered the following broad definition for edition in hand-printed books: "An Edition is the whole number of copies of a book printed at any time or times from aubstantially the same setting of type-pages." (Bowers, P.39). A requirement for a new edition, therefore, is the resetting of a large number of the pages. A reimprassion, the new printing of sheets from standing type (the type of the rages kept in stcrare), does not constitute a new edition in this terminology. However, in the time of hand-printire, type tas rarely left standing and it is not necessary to use reinpression for books of this period.

İ́s defirition for isoue is: "An Is sue is the whole number of copies of a form of an edition put on sale at any time or time as consciously planned unit and varyFurther on $(p .77)$ he explains 3 major criteria for issue: "(1) the form of the book must difer in sone vay fron the copies of the edition first put on the market. but nust still be largely composed of the original sheets or, in special cases, inpressed from substantially the original type; (2) ordinarily the altered copies must be put on the market as a unit, consistent in their forn except for variant states, at a later date than the issue of the earlier copien and as part of a purposeful re-issue; (3) if issue of some copies is not removed from others in point of time. it must comprise a different form of the book planned for 6 ale as a sarate publishing venture from the rormal issue as consequence of alcered makeup. Ordinary large or finepaper copies are excluded except under special circumstances." Except for the last restriction the word issue is used in connection with the promotion of sale "as a separate publishing venture".

The common form of issue is the re-issue, as a rule with a cancellans title-page. The reason for not including large paper copies and fine paper copies in the concept of issue is not clear to me; they were made especially to be sold at a higher price, in the same way as reimpositions in another format, which Bowers considers to represent other issues (Bowers, p.103-105). Simply for convenience I have used the term state for both forms, though theoretically the term issue should be preferred. Under Hooker, lusci exotici, impositions in $4^{\circ}$ and $8^{\circ}$ format of the same type pages are described; they differ in some signatures, the width of the margins, especially between the inner fold and the type-page, probably also in the sheet size and the paper quality.

In cases of different impositions in which the same text is distributed over different pages, Bowers speaks of separate issues, but Mckerrow somewhat reluctantly prefers the term edition. This term is definitely preferred by botanists, since it is the usual indication for the different forms of the book, which has to accompany unambiguous citations of pase numbers. Moreover, edition is an internaticnal term, and state and issue are not. Finally, this use of the term editions for forms of a book with different type-pages is in agreement with Bowers' definition of edition, quoted before: "printed... from substantially the same setting of type-pages."

State, in its broadest sense, is defined by Bowers as covering "ali alterations in a book, even those made after sale has begun, where no change is made to the original title-page by cancellation. . . changes seem made chiefly to create, after some delay, an 'ideal copy' of an edition by various improvements. ..." (Bowers, p.42.) Moreover he writes: "in its narrowest sense state is gnonymous with variant, and can be applied to any part of abok exhibiting variation in type-setting, including the addition or deletion of material in some copies, caused by alterations executed in the course of the original printing before public gale." (Bowers, $p .41-42$.) Bowers defines an ideal copy as follows: "an ideal copy is book which is complete in all its leaves as it ultimately left the printer's sop in perfect condition and in the complete tate that he considered the final and the most perfect otate of the book." (Bowers, p.113.) It is not necessarily identical with an existing copy; it contains "all the blank leaves intended to be issued as integral parts of its gathering but also all excisions and cacellan leaves or insertions which represent the most perfect etate of the book as the printer or publisher finaliy intended to issue it in the issue described"i it does not represent the cuthor's ideal of the book. In my opinion the ideal copy should not be defined with the help of the words state and issue.

To summarize Bowers' terminology: a otate is any variation in the same typesetting meant to achieve an ideal copy; an isoue has primarily a changed title to promote the sale with the remainder in the same type-setting; editions differ in a substantial part of the set type-pages. 
The application of tiese terns to boteny and especially to problers ci rocienclature is discussed by llacPhail (auntia 2: 280-285. 1065). :laintainirs the kasic distinctions nade by lickerrow and Bowers, he stresses the importance of alteraticns after publication for noronclature. He classifies forms whicil do not have changed title-pages as states, and introduces the tem post-pujiication state for the alterations mentioned. An example of this is iiedwig's Speoies muscorum, 1801; early reviews noticed the absence of a certain species. Its description vas supplied afterwards on an additional leef (p.231). This clearly is a belated attempt to produce an ideal copy. In this case there are no consequences for nomerclature because this book is the starting-point for nomenclature of liusci (sphagnum excepted), and an arbitrary date is assigned to it, self-evidently concennirg the ideal copy. inen an author corrected a new name, it is important to know whether jt was before or after publication. A cancellans is not automatically a post-publication state. On the contrary, cancellantia are normally part of the book as published. This has to be taken for sranted.

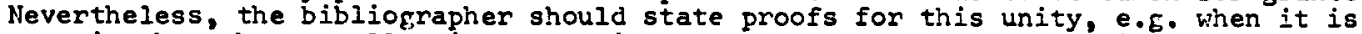
certain that the cancellantia were printed as part of a sheet with final gatherings cr preliminaries of the book. The post-publication state of a cancellans or inserted leaf, however, should never be taken for granted, and has to have explicit proofs, either internal (e.5. a later vatermark) or collateral (as in the case of redwig's species muscorum). Without this proof the corrected version is the valid one for nomenclature, since it is at the moment of effective publication the version accepted by the author. If post-publication is proved, the version not corrected is valid and legitimate and has priority over the corrected version in the same way as if the correction were published in a second edition.

Another complex of problens is indicated by the words often used in botanical bibliography: reprints and preprints. Then a botanist offered an article to a periodical, he could often order off-prints of it, or have a certiin number free. Usually these are referred to as reprints, but this name is bibliographically confusing and I will therefore use the term separates, borrcwed from the French, which indicates their character. These separates can be produced in different ways. Firstly, they can be rade from the sheets as printed for the serial, by cutting away the leaves not involved. Biblingraphically, these detached leaves do not have any standing. It would be equivalent to a mutilated book. Secondiy, the inposition could be changed to print the separates on complete sheets. Usualiy this was accompanied by press-alterations of the signatures and also of the page numbers. Sometimes the lines were redistributed over the pages too, to fit the leaves of complete sheets. These changes make the separate an issue, especially when a title-page is added. inen the first article of a periodical volume was concerned and consisted of a full number of sheets, the separate did not need renumbering and resignirg, and here a title-page remains the only distinguishing feature for classifying it as an issue.

For the taxonomical hotanist interested in correct nomenclature, these bibliomaghical considerations, however, are suhordinate to the question of the date of effective rublication, as defined in the Intemational Code of Botanical !onenclature. This is not identical with the usual bibliopraphical interpretation of publication. The former includes the distrihution of copies to other botanists which might not have been offered for sale. If a separate can be proved to have been published in this ray before the actual date of publication of the fascicle of the periodical, the botanical names in it have priority, whatever the bihlingraphical classification may be. Popularly they are referred to as preprints.

The publication dates of these separates usually have to be settled by collateral evidence. Nevertheless the careful research of the bibliographer can be helpful. The painstaking work of reporting mistakes in pagination, of which the botanist sonetimes doubts the efficiency, proved to be an indication in decicing the order of printing of separate and periodical for Cambessèdes, Enumeratio plantarum quas in insulis Balearibue collegit.... Paris, 1326. In a cofy of the periodical ore cor:plete gathering had all page-numbers wrong, as well as the signature. On checking the separate I found that the numbers and signatures were exactiy those of the separate. This could be explained by supposing that the compositor happened to forget to change these features in the sheets destined for the periodical. This would be an indication that the separate had been printed earlier. However, another copy examined does not have the mistakes. It can be explained by either a stop-press correction or a stray sheet from the wrong pile. In the case of Arnott, Dieposition mithodique des espdoes ie mousecs, Paris, the year on the title-pages of the separate and of the fascicie of the periodical are different. This is an indication that the separate was a preprint. 
The terr: preprint, which has some attraction because of the reserblance to reprint, coes not exactiy express what is meant. The criterion is solely the earlier fublication of the sefarate as compared with the periodical, and not the actual Erinting. Therefcre, as the correct tern I propose pre-pubication eaparate, or where desired prepuibication otate, and p'e-publication isoue. It could be argued that these terms are alsc not compietely correct, since actuaj. publication of the sefarate (in the botanical sense) is what is rieant, and not scmething before this. The meaning is, of course, that the separate is publisined before the bulk of the sheets, that is, those of the feriodical. Sinilarly, iacPhail's term "post-publication state" indicates publication of inserts or cancellantia later than the bulk of the sheets of the book. If desired, the indication could be shortened to pre-separate.

\section{TITLE-DESCRIPTION}

The imfortance of the title-page has already been stressed. A bibliographical description begins with the tit?e-page, either by giving a facsinile or a transcription. This transcription can account for everything printed on the title-page and is then callec quasi-facsimile, or can omit a number of details, being a simpliried transcription, which will not be discussea here. It has been argued that a facsinile reproduction is complete, exact, and eiiminates the work and time of the highly skilled bibliographer in preparing the quasi-facsimile, and correcting it, from manuscript to final printing. On the other side, as pointed out by Bowers, facsimile reproductions have drawbacks too: (1) impurities cannot be recognized (the title-page of a Shakespeare work had long been misread because of a flyspeck in a reproduction); (2) retouching can falsify the facsimile; (3) parts which are either inconpletely inked or overinked can become illegible in the facsimile, where the quasi-facsimile can be correct; (4) when only a number of incomplete title-pages is available, it is very difficult to combine these into one facsimile, but easy in a quasi-facsimile. Scme of these difficulties can be overcome by notes added to the reproduction, especially when variant titles have been found. From this it is clear that a trained bibilographer should supervise the photographing.

These reasons are sufficient to add here remarks about the usual methods followed in a quasi-facsimile transcription.

When some border surrounds the title, the quasi-facsicile begins with its descrifticn. Euch a border is ermed a compartment, when originally it consists of one carvea or encraved piece, or, nure pieces but evidently forming part of a single design when assembled, and $a$ jrame in all other cases (Bowcrs, p.141-142). Winere an opening is left for letterpress in the border, this is referred to as a slot, and its contents are described in the regular order, preceded by the indication: "within a slot".

In the description of the letterpress the individual lines are separated by a vertical bar: |. The differences in type sizes of different lines are neglected. The tyre-fonts roman, italics and gothic are indicated or printed as such, if possible, as are capitals and lower case. Small capitals are usually printed as such too. In this thesis they are only slightly smaller; if the first letter of a word in scali capitals is a large capital, this letter has been enlarged for clarity. Srall capitals are incicated only when they are present in the same line with large capitals. I have made one excertion to this rule: when a block of lines is printed in the same size of small caritals, but sore lines by chance do not have large capitals; such a line is also transcribed in small caps. Brcken letters and spacing between letters or lines are ignored; they may incicate variant titles, but even so they are difficult to describe. Tyie crnar:ents are mentioned; woodcuts and engravincs are concisely described; lines or words printed in color are noted. Rules are mentioned with a rough indication of their relative length, e.g. long strelled rule, short wavy rule. I propose the indication full iule for a rule of the sane lencth as the type-page or the longest line with type on the title. ilisprints are given exactly as in the title, followed by the indication "[sic]". Ail interpolated notes and indications other than letterpress are enclosed in square brackets! j.

The running titzes are the short titles at the top of nost pages, usually or the same line as the page number. They vary in different books, sometimes repeating the bcok title in a short =orm, sometines giving chapter title or stating subjects treated on the pages. It is a bibilographical practice to give a description of these running titles, abbreviated RT. If the parts on the left and the corresponding right page differ, they are separated in the description by the vertical line "I". In older books this description has been useful for detecting variants, but I have not yet seen a botanically important use. 


\section{BIBLIOGRAPHICAL FORMAT}

Bibliographically the term format is defined by the number of leaves derived from one original sheet. For the usual formats latin names are international: folio, quarto, ootavo (in the same order 2, 4, and 8 leaves from one sheet). For other types English indications are in use besides the Latin terms: duodeoimo, 12 leaves from one sheet, is indicated as "in twelves", or with a hybrid word "twelvemo". In the bibliographical descriptions in this thesis the format is always indicated by the number of leaves per sheet followed by the degree-8ign: $2^{\circ}, 4^{\circ}, 8^{\circ}$, etc.

The bibliographical format should be distinguished from the division in size classes, for which confusingly the same terms and symbols often are used. The limits of the classes are set arbitrarily; in Rehder's Bradley bibliography they are explicitly stated. The system of other catalogues is uncertain; e.g. in Pritzel's Thesaurus the format $18^{\circ}$ is consistently neglected and usually rendered as $12^{\circ}$. In the book descriptions in this thesis the actual leaf height is stated in the paragraph "Paper". The relation leaf height: leaf width is discussed below.

The format is closely related to the number of leaves per gathering. This word, which has already been mentioned, is used for the set of leaves which are folded together as a unit in binding. In English the word "signature" often has been used, but this term is better reserved to indicate the symbols with which the first leaves of a gathering are signed. The word "quire" has also been in use, but this can be reserved for a paper quantity. Equivalents of the word "gathering" in other languages are: Bogen (German) and feuille (French), both literally indicating "sheet"; katern (Dutch), quaderno (Italian), cuadernillo (Spanish), derived from the Latin quaternion, meaning a gathering of four pairs of leaves. The leaves of such a pair, united by a fold in the spine, are called to be confugate. Folds uniting leaves at other margins are referred to as bolto. The number of pages, of course, is twice the number of leaves. The individual leaves of a gathering are always indicated by their numerical position in the gathering. Usually they are signed this way at the front side, or recto. The first leaf has the signature "A", meaning "A,"; the second leaf "A,". Other leaves are not always signed. In olaer books signatures were placed on the half of all leaves of a gathering plus one; later the signatures were restricted to two leaves and still later to only one leaf. In the formats $12^{\circ}$ and $18^{\circ}$, and the smaller ones related to these, cut parts of the sheets were usually signed separately In such gatherings of six leaves, leaves 3 and 4 consist of such an inlaid part. Its leaf 3 bears a special signature, even if leaf 2 is unsigned. It can be an asterisk, or it can be the indication "A2" obviously meaning the second part of gathering A. In this case the bibliographic indication of the leaf remains $A_{3}$ notwithstanding the signature. Conjugate leaves are indicated by the individual leaf numbers united by a period: $A_{1,12} A_{2,11} A_{3.10}$ etc. In a normal gathering the sum of these leaf numbers is the total number of leaves in the gathering plus one.

I will use the ampersand, "8", to indicate bolted leaves, usually those with the original fold at the top sides of the leaves. Copies with these bolts still intact are referred to as unopened copies in bibliography. In such copies the format is easily determined. Cancellantia are recognized at once, either by their place with the gathering as printed or by the removal of the canceilanda and the resulting torn edges. An opened copy is called an unout oopy when the deckle-edges and torn edges have not been cut off; a neatly trimmed copy (cut with a paper cutting machine) is a out oopy. I use the term olightly trimmed oopy when some trimming was done, especially at the bottom, where too far protruding margins were removed, but where in the main the deckle-edges or torn edges are still visible. In such cases the bolts can be reconstructed by matching the irregularities of their torn edges. In cut copies the chainlines and the watermarks can be compared, and, if absent, irregularities in the paper could be used to determine the original bolts.

A gathering can consist of two or more sheets folded together, quired. This is usual in older books of folio format. It is not frequent in quarto and extremely rare in octavo (the only example I 8 aw up to now in $8^{\circ}$ was the general index of vol.64 of the periodical Biblioteoa Italiana, with $2 \frac{1}{2}$ quired sheets). Quiring allows the binder to work faster; moreover it results in stronger binding. However, it becomes more difficult to stitch a high number of folds and for smaller formats guiring is impractical. Quiring can be recognized by the deckle-edges, matching chain-lines and watermarks, or irregularities. 
On the other hand a gathering can consist of a partial sheet. Occasionally some gatherings do not represent full sheets, especially the first and last gatherings. If in an octavo book the text plus index only needed a gathering of six leaves at the end, the remaining pair often was used for the preliminaries, the title and the preface, or a half-titie and the title. In this case the bound book begins with a gathering of two leaves and ends with a gathering of six leaves.

Special impositions result in books in which all gatherings consist of partial sheets. An example is half-sheet imposition. The sheets, as explained before, are printed completely, either from one forme on both sides and afterwards separated in two identical half-sheets, or from an outer and an inner forme, separated afterwards into two consecutive gatherings on half-sheets. Both cases result in half the number of leaves per gathering as indicated in the format. In $18^{\circ}$ the sheet may be divided into 3 equal gatherings, each having 6 leaves. In smaller formats quarter-sheets can be used for one gathering, or even smaller parts. It is not enough to take the number of leaves in the first gathering as being representative for the format, since in special types of imposition two unequal gatherings are printed from each sheet. The result is alternating gatherings with different number of leaves. In $12^{\circ}$. gatherings of 8 leaves can regularly alternate with those of 4 , and in $18^{\circ}$, gatherings of 12 with those of 6 leaves.

The regular number of leaves per gathering is indicated after the format: $2^{\circ}$ in 68 (folio in sixes), $18^{\circ}$ in $9 \mathrm{~s}, 18^{\circ}$ in 128 and 68 , etc. The first example indicates folio with 3 quired sheets folded together, the second one $18^{\circ}$ in halfsheets of 9 leaves, and the third one $18^{\circ}$ with unequal gatherings of alternately 12 and 6 leaves.

Normally the leaf height is larger than the leaf width. This is taken for granted in the descriptions. When the opposite is the case, the indication "oblong" is added to the format: Ohviously another imposition scheme is needed for oblong books; Johnson (Typographia, 1824) gives the schemes for quarto and octavo: the chain-lines have another direction than in the usual size with the leaves higher than wide. A special case is the square size, in which height and width do not differ much. Special impositions in $12^{\circ}$ and $24^{\circ}$ give this and can be indicated by this term. Finally unusually narrow leaves can be produced, especially in the formats of the $12^{\circ}-$ family $\left(24^{\circ}, 48^{\circ}\right)$. Normal $12^{\circ}$ is already narrower than normal octavo, but by a special imposition the relation of width to height can be made still smaller, that is, the leaves narrower. These are named by Johnson "long twelves" and "long twenty-fours". I have retained these indications, although "narrow" could have been used too. Rehder's Bradiey bibliography arbitrarily classifies books into the four groups. These are: (1) narrow, width less than $3 / 5$ of the height; (2) normal (without a special indication), width from $3 / 5$ to $3 / 4$ of the height; (3) square, width more than $3 / 4$ of the height but not exceeding it; (4) oblong, width greater than height.

The definition of format, so far, has not led to difficulties. However, there is one problem that has to be mentioned in connection with the key to the formats, though I have not met it in the works treated in this thesis.

It appears that some books, especially in the middle of the eighteenth century, were printed in $4^{\circ}$ imposition, although the chain-lines are vertical and the watermark is at the inner top corners. This is attributed to the use of very large paper, doubling the normal size, and cut into two before printing. According to the definition of format giver, this should be treated as $8^{\circ}$ in 48 . Without doubt the original printer regarded this as a quarto imposition, since from his viewpoint it did not make any difference whether he used this paper or nomal complete sheets. This could be disregarded by bibliographers, since they set it as their task to describe the books as they exist according to their definitions and not to the occasionally loose customary usage. Bowers recommends Greg's formula, indicating the apparent format before that according to strict bibliographical definition: " $\left(4^{\circ}-\right.$ form $^{\circ} 8^{\circ} \mathrm{n}$, treating it as $8^{\circ}$ but indicating the $4^{\circ}$ imposition.

Depending only on the supply of these paper types, the printer might use both types indiscriminately in different gatherings of the same book. It is not very satiofying to say that some latherings are $4^{\circ}$ format, and others $8^{\circ}$, or even that the same gathering was in a part of the edition as $4^{\circ}$ and in another part as $8^{\circ}$, just because some other type of pape:' was used. This, in my opinion, might warrant a redefining of the term bibliographica. format, to avoid this ambiguity. It could be done by excluding half-sheets div ded before printing. This will raise other problems, since, in many cases, it might be extremely difficult to prove how the printing was done. 
Another problem is the format of tables of which the text extends over more than one sheet. I mentioned a Carte botanique by Deshayes, in the Adanson collection (Adanoon 1: 289-290. 1963, $\mathrm{AD} \mathrm{48;}$; in the meantime I ascertained that the author was Pierre Marie Deshayes, indicated as "botaniste, oeardaire-adfoint Arohiviste" of the Societe Linnéenne de Paris: Msm.Soo.Linn.Pario 1: 74.1822). It consists of one unit of text printed over four sheets, giving a large wall table when mounted together. If we consider this mounted unit as one leaf, the format indication would be 1. one sheet giving one fourth leaf. Of course, this is not a regular book and the indication is not necessary, since the term broadsheet with an explanation will suffice. However, the fraction indication has been used in bibliography for something quite different: $\frac{1}{2}$ signified an unfolded half-sheet of printed paper. In my opinion, this indication is not logical here and should be avoided.

General formats are discussed below. Johnson, in his Typographia, London, 1824, published diagrams of a considerable number of imposition schemes destined for the compositor. Hence, these represent the mirror images of the sheet as printed in full, which should be kept in mind when his schemes are studied. It is very helpful to fold pieces of paper according to these schemes. The chain-lines, watermarks, deckle-edges and torn edges can be reconstructed and compared with the actual features of a book of which the format has to be determined. Actually, a bibliographer should have the usual folding types at his fingertips, and should be able to visualize the relative position of their leaves easily.

Broadsheet or broadoide, $1^{\circ}$. Each leaf is formed by a complete sheet without folding. Chain-lines are horizontal. The leaves have to be stitched together through the inner margin. This format was used for posters, and for some plate-books in which the plates had to be stitched anyway.

Folio, $2^{\circ}$. The sheet is folded once parallel to the shorter sides; the chainlines are vertical, the watermark if nomal is in the center of the leaf. Quarto, 48. The sheet is folded twice, the first fold parallel to the shorter sides, the second fold perpendicular to the first one. The chain-lines are vertical; the watermark is in the fold of each conjugate leaf pair.

Sexto. An imposition in 6 leaves seems unlikely. In the normal size, higher than wide, this will result in a set of 4 leaves folded as normal $4^{\circ}$ with $2^{\prime}$ leaves not conjugate with any other. I actually saw a journal folded in this way, but I think it more likely that it is the result of the imposition called "long twelves" by Johnson, in half-sheet imposition (see p.4). In an oblong format, however, $6^{\circ}$ would be quite possible and produce a gathering with 6 leaves in conjugate pairs. I have not seen any mention of this format except in Labarre, Diotionary and enoyoiopaedia of paper and paper-making, ed.2, $1952, \mathrm{P}, 245,109$, as a format without much information, and p.239, where after the correct definition ". aheet of paper folded to form a gathering of six leave" is added the confusing remark between parentheses: "(a half sheet of twelves)". For a half-sheet of $12^{\circ}$, the term of course is not correct. If this remark would imply that it is always a half-sheet, the term should be dropped in bibliography. Although the format may not exist, I include it in the key because of the journal referred to, explicitly mentioned on $\mathrm{p} .13$.

octavo, $8^{\circ}$. The usual format for books is achieved by folding the sheet three times, each time parallel to the resulting shorter sides and the part with the bolts at the outer sides of the pages always in the last half. The chain-lines are vertical. The watermark is situated at the upper inner corner of the leaves, often incomplete by trimming. Where leaves with wide margins are present, the position of the watermark may shift to the upper sides of the first 4 leaves of the gathering. The bolts over the top unite leaves $1 \& 4,2 \& 3,5,8$, and 6 , Half-sheet imposition offers

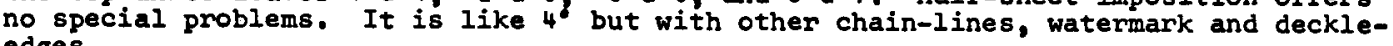
edges.

Duodeaimo, $12^{\circ}$. In its normal form, $12^{\circ}$ consists of the sheet folded firstly parallel to the longer sides. By the next two folds, perpendicular to the first one, the sheet is divided into three equal parts. The next fold is parallel to the first fold. One third is usually cut off; it forms a strip of four leaves. The remaining part resembles octavo in its folds, except for torn edges at the botton sides of the leaves $3,4,5$, and 6 . The strip of 4 leaves is either placed in the middle of the larger part, or treated as an independent gathering following the other part (regular alternation of 88 and 48). Johnson, Typographia 2, imposition 13,8 , ges also a scheme for "twelves without cutting", in which the strip of 4 leaves which is cut off in the usual method, is folded inwards instead. Nevertheless, this type seems to have 
come into general usage only much later. I guess that this was after the large-scale use of machine-made paper, since it involves an unfolded border of the paper at the top of the strip of 4 leaves. With deckle-edges this is very unsatisfactory; it was a general usage to have a folded or straight cut border at the top of the leaves to provide equal margins from top to text, even in uncut copies. The straight cuts between "sheets" of machine-made paper will have made this possible for the inward folding too. (This will apply to other types without cutting in the $12^{\circ}$ family of formats also,) Normal half-sheet imposition produced gatherings of 6 leaves, 4 folded as quarto and the remaining 2 either folded and laid in the middle of these, or folded inwards without cutting (two different schemes in Johnson, *125). These impositions all result in leaves which are usually narrower than those of comparable octavo inposition, which gives the bibliographer already an external impression of $12^{\circ}$. However, $8^{\circ}$ with very broad margins and heavily trimmed, can give exactly the same size. A more reliable criterion is found in the chain-lines, which are horizontal in all $1^{\circ}$ impositions mentioned up to now; the watermarks will be found in the upper half of the outer margins of the leaves 7 and 8 , and 11 and 12 . (This does not apply to imposition without cutting, which as explained is to be expected in wove paper only, or half-sheet imposition, for which see the key.)

An unusual type of $12^{\circ}$ imposition is called by Johnson "long twelves" (Johnson, *18-19). Here again the first fold is parallel to the long sides, but now the five other folds are perpendicular to this first one. Two of these five folds again divide the sheet into three parts. The remaining three folds are parallel to the two just mentioned; they could be folded together, and divide these parts into two. This produces a much higher leaf, in fact, if from the same sheet size, comparable to quarto, but much narrower. The chain-lines are vertical; the watermark will appear over the top bolts of two sets of leaves. The actual scheme given by Johnson produces after opening two unequal gatherings, the first of 8 , the second of 4 leaves, only identified as belonging together by one signature. Other methods of imposition for this type can be imagined. The 6 pairs of conjugate leaves could be folded in each other, by which the watermark would come in other pairs of leaves. A strange format is present in the Scandinavian short-lived journal Linnsoka Samfundets Bandingar for An 1832 which $I$ interpret as long $12^{\circ}$ in half-sheets. The unusual feature is that the gatherings of 6 leaves have the last two leaves not conjugate with any other. Chain-iines are absent in the wove paper, and I have only seen a cut copy by the kindness of my colleague of the Hunt Botanical Library, Irs. N.E. Smith.

I saw another unusual type of $12^{\circ}$. not mentioned bv Johnson: Dierbach. Flora Beidelbergensis. I explain it as follows: the first fold is parallel to the short sides of the sheet; the next two folds are perpendicular to the first one, dividing the sheet into three equal parts; and the last folds, parallel to the first fold, result in nearly square leaves. The third part probably was cut off; I did not check the possibility of an imposition without cutting. I will refer to this type as "square $12^{\circ}$ ". Its chain-lines are vertical (kindly rechecked for me by my colleague Mr. D. Kalk).

Sexto-decimo, $16^{\circ}$, is octavo folded once more, which will give bolts over the bottom sides of the leaves. This will necessitate trimming at this side, to make opening possible. Easier is half-sheet imposition, giving half-sheets folded the same way as normal octavo. The chain-lines are horizontal in both cases.

octo-deoimo, $18^{\circ}$, is a type neglected in handbooks of descriptive bibliography, though clearly described by Johnson. A usual form is imposition in 3 gatherings of 6 leaves, either separately signed, or the second and third identified by the addition of one or two asterisks. Some cases can be recognized by the direction line, having the book title only in the first leaf of each group of 3 gatherings. It is produced after printing by first cutting the sheet in three equal parts parallel to the short sides, and treating these as normal $1^{\circ}$ half-sheets (see Margadant, Buntia 2: 164-169. 1965). Less frequent are imposition in two unequal gatherings, in 128 and 68 , and full-sheet imposition in 18s. Unusual, but not difficult to identify, is half-sheet imposition, giving 9 leaves per gathering. This shows that bibliographers cannot dogmatically follow the rule that gatherings consist of an even number of leaves. The other peculiar feature here is, that the forme has to be changed between printing the blank sheet and the other side: four type-pages have to be interchanged, "transposed", to achieve the correct half-sheets. Very difficult to differentiate from $8^{\circ}$ is the other type of half-sheet imposition in which one leaf is discarded per half-sheet, giving 8 leaves, of which only 1.2 and 7.8 originally were bolted over the top. 
All these $1^{\circ}$ types have vertical chain-lines, as has octavo. The place of the watermark is a good criterion, being in the middle of a leaf. Uncut copies are helpful, though the complete mapping out of a sheet requires time. A printing "out of register", that is: the recto and verso printing not completely matching but slightly askew, helped in a particular case to indicate the format. The bibliographer should have an eye open for these sorts of things, where other indications are scarce.

Vicesimo-quarto, $24^{\circ}$. This is a duodecimo once more folded, or better, cut. It is usually done in half-sheets, giving 12. leaves per gathering. Johnson did nct report any imposition for 24 leaves per gathering. Probably the practical limits of folding paper repeatedly, and sewing through too many leaves, had been reached. His first scheme is a regular half-sheet, resulting in the watermark extending from the middle of the outer margin of leaves 9 and 10 , at random. His last scheme represents the same, but without cutting, which will, as explained under $12^{\circ}$, be found on wove paper only. Fis second schene represents a full sheet with two signatures, which would give the watermark at the same places as in the first manner, but each pair of odd and even numbered gatherings displaying watermark and countermark (provided the half-sheets were not mixed after cutting). The chain-lines in these schemes are vertical. The third scheme is again a regular half-sheet imposition, similar in size to the one under $12^{\circ}$ as "square". Johnson names it "A Half sheet of Twenty-fours, the sixteen-way", possibly because the leaf-height is the same as that of $16^{\circ}$ of the same sheet size and the imposition resembles that of $16^{\circ}$ in $8 \mathrm{~s}$, with a set of 4 extra leaves to be laid in the middle of the gathering, and which is folded as quarto. A part of the watermark and of the countermark would extend from the middle of the bottom of the leaves 9 and 10 . The chain-lines are vertical also, as the square $12^{\circ}$, leaving the place of the watermark as the distinguishing criterion. A fourth type, also with vertical chain-lines, given by Johnson, has a regular half-sheet imposition with two unequal gatherings, one of 8 and one of 4 leaves, comparable to the same type in $12^{\circ}$. the 4 consisting of a row of leaves. Its watemark will extend from the middle of the outer margins of leaves 5 and 6 , of course from the first gathering of each group of 2 . A half-sheet imposition not given by Johnson is $24^{\circ}$ in 68 , with vertical chainlines. Its possibility is a challenge for the bibliographer, because of its resemblance to $18^{\circ}$ in 68 , which would have (from the same sheet size) the same leaf size and also vertical chain-lines. The narrower leaf in $24^{\circ}$ is an indication, but could also be achieved by broad margins in $18^{\circ}$ and strong trimming. Without watermarks and deckle-edges these impositions would be virtually indistinguishable.

The last type of $24^{\circ}$ to be discussed is the "Half sheet of Long Twenty-fours" of Johnson. Here the chain-lines are horizontal, the leaf height will be the same as that of $8^{\circ}$ from the same sheet size, so that it could easily be taken for $12^{\circ}$. In the exact imposition as given by Johnson, the sheets will be divided in two unequal gathen ings of conjugate leaves, though with only one signature, one with 8 and the other with 4 leaves, which would be an indication. Still, by a rather unimportant change in the imposition, the second set of 4 leaves can be laid in as the middle of a gathering of 12 conjugate leaves. The major difference with nomal $12^{\circ}$ will be that this set of 4 is folded as quarto, while the 4 laid in the middle or making the second gathering in normal $12^{\circ}$ consist of 4 leaves in a row. A bibliographer aware of this problem will usually find some irregularity in the paper to match the leaves which had been together before trimming, if the nommal criteria cannot be checked.

Trigesimo-duo, $32^{\circ}$. This format has 32 leaves per sheet. Johnson's scheme implies that this number actually has been used for gatherings. If so, I suppose it will have been cut the first time instead of folded, since too much repeated folding will give irregularities at the comers and will destroy the regularity af the typepages when trimmed. Most likely the printers preferred half-sheet imposition, with 16 leaves per gathering, or quarter-sheets with 8 . The chain-lines will always be vertical; the watermark will extend from the outer bottom corner of 4 leaves.

Johnson also gives schemes for the following formats, which need not be discussed in detail: $20^{\circ}$ in $108,36^{\circ}$ in 188 or $128,40^{\circ}$ in $208,48^{\circ}$ in 128 or in 88 and 48 , $64^{\circ}$ in 328 (see remark under $32^{\circ}$ ), 168 or $88,72^{\circ}$ in $128,96^{\circ}$ in $88^{\circ} 128^{\circ}$ in 88 . To quote Johnson ( $\mathrm{p} .9$ ): "chemes of various other irregular izes might have been introduced, but they could anawer no other purpose than that of pleasing the fancy, by exhibiting the poseibility of folding sheet of paper into co many different forme." This is just what we could express in interpreting the Dutch proverb: "paper is patient". as: it can be folded in many and odd ways. 


\section{KEY TO BIBLIOGRAPHICAL FORYATS}

Determining the format from internal evidence is not difficult for the normal impositions. For unusual formats and impositions it is rather complicated. I prepared a key similar to keys for taxonomic groups in biology to have a guide. The key is primarily based on the imposition schemes published by Johnson: Typographia.... vol.2: 145-190, 1824. I added a few variants which I saw and some other schemes which would be a problem for the bibliographer. Nevertheless the key is not sufficient for all books. I excluded oblong formats (oblong $4^{\circ}$, oblong $6^{\circ}$, etc.), since I do not expect difficulties in their identification. The direction of the chain-lines and the places of the watermarks differ from those in the normal impositions of the same formats. The variant impositions in the $12^{\circ}$-family indicated by Johnson as "without cutting" are excluded too, since I suppose them to occur mainly in machine-made paper.

The key is prepared for books with laid paper which has normal chain-lines and watermarks as well as countermarks, each in the center of a half-sheet. If a countermark is absent, the number of leaves mentioned in the key will have to be divided by 2 . The user of the key should be aware of unusual places of the watermark, e.g. in the center of a full sheet. An abnormal place of the watermark in the book leaves can be caused by the use of small type-pages, where large outer margins of the sheet are left blank. This is mentioned explicitly under $8^{\circ}$ in the key; it might also explain other cases. Small watermarks can easily be overlooked (single letters in the folds of $4^{\circ}$ leaves), or may have disappeared in cut copies (line of words in top bolt of $8^{\circ}$ leaves) On the other hand the watermark may have a considerable size, e.g. several lines with long words, or a large figure. In the smaller formats such marks will occupy more leaves than are mentioned in the key, in which the place of the center of the watermark is meant. Its position is stated in brief terms, e.g. "outer leaf top" means the outer top corner of the leaf, "middle of 2 leaf bottoms" means the middle of the lower border (bottom) of two leaves, and "in fold of leaf pair" means in the fold of a conjugate pair of leaves.

Deckle-edges should be checked in uncut copies. Slightly trimmed copies will show many torn edges and traces of deckle-edges, which may be enough to conclude the position of all deckle-edges. If deckle-edges are cut off the chain-lines may help in locating some sheet borders. In some papers the two pairs of chain-lines near each outer border of the sheet have a smaller distance between each other than the majority of the chain-lines. For brevity deckle-edges at the several borders of a leaf will be called "top deckle-edges", "outer deckle-edges" and "bottom deckle-edges".

Leaves which occupied a corner position in the sheet show outer deckle-edges and either bottom decikle-edges or top deckle-edges. In these "corner-leaves", bottom deckle-edges are normaliy present, top deckle-edges only in unusual impositions, e.g. in those of the $12^{\circ}-$ family "without cutting". Four corner-leaves indicate a full' sheet.

It is a rule, agreeing with an explicit imposing instruction stated by Johnson, that the first ieaf from a sheet is a corner-leaf; that is the first leaf of the first gathering of a set printed from a full sheet. The first leaves of other gatherings of the same set are not necessarily corner-leaves, and the sets should be grouped correctly, containing four corner-leaves. As an example, the imposition of $18^{\circ}$ in 68 has sets of 3 gatherings from 1 sheet; the 2nd gathering of the set does not have any corner-leaves and in the 3rd gathering the corner-leaf is usually leaf 2 , but in a variant it would be leaf 1; in that case this gathering should not be taken as the first one of a set. The text, as a rule, begins with the first gathering of a set; occasionally the title or other preliminaries mark this beginning.

In sets of unequal gatherings the first of each pair is called the "large gathering" "having more leaves than the second or "small gathering".

Wove paper books can be determined with the help of the deckle-edges and torn edges in uncut copies. In the case of cut copies they are difficult to determine from internal evidence. A watermark, if present, is usually placed along the long border of the sheet, especially in the left half-sheet or the left quarter-sheet, coming in the fold of two conjugate leaves or in one leaf of the first half of a gathering of $8^{\circ}$. other pecularities may be of help; in a case of $18^{\circ}$ in $6 \mathrm{~s}$ the direction-line of every first leaf of sets of tiree gatherings had a volume indication which was not present in the other gatherings of the same set.

Johnson numbered $t$ ie figures with the imposition schemes (which, as stated before, were given for the compssitor and represent a mirror image of the printed sheet) This number, without its asterisk, is mentioned in the key, preceded by the abbreviation "JT"; the words "top" II "botcom" refer to the place of the scheme in the figure. The abbreviation "im" means either watermark or countermark, since they will show at random. The word gathering is abbreviated to "gath." plural "gaths." in the key. 
A Quired sheets present (check deckle-edges, chains and wm to determine full sheets); if so, the format is found by counting the number of leaves per sheet.

$A^{n} \quad$ No quired sheets (at most one sheet per gathering) $\rightarrow$ B

$\begin{array}{llll}\text { B } 1 & \text { Only single leaves present } & + \\ \text { B } 2 & \text { Two leaves per gathering } & + \\ \text { B } 4 & \text { Four leaves per gathering }\end{array}$

B 4/1/1 Gatherings of four leaves followed by two single leaves (possibly two single leaves laid in the middle of the four) $\rightarrow$ F

B 6 Six leaves per gathering $\rightarrow G$

B 6/4 Gatherings of $\mathrm{six}$ leaves and of four leaves regularly alternating $\rightarrow \mathrm{J}$

B 8 Eight leaves per gathering $\rightarrow \mathrm{K}$

B 8/4 Gatherings of eight leaves and of four leaves regularly alternating $\rightarrow R$

B 9 Nine leaves per gathering $\rightarrow Y$

B 10 Ten leaves per gathering $\rightarrow Z$

B 12 Twelve leaves per gathering $\rightarrow$ AA

B 12/6 Gatherings of twelve leaves and of six leaves regularly alternating $\rightarrow$ II

B 16 Sixteen leaves per gathering $\rightarrow J J$

B 18 Eighteen leaves per gathering $\rightarrow$ LL

B 20 Twenty leaves per gathering $\rightarrow$ M

B 32 Thirty-two leaves per gathering $+\mathrm{NN}$

only eingle leaves present

cl Chains horizontal

full sheets with both wm and countermark present; $\quad$ Broadsheet, plano, $1^{\circ}$

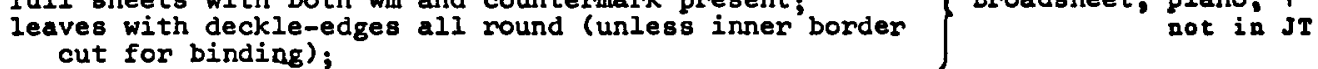

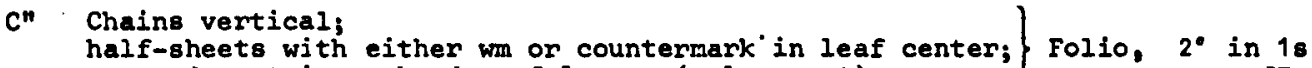
torn edge at inner border of leaves (unless cut); compare JT 1 top

Theoretically other formate might occur with oingle leaves;

they should be recognized by the place of chains, wm, and deckle-edges.

\section{Two leaves per gathering}

D' Chains horizontal;

wm in middle of fold of conjugate leaves; top borders of leaves with tom edges;

Dn Chains vertical;

wh in center of each leaf;

deckle-edges at 3 borders of each leaf;

An unusull folding of $8^{\circ}$ wes observed with consecutive pairs

of conjugate leaves, which would key out here except for the

watermark and the deckle-edges bee Buntia 28 163.1965. 


\section{Four Leaves per gathering}

E Chains horizontal;

wm in middle of fold of conjugate leaves;

all leaves corner-leaves;

En Chains vertical;

Wm in inner top corners of all leaves (if wide sheet margins are not used for letterpress, wm may shift to top borders of leaves 1 and 2 );

2 corner-leaves per gathering;

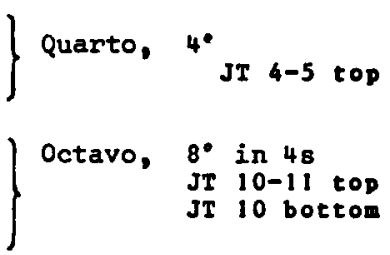

Gatherings of four leaves followed by two oingle leaves (posibly two single leaves laid in the middle of the four) unpractical impositions for book-binding: ve discussion on p.l2.

$F^{\prime}$ Chains horizontal; Wh in center of leaves 3 and 4 ; 4 corner-leaves: 1 and 2 , and the two single leaves;

F" Chains vertical;

wm in middle of top border of leaves 3 and 4;

2 corner-leaves: 1 and 2 only;

Sexto could exist with vertical chains and wm in inner

half of top border of leaves 1,2 and the 2 loose leeves;

corner-leaves as in "long exto"; leaf form nearly iquare.

size Laves per gathering

G' Chains horizontal

$\mathrm{H}^{\prime}$ Wm in middle of upper half of 2 outer leaf borders; $\}$ Duodecimo, $12^{\circ}$ in 68 2 comer-leaves per gath.

$\mathrm{H}^{\prime \prime} \quad$ Wm in middle of 1 outer leaf border in each 2 nd gath. $48^{\circ}$ in 68 not in $\mathrm{J}$ 2 corner-leaves in sets of 4 gaths. (half-sheets);

G" Chains vertical

I' Sets of 3 gaths. per sheet;

wm in center of 1 leaf in $18 t$ and of 1 in 3 rd gath.; $\quad 18^{\circ}$ in 68

bottom deckle-edges in 4 leaves per gath.;

JT 26-27 bottom

In Sets of 4 gaths. per sheet;

wm in middle of 4 leaf bottoms per set (in variants $24^{\circ}$ in 68

in middle of 2 leaf tops);

4 corner-leaves in 4 gaths.;

not in JT

Gatherings of ix leaves and of four leaves regularly alternating

$J$ Chains horizontal;

1 corner-leaf per gath.;

leaf form nearly square; 


\section{Bight leaves per gathering}

$K^{\prime}$ Chains horizontal

L' Wm in 4 outer leaf tops per gath.;

2 corner-leaves per gath.;

$L^{n} \quad$ Wm in another position;

at most each gath. with 1 corner-leaf;

11" Sets of 3 gaths. per half-sheet;

wm in both $18 t$ and in 3 rd gath. in middle of 1 outer leaf border;

2nd gath. without botton deckle-edges at all and with only 2 outer deckle-edges; 1 corner-leaf in 1 st gath. and 1 in 3 rd gath.;

$M^{n}$ Sets of 4 gaths. per half-sheet; wm in outer bottom corner of 1 leaf per gath.;
2 corner-leaves per 4 gaths.;

K" Chains vertical

$N^{\prime}$ Top bolts in 2 leaf pairs;

wm in center cf 1 leaf;

2 corner-leaves per gath.;

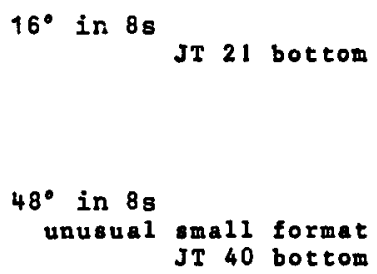

$18^{\circ}$ in 88 unusual imposition JT 23 top

N" All 4 leaf pairs united by top bolts ( 1 \& 4, 2\&3, etc.); wm not in leaf center

$0^{\prime}$ Wm in inner top corner of all leaves (if wide sheet margins are not used for letterpress, wh may shift to top borders of leaves (1-4);

bottom deckle-edge in each leaf;

4 corner-leaves per gath.;

Octavo, $8^{\circ}$

very common format JT $8-9$ top

on Wm in some leaf bottoms;

bottom deckle-edges in at most 4 leaves per gath.

p' Sets of 4 gaths. per sheet;

wm in 2 outer leaf bottoms per gath.;

bottom deckle-edges in 4 leaves per gath.;

P" Sets of more than 4 gaths. per sheet;

wm center not in each gath.;

corner-leaves not in each gath.;

Q' Sets of 6 gaths, per half-sheet; wm in 2 gaths. per set, low in fold of 1 leaf pair;

2 corner-leaves per 6 gaths.;

Q" Sets of 8 gaths. per half-sheet; wm in 2 gaths. per 4, in 1 outer leaf bottom;

2 comer-leaves per 8 gaths.; $32^{\circ}$ in 88

JT 34-35 bottom

JT 36 top 


\section{Gatherings of eight leaves and of four leaves regularly alternating} (occasionaliy signed as ore group of 12 leaves)

$R^{*}$ Chains horizontal

S' Small gaths, folded as $4^{\circ}$ with 2 top bolts;
wm at inner top corner of 4 leaves in large gaths.; 1 corner-leaf per gath.;

Johnoon indicates JT 32 top as "Long 24" " but I find no size

difference with JT 31 top. "Twenty-foura." the Sixteen-way";

the main difference is that large gaths. are folded in con-

cecutive pair and not in $8^{\circ}$ a in the latter and ite variant.

sn Small gaths. folded from strip of 4 leaves with 1 outer bolt

T' Wm in middle of folds of 2 leaf pairs in

large gaths.;

2 corner-leaves per gath.;

$\left\{12^{\circ}\right.$ in 88 and 48 JT 16

T" Wm along outer border of some leaves

$U$ ' Wm in middle of upper half of 1 outer leaf border per gath.; hottom deckle-edges in 4 léaves per gath.; 1 corner-leaf per gath.; leaf form very narrow in relation to height;

$24^{\circ}$ in 88 and 48 varient of JT 32 in other direction

$u^{n}$ Wm in middle of 1 outer leaf border in large gaths.; bottom deckle-edges in 4 leaves of large gaths. only;

1 corner-leaf in large gaths. only;

leaf form not very narrow;

Chains vertical

$V$. Leaf form square or nearly square

$W^{\prime}$ Wm in middle of fold of 2 leaf pairs in large gaths.;

small gaths. folded from strip of 4 leaves with 1 outer bolt;

2 corner-leaves in each gath.;

$W^{\prime \prime} \quad$ Wn in middle of 1 leaf bottom per gath.; small gaths. folded as $4^{\circ}$ with 2 top bolts; 1 corner-leaf per gath.;

$V^{\prime \prime}$ Leaf form clearly rectangular

$X^{\prime}$ Wm in midale of 2 leaf tops per gath.; small gaths, folded as $4^{\circ}$ with 2 top bolts; 2 corner-leaves per gath.;

$48^{\circ}$ in 88 and 48 JT 39 top unueual small formet

In the actual imposition as given by Johnson one set of large and small gatha. is signed witb 1 signeture; the 8 leaves of large gatho. are folded with topa united consecutively; folding as $8^{\circ}$ instead is possible, though not likely.

$X^{\prime \prime}$ Wm in middle of 2 outer leaf borders in large gaths.;

gmall gaths. folded from strip of 4 leaves with 1 outer bolt; 1 corner-leaf per gath.; 

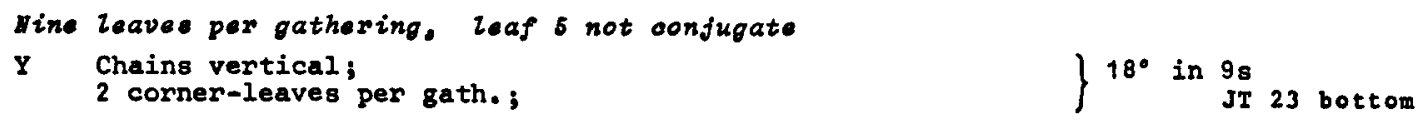

\section{Ten leaves per gathering}

Z Chains horizontal;

2 corner-leaves per gath.;

leaf form nearly square;

$\left\{\begin{array}{r}20^{\circ} \text { in } 108 \\ \text { variant of } \\ \text { JT } 28 \text { bottom }\end{array}\right.$

\section{Twelve zeave per gathering}

$A A^{\prime}$ Chains horizontal

$\mathrm{BB}^{\prime}$ Leaves $5^{-8}$ folded as $4^{\circ}$ with 2 top bolts;

$\mathrm{wm}$ at top of folds of 2 leaf pairs per gath.;

2 corner-leaves per gath.;

$\int 24^{\circ}$ in $12 \mathrm{~s}$ JT 31 top

$A$ variant of JT 32 top, "Long 24"n, will give the eame leaf ire

with top bolte in conecutive leaf paira compare note to $S^{\prime}$.

$\mathrm{BB}^{\prime \prime}$ Leaves 5-8 folded from strip of 4 leaves with 1 outer bolt

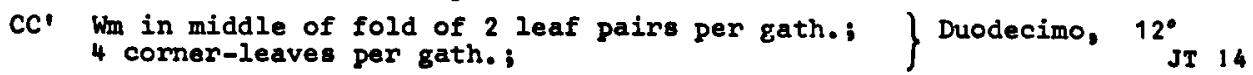

CC" him along outer border

DD 1 gath. per half-sheet;

wm in middle of upper half of 2 outer leaf borders;

2 corner-leaves per gath.;

leaf form very narrow in relation to height;

$24^{\circ}$ in 128

variant of

JT 30 bottom

DD" Sets of 2 gaths. per half-sheet;

wm in middle of 1 outer leaf border per gath $48^{\circ}$ in 128

1 corner-leaf per gath.;

AAn $^{n}$ Chains vertical

leaf form not very narrow;

JT 39 botton

$E E$ ' Leaf form 'square or nearly square

FF' Wm in middle of fold of 2 leaf pairs per gath. 1

leaves $5-8$ folded from strip of 4 leaves with 1 outer bolt;

4 comer-leaves per gath.;

FF" Wh in middle of 2 leaf bottoms per gath.; leaves $5-8$ folded as $4^{\circ}$ with 2 top bolts;

2 corner-leaves per gath.;

$E E^{\prime \prime}$ Leaf form clearly rectangular

GG' Wm in middle of 4 leaf tops per gath.;

leaves 5-8 folded as $4^{\circ}$ with 2 top bolts;

4 corner-leaves per gath.;

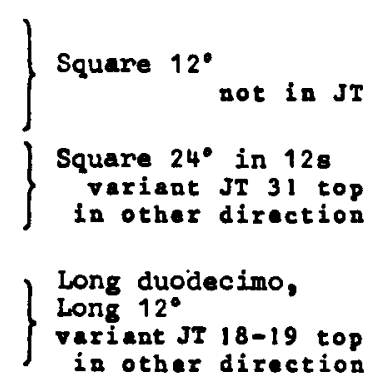

GGn Wm in outer or bottom border of 2 leaves per gath. or less; leaves 5-8 folded from strip of 4 leaves with 1 outer bolt

HH' 1 gath. per half-sheet; 2 corner-leaves per gath.;

$H^{n}$ Sets of 3 gaths, per half-sheet; wm in in 1 st and $3 r d$ gath. low in fold of leaf pair (variant: high in fold); 1 corner-leaf in $1 \mathrm{at}$ and in $3 r d$ gath. each;

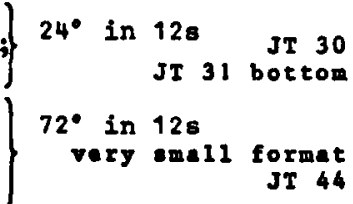


Gatherings of twelve leaves and of ois leaves regularly alternating

II' Chains horizontal;

wa in middle of fold of 1 leaf pair in large gaths.;

2 corner-leaves in large gaths. only;

II" Chains vertical;

Wn in center of 1 leaf per gath.;

2 corner-leaves per gath.;

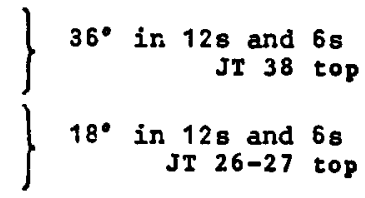

\section{sixteen leaves per gathering}

JJ' Chains horizontal

KK' 1 gath, per sheet;

wm in outer top corners of leaves 9m-16;

4 corner-leaves per gath.;

KK" 2 gaths, per half-sheet;

wm in 2 outer leaf bottoms;

1 corner-leaf per gath.;

JJ" Chains vertical;

1 gath. per half-sheet;

wrm in 4 outer leaf bottoms per gath.;

2 corner-leaves per gath,;

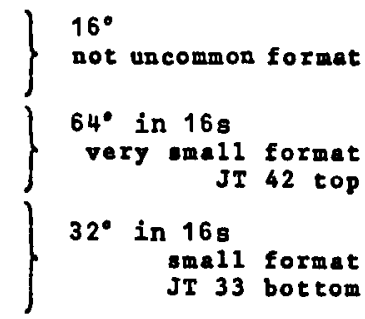

\section{Bighteen leaves per gathering}

LI' Chains horizontal;

2 saths, per sheet;

wm in middle of fold of 1 leaf pair per gath.;

2 corner-leaves per gath.;

LL" Chains vertical;

1 gath. per sheet;

$\mathrm{wm}$ in center of 2 leaves;

4 corner-leaves per gath.;

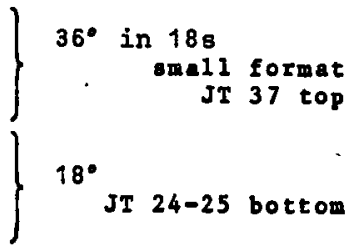

\section{Twenty Zeaves per gathering}

MM' Leaf form nearly square;

chains horizontal;

wm in upper or lower quarter of 4 outer leaf borders;

4 corner-leaves per gath.;

MM" Leaf form rectangular;

chains vertical;

Wm in middie of 2 outer leaf borders per gath.;

2 corner-leaves per gath.;

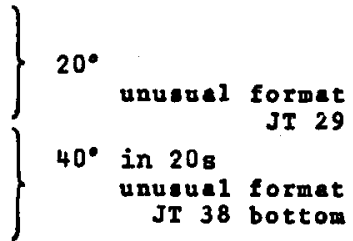

Thi $40^{\circ}$ impoeition given by Johnoon allowe variant with the

heet in the other direction cheins horizontel, leaf form

nerrower, wm in upper or lower outer leaf borders, 2 per gath.

Thirty-two leaves pex gathering, very unusual impositions, probably not prectical

NN' Chains horizontal;

wm in 4 outer leaf bottoms per gath.;

2 corner-leaves per gath.;

$64^{\circ}$ in 328 JT 43

NN" Chains vertical;

wm in 8 outer leaf bottoms per gath.;

$32^{\circ}$

4 corner-leaves per gath.; 
9.

THE COLLATIONAL FORTULA

The collational formula is, as it were, the heart of the bibliographical description. It gives the physical structure of the book, that is the number of gatherings and their number of leaves, in a condensed form.

The collational formula is based on the signatures printed in the book (letters, numerals, or typographical signs such as asterisks etc.) An unambiguous signature is assigned to unsigned gatherings or to those which repeat a signature already used in the book.

The number of leaves covered by one signature is indicated by a superscript after the signature: $A^{4}$ means a gathering of 4 leaves signed $A$, and $B^{6}$ one of 6 leaves signed $B$. In the formula groups of gatherings with equal numbers of leaves are united in one block: $1-20^{8}$ means a book with 20 gatherings of 8 leaves each; its total number of leaves is 160 and of pages 320 .

If letters are used, the roman alphabet used by the printers is taken for granted: either $I$ or $J$, and either $U$ or $V$, and no $W$. This alphabet, therefore, has 23 letters, and the formula $A-Z^{8}$ means a book with 23 gatherings of 8 leaves. Whenever more than 23 letters are present in the alphabet of the signatures, this should be stated explicitly: $\mathrm{A}-\mathrm{U}^{8} \mathrm{~V}^{8} \mathrm{~W}-\mathrm{Z}^{8}$. Title-pages and half-titles are, as a rule, unsigned, so that this is taken for granted.

A gathering only signed on its third leaf on its 3 rd leaf is still considered a signed gathering. Unsigned gatherings are those which do not have a signature on any leaf. When unsigned gatherings occupy corresponding gaps in the normal sequence of signatures, the missing signatures are used as inferred signatures. These are always printed in italics (underlined in type-script) in the collational formula: $A^{8} B-F^{B} G-K^{8} L-Y^{8} Z^{8}$, where gatherings $A, G, H, I, K$ and $Z$ are unsigned.

When a book consists of more than 23 gatherings signed with letters, usually a second alphabet is used with double letters: Aa-zz; is this not sufficient, a third alphabet follows: Aaa-zzz, and so on. Instead of repeating the letters, the later alphabets can have a number before the letter: $2 \mathrm{~A}-2 \mathrm{Z}, 3 \mathrm{~A}-3 \mathrm{Z}$, etc. In the collational formula these later alphabets are referred to in the last manner, since it is clear and short. The signing with two or more capitals, AA or AAA, is also treated as equivalent, but the signatures all consisting of lower-case letters, aa or aaa, are noted as the lower-case letter with the numeral: $2 a, 3 a$, etc. So the formula $A-3 Z^{2}$ implies a book of $3 \times 23=69$ gatherings of 2 leaves. If the first alphabet is not completed, it should be stated as far as it goes: A-V ${ }^{8} 2 A-2 G^{8}$ describes a book with 20 gatherings signes $\mathrm{A}-\mathrm{V}$ and 7 gatherings signed $2 \mathrm{~A}-2 \mathrm{G}$. (Bowers omits the 2 before the $G$ of the second alphabet, but $I$ prefer to maintain it to avoid confusion)

A second alphabet or a second numbered series may be present, repeating exactly the first series in the same volume. This has to be identified in the bibliographical treatment, so that each individual gathering has an unambiguous signature in the collational formula This is realized by adding a superscript before the signature quoted: leaves. More alphabets or series are treated in the same way.

When gatherings are signed by conventional typographical signs, such as asterisks, daggers, these are given as such in the collational formula. Sometimes, in my opinion, it is convenient to place these signs between quotation-marks: ") (" since parentheses and especially square brackets are very confusing without a special indication that they are quoted. Italicizing to indicate inferred signatures of some of these marks is rather difficult; an italic asterisk, e.t., is not feasible. In such cases the sign should be placed between square brackets, indicating, as usual in bibliography, that it was not actually printed. When the signatures are in fact printed between parentheses or brackets, these are omitted in the description unless they identify another alphabet in the book.

Unsigned gatherings and leaves, which cannot be assigned inferred signatures, are referred to by Greek letters, $\pi$ (pi) concerning preliminaries (the title-page, dedication, and preface) and $x$ (chi) when it concerns other matter. A usual collation is: $\pi^{4} A-x^{8} x^{1}$. If only one leaf is present, these symbols form an exception to the general rule that the gatherings are treated in terms of pairs of con jugate leaves, or, in other words, that the superscript is always an even number. Many bibliographers do not treat the 1 as a superscript in this case, but I prefer the same treatment throughout the collational formula. If several gatherings of this type are present, they are distinguished by additional numbers before the symbol, a superscript is not necessary here: $\pi-4 \pi^{4} A-G^{8} x^{4} \quad H-K^{8} 2 x^{4} L_{-2} 3 x^{1}$. 
An exception for designating unsigned preliminaries as $\pi$ is made when one signature was reserved and actually more were needed. In this case the one inferred signature is taken to apply to the first gathering and a $x$ is assigned to the remaining unsigned preliminary gatherings: $A^{4} \quad x-3 x^{4}$ B-Z ${ }^{4}$ indicates that the main gatherings begin with signature B, and that 4 unsigned gatherings precede it (usualiy all with preliminaries). If the preliminaries happen to have the same signatures as the body of the text, they are identified by a superscript $\pi$ before the symbol: "A-D ${ }^{4} \mathrm{~A}-\mathrm{Z}^{3}$. Signatures used twice in any other place are usually preceded by the superscript $x$. Formerly a number superscript was used for individual repetitions, but these are now reserved for alphabets.

A special notation has been developed for gatherings with regularly alternating numbers of leaves (the several types of imposition with unequal gatherings):

Since the collational formula is meant to express conjugacy, I propose a new notation for books with irregular conjugacy, that is several gatherings covered by one signature. In this notation the superscript is written in 2 or more terms, each indicating a group of conjugate leaves; the sum total of these terms indicates the total number of leaves covered by the signature. Some examples are:

(1) Arrhenius, J.P.: Monographia Ruborum Sueaiae, Upsala, $1840,8^{\circ}$, which I discussed in Euntia 2 162-164, 1965, can be expressed in the formula: $1-52+2+2+2(-3$,$) ;$ (2) Demerson, L.: Calendrier francaio, Paris, $182518^{\circ}$ discussed in Buntia 2 : 165-167. 1965, can have a simple notation: $\pi^{2}+1-86+6+6 \quad 92+6$ ( $\$ 7$ signed $\$ *$, $\$ 13$ signed $\$ *, 9_{3}$ signed $9^{*}$, unsigned $9_{7}$ );

(3) Johnsón's format "Long Twelves" can be written $A-Y^{B+4}$.

When a book has no signatures at all, the bibliographer assigns arabic numerals to all gatherings, which are treated as inferred signatures.

Leaves inserted in gatherings have to be exactly indicated as to place, number. and conjugacy. The usual method is to refer to these leaves with the signature of the foregoing leaf and a figure indicating their number: $A-B^{4} C^{4}\left(C_{3}+2\right)$ D- $Z^{4}$, or, when these two inserted leaves are conjugate, the leaf numbers separated by a period: $A-B^{4} C^{4}\left(C_{3}+1.2\right) \quad D-Z^{4}$. An altemative is indicating these inserts with the symbol $x$ too: $A-B^{4} C^{4}\left(C_{3}+x^{1}, 2 x^{1}\right) \quad D-Z^{4}$, or, for conjugate leaves: $A-B^{4} C^{4}\left(C_{3}+x^{2}\right) D^{2} Z^{4}$. When references are needed, they are indicated as " $C_{3}+1$ " and " $C_{3}+2$ " in the first method, and as " $x$ " and " $2 x$ " (when not conjugate) or " $x_{1}$ " and " $x_{2}$ " (when conjugate) in the latter method. For the identification of the gathering in which the inserts occur, its signature can be added as a superscript: "C $x_{1} "$ and "C $x_{2}$ " In inserts between gatherings, the signature of the foregoing gathering may be used as the identifier. Personally, I definitely prefer the less cumbersome indication $x$ over $\mathrm{C}_{3}+1$ for an insert in a gathering.

Leaves removed from gatherings and disturbing the conjugacy are indicated by minus signs (-), preferably different from the hyphen (-) in the formula. Missing pairs of conjugate leaves are simply indicated in the superscript: $Z^{6}$ in an $8^{\circ}$ book means that 3 conjugate pairs are left in this gathering $z^{8}\left(-z_{7,0}\right)$ means that $z_{1}$ and $z_{2}$ are not conjugate with another leaf. Such incomplete gatherings have to be checked carefully for conjugacy: the fold $l i e s$ between $z_{2}$ and $z_{3}$ in the former case and between $\mathrm{Z}_{4}$ and $\mathrm{Z}_{5}$ in the latter. If one leaf of a gathering has been removed, its place has to be checked too; usually it is the last leaf: $Z^{8}\left(-Z_{8}\right)$, but occasionally another leaf was chosen. If the first leaf is missing, the correct notation is: $z^{8}\left(-z_{1}\right)$. I use the formula $z^{6} x^{1}$ when I do not have definite proof that the last leaf really belonged to the same sheet; the advantage is simplicity with regard to the notation of the individual leaves. In the former notation the leaves actually signed $\mathrm{Z}_{1}$ etc. have to be corrected in $\mathrm{Z}_{2}$ etc.; in the latter one the actual signatures are taken as correct.

Cancels have already been mentioned. The presence of a cancellans is indicated by a plus-minus sign: $A^{4}\left( \pm A_{3}\right)$. In the case of a conjugate pair replaced by another conjugate pair the notation is: $A^{4}\left( \pm A_{2.3}\right)$. More complicated cases should be written in full, $e_{. g}: A^{B}\left(-A_{5,6}+A_{5.6}\right)$, where the two cancellanda are not conjugate but the cancellantia are. A special case is present in Bridel: Bryologia univerea, vol.2: $2 F^{\hat{0}} 2 G^{\hat{\theta}}\left(-2 F_{8}-2 G_{1}+2 G_{1}\right)$. Here the cancellans $2 G_{1}$ replaced two leaves of different gatherings; the pages of the cancellans each received double page-numbers.

The purpose of the collational formula is to give as much information as possible in a condensed fcrm. Nevertheless, bibliographers usually write in full all gatherings which have $c$ missing leaf or a cancel: $\pi^{1} A-C^{4} D^{4}\left( \pm D_{2}\right) E^{4}\left(-E_{4}\right) F-I^{4}$ $K^{4}\left(-K_{4}\right)$. Stevenson simplified this without 1088 of information to: $\pi^{1} A-D^{4}\left( \pm D_{2}\right)$ $E^{4}\left(-E_{4}\right)$. $F-K^{4}\left(-K_{4}\right)$. I shorten this by stating in one block all missing leaves and cancels occurring in each set of gatherings of the same type: $\pi^{2} A-K^{4}\left( \pm D_{2}-E_{4}-K_{4}\right)$ 
This condensed formula gives exactly the same information as the two others. It has been argued that this requires more carefulness on the part of the bibliographer who compares another copy with the collation. A bibliographer has to be careful anyway, and in my opinion this collational formula can be read more easily, since the attention is at once drawn to the deviations and sets of equal gatherings are clearly shown.

Leaves exclusively devoted to engravings, etchings or lithographs are not included in the collational formula, but treated in a special paragraph, since they cannot be printed together with the text. Title-pages in such techniques, however, are included hecause of their importance, but their nature is indicated between brackets. Enrraved tables are also enumerated and described in the paragraph Plates. I include typorraphical tables in the collational formula when they form an integral part of text sheets or a small minority compared with the plates, e.g. Hedwig: Species muscorum. In most other cases typographical tables are treated in the paragraph plates. For woodcuts and engravings on leaves with letterpress see text-figures $(p, 26)$.

For those plate-books in which the leaves of the printed text are identified by the plate numbers only, the lambda treatment was introduced by Alan Stevenson in vol.2 of the Bunt Catalogue. The letter $\lambda$ (lambda) followed by the plate number indicates the text leaves. A superscript after tie plate number (or group of plate numbers) indicates the number of leaves in a gathering with the text to this plate (or group of gatherings each with text to individual plates). So $\lambda 1-40^{2}$ means: text consists of 40 gatherings of 2 leaves, each identified by a consecutive plate number and bearing the text to the plate concerned. This, however, is rarely the case (e.g. in parts of Hooker: Britioh Jungermanniae). Usually the leaves with text to individual plates do not coincide with gatherings. If each plate is accompanied by one leaf of text, no extra indication is needed: $\lambda 1-40$ simply means 40 single leaves, each with text to an individual plate. This does not indicate the conjugacy of the leaves, the structure of the gatherings, or the way in which the sheets with text were printed. If the text to individual plates is consistently printed on two leaves which are not conjugate, a subscript after the plate number could be used: $\lambda 1-40_{2}$. Books with regularly single text leaves to individual plates occasionaliy have such a long text to one or a few plates that two or more text leaves were needed. If these are not conjugate, extra leaves are treated as inserts: $\lambda 40+2$ means that three leaves, not conjugate, bear the text to plate 40. A complication arises when two or more plates are devoted to the same subject (plant), so that the accompanying text leaf (or set of leaves) has to be identified by two or more plate numbers. In the collational formula it is not possible to combine these numbers with a hyphen, since this is used for a set of plates with different subjects. It could be stated as $\lambda f \frac{4}{5}$ but this is cumbersome in printing. The slanting line is not occupied in the collational formula and I therefore propose its use in this case: $\lambda 149 / 150$ will mean one leaf of text to the two plates 149 and 150 picturing the same subject. Gatherings or extra leaves for this text are indicated in the same way: $\lambda 149 / 150^{4}$ indicates a gathering of 4 leaves with text to these plates; $\lambda 149 / 150^{2}+2$ a gathering of 2 conjugate leaves with 2 extra leaves (not conjugate with those of the text to these plates); $\lambda 149 / 150+3$ means the text to plates 149 and 150 on 4 leaves which are not conjugate (at least with each other). Similar to signature notations, italic plate numbers mean inferred numbers, not actually present in the book, used for purposes of reference.

In Stevenson's method the Greek letter $\lambda$ precedes the part of the formula which treats the leaves in this way; other bibliographers omit this indication and simply enumerate the leaves by plate numbers. I have repeated the symbol before each group of equal leaves for clarity.

The advantage of this method is the simplicity of the formula and of references. A decided disadvantage is that this method does not show the gatherings as printed, since one gathering is not necessarily devoted to one plate or subject. Apart from the academic question of pure bibliography, this can be a serious problem for the botanical bibliographer who has to work out the exact contents of books published in fascicles, e.g. Hooker: Exotio flora, and Greville: Soottieh aryptogamio flora. Truly, many copies of these works have the leaves cut loose at the inner side, to accomodate the binding of plates and text togsther, or the whole is bound so tightly 
that no traces of conjugacy can be found. If no loosely bound copy turns up, other evidence must be used, in which watermarks especially prove helpful. The octavo half-sheets of the two works cited had for a large part paper with the watermark in the lower half of the fold of leaves $1+4$, or $2+3$. Deckle-edges or torn edges are helpful too, and the usual make-up of a fascicle in these works is one gathering of 4 leaves ( $8^{\circ}$ half-sheet imposition) and 1 loose leaf accompanied by 5 plates. This information is lost in the $\lambda$-treatment. I have not found a satisfying method to combine the clarity and simplicity for reference of the $\lambda$-treatment with the indication of the individual gatherings and I have stated these under the unusual heading Dates as proofs of the fascicle contents.

The way of signing the individual leaves is briefly indicated after the collational formula between parentheses. Individual leaves are referred to by their positional number in the gathering concerned, with regard to the normal folding: $A_{1}, A_{2}, A_{3}$ and $A_{4}$ in a gathering of four leaves whether they are all signed or only one. When the gatherings are signed with numerals, their individual leaves are indicated by an inferior numeral (or in some type-fonts a smaller numeral) after the number of the signature: $3_{1}, 3_{2}, 3_{3}$ and $3_{4}$. For unsigned gatherings, of course, the inferred signature or the arbitrary indication is used.

Alan Stevenson introduced the sign for a special bibliographical usage: the indication of all or of particular leaves in all gatherings; \$3 meaning the third leaves in all gatherings of the book. The indication "\$1-3 signed" therefore means: all gatherings have the first 3 leaves signed, self-evidently title-pages, halftitles and dedications excepted. Other exceptions are stated within the same parentheses. Actually Stevenson used in his case "\$3 signed" but I have reserved this for those cases where the second leaves are unsigned. If nothing is stated, the first leaf of every gathering is signed only. If a certain leaf in all gatherings is signed with an asterisk without a gathering indication I state: "\$3 signed '. " " if the asterisk follows the gathering indication I report: "\$3 signed $\$ *$ ". If the third leaf of every gathering is signed with the gathering indication foliowed by a 2 . I use the notation: "\$3 signed $\$ 2 "$.

As said before, it was a general usage to sign a certain proportion of the leaves per gathering, e.g. half the number of all leaves in each gathering, or this number plus one. To simplify the enumeration of signatures of unequal gatherings, I propose an indication of the general method by using the Greek letter y (gamma) for

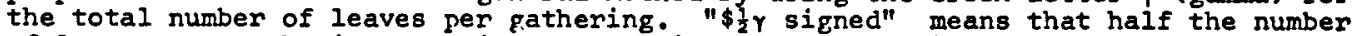
of leaves per gathering are signed, $e . g$. in the format $12^{\circ}$ in $8 s$ and 48 this means that leaves $1-4$ in all gatherings with 8 leaves and leaves $1-2$ in those with 4 leaves are signed; " $\$ \frac{1}{2} \gamma+1$ signed" means that one more leaf is signed than half the number per gathering, that is in the same example leaves $1-5$ in odd numbered gatherings and leaves $1-3$ in even numbered gatherings.

Missignings are recorded in the same set of parentheses. Reporting these seems trivial, but it is one of the methods to trace variants, since these mistakes were often corrected during printing. The whole method of signing may be an indication of a printer, or even compositor, and especially when a sudden change is present this may be an indication of a change of compositor or printer.

\section{PAGINATION}

The collational formula is immediately followed by an account of the pagination, separated by a semicolon. Every page is accounted for with a symbol, preferably the printed page number. Inferred page numbers are assigned to unnumbered pages whenever they fit gaps in the printed pagination, and are reported in italics. For conciseness I report interpolated inferred page numbers between parentheses at the end of the pagination, together with mistakes in page numbers: "422 as '22' ". This treatment of the inferred page numbers is different from the usual methods, but it gives the same information in a more condensed form.

Arbitrary numbers are assigned to unnumbered pages which can not have inferred page numbers, in such a way that each page in a certain volume or part has an unambiguous reference. If only arabic numerals are present, the case is simple: lowercase roman numerals are assigned to all other pages. When roman numerals are al. ready used, the other type is used for the unnumbered pages, e.g. when upper-case roman numerals are used for the preface, beginning with I (or inferred $I$ ), the numbers $i-i v$ will be assigned to the half-title and the title, and vice-versa. 
Inferred pare numbers, extrapolating the nrinted papination, are assigned to unnurbered pares at the end, even of blank leaves, unless another circumstance makes this imposible, e.f. the continuation of the papination in a following part of the book. The inferred page numbers are stated before the parentheses, for an easy calculation of the total number of pages per part or volume. For the same reason the correct number can be stated with the last page, if some page numbers are completely ignored in the book. that is, not present and not destined for unnumbered pages (text as well as conjuracy should be checked in such cases), e,g, 1-20 23-34 [=32]; the nares 21 and 22 are absent and the total number of pages is 32 , not 34 .

A new pagination in a volume which is not easily indicated as a second part is identified with superscript before the page number in the same way as was already done for signatures. This method can be used to indicate duplications of sets of page numbers in a nomal pagination. The existing method of adding letters to the page numbers can be advocated too.

An example of the pagination formula is: I-IV $i-v$ vi-xv $x v i \quad 1 \quad 2-268$

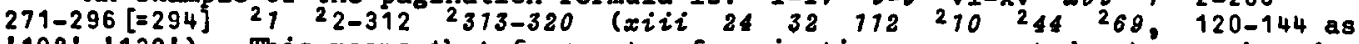
(108'-'132'). This means that four sets of pagination are counted: 4 unnumbered pages (half-title and title), the preliminaries with 16 pages, partly numbered but consistent if the inferred pages are taken into account, a first set of 294 pages in which 269 and 270 are omitted and set 120-144 is misnumbered, and a second set of 320 pages; moreover the unnumbered pages are stated.

If instead of pages columns or leaves are numbered, a relevant indication should precede the enumeration of the numbers. The unnumbered pages of the plate-books treated under the lambda-method are not enumerated; instead at least the total number of leaves is reported, separated by a comma from the part with a normal pagination, in some cases the $\lambda$-numbers are reported, especialiy when there are differences with the enumeration in the collation.

\section{CONTENTS.}

The bibliographical description contains an enumeration of the contents of the book, in this thesis as a separate paragraph. The details of the description may differ according to the purpose of the bibliography. For a botanical bibliography it is unsatisfactory to treat the major part of the contents with the one word "text", while going into minute details for the preliminaries. To achieve better balance I tried to indicate for floras the information given per species, in order to enable the botanist to judge at a glance the importance of the book directly, although the importance of the book is evaluated briefly in the notes. Since I selected the titles for the bryological contents. I enumerate the cryptogamic groups which are present in the book. It is self-evident that phanerogamic plants are included in a flora, but frequently the cryptogams are only partly treated and it is not always clear from the title which groups are included and which are not.

The enumeration of the contents closely follows the pagination. Each page has to be accounted for, including blank pages. These are indicated by a special symbol, an empty rectangle, $Q$, proposed by Alan Stevenson. Cancellantia are referred to by their page number followed by the plus sign: $860+$; the corresponding cancellanda by page number and the minus 8 ign: 860 -.

The references in the paragraph Contents are usually made, in descriptive bibliography, to the bibliographical notation of the leaf or signature (as developed in the paragraph collation), with the addition of an " $r$ " or a " $v$ " for the recto or verso (front or back) side of the leaf. However, this method is used primarily for incunabula and 17 th century literature, and I certainly prefer the simpler page reference for 19 th century books, in which pagination was quite regular and not so erratic as in the early periods of printing. I can cite Bowers (p.315-316): "since in the eighteenth century booke are ordinarily paged, there is marked tendency for bibliographers to use paginetion than oigning for reference in the contents peragraph and other parte of the description. Signature reference is used in books of the two previous centuries, even when pagination or folietion is present, for two mein reasons a bibliography ought to be consistent in its method, and in the earlier period, when many books are unnumbered, signeture reference is the only conlistent yetem posible secondly, pagination in earlier books is too erratic in accuracy to be trustworthy guide. Both oituetions are changed in the eighteenth century where it is possible to be reasonably consistent vith page references and where accuracy of pagination, while not invariable, is et leat a general rule." 
"The only argunent for page reference is itseas both for the reader and the bibliographer. Through the whole ere of hand-printing it has [p.316] these advantages. Its accuracy is not complete, for mispagination does occasionally exist to create some problems of reference. Mispagination was often corrected in prese so that reference tc a secific page nay be accurate for one copy and inaccurate for another, giving rise to various nisunderstandings. However, the main objection is that it is not a etructural system. Vith the collation of the book by signatures before his eyes, a reader working his way through the contents note with signature references can understand at a glance the oystem of printing of the various sections, as well as any abnormalities. When the sole reference is to pages, the relation of the contents to the make-up of the book is completely obscured and can be painfully reconotructed after some calculation. These difficulties are serious ones, but the advantages of quickness of reference in ighteenth-century books and later are usually felt to outweigh the objectione to pagination reference, and the common practice is to make all references by pege number whenever posaible. Signatures may be added in parentheses when special accuracy is neceseary." So far this statement of Bowers. Though it is clear. I think, that he $s$ till prefers references to signatures in eighteenth century books, the other custom is 80 wide-spread that he has to indicate it. For nineteenth and twentieth century books he has only a short sentence ( $p .438$ ): "Reference is made by page-number." His main point is that this applies to machineprinted books.

Originally I prepared nearly all the paragraphs Contents of the books for this thesis with signature references. I never admired the system, since it is useless for the many botanists who do not have the time to study descriptive bibliography intensively. Further, it is very time-consuming to check these references in those books in which only a few leaves are signed. For the same reason mistakes can easily creep in. Even for the main service of descriptive bibliography, the determination of fascicle contents, the page references are indispensable. After ample discussion it was decided to use page references in the large project Bibliographia Buntiana of the Hunt Botanical Library. Consequently I adopted this system. Moreover I had to. refine the pagination statements to make unambiguous page references possible, comparable to the unambiguous signature references.

Text figures are described in a separate paragraph. Typographical or other ornaments (woodcuts) without relation to the text are usually described in the contents in connection with the identification or possible identification of printers. This subject is not treated in this thesis, so I do not report those ornaments. Printer's imprints are shortly mentioned with their pages, but the information is mentioned in a special paragraph, in which succinct biographical data are stated when known to me. Publishers have another paragraph. I did not make exhaustive efforts to trace biographies of printers and publishers.

\section{PLATES}

A special paragraph in the bibliographical description is devoted to plates. This may include real plates as well as typographical tables, although I include many tables in the contents (see the discussion there). The total number of plates is recorded which are bound in the book as individual units. These units were not necessarily printed as separate units. As I explain elsewhere (Buntia 3, 1968, in press), several individual units could be printed together from one copper plate, to be separated after printing. In the main example which I discussed there, the original combinations could be reconstructed with the help of torn edges from an uncut copy of Gérard: Elora Galloprovinoialis, Paris, 1761. I was not successful in mapping out the places of the plates of Sturm: Deutsohlands Floxa Abth. II, Kryptogamen, nor did the watermarks of the plates of one fascicle match. Apparently in this case the "page plates" were separated for coloring before the fascicles were prepared, and a statistical analysis of the places of the watermarks might shed more light on their distribution. Nevertheless $I$ an convinced that at least 8 units were printed from one copperplate. The presence of engraved dividing lines between the units is a sure sign for this method, the economic advances of which are obvious. A result is that the plate-mark is not visible all around the plate, or not at all. The plate-mark is the rectangular line where the sharp edge of the copper plate left an embossment in the paper. 
The second element stated for the plates is the technique or techniques used. Most books treated in this thesis have copper encravings or etchings, some have lithographs. Lithograpis do not have plate-narks and are usually indicated as such somewhere in the book. The difference between engraving and etching is often very difficult to distinguish in the printed plates; noreover etchings were often finished by engraving, e.g. in the lettering. Engraved lines are straight and taper into fine points; etched lines are not so straight and end bluntly. I gratefully acknowledge the help in these identifications of Ir. J.V. Brindle, curator of prints of the Hunt Botanical Library.

The methods of coloring the plates are stated: hand-coloring or color-printing. In several cases the color-printing was done with two or more colors by inking the copper plate with different coiors in special places, e.g. a stem with leaves in green, the root part in brown, and the name in black. After the French name of the ink ball, poupée, this method'is called d la poupke. Usually surface colors were added by hand.

The first color-prints of complete moss plants which came to my knowledge, were published in the period treated in this thesis (see Chevallier and Sommerfelt), and before that T.F.L. Nees von Esenbeck published plates printed in one color of protonema stages of mosses.

The subjects of the drawings are succinctly described. In works in which the plates were published before the corresponding parts of the text (see Gaudichaud) it is important to indicate whether the plates contain "analyses" and Latin names, since it is a critenion for valid publication in the International Code of Botanical Nomenclature for plates published without text (before a certain date only).

The dimensions of the plate-mark are given in millimeters for one or a few plates, height first. Artists and engravers are listed in separate paragraphs with the numbers of the plates prepared by them, and succinct biographical details, when known to me.

\section{PAPER DESCRIPTION}

Under the heading Paper the leaf height is given of the largest copy seen, and the width when unusual. Occasionally the sheet size is stated, when it has been possible to measure this from uncut copies. The color of the paper is given only if it is other than white (browning is not mentioned unless it indicates some paper difference). The structure of the paper, laid or wove, is stated, and if laid, the direction of the chain-lines. An effort has been made to list the watermarks of at least one copy of each work; it has already been mentioned that this is not necessarily identical in all copies of the edition or issue, but normally the differences will only occur in those gatherings where a shift to another supply of paper took place.

\section{DATES OF PUBLICATION}

The research on dates of publication is one of the main objects of the bibliography of natural history. In a special paragraph in each treatment I combine the results of the research on the internal structure (especially the fascicle contents) and collateral evidence concerning the dates of publication of the book and its parts.

According to Dr. W.T. Stearn, undoubtedly one of the experts on precise dating of botanical publications, three independent data must be available to settle a date of publication beyond doubt. This is a sound principle. In practice, in many cases the data are so few that we have to evaluate their trustworthiness. Prepublication announcements, as a rule, cannot be trusted too much. The sentence "will shortly be published" may precede actual publication by a year or so, but it definitely indicates a date on which the book was not yet available. Announcements for the German book fairs at Leipzig often include books not actualiy ready at the fair. Reviews are proofs that the book was published, except for the possibility of pre-publication review copies. Bowers cites a modern example ( $p .376)$ in which from advance copies and early orders it became apparent that sale had been underestimated, hence the 4000 ready copies were all shinped from New York to California; and a second impression was ordered for Eastern distribution; the copies for the West got sidetracked and did not arrive until after the official publication date, and the planned pre-publication second impression for the East was not finished in time; as a result, on publication day no copy was placed on sale anywhere. 
Trustworthy are the notices of receipt by societies, academies and libraries, published in their periodicals, or present in their archives. Even here exceptions can occur, as I explain under the reprint of Arnott's article Dioposition des mousess ... Personal letters fron the author accompanying a copy are very useful and as a rule trustworthy. They may precede publication in the bibliographical sense, but certainly can be admitted as proof of publication in the sense of the code of botanical nomenclature; strictly speaking the existence of another copy should be substantiated, but this is often difficult.

Usually, I only state one citation which indicates the earliest day of possible publication, when I consider this reliable enough, in the paragraph of Dates. Under Reviews and announcements other indications may be found, which are later.

\section{REVIEWS, ANNOUNCEMENES, BIBLIOGRAPHICAL STUDIES, REFERENCES}

Under a separate heading I list the reviews known to me, or announcements which have some information, not easily found elsewhere, e.g. on the date of publication. The abbreviations of the periodicals are extensive enough to recognize the full title. I refrain from giving a full list of these abbreviations, since a large list of such abbreviations of importance to botany, Botanioo-Periodioum-Buntianum, was recently published by the Hunt Botanical Library.

Under the heading Bibliographioal studies references are given to other publications treating the dates of publication of the title concerned.

Under References a number of catalogues and other lists are cited, which mention the book in question. Obviously, it was not possible to refer to every published catalogue and the selection given is rather arbitrary; even some important catalogues have not been included and some are only mentioned occasionally. These references are given in very short abbreviations, which are explained in the list of abbreviations. The number after the abbreviation self-evidently is the page number. unless preceded by the letter $n$. indicating the item number. Locations of copies can be traced from some of these references. The location of the copies studied is not consistently stated; one copy is usually mentioned under leaf height or -size; but as a rule at least one other copy was compared. Library abbreviations are the same as the standard abbreviations for herbaria in Index Berbariorum, with some exceptions.

\section{SIGNS}

I separates lines in quotations and title transcriptions; indicates regular alternation of unequal signature in collational formulas; and of the parts of continuous running titles at the top of opposite pages

1 in a collational formula: sign uniting plate-numbers for the same subject

- in a collational formula: sign for a removed leaf

+ in a collational formula: sign for an inserted leaf

- in a collational formula: sign for a cancellans replacing a removed leaf

= separates watermark and countermark descriptions

I identity sign, indicates a homotypic nomenclatural synonym

[] in a quotation or transcription: enclosing a remark or description not present in the original text

(] blank page

$\$ x$ leaf $x$ in all gathering of a book

$\gamma$ number of leaves per gathering

$\lambda$ leaf in plate-book identified by plate-number

$\mu$ micron, 0.001 millimeter

$x$ unsigned gathering in text

- unsigned gathering in preliminaries 


\section{ABBREVIATIONS}

\begin{tabular}{|c|c|}
\hline $\begin{array}{l}\text { Def. } \\
\text { Beil. } \\
\text { betw. } \\
\text { BIBIB }\end{array}$ & 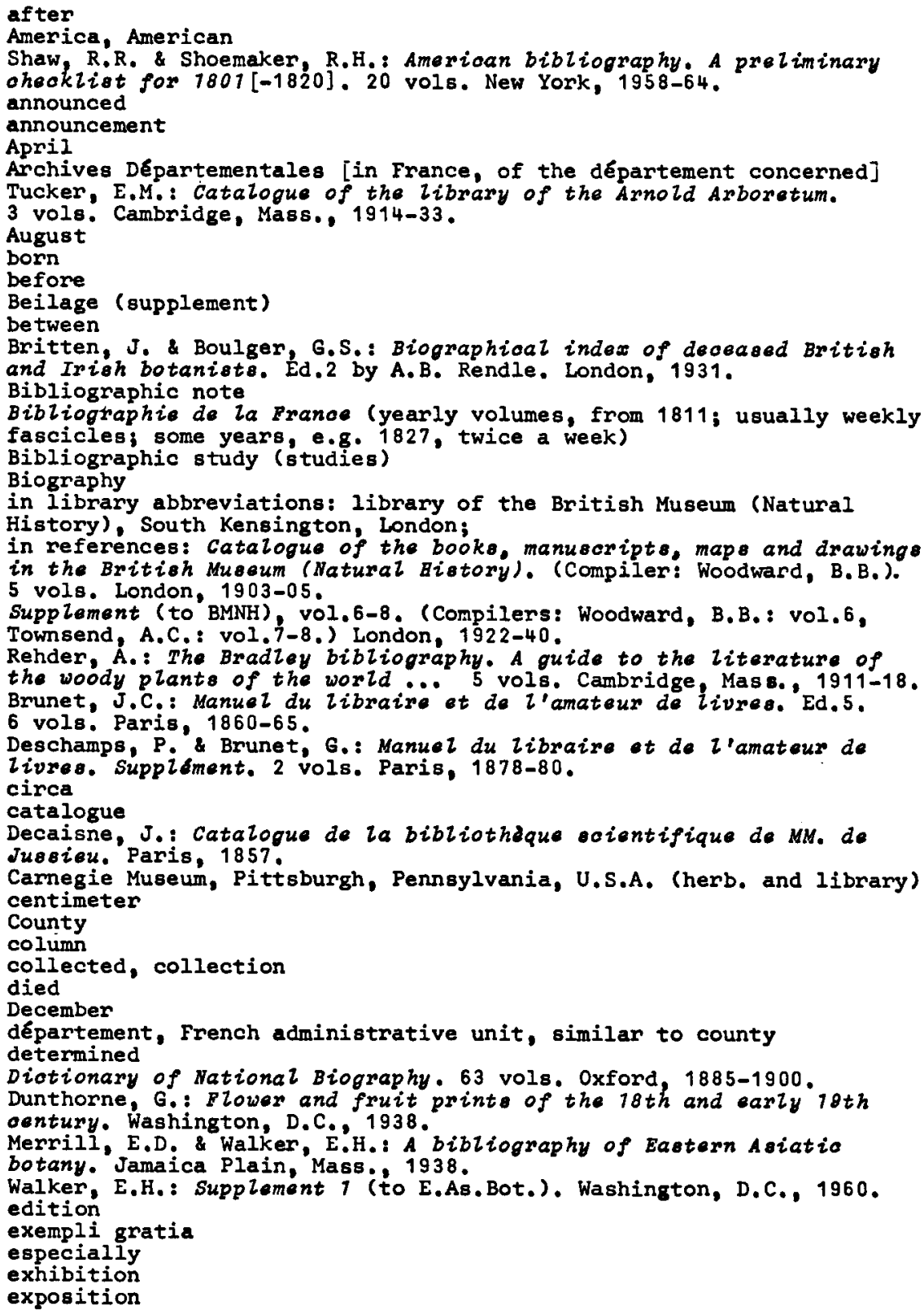 \\
\hline
\end{tabular}


FH

fasc.

Feb.

fid.

$f l$.

G

gath., gaths. gen.

GH

Graesse

GRO

HBL

Heawood

Heins.

herb.

hon.

ICBN

incompl.

Jacks.

Jan.

JT

JuI.

Jun.

Kew

Kew-S

Krieg

Krok

Krüg.

L

1.c.

LCC

Lindl. Cat.

Linn. Soc.

LL. D.

Lownd.

$M$

Mar.

Mass .HS-H

Mass.HS-M

M.D.

Meis.

Mich.Fair

Milt.

$\mathrm{mm}$.

ms. ms 8 .
Farlow Herbarium, Harvard University, Cambridge, Mass, U.S.A. fascicle, fascicles

February

fide (according to, on the authority of)

flourished (in biographies: years in which the person was living)

Conservatoire de Botanique, Geneva, Switzerland

gathering, gatherings

general

Gray Herbarium, Harvard University, Cambridge, Mass., U.S.A.

Graesse, J.G.T: Trésor de livres rares et précieux. 8 vols.

Dresde, 1859-69 (consulted: Milan reprint).

Botanisch Laboratorium, Rijksuniversiteit, Groningen, Netherlands Hunt Botanical Library, Carnegie-Mellon University, Pittsburgh, Pa. Heawood, E.: Watermarks of the 17th and $18 t h$ oenturies. Hilversum, 1950 Heinsius, W.: Allgemeines Büaher-Lexioon ... 19 vols. Leipzig, 1812-94 (consulted: Graz facsimile 1962-63). herbarium

honorary, honoris

International Code of Botanioal Homenolature adopted by the Tenth International Botanical Congress, Edinburgh, Aug. 1964. Utrecht, 1966. (Regnum vegetabile vol.46).

incomplate

Jackson, B.D.: Guide to the botanioal literaturs of botany. London; 1881.

January

Johnson, J.: Typographia. London, 1824.

July

June

Catalogue of the library of the Royal Botanio Gardens, Kew. London, 1899.

Supp iement (to Kew). [London], 1919.

Krieg, M.0.: Mehr nioht ersohienen, Ein Verseichnise unvollendet

gebliebener Druokwerke. 2 vols. Bad Bocklet etc. 1954-58.

Krok, Th.0.B.N.: Bibliotheaa botanioa Suecana. Uppsala-Stockholm, 1925 .

Krulger, M.S.: Bibliographia botanioa. Handbuoh der botaniochen

Literatur ... Berlin, 1841 .

Rijksherbarium, Leiden, Netherlands (herbarium and library)

loco citato; at the cited place (only used with reference to a citation in the same entry or paragraph)

Library of Congress catalogue of printed books ...

The Lindiey Library oatalogue of books, pamphlets, manusoripts and drawinge. (Compiler: Hutchineon, H.R.). London, 1927.

Catalogue of the printed books and pamphlets in the Library of the

Linnean Sooiety of London. (Compiler: Savage, S.). New ed. London, 1925.

Litteris Doctor

Lowndes, W.T.: The bibliographer's manual of Englioh Ziteraturs.

Ed.2 (by Bohn, H.G.). 4 vols. London, 1864.

Botanische Staatssammlung, München, Bavaria

March

Catalogue of the library of the Maseachusetts Hortioultural Society. (Compiler: Hewett, M.C.). Cambridge, Mass., 1918.

Dictionary catalog of the library of the Masoqahuette Bortioultural Society. (Compiler: Manks, D.S.). 3 vols. Boston, 1962. Medicinae Doctor

Meisel, M.: A bibliography of Amerioan natural history ... 1769-1865. 3 vols. New York, 1924-29.

Michaelmas Fair (Michaelismesse), book fair at Leipzig

Miltitz, F, von: Bibliotheca botanica. Berlin, 1829.

millimeter

manuscript, manuscripts 
Nis8 nom,cons. nom.illes. nom.rej. Nov. NYBG

Oct.

P. pagin. PBN PC period. pl.s pls. Plesch

PMusBC Pr.ed.1 Pr.ed. 2 pref. prob. public. 5 recd. ref., refs. reg. rev. Roorb.

RSC

RT

Sayre

sem.

Sep.

sep.

Sitw. Blunt

Souls by

Soulsby Add. Stafl. TL

Ttyl.

Teyl.

t. $-\mathrm{p}$.

t. -p. vol. trim. U

UB Utr.

Utr.

v vol., vols. W

Wikstr.

wm.

$x$ number

Nissen, C.: Die botanisohe Buchilluetration ... Stuttgart, 1951. nomen conservandum (conserved name)

nomen illegitimum (illegitimate name)

nomen rejiciendum (rejected name)

November

New York Botanical Garden, Bronx, New York

October

page

pagination

Bibliothèque Nationale, Paris

Laboratoire de Cryptogamie, Muserun d'Histoire Naturelle, Paris

in chronological liste: article in periodical

plate, plates

Bibliothdque Arpad Plesoh "La Ldonina". I Botanique. (Compiler: Pley, J.) Monte-Carlo, 1954.

Bibliothèque Centrale, Muséum d'Histoire Naturelle, Paris.

Pritzel, G.A.: Thesaurus literaturae botanicae, Leipzig, 1851. [same]. Ed.2. Leipzig, 1872-77.

preface

probable, probably

publication

in collational references: recto (front side)

received

reference, references

register

review (reviews)

Roorbach, G.A.: Bibliotheoa Amerioana. Catalogue of American publioations ... 1820 to 1850. New York 1939.

Catalogue of coientifio papers (1800-1883). Compiled and published by the Royal Sooiety of London. 6 vols. London, 1867-72. muning title

Sayre, 6.: Dates of publioatione desoribing Nusoi, 1801-1821. Troy. N.Y. 1959 .

semester

September

separate

Sitwell, S. \& Blunt, $W_{\text {: }}$ Great flower books 1700-1900. London, 1956, A oatalogue of the works of Linnaeus (and ... relating thereto... T. (Compiler: Soulsby, B.H.). London, 1933.

additional numbers in Soulsby

Stafleu, F.A.: Taxonomio literature. A seleotive guide to botarical publications with dates, commentaries and types.

vol.52). Utrecht-Zug, 1967.

in library abbreviations: Library of Teyler Foundation, Haarlem, Netherlands

in references: Ekama, C.: Fondation Teyler, Catalogue de la bibliothique. I. Soienoes exaotes et naturelies. Haarlem, 1885-88. title-page

title-page of the volume, in contradiction to t.-p, of fascicle trimester

Botanisch Museum en Herbarium, Rijksuniversiteit, Utrecht, Netherlands

Universiteits-bibliotheek, Rijksuniversiteit, Utrecht, Netherlands Catalogue van botanisohe boekwerken in de Univereiteitobibliotheek ... te Utreoht. (Compiler: Danner, W.H.). Utrecht, 1936.

in collational references: verso (back side)

volume, volumes

Naturhistorisches Museum, Wien, Austria

Wikström, J.E.: Conepeotue litteraturae botanioae in sueaia... Stockholm, 1833 .

watermark

in plate-mark dimensions: the unknown short distance missing when the plate-mark is cut off at one border 
18. SOURCES

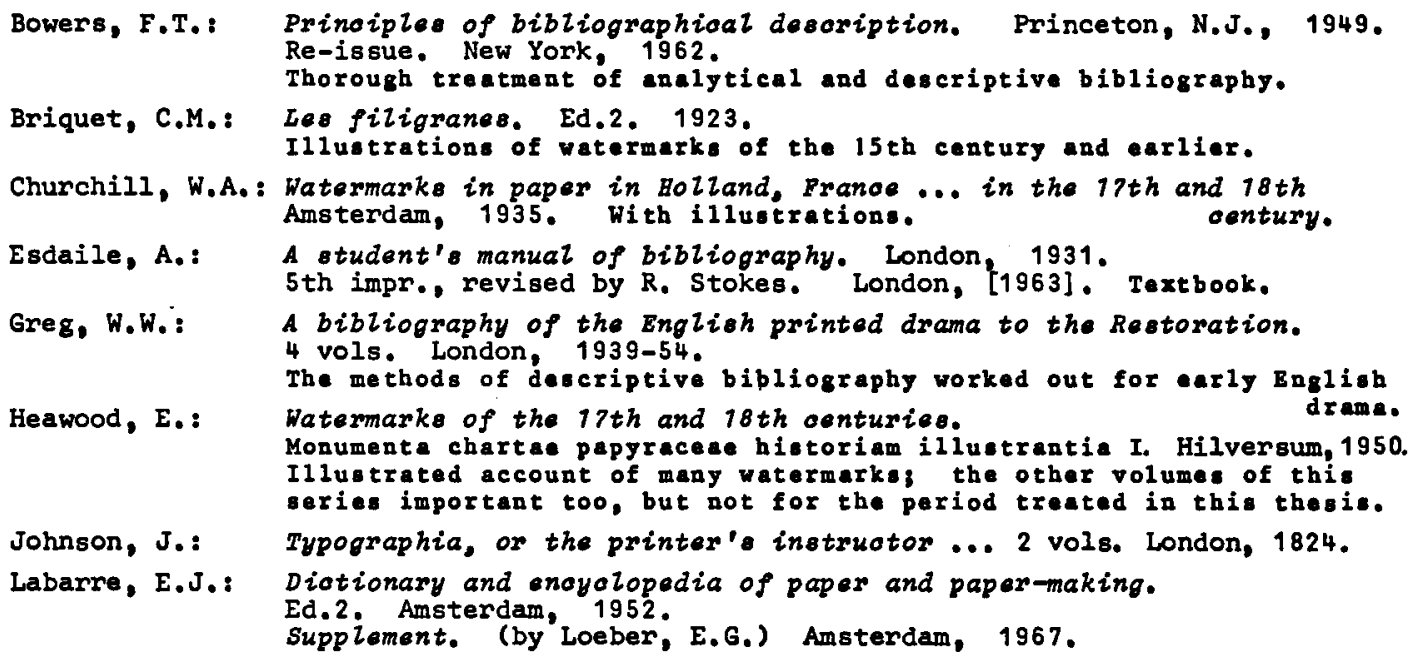

Mckerrow, R.B.: An introduction to bibliography for literary etudenta. 0xford, 1958. Several impressions or reprints, up to 1965 .

MacPhail, I.: Edition, issue and state in botanical bibliography. Huntia 2: 280-285, 1965 .

Margadant, W.D.: Remarkable features in book collectione. Huntia 2: 163-170. 1965. Pritzel, G.A.: Thesaurus literaturae botanicae. Ed.2. Leipzig, 1871-77.

Rehder. A.: The Bradiey bibliography. A guide to the literature of the woody plants of the world ... 5 vols. Cambridge, Mass., 1911-18.

Quinby, J. \& Stevenson, A.: Catalogue of botanioal books ... Raohel MoMasters Millex Bunt. 2 vols. Pittsburgh, Pa., 1958-61.

Sayre, G.: Dates of pubiications deecribing Nusci, 1801-1821. Troy, N.Y.. 1959.

Stafleu, F.A.: Taxonomio literature. A seleotive guide to botanioal publioations with dates, commentaries and types. Regnum vegetabile 52. Utrecht,

Stevenson, A.: A bibliographical method for the desoriptions of botanioal books ... Catalogue of botanical book. ... of Rachel McMasters Miller Hunt 2(1): cxli-ccxliv. Pittsburgh, Pa., 1961.

Thorough introduction to the method used by A. Steveneon in vol.2(2) of this catalogue, the epplication of descriptive bibliography to botanical books.

Voorn, H.: De papiermolens in de provinoie Noord-Holzand. Haarlem, 1960. History of paper mills in North Bolland, with details of paper making, e.s. the use of the Dutch word "huscel". 


\section{ARNAUD, Jean André Michel}

Biogr. Born 1760 Seo. 28, Le Puy en Vélay, France.

Died 1831 Nov. 24, Le Puy, dép. Haute-Loire, France.

Arnaud was educated at the "Collège du Puy" and later at the "Faculté de Médecine de Montpellier", where he received the degree of Dr. Med. on $16 \mathrm{Jul}$. 1782. He became physician at Le Puy and finally "Médecin en chef des hôpitaux et des prisons du Puy" (Chief physician of hospitals and prisons at Le Puy). He married Marie-Antoinette Nogier de Solignac on $11 \mathrm{Jan}$. 1809; they had four children. (Information: courtesy Arch.Départ., Le Puy.)

Ref.: Paul, G.: Recueil des evénements qui ont eu lieu au Puy et aux environe depuis i'an 1775 jusqu'en $1875 .$. p.15-41. Le Puy, 1931.

1 Flore du departement de la Haute-Loire...

Le Puy, 1825 .

Title: "FlORE | DU DEPARTEMENT | DE LA HAUTE-LOIRE, | OU | TABLEAU DES PLANTES QUI $Y$ CROISSENT, | DISPOSEES SUIVANT LA MÉTHODE NATURELLE; | PAR J.-A.-M. ARNAUD, D. M. M., I Médecin en chef des hôpitaux et des prisons du Puy, Membre | de la Société d'Agriculture, Sciences, Arts et Commerce de cette ville, du Jury médical du département de la Haute-Loire, I de l'Académie de Dijon, des Sociétés médicales de Bordeaux l et de Lyon, des anciennes Sociéte royale et Société de la l Faculté de Médecine de Paris. | IMPRIMÉ PAR ORDRE DE LA SOCIÉTÉ D'AGRICULTURE, SCIENCES, I ARTS ET COMMERCE DU PUY. | [medium long swelled rule] I AU PUY, | DE L'IMPRIMERIE DE PASQUET PERE ET FILS, | IMPRIMEURS DE LA PREFECTURE. I [short rule] | $1825 . "$

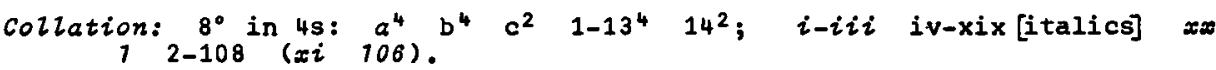

Contents: $i$ title; ii 0 ; $i$ ii-x preface and introduction, headed: "AVERTISSEMENT.", ending with a list of abbreviations, including sources ( $i x-x)$; $x i-x i x$ list of genera in the (modified) Linnaean classification with page references; $x$ table of de Jussieu's natural classification: "TABLEAU SYNOPTIQUE DE CLASSIFICATION."; 1 head-title as book title; 1-105 text, list of flant species of all groups, arranged in natural families, with French and local names, flower colors and habitat and localities, 106108 alphabetical index of local plant names: "TABLE | DES NOMS EN PATOIS DONNES A QUELQUES PLANTES." RT: French names of plant families, or chapter heading. Language: French.

Paper: leaf height $197 \mathrm{~mm}$. (HBL copy, cut).

Printers: firm "Pasquet père et fils", Le Puy. Pierre Pasquet died 26 Jan.1838, aged 62. In fact the firm was headed by L. Lajugie from 1821-1830; see: Le Blanc, Paul: Les debuto de $l^{\prime}$ imprimerie au Puy ... P.48-50. Le Puy, Marchessou, 1894. (Information: courtesy Arch.Départ., Le Puy.)

Publisher: Societé d'Agriculture, Sciences, Arts et Commerce du Puy. Date: 1825 (t.-p.), bef. 2 Jul. (Bibliogr.France 14 (27): 441.1825 ). Refs.: Bradl.1:407 Krug.147 Milt.121 Pr.ed.1 n.298, ed.2 n.246.

Bibl.note. Probably gathering c has been printed on the same sheet as 14, but I have no positive proof.

Bot.note. Regional flora, which may be of importance for specialists of the region and of vernacular names, on which probably original information is present. 
Biogr. Born 1799 Feb. 6, Edinburgh, Scotland. Died 1868 Jun. 17, Glasgow, Scotland.

Arnott received elementary education' at Arlary (Kinrosshire, Scotland); in 1807 he went to the High School of Edinburgh, retaining a friendship for life with his school-fellows, as Dr. William Jameson and Dr. Robert Wight. He entered Arts Classes of the Edinburgh University in Nov. 1813, published papers on mathematical subjects $(1817,1818)$, and became interested in natural sciences by the lectures of Prof. Robert Jameson (1774-1854), mineralogist. With R.K. Greville (which see), he attended extra-academical lectures of John Stewart (died 1820) on cryptogamic botany in 1817 and 1818. Mineralogy was dropped in favor of botany, and, as Dr. Wight later wrote, there was a friendly rivalry in the formation of our herbaria (Cleghorn $\mathrm{p} .4$; for full reference see the end of this biography).

In 1818 Arnott received the degree M.A., and after further study he was admitted a member of the Faculty of Advocates in 1821; he appeared as an advocate only three times, as he disliked public speaking. His attention was more strongly directed to botany by the contact with Dr. W.J. Hooker whom he first met at a summer course of lectures (by Hooker) in 1821, with an introduction from R.K.Greville (Cleghorn p.5), and not in 1825, as supposed by J.D. Hooker (Ann.Bot.16: xxxvii. 1902). After this Arnott frequently visited Hooker and attended his excursions to the Highlands.

It is understandable that Arnott's interest was for a large part focused on bryophytes, since Hooker had finished his beautiful British Jungermanniae (1816), the first edition of Musoologia Britannica (1818), had prepared the second volume of Musoi Exotioi (1819-20) and was still contemplating a third volume, while the mosses cannot escape being noticed in the Scottish Highlands. Arnott received many herbarium duplicates from Hooker, and doubtless many mosses were included. Arnott's activity in collecting can be judged from the many times his name was mentioned in Hooker's Flora Sootica.

In the same year, 1821, Annott visited Paris and studied plants in the herbaria of Delessert, Mérat, and of the Muséum d'Histoire Naturelle. Also, he attended the last botanical excursion in which Antoine Laurent de Jussieu took part and which was directed by Adrien de Jussieu. This stay in France will certainly have strengthened his interest in the natural classification, and have encouraged him to work out a new one for the mosses.

Back in Edinburgh he wrote to Ad. Brongniart on 14 Nov. 1821: It is now time to write about the synopsis Nuecorum, with the greatest regret, I find that for the present I must give up the task: of the mosese already desoribed figured by the authors. I find, notwithstanding the many I have, that I posese few more than the half: and of unpublished speoies. I understand there may be nearly 3 hundred arrived in Britain, which it is imposeible for me even to get a sight of: I hope however that in time I may be able to do something. in the interval. I shall at my leisure examine and describe those that I possess."

Nevertheless, in collaboration with Greville, he began to produce the Tentamen methodi muscorum to attempt a new classification of the mosses. Its first part, as a separate, came out on or before $22 \mathrm{Apr}, 1822$, the date of a letter to Brongniart in which Annott announced the shipment of a number of copies. This same letter is interesting in showing Arnott's decided preference for "lumping" over "splitting": Hornsohuoh is publishing at present a Bryologia Germanica. He makes every variety a speaies: he has nearly 100 opeaies of Bryum that will never do - I do not think there are 30 in all Germany -, to which must be taken into account that the circumscription of this genus was much larger than in the 20 th century. In another letter to Brongniart, dated 7 Jun. 1822, Arnott confirmed the sending of the books and added: by a friend; from this may be inferred that copies were already available to Annott for some time, but not before 14 March, on which date he had sent an earlier packet to Brongniart; apparently he utilized opportunities whenever these turned up, to avoid postage.

The second Memoir by Greville and Arnott was referred to in a letter from Arnott to Ad. Brongniart, dated Edinburgh, 7 Apr. 1823, telling him that it was written, but not yet printed. He was especially eager to get more information on 
the structure of the sporophyte and calyptra of the genus Drepanophy 2 lum of C. Richard. In the next letter, dated $25 \mathrm{Apr} .1823$, Arnott offered Brongniart a set of the Memoirs of the Wernerian Natural Bistory Sooiety at a reasonable price. The second part of the 4 th volume was to be published immediately.

Another letter to Brongniart is quoted in full, since it has a bearing on a similar situation concerning the Nouvelze disposition methodique in 1825-26. one of the important publications of which I wanted to trace the history:

Uy dear friend.

In my last letter, which I sent you | by $\mathrm{Mr}$. Hardie, I mentioned that $I$ had re-loeived oome mosses from Rio de Janeiro; I I am corry that the opecimene are too small I to allow me to send you any of them. I I have drawn up descriptions of them, which I may not be printed in this oountry. $I$ therefore oend | you a manusoript oopy, which I should I feel obliged if you would present to your I Sooiety of Natural History. - if they think proper I to insert it in their Hemoirs, they are welloome [sic] | to print it, but in that oase, you had better trans-liate into French what I have written in | Engiish.

I am just now in a great hurry, as I I set off tomorrow for our highlands in search | [verso] of plants, of which if I find any thing good I shail aend some to you. I know I shall l get the zygodon oonoidus! \& Hypnum flage Ilare!

If I can get part of my property oold I I intend to be in Paris next

year, but I wish | you would visit me first - when I go to Franoe I I shall be nearly two years from home, so that I may not be next year exactiy. Believe me ever yours eincerely

\section{July 1823 | Edinburgh} What is the price of D.C.'s Synopsis? of I Kunth's synopsis? of Richards Medioal I properties of Plante?

In the next letter to Brongniart, dated 11 Sep. 1823 , Arnott says he has not heard from him since the letter sent by Mr. Hardie. This new letter was to be brought by Nr. Scoolar - one who is a good practical botanist for Soottish plants - he studied under Dr. Hooker at Glasgow -, apparently John Scouler (1804-1871). M.D. Glasgow 1827. Arnott mentioned his excursions to the mountains, where he found a moss two or three weeks after Hooker discovered it as new for Scotland: Bryum demissum, and enclosed a new Grimmia for Brongniart. Arnott appeared not to approve of German authors too much: Schwaegrichen'e 2nd Supplement to Hedwige species muscorum - It is nonsense from beginning to end - oedipodium is a bad genus - Thesanomitrion Richardi is only Dioranum flexuosum, as is also Dioranum filiforme!!! Have you seen also Hornsohuche Bryologia Germanica - he has made numbers of now speoies, without one good character. More important, we learn that $M_{y}$ ind Nemoir on the genera of moses is now printing... Further, he still contemplated a large work on mosses: I have not altogether given up hope of finishing a Muscologia, but some time must elapse - and I must restriot myseif to ouoh opecies as have been desaribed by others ouoh new opecies as I myself posese I propose to give specifio differences in Latin, a any short observations in English. How would it do to print in Paria ... \& what bookselier would undertake it. I should think there might be 4 or 500 pages - like DeCandolles Systema vegetabilium - \& no plates.

It must have come as an embarrassment to Arnott, when Brongniart wrote him that the paper on the Rio de Janeiro mosses was being printed, for he reacted at once by the following letter:

My dear sir

Edinburgh 218t Nov. 1823

I on $l_{y}$ received your letter this morning, but would not have I answered you for some little time, were it not for a oiroumetanoe | in which I think you must cortainly have misunderstood me I I allude to the paper I sent you "on the Mosese of Rio de Janeiro ["]. I If I reoolleat well I tated that it had been previously read | to the Wernerian Sooiety. and 


\begin{abstract}
that it was in their power to I print it; and of course, it was not my intention that it should | be published at Paris as an original Memoir indeed I it has been just printed in the Transactions of the Wernerian Sooiety. Will appear soon: and you would oblige me muoh if | you will not permit it to be publiahed in the Memoirs of your sooiety. I If it has been already printed (but I hope that it has not) I I would wish that you will place a notice at the l end of the volume to this effect: "Le memoire 8 up des mousses de Rio de Janeiro $\{$ etoit imprime ici sans connaissance de l'auteur: le manu-leorit original soit donne et $l_{u}$ a la sooiste Wernerienne d'histoire naturelle $\mid$ d'Edimbourg, dans les aotes de quelle sooiste il a ets publis." | Excuse my bad Exenoh - I hope that you will be able l to do one of these, but write me, on this point, the moment | that you can determine what you can do.
\end{abstract}

The rest of the letter is for a large part devoted to bryology, and for the other part about publications to be sent or acquired, or even copied. Written on the last leaf is a Notice on Sohwaegriohen's 2d Suppt. volume. Arnott wrote of this: ... which I have no objections you should use in the "Bulzetin des annonces Soientifiques" ... There is no indication that this was published; it is very critical. Arnott did not accept a large number of species distinguished by Schwaegrichen.

In the next letter, dated 18 Dec. 1823, Arnott apologized: I reobived your lettex of the 28 Novemb. on ly the other day - you mus be quite right about the papex I sent you, but I had quite forgot any thing about it, - more than $I$ stated to you in my letter and I am very sorry for the trouble I have given you. The article actualiy was published in Paris in 1823 (see n.1 of the following descriptions) and also in Edinburgh in 1824 as a part of a larger paper (see n.2). Brongniart cannot be blamed for the duplication. In his hasty letter of 2 July, Arnott clearly asked him to publish it, probably supposing that he would receive word of Brongniart before printing began, and then forgot all about it during his trip in the mountains. The preparations for printing in scotland went their regular course, however slowly it may have appeared to Arnott. Astonishingly the same must have happened to him in Paris in 1825 or early 1826 .

The same letter gives us welcome information on the second memoir by Greville and Arnott: I send also the second memoir on the Genera of moses, though the volume in which it is to appear has not yet been published. Other information concerns the prospectus of a work by Brongniart, of which 12 copies were on their way to Scotland, but not yet received, and the high expense of the post in Scotland for it (not by weight, as in France, but by each piece of paper), and about the planned work by Hooker, a species plantarum in the natural arrangement, 8 volumes, one every 8 months, announced on the cover of Curtis' botanical magazine (a plan that was never realized).

On $15 \mathrm{Jan} .1824$ Arnott was able to send (by an intermediary) a few copies of the memoir we have had some correspondence about, apparently the prepublished separate of the paper referred to, concerning Rio de Janeiro. The date on this letter is not too clear, since it can be read as July as corrected from June, but the next letter leaves no doubt, being dated $16 \mathrm{January} 1824$ in full, and confirming the letter of the day before. The main reason for this letter was to tell Brongniart that the packet with the large number of the prospectus referred to earlier, had such an immense postage that he refused it, since he already had rereived a single prospectus and had made it known in English, and to different booksellers.

In the last letter of this series to Brongniart, dated 20 May 1824 , Arnott announced the sending of the new volume of the Wernerian transactions 5 (1) which was ready for some time: ... this io the first opportunity I have had... From the same letter it is clear that Arnott did not yet possess the Bryologia Germanioa, though he had seen a copy before.

The voyage to France was indeed realized, and again I have to treat some details because of its consequences for dating the forms of Arnott's article. He arrived in Paris $12 \mathrm{Feb} .1825$, attended his private affairs and studied in the herbaria of Paris botanists, e.g. the mosses of Gaudichaud and Delessert. His treatise Nouvelle dioposition ... was read at the Societé d'Histoire Naturelle on 
18 March 1825, and on 22 March Arnott left Paris for his large "Tour" to southern France. Most likely he attended the meeting himself, and printing obviously could not have begun in the few days he still was in Paris. The journey lasted a very large part of the year, and was in part described by Arnott in the Edinburgh New Philosophioal Journal. The story was told of the visit to Andorra, where the only bed in the principal inn was occupied by the sick cwner. In the other inn the master offered his own bed, which was accepted. In the copy of the reprint, present in the Edinburgh Botanical Garden, a humorous annotation is inscribed at this point: Here the author fell as leep and seoms never again to have awaked for no more was published.

It has been stated that this break of the narrative really was caused by the account published by his companion George Bentham $(1800-1884)$ in his Catalogue des plantes indigenes des Pyreness et du Bas Langusdoc, Paris, 1826. This is hardly the main reason, since Arnott cited. Bentham already in the fourth instalment out of the nine which were published. A more important cause will have been the journey to Russia, which Arnott undertook in 1828, and possibly later his marríage.

From Bentham's account it is clear that the tour to the Pyrenees ended 19 Aug. 1825, the date of the return to Montpeliier (1.c. p.45). The return and the arrangement of the numerous collections made during the journey must have taken up time; anyway Arnott was on his return nonthwards 19 Sep. 1825 , when he passed Tain and Tournon (Tour to the South of France and the Pyrenees, [1]: 10, footnote. [1826]). On his return journey Arnott visited A.P. De Candolle in Geneva, at an unfortunate period, since the second son of De Candolle had just died very unexpectedly (HEmoires t oouveniro de Augustin-Pyramus De Candolle... Éorits par lui-même et publiés par on fils, p.411, Genève-Paris, 1862). Annott studied the herbarium of De Candolle for three months (Cleghorn, p.7), staying with and having the guidance of Seringe. This means that Arnott was still in Geneva during the first half of Dec. 1825. Soon after he will have reached Paris, probably late in December.

Back in Paris Annott found apparently that the Societe d'Histoire Naturelle de Paris had not yet published his article read 18 March 1825 . At least, this is my explanation for the fact that he offered the article to another society, the Soniété Linnéenne de Paris, possibly in the same impulsive way in which he wrote the letter quoted before concerning the article on Jameson's mosses. The result was that the article, the Nouvelle disposition methodique des especes de mouses exactement connues, appeared in four forms, both societies printing also separates of the article. I will indicate these four forms by the format of the journal with the indication periodical or separate. Noreover I found a fifth form (n.11).

Definitely the first form which appeared is the $4^{\circ}$ separate, a preprint from the USmoires de la Societe d'Histoire Naturelis de Pario with separate pagination, provided with a title-leaf and a conjugate leaf with errata. Its title is shortened to Disposition methodique des espeses de mouses, though the head-title on $p .1$ gives the full title, and the head-title on p. 6 also has the word "Nouvelle". This is stressed here, since the short title would suggest an article completely different from the later forms with the added word "Nouvelle", which is not the case.

The second form is the article, with the full title as head-title, in the $4^{\circ}$ periodical Hemoires de la Sooiste d'Bistoire Natureile de Paris 2(2): $249-323$. 1826 (April); a list of errata in the same fascicle on p.412-414 states 48 corrections to the article of Arnott.

As the third form I treat the article in the $8^{\circ}$ periodical Mémoires do la $^{\circ}$ Sooisté Linnéenne de Paris 5(3): 214-324.1826 (Jul). The article is accompanied by a report, numerous observations and a conclusion, all by B.M. Kittel ( p.205324), who was requested by the Société Linnéenne de Paris to study the article. The report was read $23 \mathrm{Feb}, 1826$ and the recommendation of Kittel that Arnott be nominated "Correspondant" of the society was accepted unanimously in this meeting. From the 48 corrections of the $4^{\circ}$ form only 41 were incorporated in the $8^{\circ}$ form. This implies, in my opinion, that Arnott sent the article to the Societe Linnénne before preparing the final corrections for the Societe d'Histoire Naturelle.

The fourth form finally is the $8^{\circ}$ separate from the Memoires de la Sooiete Linnesnne de Pario, published under the title: M. B. Kittel - Memoires d'hiotoire 
nature $2 l_{e}$, Paris, 1826, with a new pagination. Here the article of Arnott with the report and other remarks of Kittel is preceded by an article on Aphids by Kittel, from the same fascicle of the periodical. I have not been able to ascertain a precise date for this separate, and in absence of any indication to the contrary I take it for granted that it was issued later than the $8^{\circ}$ periodical article. I found that this indeed was the case for another article in the same periodical: the separate of the article by Desvaux: Prodrome de la familie des fougdres, Paris, 1827, which is treated in this thesis. Amazingly, a fifth form was published much later: a reissue of sheets of the $8^{\circ}$ periodical article as part of a publication by A. Saumaises: Cours d'agrioulture, de botanique et d'histoire naturelle, 2 vols., Paris, 1837. Summarizing, the five forms of Arnott's article' ilouvelie disposition methodique des especes de mousess exactement connues, are:

\begin{tabular}{|c|c|c|c|c|}
\hline n.t. & format & issue & indication & date \\
\hline \begin{tabular}{r|}
5 \\
6 \\
7 \\
8 \\
11
\end{tabular} & $\begin{array}{l}4^{\circ} \\
4^{\circ} \\
8^{\circ} \\
8^{\circ}\end{array}$ & $\begin{array}{l}\text { preprint } \\
\text { period. } \\
\text { period. } \\
\text { separate } \\
\text { re-issue }\end{array}$ & 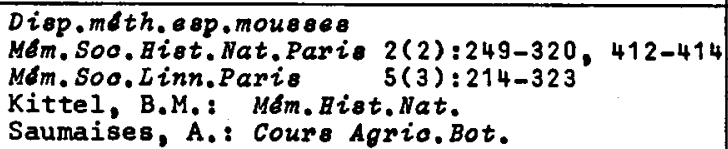 & $\begin{array}{l}\text { Paris, } 1825 \text { [Jan.1826?] } \\
\text { Paris, } 1826 \text { Apr. } \\
\text { Paris, } 1826 \text { Jul. [Aug.] } \\
\text { Paris, } 1826 \text { Aug. } \\
\text { Paris, } 1837\end{array}$ \\
\hline
\end{tabular}

The date of publication of the first form is important for nomenclature, since the new valid names in it count from this date. As stated at length in the relevant place I have been able to narrow the limits of possible publication to late December 1825 and late January 1826. This result is in agreement with the policy I adopted while preparing the Index Uuscorum: later than the publications of 1825 and earlier than those of 1826; the exact citations however, have to be corrected to those of the $4^{\circ}$ separate.

The dates of the other forms seem to be irrelevant to nomenclature, were it not that Amott referred to descriptions which he thought were published in 1824 , but in fact date from 1826 or 1828 .

This digression from Arnott's biography was necessary with regard to the importance of the article of Arnott for this study, since it is one of its key problems, and its unraveling is closely connected with his biography. Some unsolved or even puzzling problems remain, e.g. the exact date of his return to Paris and the monent he submitted the article to the second society for publication, and at which time he probably should have known that the $4^{\circ}$ journal and its separate already were printed (without corrections).

From the narrative of the tour to the Pyrenees it is clear that the Mediterranean flora as well as the mountain flora, made a great impression on Arnott, and that his interest in mosses diminished. Bentham sent all his Pyrenean mosses (Bentham: Cat.Fl.Indig.Pyren. p.13. 1826), but I am not aware of a published account except for occasional remarks on mosses in his narrative of the tour, and these were primarily his own observations. Arnott returned home early in 1826 , probably arriving in London before
6 February and in Edinburgh on or shortly before 20 February. After this voyage he only occasionally published on mosses.

In 1828 Annott visited Russia, at the instigation of and together with

Mr. Barclay, a Scottish merchant with important commerce in St. Petersburg. There he met several Russian botanists, e.g. Fischer and Ledebour, He was elected member of the Imperial Society of Natural History at Moscow in 1829.

In 1831 Arnott married Mary Hay Barclay, born at Paris, Perthshire, Scotland, the daughter of Mr. Barclay just mentioned.

Residing at Arlary, Arnott continued his botanical work, mainly on flowering plants, and enlarged the house for his herbarium and library. He studied, with Hocker, the botanical collections of Captain Beechey's voyage to the Pacific and Behring's Straits. With Wight he prepared the Prodromus of Fiorae Peninsuiae Indiae Orientalis ... London, 1834 , of which only one volume appeared. Its introduction was largely written by Arnott from Wight's origjnal notes (Bot. Inst. Glasgow Univ.; ms.). Arnott saw it through the press after Wight's return to india. In 1837 Arnott received the degree of LL.D. from King's College, Aberdeen. Arnott wanted to have a more regular income from botany for his growing family, 
and he hoped to obtain the professorship at Glasgow, when W.J. Hooker became director of the Royal Botanic Gardens, Kew, in 1841. In 1837 he had already lectured in Glasgow, when Hooker was absent. In order to strengthen his application for professorship, Amott published a seleotion from testimonialo in favour of George A. Kalker Arnott ... as oandidate for the regius profeseorship of botany in the University of Glasgow, Edinburgh, 1841, which is a collection of testimonials from 22 persons as to the qualities of Arrott for a chair in botany, closing with one from Sir William Jackson Hooker, dated 26 March 1841 , who had just had his resignation confirmed. The preface was: BOWEvER disagreeable it be for a candidate to collect and publish Teetimoniele in his own favour, the prectice hes of late yeare beciome so very general that I have been induced to wake the following selection, arrenged according to their dates, from those which I heve been honoured from different parte of the vorld. G. A. W. A. Glasgow College, 27th March 1841. The chair, however, was given to John Hutton Balfour (1808-1884).

When Balfour was appointed Professor of Botany at the University of Edinburgh in 1845, Arnott became professor at Glasgow. In this new position he was able to devote himself completely to botany. In the last part of his life he became deeply interested in. the study of diatoms. Going to France again in 1866 , he even spent about 10 days with $A$. de Brébisson for the study of diatoms. In the letters of Arnott to Balfour, kept in the Edinburgh Botanical Garden, I found notes on an unexpected meeting of student excursions of both professors in the field, which did not please Arnott, and we can imagine that some rivalry between the two cities was apparent in the reactions of the students. Anyway, Axnott asked Balfour to announce plans for excursions to each other ahead of time to prevent such meetings. However, I saw only one later letter of Arnott announcing a plenned excursion himself.

In 1867 Arnott's health began to decline. He still tried to lecture at the beginning of the summer sessions, but after a few days he had to give up, and the tedious and painful illness (jaundice, appearing in April 1868) proved fatal.

Cleghorn, who during this period Iived at Annott's house and carried on the duties of the class, states that Amott died 17 June 1868 . This date is clearly confirmed in Gard. Chron. 1868: 662. $20 \mathrm{Jun}, 1868$, and 683, 27 Jun. 1868, the latter stating "17 inst." This I consider more reliable than the later stated months of April (DNB) or May (Britt. Boulg., BIBIB ed.2:10.1931, ed.A.B.Rendle). Rendle made an overcorrection by stating Arnott's second name as "Arnold". I found 6. Arnott Walker Arnott in most other sources checked. To settle this point decisively, I inquired at the Register-House, Edinburgh, for his entry of baptism, but it could not be found in the books of the four parishes of Edinburgh of the time. Continued research, however, made a copy of his will available, which definitely states in a clear clerk's hand: George Arnott Walken Arnott, thus removing any doubt about his legal name.

The same will stated about his herbarium, that it should be offered to Glasgow University for purchasing if within one year after his decease none of his sons turned to botany. This was the case and the University acquired his herbarium and his botanical library. Recently the phanerogams were transferred to the Edinburgh Botanical Garden with those of the Glasgow herbarium (Taxon $15(1): 46,1966)$.

He was survived by his wife, three sons and five daughters.

His name is commemorated in the generic name Arnottia A.Richard 1824 (Orohidaceae).

Refo.: Cleghorn, Hugh: Biographical notioe of the late Dr. Nalker-Arnott, Regiue Professor of botany in the University of Glasgow. Edinburgh, Neill and Company, 1868. Separate from: Trans.Bot.S00.Edinburgh 9: 414-426. 1868; a similar account was also published in the Glasgow Herald (not seen). Gard.Chron. 1868: 662. Jun.20, 1868; 683. Jun.27, 1868 (extract from Cleghorn). J.Bot.Brit.For, $6: 223-224,1868$. Proo.Linn.Soo. [London] 1869: 101-102. 1869 (erroneously Edinburgh as place of death). Britten, James: Diat.Natz.Biogr. 2: $120^{b}-121^{a}, 1885$. 
1 Tentamen metiodi muscorum, a new arrangement of the genera of mosese. Memoir 1; 2; 3. Edinburgh, 1822; 1824; 1826 .

(See Greville Arnott $\mathrm{n}, 1-4$, )

2 Sur que lques mousses de Rio de Janeiro. Mém. Soc. Hist. Nat. Paris 1: 346-352. 1823.

Tit le: "NOTICE | SUR I QUELQUES MOUSSES DE RIO-JANEIRO. | PAR M. WALKER ARNOTT. I (LUE DANS LA SÉANCE DU 29 AOUT 1823.)"

Colzation: $4^{\circ}: 441 \mathrm{v}-444^{\mathrm{V}} ; 346 \quad 347-352$.

Contento: 346 head-title and introduction; 346-352 descriptions of Lycopodia, Husoi and Hepatioqe, collected in Brasil by $W$. Jameson.

Paper: leaf height $266 \mathrm{~mm}$; wove; no wm.

Date: late Nov., or Dec. 1823 (correspond. Arnott-Brongniart).

Ref.: RSC 1: 98 .

Notes. Arnott sent the manuscript to Brongniart on $2 \mathrm{Jul}, 1823$ (see p, 37), who will have translated the English part. He announced that it was in print shortly before 21 Nov. (see Arnott's answer, p.37). In the next letter (recd. by Amott 17 Dec.) the printing was announced as a fact and possibly the publication too. I have no indication of different parts of vol.1 of this periodical, nor of separates. New species and varieties collected by W. Jameson are described in Latin.

3 Notice of a journal of a voyage from Rio de Janeiro to the ooast of Peru.

Edinburgh, 1824 [separate].

Titze: "NOTICE | OF A | JOURNAL OF A VOYAGE | FROM RIO DE JANEIRO TO THE COAST OF PERU."

Head-titie: "[thick-thin rule] | Notice of a "Journal of a Voyage from Rio I de Janeiro to the Coast of Peru, by Hr. WIL-ILIAH JAHESON, Surgeon, Correoponding Mem-|ber of the Wernerian Natural History Socisty." | [short rule] | by G.A. WALKER ARNOTT, Esq.A.M. F.R.S.E.| M.W.S., \&. I [very short thick-thin rule]".

Colzation: $8^{\circ}$ : gatherings not studied; 1-3 4-21 22 .

Contents: 1 title; $2 \square ; 3$ head-title; 3-7 text, report of the voyage in the form of many quotations and a few condensed remarks; 8-9 meteorological tables, headed: "UETEOROLOGICAL JOURNAL from the Mouth of the Rio de la Plata i to the Coast of Peru."; 10-14 tables: "Table showing the Daily Differences and Rates of three Chronometers kept on board the Fifeshire Paoket, in | the pasage from Rio de Janeiro to the Coast of Poru."; 15-21 descriptions of two Lyoopodium taxa (one a variety without clearly distinguished epithet) and 26 bryophyte species, collected by W. Jameson near Rio de Janeiro (including 5 hepatics); 220 .

Paper: wove.

Printer: Neill, Patrick, Edinburgh (biogr. see Greville n.5).

Date: shortly before $15 \mathrm{Jan} .1824$ (letter from Arnott to Brongniart).

Hrapper: traces of grey wrapper seen on the copy Edinburgh Bot. Gard. Library.

Note. Pre-publication issue of the following article; the descriptions of new plants already in the preceding French publication $(n .2)$. 
4 Notioe of a journal of a voyage from Rio de Janeiro to the coast of Peru. Mem. Wernerian Nat. Hist. Soc. Edinburgh 5(1): 187-205. 1824.

Head-title: "[thick-thin rule] | X.-Notioe of a "Journal of a Voyage from Rio | de Janeiro to the Coaet of Peru, by Mr WIL-lLIAll JAllESON, Surgeon, Corresponding Hem-|ber of the Wernerian Natural History Society [sic]." | By G A. WALKER ARNOTT, Esq. A.M. F.R.S.E. I M.W.S., \&. I (Read 26th Apriz 1823.) | [very short thick-thin rule]".

Collation: $8^{\circ}: \mathrm{M}_{6}-\mathrm{N}_{7} \mathrm{r} ;$ 187-205.

Contents: not different from pre-publication issue, as far as checked, except page-numbers and head-title.

Paper: wove; no wm. (HBL copy).

Printer: Neill, Patrick, Edinburgh (biogr. see Greville n.5).

Publisher: Wernerian Natural History Society, Edinburgh.

Date: 1824 (title fasc.), after 21 Mar. (last date in fasc.), before or on 20 May (letter from Arnott to Brongniart, p.38).

Ref.: RSC 1: 98 .

lloter. Final publication of the article, containing a number of meteorological observations made by $W$. Jameson during his voyage from Brasil to Peru, with some natural history observations, a list of plants collected by Jameson and studied by Arnott, with descriptions of new species or varieties; the list of plants is on p.199-205.

5 Disposition methodique des esploes de mousers.

Paris, 1825 [1826?] $4^{\circ}$ [separate].

Titze: "DISPOSITION MÉTHODIQUE | DES I ESPECES DE MOUSSES I PAR I G. A. WALKERARNOTT, A. M. | MEMBRE DES SOCIETES ROYALE ET WERNERIENNE D'EDDIMBOURG CORRESPONDANT DE LA SOCIÉTE D'HISTOIRE NATURELLE DE PARIS ET DE LA SOCIÉTE ROYALE | DE BOTANIQUE DE RATISBONNE | [short swelled rule with diamond in the middle, partly open] | PARIS, IMPRIMERIE DE J. TASTU, RUE DE VAUGIRARD, No $36 . \mid$ [rosette] | 1825."

Colzation: $4^{\circ}: \pi^{2} 1-9^{4} ; \quad i-i v 72-72$ (6).

Contents: $i$ title; ii 0 ; iii-iv corrections; 1-5 introduction with headtitle: "[fuli double rule] | NOUVELLE | DISPOSITION MÉTHODIQUE | DES ESPECES DE MOUSSES I EXACTEMENT CONNUES *; PAR M. G. -A. WALKER-ARNOTT, I MEMBRE DES SOCIETES ROYALE ET WERNERIENNE D'EDIMBOURG, ET CORRESPONDANT DE CELLE | D'HISTOIRE NATURELLE DE PARIS. | (LUE A LA SOCIETE D'HISTOIRE NATURELLE LE 18 MARS 1825.) ( [short swelled rule with diamond in the middle, partiy open]", and with footnote on the same page below a full rule: "Extrait du tome II des Memoires de la sooiete d'Bistoire Naturelle de Paris." above the direction line; 5 sources; 6-72 text, headed: "NOUVELLE DISPOSITION MÉTHODIQUE | DES | ESPECES DE MOUSSES." "systematical arrangement; in two columns per page, of the moss genera, species and varieties accepted by Amott, with occasional discussions of the status of taxa and some descriptions. RT: "NOUVELLE DISPOSITION MÉTHODIQUE DES ESPECES DE MOUSSES." Language: French, with some descriptions (of genera and some other groups) in Latin.

Paper: sheet size $546 \times 418 \mathrm{~mm}$. (sheet 1 to extreme borders, PC copy); laid, chains horizontal; wm.: letters in the fold, not determined.

Printer: Tastu, J., Paris,

Publisher: the author had a financial arrangement with the Societe d'Histoire Naturelle de Paris for reprinting. 
Date: 1825 (t.-p.); between circa 20 Dec. 1825 (a) and 6 Feb. 1826 (b), probably in jan. 1826 (c).

(a) Very likely Arnott was not back in Paris before 20 Dec. 1825 , and the corrections were prepared after his return. This is clear from a footnote to the corrections in the $4^{\circ}$ periodical, stating that the translation and the printing were done during his absence; by implication the corrections were added during his stay in Paris. Moreover this note stresses that many additions and rectifications were not present in the original manuscript, to which Arnott requested the attention of the reader. Included in the corrections is Grimmia nigricane D.C. with a reference to the herbarium of De Candolle, which is additional evidence for the late date of the corrections. (b) The copy of the Linnean Society [London] was received in the meeting of $6 \mathrm{Feb} .1826$ (ms. information, courtesy of the Librarian of the Linnean Society). The copy of the Royal Society Edinburgh was received 20 Feb. 1826 (Trans.R.Soo.Edinburgh 10(2): 483, 1826).

(c) I infer that Arnott himself brought copies to London and Edinburgh; since his voyage will have taken a couple of days, it is probable that the work was available in Paris already late in January. I know of only one indication which seems to confirm the title-date 1825. In my opinion, however, this is not completely independent. The list of printed works offered during 1825 to the Societe Linnéenne de Paris includes the title of this separate. The list is titled: "LISTE | Des ouvrages imprimes offerto d La Sooiste | Linneenne de Pario pendant l'anne 1825, | et deposes dano ces arohives"; the citation for the page with the "brochure" of Arnott is: M\&m.Soo,Linn,Paris 4(6): CXXXV. 1825[1826]. Arnott is mentioned there as "correspondant", which proves that the final version of this list was prepared after 23 Feb. 1826 , the date of his nomination. The possibility that the list includes titles not actually received (or even offered) in the year concerned, but only on account of the year of the title, is positively indicated by the list of the following year. (A remark after the entry of Hova Aota Phys.Med. 13(1), Bonn, 1826, states that this part was received at the actual moment of printing of the list, which was certainly in 1827 and not in 1826: M\&m. Soo.Linn.Paris s(6): CXLIV. 1826 [1827, first announcement 3 Mar. 1827]). Some other arguments of a more or less subjective character point to publication in Jan. 1826. Why should the Societe Linneenne de Paris have asked Kittel to report on Arnott's manuscript if the $4^{\circ}$ preprint was already in its library? Thiébaut de Berneaud, the secretary, was active in botany (see the notes to Desvaux $n .2$ ), and should have been able to realize the situation. The time Annott needed for the several activities involved, all probably after his return to Paris, scarcely allowed the printing and other preparations for publication (binding) to be completed in the remaining days of Dec. 1825. He apparently received a French translation, prepared 41 corrections, presented this form to the Societé Linnéenne de Paris, afterwards added 7 more corrections and presented the 48 corrections to the editor of the Societe d'Histoire Naturelle de Paris, after which printing of the title and the corrections could begin. Admittedly, it is quite possible that all this was done in Dec. 1825, but, in my opinion, it is rather unlikely.

Reviewe: Linnaea 1(3): 482 , 1826 ;

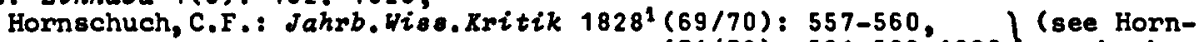
$(71 / 72): 561-569.1828$ schuch n.10);

Fünrohr, A.E.: Flora $10^{2}($ Beiz, 1): 22-86. 1827 (see Fünrohr n.1).

Refo.: BMNH 63

Cat.Juss n.2289

Jacks. 153

\section{Kew 16}

Kew-S 12 (annotation copy)

Linn. Soc. 23
Pr.ed.1 n.10920

Pr.ed.2 n. 249

Un.Edinb.1: 167 .

Bibl.notes. Separate, pre-publication issue (preprint) of the following article (Arnott n.6). A new title-leaf with a conjugate leaf with corrections was added. Pagination and signatures were changed, and at the bottom of p.1 the source was added; no other changes noted. The title was shortened, giving the erroneous impression that another article was involved than the periodical article with the full title. 
Bot.notes. Arnott arranged those species of mosses which he accepted rather conservatively in genera, and the genera (Andreaea and Sphagnum excepted) in groups of higher rank. He did not indicate the exact rank of the latter groups, except for the occasional remark "Cet ordre" in the discussion of Orthotrichoideae (p.13), the only one in this rank with a description. His delimitation of genera and species was very wide and in several cases he closely followed the concepts of W.J. Hooker. The new genus Macrodon (p.51) was proposed with a valid description, before Leucoloma Brid. 1827 (which later became a nomen conoervandum). One new species was proposed with a valid description: Didymodon megalocarpus (p.36, based on an earlier variety). Of Fontinalis disticha Sprengel-Bosc ( $p .70$ ) Arnott did not know an earlier description and he described one character, just enough for a valid description. Many new combinations in the specific and varietal level were proposed, with valid references to earlier descriptions. A large number of species was reduced to synonymy, especially those of German authors. It gives the impression of an early example that lumping can be done as superficial as splitting: Arnott judged some species from plates only. There is a special problem with regard to the references to "Sohw. et Gaud.", explained in the sources as: "Descriptions des Mousses trouvés par if, Gaudichaud, par Schwaegrichen", with the note: "Ces description.

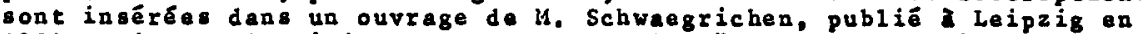
1824 , mais que je n'ai pas en ma possession." Probably a misunderstanding is involved; I do not have any indication of a special publication of Schwaegrichen in 1824 concerning Gaudichaud's mosses. Indeed, a few mosses of Gaudichaud were published by Schwaegrichen in 1824 in his Supp I.Speo. Husc. 2, vol.1(2), e.8. Leptotheoa gaudiahaudi Schwaegr. However, this was correctly cited by Arnott under his Bryum gaudichaudi (p.47), so this was not the work Arnott referred to in the former case. In 1826 another species from the Gaudichaud collections was published: Mcoromitrium piliferum Schwaegr., Suppl.Speo.Huso. 2 vol.2(1): 66. pl.172. 1826 (before 15 May), and the rest in 1828 , with descriptions by Schwaegrichen in the part Botanique, by Gaudichaud, of. Freycinet, Voyage autour du monde ... l'Uranie et $2 a$ Physiaienne, the fascicle with the Bryophyta. For this reason it is important to ascertain the dates of the later forms of Arnott's article too. A minor point is the validity of the name orthotriohum lanosolatum (p.16), based by Arnott on the Maoromitrium piliferum Schwaegr. "et Gaud." mentioned above. This reference is invalid in the $4^{\circ}$ preprint. However, a remark is added: "L'entrée de l'urne est petite et pliée comme celle de l'o. miorootomum." Though technically this may be taken as a valid description (the rules do not require a differential description), I advocate the view that this particular sentence does not represent a valid description since the author supposed it had been described, and simply supplied these remarks to justify the arrangement close to orthotriohum miorostomum. A complication is that Schwaegrichen's name served as the type-bringing synonym for another name proposed by Arnott: Orthotrichum piliferum (p.17). There is no indication that Ar nott proposed two species for different parts of the material of Gaucichaud. Two specific names, Bypnum ocabrisetum (p.62) and H. oyparioides Fook. (p.69) were printed, but canceled in the corrections; these names, therefore, are invalid, not being accepted by the author.

6 Houve IZs disposition méthodique des espèces de mousses...

Mém. Soc. Hist. Nat. Paris 2(2): 249-320, 412-414, $18264^{\circ}$ [periodical].

Head-titie: "[full doLble rule] | NOUVELLE | DISPOSITION METHODIQUE | DES | ESPECES DE MOUSSES I EXACTEMENT CONNUES; | PAR M. G.-A. WALKER-ARNOTT. MEMBRE DES SOCIÉTES ROYALE ET WERNERIENNE D'EDIMBOURG, ET CORRESPONDANT DE CELLE | D'HISTOIRE NATURELLE DE PARIS. | (LUE A LA SOCIÉTE D'HISTOIRE NATURELLE, LE 18 MARS 1825.)"

Collation: $4^{\circ}: 32-40^{4} ; 249250-320$ (254); [corr.:] 522v-533v; $412413-414$. 
Contente: 248 head-title; 248-253 introduction; 253 sources; $254-320$ text, in two columns (heading and contents as in Arnott n.5); $\$ 12-414$ errata, 48 corrections, placed between errata to other articles.

Paper: leaf height $252 \mathrm{~mm}$. (HBL copy, cut); laid, chains horizontal; wm.: letters in the fold, not determined.

Printer: Tastu, J., Paris.

Publieher: Societe d'Histoire Naturelle de Paris, and for sale with: Baudouin Freres, Paris, and Rey et Gravier, Paris.

Date: 1826 Apr. (fasc. title, seen in BMNH).

Ref.: RSC 1: 98 .

Bibi.notea. The article in the periodical was printed at the same time as the prepublication issue (the preprint, Arnott $n .5$ ), in the treatment of which the differences are noted. The corrections were placed after the index of the volume and are included between corrections to preceding and those to succeeding articles.

Bot.notes. Identical with the preceding pre-publication issue (except for the form of the corrections) and probably not published late enough to have valid indirect references to Schwaegrichen: Suppl.Speo.Muso. 2 vol.2(1).

7 Houvelle disposition methodique des esplose de mousses... Mém. Soc. Linn. Paris 5(3): 214-323. $18268^{\circ}$ [periodical].

Head-title (of the full paper, including Kittel's report, p.205): "[full wavy rule] | NOUVELLE DISPOSITION | MÉTHODÍQUE | Des espdoes de Nousees exactement oonnues, I par M. G.-A. WALKER ARNoT T, Correspondant I a Edimbourg; précede d'un rapport fait d on | oujet a la'sooisté linnéenne. par M. B. KITTEL, I d. m.; suivie de notes oritiques et d'additions | qui compldtent oe travail et le mettent d la | hauteur des connaiseanoes actuelies. | [short rule]".

Part-title (of Arnott's part proper, p.214): "NOUVELLE DISPOSITION MÉTHODIQUE | DES ESPECES DE MOUSSES."

Collation: $8^{\circ}$ in 8s: (full paper, with Kittel's report): 14,r-214v; 205 206-324; (Arnott's part proper): $145 \mathrm{v}-214 \mathrm{r} ; 214-323$.

Contente: 214-323 text of Arnott's part proper, with part title; text interspersed with observations by B.[M.] Kittel, marked with asterisks and printed in larger type than Arnott's text. Note: in the index to the volume, M\&m.Soo.Linn. Pario 5 (Buil.Linn,6): 60-61, 1826 [1827] alphabetical lists of the names of "tribu" and of the genera of Amott's article are present. No RT. Language: French, with a number of Latin descriptions.

Paper: leaf height $215 \mathrm{~mm}$. (HBL copy of re-issue Saumaises, uncut); laid, chains vertical; w.: "L [partly outline] Chapelle [erect script, in the middle of the lower left quarter of the sheet]".

Printer: Decourchant, Paris.

Publisher: Société Linnéenne de Paris, possibly in collaboration with Decourchant and Gallay, Paris (fascicle wrappers should be checked; these names occur on the wrapper of Kittel's separate).

Editor: Kittel, B.M. (which see), was asked by the Societe Linnénne de Paris to study the article of Arnott; his report (p.205-214) precedes the article, his "conclusions" are printed at the end (p.323-324) and his observations are interspersed in the article itself. Apart from this, the "secretaire perpétuel" of this society. Thiébaut de Berneaud, probably did some editing; maybe he was responsible for the spelling of the word cespitosum (in the $4^{\circ}$ forms printed ocospitosum). 
Date: 1826 Jul. (t.-p. fasc.); bef, 9 Aug.? (bef. Arnott n.8?);

bef. 27 Sep.? (see Mém. Soa, Linn,Paris);

bef. 30 Sep. (Bibliogr.Franoe $15(78): 834.1826)$.

Reviev: Bridel, S.E.: Bryol.Jniv.1: IV. 1826[1827], dated 16 Dec. 1826.

Bibl.notes. I did not see wrappers of this volume of the periodical; therefore I took the incomplete gatherings as the indications of the fascicles (see the treatment of the journal under its own title). In typography this $8^{\circ}$ form differs from the $4^{\circ}$ forms in several important respects.

Bot.notes. As noted before, the text of this form is identical with the $4^{\circ}$ edition, except for the incorporation of 41 of the 48 corrections of the $4^{\circ}$ form, the most conspicuous of these being the cancellation of the two Bypnum names mentioned under the $4^{\circ}$ preprint, involving a renumbering of the remaining bypnum species. The combination orthotriohum piliferum ( 0.235$)$ may be considered as validly published in this form, since presumably it was issued later than the relevant part of Schwaegrichen's Supplement. Two names of "Tribus" were proposed and described by B.M. Kittel: Andreaeoideae (p.214, spelled AIDRAOIDEF) and Sphagnoideae (.$_{2} 215$, spelled by error SPAGROIDEF, the French word on $\mathrm{p} .214$ being sphagnoidese); the other groups of the same rank were considered by Kittel to represent "tribus" too.

B Houvelle dieposition mbthodique des espdees de mousese. In: Kittel, B.M.: Msmoires d'histoire naturelle, P.35-143. Paris, 1826, $8^{\circ}$

Titze, collation, contents eto.: see: Kittel n.2.

Date: 1826, bef. 9 Aug. (see Kittel n.2).

Refo.: BliNH 63 Cat.Juss. n.2289 Pr.ed.1 n.5246, ed.2 n.4705.

Bibl.notes. Separate prepared by Kittel, as is clear from the change of the title of his report (see Kittel n.2). Apparently Arnott did not know about this reprint, he probably did not have one (I found no reference in the Glasgow University Library where his botanical books are) and he was certainly not able to distribute copies.

9 Tour to the South of Iranoe and the Pyrenees, in 1825.

Edinburgh, 1826-1829 [separate].

Titze: "TOUR | TO THE | SOUTH OF FRANCE AND THE PYRENEES, | IN 1825."

Head-titles: [1]: "TOUR | TO THE SOUTH OF FRANCE AND THE PYRENEES, In 1825. By G. A. Walker ARnotT, Fisq. A.M. F.L.S. R.SE, \&c. I In a letter to Professor JAMESOM. | [iong rule] | Brom the Edinburgh Now Philosophioal Journal. | [long rule]";

[2]: "TOUR | TO THE | SOUTH OF FRANCE AND THE PYRENEES. I IN

1825 , Continued. I BY | G. A. WALKER ARNOTT, Esq. A.M. F.L.S. \& R.S.E.

\&c. [short rule] | rom the Edinburgh New Philosophioal Journal. |

[short rule]";

[3]: "Tour to the south of France and the Pyrences. in 1825. By I G. A. WALKer ARNotT, Esq. A.M. F.L.S. \& R.S.E. \&C. | [long rule] | $\mathrm{grom}$ Edin. New Phizosophioal Journal. | [long rule]";

[4]: "A Tour to the South of Brance and the Pyrenees, in the year | 1825. By G. A. WALKER ARNOTT, Esq. M.W.S. | [Iong rule] I From the Edinburgh Hew Philooophiaal Journat. | [long rule]",

[5]: "A Tour to the South of France and the Pyrenees in the year | 1825. By G. A. WALKE ARNOTT, Esq. F.R.S.E. F.L.S. |M.W.S. \&c. (Continued.) | [long mule] | Irom the Edinburgh New Philosophioal Journal. | [long mule]"; 
[6]: "A Four to the South of Brance and the Pyrenees in the year I 1825. By G. A. WALKER ARHOTT, Esq. F.R.S.E. F.L.S. I.W.S. \&c. Continued. [Iong rule] | From the Edin. New Philosophical Journat. [ [Iong rule]", [7]: "A Tour to the South of 7 ranoe and the Pyrenees in the year | 1825. By G. A. WALKER ARNOTT, Esq. F.R.S.E. F.L.S. M.W.S. \& . -Continued. I [Iong rule] | From the Edin. New Philosophical Journal. | [long rulej"; [8]: "A Tour to the South of Franoe and the Pyrenees, in the year | 1825. By G. A. WALkER ARNOTT, Esq. M.W.S. [ [long mulej] From the Edin. Wew Philooophioal Journal. | [long rule ]";

[9]: "A Tour to the South of France and the Pyreneese in the year | 1825. By G. A. WALKER ARNOTT, Esq. F.L.S. \&c. | [long rule] I From the Edinburgh Jew Philosophical Journal, January-ilaroh 1829. I [long rulej".

Colzation: $8^{\circ}:$

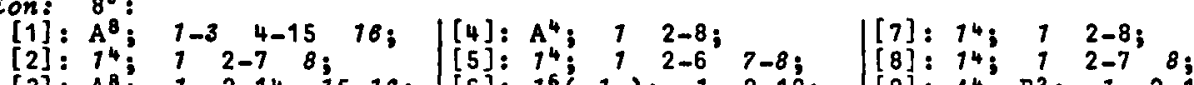

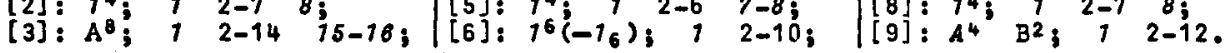

Contents: [1]: 1 title; $20 ; 3-15$ text; $16 \square$;

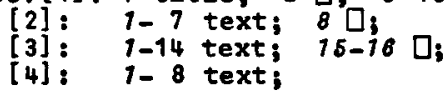

[5]: 1-6 text; 7-8 0 ;

[6]: 1-10 text;

[7]: 1- 8 text;

[8]: $1-7$ text; 80 ;

Paper: wove.

Printer: Neill, Patrick; Edinburgh (see Greville n.5).

Dates: (assumed to be the month after the period covered by the periodical fascicle): [1]: Aug. 1826;

[2]: Oct. 1826; $\quad[5]:$ Oct. 1827 ;

[3]: Apr. 1827;

$[6]:$ Jan. 1828 ;

[7]: Apr. 1828;

[8]: Oct. 1828;

[9]: Apr. 1829.

Bibl.notes. The general form of the printing is the same as that of the Wemoirs of the Vernerian Natural Bistory Soaiaty, and since the same printer is involved, pre-publication of the separates may have been usual here too. However, I did not investigate this point. The lines for the separates have been rearranged occasionaliy to fit a definite number of leaves; pagenumbers, therefore, cannot be automatically compared by subtraction or addition of a fixed amount per part. For the pages in the periodical, see Annott n.10.

Bot.notes. The narrative is an interesting account of a botanical travel in France and parts of Spain in the period. In the beginning an account is included of Amnott's study on the mosses in the herbarium of Palisot de Beauvois, kept by Delessert, from which the extreme lumping of Arnott can be seen; he again did not hesitate to give an opinion on moss species which he had not seen. Bryological remarks are interspersed throughout the narrative though they are in a minority compared to the discussions of other plants. Occasionally a complete description is given of a species already described earlier, but redefined: Bypnum ourvisetum, 3: 2 (footnote), 1827 , or an incomplete description of a new species: Didymodon benthamii Arnott, 3: 6. 1827. The flowering plants claimed Arnott's full attention, and he included occasionally descriptions and even keys (Biooutel2a, 6: 13-14, 1827), and many times critical remarks in the specific characters of different plants. Information is also given on herbaria of local botanists, many of whom had material which served as a source for the flora of Lapeyrouse, which was heavily criticized by A.P. de Candolle and of which Bentham also did not accept many new sfecies. 
[A] Tour to the South of France and the Pyrenese, in 7825.

[serial in] Edinburgh New Philosophical Journal vol.1-6, Edinburgh, 1826-1829.

Head-titles: not studied; similar to those of Arnott n.9, except for sources.

Pagination

\& dates:

\begin{tabular}{|c|c|c|c|c|}
\hline fasc. & vol. & pages & wrapper dates & probable date \\
\hline $\begin{array}{l}1 \\
2 \\
3 \\
4 \\
5 \\
6 \\
7 \\
8 \\
9\end{array}$ & $\begin{array}{l}1(1) \\
1(2) \\
2(2) \\
3(1) \\
3(2) \\
4(1) \\
4(2) \\
5(2) \\
6(2)\end{array}$ & $\begin{array}{r}66-78 \\
268-275 \\
241-255 \\
157-164 \\
350-356 \\
130-139 \\
355-362 \\
319-325 \\
250-262\end{array}$ & $\begin{array}{l}\text { Apr.-Jul. } 1826 \\
\text { Jul.-Oct. } 1826 \\
\text { Jan.-Mar. } 1827 \\
\text { Apr.-Jul. } 1827 \\
\text { Ju1.-Sep. } 1827 \\
\text { Oct.-Dec. } 1827 \\
\text { Jan.-Mar. } 1828 \\
\text { Jul.-Sep. } 1828 \\
\text { Jan.-Mar. } 1829\end{array}$ & $\begin{array}{l}\text { Aug. } 1826 \\
\text { Oct. } 1826 \\
\text { Apr. } 1827 \\
\text { Aug. } 1827 \\
\text { Oct. } 1827 \\
\text { Jan. } 1828 \\
\text { Apr. } 1828 \\
\text { Oct. } 1828 \\
\text { Apr. } 1829\end{array}$ \\
\hline
\end{tabular}

Contente: all pages text, every first page of a part with head-title.

Paper: wove.

Printer: Neill, Patrick, Edinburgh (see Greville n.5).

Publisher: not studied.

Editor: Jameson, Robert (1774-1854), professor of mineralogy, Edinburgh.

Refe.: Bradl.1: $408^{\text {a }}$ RSC 1: 98 :

ilotes. The article in the periodical is enumerated here after the reprint because I studied the reprint before the periodical and not because of differences in actual dates of publication, for which I do not have any indication. I assume that each reprint and the corresponding fascicle of the periodical both were printed in the month after the period covered by the part of the periodical as stated in its heading, since the fascicles contain meteorological data of the entire periods. I did not make a close comparison to check possible variations. For botanical comment see Arnott $n .9$.

11 Nouvelie disposition méthodique des especes de mousess ....

In: Saumaises, A.: Cours d'agrioulture, de botanique et d'histoire naturelle -.. Paris, 1837, vol.1: 214-323.

$\left[8^{\circ}\right.$ re-issue of sheets of some volumes of M\&m. Soo. Linn. Paris.]

Head-titie (of Arnott's article and Kittel's report and observations):

see Arnott n.7.

Collation and contente: see Arnott n.7 (compare Saumaises n.1).

Date: $1837\left(t .-p_{0}\right)$.

Bibl.note. Saumaises put a considerable number of unsold sheets on the market in the disguise of a new book in 2 volumes with cancellans titles and at the beginning and at the end new short articles. The article of Arnott present in these sheets constitutes a valid new publication, a re-issue of the $8^{\circ}$ periodical article $\left(8^{\circ}\right.$ re-issue).

Bot.note. This re-iscue is only of importance for the validation of the names published by Annott with a reference to "Schw, et Gaud." since the descriptions of Schwaegrichen were published by Gaudichaud in 1828 (see Gaudichaud n.1). 


\section{BALBIS, Giovanni Battista}

Biogr. Born 1765 Nov. 17, Moretta (Saluzzio), Italy.

Died 1831 Feb. 13, Turin, Italy.

Balbis was a pupil of Allioni. He studied at the University of Turin and traveled in Italy when the University was closed in 1792. Returning to Turin in 1793, he joined a revolutionary club gathered around the physician Ferdinando Barolo. A conspiracy with Tilly, French minister, in Genoa, against the house Savoie, was discovered and Balbis had to flee from Piedmont.

He was nominated in 1794 as a physician to the French army and was promoted in 1797 to chief-physician. He returned to his country in 1798 and participated in the provisional government of Piedmont until late 1799, when he had to avoid the Austrian-Russian troops. In 1801, with another change in government, he becans successor to P.M. Dana as director of the botanical garden in Turin and devoted himself to botany. He was dismissed in 1814 after the "Restauration", with a pension. In this period he could work on the Flora tioinese, in collaboration with Nocca. In 1819 he was nominated director of the botanical garden of Lyon, France, from which he rad to retire in 1830 as a result of a change in government. He then returned to Turin.

His herbarium finally came to the botanical garden of Turin. His name is commemorated in the generic names Balbisic Cavanilles 1804 (Geraniaceae), nom. cons. and Baibieia Willdenow 1803 (Compositae), nom. ref.

Refe.: de Candolle, A.P.: Biblioth.Univ. 1831: 214. Feb. 1831. Colla, L.: Hemorie R.Acoad.Soienze Tcrino 36. Torino, 1833. Bollea, L.C.: Il rieorgimento italiana 19. Torino, 1926. Bollea, Luigi Cesare Mattirolo, Oreste: Enoiolop.Ital. 5: 906. 1930

\section{Enumeratio plantarum offioinalium}

\section{Taurini [Turin], an XIII, 18005.}

Not studied. Pr.ed.2 n.364.

Date: in a letter written to Dégerand, Secr. gén. du ministère de l'intérieur, dated: Turin, oe $10 \mathrm{r}$ Avril 7806 , Balbis announced sending a copy; this letter is preserved at the Archives Nationales, Paris, sub F17 1031, dossier 7 .

2 Flora taurinensis ...

Taurini [Turín]. 1806.

Not studied. Pr.ed.2 n.365.

Date: in the letter of 1 Apr. 1806, mentioned under $n .1$, it is announced that a copy of this title was sent too. Dr. Sayre had no information on the date.

2 vols. in 3 parts, Lyon, 1827-28. [See for Supplement, 1835: Roffavier n.1.]

ritle: "FLORE | LYONNAISE, [line in shadow outline letters] | OU | DESCRIPTION | DES PLANTES QUI CRÓISSENT DANS LES ENVIRONS DE LYON | ET SUR LE MONT-PILAT; | PAR LE DOCTEUR J. B. BALBIS. I PROFESSEUR DE BOTANIQUE, I DIRECTEUR DU JARDIN DES PLANTES, | PRESIDENT DE LA SOCIETE LINNEENNE, | MEMBRE DE L ACADEMIE ROYALE DES SCIENCES, | DE LA SOCIETE D'AGRICULTURE ET DE LA SOCIETE DE MEDECINE DE LYON; |'PROFESSEUR EMERITE A L'UNIVERSITE DE TURIN, | MEMBRE DE L'ACADEMIE ROYALE DES SCIENCES, | DE LA SOCIÉTÉ ROYALE D'AGRICULTURE | DE LA MEME VILLE, etc. [long swelled rule with pearl in the middle, shadowed] TOME PREMIER. [2: TOME SECOND.] | [short rule] [2: absent] | PREMIERE PARTIE. [1(2): DEUXIEME PARTIE.] [2: absent] [long swelled rule with pearl in the middle, shadowedi | LYON, I IMPRIMERIE DE C. COQUE, RUE DE L'ARCHEVECHE, [2: IMPRIMERIE DE | D. L: AYNE, RUE DE L'ARCHÉVECHE,] | No 3. | [short rule of pairs of light and dark pearls] | 1827. [2: 1828.]" 
Collation: $8^{\circ}$ in 45: vol.1(1): $\pi^{2} a-b^{4}[i t a l i c s]$ 1-594; I-IV i-iii iv-xvi $7 \quad 2-471 \quad 472 \quad\left(385-424\right.$ as $\left.1383^{\prime}-1422^{\prime}, 443\right)$; vol.1(2): $\pi^{2} \quad 60-111^{4} 112^{2} \quad A-D^{4}\left(-D_{4}\right) ; \quad i-i v \quad 473 \quad 474-890 \quad 891-892$ $21 \quad 2-230 \quad(881,888)$; vol.2: $\pi^{4} 1-46^{4} 472 ; \quad i-v$ vi-viii $12-371372 \quad(332-334 \quad 347)$.

Contente: vol.1(1): I half-title; IID; III title; IV D; i dedication to Matthieu Bonafous (1794-1852), director of the botanical garden at Turin; ii D; iii-xvi preface, dated Oct. 1827; 1-471 text, descriptions of plant groups in the natural classification, headed: "FLORE | LYONNAISE. | [long swelled rule] | PREMIERE DIVISION, | [short wavy rule] | PLANTES VASCULAIRES | OU COTYLEDONEES", Clematio through Nonotropa; 472 D;

vol.1(2): i half-title; ii $\square$; iii title; iv $\square$; 473-872 text, vascular plants concluded, Lilao ( $=S y$ ringa) through Adiantum; 873-880 additions; 881-887 index of French names of families and Latin names of genera; $888-890$ corrections of essential errors; 897-892 $[$; $21-230$ synoptical table of genera according to the Linnaean classification: "TABLEAU SYNOPTIQUE | DES GENRES | DE LA FLORE LYONNAISE, † Dispos\&es d'apres le oyotème de LIINÉ, avec le renvoi aux | pages ou il en est traits dans la Flore."; vol.2: i half-title; ii D; iii title; iv $\square$; v-viii preface to vol.2, "troisième partie", headed: "AVERTISSEMENT.", dated: "1er mai 1828."; 1-331 text, descriptions of non-vascular cryptogams, headed: "FLORE I LYONNAISE. I [long swelled rule] | DEUXIEME DIVISION. [short wavy rule] | VEGETAUX CELLULAIRES | OU ACOTYLEDONES." , including: 1-81 Musoi, 82-101 Hepatioae, 102-174 Lichenes, 174-207 Bypoxyla, 208-319 Fungi and 320-331 Algae; 331 explanations of signs and abbreviation; 332-333 table over two pages of the main divisions: "TABEEAU des Divisions principales de la Flore ..." "; 334-340 systematical enumeration of families with differential descriptions, in the divisions indicated in the foregoing table: "TABLEAU SYNOPTIQUE | DES FAMILLES DE LA FLORE LYONNAISE, | ..."; 347-371 index of French names of families and Latin names of genera and species to vols. 1 and 2 (volume numbers only indicated after families and genera); 372 corrections to vol.2 (including one change of name: p. 280 line 17 Boletus eulfureus DC. read Boletus hispidus DC.) [page blank in G copy]. RT: French names of plant families. Language: French, with "phrases" in Latin.

Paper: G copy: leaf size $200 \times 126 \mathrm{~mm}$. (cut); wove; wm.: "[shell]"; normal copies: laid, chain-lines vertical; wm.: "[grapes] $=$ [monogram in wreath [?]]" (HBL copy).

Printere: vol.1: Coque, C.; Lyon, France; vol.2: Ayné, D.L., Lyon, France, successor of Coque (same address).

Publishers: probably the printers.

Dates: vol.1(1): between 0ct. 1827 (preface), and 21 Nov. (Bibliogr.Rrance vol.1(2): late in 1827 (see part 1) bef 21 Nov (16 (93): 956. 1827); vol.2: after 1 May 1828 (preface), bef. 5 Jul. (Bibliogr. France $17(27): 499.1828)$.

Reviewe: vol.1: Linnaea 5: 59. 1830; vol.1-2: Annali stor.Nat.Bologna 1(1): 142. 1829 ; Mérat, Bu22.Soi.Nat. 17(5): 239-240. 1829.

Refe.: Arn.Arb.1: 54 BMNH 1: 91 Bradl.1: $408^{\circ}$

$\mid \begin{aligned} & \text { Brun.6 n.5074 } \\ & \text { Cat.Juss: n.1646 } \\ & \text { Graesse 1: } 279^{a}\end{aligned}$

Jacks. 286
Kew 27
Pr.ed.1 n.431
Pr.ed. 2 n. 368

Un.Edinb.1: 221

(index only).

Variants: the Geneva copy, apparently an early present to De Candolle, has wove paper and lacks the corrections to vol.2 on p.372. The existence of copies without and $\mathrm{nith}$ corrections indicates a post-publication state. 
Bibl.notes. The three title-pages appear to have the same type-setting except for the necessary change in volume-indications, and in vol.2 of the publishers. The title of vol.2 was printed from standing type.

Bot.notes. Regional flora of an experienced botanist, critically working over the herbaria of the region available to him, and here adopting the natural classification, leaning heavily on De Candolle's Flore frangaise. Some points are conspicuous: no varieties were admitted, and no attempts were made to create many new species. The Uusci were treated according to Bridel's recent Bryologia Universa, and I have not noted new species or combinations. For Liohenes the citations from Acharius: Synopais, were added. For the Fungi the divisions of Persoon were preferred to those of Fries. For a supplement see Roffavier n. 1 .

BARON, P. Alexis

Biogr. Born 1754, Castelnau-Montratier (now dép. Lot), France.

Baron was a surveyor and naturalist, who for a considerable time lived in the then French island St.Domingue. He published a Carte generrale et cadastrale of this island, which was after the restauzation the only source with which landowners from before the revolution could prove their claims. he also worked on an Ouvrage statiotique sur Saint Domingue, for which only a prospectus appeared at Cap-Français in 1799, at the eve of the revolution there. After his return to France he apparently became a teacher of natural history at the "Ecole centrale du département du Lot" and a member of the "Classe des Sciences" of the "Académie de Montauban". Enquiries at the "Archives Départementales" of the départements Lot and Tarn-et-Garonne (Montauban) did not result in more data.

Refo.: Quérard, J.M.: La Franoe litteraire 1: 186. 1827. Pr.ed.2: 14 (probably derived from Quérard).

\section{Flore des départemeno meridionaux de la France...}

Titze: "FLORE | DES DEPARTEMENS MERIDIONAUX I DE LA FRANCE, I ET PRINCIPALEMENT DE CELUI DE TARN-ET-GARONNE, | OU | DESCRIPTION DES PLANTES | Qui croissent naturellement dans ces départemens, et de celles | qu'on cultive communément dans les jardins, disposées I suivant le système sexual de LINNÉ; | AVEC UNE NOTICE PREECISE DE CHAQUE ESPECE, | Et quelçues observations modernes ajoutées aux caractères botani-|ques qui les distinguent; I A laquelle on a joint l'époque de leur floraison, la nature du terrain ou elles naissent, leurs vertus les moins équivoques en Médecine, | et leur utilité dans les Arts. | PAR M. BARON, Ancien Ingénieur des Colonies, ex-Ingénieur-Vérificateur du Cadastre, ancien I Professeur d'Histoire naturelle à l'Ecole centrale du département du Lot, | Membre de la classe des Sciences de l'Académie de Montauban. | [short swelled rule] | A MONTAUBAN, | CHEz J. P. F. CROSILHES, LIBRAIRE, PLACE BOYALE. | $1823 . "$

Collation: $8^{\circ}: 7^{8} \quad 2-31^{8} 32^{4} ; \quad i-v$ vi vii viii-xxxvi $1-3 \quad 4-468$ (447 459 464,468 as $1468+36=514$, '(8ic]).

Contents: $i$ half-title; ii imprint: "DE L'IMPRIMERIE DE PH. CROSILHES, PLACE D'ARMES."; iii title; iv $\square$; v-vi preface, headed: "AVERTISSEMENT"; vi $i-x \times v$ introduction to botany: "PRINCIPES i ELEMENTAIRES | DE BOTANIQUE." explanation of morphological terms and (xxiv-xxv) a discussion of the principles of the classifications of Tournefort and Linnaeus: "DES METHODES EN GENERAL."; xxVi-xxxVi Linnaean classification: "EXPOSITION | DU SYSTEME DE LINNE."; " 1 part title: "DESCRIPTION | DES | PLANTES."; 2 : 3-446 text, descriptions of genera and species of all groups in the region, in 
Linnaean classification, Latin binomials, without author's citations, after the French names medical properties and habitat stated, but no localities, rarely a regional indication; 447-458 dictionary of botanical teris; 459-463 index of French plant names with the addition of many verracular nanes, the latter not alphabetized; $464-468$ index of Latin generic names; 468 corrections. RT: French names of classes and orders, or shortened chapter headings. Language: French.

Paper: leaf height $204 \mathrm{~mm}$. (HBL copy, cut); laid, chains vertical; wm.: "'grapes] = [monogram]".

Printer: Crosilhes, Jean Pierre Philippe, 1778 Sep. $22-1856$ Feb. 11, printer at Montauban 1811-1832; biogr.: Forestie, E.: Bistoire de l'imprimerie d Montauban, p.333-336. 1898. (Information: courtesy Arch.Départ., Montauban.)

Publisher: Crosilhes, Jean Pierre François, Montauban, 1780 Kay 20 - 1846 Sep. 14; biogr.: Forestié, E.: Hiatoire de i'imprimerie a Montauban, 8.337-338. 1898. (Infornation: courtesy Arch.Départ., Montauban, France.)

Date: 1823 (t.-p.), bef. 20 Sep. (Bibliogr.Franoe 12 (38): 544,1823 ).

Review: BulZ.Soi. Nat.GeOZ.Paris 1(4): 355-357. 1824.

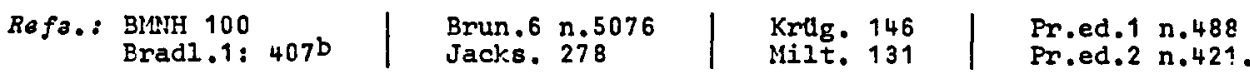

Wotes. A regional flora, completely in French, with a popular approach; no new combinations seen nor expected. The vernacular names in the index might be interesting for a epecialist, though they are mainly derived from Gatereau: Desoription des plantes qui oroissent aus environs de Montauban .... Ilontauban, 1789 .

BAXTER, Nilliam

Biogr. Born 1787 Jan, 15, Rugby, England.

Died 1871 Nov. 1, Oxford, England.

Baxter was appointed curator to the Botanic Garden of Oxford in 1813, and retired in 1851 in favor of his son W.H. Baxter $(1816 ?-1890)$. He had to work with limited means in a garden which was lying partly so low that it often was flooded in winter as well as in summer. Only when C.G.B. Daubeny became professor in 1834, large improvements were made, in which Baxter helped planning and executing from the very arrival of Daubeny.

He was a botanist of the old type, knowing phanerogamous as well as cryptogamous plants, and having learned these without the use of the compound microscope. His knowledge of mosses and leaf-fungi was especially mentioned. He had a very amiable character.

He was commemorated in the generic nanes Baxteria R. Brown ex W.J. Hooker 1843, nom.cons. (Liliaceas) and Baxtera H.G.L. Reichenbach 1828 (Asoiepiadaoeae). Refo.: Gard.Mag. 10: 110-113,1834.

Gard.Chron. 1871: $1426^{c}-1427 a$, 1871; repeated in:

J.Bot.Brit.For. 9: 380-381. 1871.

Britten, J.: Diot.Nat2.Biogx. 3: $438^{b}-433^{a}, 1885$.

Eritten Boulger, BIBIB od.2 (Rendle): 25. 1931.

1 Stippes oryptogamae Oxonienses ...

2 fasc., Oxford, 1825-1828 [exsiccata].

Tit le: "Stirpes Cryptogamae oxonienses; [line in gothic] | OR | DRIED SPECIMENS | OF | CRYPTOGAYOUS PLAITS, | COLLECTED | IN THE VICINITY OF OXFORD. | [short rule] | BY WILIIAH BAXTER, A.L.S. AND F.H.S. | BOTANICAL GARDENER TO THE UNIVERSITY. | short rule] | The more we study the works of the Creator, the more wisdori, beauty, and harmony become manifest, even to our limited I apprehensions; and while we admire, it is impossible not to adore. - sir J.E.Smith. | [short rulej| FASCICULUS I. [2: FASCICULUS II.] | [short rule] | OXFORD | 1825 !2: 1828.j| [medium long rule] | TALBOYS AND WHEELER, PRINTILRS. [2: D. A. TALBOYS, PRINTER] ". 
Colzation: $4^{\circ}$ : fasc.1: $\pi^{2}(?$, now disjunct in BMNH copy); $i-i v$; fasc. 2: $\quad \pi^{2}\left(-\pi_{2}\right) ; \quad i-i i$.

Contents: fasc.1: $i$ title; $i i$; iii sources: "BOOKS QUOTED"; iv contents of fasc.1, ilst of 50 species of cryptogans, numbered $1-50$, arranged according to the system of Greville, Fl.Edin., 1822, and notes;

fasc.2: $i$ title; $i i$ list of specimens, numbered 51-100, and a line:

"Fasciculus III will be published as soon as sufficient number of specimens can be got ready." No RT. Language: English.

Speoimens: 50 specimens per fascicle, pasted to the rectos of full quarto leaves, and with printed labels pasted at the bottom of the rectos, left or right; the labels contain 2, sometimes 3 paragraphs, e.g.: "No. 12. NECKERA pumila, E. B. 1443. Uusc. Brit. p. 77. t. | 22. Hook. F. Soot. 2. p. 138. Purt. Middie. Fl. in Lit. | НAB. On the branches of trees and shrubs. Bagley-Wood, I Berks. Rare.", and occasionally longer notes, e.g. n.25, Cuourbitaria oinnabarina Grev. Crypt. Fl.: "HAB. On dead branches of trees, especially on those of the cur-lrant. Common | The receptacle of this species so nearly resembles the Tubsroula-lpia that some botanists have considered it as parasitic on Tuberaularia vulgaris (see Purt. - MidL. Fl. v. 3. P. 476 et 477 , et Grev. Crypt. Fl. p. 135.)".

Paper: leaf size $233 \times 175 \mathrm{~mm}$. (BMNH copy); wove; no wm. observed; paper of the specimen part slightly more bluish than the paper of the labels.

Printere: fasc.1: Talboys and Wheeler, Oxford, England.

fasc. 2: Talboys, D.A., Oxford.

Publisher: apparently the author.

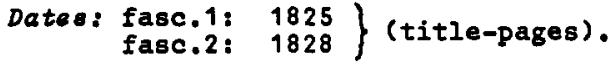

Announcement: Trans.Linn.Soc.16(3): 771. 1833 Mar. 15 (in cat. of library Linn.Soc.) Refo.: BMNH 115 Kew 36 (fasc.1).

Notes. Exsiccata of local cryptogams, consisting of 9 species of ferns, 24 of bryophytes, 9 of lichens, 3 of algae, and 55 of fungi; no new species or varieties noted. The 3rd fasc. hinted at on the verso of the title of fasc. 2 never was realized. Fasc. 1 was already in an advanced stage at the end of Aug. or the beginning of Sep. 1824 (Schultes: Bot.Misc.1: 58. 1830).

\section{BECKER, Johannes}

Biogr. Born 1769 Feb. 20, Speyer, Germany.

Died 1850 Apr. 21, Bieber, Germany.

Becker was, as far as $I$ could find, a teacher, with a strong interest in botany. In 1814 he founded a botanical club in Mergentheim. In 1816 he became a member of the Wetterauische Gesellschaft fur die gesammte Naturkunde, and in 1817 its corresponding botanist. In the same year he became "Stifts-botanikus" of the Senckenberg Institute, Frankfurt am Main, and therefore had the direction of the botanical garden. He worked intensively for it, making many connections and raising its scientific standard. He cultivated critical genera and studied their "Formenkreis" for several years indefatigably. In 1820 he became a full member ("wirklicher Mitglied") of the Senckenbergische Naturforschende Gesellschaft, to which he later sold his herbarium and library at a reasonable price. In 1824 he became a corresponding member of the Naturforschende Gesellschaft des Osterlandes and in 1827 of the Regensburger Botanische Gesellschaft.

He was commemorated in the generic names Beckera Fresenius 1837 and

Beakeropsis Figari \& De Notaris 1854 (both Gramineas).

Ref.: Fresenius [J.B.Georg W.]: Flova $17^{1}(2): 24-29.1834 \mathrm{Jan}$. 14. 
1 Blora der Gegend um Irankfurt am Main.

2 sections in 3 parts. Frankfurt a. 11., [1827-]1828.

Title: "Flora | der | Gegend un Frankfurt am llain | von | Johannes Becker. | Der Senckenbergischen naturforschenden Gesellschaft, des physikalischen Vereins zu Frankfurt a. 1. und der Vetterau. Gesellschaft f. d. Eesammte I Naturkunde virkl. I!itglied, der Königl. Bair. botanischen Gesellschaft | zu Regensburg u. der naturforschend. Gesellschaft des Osterlandes | correspondirendes Mitglied. I Erste Abtheilung. [2: Zweite Abtheilung.] ] Phanerogamie [2: Cryptogamie] | [thick-thin rule] [2: long swelled rule] | Frankfurt a. M., 182.8. in den Verlagsbuchhandlung von | Ludwig Reinherz."

Colzation: $8^{\circ}$ : sect.1: $\pi^{2} 2 \pi^{1}$ (folded table) $7^{8} 2-30^{8}(* 47) \quad 31^{6} 32^{8}\left(325^{+32 * * 4}\right.$ ) $33-34^{8} 35^{6} 36^{4}\left(-36_{4}=47\right.$ cancellans); $i-v i$ 1-3 4-502 [inserts:] 503 504-509 510, $25032504-2510511-557558 \quad(50 \quad 53 \quad 492-493 \quad 545)$; sect. $2(1): \quad \pi^{1} 1-45^{8} \quad 46^{4} \quad 47-51^{8}(-517) \quad 52^{4} ; \quad i-i i \quad 1-3 \quad 4-813814$

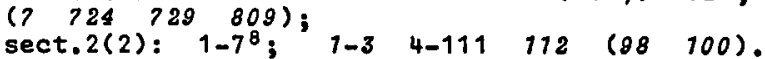

Contents: sect.1: $i$ title; ii imprint: "Gedruckt bei C.L. Bredl | in Offenbach."; iii dedication to: "Herrn Med. Doctor Neuburg | Erstem Direktor der Senckenbergischen naturforschenden | Gesellschaft zu Frankfort am Main"; iv $\square$; $v$ folded table, recto: "Tabellarische Darstellung des Linnéischen Sexualsystems."; vi ${ }^{\prime} ;$ half-title; $2 \square_{1} 3-491$ text, descriptions of phanerogams (localities of rare species only); 492 D; 493-502 additions and corrections; 503-509 supplement to sect.1, additional genera; 5100 ; 2503-2510, 511-544 index of Latin binomials; 545-557 index of German names; 558 corrections;

sect.2: i title to section 2 (complete), ii imprint; part 1: 1 part-title; 20; 3-6 introduction to cryptogams, unheaded; 7-723 text, descriptions of cryptogams except Pyrenomyoetes; 724-728 additions and corrections; $729-808$ index of Latin generic and specific names; 809-813 index of German names; 814 corrections;

part 2: 1 part-title; 2 [i $3-97$ text, descriptions of "Myelomycetes" [=Pyrenomyoe te 8]; $98-99$ additions to sect.2(1); $100-111$ index of Latin generic and specific names of sect. 2(2); 172 index of German names. $\mathrm{RT}$ : family names. Language: German.

Paper: leaf height $198 \mathrm{~mm}$. (F copy, cut); laid, chains vertical; no w. seen. Printer: Bredl, C.L., Offenbach, Germany.

Publisher: Reinherz, Ludwig, Frankfurt am Main, Germany.

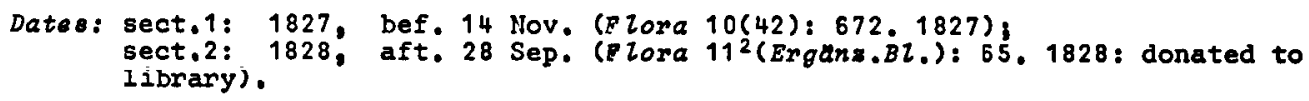

Reviews: sect:1: Elora 19(18): 273-279. 1828 lay 14; sect.1-2(1): Linnaea 5: 29.1830; sect.2(1,2): ELora 132(Ergans.BZ, $): 46-48,1830$.

Refo.: BMIH 120

Bradl.1: $377^{\mathrm{b}}$ Kew 38

Pr.ed. $1 \mathrm{n} .634$

Pr.ed.2 n.543.

Notes. Regional flora, with due stress on cryptogams, including many varieties, some without author citation and therefore difficult to check whether new or not; descriptions present. 
BEHERE, Jean Baptiste Joseph

Biogr. Born 1763 May 21, Hallotière, near Gaillefontaine,

Died 1840 canton Neufchatel [now dép. Seine-Maritime], France.

Béheré Died 1840 , Rouen, dép. Seine inf. [now dép. Seine-Maritime], France.

interested in natural mathematics at Rouen since about 1790; he was strongly

the Socied in natural history, especially in botany. He became a member of corresponding member of thon de Rouen at the foundation, 1792, and later a besides en generale, et partioul botanical works: Discours our l'utilite des soiences mathsmatiques.

Refo.: Girardin, J.: Annuaire des einq departements de L'anoienne Normandie. Sixidme annbe. Caen, Association Normande, 1840, p.477.

1 Musoologia Rothomagensio.

Bull. Soc. Émul. Rouen 1826: 77-120, 1826 [1827 ?].

Title (of periodical fascicle): Séance publique de la Société libre d'Émulation de Rouen, tenue le 9 Juin 1826. Rouen, F. Baudry, Imprimeur du Roi, rue des Carmès, no. 20. Année 1826. [Not a quasi-facsimile. The usual abbreviation is taken from a later title of the periodical.]

Collation (of periodical): $8^{\circ}: \pi^{2}$ ( $\pi_{1}=$ daste-down) A-v $v^{8}$ ( $X_{2}$ =paste-down); $i-i i$ 1 2-321 322 ( 377 , unnumbered pages not rechecked; paste-downs not included in pagination).

Contente (of periodical): i title; $i i \square_{;}$1-73 report of the session, including (19-20) a short report on Bêheré: "M. Béheré, qui s'occupe avec une infatigable perséverance des plantes cryptogames de ce pays, a présentá la sociêter un tablesu analytique dos mousses des environs de Rouen, classées d'aprés les urnes et le péristome. La plus ecrupuleuse exactitude dana la détermination des nombreuses espece de cette famille quil a recueillies, distingue ce travail, qui peut être coneidér comme faigent ouite a celui

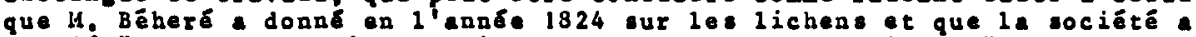
publié."; 74-315 articles printed on order of the society: "Pilces dont

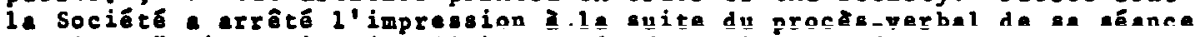
publique.", including (77-120) Musoologia Rothomageneis; 316 errata: 317-321 index; 322 Q.

Table: 1 folded typographical table, inserted after 0.80 , recto $\square$; verso systematical table of the genera of mosses: "TABLEAU SYNOPTIQUE DES GENRES

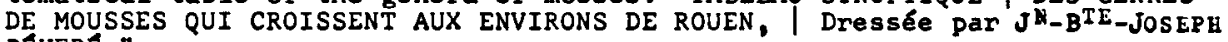
BÉHERÉ."

Printer: Baudry, F., Rouen, France.

Date: 1826 (t.-p.); after 9 Jun. (date of session in which printing of the periodical was ordered);

probably sem.2 (printing will have taken some time);

bef. $27 \mathrm{Jan} .1827$ (Bibliogr. France $16(8): 80.1827 \mathrm{Jan} .27$ ).

Bibl.note. As an exception the collation and contents of the complete fascicle are given, which includes the report on the article of Béheré.

Bot.note. See Béheré n.2. 
2 Muscologia Rothomagensis. Rouen, 1826 [1827?].

Title: "YUSCOLOGIA ROTHOMAGENSIS I OU I TABLEAU ANALYTIQUE I DES MOUSSES I DECOUVERTES JUSQU'A CE JOUR AUX ENVIRONS DE ROUEN, | classess d'apres $\eta_{e s} \mid$ URNES ET L'ORGAIISATION DE LEUR PERISTOME; i Avec les caractères des genres et | l'étymologie de leurs noms, ainsi que la synonymie des | especes et l'indication des lieux ol elles ont été trouves; I PAR $J N^{N}$. $-B^{T E}$-JOSEPH BEHERE. | Minerva head, white in black round field ROUEN, I F. BAUDRY, IMPRIMEUR DU ROI, RUE DES CARMES, N8 20 | [very short swelled rule] | $1826 . "$

Colzation: $8^{\circ}: 7^{6} \quad 2-3^{8} 4^{4} ; \quad i-i v \quad 7-5 \quad 6-48$.

Contents: i-iv $] ;$ half-title; 2 ; 3 title; $40 ; 5-8$ introduction with headtitle: "MUSCOLOGIA ROTHOMAGENSIS | OU | TABLEAUU ANALYTIQUE | DES MOUSSES | DÉCOUVERTES JUSQU'A CE JOUR AUX ENVIRONS DE ROUEN."; 9-48 text with a similar head-title, systematical enumeration of moss species of the Rouen region with synonyms and localities, and a French translation of the generic names: "étymologie". No RT. Language: French.

Table: 1 folded typographical table, inserted after $p .8$, recto $\square$; verso systematical table of the genera of mosses: "TABLEAU SYNOPTIQUE $\uparrow$ DES GENRES DE MOUSSES QUI CROISSENT AUX ENVIRONS DE ROUEN, | Dressée par JN-BTE-JOSEPE
BEHERE." Paper: leaf height $214 \mathrm{~mm}$. (PC copy, cut); laid, chains vertical; wm.

Printer: Baudry, F., Rouen, France.

Date: see discussion under n.1.

Refs.: BMNH 123 Jacks. 290 Pr.ed.1 n.655, ed.2 n.570

Bibl.note: The separate and the article in the periodical differ in the pagination and the added titles. There is no indication that the separate was published before the periodical.

Bot.note. This moss flora of the Rouen region introduced a number of new names, e.g. for linguistic reasons the generic name Dioranum was changed into Dioranodon, which is illegitimate in botanical nomenclature.

BRÉBISSON, [Louis] Alphonse de

Biogr. Born 1798 Sep. 25, Falaise, dép. Calvados, France. Died 1872 Apr. 26, Falaise.

Alphonse de Brébisson was the son of Jean Baptiste Gilles de Brébisson (1760-1832) who was an entomologist and a founder of the Société Linnéenne de Normandie. He attended the "college de Falaise", where he could develop the taste for natural history, imbued at home. He was at an early age introduced to Latreille, A.L. de Jussieu and Brongniart. His interest in botany was especially strengthened by a stay in Vire, with Dubourg d'Isigny. In 1825 he made a trip to Paris with Boisduval, and was even able to go to the French Alpes. His first publication was on orchids of Normandy, 1824 . Later a flora of Normandy followed, which went through several editions. His exsiccata of mosses (1826-39) were brought out to facilitate their study. He finally specialized on algae. He was also interested in photography, especially in microphotography. Moreover he published Statiatique de l'arrondisement de Falaise, 1826-29, 3 vols. + atlas, and studied celtic and gallic monuments. He had administrative positions, including a membership of the council if the town and of the "departement".

In 1827 he married Mélite Gaudin de Villaine, who helped him in his botanical work; she died in 1842. From their three children, the only son became a malacologist.

His name is commemorated in the generic names Brebissonia Spach 1835 , now generally considered a synonym of Fucheia L. (Onagraceas), and Brebiseonia Grunow 1860 (Baoillariophyta, liatom.), nom. oons. 
Refe.: Malbranche, A.: Notioe our $u$, de Br\&bisoon. 10 p. Rouen, 1872. (Extrait du Bull.S00.Ami Soi.Nat.Rouen, année 1872, 2e semestre.)

Morière, M.J.: Notice biographique sur Alphones de Brsbiseon naturaliste. 28 p. Caen, 1874. (Extrait du Buzz.Linn.de Normandie.)

Prévost, M.: Diat.Biogr.Erang. 7: 189. 1956.

1 Houseres de Ia Normandie.

8 fasc., Falaise, 1826-1839 [exsiccata].

Titles (not transcribed in details; main text of fasc.1-3 follows, without distinguishing letter types): "MOUSSES | DE | LA NORMANDIE, | RECUEILLIES ET PUBLIEES I PAR L. ALPHONSE DE BREBISSON, I [quotation, from:] Decandolle, Théor. Elém. de Bot. | PREMIER FASCICULE. [2: DEUXIEME FASCICULE] [3: TROISIEME FASCICULE.] | [short swelled rule] |FALAISE. [2-3: FALAISE, | Imprimerie de BREE I'alné. I A CAEN, chez MANCEL, Libraire, rue St.-Jean, A PARIS, chez MEILHAC, Lib, cloftre St.-Benoit, n8 10.] | [short rule] 1826. [2: 1828.] [3: 1829.]"; [7-8 with addition to the title, after NORMANDIE: "ET D'UNE GRANDE PARTIE DE L'OUEST DE LA FRANCE."; 8 without the name and address of Meilhacl.

Colzation (pagination not present and no inferred pagination given): $8^{\circ}$ :

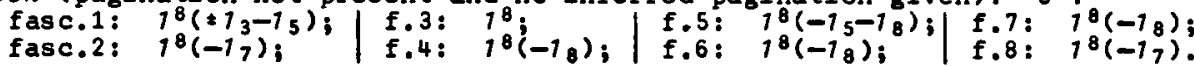

Contents (by gathering references): fasc.1: $1_{1}$ paste-down; $1_{2} 0_{3} \boldsymbol{1}_{3}$ title, $v \square ; 1_{4} \mathrm{r}$ preface, unheaded; $1_{4} \mathrm{~V} \mathrm{D} ; 1_{6} \mathrm{r}$ list of names of the 25 mosses in the specimen part, numbered 1-25, arranged systematically, Bypnum to Andreaea; $16 \mathrm{~V} \square$; remaining leaves: rectos with specimens, versos $\square$; fasc. 2-7: $1_{1}$ paste-down; $1_{2} \square ; 1_{3}$ title, $v \square ; 7_{4} \mathrm{r}$ lists of species: fasc.2: n.26-50, fasc.3: n.51-75, fasc.4: n.76-100, fasc.5: n.101-125, fasc.6: n.126-150, fasc.7: n.151-175, fasc.8: n.176-200; versos $\square$; remaining leaves: rectos with specimens, versos $\square$. No RT. Language: French.

Speoimen part: per fascicle 25 specimens as well as labels pasted to the rectos of the remaining leaves of the first gathering and those of three more gatherings without any printing until 25 leaves were filled; the last leaf in each fascicle was a paste-down and one or two leaves before the last were blank too; the labels contain a) the consecutive number, b) the Latin binomial with c) its abbreviated author citation, in italics; d) as a new paragraph one or more references to descriptions of older authors, and often to one or more synonyms; e) a new paragraph "HAB." giving ecological information (habitat) and exceptionally the locality, ending with the season, obviously of sporophytes.

Paper: leaf size $194 \times 124 \mathrm{~mm}$. (PC copy, cut), wove; no wm. Printer: de Brée l'aine, Falaise, France.

Publishere: de Brée l'aine (see Printer), Mancel, Caen, France;

Meilhac, Paris: fasc,1-7, farsc,8: variant title? (see Bibliogr.Franoe).

Datee

\begin{tabular}{|c|c|c|c|}
\hline fasc. & $\begin{array}{c}\text { Cate } \\
\text { t.-p. }\end{array}$ & publ.date & \multicolumn{1}{|c|}{$\begin{array}{c}\text { Bibliogr. } \\
\text { France }\end{array}$} \\
\hline $1 *$ & 1826 & Dec. 9 & $15(98): 1030$ \\
2 & 1828 & Sep. 27 & $17(39): 712$ \\
3 & 1829 & Apr. 18 & $18(16): 264$ \\
4 & 1830 & Apr. 10 & $19(15): 232$ \\
\hline
\end{tabular}

\begin{tabular}{|c|c|c|c|}
\hline fasc. & $\begin{array}{c}\text { date } \\
\text { t.-p. }\end{array}$ & publ.date & $\begin{array}{c}\text { Bibliogr. } \\
\text { France }\end{array}$ \\
\hline 5 & 1831 & & \\
6 & 1833 & Mar. 2 & $22(9): 134$ \\
7 & 1835 & & \\
8 & 1839 & Apr. 20 & $28(16): 186$ \\
\hline
\end{tabular}

-fasc. 1 bef. 5 Jul.? (copy sent to A.P. de Candolle with letter).

Review: fasc.1-2: Litteratur-Ber. Einnaea $4: 24.1829$.

Refs.: fasc.1-2: Krüg. 113

Stafl. TL n.134. 
Bibz,notes. Exsiccata issued in book form, in boards with a blue paper cover at the outside. The specimens were pasted to the rectos of 25 leaves of 4 gatherings. Narrow strips of paper were bound after every second pair of leaves to provide space for the thickness of the specimens; they simulate stubs of removed leaves. A copy of fasc.1 was described in Bibliogr. Franoe 15 (98): 1030 . 1826 Dec. 9 , stating that the 25 labels were printed on a half-sheet and that the specimens and labels had to be pasted on 25 leaves.

Bot.notes. Exsiccata of lusoi, following a general trend of the period in its makeup. The first series were devoted to common mosses of the local area; later (fasc.7-8) the region covered was enlarged. A number of new names or combinations were proposed; only 2 had a description: Gymnostomum serratum Bréb. 8: n.196. 1839, and Polytrichum commune var. soopularium Bréb. 3: n.61. 1829; a few others had references to previously published descriptions, though indirect, e.g. Syntrichia ruralio var. Laevipiza (Brid.) Bréb. 6: n.142.1833.

BREUTEL, Johann Christian

Biogr. Born 1788 Jan. 21, Weissenburg am Sand, Germany.

Died 1875 Feb. 18, Herrnhut, Saxony, Germany.

Breutel was a member of the Moravian Church, first at Nisky, later at Herrnhut. In the church he had some important functions, as in the Department of Finance, and later in the Department of Missions. In connection with his missionary activity he was in the Antilles, 1840-41, and also in South Africa. Finally he was consecrated bishop on 26 June 1856 , at Herrnhut.

He was interested in bryology, publishing the exsiccata and articles. On his travels he made large collections, but he was not able to study these completely. He was commemorated in the generic name Breutelia (B.S.G.) Schimper 1856 (Musoi, Bryaceas).

Refs.: Trans,Moravian Hist,So0,6:347,380, 476, 589, 1875. Urban, I.: Symb.Antizz. 3: 28.1902.

1 Nusci frondosi exsicoati.

5 centuriae. Leipzig, 1822-1863 [exsiccata].

Dates: Cent.I: 1822; Cent.II: 1843; Cent.III-IV: ....; Cent.V: 1863.

Refo.: Cent.I-V: Lynge, B.: Nyt Mag. Daturvid. 51: 112. 1913;

Cent.V : Verh,Zoot.Bot.Ges. 13(Sitzungober.): 9.1863 (announced by Juratzka, Flora 47: 112. 1864 . published by Dr. J. Holzinger);

Notes. Not seen, but mentioned to draw attention to this set, which contained at least one new name: Polytrichum graaile var. Longisetum 5: n.474. Part was destroyed by fire, according to Lynge, and was replaced by new material, which was not identical.

2 Beitrag zu der Moosgattung Sphagnum.

Flora 7(28): 433-443.1824 Jul. 28.

Date: fasc. dated; see $F$ zora.

Ref.: RSC 1: 612 .

Note. Descriptions of 4 new species of Sphagnum, all with "immersed" sporophytes, with a "Nachschrift" by C.G. Nees; later commented by Bruch ( $n .3)$.

3 Einige vergleiohende Bemerkungen aus den Gattungen Phasoum, Gymnostomum und Grimmia. Flora 9(6): 61-63. 1826 Feb. 14 .

Date: fasc. dated; see Prora.

Note. Rather unimportant; comparison of 2 series of species of different genera. 
BRIDEL, Samuel Élisée (von Bridel, von Bridel-Brideri)

Biogr. Born 1761 Nov. 28, Crassier, Vaud, Switzerland.

Bridel studied at the University of Lausanne and was called to Gotha immediately after his studies to educate the princes August and Friedrich von Sachsen-Gotha. Later he became private secretary and librarian to the prince-hereditary. He visited Paris in 1807 as the secretary of a mission to Napoléon, took part in the scientific life there, participated in botanical excursions, and studied in herbaria. On another visit, to Rome, he also found time to botanize. Finally he became Geheimer Legationsrath. From the Duke of Sachsen-Gotha he received letters of nobility, hence the name von Bridel (in French: de Bridel, in Latin: a Bridel). After he married, he added, according to Swiss custom, his wife's maiden name (Brideri) to his own.

He was an outstanding bryologist, very careful in giving complete citations of all places where moss species were mentioned, and following first Hedwig's classification, later developing his own, with quite a number of new genera and other groups. He also published translations and poems. His herbarium came to the Bot. Mus. Berlin-Dahlem and is still in existence (Stafleu, TL P.50). He was commemorated in the generic names Bridelia Willdenow 1805 (originally spelled Briedelia), Euphorbiaceae, based on Cluytia Roxb. (a later homonym of ciutia L.), and Lebidiera Baillon 1858 (an anagram of Briedelia), considered a Bynonym of Cleisanthus J.D. Hooker (Euphorbiaceae).

Refo.: Nouv.Biogr.Ano.Mod. nouv.ed. 3: 144. 1843-47.

Rose, H.J.: A new general biographical diationary 5: 53. 1857.

Nouv.Biogr. Univ. 7: 382-383. 1863.

Engler, [A.]: Alig.Deutsohe Biogr. 3: 328, 1876.

1 Muscologia recentiorum ...

2 vols. in 4 parts. Gotha-Paris, 1797-1803.

Titze: "MVSCOLOGIA RECENTIORVM [2(2): MUSCOLOGIA RECENTIORUM] I SEV | ANALYSIS, HISTORIA, [2(2)-(3) no comma] | ET I DESCRIPTIO METHODICA | ONNIVM MVSCORVM FRONDOSORVM HVCVSQVE COGNITORVM [2(1) added: ! I AD NORMAM HEDWIGII [2(1) added: ] | A | SAM. EL. BRIDEL, [2(3):SAM. EL. BRIDEL.] | [short rule] $[2(2)-(3)$ : short swelled rule] | -- ihil est quod non mortalibus afferat voum [2(3): Wihil est, quod non mortalibjo afferat vqum.] | PETRON. FRAGM. [long rule] [2(2)-(3): long swelled rule] | Tom. I. [2(1); Tom. II.|PARSI] [2(2): Tom. II. | Pars II.] [2(3): Tom. II.|Pars III.] | 2(1): fuil rule] [2(1): CVM TABVLIS SEX AENEIS.] [2(2): Cum tabulis sex aeneis.] [2(3): Cum tabulis duabus aeneis.] | [full rule of 2 long and 6 short arrows, with fancy center] [2(1): long wavy rule with four thick straight parts] [2(2): very long swelled rule with wavy middle part] [2(3): very long swelled rule with asterisk in the center] | GOTHAE, [2(2)-(3) no comma] I APVD CAROLVM GVIL. ETTINGERVM | PARISIIS [2(1) added:, ] | ARYD BARROIS IVNIOREM | MDCCXCVII. [2(1): CIJIXCCXCVIII.] [2(2): MDCCCI.] [2(3): MDCCCIII. "

Colzation: $4^{\circ}$ : vol.1: $a-c^{4}\left(2 a_{1}\right)$ A-Y $Y^{4}\left( \pm L_{2}\right) Z^{4}\left(-L_{3}-Z_{4}\right) x^{1}$ ( $\$ 1-3$ signed); $I-V$ VI-XXIV 7-3 4-179 780-782 (XI);

vol.2(1): *4 $2 * 4(-2 * 4) \quad A-2 E^{4}\left(* 2 E_{4}\right) \quad(2 * 3$ unsigned, $2 * 1$ signed '*'); $I-V$ VI-VIII 2VII-2VIII IX-X XI-XII (=XIV) 1-3 4-222 $223-224$ ( 134 as ' 112 ', 220 as ' $214^{\prime}$ ');

vol.2(2): $a^{4} b^{2}$ (italics) A-2A4 $*^{2} X^{2} \quad\left(H_{3}\right.$ as ' $\mathrm{H}_{2}^{\prime}, 2 A_{3}$ as 'Z $Z_{3}^{\prime}, X_{3}$

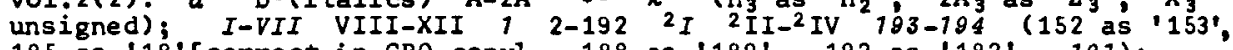
185 as ' 18 ' (correct in GRO copy], 188 as ' $180^{\prime}, 192$ as '182', 187); vol.2(3): $A^{4}$ B-Z (\$1-2 signed); I-VII VIII $9-176$ 177-184 $(73 \quad 15$, 173 as '175', 176 as ' 178 ').

Contents: vol.1: I title; II $\square$; III dedication, poem to Johann Hedwig (17301799), IV ${ }^{\prime}$; V-X preface: "PRAELOQVIVM.", dated: "4 Idus Quintiles 1795."; $X I-X X I V$ sources; 7 part-title: "MVSCOLOGIÁE | [swelled fancy rule] ] PARS I. I CONTINENS MVSCORVM ANALYSIM I ET I MVSCOLOGIAE HISTORIAM. I [swelled fancy rule]"; 2 [; 3-179 text in 11 chapters, morphology and 
classifications of Husci, including Hedwig's, and descriptions of genera (148-179); 180 contents and imprint; $187-182$ addenda et emendanda; vol.2( 1 ): I title; II ; III dedication to Johann Friedrich Karl Grimon (1737-1821), archiater at Gotha; IV $\square$; V-X preface: "PRAELOQVIVM.", datede "10 Kalendas Ianuarias 1797."; XI additional sources; XII J; 1 parttitle: "PARS II."; 2 ]; 3-208 text, descriptions of genera, species and occasionally varieties of mosses, Phasoum - Barbula; 209-214 explanations of plates; 215-222 index of Latin names and synonyms of mosses as well as of names in modern languages; 222 imprint; 223-224 addenda et emendanda; vol.2(2): I title; II $\square$; III part-title: "Tom. III."; IV D; V dedication to Antoine Laurent de Iussieu (1748-1836); VI D; VII-XII preface: "PRAELOQVIVM.", dated: "tertio Idus Decembris 1800."; 1-190 text continued, Heokera - Bypnum; 181-192 explanation of plates; 192 imprint; $2 I-{ }^{2} I V$ index to part 2; 193-794 addenda et emendanda;

vol.2(3): I title; II D; III part-title: "Tom. IV."; IV $\square$; V dedication to Ernst [Friedrich] von Schlotheim (1764-1832), palaeontologist; VI O; VII-VIII, 9-12 preface: "PRAELOQVIVM.", dated "quarto Idus Quintileo 1802."; 13-14 additional sources; 15-173 text concluded, Brivm [sic] Meesia; 174-176 explanation of plates; 177-182 index to part 3; 183-181 D. No RT. Language: Latin.

Plates: 14 copper engravings (possibly with etching) of moss species; numbered: vol.2(1): "I." "Tab. VI.", vol.2(2): "Tab. I"-"Tab VI", vol.2(3): "I"-"II". detail-figures in vol.2(3) numbered consecutively; plate-marks: $193 \times 159 \mathrm{~mm}$. (pl.1 in vol.2(1)), $226 \times 174 \mathrm{~mm}$. (pl.1 in vol.2(3)).

Artist: the author: vol.2(1) pls.5-6 and vol.2(2) pls.2-6 signed, possibly all by him.

Engravers: Liebe, [Christian Gottlob August, died Leipzig circa 1810, or Christian Gottlob, 1746-1819, Leipzig]: vol. 2(1) pls. 5-6; Schroter, Johann Friedrich (1770-1836), Leipzig, engraver to the Leipzig University: vol.2(2) pls.1-6, vol.2(3): pls.1-2; other plates unsigned.

Paper (text): leaf height $239 \mathrm{~mm}$. (HBL copy, cut); laid, chains horizontal; wm.: "F [large capital in outline script]": vol.1: a b A-D F; "C B [outline letters]": vol.1: E [seen in NYBG copy; no wm. in HBL copy in this gathering];

"I C S [outline letters in cartouche with knob]": vol.2(1): * 2* B-2E; $" 4$ I $R$ [very large outline 4 with small structure resembling $R$ attached to base of the stalk]": vol.2(1): $A$;

"S [outline slender capital] = 4 [ending in anchor below] [or countermark missing ${ }^{n}$ : vol.2(2): A-I;

"L M F [outline letters]": vol.2(2): $K-X \quad Z 2 A$, (Y uncertain); plate paper: vol.2(1): laid, chains vertical; wm.: "ETUPES" (pl.I in HBL copy) or "G.WILD" (pl.VI in HBL copy); vol.2(2)-(3): laid, chains horizontal.

Printer: Hoffmann, Carl Gottlob, "Silusiae" = Schleusingen, Germany; vol.2(3) without imprint.

Publishers: Ettinger, Carl Wilhelm, Gotha, Germany; Barrois Jr., Paris, France.

Dates: vol.1: 1797 (t.-p.); $\mid$ vol.2(2): 1801 May 9 (Sayre p. 8); vol.2(1): 1798 (t.-p.);

Reviews: vol.1: Aroh.Bot.(Leipzig) 2(1): 52-54.1799; J.Phys. (Paris) 52: 86-87. 1801 Jan.;

vol.1-2(2): De Candolle, A.P.: Bul.z.Soc.Philom.Paris 3(56): 63-64. 1801; Gott.Ge Z.Anz. $1801^{3}(167)$ : $1661 \cdot 1801$; J.Bot. (Schrad.) 1801'(1): 188-205.1802;

vol.1-2(3): Ann.Bot.(König Sims) 1(1): 35. 1804 May 1;

vol.2(3): Neues J.Bot. (Schrad.) 1(1): 150-155. 1805; Ann.Bot. (König \&ims) 2(2): 331-337. 1805 oct.1. 
Refe.: BMNH 235

Brun.1: 1255

Cat.Juss. n.2285

E.As.Bot. 53
Graesse 1: 539

Heins.1: 414

Jacks. 153

Kew 77
$\mathrm{Krug} \cdot 241$

Linn.Soc. 95

(incompl. copy) Stafl. TL n.145

Milt. 484 Un.Edinb.1: 519.

Varianta: 2 copies have been seen with the original cancellandum of $L_{2}$ of vol.1 in its place and the cancellans as part of sheet $Z$ ( $B$ copy and $F$, copy 2 ),

Bibl.notes. The cancellans title-page of vol.1, perhaps, is not present in all copies; this should be checked. I did not find the reason for the cancellans $L_{2}$ in vol.1, but I did not have time enough to check word for word. I also suspect some of the "addenda et emendanda" to have been replaced by later leaves, as I could prove for Bridel's Bryologia Universa, vol.1. The paper, though with different marks, is rather uniform and has conspicuous darker particles (lignin?).

Bot.notes. Bridel's first bryological work, giving up-to-date treatment of the group Musoi, and accepting Hedwig's delimitation of the genera. The earlier literature is well covered. By the change of the starting-point of Musoi (Sphagnum excepted) vol.2(2)-(3) became more important, being published shortly after Hedwig's posthumous speoies Muscorum. This work is not yet cited in vol.2(2), but it is in $2(3)$. The plates do not have the high quality of those of Hedwig's works.

2 Nuscologiae recentiorum oupplementum eeu epecies muscorum.

3 parts. Gotha, 1806-1817.

Titles: parts 1 \& 2: "MVSCOLOGIAE RECENTIORVM [2: MVSCOLOGIAE RECENTIORUM] SVPPLEMENTVM | SEV | SPECIES MVSCORVM | A | SAM. EL. A BRIDEL. | [medium long rule] | - - Wihiz est, quod non mortalibus afferat vsum. | PETRON. FRAGM. [long rule] | Pars I. [2: Pars II.] | [full rule of alternate round and elliptical dots with fancy middle part] [2: thick-thin double rule with fancy middle part] [ GOTHAE, APUD CAROLUM GVIL. ETTINGERVM [2: EX OFIICINA LIBRARIA ETTINGERIANA.] | MDCCCVI. [2: MDCCCXII.]"; part 3: "MUSCOLOGIAE RECENTIORUM | SUPPLEMENTUM I SEU | SPECIES MUSCORUM $\AA|S A M, E L . A B R I D E L$.$| [medium long wavy mule] | - - - Nihil est, quod$ non moxtalibus afferat uoum. | PETRON. FRAGM. | [medium long wavy rule] | Pare III. [ [full rule decorated with ivy wreath winding over the whole length] i GOTHAE, | EX OFFICINA LIBRARIA ETTINGERIANA. | MDCCCXVII."

Colzation: $4^{\circ}:$ part 1: *4 A-2L" (\$1-3 signed); I-V VI-VIII $12-271272$; part 2: $\pi^{-1} A-2 I^{4}\left(-2 I_{3}\right) \quad 2 K^{2} \chi^{2} ; \quad i-i i$ i 2-257 258-262; part 3: *4 2*2 $3 *-4 * 45 * 2$ A-O $\mathrm{P}^{2}$ (\$3 unsigned, $3 * 1$ as $1 * *^{\prime}, 3 * 2$ as $\left(* 22^{\prime}\right) ; \quad I-I I I$ IV-XXXII $12-115116$ (V-VI).

Contente: part 1: I title; II $\square$; III dedication: "A LA CLASSE I DES SCIENCES PHYSIQVES | DE | L'INSTITUT NATIONAL | DE FRANCE"; IV $]$; V-VI preface: "PRAELOQVIVM.", dated: "IX Calend. Februar. | clolocccvI."; VII-VIII additional sources; 1-269 text, descriptions of mosses, Phasoum - Barbula, including a synoptical table of Polytriohkm (81); 270-271 addenda; 272 imprint;

part 2: i title; ii D; 1-257 text, Orthotriahum - Bypnum, including synoptical tables, of Weokera (43) and Hypnum (257); $2580 ; 259-261$ addenda; 267-262 additional sources; 262 emendanda; part 3: I title; II 1 ; III-IV preface: "Praeloquium." dated: "Idus Januarias 1817."; $V$ additional sources; VI $D$; VII-XXXII index to parts 1-3, including names in modern languages; XXXII indication for the binder in German at the far bottom; $1-115$ text concluded, Gymnocephalus - Buxvaumia, 1 with correction, in footnote, to part 2 p.1; 176 emendanda. No RT. Language: Latin. 
Papar: ieaf height $239 \mathrm{~mm}$. (HBL copy, cut); laid, chains horizontal; wm,: "4|R [outline, very large 4, small $R$ attached to lower part of its stalk, possibly some other letters presentj": part 1: * (in NYBG copy, not in HBL cOFY) 2I;

"4 [stalk ending in anchor, outline]": part 2: $x$;

"W [erect swash script]": part 3: A-E, F partly (NYBG copy, not in hBL copy).

Printer: Crusen, Ge [org] C[hristo]ph Jac[ob], Schleusingen, Germany.

Publisher: Ettinger, Carl Wilhelm (imprint changed into: "Ex OrFICIMA LIBRARIA ETTINGERIANA." in parts 2 \& 3 ), Gotha, Germany.

Dates: part 1: 1806 Apr. 20 (Sayre: Dates of pubz, 27, 1959);

part 2: 1812 Sep. 27 (Sayre: Dates of pubz. 42. 1959);

part 3: 1817 Sep. 28 (Sayre: Dates of pub2. 53.. 1959: already anncd. for Mich.Fair 1816: Iois (oken) 1(1 St. 15): 114. 1817 1816; this apparently was not realized in 1816);

prob.bef. Sep. (Sayre cites J.Scav. of Sep. 1817).

Reviews: part 1: Palisot de Beauvois: J.Phys.(Paris) 67: 16-25. 1808 Jul.; J.Bot. (Desvaux) 1: 43-61. 1808 (review of foregoing review); part 2: Palisot de Beauvois: J.Bot.Appl. (Desvaux) 2: 153-157. 1813 Oct.

\begin{tabular}{l|ll} 
Refo.: BMNH 235 & Heins.1: 414, 6: 107
\end{tabular}

Brun.1: 1255

Cat.Juss. 2285

(incompl.copy)

(date of 1 as 1807)

Jacks. 153

Kew 77

E.As.Bot. $53 \quad$ Krlg. 241

Milt. 484 (date of 1 as 1807)

Pr.ed.1 n.1270, ed. $2 \mathrm{n} .1143$

Staf1. TL $n \cdot 145$

Teyl.1: 404

Un.Edinb.1: 519.

Variants: part 1: possibly copies with title-date 1807 exist; part 2: $x$ absent in some copies (HBL); its addition might be a postpublication state.

Bibl.noter. Printed on paper similar to that of Musoologia recentiorum, and probably in the same shop, in the small town of Schleusingen, about 30 miles south of Gotha. In part 2 the loose leaf $\pi$ possibly was conjugate with 2I. The general index was to be placed at the end of part 3, according to the instructions to the binder printed on P.XXXII, so the ideal copy should be reported in this condition; I prefer the simpler collation as the sheets were printed.

Bot.notes. Though the title simply says: supplement of the muscologia recentiorum, it is nevertheless virtually a new work, treating all moss genera and species of the world known to Bridel up to date, or cited from other authors. Bridel himself cited these 3 parts later under the second title: species musoorum, which practice was followed in the Index Muscorum, for brevity. New genera described are: Anodontium Brid. 1: 41 (nom. rej.) and Sohlotheimia Brid. 2: 16. The spelling of the name of the genus Cynontodium of Hedwig was deliberately changed into Cynodontium; the latter name was later conserved in a sense excluding the possible types of the genus of Hedwig and Bridel. Some other recent genera were accepted by Bridel, as Paludeila Ehrh., and Conostomum Swartz of which he did not yet cite the original publication, but of which he nevertheless gave Swartz's description. For the rest the treatment of the genera was still closely following the Hedwigian concept.

3 Methodus nova muscorum ... Muscologiae recentiorum supplementum pars 4 seu $\frac{\text { Mantisea ... }}{\text { Gotha, }} 1819$.

Titie p.II: "MUSCOLOGIAE RECENTIORUM | SUPPLEMENTUM | PARS IV | SEU | MANTISSA | GENERUM SPECIERUMQUE MUSCORUM | FRONDOSORUM UNIVERSA | A I SAM. EL. A BRIDEL. | [medium long swelled rule] | .... Nihiz est, quod non mortalibus afferat usum. PETRow. Fragm. [Iong swejled rule] i Cum tabulis duabus aeneis. I [very long swelled rule] GOTHAE | APUD A. UKERTUM | MDCCCXIX." 
Titze p.III: "METHODUS | NOVA | MUSCORUM | AD NATURAE | NORMAM MELIUS INSTITUTA | ET | MUSCOLOGIA RECENTIORUM | ACCOMMODATA| A | SAM. EL. A BRIDEL. | [TWO short swelled rules with diamond between] | .... Ilihil est, quod non mortalibus afferat usum. | PETRON. Fragm. | [medium long swelled rule] | Cum tabulis duabus aeneis. [ [very long swelled rule]| GothAE | APUD A. UKERTUM | MDCCCXIX."

collation: $4^{\circ}: \quad-2 * 4 \quad 3 * 2(-3 * 2) \quad A-2 E^{4}\left(-2 E_{4}=3 * 1\right)$ (* unsigned, $\$ 3$ unsigred); I-VI VII-XVIII $122220221-222$ (208 as '108')。

Contents: I III title Methodus Nov. Musa; IV D; V-VI preface: "PRAELOQUIUM.", dáted: "mense Majo 1818."; VII-XVIII explanation of Bridel's new method of classification of mosses: "Nonnulia de Methodo nostra Musoorum | frondosorum praemisea." with classification table and characters of genera (XII-XVIII); 1-205 text, descriptions of species of Musai, Sphagnum - Dawsonia; 206-207 appendix; 208-209 explanation of plates; 210-220 index; 221 errata; $222 \square$. RT: taxonomic groups, e.g.: "Vaginulati. Peristomi. Pleuroaarpi." Language: Latin.

Plates: 2 copper-engravings (possibly with etching) of moss species, numbered: Tab. I." and "Tab. II."; plate-mark: $224 \times 182 \mathrm{~mm}$. (pI.1).

Artist: pls. unsigned; possibly the author.

Engraver: pls. unsigned.

Paper: text: leaf height $237 \mathrm{~mm}$. (HBL copy, cut); laid, chains horizontal; wm. absent (or too small to be observed); plates: wove; wm.: "H [swash script]" in corner of plate 1 (HBL copy).

Printere: no imprint.

Publisher: Ukert [or Uckert], A., Gotha, Germany.

Date: 1818 Dec. 31 (Leipz.Lit.zeit., fide Sayre p.60);

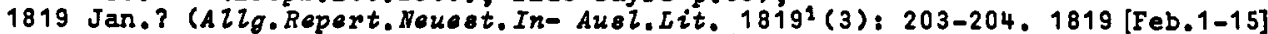
compare Isis (Oken) $3(11): 1851-1856,1818$ [1819?]).

Reviews: see Date 3 Sprengel, C [urt]: Neue Entdeok.PfLansenk, 1:184-204, 1820; Leip..Lit.zeit. 1821 Feb. 21 (fide Sayre).

Refs.: BMNH 235

Brun.1: 1256

E.As.Bot. 53

\section{$\mathrm{KrOg} .241$}

Mass. HS-H 38

Mass.HS-M 1: 292
Milt. 484

Pr.ed.1 n.1271, ed.2 n.1144 Stafl. TL n.145 Un.Edinb.1: 519 .

Variants: see title-page issue of 1822: Bridel n.4.

Bibl.notes. The first title indicates this book as Muscologiae Recentionum Supplementum 4. Several references of publication in Dec. 1818 concern, in my opinion, pre-publication announcements; I did not check this (compare Sayre, p.60). Later Bridel himself cited this issue as: "Mant. Muso.".

Bot.notes. New and complete treatment of the mosses, incorporating Bridel's views on the natural classification of the mosses. The Hedwigian classification was not completely followed anymore, as was done in the Muso. Recent.; e.g. the characters of the calyptra were used.

Bridel proposed several new genera: PLouridium XII, 10, PyramiduZa XIII. 20, Schistidium XIII, 20, Giyphomitrium XIII, 30, Campyiopus XIV, 71, Racomitrium XIV, 78, Deamatodon XIV, 86, ULota XIV, 112, Naoromitrium XVI, 132 , Antitriahia XVI, 136, Anacamptodon XVI, 136, Chaetephora 148 (spelled Chaetophora XVII, illegitimate because of the earlier homonym Chaetophora Agardh in $A$ igae), Pterigophylium XVII, 149 (rejected in favor of Hookeria Sm.). 
4 Nethodus nova muscorum... Uuscologia recentiorum supplementum pars 4 seu Hantisea...

[2nd issue] Leipzig, 1822 .

Titzes: reset, both titles ending: "... aeneis | LIPSIAE | APUD J. A. BARTHIUM | MDCCCXXII."

Collation: $4^{\circ}$ : as issue 1, except: $*^{4}\left(-*_{1,2}+* 1,2\right) ; 208$ as 1108' (Teyl. copy).

Paper (of cancellantia): leaf height $239 \mathrm{~mm}$. (Teyl. copy, cut); laid, chains horizontal; wm.: "N O [swash script, partly outline, in corner of sheet]".

Publisher: Barth, Johann Ambrosius (1760-1813), Leipzig, Germany; firm headed by his son Adolph Ambrosius Barth (1790-1851); biogr.: Mưhlbrecht: "Barth, Johann Ambrosius B." in Allg.Deutsche Biogr. 2: 99-100. 1875.

Date: 1822 (t.-p.), probably early (see notes).

Refi.: BMNH 235 Heins.7(1): 110 Kew 77 Stafl. TL n.145 Teyl.1: 404.

Bib 2.notes. The reason for this issue, as already implied by the change on the title-page, is clearly stated in an advertisement, undated, present in: Literarischer Anzeiger (Brockhaus) 1822(7): 4. 1822, in which the latest date was $24 \mathrm{Jan} .1822$. This advertisement runs:

"Aus dem Verlage Herrn Uckert's in Gotha habe I an mich gekauft: [Iines in gothic] | Bride1, Sam. El. a, Methodus nova Muscorum | ad naturae normam melius instituta et musco-|logiae recentiorum accommodata cum tab. II | aeneis. 4 ma. 2 Thlr. | Auch unter dem Titei: [line in gothic] ।

Bridel, Sam. El. a, Muscologiae recentiorum | supplementum Pars IV. geu Mantissa generum | specierumque muscorum frondosorum uni-|versa. [remaining lines in gothic] und empehlen dieser Band allen Besitzern der fruther erschie-|nenen, so wie jedem Botanik-studirenden alo ein auch für| sich bestehendes Ganze. Die Ermbsigung des Preises von | 3 Thlr. 12 Gr. auf 2 ThIr. wird dem Absatze nur forderlich | sein können. | Joh. Ambr. Barth." Here the promotion of sale is explicitly mentioned; for the new title Barth will have had the same reason, fulfilling the criterion for re-issue. Apparently Bridel was not consulted; in 1822 he was already married and would have added his wife's name Brideri.

5 Bryologia universa...

2 vols., Leipzig, 1826-1827.

Titze: "SAM. EL. A BRIDEL-BRIDERI | A CONSILIIS SECRETIS LEGATIONIS SAXO-GOTHANAE etc. | BRYOLOGIA | UNIVERSA | SEU | SYSTEMATICA AD NOVAM METHODUM | DISPOSITIO, HISTORIA | ET | DESCRIPTIO | OMNIUM | MUSCORUM FRONDOSORUM | HUCUSQUE COGNITORUM I CUM I SYNONYMIA EX AUCTORIBUS PROBATISSIMIS. I ACCEDUNT TABULAE AENEAE TREDECIM. | [long rule] | VOLUMEN PRIMUM. [2: VOLUMEN SECUNDUM.] | [full swelled rule] | LIPSIAE, 1826 [2: LIPSIAE, 1827] I SUMTIBUS JOAN. AMBROS. BARTH."

Colzation: $8^{\circ}:$ vol.1: $\pi^{1} 1-3^{8} A-2 Z^{8} 3 A^{6}\left(-3 A_{3}\right) \quad 3 B-3 H^{8} \quad x^{1}\left( \pm X_{1}\right)$ (\$1-2 signed); $i-i i \quad I$ II-XLVI. XLVII-XLVIII 7 2-856 $857-860$ (XIII XXIX XLII 21 717 747);

vol. $2: \pi^{1} \quad A-3 B^{8}\left(-2 F_{8}-2 G_{1}+2 G_{1}\right) \quad 3 C-3 I^{4} \quad 3 K^{6} \quad x^{1} \quad 3 L^{8}\left(-3 L_{7}=2 G_{1}\right.$ cancellans, $-3 L_{8}=x^{1}$ cancellans of vol.1); $i-i i, 12-463466-848$ 849-850 (760 663 668709733836 ; in inner corner: $141299 ; 463$ as '463 et 464', 466 as ' 465 et $466^{\prime}, 760$ as $\left(860^{\prime}\right)$.

Contents: vol.1: $i$ title; $i i$ the quotation from Petron[ius], used in Bridel's other bryological works on the title-page; I-XII preface: "PRAELOQUIUM." dated 16 Dec. 1826; XIII-XXVIII sources (by abbreviations); XXIX-XLI systematical arrangement of moss genera: "GENERUM MUSCORUM FRONDOSORUM | DISPOSITIO SYSTEMATICA | PER | CLASSES ET ORDINES."; XLII-XLVI trial of an arrangement of moss genera in natural families: "TENTAMEN DISPOSITIONIS MUSCORUM | FRONDOSORUM GENERUM IN FAMI-|LIAS NATURALES."; XLVII-XLVIII D; 
1-716 text, descriptions of new genera, species and varieties of Musi, Sphagnum - Cinolidium; 717-746 "APPENDIX. | Huscorum Orthotrichoideorum Dispositio emendata | et enumeratio adaucta."; 746 "FINIS | VOLUMINIS PRIMI."; 747-856 supplement to vol.1, descriptions of new genera, species and varieties and additions to those treated in vol.1; $857-858$ ist of natural history books published by J.A. Barth; 859-emendations; 860- $\square$; $859+-860+$ additions and emendations, including the corrections of the cancellandum, some again corrected;

vol.2: $i$ title; $i i \square ; 1-732$ text concluded, Paludella - Andreaca; 733-772 supplement to vol.2; 773-831 index of Latin names of genera species and varieties; 831-835 index of names and genera in German (831-832), French (832-834), English (834-835); 836-848 explanation of the plates; $849-850$ additions and emendations to vol.2. RT: in text taxonomic groups down to genera, e.g.: "PLEUROCARPI, PERISTOMI. HYPNUM." " preceded by: "SUPPL." in the 2 supplements; chapter headings in the preliminaries, indexes and appendix. Language: Latin.

Plate: 13 copper-engravings (in general stipple-engraving), numbered: "Tab. In "Tab. $\chi^{\text {" }}$ and "Supp I. I" - "Supp 2 . III" suppI.I \& II completely and suppl.III partly hand-colored; pls.1-10 illustrating sporophyte characters of genera (species indicated in the explanation); suppl pls.1-3 giving also species; plate-mark: $198 \times 108 \mathrm{~mm}$. (pl.7); pl.5 has the spelling "Cynotidium" instead of "Cinolidium".

Artiot: Clauder, C., Germany: 8 pls. $(1-3,6-10)$; unsigned: 5 pls. (4-5, suppl.1-3).

Engravere: Bohme, Johann Christian (b, 1771), Germany: 2 pls. (7, 9); Malier, Fr. Ed., Germany: 7 pls. (1-6, suppl.3); unsigned: 4 pis. $(8,10,8 u p p 1,1-2)$.

Paper: text: according to an announcement in Flora $10^{2}$ (Beil.1): 101. 1827 [Dec.], the book was available in four paper varieties: a) Druckpapier, b) Velindruckpapier, c) Schreibpapier, d) Schweizer Velinpapier; Brunet (ed.5, 1: 1255) mentions only three paper types: "pap. fin" and "pap. vél." besides the normal paper; most copies I saw up to now were on normal paper, described here: leaf height $210 \mathrm{~mm}$. (HBL copy, cut); laid, chains vertical; $\mathrm{wm}$.: "J. P. W. [partly outline script]" at left bottom quarter of sheet: vol.1: complete except sol.2: A-G 2S-3B 3C-3F (some copies);

"S P [narrow outline script]": vol.2: H-R; "[crown]" in sheet center: vol.2: $S$ 3C 3F-3L(some copies); "B" in sheet center: vol.2: 3F-3L(some copies); plate paper: wove; no wm. observed.

Printer: no imprint (printed in Leipzig, according to Flora 8(22): 352. 1825 Jun. 14). Publieher: Barth, Johann Ambrosius, Leipzig (see Bridel n.4).

Dates: vol.1: $i-i i$ 1-746: 1826 (t.-p.); trim.1 (Linnaea 1(2): 262-263, 1826 Apr.);

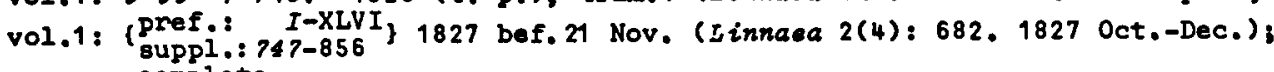

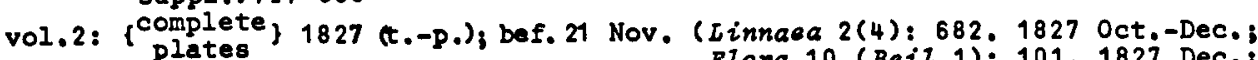
Flora 10 (Beil.1): 101.1827 Dec.: Flora 10 (43): 688 . 1827 Nov. 21).

Reviews: AlZg.Repert. Heuest.In-AueZ.Lit. 18273(4): 241-244. 1827[16-31 Sep.?] R[aspai] 1: Bull.Soi. Nat. 12(12): 383-387, 1827 Dec.

Hornschuch, C.F.: Jahrb. Hisa.Krit. 1828 (55-56): 442-448,1828, (see $(57-58): 449-464,1828 ;$, Hornschuch

Furnrohr, A.E.: RZora $12^{2}\left(E_{r}\right.$ ans.BZ. ): 1-60.1829. n.9)

Bibliogr.study: Stafleu, F.A.: Taxonomio Literature n.146. 1967.

Refe.: BINH 235

Brun. 1: 1256

E.As. Bot. 53

Heins. $7(1): 109$
Kew 77

$\mathrm{Krug} \cdot 242$

Mass.HS-H 38

Mass.HS-M 1: 292
Milt. 485

Pr.ed.1 n.1272, ed. 2 n.1145

Stafl. TL n.146

Utr. n.268. 
Bibl.notes. A number of interesting problems are to be found in this book. Firstly the date of publication was one of the three major problems which I hoped to solve, especially the relative order of publication of the parts of Schwaegrichen's Supplement and the volumes of this work. Particularly the suppl. to vol.1, which clearly was prepared after the main body of vol. 1 had been printed, needed more exact dating than the vague indication on which the date 1827 was assigned to it in Index Musoorum, as well as the preface and the long introduction. These dates are fairly well settled now, although some refinement still could be achieved. Stafleu, Tax.Lit. $n .146$, discusses the possibility of a long delay in the publication of vol, 1+2, until sem.2 of 1828. The reviews and announcements mentioned above, especialiy those in Linnaea (citing the text and even indicating a duplication in the numbering of the genera in vol.1) confirm the tentative conclusion used in Index Muscorum. Some doubt remains whether vol.1 (minus introduction and supplement) was generally available in 1826 since I know of only one review. Mougeot (which see) cited page numbers already in 1826, though from correspondence. Nevertheless, 1826 has to stand since there is no proof of the contrary. Secondly, the large number (4) of paper states in which the book was of fered is unusual. Though I was aware of the problem, I have not been able to recognize definitely different paper qualities. I am sure I did not yet see a copy on wove paper, but I might have had some copies of which I did not study the watermark and therefore may have overlooked another laid paper type. of one of the copies in Paris (PC), I carefully searched for the watermark in a sheet of the supplement to vol.1 which was still unbound, and there was positively no watemark in that sheet; but I did not check other leaves; this may have been a copy on another paper type.

Thirdly, some cancels were found. The cancellans $2 G_{1}$ in vol.2 is very obvious because of the double page numbers, since it replaces two leaves, $2 F_{8}$ and $2 G_{1}$ cancellanda. The reason for this I learned from the $G H$ copy. From the three species treated on the original leaves Bupnum starki ${ }^{2}$ was assigned another place on p.595; the others, $B$. laxifolium and $B$. ariepifolium. had already been treated as Isothecium species ( $\mathrm{p} .359,356)$. In the cancellans the remaining species, Hypnum lutesoens, was assigned a combined number, 57-60. The new text contained a short discussion of the three other species. The same copy has the cancellandum $X$ in vol.1 (as has the GRO copy), recto with corrections, verso blank, originally placed after p.746. The cancellans has recto and verso corrections, includes all corrections of the cancellandum, even corrects an earlier correction (Roggevelt had been Roggeveli in the text and Roggevelo in the cancellandum), and has a correction to the supplement, hence the place assigned to it in this collation.

Bot.notbs. This work is the culmination of Bridel's studies on Musoi. In a masterly way he treated all species known to him, arranged them in well defined genera and the genera into higher groups, elaborating his own classification of 1819. This classification is completely based on the characters of the sporophyte and surrounding organs. He used for two of his five classes the names Acrocarpi and Pleurooarpi, a time-honored distinction still useful in field work in the temperate region, though outdated in this century by the work of Fleischer and Brotherus.

Bridel proposed 40 new generic names, some illegitimate because of earlier homonyms or because types of earlier names were included. Of the remaining names several were maintained by the majority of later authors, e.g. Arohidium Catosoopium, Ceratodon, Hyophiza, Hypopterygium, Isatheoium, Philonotio and Rhizogonium, All species had ample descriptions, many new species were proposed as well as a considerable number of new specific combinations. Some genera were divided into groups, to which the rank of subgenus was assigned in the Index Musoorum, especialiy since trinomials were used; in the index and in the explanation to the plates these names were treated as generic names. with binomials, e.g. Physoomitrium. The synonymy is very extensive, with a nearly completr: citation of every place where the species in question is mentioned, which vas very helpful in tracing post-Hedwigian publications for the
Index Muocorum.

The first personal name in the parentheses after a specific name in Bridel's work indicates the collector, not the author of the name. 
BROWN, Robert

Biogr. Born 1773 Dec. 21, Montrose, Scotland.

Died 1858 Jun. 10, London, England.

R. Brown had his earliest education at the Montrose grammar school. He entered Marischal College, Aberdeen, at the age of 14 , and obtained the Ramsay bursary in Philosophy. Going to the University of Edinburgh in 1789 to study medicine, he was more interested in natural history. He became at an early age a member of the Natural History Society of Edinburgh. At the instigation of Professor Walker he made collections of Scottish plants, on which he prepared his first publication in 1791. Military service brought him to Northern scotland, London (where he met Banks, who allowed him free use of his collections and library) and also to Ireland. He accepted Bank' ' offer to join an expedition to the coast of New Holland as a naturalist, 1801-05, under capt. Flinders. On his return he brought nearly 4,000 specimens of dried plants of which many were new to science. He published Prodromus Florae Novae Hollandiae et Insulae Van-Diemen ... of which only one volume appeared, London, Apr.1810, and Appendix No. III to Elinders, M.: A voyage to Terra Australie ...., London, Jul.1814.

He was elected associate of the Linnean Society in 1798 and soon afterwards was appointed its librarian. When his friend Dryander died in 1810 he became his successor as librarian of Banks, which ended at Banks' death in 1820 . The use of his library and collections was bequeathed to him for life, with the house. In 1827 he assented to transfer the books and spesimens to the British Museum (Natural History) where he was appointed keeper of the botanical collections, a position which he held till his death.

In the meantime he had become a fellow of the Royal Society (1811), and was several times elected member of its council. In 1839 the Copley Medal was presented to him, and in 1832 the honorary degree of D.C.L. from the Oxford University; in 1833 he was elected foreign associate of the Académie des Sciences of the Institut de France. Sir Robert Peel granted him an annuity of $\varepsilon 200$, and other honors were bestowed on him.

He described numerous new species and genera, he supported the natural classification with vigor, and defined many new plant families. Fossil botany was a favorite pursuit and he formed a valuable collection of fossil woods (bequeathed to the British Museum). Moreover he discovered the nucleus of the vegetable cell, the mode of fecundation of several species of plants, the development of the polien and ovulum in Coniferae and cyoadae, and the bearing of these on impregnation in general; the relation of the flower to the axis from which it is derived, the relation of parts of the flower to each other, and the vibration of finely dispersed particles of matter in fluids, which he correctly ascribed to the impact of moving molecules and which is named after him the Brownian movement. Though he showed a tendency to keep his own information for himself after visitors had freely talked about their knowledge (see van Steenis, Flora Males. ser.1, 1: XII. 1950), he had an attractive and gentle character in private life. He was commemorated in the generic name Brunonia J.E. Smith 1811 (Goodeniaoeas).

Refe.: Hunt, R.: Diot.Natz.Biogr. 7: 25b-27b, 1886.

Farmer, J.B.: Robert Brown $1773-1958$ in Makers of British botany: $108-125$. Cambridge, 1913.

Stearn, W.T.: An Introduction ... in Brown, R.: Prodromus Zlorae Novae Hollandiae ...: xili-xxxiii. Facsimile ed. Weinheim, Codicote, New York, 1960.

\section{Chzoris Melvizliana....}

Titze: "CHLORIS MELVILLIANA | [short rule] | A | LIST OF PLANTS | COLLECTED IN | MELVILLE ISLAND, | (LATITUDE $74^{\circ}-75^{\circ} \mathrm{N}$, LONGITUDE $110^{\circ}-112^{\circ} \mathrm{W}_{\text {) }}$ ) IN THE YEAR 1820; | BY THE OFFICERS OF THE VOYAGE OF DISCOVERY | UNDER THE ORDERS OF | CAPTAIN PARRY. | [short rule] | WITH | CHARACTERS AND DESCRIPTIONS | OF THE | NEW GENERA AND SPECIES. | BY | ROBERT BROWN, F.R.S. AND L.S. | MEMBER OF THE IIIPERIAL ACADEHY NATURAE CURIOSORUH, OF THE ROYAL ACADEAY OF SCIENCES | OF STOCKHOLI, AND OE THE ROYAL SOCIETY OF COPENHAGEN; | CORRESP ONDING MELBER OF THE ROYAL ACADEIIES OF PARIS, I BERLIN AND UUNICH, | so. | [medium long rule] I LONDON: | PRINTED BY W. CLOWES, NORTHUMBERLAND-COURT, STRAND. | [very short rule] | M DCCC XXIII." 
Collation: $4^{\circ}: \mathrm{a}-\mathrm{f}^{4} \mathrm{~g}^{2} ; \quad 1-3 \quad 4-52$.

Contents: 1 title; 2 reprint indication: "*** The following List as No. XI of the Appendix to Captain Parry's Journal of I his First Voyage, commencing at page cclix."; 3-52 text, headed: "LIST OF PLANTS | COLLECTED IN MELVILLE ISLAND.", and including: prefatory remarks (3-5), list of plants with descriptions of species and varieties (the latter without epithets), and with localities, a number of new genera also with descriptions, and indications of synonyms if necessary (6-49), treating phanerogams (6-35), Musci (36-47), Liohenosae (47-49), Fungi (49), a list of plants unique to Melville Island (50), observations on plants collected by Ross during Parry's second voyage $(50-52)$; 52 imprint. RT: "APPENDIX. | BOTANY." Language: prefatory remarks: English; text: Latin.

Plates: 4 copper-engravings, lettered A-D, of new species of plants.

Artist: Bauer, Franz [Andreas] (1758-1840), Austria, botanical artist.

Engraver: Curtis, John (1791-1862).

Paper: leaf height $248 \mathrm{~mm}$. (U copy, cut); wove; no $\mathrm{wm}$.

Printer: Clowes, William, London.

Publisher: probably the author responsible for the reprint.

Date: $1823\left(t_{0}-p_{0}\right)$,

aft. 21 Apr. (Flora 6(15):249.1823, anned, to be published shortly);

bef. 31 Dec. (recd. by A.P.de Candolle in 1823 according to Kuntze);

bef. 15 Jan. 1824 (letter from Arnott to Brongniart mentioning Aplodon).

Reviews: Raspail: BulZ.Sci.Nat. 5(5): 73-78. 1825 May;

Edinb.J.Sci. 1(1): 170.1824 Jul. (no definite indication of reprint).

Transzation: German: Flora $7^{2}$ (Beiz.2): 65-135.1824 (semester 2).

Refs.: Cat.Juss. n.2004

Kuntze: Rev.Gen.1: CXXXVIII. 1891
Linn. Soc. 118
Lownd. $1: 288 \mathrm{~b}$
Pr.ed.1 n.1372

Pr.ed. 2 n.1234

Stafl. TI n.163, 164.

Bibl.notes. Pre-publication issue of Robert Brown's treatment of plants of Parry's first voyage. The book from which it was reprinted is: Parry, William Edward: A supplement to the appendix of Captain Parry's voyage for the disoovery of a North-West paseage in the years 1879-20, containing an aocount of the oubjecte of natural-history. London, 1824 , which was presented to the Royal Society. London, on 5 Feb. 1824 (Philos,Trans.R.SOo, 1824(2): 8. 1824).

Bot.notes. A number of new taxa were proposed in this report of the botanical results of Parry's first voyage: 5 genera and 37 species in Phanerogamae, 12 species in Musoi, and 1 in Lichenes. The new taxon Aplodon in Musoi has a generic description, which is imnediately followed by the remark: "Thi. subgenus of splachnum..."; its status, therefore, is ambiguous.

2 Vermischte botanische Schriften. In Verbindung mit einigen Freunden ins Deutsohe ubereetat und mit Anmerkungen versehen von Chrietian Gottfried Nees von Esenbeok. 5 vols. Numberg, 1825-1834.

Dates: vol.1: 1825 (t.-p.), trim.1-3 (Linnaea 1(1): 103. $1826 \mathrm{Jan}$.$) ;$ vol.2: 1826 (t.-p.); trim. 1 (Linnaea 1(2): 275-276. 1826 Apr.)? vol.3: 1827 (t.-p.); trim.1-3 (Linnaea 2(3): 486-487: 1827 Aug.-Óct.); vol.4: 1830 (Pritzei);

vol.5: 1834 (Pritze1)?

Notes. I studied the first volumes of this work. Though the collation is not complicated, the complete recording of the contents with the many translated articles of $R$. Brown was considered outside the scope of this thesis; the bryological parts were checked for possible annotations by C.G. Nees von Esenbeck and none were found. 


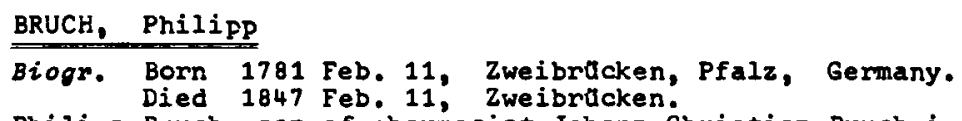

Philipp Bruch, son of pharmacist Johann Christian Bruch in Zweibrücken, was educated in Mainz for pharmacist, studied in Marburg and Paris, and inherited his father's pharmacy when he was 21. The shop thrived under his hands, leaving him time for botany. He was further encouraged in his study when D.J. Koch, author of a synopsis of German and Swiss flora, presented him with model herbarium. He studied especially mosses and his observations on Oxthotriohum were incorporated in Bridel's Bryol. Univ.1 (Suppl. 1827). He received visits from other bryologists. e.g. Fünrohr, who stayed with him for a whole summer. Later he began in collaboration with W.P. Schimper from Strasburg the Bryologia Europasa, a master piece, W.T. Gllmbel collaborating afterwards. The work was continued after Bruch's death, mainly by the energy of Schimper. In 1835 he lost his only child, a married daughter, and four grandchildren by death, which touched him deeply. His health began to deteriorate and he died on his 66 th birthday. He was commemorated in the names of two moss genera: Bruchia Schwaegrichen 1824 (Musci, Dicranaceae), and Bruohia Hornschuch 1825 (Musci) which includes the type of the conserved name Platygyrium Bruch, Schimper \& Gumbel (Musoi, Bypnaceae).

Refe.: Gumbel, W.T.: Jahreober.Polliohia 5: 10-20. 1847. Carus: Ailg.Deuteche Biogr. 3: 375-376. 1876.

1 Verseichnise [der] Laubmoose von Zweibrlacken und Umgebung. Flora 7(48): 760-765. 1824 Dec. 24.

Date: issue dated; see Blora.

Note. Study on the mosses of the local region.

2 Bemerkungen uber Phasoum alternifolium Dicks.; Ph. oubulatum Sohreb. und Ph. globiferum Bruch. Flora 8(18): 273-285. 1 pl. 1825 May 14.

Date: issue dated; see Flora.

Note. Observations on three related species, of which the original type of Dickson was not studied, leading to much confusion in generic names later.

3 Ueber Sphagna, nebet Bemerkungen au den in Nr. 88[sic for 28] der botan. 2eitung filr 1824 duroh Inopektor Breutel mitgetieilten Beobachtungen. Flora 8(40): 624-635, 1825 0ct, 28 .

Date: issue dated; see Flora.

note. Critical treatment of peat-mosses, including a new species sphagnum mollusoum (635).

4 Bryologische Beobachtungen. Flora 9(11): 161-166. 1826 Mar. 21.

Date: issue dated; see Flora.

Note. Discussion of the mosses Tetraphis ovata and $T$. Browniane (now Tetro. dontium brownianum). 161-163, and Mesia, 163-166.

5 Correspondens.

Flora 9(14): 222-223. 1826 Apr. 14,

Date: issue dated; see Flora.

Note. Includes bryological remarks.

6 Veber einige Laubmoose.

Flora 10(12): 176-182, 1827 Mar. 28 .

Date: issue dated; see Flora.

Dote. Detemination of mosses collected by Salzmann, in Spain and Tangier, and not mentioned in Bridel, Bryol. Univ.; a number of supposedly new species were described, but no specific epithets were given. 
BUCH, Christian Leopold von

Biogr. Born 1774 Apr. 26, Stolpe (castle) near Angermunde, Uckermarck, Germany. Died 1853 Mar. 4, Berlin.

Christian Leopold von Buch, Freiherr von Gellmersdorf, Sch bneberg, etc., began the study of mineralogy in Berlin in 1789. He continued in Freiburg from 1793 till 1796, living in the house of the well-known A.G. Werner (1750-1817), the militant leader of the Neptunist school in geology. Being of independent means, von Buch was able to travel widely in Europe and later to visit the Canary Islands, collecting plants and studying results of volcanic activity. Gradually he became convinced of Plutonism. He made fundamental geological studies of the South German Jura Mountains.

He had been nominated an extraordinary member of the Akademie der Wissenschaften at Berlin in 1806, a full member in 1808, and also a corresponding member of the academies of Paris and London.

He was interested in all branches of natural history; these interests, probably, helped him to stress the importance of guide-fossils. One of his latest publications was a study on nerves of fossil leaves as a help in determination. His name was commemorated in the generic name Buchia Humboldt, Bonpland Kunth 1818, now considered a synonym of Perama Aublet 1775 (Rubiaobae).

Refo.: Gümbel: Allg.Deutsche Biogr. 3: 464-475. 1876. Quenstadt, W.: Neue Deuteohe Biogr. 2: 697. 1955.

Physicalische Besohreibung der Canarischen Ineeln. 1 text-vol. Berlin, 1825; 1 plate-vol. Berlin, [1826-1831].

Tit le: text-vol.: "PHYSICALISCHE BESCHREIBUNG | DER | CANARISCHEN INSELN | VON LEOPOLD VON BUCH. | [short swelled wavy rule] | BERLIN, | GEDRUCKT IN DER DRUCKEREI DER KOENIGLICHEN AKADEMIE | DER WISSENSCHAFTEN. | [short thickthin rule] | 1825."; plate-vol.: "[double frame of laurels in 8 pieces] | ATLAS | ZUR PHYSICALISCHEN BESCHREIBUNG | DER | CANARISCHEN INSELN | VON | LEOPOLD VON BUCH | [short swelled decorated rule] | BERLIN, | GEDRUCKT IN DER DRUCKEREI DER KOENIGLICHEN ACADEMIE DER WISSENSCHAFTEN |'[short thick-thin rule] | 1825."

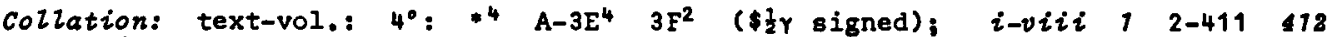
$\left(53-55\right.$ 61-63 $91-93,105-107$ 200-203 320-323, 409-411 as $\left.1405^{\prime}-1407^{\prime}\right)$; plate-vol.: $2^{\circ}[?]$ ] $\pi^{2}$ (wrapper-paste-down) $1^{1}$ (paste-down).

Contenta: text-vol.: $i$ half-title; ii $\square$; iit title; $i v \square$; $v$-vi preface headed "Vorrede." signed 28 May 1825; vii contents; viii 53 section title; $540 ; 55-60$ text of section 1, statistical survey of the Canary Islands; 61 section title; $62 \square$; $63-90$ text of section 2 , climate; 81 section title; $82 \square$; $93-104$ text of section 3 , altitude measurements; 105 section title: "IV. I Uebersicht | der | Flora auf den Canarischen Inseln. | [short swelled wavy rule] "; 106 D; 107-199 text of section 4, flore of the Canary Islands, including lists of plants: a) wild plants on the Canary Islands (137-159) with descriptions of new or rare species signed by Link or Choisy and an occasional description by A.P. de Candolle, b) wild plants arranged according to the "regions", altitudinal zones (160-185), c) endemic plants (186-188), and d) a list prepared by Robert Brown, of the plants growing wild on Madeira (189-199), this list headed: "Verzeichniss | der auf Madeira wildwachsenden Pflanzen." and accompanied by the following note: "Anmerkung. Dieses Verzeichniss ist schon vor vielen Jahren, von Herrn Robert Brown aus Masson's Journal, den Londner Herbarien und aus einige Tage eigener Ansicht, zusammengetragen und mir gütigst mitgetheilt worden. Es bleibt imner noch bei weitem das vollständigste und ohne Vergleich das zuverlassigste. ..."; it is the only list including non-vascular cryptogams (198-199); 2000 ; 201 section title; $202 \square$; $203-319$ text of section 5, geognostic description; 320 口; 321 section title; $322 \square$; $323-411$ text of section 6 , concerning the nature of the volcanic phenomena on the Canary Islands in connection with those in other regions; 412 correction; 
plate-vol.(atlas): title pasted to the recto front cover; explanation of the plates to the verso front cover, list and explanation of the plates I-XIII, with remark to pl.(Fig.) I: can be delivered by the engraver only after a few years, and to pl.(Fig.) II: awaits its completion by the engraver too; no explanation or mention of the botanical plate; paste-down on the verso back cover has a printed frame similar to that of the title,

RT (text-vol.): short section title; in botanical part: "Uebersicht der Flora | auf den canarischen Inseln." Language: German, with descriptions of new or insufficiently known plant species in Latin.

Plates: 8 engravings, of which one view of mountains has a color-surface added of a mezzotint character; the botanical plate is mainly stipple-engraving, the other plates are maps, cross-sections, or views of volcanic islands; 2 lithograph plates, printed on 8 pecial paper which was pasted to the large broadsheets of the atlas volume (the larger plate in fact consisting of 2 lithographs pasted closely together); individual "Figuren" numbered $13-13$; the botanical plate at the end unnumbered, marked: "LAURUS foetens", flowering branch and fruit details; plate-mark of bot.pl, absent, leaf cut at enclosing lines and pasted to a larger leaf.

Aptiet: pls. unsigned.

Engraver; Tardieu, Pierre, Paris: pl.1; remaining pls, unsigned.

Paper: text-vol.: leaf height $391 \mathrm{~mm}$. (UB Utrecht copy, cut); wove; wm.:

$n_{H}$. OSER [at left bottom of sheet] = IN BASEL [right bottom of sheet, all letters in outline]" :

plate vol.: outside paste-downs buff-colored; explanation paste-down not checked;

plate-paper: engravings wove, no wm.; lithographs and botanical plate

pasted to larger leaves, not checked; leaf height of bot. pl. $449 \mathrm{~mm}$.

(UB Utrecht copy).

Printer: printer of the Königl. Akademie der Wissenschaften, Berlin, Germany.

Publioher: privately issued by the author; not in trade; copies in libraries are usually inscribed by the author as presentation copies.

Bot.0olzaboratore: Brown, Robert (which see): list of Madeira plants; de Candolle, Aug.Pyr. (which see): a few descriptions;

Choisy, Jacques Denys (1799-1859), Genève: a number of descriptions; Link, Heinrich Friedrich (1787-1851), Berlin: most descriptions.

Dates: text-vol.: 1825 ( $\left.t .-p_{.}\right)$, after 28 May (pref.); plate-vol.: "Fig."3-13: 1826, bef. 22 Apr. (G8tt.Get.Ans. 1(64):625-634. 1826); "Fig."1 not before 1831 (inscription "Gravie ... en 1831."); "Fig." 2 never published; date of bot. pl. not ascertained.

Reviews: Gott.Gel.Ans. 1(64): 625-634. 1826 (stated that the text was published some time ago);

Isis (Oken) $22(7): 695-702.1829$.

\begin{tabular}{c|l|l|l}
$R e f 8 .:$ Arn.Arb. & BMNH 274 & Brun.1: 1367 & Pr.ed.1 n.1455 \\
$1: 120 \mathrm{a}$ & Bradl.1: 497a & Graesse 1: 562 & Pr.ed.2 n.1308.
\end{tabular}

Variante: My colleague of the HBL, Dr. 6. Buchheim, informed me that he saw copies of the atlas with a larger leaf with explanations in another type-setting. 
Tranalation: A French translation of the botanical part was published in Archives de botanique 1, apparently in two fascicles.

I saw an undated copy of a separate: "Coup d'oeil our la flore des tles Canaries.", 56 p. $8^{\circ}$, the second part $(29-56)$ with the title: "Catalogue des plantes opontankse qui ont ste jusqu'ioi trouveses dans les tles Canaries." The article probably was translated by Adrien de Jussieu, since the French introduction is signed "A. J." and contains a reference to the herbarium of the Muséum d'Histoire Naturelle at Paris.

Bibl,notes. Reprint in book form of earlier essays of Buch on the Canary Islands, with additions. The botanical part was already published as: "A IIgemeine Uebersioht der Flora auf den Canarisohen Inoeln." Abh. Physik. Klases Kön. Preuse.Akad.Wise. 1816-1817: 337-382, 383-384. 1819. The latter pages had the supplement: "Waohtrag sur Abhandiung uber die Blora auf den Canariochen Inseln." On p.372 R.Brown's list of Madeira plants was given, only containing 18 phanerogams and no cryptogams.

The bibliographical format of the atlas, usually stated as folio, might be broadsheet. However, I have no certainty, since no gatherings are present; the explanation leaf could have been printed as a single broadsheet as well as half folio sheet. The larger type-setting state points more to broadsheet.

Bot.notee. This work is important for the geology of the Canary Islands; its flora was checked because of a reference to the name Fiosidens bryoides var. giganteus. This name is present on $p .199$ in the list of Madeira plants, attributed to Robert Brown; a description is absent. The name was validated in Bridel, Bryol. Univ. 2: 688. 1827 by a short description. The Laurus foetidus of the botanical plate is mentioned on p.140 without a description or a reference to the plate, but with the synonym "( $T i Z,[s i c]$ maderensio Lam.)". The introduction gives botanical notes in biographies of travelers who visited the Canary Islands, esp. In that of Christian Smith (1785-1816).

\section{CAMBESSEDES, Jacques}

Biogr. Born 1799 Aug. 6, Montpellier, France.

Died 1863 Dec. 20, Férussac, near Meyrueis, dép. Lozère, France.

Cambessèdes began the study of law at Aix in 1818; he changed to medicine at Montpellier in 1819. In 1822 he went to Paris, and he made connections with the foremost naturalists there. He undertook a botanical journey to the Landes, Pyrenees, the Baleares, and visited on his return the "Massif Central". The results were published in 1827. He collaborated with A. de Saint-Hilaire for the Flora Bras. Merid. Entering the "garde nationale parisienne" after the 1830 revolution, he became captain and was a "guide de camp" to general Mathieu Dumas. In 1831 he obtained an appointment as "aide-naturaliste" at the Museum d'Histoire Naturelle, Paris, to justify his staying in Paris to his father, who wanted him to return to his country-seat. At the Muserum he classified the collections of Victor Jacquemont (1801-1832) from 1833-35.

The death of his father caused him to leave Paris and to devote himself to the care of the country-seat "Pradines" in the "Causse-Noir", Cevennes. He applied his scientific knowledge now to agriculture and introduced new crops and better methods. In 1855 he moved to Férussac, to devote his energy to improve another property. Throughout his agricultural period he remained strongly interested in natural history, and guided visiting naturalists to the Cevennes area. His well kept herbarium was left to the "Faculté des Sciences" at Montpellier. His name was commemorated in the generic names Cambessedea Kunth 1824 , nom. rej., now a synonym of Buohenania Spreng. (Anacardiaceas), and Cambessedesia A.P. De Candolle 1828, nom. cons. (Melaetomataceae).

Refs.: Planchon, J.E.: Notios sur la vie et les travaux de Jaoques Cambessdes. [separate.] 44 p. Mende, 1865.

Also in: Bull.Soo.Bot.Franoe 10:543-584, 1865.

Le Tourneur, St.: Diot.Biogr.Erang. 7: 953-954. 1956. 
1 Enumeratio plantarum quas in insulis Balearibus collegit...

$$
\text { Paris, } 1827 \text { [separate]. }
$$

Titze: "ENUMERATIO PLANTARUM | QUAS | IN INSULIS BALEARIBUS | COLLEGIT J. CAMBESSEDES, I SOCIET. PHILOM. ET HIST. NAT. PARIS, I EARUMQUE I CIRCA MARE MEDITERRANEUM | DISTRIBUTIO GEOGRAPHICA, ' [ swelled rule] PARISIIS, EX TYPIS A. BELIN, VIA MATHURIHENSIU1, N: 14 | !very short rule ] | $1827 . "$

Collation: $4^{\circ}: \pi^{2} 1-21^{4} \quad\left(9_{1}\right.$ as ' 81$) ; \quad i-i v 112-168$ (6 $28-29763765$, 105 as '107', 106 as 108', 107 as '105', 108 as $106^{\prime}, 109$ as '11', 110 as '112', 111 as '109', 112 as '110'?.

Contents: i half-title; it D; iii title; iv D; 1-5 "Avertissement."; 6-27 introduction; 28 sources; $29-162$ text, list with descriftions and synonymy and occasionally long discussions of the species collected in the Baleares; 163-164 corrections and additions; $765-168$ alphabetical index of generic names. RT: names of plant groups, e.g.: "DICOTYLEDONES | ANONACEAE.-NYMPHAEACEAE.", or chapter headings. Language: text in French, descriptions in Latin.

Paper: sheet size $547 \times 418 \mathrm{~mm}$. (gathering 19, PMusBC copy); laid, chains horizontal; wm.: "T [small triangle]. A [partly outine]".

Plates: 9 copper-engravings, each numbered in right top corner: "Pl. 1" - "Pl. 9 " as well as in left top comer: "Tom. $14 \mathrm{PI}$. 10" - "Tom. $14 \mathrm{PI}$. 18", illustrating the following plant species:

1: Brasioa Baleavioa[sic] Pers.,

2: Belianthemum oerrae Nob.,

3: Silene dietioha bild.,

4: Silene villosa var. nana,

5: Geniota Zuoida Nob.,

Lotus tetraphylzus Linn.fil., Belichryoum lamarokii Nob., Be liohry oum fontanesit Nob., Dieandra africana Nob.

Artists, engravers: plates unsigned.

Printer: BElin, A., Paris.

Date: 1827 (t.-p.), bef. 2 Jun, (Bibliogr. Franoe 16 (44): 4E1. 1827).

Review: Isis(Oken) 21(7): 663-671, 1828,

Bibliogr.study: Stafleu, F.A.: Taxonomio iiterature n.190. 1967.

Refe.: Arn.Arb.1: 132

Brad1.1: $420 \mathrm{a}$

Cat.Juss. n.1669

Jacks. 341

Kew 95

Lindl.Libr. 65

Linn. Soc. 137

Pr.ed.1 n.1636

Pr.ed.2 n.1432.

Bibl.notes. Separate of $\mathrm{n} .2$, with new title leaves and independent pagination. Pre-publication seems to be indicated by the nearly 4 weeks difference in the announcements of separate and fascicle of the periodical in Bibliogr. France. However, the periodicals are listed quarterly. Another indication is present in one copy of the periodical (see n.2). The first announcement stetes that the separate was printed in 100 copies which were not for sale.

Bot.notes. Important paper for the region, the first one with long discussions and descriptions of the species. Older records were critically reviewed. The species were compared with Mediterranean relatives. New species and combinations were proposed. One new moss species, Didymodon subulatus, $\mathrm{p} .160, \mathrm{n} .665$, was overlooked by bryologists. For the names of phanerogans checked the Index Kewensis refers to the periodical. The Index Londinensis (Stapf) refers to both separate and periodical except for plate 1 , where only the citation of the periodical is given. 
2 Enumeratio plantarum quas in insulis Balearibus collegit...

Mém. Mus, Hist. Nat, Paris 14(9)-(10): 173-335, 1827

Bead-title: "[full thick-thin rule] | ENUMERATIO PLANTARUM | QUAS IN INSULIS BALEARJBUS COLLEGIT | J. CAMBESSEDES | SOCIET. PHILOM. ET HIST. NAT. PAR. | EARUIQUE CIRCA MARE IIEDITERRANEUM DISTRIBUTIO GEOGRAPHICA. | [ rule] ".

Collation: $4^{\circ}$ : fasc.[9]: $23-32^{4} ; 173$ 174-252 (778 200 207); fasc. [10]: $33-42^{4} \quad 43_{1,2} \mathrm{r} ; 253-335$.

Contents: 173-177 preface: "AVERTISSEMENT."; 178-199 introduction; 200 sources: "Liste des auteurs oites les plus frequemment pour la l gégraphie des plantes des Baleares."; 201-333 text, headed: "ENUMERATIO PIAITARUM I IN INSULIS BALEARIBUS NASCENTIUM", enumeration of species collected in the Baleares, with the descriptions of a number of species either new or not sufficiently known at the time: $334-335$ corrections and addenda. RT: chapter headings; in the taxonomical part names of class and family, e.g.: "DICOTYLEDONES. GERANIACEAE." Language: French, with Latin descriptions,

Plates, artists and engravers: see n.1.

Paper: see MEm,Mus, Bist.Nat. Paris.

Printex: Bélin, A., Paris.

Publishers: Muséum d'Histoire Naturelle, Paris; Bélin, A., Paris.

Date: 1827 (t.-p. vol.); trim.2, bef. 27 Jun. (Bibliogr.France 16 (51): 540. 1827 Jun. 27 ; see Bibl.notes).

Review: Bot.Lit.Blatt. 1: 41-47. 1828 .

Refo.: Bradl.1:423a RSC 1: 772 .

Bibl.notes. The announcement in Bibliogr.France mentions fascicles $8-12$ of the periodical together, and is nearly 4 weeks later than the announcement of the separate. However, the periodical fascicles were listed quarterly except for the first fascicle in the year. Hence the different fascicles 8-12 could have been published sometime in the second quarter of 1827. The break between fascicles 8 and 9 is indicated in the Teyler copy by the place of plates 10-14, which apparently were bound in at the end of fascicle 8 .

An indication of earlier printing of the separate is a set of mistakes in one gathering of the copy of the periodical at the Bibliotheque Central du Muséum d'Histoire laturelle, Paris, the publishing institute. Gathering 41 was missigned $199^{\prime}$ and $i t s$ pages were completely misnumbered: '145'-'152', exactly those of the corresponding gathering of the separate. If the whole edition of the periodical had the wrong numbers, it would be proof that the separate was a preprint (the compositor would have forgotten to change these numbers from the earlier printed separate). However, I checked another copy of the periodical (Teyler. Haarlem) which has the correct signature and page numbers. This difference can be explained in two ways: the Paris copy was made with an incidental sheet from the wrong pile, or the mistakes were corrected by stop-press corrections after the sheets of the Paris copy had been assembled. In the last case the separate was printed earlier, and an argument for this possibility is that the copy of the Muséum will have belonged to an early set of copies. Nevertheless it is quite possible that fasc.9 of the periodical was published before the separate or fasc.10.

I hoped to find an answer in contemporaneous financial documents of the Museum, but in the short time at my disposal I was unable to check the existence of sich documents in the Archives Nationales, Paris. The matter is worth further investigation.

Bot.notes. The conterts do not differ from those of the separate, except for the page numbers which, of course, are 172 higher. The moss species, Didymodon oubulatus, is cescribed on P.332. Further see n.1. 
Biogr. Born 1778 Feb. 4, Genève, Switzerland.

Died 1841 Sep. 9, Genève.

A.-P. de Candolle was born in an influential family in the government of the republic of Geneva, a stronghold of Protestantism. His youth was spent in Geneva; in June 1792 he entered the "auditoire de belles-lettres" of the "Acadêmie" at Geneva, while a French army threatened the city. A revolution in Dec. 1792 replaced the government by a provisional council; the father of de Candolle retired to Champagne, a small village near Neuchatel (Switzerland), where he had bought a country-seat.

De Candolle became interested in botany through a course of lectures by Vaucher (Jean Pierre Etienne, 1763-1841, professor of theology in Geneva, a wellknown algologist), attending only a few of the first lectures. He studied the plants at Champagne without knowing any plant name or classification, therefore without prejudice, and with the mind open for a natural classification. He completed his studies in Geneva with a course in philosophy and sciences, and departed in Harch 1798 for Paris, because the independence of Gereva was threatened and indeed lost some months later, which reduced the chances for his future there.

In Paris he studied botany actively, and he laid many contacts with

scientists. He studied in several herbaria, especially of L'heritier, and of the Museum. He wrote some articles for Lamarck's Enoyolopsdie methodique, Botanique, and the text to the famous work Histoire des plantes grasers, illustrated by Redouté, which he prepared under the guidance of Desfontaines. He married Fanny Torras, of Genevan descent, in Paris, 4 Apr. 1802. To earn a living, he accepted Lamarck's offer to prepare a new edition of the Flore française, which he completed in 1805. In the meantime he lectured on natural history in Cuvier's place at the Collège de France, taking plant physiology as his topic. He received the degree of Doctor of medicine from the Ecole de medecine in 1804 . After the completion of the new edition of the Elore frangaise he prepared with the help of some friends a cheap extract, synopsio plantarum in Flora Gallioa desariptarum, at the request of the publisher, to compete with another botanical book which was purported to be an extract too.

The French government charged him to travel in botanically "white" regions of the map of France, to study the botany and agriculture. Candolle applied for membership of the Academie, then Institut, de France, first to fill the list of required candidates, later hoping to obtain a place. This hope was not fulfilled, owing to intrigues in Paris, in connection with his religion. In 1807 , at the death of Broussonet, a professorship at Montpellier was offered to de Candolle, which he first refused, since he preferred to continue his botanical travels in France. Finally he accepted, when he had the choice between both or nothing. He was appointed $15 \mathrm{Jan}$. 1808 .

He organized his courses in botany in Montpellier during the spring, to be able to travel during summer. He was able to expand the botanical garden, and he prepared a number of books in Montpellier, including his Theorie lementaire, and the beginnings of his "Systoma": Regni vegetabilis oystema naturale, 1818-1821. During the royalist government of 1813 he applied for the position of Rector of the University, which was left open because the candidate of the predominant religion was insignificant. He was nominated by the government of Napoléon's return (the "Hundred days"), and managed to have the University undamaged through this difficult time, in which partisan feelings ran high in France. He received a congratulation on this from an official of the second restauration government on his report to the Napoleonic government. Nevertheless, he was dismissed as rector, and religious zealots exploited minor details to discredit him.

De Candolle preferred a professorship in natural history in Geneva, though his income there was considerably lower than in Montpellier. He began his lessons in Geneva in the autumn of 1816 , but was nominated as from $1 \mathrm{Jan}$. 181.6, to be reimbursed for the move of his library and herbarium. He became director of the botanical garden in Geneva in 1817 , and spent the rest of his active life there, except for a number of travels in Europe and a course in botany in Montpellier in 1817. In Geneva he filled a number of other posts, in the Council of the republic, 
Rector of the University, and in some social organisations in which he was interested. Likewise he had already early in his Paris period founded a charitable society (Société philantropique) and one for the encouragement of industry (Société pour l'encouragement de l'industrie nationale).

He suffered from illness and retired from active life in 1835 , becoming "professeur honoraire". He realized that he would not be able to finish his iffework, the Prodromus syotematis naturalis regni vegetabilis. He was survived by his only remaining child Alphonse L.P.P. de Candolle, botanist in his own right. His collections came to the "Conservatoire et Jardin botanique de Genêve". Several genera were dedicated to him: Candollea Mirbel 1803, according to Christensen, Index Eilioum, a synonym of Cyolophorus Desvaux; Candollea Labillardiềre 1805 , nom. rej., = stylidium Swartz nom. oons. (stylidiaceae); Candollea Labillardière 1806 (Dilleniaceae); Deoandolia Bastard 1809, nom. illeg., including the type of Agrostis L. (Gramineae); Candolzea Raddi 1818, including species of the genera Plagioohila Dumortier and Radula Dumortier, nom. cons. (Erpatiaae).

Ref.: Candolle, Aug. P. de: Mémoires et souvenirs de Augustin-Pyramus de Candolle... Eorito par lui-meme et publiss par on filo. Genève, 1862. XVI, $599 \mathrm{p} .8^{\circ}$. This includes a bibliography and a number of lists such as of left manuscripts and botanical plates, numbers of new species described, generic names dedicated to persons, and a list of other biographies.

\section{Organographis végetale...}

2 vols. Paris, 1827.

Titze: "ORGANOGRAPHIE | VEGÉTALE, | OU | DESCRIPTION RAISONNEE DES ORGANES | DES PLANTES, | POUR SERVIB DE SUITE ET DE DEVELOPPEHENT A LA THEORIE | ELEHENTAIRE DE LA BOTANIQUE, ET D'INTRODUCTION A LA | PHYSIOLOGIE VEgETALE ET A LA DESCRIPTION DES FAUILLES; AVEC 60 PLANCHES EN TAILLE-DOUCE; | PAR M.I AUG -PYR. DE CANDOLLE, I Membre du Conseil souverain de la République et Canton de Genève, | Professeur d'Histoire naturelle a l'Académie, Directeur du Jardin | botanique, Membre de la Société de Physique et d'Histoire naturelle, | Président de la Société des Arts de Genève; | [new paragraph:] Associé étranger de l'Académie des Sciences de l'Institut royal de France, | des Sociétés royales de Londres et d'Édimbourg, des Académies royales de I Copenhague, Munich, Naples, Stockholm, Turin, de I'Académie C. L. C. I des Curieux de la Nature, de l'Académie royale de Médecine de Paris, I des Sociétés d'Horticulture de Londres, d'Agriculture de Paris, Moscou, | etc., de la Société helvétique des Sciences naturelles, etc., etc., etc. I TOME I.er [vol.2: TOME II.] [swelled rule with fancy middle part] | A PARIS, | CHEZ DETERVILLE, LIBRAIRE, | RUE HAUTEFEUILLE, N. $8 . \mid$ 1827 ."

Series-titie: "COURS DE BOTANIQUE. I [long wavy rule] I PREMIERE PARTIE. I [long wavy rule] | ORGANOGRAPHIE. I [short double rule] | volUME I.er [vol.2: VOLUME II.]"

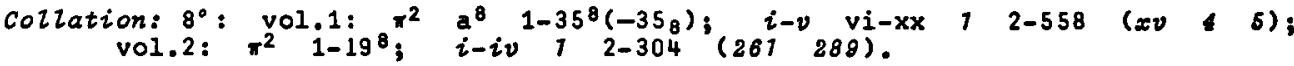

Contents: vol.1: $i$ series-title; ii addresses of four booksellers in different countries where the book is available; iii title; iv imprint; v-xiv preface, dated: "30 septembre 1826."; xv-xx contents of vols.1-2; 1-558 text, introduction and organography through "organes reproducteuses (structure des fleurs)";

vol.2: $i$ series-title; ii list of booksellers as in vol.1; iii title; iv imprint; 1-260 text, concluded, "organes reproducteuses (structure du fruit)" to end; 267-288 explanation of the plates; $289-304$ index of names of gener. and families. RT: subject indications, e.8.: "ORGANES ELEMENTAIRES." Language: French. 
Plates: 60 copper-engravings, mainly line-engravings, some with roulettestippling, including 3 folded plates, numbered: "PI. 7 . " "PI.60." "illustrating morphology and organography of plants, including a few Fungi.

Artisto: de Candolle, Alphonse Louis Pierre Pyramus (1806-1833), Swiss botanist, son of the author: pls. 4 and 43 ;

Heyland, Jean Christophe (1792, Frankfurt a.M. -1866 Aug. 29, near Genève), painter and water-colorist (biogr.: Bénézit 4:695. 1955): ail plates except pls. $4,10,33,37,43,44,55-59$ : partlv only: pls. 34,48 ; Moricand, Mofse Etienne (1779-1854 Jun. 26), botanist: pl.37; Node Véran, Montpellier, draughtsman (trained by A.P. de Candolle, Mémoirea 208, 213, 1862): pls. 10, 33, 55-59; partly pl. 34;

Redouté,' Pierre Joseph (1759-1840), botanical artist (biogr.: Stafleu, F.A. in Cat. Redouteana p.1-31. 1963): pl. 44; partly pl. 48;

Turpin, Pierre Jean François (1775 Mar. 11, Vire, France -1840 May 1, Paris), botanist: partly pl. 34 ?

Engravers: Plée père [Sr., Auguste? fl. 1801-1827];

Plée (fil.), F [rançois], fl. 1827-35 (Bénézit, 6: 725. 1956);

all plates signed: "Plé pdre et $F$. fils $80 . "$

Paper: leaf height $207 \mathrm{~mm}$; laid, chains vertical; wm.:

"D [script]": majority of vol.1, some leaves in vol.2;

"AD [...] serces [script, $A D$ in monogram] ": majority of vol.2, some leaves in vol. i;

"V [script] ": last part of vol.2 and gath. a of vol.1;

plates: white, thicker than of text; laid with wm: "M[script]" near border:

pls. 1-13, 16-20, 23-60; or wove wi thout wm.: pls. 14, 15, 21, 22 .

Printer: Moèssard, Adrien.

Publishor: Déterville, Paris.

Date: 1827, bef. $25 \mathrm{Apr}$. (Bibliogr.France 1827(33): 350. 1827).

Reviews: Duby: Bibl.Univ.Sci. 35(5):65-83, (6): 112-128, (7): 216-234. 1827;

Guillemin: Buil.Soi.Nat, 11(6): 247-251. 1827;

Linnaea Litt. Ber. 3(1): 12 . 1828 ;

Isis (Oken) 21(10): 970-971. 1828

Bartling: Gott.Gel.Anz. 1829, (58/59): 572-582. 1829;

Link, H.F : Jahrb.Wiso.Kritik 18292(19): 148-152, (20): 153-156. 1829;

Edinb.Review 99 (not seen); [translated in:]

Antologia Straniera Gioxn.Soi.Torino 1(1): 65-77, (2): 161-177. 1830;

J. Savana Paris 1833(4): 243-250. 1833;

de Candolle, A.P.: Mémoires ... 391-392. 1862.

Refe.: Arn.Arb.1: 138

BMNH 311

Bradl.1: $100 \mathrm{~b}$

Brun.1: 1538

Cat.Juss. n.715

\author{
Kew 99 \\ Krủg. 71 \\ Linn. Soc. 143 \\ Milt. 49 \\ Niss. $n .326$
}

Pr.ed.1 n.2269

Pr.ed. 2 n.1501

Teyl. 320

Un.Edinb.1: 671 .

Bot.notes. Fundamental textbook for its period, giving a wealth of details concerning the organs of plants, their structure, and indicating the functions. Many of de Candolle's own observations were included; his opinions on unsettled questions were sometimes very carefuliy expressed and further observations were suggested; some other opinions were later found to be incorrect. The structure of mosses is discussed in vol.1: 367-374 (de Candolle doubted the report of stomata in Splachnum capsules); the structure of hepatics is treated in vol.1: 374-377, the reproduction of mosses in vol.2: 142-152, and that of hepatics in vol.2: 152-157.

The German translation is treated below; an English translation by Kingdon was published in London in monthly parts fror. Feb. 1839 to Mar. 1840 (not
seen). 
2 Organographie der Gewäches ...

2 vols. Stuttgart \& Tübingen, 1828 .

Tit te :in gothic]: "August Pyramus De Candolle's | Organographie der Gewächse | oder | kritische Beschreibung | der | Pflanzen=Organe. | Eine | Fortsetzung und Entwicklung [vol.2: Entwickelung] der Anfangsgrllnde der Botanik I und Einleitung zur Pflanzen-Physiologie und der Beschreibung der Familien. | Mit 60 Steintafeln. [Iine absent in vol.2] | Aus dem Franzosischen ubersetzt 9 und | mit einigen Anmerkungen versehen von | Dr. [roman] Carl Friedrich Meisner, [vol.2: Carl Friedrich Meisner[gothic] M.D.[roman]] | Mitglied der allgemeinen schweizerischen Gesellschaft fü die Jlaturwissenschaften. [vol.2: ordentl. Offent1. Professor der Physiologie und allgemeinen Pathologie an der | Universitat zu Basel; der allgemeinen schweizerischen Gesellschaft für die | Naturwissenschaften Mitglied.] | short swelled rulej| Erster Band: Vol.2: Zweiter Band.] | [full swelled rule] | Stuttgart und Tubingen, I in der J. G. Cotta'schen Buchhandlung. | 1828." Series-title [in gothicj: "A. P. De Candolle's | Vorlesungen | uber die I Botanik. | short swelled rule] | Erster Theil. | Organographie. | [very short thin rule | Erster Band. [vol.2: Zweiter Band.] | [full swelled rule] | Stuttgart und Tübingen, $\mid$ in der J. G. Cotta'schen Buchhandlung. | 1828."

Collation: $8^{\circ}$ : vol.1: *8(unsigned) $2 * 4 \quad 3 * 2 \quad 1-31^{8}\left(-31_{8}\right) ; \quad I-V$ VI-XXVIII $\begin{array}{llllllllllllllll}1 & 2-491 & 492-494 & (X V & X X V & 3 & 8 & 24 & 49 & 53 & 63 & 73 & 78 & 81 & 85 & 100\end{array}$ $\begin{array}{llllllllllllll}104 & 107 & 170 & 712 & 716 & 119 & 127 & 122 & 204 & 227 & 314 & 339 & 343 & 3953 ;\end{array}$ vol.2: $\pi^{4}\left(-\pi_{4}\right) \quad 1-16^{8} 17-18^{4} 19^{2}\left(-19_{2}\right) ;$ I-V VI 1 2-273 274 (67 102708756757,65 as $\left.156^{\prime}\right)$.

Contento: vol.1: I series-title; II the translator, dated 31 Dec. 1827 ; XV-XXIV preface; XXV-XXVIII table of contents to vol.1; 7-491 text, introduction and orgariography through structure of flowers; $482 \square$; $493-494$ corrections; vol.2: I series-titie; II U; III title; IV U; V-VI table of contents to vol.2; 1-226 text concluded, structure of fruits to end; $227-252$ explanation of plates; $253-273$ index of plant names; 274 corrections.

Plates: 60 lithographs, numbered 1-60, copied from the French edition.

Artista: see $\mathrm{n.1}$; however, these plates unsigned, but the names stated in the explanations.

Engraver(o): plates unsigned; not ascertained.

Paper: leaf height $210 \mathrm{~mm}$. (HBL copy, cut); laid, chains vertical; no wm.; plates: wove; as fold-outs tipped to leaves (which have chain-lines horizontal, wm.: "[unicorn]" and countermark [?] "Niederohm [script] ").

Printer: not ascertained (far from Berne, probably in Germany).

Publisher: Cotta, J.G., Stuttgart \& Tubingen, Germany.

Trans Lator: Meisner or Meissner, Carl Friedrich (1800-1847), Swiss botanist who studied under A.P. de Candolle (biogr.: de Candolle, Alph.: BulZ.Soc.Bot. Franoe 21: 279-283, 1874).

Date: 1828 (t.-p.). in or shortly bef. Jul. (Jahrb.Wise.Kritik $1828^{2}$ (wrapper Jul. fasc.) announced as "soeben erschienen").

Review: Linnaea Litt.Ber. 3(4): 171. 1828 .

Refs.: Arn.Arb.1: $138^{\mathrm{a}}$ Bradl.1: $100 \mathrm{~b}$

Heins.8(1): $166^{b}$ Kräg. 71
Milt. 49

Niss. $\mathrm{n} .326$
Pr.ed.1 n.2269

Pr.ed. 2 n.1501.

Notes. German translation with many additonal footnotes by the translator, giving information on the points discussed, especially from Geman authors. but also from others, e.g. Robert Brown's observations on the leaves of $B u x-$ baumia and Fisoidens (p.322 and 323 ), not mentioned by de Candolle, and observations on the presence of stomata in moss capsules. 
CASSEBEER, Johann Heinrich

Biogr. Born 1785 . . . 18 , Gelnhausen, Germany.

Cassebeer was a pharmacist in Gelnhausen. He was interested in mosses, and began an exsiccata series in 1814. Later he experimented extensively with germination of moss spores and though his approach to the experiments was sound, he nevertheless did not interpret his observations correctly.

His herbarium, according to Grimme, is preserved in FR.

He was commemorated in the generic names Cassebeeria Dennstedt ex 0. Kuntze 1891, considered a synonym of Soneriza Roxburgh (Molastomataceae) and Casecbeera Kaulfuss 1824 (Polypodiaoeae).

Refe.: his works;

Ascherson \& Graebner: Syn,Mitteleur, $F 2$. 3: 86.

Grimme, A.T.: Abh.Ver. Naturw.Kasel 58: 135. 1936.

1 Wetterauische Laubmoose.

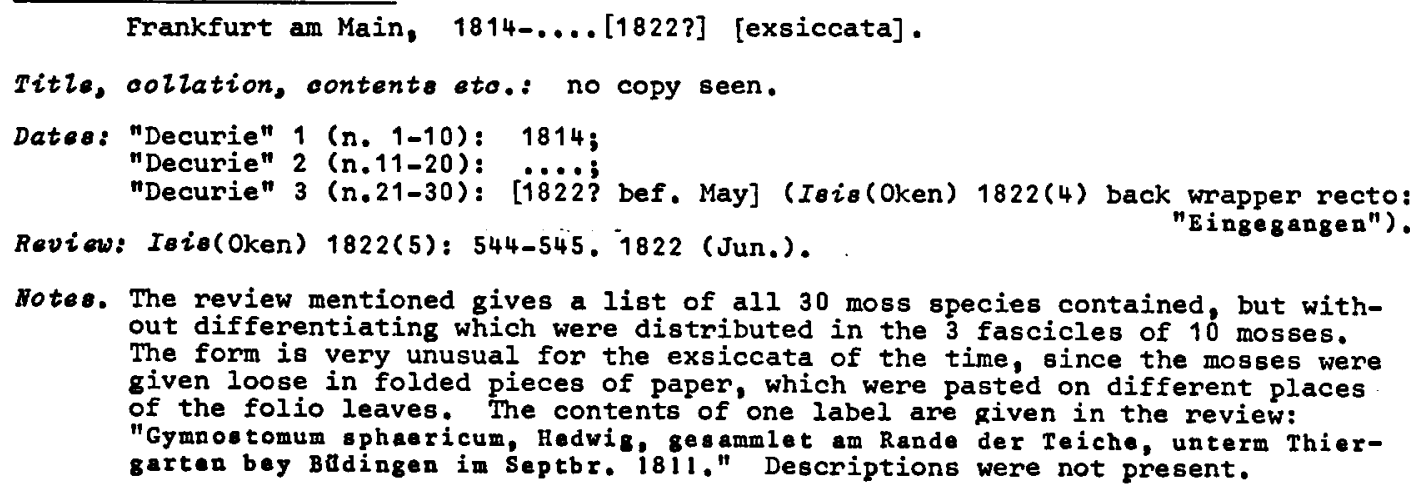

2 Ueber die Entwiokelung der Laubmoose.

Frankfurt an Main, 1823.

Titze [in gothic]: "Ueber die | Entwickelung der Laubmoose. | Von | Johann Heinrich Cassebeer, I Apotheker zu GeInhausen. I Mehrerer gelehrten Gesellschaften Mitglied. I [short swelled rule] | [full thick-thin rule] | Frankfurt am Kain, | Verlag des Hermannschen Buchhandlung | 1823."

Colzation: $\left.16^{\circ} ?: \quad \pi^{1} \quad 2 \pi^{2} \quad 3 \pi^{2} \quad 1-4^{8} \quad 5^{4} \quad 6^{4}(-6)^{4}\right) ; \quad I-V$ VI-VIII IX-X $7 \quad 2-77 \quad 78$.

Contents: I title; II 口; III quotation from Kurt Sprengel; IV D; V-VIII preface: "Vorerinnerung. [gothic]", dated: "Gelnhausen, im Dezember 1822. | Der Verfasser. [gothic]"; IX contents; $X[$; 1-77 text; 78 imprint.

Paper: leaf height $161 \mathrm{~mm}$; laid, chains horizontal; wm. probably: "W[erect swash script]" as in Bridel n.2 (part 3), though in some sheets the marks seem to
differ.

Printer: Kittsteiner, J.G., Hanau, Germany.

Publisher: Hermannsche Buchhandlung, Frankfurt arn Main, Germany.

Date: 1823 (t.-p.), bef. 30 Nov. (review). 
Review: Allg.Repert. Weuest.In- Aus Z.Lit. $1823^{3}(6): 406-408,1823$ Nov. $30 ;$ Leipa.Lit.Zeit. $1824(58)$.

Refo.: BMNH 323 Heins.7(1): 132 Milt.74-75 Pr.ed.1 n.1725, ed.2 n.1577,

Bibl.notes. The size suggests normal octavo; nevertheless the horizontal chainlines would indicate $16^{\circ}$, but it also could be a case of horizontal chainlines in the sheet. The paper reminds one, besides in the curls in the fragments of the watermark seen, of the paper in Bridel's lusoologia and supplements by the many brownish fragments present, which resemble wood fragments, though the copies compared in Farlow Herbarium were markedly different: Bridel much fogged and Cassebeer not. The structure of the $\pi$ 's was settled by checking the conjugate leaves; it is evident that they can form a complete sheet together with 6, but the chain-lines have not been checked to confirm this.

Bot.notes. Interesting discussion of experiments about generatio spontanea, which was advocated for microscopic organisms at the time, especially for the "Priestleyan green matter", said to be formed in water under the action of sunlight. The experiments first were directed to obtain pure water. without germs from outside, and the author stated that he achieved this by cleaning the vessels with steam and keeping them closed with a cork or paper. However, in the next step he apparently did not realize the importance of germs of bacteria etc. in the order of magnitude of $1-10 \mu$. He crushed sporophytes of different species of mosses in a mortar and put some of this in the vessels. He observed different forms of growth for the different species, and concluded that the so-called generatio aequivoca was correct, and not generatio spontanea, the idea apparently being, expressed in modern terms, that the cell constituents of special species would give rise to small forms of life, different from those of other species. This is reminiscent of the recent ideas of 0lga Kosinskaya on the origin of life based upon observations in protoplasm of chicken eggs without nuclei. The observations in both cases may have been correct, but the interpretations given not. Cassebeer probably had different contaminations.

3 Ueber die leichteste Nethode, unmittelbar aus der reifen Noosbahoe die Conferve darzustelien.

Isis (Oken) 1826(3): 289-293. 1826 .

Hcad-title: "Ueber die leichteste Methode, unmittelbar aus der reifen Moosbuchse | die Conferve darzustellen, von Senator Cassebeer zu | Gelnhausen."

Collation: $4^{\circ}$ : $19_{1} \mathrm{r}-19_{2} \mathrm{r}$; $289-293$ (columns).

Date: fasc.3 of the periodical Iois (Oken), nominally over Apr., but certainly issued later, probably May 1826.

Paper: laid, chains horizontal; wm. not checked.

Ref.: RSC 1:813.

Notes. An account of experiments with the germination of mosses, including those with crushed cor tents of capsules, which were cultivated in clean boiled vessels. The gr $3 e n$ matter observed was attributed to "Larven der niederen Pflanzen, Larver des Laubmooses" (col.291). The other part contains correctly interpreted observations on experiments with germination of moss spores in closec tubes with water, left standing in the sun, in which the protonema, indi: ated as confervae, was seen developing. 
CHEVALLIER, Françoj.s Fulgis

Biogr. Born 1796 JuI. 2, Paris, France.

Died 1840 Dec. 24, Freiburg im Breisgau, Baden, Germany.

Ho biography available to me. F.F. Chevallier botanized in the Paris region, and worked on a Flore de la Franoe, in which he developed in more detail the bases of the classification proposed in the work below (Quérard: La F'anoe Litt. 2: 182-183. 1828).

After Nestler's death (1832) he applied for the chair of botany in Strasburs For the "concours" that followed he apparently prepared: Notioe our les travaux soientifiques le F. F. Chevallier... oandidat d la Chaire de Botanique de la Baoult de llsdecine de Strasbourg, Colmar, no date, $4 \mathrm{p}$., but he withdrew when he realized that Fée's rights were better founded than his own (mss. in Archives Départementales, Strasburg). His death prevented the completion of his large work on Fungi.

He was commemorated in the generic name Chevaliera Gaudichaud 1843 (Bromeliaceae).

Ref.: Pr. ed.2: 61.

1 Flore générale des environs de Paris, selon la méthode naturelie. 2 vols. in 3 parts. Paris, 1826-1827.

Colzation: $8^{\circ}$ : vol.1: $a^{8} b^{4}$ (italics) $1-40^{\circ} 41-44^{4} 45^{2}$; I-IX X-XXIV $72-674675-676(X V$ XVII XXIII 28 570 641 649); vol.2(1): $\pi^{2} 1-32^{B} ;$ i-iv $12-512$ (129); vol.2(2): $\pi^{2} \quad 33-59^{8} 60^{2} 61-64^{4} 65^{2} ; \quad i-i v \quad 513-980 \quad 981-984$ (849, 839 as ' $339^{\prime}, 923$ as ' $223^{\prime}, 953$ as ' 593 ').

Contente: vol.1: I-II ${ }^{\text {? }}$; III half-title; IV imprint; V title; VI $\square ; V I I$ dedication to "PETR. EL. FOUQUIER" (1776-1850, physician); VIII $\square$; IX-XIV preface; $X V-X V I$ introduction to the study of the two kingdoms, animal and vegetable; XVII-XXII separate treatment of osaillatoria, considered a connection between the animal and vegetable kingdom; XXIII-XXIV considerations on the division of the plant kingdom; 1-638 text, descriptions of classes, sections, orders, genera and species of Algae, Fungi ("Champignons") and Lichenes; 639-640 corrections and additions to vol.1; 641-674 index of generic and specific names referring to pages as well as to plates; 675-676 omissions;

vol.2(1): i half-title; ii imprint; iii title; iv 0 ; 1-512 text, descriptions of taxa of the same ranks of Hepaticae. Uusoi, Filices. Synarthrophytae [=Equisetaoeas + Characeae] and Phanerogamae, Alopecurus Erythraea vaiziantii;

vol.2(2): i half-title; ii imprint; iii title; iv $\square$; 513-948 text, Phanerogamas concluded, Erythrasa vailiantii - ciematio recta and the omitted order Juglandaceae with Juglans regia; $949-980$ index of generic and specific names of vol.2; 987 explication of botanical signs; $982-983$ corrections to vol.2; 984 D.

Plates: 18 copper-engravings, possibly with etching, numbered 1-18 (vol.1: $15 \mathrm{pls}$, vol.2: 3 pls.), illustrating cryptogams, many species per plate, indicated with arabic numerals and letters, no names; plate-marks partly visible (copy PMusBC).

Artiot: Duménil, Paul Chrêtien Romain Constant (biogr.: Bénézit 3: 398. 1955): all plates.

Engravers: Dien [? Claude Marie François (1787 Nov. 11 - 1865 Aug. 20, Paris) (biogr.: Bénézit 3: 259.1955)]: pls. 12-14; Joyeau ...: pls. 16-18; Lanvin ..... Paris (biogr.: Bénézit 5: 405. 1956): pls. 1-6;
Plée, Veuve"[Widow] ...: pls. 7-11, 15 (pls.7-9 signed: "V. Plée"). 
Paper: leaf height $207 \mathrm{~mm}$. (copy PMusBC, cut); laid, chains vertical; wm.: "P I [script, last letter possibly incompletej" in left top corner of sheet; plates: wove; no wm. seen.

Printer: Decourchant (or De Courchant), Paris.

Publisher: Ferra jeune (vol.2), Paris. [N.B.: Quérard: La Franoe Litt. $2: 183$. 1828 , indicated that the publisher was Gaury, Paris. Not studied further.]

Dater: vol.1: $1826\left(t,-p_{.}\right)$, bef. 5 Aug., with all (18) plates

2. 1827 (Bibliogr,Franoe 15 (62):681.1826);

vol.2: 1827 (t.-p.), bef. $5 \mathrm{Jan} .1828$ (Bibliogr.France 17 (1): 5.1828 ).

Review: R[aspail]: BulZ.Soi.Nat. 14(7): 337-338. $1828 \mathrm{Jul}$.

Refe.: Arn.Arb, 1: $153 \mathrm{ab}$

$\mathrm{BMNH} 343$

Bradl. 1: 408 a

Cat.Juss. n.1608

Kew 111

Krüg. 146

Milt. 131
Niss. n. 353

Pr.ed.1 n.1824

Pr.ed. 2 n.1691

Stafl. TL $n .231$.

Bibl.notes. Quérard, La France Litt. 2: 182-183. 1828, indicated states with uncolored plates and with colored plates (prices 24 francs for the first and 32 for the latter). I did not see a copy with colored plates of this edition and do not know if the color was partly printed as in ed.2. If so, it would be a close second for color prints of mosses as far as $I$ know (compare Sommerfelt $\mathrm{n.2}^{2}$ ). Leaf $a_{1}$ is included in the printed pagination of the remainder of the gathering; however, I have not seen a copy in which it was preserved, and I assume that it was blank. I did not transcribe the title.

Bot.notes. In this regional flora the natural classification of A.L. de Jussieu and A.P. Je Candolle was used, and especially applied to the Cryptogamae, which were extensively treated. In Musoi, not a specialty of the author, a number of new combinations and some new taxa of specific and varietal rank were proposed, which have been overlooked by bryological indexers up to now. New names in ferns and phanerogams were listed by Beckerer: Repert.Speo.Nov. 27: 366-368. 1930.

2 Flore gonerale des environs de Parie...

Titze: "FLORE | GENERALE | DES ENVIRONS DE PARIS, | SELON LA MÉTHODE NATURELLE. | ... | PARIS, | FERRA, LIBRAIRE-EDITEUR, | ... | 1836."

Collation: $8^{\circ}: \operatorname{vol} 1: a^{8} b^{4}(i t a l i c 8) \quad 1-40^{8}\left(-17_{6,7}+17_{6.7}=39_{1.8}\right) \quad 41-44^{4}$ $45^{2}\left(-45_{1}\right) x^{4}\left(-x_{1}\right) \quad 2 x-3 x^{1} \lambda 1-\lambda 14 \quad\left(42_{1}\right.$ as $\left.I_{2}^{\prime}\right) ; \quad I-I X \quad X-X X I V \quad 7,2-680$ 681-684 [14 leaves:] $11-\lambda 14$ (XV XVII XXIII 28 510 648 675);

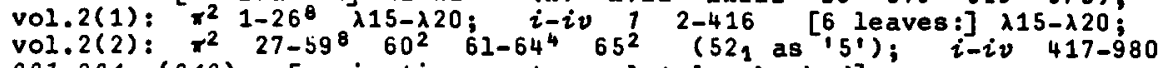
$987-984$ ( 949 ) [paginations not completely checked].

Contente: essentially the same as of ed.1, except: vol.1: 675-680 index; 681-682 omissions; 683 part-title to explanations of the plates; $684 \mathrm{C} ; \lambda 1-\lambda 14$ rectos $\mathrm{D}_{\text {; }}$ versos explanations of plates 1-14, headed: "PLANCHE I." - "PLANCHE XIV."; vol.2: $\lambda 15-\lambda 20$ rectos $\square$, versos explanations of pls. 15-20.

PZates: 20 copper-engravings (possibly with etching), black and white, or colored if so, pls.1-14 only hand-colored, pls.15-20 printed in two colors "à la poupée" and finished with hand-coloring; numbered: vol.1: I-XIV, vol.2: $X V-X X$; no complete plate-marks seen. 
Artists engravere: pls.1-18 not different from those of vol.1; pls.19-20 not checked.

Paper: not studied.

Publisher: Ferra, Paris.

Date: 1836 (t.-p.), bef. 2 Apr. (Bibliogr.France 25 (14): 160, 1836 ).

Refe.: Arn.Arb.1: 158 BMNH 343

Graesse 2: 131 Kew-S 61
Pr.ed.1 n.1824, ed.2 n.1691 Stafl. TL n.23i.

Bib2.notes. An uncut copy was studied because of its interesting cancels. I did not have the two editions on hand at the same time; a comparison of the collation indicates that the second edition consists mainly of sheets of the first edition with reset preliminaries, the cancellantia and the addition of the explanation to the plates. The leaves concerned, $3 x, \lambda 1-\lambda 20$, were all printed at one side of a few sheets and cut before binding, which is indicated by the places of the torn edges.

Some plates were added; the color-prints of mosses are already referred to under n.1. Bot.note. For additions or changes only the explanations and cancellantia have to
be studied.

\section{DEMERSON, L.}

Biogr. According to the card catalogue of the Bibliothèque Centrale, Muséum d'Histoire Naturelle, Paris, this is a pseudonym or a later name of $L$. Hanin. I have found no confirmation, nor any other indication of this identity.

Hanin, Louis, was born in Metz in $17 \ldots$ published botanical papers in the Napoleonic era, but not later. I could not find the date of his death. Possibly a name change was involved, which would explain both. It is less probable that the name Demerson was a pseudonym to avoid difficulties in the changed political circumstances, since the title of the work treated below indicated Demerson as a "chevalier de l'ordre royal de la Legion-d'Honneur", and the third edition of the calendrier frangais gives his address, as he was its publisher (rue de l'Échiquier, n. 4. Paris).

The name Demerson can be found without an accent, or with an acute accent over the first a: Démerson. Since the earliest indications do not have an accent I have adopted this. Demerson also published in other fields in lesson-form, e.g. chemistry, and three editions of a Calendrier frangaio, which have some botanical phaenological information, but no bryology. These I described biblioeraphically in Huntia 2: 164-168. 1965.

\section{La botanique enoeignese en vingt-deus legons.... Paris, $1 \overline{8} 25$.}

Titze: "LA BOTANIQUE [shadowed outline] I ENSEIGNEE I En vingt-deux Legons, [line in gothic] | OUVRAGE DANS LEQUEL SONT EXPOSÉS L LES ELEMENS [sic] ET LES PRINCIPES | RELATIFS A CETTE SCIENCE | ET ORNE DE ONZE PLANCHES COLORIEES; PAR M. L. DEMERSON, I CHEVALIER DE L'ORDRE ROYAL DE LA LEGION-D'HONNEUR, DOCTEUR EN MEDECINE, PROFESSEUR DE PHILOSOPHIE NATURELLE, I ET MEMBRE DE PLUSIEURS SOCIETES SAVANTES, [short shadowed swelled rule with pearl] PARIS, I P. PERSAN ET CIE, EDITEURS, I RUE DE L'ARBRE SEC, $N^{\circ} 22$. | [short rule] | $1825^{n}$.

Collation: $12^{\circ}: \pi^{2} 2 \pi-4 \pi^{2} 1-19^{12} \cdot 20^{4}\left(-20_{4}\right)$ (\$5 as $)$ ) i-vii viii-xiv

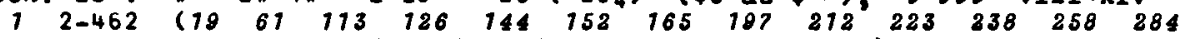
$\begin{array}{lllllllllll}295 & 370 & 326 & 342 & 351 & 381 & 477 & 424 & \$ 38 & 160 & 467) .\end{array}$ 
Contents: $i$ half-title; $i i$ announcement: "Se trouve I CHEZ AUDIN, QUAI DES AUGUSTINS, $\mathrm{N}^{\circ} 25 . "$, and imprint at bottom; iii title; iv D; v-xiv introduction; 7-437 text in 22 chapters named "leçon"; 438-459 word list: "ETYMOLOGIE | DES MOTS EMPLOYES DANS CES LEÇONS.; 460 []; $461-462$ contents. RT: chapter headings, e.g.: "BOTANIQUE | LEÇON"V." Language: French.

Plates: 11 hand-colored copper-engravings, frontispiece illustrating Dionaea muscipula, and 10 plates numbered: "PL. I." - "PL. X.", illustrating botanical terms; plates trimmed, probably several plate-pages combined into one copper-plate.

Artist: plates unsigned.

Engraver: Bonnet, Paris?: all 11 plates.

Paper: leaf height $168 \mathrm{~mm}$. (HBL copy, cut); laid, chains horizontal; wm.: "J [diamond] $B=L$ [outline letters]".; plates: laid, chains vertical; wm. " [she11]" and fragments of erect script letters.

Printer: Casimir, Paris.

Puolisiner: "P. Persan et compagnie". Paris, and in stock with Audin, Paris. Date: 1825 (t.-p.), bef. 20 Aug. (Bibliogr.Franoe 15 (34): 557. 1825). Refa.: Bradl.1: 85 $5^{b} \quad K r u ̈ g .54 \quad M i l t .47 \quad$ Pr.ed.1 n.2434, ed.2 n.2153.

Variants: The announcement of 20 complete sheets (Bibliogr.Franoe 1825(34): 557. 1825) seems to indicate another state, with two more leaves, although these might have been blanks and then represent the ideal copy. The announcement at the verso of the half-title, of bookseller Audin who was the sole publisher of the third edition, possibly indicates a variant.

Bibl.notes. This book is regular except for the preliminaries in which a single leaf $\pi^{1}$ is followed by three corsecutive pairs of conjugate leaves. I have not been able to prove that $x^{1}$ had been conjugate with leaf $20_{1}$, because the places of the chain-lines in the many different leaves do not vary conspicuously; in these two they do not contradict this supposition.

Bot.notes. This work is only of interest for the history of teaching of botany. Musoi are treated succinctly (433-435) with scant references to literature.

2 La botanique enseignés en vingt-deux legons ...

Ed.2. Paris, 1826.

Titie, oozzation, oontents eto.: no copy seen.

Date: 1826, bef. 1 Apr. (Bibliogr.France 15 (26): 278, 1826, announced as $12^{\circ}$, with 19 t sheet; and plates).

Refo.: Bibliogr. Prance (see Date) states: Nles faux titre et titre sont suivie Quérard: France Lit. 2: 469.1828. d'onglet".

Notes. Querard supposed that this was a re-issue with a new title-page. The indication of sheets in the announcement cited under Date confirm this if we assume that the leaf with contents was bound with the preliminaries, and that these were not included in the count given. This would be represented by the following hypothetical collation: $\pi^{1}\left( \pm \pi_{1}\right) 2 \pi-5 \pi^{2}\left(-5 \pi_{2}\right) 1-1912$ $20^{4}\left(-20_{3}=5 \pi_{1}-20_{4}\right)$. 
3 La botanique enseignee en vingt-deux lecono...

Ed.3. Paris, 1827 .

Titze: "LA BOTANIQUE | ENSEIGNEE | En vingt-deux Lecons [line in gothic] | OUVRAGE DANS LEQUEL SONT EXPOSES | LES ELEIENS ET LES PRINCIPES | RELATIFS A CETTE SCIENCE, | PAR M. L. DEMERSON, | CHEVALLIER DE L'ORDRE ROYAL DE LA LEGION D'HONNEUR, I DOCTEUR EN MEDECINE ET PROFESSEUR DE PHILOSOPHIE NATURELLE. I Troisième Edition, [line in gothic] | ORNEE DE ONZE PLANCHES COLORIEES. | [short interrupted swelled rule] | PARIS, | CHEZ AUDIN, LIBRAIRE, | QUAI DES AUGUSTINS, No 25. | [short wavy rule] | 1827."

Lithographed title (in calligraphy): "IAA BOTANIQUE | enseignee | en XXII legons, | PAR MF DEMERSON | $D$. M. Chev. "er" de la Z\&gion d'honneur. | 3ẹ EDITION | CORRTGEE ET AUGMENTÉ, | Paris. [in gothic] | Audin Libraire, Quai deo Auguetins, 25. | Editeur de la Colleation | d'ouvrages en legono. | 1827."

Colzation: $12^{\circ}: \pi^{2} a^{2} a * 4 \quad 1-21^{12}(-21,0,11,12)$; $i-v$ vi-xv xvi 1 2-498

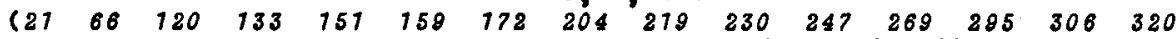

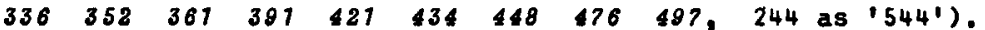

Contente: i half-title; ii imprint: "Imprimerie et Fonderie de J. Pinard, | Rue d'Anjou-Dauphine, N. 8, A Paris."; iit title; iv 0 ; v-xv introduction; xvi D; 7-475 text, popular treatment of botany; 476-496 etymology of words: "Etymologie des mots employés dans ces leçons."; 497-498 contents. RT: chapter headings, e.g.: "BOTANIQUE | LEÇON VIII". Language: French.

Plates: 1 lithographed title between $\pi_{1}$ and $\pi_{2}$, and 11 hand-colored copperengravings, frontispiece illustrating Dionaea musoipula (probably with changed or erased page-number indication, not checked), 10 plates numbered I-X as in ed.1, illustrating botanical terms; plate-marks partly visible.

Paper: leaf height $172 \mathrm{~mm}$. (BR copy, cut); laid, chains horizontal; wm.: "Y [diamond] $B=L$ [letters in outline]"; plate paper: laid, slightly bluish, chains not checked; no wm.

Printer: Pinard, J., Paris.

Publisher: Audin, Paris.

Date: 1827 (t.-p.); bef. 25 JuI. (Bibliogx.France 16 (59): 609. 1827 ).

\begin{tabular}{l|l|l} 
Refe.: & BMNH 439 & Pr.ed.1 n.2434 \\
Plesch 57 & Pr.ed.2 n.2153 & Querard: France Lit.2:469.1828.
\end{tabular}

Jotes. No important changes noted over the first edition. Querard supposed this edition too to consist of the same sheets as edition 1.

4 La botanioa ineegnata in ventidue lesioni...

Milano, 1826 .

Titie, oontents, eto.: no copy seen.

Collation: $8^{\circ}: \ldots$; 100 p.

Announcements: Bibliot.Ital. 44(11): 268-269. 1826 Nov.;

Flora $10^{2}$ (Beil.3): 89.1827 .

Translator: Ferraro or Ferrario, Ottavio.

Hote. According to Flora (see Announoements) this is merely a translation. 
DESMAZIERES, Jean Baptiste Henri Joseph

Biogr. Born 1786 Jul. 10, Lille [now dép. du Nord], France.

Died 1862 Jun. 23, Lambersart near Lille.

Desmazières apparently lived on an estate. As a botanist he first concentratec on the regional flora, and he found many additional species. Gradually he concentrated on cryptogams, especially on lower fungi, in which group he became an expert. He did not study mosses thoroughly. His other interests were mainly agricultural; no definite details are available to me. He was commemorated in the generic names Desmaraeria Dumortier 1823 [corrected to Desmazeria Dumortier] (Gramineae), Desmazieria Montagne 1825 (Lichones) and Desmazieralla Libert $1829(F u n g i)$. A prize, prix Desmazières, for cryptogamic publications in France, commemorates his name too.

Refe.: Bull.Soc.Bot.France 9: 321-323. 1863.

Bul2.Soc.Bot.Be $Z_{g}$ 1: 102-105. 1862 (date of death: 24 Jun.). Pr. ed.2: 81. 1872 (year of birth: 1796).

Le Tourneur, St.: Diot.Biogr.Frang. 10: 1456. 1965 (date of death: $25 \mathrm{Jul}$ ).

\section{Plantes oryptogames du Nord de La France.}

44 fasc. + index-vol. Lille, 1825-1851 [exsiccata].

Title: "PLANTES | CRYPTOGAMES | DU | NORD DE LA FRANCE, | Par J.B.H,J. DESMAZIERES, I MEMBRE DE LA SOCIÉTE D'AMATEURS DES SCIENCES, DE L'AGRICULTURE ET DES ARTS, A LILLE; CORRESPONDANT DE LA SOCIÉTÉ LINNÉENNE DE PARIS; DE LA SOCIETE DE | FLORE DE BRUXELLES; DE LA SOCIETE ROYALE D'AGRICULTURE ET DE BOTANIQUE DE GAND; I DE CELLE D'HORTICULTURE DE TOURNAI; DE LA SOCIÉTE POUR L'ENCOURAGEMENT I DES SCIENCES, DES LETTRES ET DES ARTS, A ARRAS, etC. [long rule at right], Herbarium praestat omni icone, necessarium omni Botanico.[at right] | LINN., Phiz. Bot. p. 7.[at extreme right] | [long rule at right] I FASCICULE I,er | [wavy rule] | A LILLE, I IMPRIMERIE DE LELEUX, GRANDE PLACE. | [very short double rule] | JANVIER . 1825.";

fasc.2: as fasc.1, same type-setting with second I added: "FASCICULE II." and date line changed into "1825.";

fasc.3: as fasc.2, same type-setting except: "FAscicule III." and "1826." (the 6 clearly different from other numerals);

fasc.4: as fasc.3, except: "FASCICULE IV."; reset (partly?);

fasc.5: as fasc.4, (same type-setting?) except: "FASCICULE $V$ " " and "1827.";

fasc.6: as fasc.5, same type-setting except: "FASCICULE VI" and "1827" (the I in VI and the 7 in 1827 clearly heavier than the rest);

fasc.7: as fasc.5, same type-setting except: "FASCICULE VII" and "1828";

fasc.8: reset (partly?); same title except: "MEMBRE TITULAIRE DE LA SOCIÉTE ROYALE DES SCIENCES DE L'AGRICULTURE ET DES ARTS," ... "FASCICULE VIII." and "1829.";

fasc.9: as fasc.8, same type-setting except: "FASCICULE IX";

fasc.10: as fasc.9, except: "FASCICULE X" and "1830" (setting not studied); fasc.11: as fasc.10, same type-setting except: "FASCICULE XI." and "183I."
[sic] (the I's clearly added);

fasc.12: 1832, fasc.13: 1833, fasc.14: 1833, fasc.15: 1834, fasc.16: 1836 , not studied in detail

fasc.17: "PLANTES | CRYPTOGAMES | DE FRANCE, | Par J.B.H.J.DESMAZIERES, | MEMBRE TITULAIRE DE LA SOCIÉTE ROYALE DES SCIENCES, DE L'AGRICULTURE ET DES ARTS, DE LILLE, I CORRESPONDANT DE LA SOCIÉTÉ D'HIŚTOIRE NATURELLE DE PARIS ET DE CELLES DES SCIENCES PHYSIQUES, | CHIMIQUES ET ARTS INDUSTRIELS DE LA MÊME VILLE; DE LA SOCIÉTE LINNEENNE DU CALVADOS; DE I L'ACADEMIE ROYALE DES SCIENCES, BELLES LETTRES ET ARTS DE ROUEN; DE LA SOCIETE LIBRE I D'ÊMULATION DE LA MEME VILLE, DE LA SOCIETE ACADEMIQUE DE FALAISE; DE CELLE POUR । L'ENCOURAGEMENT DES SCIENCES, DES BELLES LETTRES ET DES ARTS, A ARRAS; DE LA SOCIETE CENTRALE | D'AGRICULTURE, SCIENCES ET ARTS DU DEPARTEMENT DU NORD; DE LA SOCIÉTE ROYALE D'EMULATION | D'ABBEVILLE; DE LA SOCIETE DES 
NATURALISTES DE LEIPZIG; DE LA SOCIETE ROYALE D'AGRICULTURE ET | DE BOTANIQUE DE GAND, DES SOCIETES D'AGRICULTURE ET D'HORTICULTURE DE LILLE, BOULOGNE, | BRUXELLES, TOURNAI etc. | [rule above quotation at right] | Herbarium praestat omni icone, necessarium omni Botanico. | LINN.'Phiz. Bot. $P_{i}{ }^{7}$ | [rule below quotation] | FASCICULE XVII. | [wavy rule] | A LILLE, | IMPRIMERIE DE LELEUX, GRANDE PLACE. | [very short double rule] | 1836 ." ; fasc.18-20: similar, except: $1837,1838,1839$;

fasc. 21: "PLANTES |' CRYPTOGAMES |'DE FRÁNCE, Par J.B.H.J.DESMAZIERES, | MEMBRE DE PLUSIEURS SOCIETÉS SAVANTES. | [same quotation between rulés] FASCICULE XXI. I [wavy rule] I A LILLE, IMPRIMERIE DE LELEUX, GRANDE PLACE. | [short double rule] | 1839,";

fasc. 22: same type-setting, except: "FASCICULE XXII." and "1840.";

fasc.23-44: 1841-1851, not studied in detail;

index-vol.: "INDEX | GENERUM, SPECIERUM ET SYNONYMORUM | IN I J. B. H. J. DESMAZIERES, | PLANTES CRYPTOGAMES DE FRANCE, | EDIT. I, SER. I, FASC. I-XLIV, 1825-1851. I EDIT. II, ser. I, FASC. I-XXXVII, 1836-185i. I [ short fancy swelled Fule] | LILLE, | IMPRIMERIE DE LELEUX, GRANDE PLACE | [very short rule] | 1851."

Collation: $4^{\circ}:$ fasc.1: $\pi^{4}\left(\pi_{1}=\right.$ paste-down) $1-3^{4} x^{4} ; \quad i-v i \quad 1 \quad 2-23 \quad 24-86$

fasc. 2: $\quad \pi^{4}\left(\pi_{1}=\right.$ paste-down, $\left.-\pi_{4}\right) x^{i} ; \quad i-i v \quad 1-8$;

fasc. 3: $\pi^{2} x_{-2}-2 x^{1} ; i-i v 1-4 ;$

fasc.5: $\pi^{4}\left(\pi_{1}=\right.$ paste-down $) x^{1} ; i-v i \quad 1-2$;

fasc.6: $\quad \pi^{4}\left(\pi_{1}=\right.$ paste-down $) x^{2} ;$ i-vi $1-2 ;$

fasc.7-20: not studied in detail (not essentially different)

fasc. 21: $\pi^{2} 1^{2} x^{1} ;$ i-iv $1-6 ;$

fasc.22-44: not studied in detail

index-vol.: $\pi^{2} \quad 1^{2} 2-7^{2} ; \quad 1-5$ 6-31 32 .

Contente: fasc.1: i half-title; $i i$ announcement of addresses where the set was for sale, and condition ( 8 fr. per fasc.); iii title; iv $\square$; v-vi dedication to $\mathrm{C} . \mathrm{H}$. Persoon (1755-1837); 1-23 preface, with announcement that fasc. 2 would appear within four months, and the others with more or less the same interval, each would contain 50 specimens of cryptogams, methodically arranged from "Algues" to "Naiades"; $240 ; 25$ index of specimens preceded by short list of families; 26 ,

fasc.2: i half-title; ii announcements as in fasc.1; iii title; iv $\square$; 1 index to 8 pecimens as in fasc.1; 2 ;

fasc.3: i half-title; ii announcement; iit title; iv 0; $10 ; 2$ whole page description to n.101; 3 index to specimens as in fasc,1; 4 ; fasc.4: $i$ half-title; ii $\square$; iii title; iv $\square$; 1 index to specimens; 2 ; fasc.5-20: not studied in detail; essentially the same make-up;

fasc.21: i half-title; ii ; $_{\text {i }}$ ii title; iv $\square$; 1 introduction; 2-4 monography, headed: "CERAMIUM", with descriptions of four subgenera proposed by the brothers Crouan after their manuscript notes; 5-6 "Observations sur les Tétraspores des Algues | par MM. Crouan Frères."; fasc.22-44: not studied in detail;

index-vol.: 1 half-title; 2 ; 3 title; \& D; 5-31 index, headed: "INDEX | GENERUM, SPECIERUM ET SYNONYMORUM"; 32 口.

Speoimen-parts: quired gatherings of 8,10 or 12 leaves, of which the last leaf is usually a paste-down, the last but one a blank leaf, before which the printed $x$, the index, is tipped in; 50 leaves per fascicle are devoted to the specimens, these being pasted usually on slips of paper, which in turn are pasted to the rectos of the leaves, one per leaf, and printed labels pasted to the same side (in one case a whole printed page is devoted to a long description and serves as label, facing the specimen); the labels contain: number, binomial, a reference to literature in italics, as the case may require synonyms, the habitat, the season, and descriptions when not yet described or when the taxa were also published by Desmazieres in a contemporaneous journal. 
Paper: laid, chains horizontal, or wove; wm. not studied;

text: laid: fasc.1-20, 21x, 25-44;

wove : fasc. 21 (except $x$ ) , 22-24;

s pecimen-part: laid: fasc.1-19, 22-44;

wove: fasc.20-21.

Printer: Leleux, Lille, France.

Publisher: the author.

\begin{tabular}{|c|c|c|c|c|c|c|c|}
\hline Deter: : & fasc. & $\begin{array}{c}\text { specimen } \\
\text { numbers }\end{array}$ & $\begin{array}{l}\text { date } \\
\text { t. -p. }\end{array}$ & other data & fasc. & $\begin{array}{l}\text { s pecimen } \\
\text { numbers }\end{array}$ & $\begin{array}{l}\text { date } \\
\text { t. -p. }\end{array}$ \\
\hline & $\begin{array}{r}1 \\
2 \\
3 \\
4 \\
5 \\
6 \\
7 \\
8 \\
9 \\
10 \\
11 \\
12 \\
13 \\
14 \\
15 \\
16 \\
17 \\
18 \\
19 \\
20 \\
21 \\
22\end{array}$ & $\begin{array}{c}\text { preface } \\
1-50 \\
51-100 \\
101-150 \\
151-200 \\
201-250 \\
251-300 \\
301-350 \\
351-400 \\
401-450 \\
451-500 \\
501-550 \\
551-600 \\
601-650 \\
651-700 \\
701-750 \\
751-800 \\
801-850 \\
851-900 \\
901-950 \\
951-1000 \\
1001-1050 \\
1051-1100\end{array}$ & \begin{tabular}{|r|}
$J$ an. 1825 \\
1825 \\
1826 \\
1826 \\
1827 \\
1827 \\
1828 \\
1829 \\
1829 \\
1830 \\
1831 \\
1832 \\
1833 \\
1834 \\
1834 \\
1836 \\
1836 \\
1837 \\
1838 \\
1839 \\
1839 \\
1840
\end{tabular} & $\begin{array}{l}\text { Dec.1824 } \\
\text { bef.28 Feb. } \\
\text { bef.Jun.1826 } \\
\text { bef.Jun.1826 }\end{array}$ & $\begin{array}{l}23 \\
24 \\
25 \\
26 \\
27 \\
28 \\
29 \\
30 \\
31 \\
32 \\
33 \\
34 \\
35 \\
36 \\
37 \\
38 \\
39 \\
40 \\
41 \\
42 \\
43 \\
44 \\
\text { inde }\end{array}$ & $\begin{array}{l}1101-1150 \\
1151-1200 \\
1201-1250 \\
1251-1300 \\
1301-1350 \\
1351-1400 \\
1401-1450 \\
1451-1500 \\
1501-1550 \\
1551-1600 \\
1601-1650 \\
1651-1700 \\
1701-1750 \\
1751-1800 \\
1801-1850 \\
1851-1900 \\
1901-1950 \\
1951-2000 \\
2001-2050 \\
2051-2100 \\
2101-2150 \\
2151-2200 \\
-v 01 .\end{array}$ & $\begin{array}{l}1841 \\
1842 \text { ( In aded } \\
1842 \\
1843 \\
1843 \\
1845 \\
1845 \\
1846 \\
1846 \\
1847 \\
1847 \\
1848 \\
1848 \\
1849 \\
1849 \\
1849 \\
1849 \\
1850 \\
1850 \\
1851 \\
1851 \\
1851 \\
1851\end{array}$ \\
\hline
\end{tabular}

Reviews and date-oonfirming announoements:

preface (bef. 28 Dec.?): M\&m.So0.Linn,Parie 3(6): XLII, CVIII. 1825;

fasc.1: Philos. Mag. J. 65: 132. 1825 Feb. 28;

Bory de St. Vincent: Bull.Soi,Nat, 5(5): 90-91. 1825 May;

Dumortier, B.C.: Meseager Soi.Arte $1825(3 / 4): 70-73.1825$ Mar.-Apr.;

fasc.2-3: Dumortier, B.C.: Meseager Soi,Arts 1826(3/5):49-51.1826 Mar.-May.;

fasc.4: Gaillon, B.: Buli.Soi.Nat. 16(2): 259-261. 1829 Feb.;

fasc.16-17: Desmazières: Ann.Soi.Nat. ser.2, 6: 242-247. 1836 0ct. 6;

fasc.17: Ann. Ma. Nat.Bist. (London) 1(1): 69-70. 1838 Mar.;

fasc.21: Ann.Mag.Nat.Hist. (London) 6: 146. 1840 Oct.

Refo.: BMNH 445 Krig. 113 Milt. $276 \quad$ Pr.ed.1 n.2512 Stafl. TL P.104,

Bibl.notes. This large series of exsiccata has some peculiarities which warrant careful research. The title-page setting was used for quite a number of fascicles, possibly printed in advance. In several cases the changed numerals (e.g. the last digit of the year) clearly stand apart in a number of volumes, and the position of broken letters indicate the same type-setting. In some others the digit is even not printed but filled out by hand. This indicates that these title-pages were printed so far ahead of publication, that tirere was no reasonable certainty about the year. Therefore, a chance exists, that of other fascicles with completely printed year numbers the date is too early. In several of the early fascicles the first leaf of the printed gathering was used as a paste-down against the front 
cover (this, of course, is not counted in the pagination). The fascicles from the same imposition should have the same position of the leaves in the gathering; from standing type another imposition can be expected. This seems to be the case in fasc.3. However, this might be the same imposition as fasc.1 and 2 , when the blank pair of conjugate leaves $\pi_{4}+\pi_{4}$ is placed before the pair $\pi_{2}+\pi_{3}$. I realized this too late and cannot recheck the conjugacy and matching chain-lines to settle the possibility of standing type.

The thickness of the specimen-part was in some gatherings counterbalanced by extra folds in the spine. The mixture of laid and wove paper is interesting; at a certain moment apparently only wove paper was available; the printed part shifted back later than the specimen-part, which also indicates that the titles of a number of fascicles were printed at the same time, long before actual publication.

Finally a large number of corrections to earlier specimens were issued in later fascicles, often in the form of slips of paper with the corrected names, which could be pasted over the old names, as well in the indexes of the fascicle volumes as on the specimen-leaf, or even complete new labels for the latter. The author's copy in Paris, PC, has these all in place.

Bot.notes. This series of exsiccata reflects the author's interest. Though containing cryptogams of all groups, the $A l_{g}$ ae and especially lower Fungi are better represented than other groups, with many new or recently described species and varieties. Many of these were published by Desmazières in journals of the same year, some clearly not yet published when the text of these exsiccata was prepared, so that the precise dating of many fascicles is important. However, since I did not find new names of Huoci in the series except the first valid publication of the name orthotrichum oriopulum Bruch (as far as I am aware). I did not concentrate on determining the precise dates. There is a possibility to find information in local newspapers, but this was outside the scope of my work.

\section{Plantes aryptogames de Franoe.}

\section{Ed.2. 37 fasc. Lille, 1836-1851 [exsiccata]}

Title, collation and contents: no copy seen.

Refo.: Brun.2: 627 Graesse 7: 242 Kew 153 Pr.ed.1 n.2512 StafI. TL p.104.

Reviewe: fasc.1-6: S[chimper], W.P.: Flora $22^{2}$ Lit.Ber.9(9): 129-130. 1839; fasc.5-6: Desmazières: Ann.Söi.llat. ser.2, 10: 308-314. 1838 .

Notes. Apparently the supply of many fascicles of the first edition had become exhausted, so that at.the same time with the change of the title of the first edition this second was begun, in which many species of the foregoing fascicles could be issued again, probably from another locality.

3 Plantes cryptogames de France.

[Ed.2 ser.2, or Ed.3.] 16 fasc. Lille, 1853-1860[1861] [exsiccata].

Title, collation, oontents, eto.: no copy seen.

Ref: Kew 153 Stafl. TL P.104.

Notes. Listed because of the complicated references to the series as a whole. An indication of series or edition is lacking on the title-page, but is imperative in citations of specimens. In the author's copy (PC) the last fascicle, dated 1860 in print on the title-page, had the spine-label with the date 1861 in which the last digit was filled out by hand, a feature which I referred to in the bibliographical introduction as a help in dating. 
DESVAUX, Nicaise Auguste

Biogr. Born 1784 Aug. 28, Poitiers (now dép. Vienne), France.

Died 1856 Jul. 12, Bellevue near Angers, dép. Maine-et-Loire, France. No biography available to me. According to his own statement in 1827 he studied mosses with Palisot de Beauvois during 10 years and had studied ferns for 15 years. He edited the Journal de botanique (Desvaux), which was interrupted and finally stopped because a servant of the printer had stolen the copper plates of the volume ready for printing when Desvaux was not in Paris from 1818 to 1820. This he wrote to Ad.Brongniart in a letter dated 20 Sep. 1827 , from which it is also clear that the stock of the first two volumes was with the publisher Dufour, and that Desvaux himself had the stock of the remaining volumes, though incomplete. He became director of the botanical garden at Angers.

His Christian names are usually cited: Augustin Nicaise, but contemporaneous references were to N.A. Desvaux, and I therefore prefer to follow the names as given in the Barnhart file: Nicaise Auguste.

He was commemorated in the generic names Deovauxia $R$. Brown 1810, considered a synorym of Centrolepie Labillardière 1804 (Centrolepidaoeae) and Desvauxia Pal. Beauvois ex Desvaux 1828 (Eriooaulaceas).

Refs.: BulZ.Soc.Bot.Brance 3: 637-638, 1856, 22: 1xxxvi. 1875 (herb. at Angers).

1 Exposition methodique des genres de la famizle des mousses... Mém. Soc. Linn. Paris 3(2): 211-228. 1824 May.

Bead-titie: "[full fancy wavy rule] | EXPOSITION METHODIQUE | Des genres de $l_{a}$ famille des Housses, pour servir| de oomplement au travaiz de feu PALISOT DE | BEAUVOIS (I), par M. DESVAUX, directeur | du Jardin des plantes a Angers, correspondant | [short rule]" with footnote: "(I) Inséré dans le | premier volume des Mémoires de lá Société."

Colzation: $8^{\circ}: 15_{2} \mathrm{r}-16_{2} \mathrm{v}_{3} 211212-228$ (see M\&m.Soo.Linn.Paris).

Contents: 211 head-title; 217-214 introduction and general discussion; 214-216 keys to genera (no taxa higher in rank than genus); 217-218 description of 63 genera. No RT. Language: French.

Paper: leaf height $200 \mathrm{~mm}$. (Teyl. copy, cut); laid, chains vertical; no wm.

Printer: Lebel, Paris.

Publisher: Sociéte Linnéenne de Paris.

Date: 1824, May (fascicle title); bef. $10 \mathrm{JuI}$. (see Móm.Soc.Linn,Paris).

Ref.: RSC 2: 275 .

Bibz.note. Article in periodical.

Bot.notes. This article was written to form a complement to the article of Palisot de Beauvois of 1822 in the same journal. Palisot de Beauvois died before his article was published; therefore, discrepancies existed between the names in the text and in the plate-part, which was prepared long before. These discrepancies were straightened out by Desvaux who retained the classification and most of the generic delimitations of the older author. The new generic neme Codrionophorus was said to be an error; Desvaux changed it into Codonophorus and supplied description. The illegitimate name Chastephora Brid. was replaced by Calyptroohaete Desv.

Desvaux, in his introduction, did not support the idea of Palisot de Beauvois concerning the sexual function of the columella, observing that particles like those to which the role of propagation was assigned, come from several sorts of tissue which definitely have no sexual function. 
2 Prodrome de la famille des fougdres.

Mém. Soc. Linn. Paris 6(2): 171-212. 1827 May, 6(3): 213-337. 1827 Jul.

Bead-title: "[full wavy rule] | PRODROME | De le famillo des Bougdres; | par M. DEsvaux, | Directeur du Jardin des Plantes d'Angers, | Correspondant. | [very short rule]".

Collation: $8^{\circ}$ : part 1: $122-12813^{8} 14^{6} ; 177$ 172-212 (176); part 2: $15-21^{4+4} 22^{4} 225-227 \mathrm{r} ; 213-337$.

Contente: 171 head-title; 171-172 introduction; 172 key to the higher taxa of ferns; $173-175$ key to the genera of ferns; 176 head-title to the taxonorical part: "[full wavy rule] | PRODROMUS | FILICUM. | Nullum vocabulum in differentia specifical superfluum erit. I LINNE, Phil. bot.. $n^{\circ} 292$ | [short rule]"; 176-335 enumeration of families, genera and species of ferns (families, genera and new species with descriptions); $335-336$ appendix, descriptions of 2 additional genera and enumeration of their species; 336-337 explanations of the plates. No RT. Language: text French, descriptions Latin.

Plates: 2 copper-engravings of ferns, numbered: "Pl.VII." - "PI.VIII.", both titled: "FOUGERES Inédites" (last word in italics in pl.7); plate-marks: partly cut off.

Artiat: Millet: 2 pls.

Engraver: Tourcaty: 2 pls.

Paper: leaf height $198 \mathrm{~mm}$. (Teyl. copy, cut); laid, chains vertical; wm.: different marks, possibly at random in the sheets: "L $=C$ [dianond] D", "B F ...", "D" [triangle] T" [all letters in outline].

Dates: part 1: 1827 May (fasc.title), bef. 30 Jun. (Bibliogr.Franoe); part 2: 1827 Jul. (fasc.title); bef. 20 Sep. (letter Desvaux, see below).

Refs.: E.As.Bot.S. $55^{\mathrm{a}}$ RSC 2: 276.

States: detached leaves of the periodical fascicles were used for separates, with the original fascicle wrappers as covers (NYBG copy, see Bibl. noter); they were certainly not issued before the publication of the fascicles.

Bibl.notes. In bound copies of the periodical the breaks between fascicles are not easily found, unless all plates of a fascicle were bound at the end of the corresponding fascicle. The fascicle wrappers of the two fascicles concerned state the exact fascicle contents in print; moreover they have the fascicle title Annales de la sooiste Linnesnne de Paris (see the treatment under Mémoires de la sooifte Linnéenne de Paris).

Bot.notes. Though not containing any Musci, I include this article since it is important for the knowledge of the structure of the periodical which has several bryological articles. Moreover I found in my research some other information worth recording. This was contained in a letter from Desvaux to Ad. Brongniart (in PMusBC), dated 20 Sep. 1827. Desvaux wrote: "J'aurais desire Monsieur pouvoir Vous faire parvenir un exemplaire de mon prodromus-filioum. extrait des annales Linnsennes ou it a ste asess mal et infidelement imprims, mais je n'en ai pas regu le tirage edparement. Probablement vous pourres avoir oocasion de la consulter: maie je vous prie de oroire que je nai point un Gymnogramme Thiebautii, it y avait Boryi. pares que 'est le Botaniste qui l'a communique a Willd. ... je ne prend point our mon compte les oitations d'herbier Thiebaut et herbier de la Societe Linnénne. 'est bien asees de mes propres erreurs sans que l'on aille s'autoriser d'herbier que je ne oonnai pass pour trouver les espees que je nai eu en vue. Je ne dis pas que les plantes indiquses ne puisent oe trouver dans ce oollection, maio j'ai la oonviotion que toutes ne peuvent $y$ tre et je orois $q u$ 'il faut [?] un autre botaniste que $M r$. Ie searetaire de la sooiete Linneenne pour juger de l'identite des eopdees d'une familie our laquelie f'ai publid des matdriaux depuis quinxe annés. 
Le Dr. Grevilie d'Edimbourg, publiant un ouvrage our les fougdres, 'il allait conoulter les herbiers oitso, pourrait nul juger de meo veritableo espdoes ....". From this letter three points can be discussed. Firstly, it is clear that separates were not available to the author on 20 Sep.1827 and that the fascicles of the periodical definitely existed on that date. The separate, therefore, has no nomenclatural consequences. Secondly, whatever names the author wrote in his manuscript, the name appearing in print is the effectively published one. Even the author's citation is not affected by the change of the name, since there is no indication in print accompanying the article, that the editor was responsible for the change. Nevertheless it does no harm to cite in this case: Gymnogramme thisbautii Thiébaut ex Desvaux, indicating that Desvaux is responsible for the description. Thirdiy, the fact that the editor introduced in print the citation of specimens not seen by the author, must be taken into account in the selection of type specimens for new taxa, even if they were the only specimens cited. The specimens examined by the author remain decisive. Desvaux proposed 13 new genera, and a number of new species and new combinations. For the new generic names the page in the key with the French description in the May fascicle should be cited together with the later page of the Latin description in the May or July fascicle. This also reveals an occasional printing error, e.g. Polyaetnium, P.218, is correctly Polytaenium, P.174.

\section{DIETRICH, David Nathaniel Friedrich}

Biogr. Born 1799 ... Ziegenhain, Hesse-Nassau, Germany. Died 1888 Dec. 23; Jena, Germany.

D.N.F. Dietrich belonged to a family of botany-minded gardeners; he was a nephew of F.G. Dietrich. He settled as "Privatgelehrter" in Jena and became in 1828 botanical gardener of the University there. In the last years of his life he was curator of the University herbarium at Jena, under Prof. E. Stahl.

Together with Zenker he published exsiccata of mosses of Thuringia.

Refo.: Ann.Bot. 2: 399. 1888 (with list of publ.).

Balzer, G.: Weue Deutsche Biogr. 3: 694. 1957.

1 Musoi Thuringioi. 1821-1825.

See: Zenker \& Dietrich n.1.

\section{DIETRICH, Friedrich Gottlieb}

Biogr. Born. 1765 Mar. 9, Ziegenhain, Hesse-Nassau, Germany. Died 1850 Jan. 2, Eisenach, Thuringia, Germany.

When young F.G. Dietrich came to Weimar; he had the good luck to accompany Goethe on a tour from Weimar to Karlsbad in 1785 , on which the latter enjoyed the enthusiasm of the young botanist. This provided him help from the Duke Karl August of Weimar who enabled him to study. at Jena and to travel to England (Kew and Chelsea). He was ducal gardener from 1792-1801, from 1794 with the title "Hofgurtner", in Weimar. He provided Goethe with the plant material for his botanical studies. In 1807 he moved to Eisenach, where he helped to create and later directed another ducal botanical garden, in Wilhelmsthal. Here he became "Grossherz. Rath", acquired the degree of Dr.Phil. and was appointed professor of botany. Though his main work is much of a compilation, Dietrich included his own observations.

He was commemorated in the generic name Dietrichia Trattinick 1812, now considered a synonym of Roohea A.P. De Candolle 1810 (Crasoulaceae).

Refe.: Balzer, G.: Neu, Deutsohe Biogr. 3: 694-695. 1957 (giving the Christian names: Johann Caristian Gottlieb). 
1 Vollstandiges Lexioon der Gartnerei und Botanik.

11 vols. Weimar or Berlin, 1801-1811.

Titles, oolzation, contents eto.: not studied in detail.

\begin{tabular}{|c|c|c|c|c|c|c|}
\hline \multirow{3}{*}{$\begin{array}{l}\text { Dates } \\
\text { seviews: }\end{array}$} & vol. & year & trim. & place & Physik.Ok.Bibl.Beckman & Ann.Bot. (König \& Sims) \\
\hline & $\begin{array}{l}1 \\
2 \\
3 \\
4 \\
5 \\
6 \\
7 \\
8\end{array}$ & $\begin{array}{l}1802 \\
1803 \\
1804 \\
1804 \\
1805 \\
1806 \\
1807 \\
1808\end{array}$ & $\begin{array}{l}4 \\
1 \\
3 \\
4 \\
2 \\
4\end{array}$ & $\begin{array}{l}\text { Weimar } \\
\text { " } \\
\text { Ber"lin } \\
\text { " } \\
\text { " }\end{array}$ & $\begin{array}{l}21(4): 581-583 \cdot 1802 \\
22(1): 68-70: 1803 \\
22(3): 323-326 \cdot 1804 \\
22(4): 496-499: 1804 \\
23(2): 257-258 \cdot 1805 \\
23(4): 527-528 \cdot 1806\end{array}$ & \multirow[t]{2}{*}{ f $1(1): 55.1804 \mathrm{May}$} \\
\hline & $\begin{array}{c}10 \\
\operatorname{Gen} \cdot \operatorname{Reg} .\end{array}$ & $\begin{array}{l}1810 \\
1811\end{array}$ & 3 or 4 & $n$ & (after 28 Sep., pref.) & \\
\hline
\end{tabular}
\begin{tabular}{l|l|l|l|l|l} 
Refs.: & BMNH 461 & Heins.1: 684, 5: 132 & Kräg. 66 & Pr.ed.1 n.2615 \\
Bradl.3: 74a & Kew 161 & Milt. 340 & Pr.ed.2 n.2274.
\end{tabular}

Noter. Though outside the scope of my proper period, I include a short treatment here, as this title was not mentioned by Dr. G.Sayre (Dates of Publioations desoribing Musai, 1801-1821), nor were the contents checked for Index Muscorum. Some revalidation of moss names may be present, as it was published shortly after Hedwig's Speoies Muscorum.

2 Vollatandiges Lexioon der Gartnerei und Botanik.

Ed.2. 2 vols. Berlin, 1820-1824.

Titie, ooliation, contents, etc.: no copy seer.

Dates and reviews:

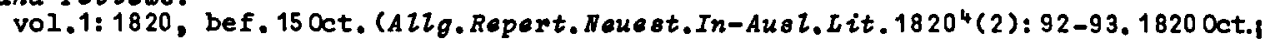
Bot.Tasohenb. (Trattinick) 1: 277-278, 1821);

vol.2:1824, in or bef. Oct.? (Ieis (Oken) 15(9): 962.1824).

Ref.: Heins.7: 178 (vol.2 only).

Note. Second edition, apparently because the stock of the first edition of these two volumes was exhausted.

3 Nachtrag sum vollatandigen Lexioon der Gartnerei und Botanik.

10 vols. Berlin, 1815-1824.

Title, oontents, eto.: not all copies seen.

Collation: $8^{\circ}: \ldots$

Dater \& reviewe: see table next page.

Refo. Bradl.3: 74a

Heins.5: 132, 7: $178 \quad$ Kew 161

KrUg. 66

Pr.ed.1 n.2615

Notes. Not of importance for mosses and other cryptogams, which are referred to a supplement for cryptogams, which never appeared. See however n.5. 


\begin{tabular}{|c|c|c|c|c|}
\hline \multirow{11}{*}{$\begin{array}{l}\text { Dates } \\
\text { a } \\
\text { reviews: }\end{array}$} & vol. & $\begin{array}{l}\text { date } \\
\text { t.-p. }\end{array}$ & publ. date & sources \\
\hline & 1 & 1815 & after 0ct. & (pref.) \\
\hline & 2 & 1816 & & \\
\hline & 3 & 1817 & $\begin{array}{l}\text { Easter Fair? } \\
\text { (Apr. 20) }\end{array}$ & $\begin{array}{l}\text { Iais (Oken) } 1^{7}(127): \text { 1016. } 1817: \text { "now } \\
\text { appearing"; } 1^{7}(130): 1037.1817 \text { (from } \\
\text { Easter Fair cat., no pages cited). }\end{array}$ \\
\hline & 4 & 1818 & & \\
\hline & 5 & 1819 & circa Oct. & $\begin{array}{l}\text { Isio (Oken) 5(8): 1316-1317. 1819, rev; } \\
\text { Azig.Repret.Neuest.In-Ausi.Lit. 18192(2): } \\
\text { 72. 1819, rev. }\end{array}$ \\
\hline & 6 & 1820 & in or bef. Oct. & $\begin{array}{l}\text { Alzg.Repert. Neuest.In- Ausz.Lit. } 1820^{4}(2) \text { : } \\
91-92.1820, \text { rev.; } \\
\text { Bot.Tasohenb. (Trattinick) 1:306-307. 1821; } \\
\text { Isig (Oken) } 9(9): 839-847.1821 .\end{array}$ \\
\hline & 7 & 1821 & bef. $15 \mathrm{Jul}$. & $\begin{array}{l}\text { Alzg.Repert. Neuest.In- Ausz.Lit. } 1821^{3}(1) \text { : } \\
\text { 9-10. 1821, rev. }\end{array}$ \\
\hline & 8 & 1822 & $\begin{array}{l}\text { Jun. or Jul. } \\
\text { bef. Jul. }\end{array}$ & $\begin{array}{l}\text { Isis (Oken) 11(6): back wrapper recto, over } \\
\text { Jun, possibly published JuI.; } \\
\text { AL2, Repert. Neuest.In-Aus2.Lit. } 1822^{3}(1): \\
\text { 12-13 } 1822 \text { rev; } \\
\text { Ioig (Oken) } 12(1): 94-95,1823 \text {, rev. }\end{array}$ \\
\hline & 9 & 1823 & bef. 15 Aug. & $\begin{array}{l}\text { Aizg.Repert.Neuest.In-AusZ.Lit. } 1822^{3}(3): \\
\text { 169-171. 1823. }\end{array}$ \\
\hline & 10 & 1824 & bef. Feb. $1825 ?$ & Iois (Oken) $1825(2): 206.1825$ Feb.? \\
\hline
\end{tabular}
$\frac{\text { Berichtigungen und Bemerkungen uber den Inhalt ... des vollatändigen Lexicons... }}{\text { Berlin, } 1824 .}$

[No copy seen.]

Title (cited from $I_{a i \theta}$ ): Berichtigungen und Bemerkungen Uber den Inhalt und die Bearbeitung des vollständigen Lexicons der Gärtnerei und Botanik $I-X$. Band 1802-1810 Nachtrag I - X. Band 1815-1824. [Berlin, 1824].

Collation and contente: not studied; $8^{\circ}$.

Date \& review: 1824, bef. Sep.? (Iois (Oken) 15(9): 962-965. 1824).

5 Neuer Nachtrag zum vollstandigen Lexicon der Gartnerei und Botanik

[alternative title:] Neu entdeokte Pflansen ...

10 vols. Berlin or U1m, 1825-1840.

Titlea: not transcribed. 
Collation: $8^{\circ}:$ vol.1: $\pi^{2} a^{4}\left(-a_{1}\right)$ A-2PB $2 Q^{4}\left(-2 Q_{4}\right) \quad 2 R^{4} \quad(\$ 1-2$ signed in gothic letters); $i-i i$ I-III IV-VIII $122-618$ 619-628 (473 675, $123 \mathrm{as} ' 223^{\prime}, 264$ as '624',504 as '304'); vol.2: $\pi^{2}$ A-20 $2 P^{6}\left(-2 \mathrm{P}_{6}\right) ; \quad i-i v \quad 1 \quad 2-599 \quad 600-602 \quad$ (596); vol.3: $\pi^{2}$ A-2R $2 S^{6}$; $i-i v$ 7 2-650 657-652 (566 as 1588', 644); vol.4: $\pi^{2} \mathrm{~A}-2 \mathrm{~T}^{8} 2 \mathrm{U}^{6}$ i-iv 7 2-681 682-684 (676); vol.5: $\pi^{2} \mathrm{~A}-2 \mathrm{P}^{\circ}(-2 \mathrm{P} 7-2 \mathrm{Pg}) ; \quad i-i v 12-603604$ (598);

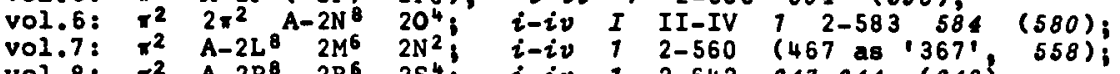
vol.8: $\pi^{2} A-2 P^{8} 2 R^{6} 2 S^{4} ; \quad i-i v \quad 1$ 2-642 643-644 (640); vol.9: (not seen);

voI.10: $\pi^{2} 2 \pi^{4}\left(2 \pi \ldots+3 \pi^{2}\right)$ A-3AB $(-3 A B) ;$ I-V VI-XIII XIV 1 2-750 $\left(\begin{array}{llll}21 & 33 & 281 & 595\end{array}\right)$.

Contents: vol.1: $i \square$; ii title: "NEUER NACHTRAG ..."; I title: "NEU ENTDECKTE PFLANZEN ..."; II D; III-VIII preface, dated April 1825; 1-614 text, dictionary Abilioea-Bomarea; 616-618 index of German plant names; 618 corrections; 620 imprint; 621-622 D;

vol.2: $i$; $i i$ title: "NEUER NACHTRAG ..."; iii title: "NEU ENTDECKTE

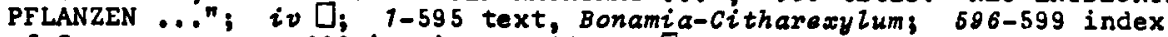
of German names; 600 imprint; $601-602$;

vol.3: i-iv titles as in vol.2; 1-643 text, Citrosma-Eysenhardtia; 6\$-oju inaex or berman names; 851 corrections; 652 [;

vol.4: i-iv titles as in vol.2; 1-675 text, Fabiana-Iungermannia; 676-681 index of German names; 682 ; 683-684 announcements of books available in $\mathrm{J}$. Ebner's bookshop;

vol.5: $i-i v$ titles as in vol.2, 1-597 text, Jungia-Momordioa; $598-603$ index of German names; 604 corrections;

vol.6: $i-i v$ titles as in vol.2; I-IV publisher's preface at the occasion of the commemoration of Dietrich's 50 years botanical authorship, with quotation from Rlora $1835(25), 8 i$ gned Dr. F.H-L, in which Goethe is cited and his connection with Dietrich, also including announcement that vol.7 is under the press and will be ready for shipment at the "Jubilate-Messe $1837^{\prime \prime}$; 1-579 text, Nonachanthus-Phytoxys; 580-583 index of German names; 584 corrections;

vol.7: i-iv titles as in vol.2; 1-557 text, Pioina-Rhytiphzooa; 557 corrections; $558-560$ index of German names;

vol.8: i-iv titles as in vol.2; 1-639 text, Sabal-Tittmannia;

640-642 index of German names; 643 corrections; 644 announcement of four horticultural titles;

vol.9: i-iv titles probably as in vol.2; 1-... text, Tmesipteris-2ymum "mit Anhang" (with Appendix); ... index of German names; ... ;

vol.10: $I-I V$ titles as in vol.2; V-VI preface: "Vorwort", dated: "Mai 1840"; VII-XIII contents; XIV corrections; 1-20 introduction; $21-22$ preface: "Vorbericht"; 23-32 synopsis of the classification and arrangement of the natural plant families in Reichenbach's system; 33-280 condensed treatment of 98 plant families, following Reichenbach, ending with "Botanische Pflanzkunst" (277-280); 287-594 appendix and supplement to the lexicon; $595-742$ general index of German plant names; 742 corrections to vol.10; 743-748 corrections to vols. 1-10; 749-750 advertisement of "Neuestes vollstindiges Gartenbuch".

Paper: leaf height $188 \mathrm{~mm}$. (NYBG copy, cut); laid, chains vertical: vols.1-2, 5-7, or wove: vols. 3-4,8 (9 10 not checked); wm. not studied.

Printer: Froebel, "hofbuchdruckerei", Rudolstadt, Germany: vols, 1-2; no indication in the other volumes. 
Publishera: Gădicke, Gebr., Berlin, Germany: vols, 1-2; Ebner, J., Uim, Germany: vols. 3-10. Dates: vol.1: 1825 (t.-p.), trim.1-3 (Linnaea 1(1): 134. $1826 \mathrm{Jan}$. );

vol.3: 1834 betw. $15 \mathrm{Jan}$. and $12 \mathrm{Mar}$ (Flora 17(15): 258. 1834);

vol.4: 1835 probably after 14 Nov. (BLora 182 Intelizgensbi.1: 14. 1835, announced as in press);

vol.5: 1836 betw. 11 May and 13 Jul. (Floxa 19(27): 451, 1836);

vol.6: 1837 probably trim.1 (see vol.7); bef. 15 Sep. (see Reviewa);

vol.7: 1837 probably Jubilatemesse (3rd Sunday after Easter), (announced in vol.6 as being in press, and ready for sale at "Jubilatemesse"); first other announcement found:

$30 \mathrm{Apr} .1838$ (Flora 16(2): 146-147, 1838);

vol.8: 1838 bef. 1 Sep. (Flora 21(35): 565.1838);

vol.9: 1839 bef. 7 Mar. (see review);

vol.10: 1840 bef. 15 oct. (see review).

Reviews: vol.3: Flora 17(15): 258. 1834;

vol.5: Repert.Gesammt.Deutsah.Lit. (Gersdorf) 10(2): 166. 1836;

vol.6: $13(4): 347-348.1837$;

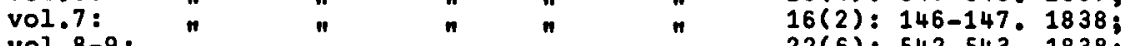

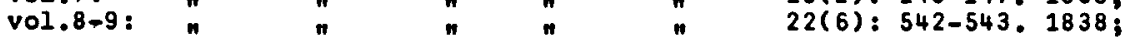

vol.10: " $"$ "

Refo.: Heins.7: 178 (vol.1-2)

9: $203^{a}($ vol.5-7)

10(1): $192^{b}($ vol.8-10)

Bradl . 3: $74^{2}$

Kew 1: 161

$\mathrm{KrH}_{\mathrm{g}} \cdot 66-67$ (7 vols.)
Milt. 340

Pr.ed.1 n.2616

Pr.ed. 2 n.2275.

Noter. This new supplement to Dietrich's Vollotandiges Lexioon der Gartnerei und Botanik shows a shift from laid to wove paper, and again laid paper in a later volume, indicating that the price difference began to diminish. Essentially a botanical compilation of new genera and species published since the earlier supplement, with horticultural remarks; it was neglected by some contemporary botanists, even if it contained new species with descriptions (no attempt was made to trace any in this supplement; the preface to the first supplement implies new species with descriptions). In the first two volumes the cryptogams, when mentioned, were referred to a cryptogamic supplement (as in first supplement), or given very short description or reference to an accepted generic name before this indication: "s. Nachtr. Kryptogamie." In vols.3-9, after the change of publisher, this plan apparently was given up, since this reference no longer appeared and cryptogams were treated in their alphabetical place. No new combinations in Musci were seen nor expected, since Dietrich's interest was mainly in phanerogams and probably vascular cryptogamous plants (ferns).

\section{DRUMMOND, James Laws on}

Biogr. Born 1783 ... Larne, Co. Antrim, Ireland. Died 1853 Mày 17, Belfast, Ireland.

J.L. Drummond was from 1807 to 27 May 1813 a navy surgeon in the Mediterranean. Having received the M.D. degree at Edinburgh on 24 Jun. 1814 , he became a practising physician at Belfast. He was nominated first professor of anatomy and physiology in the Belfast Academical Institution on $15 \mathrm{Dec}$. 1818. In 1820 he was one of the leading projectors of the Botanical Garden at Belfast. He founded with others the Belfast Natusal History Society on 5 Jun. 1821, which became in 1840 the Belfast Natural History and Philosophical Society, and helped in 1830-31 to create the museum of this society, of which the building stone was laid 4 May 1830, it opened 1 Nov. 1831 .

He married three times, but had no issue.

As far as I can ascertain, he was commemorated in the generic name Drummondita harvey 1855 (Rutaceae). 
Refe: G[ordon], A[lexander], Diot,Natz,Biogr, 16:33-34, 1888 . Belfaet Wat. Bist.Soo.Cent. vol,72,73: 126. Proo.Belfast Nat.Cl. ser.2, 6: 618. 1882 . MoMilian, N.F.: Irish Natural.J. 12(9): 222-223. $1958 \mathrm{Jan}$.

1 Pirst etepe to botany ...

Ed.2. London, 1826 .

Titze: "FIRST STEPS TO BOTANY, | INTENDED AS | Popular Illustrations [line in gothic] | OF THE SCIENCE, | LEADING TO ITS STUDY AS A BRANCH OF | GENERAL EDUCATION. | [short rule] | BY JAMES L. DRUMMOND, H.D. | PROFESSOR OF ANATOMY AND PHYSIOLOGY IN THE | BELFAST ACADEMICAL INSTITUTION. | [short rule] | SECOND EDITION. | [short rule] | [woodcut or engraving, stone with inscription: "LINNAEUS." gurrounded by flowers] | LONDON: I PRINTED FOR LONGMAN, REES, ORME, BROWN, AND GREEN, | PATERNOSTER-ROW, | 1826."

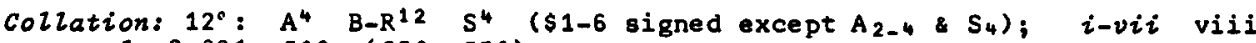
$1 \quad 2-391392 \quad(378 \quad 378)$.

Contente: $i$ half-title; ii poem, unsigned; iii title; iv imprint: "LoNDON: | Printed by A. \&. Spottiswoode, | New-Street-Square."; v dedication to the officials of the Belfast Academical Institution; vi $\square$; vii-viii preface, dated 27 May 1826; $1-377$ text, containing 8 chapters with descriptions of morphological terms from root to fructification and nectary (1-233), a chapter of the Linnaean classification (234-365), with short observations for each class and order and giving a few names of species in these groups and a conclusion (366-377); 378 [ $379-391$ index; 392 imprint. RT: chapter headings (versos) and subjects (rectos). Language: English.

Text illustrations: 89 numbered wood engravings, illustrating morphological terms and plants in different groups, and 11 vignettes, unnumbered, mostly not related to the text, probably wood engravings too.

Aptiots: Bonner, G.W.: "the greater number";

Drummond (the author): "a few";

Sowerby: "a considerable number";

see preface.

Engraver: Bonner, G.W.: all figures.

Paper: leaf height $178 \mathrm{~mm}$. (HBL copy, cut); wove; no wm.

Printere: A. \&. Spottiswoode, London.

Publiohers: Longman, Rees, Orme, Brown, and.Green, London.

Date: 1826, after 27 May (preface), and bef, 1 Oct. (see review).

Review: Linnaea 1(1): 155. 1826 oct. 1.

Refo.: BMNH 481

Bradl.1: $85^{\mathrm{b}}$ Krag. 54

Linn. Soc. 225

Mass.HS-H 82 a
Mass.HS-M 1: 527

Milt. 47 (without datel

Wotes. A popular introduction to botany, second edition (first edition not compared). In the preface to this edition it is stated that the suggestion to add a sketch of the natural classification of de Jussieu was not followed, since it would be "too short to afford sufficient information, or too long to be compatible with the general nature and object of the work." The first edition is dated 1823 ; an octavo third edition is indicated in Edinburgh Now Fhil.J. 11(2): 406, 1831. A number of poems are partly quoted as to some passage in connection with flowers; the author is usually cited in a footnote.

Some details of the collation and contents were kindly checked for me by my colleague Mrs. H. Lancour. 


\section{DRUMMOND, Thomas}

Biogr. Born circa 1780 , Perth?, Scotland.

Thomas Drummond worked during the early part of his life in Don's nursery, was active in field botany, and prepared Mue oi scotioi. For Sir Franklin's second land expedition he was appointed assistant naturalist to Dr. Richardson. He sailed from Liverpool $16 \mathrm{Feb}, 1825$ and arrived at New York $15 \mathrm{Mar}$. 1825. They traveled up the Hudson River, along Lake Ontario and via Winnipeg to the Mackenzie River. In Cumberland Drummond left the expedition to proceed to the Rocky Mountains.

From 1828-31 he was curator of the Belfast Botanical Garden, and he went for a second time to America to collect plants for this garden. In spring 1831 he traveled on foot through the Allegheny Mountains, came to St. Louis in July, but then he fell ill so that he was unable to join the fur traders to the north. Instead he went to the New Orleans region and made a botanical tour in Texas. In Velasco he was attacked by cholera; he was said to be the only one from those attacked to recover. He embarked for Havana $9 \mathrm{Feb}$. 1835, where he died soon after his arrival.

He was commemorated in the generic name Drummondia W.J. Hooker 1828, nom. cons. (Musci, Orthotrichaceas).

Ref.: B. D[aydon] J[ackson]: Diat. NatZ. Biogr. 16: 41.1888

1 Musci scotici or dried speoimens of the mosees that have been disoovered in

Scotland, with reference to their looalities.

2 vols. 1824-1825 [exsiccata].

Title, collation, oontents eto.: no copy seen.

Dates: vol.1: 1824, bef. Oct.;

vol.2: 1825, bef. Apr. (Edinb.J.Soi. 2(2): 354.1825 Apr., announcement: "has now appeared").

Review: Edinb.J.Soi. 1(2): 365-367. 1824 Oct. (with list of species): 2 vols. with 200 specimens.

Notes. To quote the review in Edinb.J.Soi. (probably written by W.J. Hooker from an advance copy): "Two volumes with 200 dried secimens. Bach volume has 100 leaves upon which an excellent specimen and the names, syonym and habitats are given on a label below" "The labels had references to Hooker \& Taylor, Muscologia Britannica, 1818, Hooker, Fiora Sootiaa, 1821, and Greville, Flora Edinensio, 1822. I have not seen a reference to any description on the label, and took the absence of descriptions for granted in the preparation of Index Huscorum. At least one name is reported to be published here for the first time: Grimmia opiralio Hooker Taylor, vol.2, n.20.

2 Musci Americani exsicaati or dried opecimsne of 286 speoies of mosese from Britioh North America.

2 vols. Glasgow, 1828 [exsiccata]

Titze, colzation, contents eto.: no copy seen.

Specimens: 286 specimens pasted to rectos of the leaves.

Date: 1828 .

Review: Hooker, W.J.: Bot.Misc. 1: 93-94. 1829

Wotes. Important set of exsiccata of the North American bryoflora. According to literature reisrences descriptions are present. About 20 new species were proposed, some described and signed by W.J. Hooker, one new genus, Drummondia W.J. Hooker, ind at least one new varietal combination, Bypnum abietinum var. oitum (P. Becuvois) Drummond. Names of interesting species are given in Hooker's review cited. From Drummond's collections of his second tour a new series of $\epsilon$ xsiccata was prepared by W. Wilson and W.J. Hooker in 1841 . 
DURET, L. See: Lorey D Duret.

EATON, Amos

Biogx. Born 1776 May 17, New Concord, Chatham, Columbia County, New York. Died 1842 May 10, Troy, New York.

Eaton entered Williams College, Williamstown, Mass.. in Sep. 1795, and received the A.B. degree in 1799. He began the study of law in Sep. 1799 under Hon. Elisha Williams in Spencertown, N,Y, and continued in 1800 under Hon. Josiah Ogden hoffman, Att. Gen. at New York, in the meantime studying botany, chemistry and natural philosophy under David Hosack and S.L. Mitchill. He was licensed as an Attorney on 30 Oct. 1802 and became land agent in Oct. 1802 .

He had a flourishing business in the region of Catskill, N.Y., and began a "Catskill Botanical School", for which he produced his first botanical book. His position there, however, was ruined by machinations of persons who wanted his downfall and finaliy succeeded in a suit for forgery, for which he was sentenced to imprisonment, 26 Aug. 1811. During his term he became friends with John Torrey, with whom he studied botany, and also studied mineralogy and chemistry, preparing books on these subjects. He was pardoned conditionally 17 Nov. 1815 (the condition being that he depart from the state of New York) and unconditionally 23 Feb. 1817, which enabled him to return to his state.

He arrived in Yale College, New Haven, 23 Feb. 1816, making mineralogical observations while traveling. He studied botany under Eli' Ives, chemistry, mineralogy and geology under Benjamin Silliman, and remained there a year acquiring certificates for teaching from Ives and Silliman. From March 1817 he lectured at Williams College, Williamstown, Mass., in botany and mineralogy, in the meantime qualifying himself for a degree there: M.A., 3 Sep. 1817 . He was named corresponding member of the Lyceum of Natural History, New York.

From 1817 to 1824 he was an itinerant lecturer, giving courses in botany, mineralogy and chemistry at several places in New England and New York. A Lyceun of Natural History was formed at Troy, N,Y, in 1819, of which he became official lecturer 8 Nov. 1819 . He also officially lectured at Castleton ledical Academy, Vermont, at the new College at Amherst, Mass, and gave a course to members of the Legislature at the Capitol, Albany, N.Y. These lectures were successful in popularizing natural sciences.

Eaton made a geological survey of Rensselaer County and of other counties in New York, and of the region of the Erie Canal, on which he worked several summers. 5 Nov. 1824 the Rensselaer School was founded at Troy, N.Y., later named Rensselaer Institute and now Rensselaer Polytechnic Institute, of which Eaton was the driving force. He served as senior professor and principal till his death. Strong emphasis was laid on the practical work by the students, and though their numbers were small, the School had a great qualitative influence.

Eaton married four times, losing three wives by death. Moreover he lost a number of sons by death, two after they had entered Rensselaer School. The son he loved most. Anos Beebe Eaton, studied at West Point and had a worthy military carreer. A son of this son, Daniel Cady Eaton, became a botanist in his own right. Eaton's importance as a botanist lies mainly, as he stressed himself, in the field of teaching and popularizing. He was able to reach large numbers of people through his lectures, and to prepare the ground for the reception of works of more thorough botanists like Torrey.

Apart from the 7 editions of the Manual of Botany, treated here, Eaton published other small botanical books: A botanioal diotionary, in several editions, translated from Bulliard and kichard, Botanioal exeroiees, Albany 1820, and $A$ botanical grammar, in some editions combined with the dictionary. Though closely related to his manual, they are not treated here, since they are not important for bryology. The eigth edition of the manual was publjshed under a new title: Eaton, Amos, and Wright, John: North Amerioan Botany... Troy, 1840 (vi + 625 p.) Eaton himself considered his botanical science of minor importance, but laid more stress on his contributions to geology.

Eaton's herbarium is reportedly deposited in the Osborn Botanical Laboratory, Yale University. It is described by Merrill and Reeder as "amateurish", even taking into account the general neglect of labels and information in herbaria of the period. He was commemorated in the generic name Eatonia Rafinesque 1819 (Gramineae). 
Refo.: McAllister, Ethel M.: Amos Eaton ooientist and eduoator 1776-1842. Philadelphia, Univ, of Penna. Press. 1941.

Good, H.G.: Amos Eaton (1776-1842) scientist and teacher of ecience, Soi. Monthily 53: 464-469. 1941 Nov.

Merrill, E.D. \& Reeder, J.R.: New plant names published by Amos Eaton between the years 1817 and 1840 . Bartonia 24: 26-79. 1947 Feb, 15. Merrill, E.D.: Am.Bern Journal 37: 6-10, 1947. Merrill, E.D.: The Amos Baton herbarium. Rhodora 48: 201-205. 1948.

1 A Manual of Botany for the Northern etates ...

[anonymous] Albany, 1817.

Titze: "A | MANUAL OF BOTANY | FOR | The Northern States. [line in gothic] | COMPRISING | GENERIC DESCRIPTIONS OF ALL PHANEROGAMOUS AND CRYPTO- GAMOUS PLANTS TO THE NORTH OF VIRGINIA, HITH-|ERTO DESCRIBED; WITH REFERENCES TO THE NATURAL ORDERS OF LIN-|NEUS AND JUSSIEU. | Each Genus is further illustrated by short Descriptions of | its most common Species. [ [short fancy rule] | By THE MENBERs OF the botanical Class In | WILliams' COLLEge (Mass.) | From a Manuscript System, | COMPILED BY THE AUTHOR OF I RICHARD'S BOTANICAL DICTIONARY. | [very long fancy rule] | ALBANY: [swash A's and N] | PRINTED BY WEBSTERS AND SKINNERS. | [very short stippled rule] | 1817."

Collation: $12^{\circ}$ in 6s: $A-0^{6} P^{2}\left(-P_{2}\right)$ ( $\$ 3$ signed $\$ 2, O_{1}$ as ' $M$ ', $O_{3}$ as ' $M 2^{\prime}$ $P_{1}$ as ' $N$ '); $i-i i$ iii-vi 1-164 ( $i v-v$ 6-7 751 163, 107 as '701').

Contents: $i$ title; ii-iii letter of appreciation "to the author | of I Richard's botanical dictionary", dated 8 Apr. 1817 and signed by the members of the course on mineralogy, nearly completed and of the coming course of botany (Williams College, Mass.), in which they thank the lecturer for the systematic description of vegetables which was presented to them gratuitously, for publication; iv $]_{;} v-v i$ preface; $1-5$ Linnaean classification, as modified by Willdenow ( 22 classes); 5 explanation of signs; 6 ; $7-142$ text, descriptions of plant genera in the Linnaean classification; 142-150 index of Latin names of genera; 157-162 index of vernacular names; 163-164 errata. RT: class and order number, none in preliminaries. Language: English.

Paper: leaf height $185 \mathrm{~mm}$., sheet size $549 \times 440 \mathrm{~mm}$. (Belnecke Yale copy); wove; no wm. Printers: Websters and Skinners, Albany, N.Y.

Date: 1817 (t.-p.); between 18 and 31 Jul. (two letters from Eaton to Torrey, quoted by MaAllister: Amos Eaton 175, 1941).

Review: R[afinesque]: Am.Month Z.Mag. 1(6): 426-430, 1817 Oct:

Bibliogr.etudies: Sayre, G.: Dates of publ. 54. 1959 . Stafleu, F.A.: Taxonomic literature n.329i. 1967.

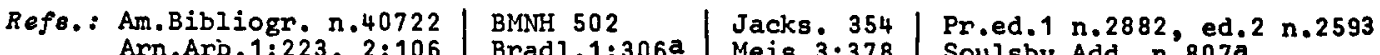
Arn.Ard.1:223, 2:106 Brad1.1:306a Meis.3:378 Soulsby Add.n.807a.

Bib2.nots8. As the author explained in the preface, the format was chosen to enable buyers to bind it together with his translation of Richard's dictionary published at New Haven, with which it should be used.

The double use of the signatures is a problem; the collation could be written in another way: A-N $x^{6} 2 x^{1}$ ( $x_{1}$ as ' $M 1^{\prime} ; x_{3}$ as ' $M_{2}{ }^{\prime} 2 x_{1}$ as ' ' $\left.N^{\prime}\right)$. An unusual point is the type-font of the headings on $A_{3} r$ : "PREFACE." and on $P_{1} r$ : "ERRATA", swash capitals leaning backwards. According to the preface of the second edition 500 copies were printed, and apparently it sold well.

Bot.notes. Eaton attempted to produce an inexpensive introduction to botany. For this he condensed the characters of each genus into a few lines, not too difficult to understand. Under each genus one or two common species were mentioned. The book was critically reviewed by Rafinesque, and probably also received with reserve by other botanists, who had learned their plants the hard way. Nevertheless it helped popularize botany, in connection with his lecturing in New England and New York State. Musoi are treated on P.125-130, Bepaticae on p.130-132. In Mus ai the spelling Diphasoum ( $p_{.128}$ ) was used for Diphyscium. For names of phanerogamous plants of this and all other editions see Merrili : Reeder, 1947 . 
2 A Manual of Botany for the Northern and liddie states.

Ed.2. Albany, 1818 .

Title: "A | MANUAL OF BOTANY | FOR THE | NORTHERN AND MIDDLE | STATES. [thin-thick outline] | [very short fancy rulej | PART I. [swash A] | CONTAINING | GENERIC DESCRIPTIONS OF THE PLANTS TO THE REFERENCES TO | THE NATURAL ORDERS OF LINNAEUS | AND JUSSIEU. | [Very short fancy rule] | PART II. [swash A] | CONTAINING | SPECIFIC DESCRIPTIONS OF THE INDIGENOUS | PLANTS, WHICH ARE WELL DEFINED I AND ESTABLISHED; AND OF THE | CULTIVATED EXOTICS. | [short double rule; | BY AMOS EATON, A. M. | Lecturer on Botany, Mineralogy and Chemistry. I Corresponding Member of the Lyceum of Natural History | of New-York. I ishort double rulej I Second Edition, correoted and enlarged. I imedium double rulej | ALBANY: | PRINTED AND PUBLISHED BY WEBSTERS AND SKINNERS. | [short rule of asterisks] | 1818."

Colzation: 12 in 6s: $A-B^{6} x^{6} \quad C-U^{6} V^{6} W-2 S^{6} 2 T^{4} \quad\left(\$ 3\right.$ signed $\$ 2, x_{1} a a^{\prime} B b^{\prime}$

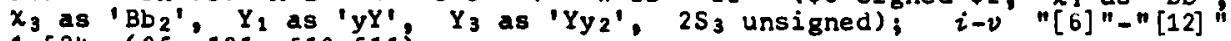
$1-524(25 \cdot 121510-511)$.

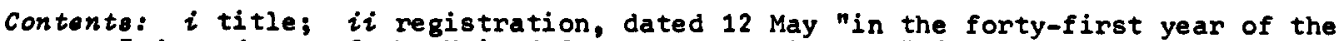
Independence of the United States of America ..." (1818); iii dedication, to Zephaniah Swift Moore (1770-1823), Chester Dewey (1784-1867), and Ebenezer Kellogg, president and professors of Williams College (Mass.); iv D; v-"[12] " preface, including the transcript of a letter dated Nov. 24, 1817; 1-24 introduction, including tables of the Linnaean classification (modified) and a list of the natural orders of [de] Jussieu; 25-119 text, a system of genera with descriptions of plant genera in the Linnaean classification, ending with; end of part I; 120 abbreviations; 121-501 text, species of plants, alphabetically arranged descriptions of species, ending with: end of part II; 502-509 additions and corrections, including improvements after Nuttall's genera of North American plants, received when "432 pages were struck off"; s10 "ADVERTISEMENT.", mentioning the number of species included; 571 -524 index of vernacular nanes. RT: class and order number in part I and generic names in part II, chapter headings in introduction and index, none over preface. Language: English.

Paper: leaf height $177 \mathrm{~mm}$. (HBL copy, cut); wove; no wm.

Printere and publishare: Websters and Skinners, Albany, N.Y.

Date: 1818 (t.-p.); aft. 2 Jun. (letter from Eaton to Torrey: "not yet publiohed", quoted by McAllister: Amos Eaton 226. 1941);

Jul. (Rickett Stafleu: Taxon 10(3): 81. 1941);

bef. 8 Sep. (A Lbany Gasette Daily Advertiser quoted by McAllister: Amos Eaton 223. 1941).

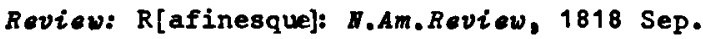

Bibliogr. otudies: Sayre, G.: Dates of pubz. 55, 1959; Rickett \& Stafleu: Taxon 10(3): 81. 1961.

Refe.: Am.Bibliogr. n.43907

Arn.Arb. 2: 106

Bradl.1: 306a

Mas8.HS-H 86

Mass, HS - H 1: 539

LCC $43: 173$

Meis.3: 378

Pr.ed.1 n.2882

Pr.ed. 2 n. 2593

Soulsby Add. n.807b

Stafl. TL n.329i.

Variante: the error Naphar instead of Nuphar was printed in about of the edition; the error Solidago rauta $(\mathrm{p}, 445)$ was corrected to $S$. arguta in part of the edition.

Notes. In the first set the page numbers were printed between square brackets; the unnumbered pages are reported here in roman numerals for simplicity. The experiment with the first edition proved successful and Eaton felt justified to add his name on the title-page of the new edition. He considerably augmented the usefulness by adding condensed descriptions of species, though their arrangement in alphabetical order of the generic names removed these far from the generic descriptions. 
Manual of Botany, for the Norhterm and liddle states of America.

Ed.3. Albany, 1822 .

Title: "MANUAL | OF | BOTANY, [shaded outline] | FOR THE | NORTHERN AND MIDDLE STATES | OF AMERICA. CONTAINING GENERIC AND SPECIFIC DESCRIPTIONS OF THE INDIGENOUS PLANTS AND COMMON | CULTIVATED EXOTICS, GROWING . NORTH OF VIRGINIA. I TO WEICB ARE PREFIXED, | THE NATURAL AND ARTIFICIAL CLASSES AND ORDERS OF LINNEUS; I AND THE NÁTURAL ORDERS OF JUSSIEU, WITH THE | MEDICINAL PROPERTIES OF EACH ORDER. | [short rule? | BY" AMOS EATON, A. M. I Professor of Botany and Chemistry in the Vermont Medical Institution, which is con-/nected with Middlebury College, and Lecturer in the Troy Lyceum; | Member of the American Geological Society; Corresponding 1 Member of the New-York Lyceum of Natural History, and Honorary Member of | the Hudson Lyceum. [ [short rule] | "THAT EXISTENCE IS SURELY CONTEMPTIBLE, WHICH REGARDS ON-1" LY THE GRATIFICATION OF INSTINCTIVE WANTS, AND THE PRESER-|"VATION OF A BODY, MADE TO PERISH:" [space] Linneus. | [long double rule] | THIRD EDITION, REVISED AND CORRECTED. [long double rule] I ALBANY: [swash $A^{\prime} s$ and $N$ ] I PRINTED AND PUBLISHED BY WEBSTERS AND SKINNERS. | [very short fancy
mule] | 1822."

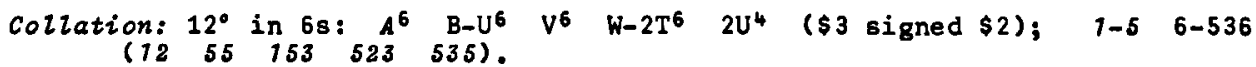

Contents: 1-2 $;$; 3 title; 4 registration of the second edition with its date 12 May 1818 ; $5-11$ preface to ed. 3 , dated $17 \mathrm{Jan} .1822$; 12 [; $13-16$ artificial classes and orders (Linnaean); 16-17 rules for distinguishing poisonous plants; 18-54 natural orders of Linnaeus and of de Jussieu, the latter amply treated, including medicinal properties; 55-150 text, description of genera in Linnaean classification (modified); 151-152 explanation of abbreviations and signs; 153-520 text, descriptions of species in alphabetical arrangement; 521-522 additions and corrections, including a remark, softening his criticisms of conterporary botanists; 523-534 index of vernacular names; 535-536 notices, being an advertisement, mentioning the number of species included. RT: numbers of class and order in the genus part, generic names in the species part, elsewhere chapter indications. Language: English.

Paper: leaf height $182 \mathrm{~mm}$. (HBL copy, cut); wove; no wm.

Printers and publishers: Websters and Skinners, Albany, N.Y.

Date: 1822, after $17 \mathrm{Jan}$. (preface); betw. 23 Mar. (letter by Torrey to Eaton, congratulations on the finishing of the printing, quoted by McAliister: Amos Eaton 229. 1941), and $23 \mathrm{Apr}$. (Rickett \& Stafieu: Taxon 10(3): 81.1961)

Refo.: Bradl.1: 306 a Meis.3: 378
Pr.ed.1 n. 2882

Pr.ed. 2 n. 2593
Soulsby Add. $\mathrm{n} .807 \mathrm{C}$

Staf1. TL n, 329i.

Noter. Revised and augmented edition, in which author names were added to the binomials; several species, however, were placed in other genera than the author cited had done; this makes identification of the name sometimes difficult. New name in Musci: Grimmia michauxi Torrey, based on Grimmia gracilis Michaux 1803 (non G. gracilis (Hedw.) Weber et Mohr 1803), now considered a gynonym of Blindia aouta (Hedw.) B.S.G. Bypnum torreyanum Sprengel is given on p.315, without a description. Diphasoum is replaced by Diphysoium $\left(p_{.133}, 266\right)$. For combinations in phanerogans see Merrill and Reeder, 1947 . 
4 A Nanuai of Botany for the Northern and Niddle States of Amerioa.

Ed.4. Albany, 1824.

Title: "A | lanual of Botany, [line in gothic] | FOR THE | NORTHERN AND IIIDDLE STATES | OF AMERICA, | CONTAINING GENERIC AND SPECIFIC DESCRIPTIOHS OF THE INDIGEN-|OUS PLAITS AIID COYHION CULIIVATED EXOTICS, GROW-|ING NORTH OF VIRGINIA. | TO WHICH IS PREFIXED: | A GRAITIAR AND VOCABULARY; | ALSO, THE NATURAL ORDERS OF LINIEUS AND OF JUSSIEU, WITH | THE IIEDICINAL PROPERTIES OF EACH ORDER. | [short rule] | BY AMOS EATON, A. M. | Late Professor of Botany, and now Professor of Chemistry and Natural Philosophy I in the Vermont Academy of lledicine, and Lecturer in the Troy Lyceum; Member I of the American Geological Society; Corresponding lember of the New-York | Lyceum of Natural History, and Honorary llember of the Hudson and Newburgh $\mid$ Branches. Ishort mule] I THAT EXISTENCE IS SURELY CONTEMPTIBLE, WHICH REGARDS ONLY | THE GRATIFICATION OF INSTINCTIVE WANTS. AND THE PRESERVA-|TION OF A BODY MADE TO PERISH. [space] Linneus. I [very short swelled rule] | FOURTH EDITION, REVISED AND CORRECTED. | [medium thick-thin rule] I ALBANY: [swash $A^{\prime} s$ and $N$ ] | PRINTED AND PUBLISHED BY WEBSTERS \& SKINNERS, I Corner of State and Pearl-streets. | [very short swelled rule] | 1824."

Collation: $12^{\circ}$ in 68: A-V6 $\mathrm{W}-2 \mathrm{U}^{6} \mathrm{2V}^{6}$ (\$3 signed \$2); i-iii iv-ix $10-11$ $12-539540(86 \quad 184508-508 \quad 516-517)$.

Contente: i titles ii registration, dated "the twelfth of May, in the fortyfirst year of the independence of the United States of Anerica ..."; iii-ix preface to the third edition repeated; 10 preface to the fourth edition, dated "Troy (N.Y.) 1823."; 11-78 grammar of botany, including: 11 physiology, 12-13 growing, 13-23 morphological terms, $24-37$ the Linnaean classification (Wilidenow's modified form with 22 classes), 38-42 natural orders of Linnaeus, 42-77 natural orders of [de] Jussieu, 77-78 general rules for avoiding poisons; 79-93 vocabulary of botanical terms; $94-95$ explanation of numbers, signs and abbreviations used in the descriptions; 96 ; 97-183 generic descriptions in the Linnaean classification (modified); $184 \square$; 185-507 descriptions of species (alphabetical); 508 D; $509-515$ index of vernacular names; $516 \square$; 617-539 appendix, with a short introduction, signed: "Albany, Feb. 1 , 1824 LEWIS C. BECK." " atating that he prepared additions mostly from Torrey, PZ.W. Niddie States, and Halsey, Ann,New-York Lyo.; 540 D.

Paper: leaf height $180 \mathrm{~mm}$. (HBL copy, cut); wove; no wm.

Printere and publishers: Websters and Skinners, Albany, N.Y.

Collaborator: Beck, Lewis Caleb (1798-1853).

Date: 1824 (t.-p.); after 1 Feb. (appendix, P.519).

Bibliogr.etudy: Stafleu, F.A.: Taxonomio literature n.3291. 1967.

Refe.: BMNH 502

Brad1.1: $306^{a}$

Lindl. Libr. 130

Meis.3: 378

Pr.ed. 2 n.2593

Soulsby Add. $\mathrm{n} .807 \mathrm{~d}$.

Hotee. New edition, with "but few alterations", "a concise grammar of botany, and a vocabulary of technical terms", and an appendix by L.C. Beck, who also corrected the proofs (see footnote on p. ix of the 6 th edition). 
5 isanual of botany, for liorth Amerioa: containing generio and speoifio desoriptions of the indigenous plante and oommon oultivated exotios, growing north of the Gulf of Hexioo.

Ed.5. Albany, 1829 .

Title, collation, oontents eto.: not studied. $12^{\circ}$.

Paper: leaf height $190 \mathrm{~mm}$.

Printers and publishers: Websters and Skinners, Albany, N.Y.

Collaborators: Aikin, William Edward A. (1807-1888); , see ed.6, preface, p. vi.
Eaton, Hezekiah Hulbert $(1809-1832) ;$

Date: $1829\left(t,-p_{.}\right)$, bef. 25 Sep. (letter from Torrey to G.W. Clinton, quoted by McAllister: Amos Eaton p.231. 1941).

Refe.: Brad1.1: $306 a$

LCC $43: 173$

Mass.HS-H 86
Mass.HS-M 1: 539
Meis.3: 378
Pr.ed.1 n. 2882

Pr.ed. 2 n.2593

Stafl. TL n.329i.

Noter. This fifth edition was "revised, corrected, and much extended", according to the title-page. Bypnum cooteyanum S[prenge] 1 is mentioned on p.253 and described in the Appendix, P.3 (courtesy I. MacPhail, Beinecke Library, Yale University). Torrey's judgment (see letter under Date) was: "a hasty compilation".

$\frac{\text { Manual of botany for North Amerioa .... }}{\text { Ed.6. Albany, 1833. }}$

Titze: "MANUAL OF BOTANY, | FOR | NORTH AMERICA: | CONTAINING | GENERIC AND SPECIFIC DESCRIPTIONS OF | THE INDIGENOUS PLANTS AND COMMON | CULT IVATED EXOTICS, | GROWING | NORTH OF THE GULF OF MEXICO. | [very short fancy rule] | BY PROF. AMOS EATON. | [very short fancy rulej | "That existence is surely contemptible, which regards only the gratification of instinctive I wants, and the preservation of a body made to perish." [space] Linneus. | [long rule] | SIXTH EDITION, | WITH THE ADDITION OF THE MOST APPROVED NATURAL ARRANGEMENT OF GENERA: I ALSO THEIR ETYMOLOGIES AND ACCENTUATION | [long rule] | ALBANY: | PUBLISHED BY OLIVER STEELE, | And for sale by Grige Elilott, Carey, Lea \&lanchard, Desilver \& Thomas, Hogan \& Thompson, U. Hunt, and Perkins Marvin, Philadelphia; Colíns t Hannay, N. J. White, S. Wood Sons, and G. C. H. Carvill, Hew-Yoxk; Carter Hendee \& Co. I Lilly, Wait \& Co., Stimson a Clapp, and Crooker * Brewster, Boston; F. Adancourt, W. S. Parker Son, and Z. Clark, Froy. | [very short fancy rule] | $B$. Adenoourt, [swash A] Printer, Troy. | 1833."

Collation: $12^{\circ}$ in 68: $A^{6}{\mathrm{~B}-\mathrm{H}^{6}}^{6} \mathrm{I}^{4}$ 1-336 $34^{2} \quad 35-46^{6}$ (A3 signed '1*1); [pagination arranged in three sets:] part 1[1]: i-iii iv-x 11-13 13-103 $104(2426,27)$, part 1[2]: $12-401408-404$, part 2: 1-3 4-137 $738-740 \quad(17 \& 716)$. 
Contente: part 1[1]: i title; ii registration: "in the year 1833"; iii-x preface, dated: "May 22, 1833"; 11 part-title of "part first"; 12 [l; 13-23 ciassification of plants, systems of Linnaeus, de Jussieu and subdivisions by "Lindley and others"; 24-25 abbreviations and signs; 26 particular directions for the student in botany; 27-103 text, descriptions of genera; 104 : part 1[2]: 1-401 text, descriptions of species in alphabetical order; $402-404 \square$

part 2: 1 title of "part second"; 2 [; 3-113 descriptions of natural orders of [de] Jussieu, with generic and specific descriptions of nonvascular cryptogams; $714 \square$; 115-137 vocabulary and index; 138 additions and corrections; $138-140$ b. RT: class and order number in the genus part, generic names in the species part, subject or chapter heading in the other parts, except p.x, having "APPENDIX" instead of "PREFACE". Language: English.

Paper: leaf height $179 \mathrm{~mm}$. (HBL copy, cut); wove; no wm.

Printer: Adancourt, F., Troy, N,Y.

Publieher: Steele, Oliver, Albany, N.Y.

Collaboratore: Williams, S.W. (1812-1884): etymologies; Lehmus: revised the etymologies;

Hall, James (1811 Sep. $12-1898$ Aug. 7): inserted new localities from many sources (mentioned in preface), and read the proofs.

Date: 1833 (t.-p., registration), after 22 May (preface), on or bef. 3 Jun. 1833 (letter from Eaton to 0 . Steele, 12 copies already received, quoted by McAllister: Amos Eaton 234, 194i).

Refe.: Arn,Arb.2: 106 BMNH 502

Brad1.1: 306a Kew 177
LCC 43:173

Mass.HS-H 86

Mass.HS-M 1:539

Meis. $3: 378$
Pr.ed.1 n.2882, ed.2 n.2593

Roorb. 170

Soulsby Add. $\mathrm{n} .807 \mathrm{e}$

Stafl. TL n.329i.

Bibl.notes. The change of publisher and Eaton's reasons for it were discussed by McAllister in her biography of Eaton. The three series of page numbers make citation ambiguous, but clarity can be achieved by taking the first two sets as subdivisions of part 1: 1[1] for the generic descriptions, and 1[2] for the species descriptions; the cryptogans and the natural orders in the third set have to be cited as part 2 .

Bot.notes. Eaton held in the preface a philippic against the natural classification as the best way of learning botanical taxonomy, beginning: "Since Dr. Bautus first exhibited his printed bibles in the year 1463 , no book has, probably, exited such coneternation and dismay, as Dr. Torreg' edition of Lindley'. Itroduction[sic] to the Natural System of Botany." In an addition to the preface, apparently written later, Eaton mentioned L.C. Beck: Natural oystem of the plants of the States North of Virginia (pubiished by Websters and Skinners), as just received, and gave an impartial review of it.

An important change in this edition is the transfer of the descriptions of the genera and species of cryptogams to the part with the natural classification, which will have made this part more useful. The Musci (2: 68-80) include Bypnum cooleyanum S [prenge] 1 (2: 75). According to Eaton about 100 genera were added and 140 new species. For new names and combinations in vascular plants see Merrill and Reeder, 1947. 
7 Manual of botany for North Amerioa ...

Ed.7. Albany, 1836 .

Titze: "MANUAL OF BOTANY, | FOR | NORTH AMERICA: | CONTAINING | GENERIC AND SPECIFIC DESCRIPTIONS | OF THE INDIGENOUS PLANTS AND COMMON | CULTIVATED EXOTICS, | GROWING | NORTH OF THE GULF OF MEXICO. | BY AMOS EATON, A. M., I Senior Prof. in Rensselaer Institute, and Prof. of Civil Engineering; Member I of the American Geological Society; Acad. Nat. Sci. Phil.; N. York | Lyc. Nat. Hist.; Albany Inst.; Troy Lyceum Nat. History. [ Also, of the more recently established learned Societies I of Hudson, Utica, Detroit, Newburgh, \&c. " "That existence is surely contemptible, which regards only the gratification of | instinctive wants, and the preservation of a body made to perish."Linneus.| SEVENTH EDITION, | with an improved and modernized GRAMLAR and DICTIONARY; and about $\{500$ new Species, chiefly from the Oregon and Arctic regions. | [short double rule] | ALBANY: | PUBLISHED BY OLIVER STEELE, I And for sale by Grigg Elliott; Carey Hart; Desilver, Thomas \& Co.; Hogan \& Thompson, and N. Hunt, Philadelphia: B. S. Collins; N. J. White; I G. C. Carvill Co.i S. Wood Sons; Robinson, Pratt \& Co., and I Leavitt, Lord Co.. New York: Hilliard, Gray Co.. and | Marsh, Capen Lyon, Boston; W. S. Parker Son, I and Z. Clark, Troy. | N. [swash capital] Tuttle, printer, Troy.| 1836."

Collation: $12^{\circ}$ in 6s: $A^{6} 1-55^{6}$ ( $\$ 3$ signed $\$ 2$ ); i-iii iv-vi 7-672 (11 $37 \quad 138600-601658,370$ as '270').

Contents: $i$ title; ii registration: "in the year 1836"; iii-vi preface, dated 22 Mar. 1836; 7-8 directions; 9-10 abbreviations and signs; $17-36$ synopsis of taxonomy, including the classifications of Linnaeus and de Jussieu; 37-658 text, including 37-138 descriptions of genera in the Linnaean classification, 138-599 descriptions of species in alphabetical order; 600 ; 601-658 species of [non-vascular] cryptogams in alphabetical order; 659-670 index of vernacular plant names; 670-672 corrections and additions, including 15 species of Carex, published by Dewey. RT: class and order number in genera part, generic names in species part, chapter headings elsewhere. Language: English.

Paper: leaf height $181 \mathrm{~mm}$. (HBL copy, cut); wove; no wm.

Printer: Tuttle, N., Troy, N.Y.

Publioher: Steele, Oliver, Albany, N.Y.

Collaborator: Hall, James (1811 Sep. 12 - 1898 Aug. 7): selected additional species and translated their descriptions.

Date: 1836 (t.-p.); after 22 Mar. (preface); Apr.? (Rickett \& Stafleu: Taxon 10(3): 81. 1961); on or bef. 8 Jun. (letter from Eaton to Steele, the publiaher, with directions to send copies to particular persons, quoted by McAllister: Amos Eaton 236. 1941).

Refa.: Arn.Arb. 2: 106

Jacks. 355

Bradl. 1: $306^{\mathbf{a}}$

Meis.3: 378

Pr.ed.1 n.2882, ed.2 n.2593
stafl. TL n.329i.

Notes. Bound together with the fourth edition of Eaton's Botaniaal Grammar and Diotionary, ed.4. This is referred to in the preface, as added because of criticisms of the former edition, where it was lacking. The close connection between descriptions of genera and of species of non-vascular cryptogams introduced in the 6 th edition, was abandoned, and they are again widely separated in place. The species descriptions were again alphabetically arranged, all non-vascular cryptogams of different groups mixed, which must have been a disadvantage over the 6 th edition. About 80 genera were added, and about 400 species, particularly from the Western and Northern part of the continent, derived mainly from W.J. Hooker, Blora Boreali Amerioani, vol, $1,1833$. 
FLORA oder Allgemeine botanische zeitung.

Vol. 8-10. Regensburg, 1825-1827.

Titles: vol.81: "Flora | oder | Botanische Zeitung | welche | Recensionen, Abhandlungen, Aufsatze, | Neuigkeiten und Nachrichten, | die | Botanik betreffend, enthalt. |' [medium swelled rule] | Herausgegeben | von | der Königl. baier. $\left[8^{2}-10^{1} ;\right.$ bayer. $]$ botanischen Gesellschaft $\mid$ in Regensburg. | [medium fancy rule] | Achter Jahrgang. | [short rule] | Erster Band. | Mit 10 Bogen Beilagen und 1 Kupfertafel. I [full fancy rule] | Regensburg, 1825." ;

vol.82: same except: "Achter Jahrgang. | [short rule] | Zweiter Band; Mit 5 Bogen Erganzungs-Blatter, 6 Bogen Beilagen | und 1 Kupfertafel. | [full fancy rule] | Regensburg, 1825.";

vol.91: same except: "Neunter Jahrgang. I [short rule] I Erster Band. Mit $6 \frac{1}{2}$ Bogen Beilagen und 2 Tafeln. | [full fancy rule] | Regensburg, $1826 . "$;

vol.92: same except: "Neunter Jahrgang; | [short rule] | Zweiter Band. | Mit $6 \frac{1}{2}$ Bogen Beilagen und 1 Steintafel. | [full fancy rule] | Regensburg, 1826." ;

vol.10i: same except: "Zehnter Jahrgang; [short rule] | Erster Band. I Mit 7 Bogen Beilagen und 2 Abbildungen. [full fancy rule] | Regensburg, 1827."; vol.102: "Flora | oder | Botanische Zeitung | welche | Recensionen, betreffend, | enthilt. |' [medium swelled rule] | Herausgegeben | von | der königl. bayer. botanischen Gesellschaft | in Regensburg. I [medium fancy rule] | Zehnter Jahrgang. | [short rule] | Zweiter Band. | Mit 7 1/2 Bogen Beilagen und 3 Abbildungen. [full rule] | Regensburg, 1827."

Collation. The format is $8^{\circ}$. In the table (see next page) the collation of the fascicles of vol.8 is given, and of those parts in vol.9 and 10 which differ from vol.8. The preliminaries $\pi^{2}$ are, of course, bound in at the beginning, though issued last. The table contains in columns firstly the number of the fascicle (issue, "Lieferung" in German); secondly the signature of the gathering; thirdly the page numbers per unit, simplified by indicating the first, unnumbered, page and the last page (the pages between were duly numbered, except for mistakes reported in footnotes); lastly the dates as printed on the first page of the fascicle, in its head-title (the year is only given at the top of the column). Bound in with each half-yearly part are one or more "Beilagen". supplementary parts, treated in the same way except for the dates, since they do not bear precise dates. The collations of vol.9 and 10 are identical with that of vol.8 except for the years, the "Beilagen", and mistakes in page numbers. A cancellans, $M_{8}$, in voi.10, is not especially noted.

Plates: not studied; not belonging to articles with bryology.

Paper: leaf height $178 \mathrm{~mm}$. (U copy, cut); laid, chains vertical; wm.: vol.5-6 (1822-23): "L $=R$ [outline]", except vol. $6^{2}$ title and index; vol. 7 (1824): script letters (also in vol. 62 title and index): vol. 8 (1825): usually "BlasoheX [script, swash $K]^{\prime}$, combined with marks in the border of the sheet:" $H N$ [swash script] 3 [partly outvol. 9 (1826): "F[outíne]"; vol.10 (1827): letters, possibly: "L $=R$ [outline]"; not studied in detail.

Dates: issues dated (see table of collation); no attempt was made to collect the many announcements and reviews in contemporaneous literature, of which I saw a few. Usually a number of fascicles were announced or reviewed together; I do not remember having seen any other case, but realizing too late the importance of this point, I did not make notes of the particular fascicles reviewed or announced.

Bibliogr.otudy: Stafleu, F.A.: Taxonomio literature n.549. 1967. 
Collation:

\begin{tabular}{|c|c|c|c|}
\hline "Lieferung" & gath. & pages & 1825 \\
\hline $\begin{array}{c}1 \\
2 \\
3 \\
4 \\
5 \\
6 \\
7 \\
8 \\
9 \\
10 \\
11 \\
12 \\
13 \\
14 \\
15 \\
16 \\
17 \\
18 \\
19 \\
20 \\
21 \\
22 \\
23 \\
24 \\
1 . \text { Beilage } \\
2 . \text { Beilage } \\
3 . \text { Beilage } \\
4 . \text { Beilage } \\
5 \text { Beilage } \\
{[\text { titles] }}\end{array}$ & $\begin{array}{r}A^{8} \\
B^{8} \\
C^{8} \\
D^{8} \\
E^{8} \\
F^{8} \\
G^{8} \\
H^{8} \\
I^{8} \\
K^{8} \\
L^{8} \\
M^{8} \\
N^{8} \\
O^{8} \\
P^{8} \\
Q^{8} \\
R^{8} \\
S^{8} \\
T^{8} \\
U^{8} \\
X^{8} \\
Y^{8} \\
Z^{8} \\
2 A^{8} \\
1-4^{8} \\
5-6^{8} \\
7^{8} \\
8-9^{8} \\
10^{6} \\
T^{2}\end{array}$ & $\begin{array}{r}1-16 \\
17-32 \\
33-48 \\
49-64 \\
65-80 \\
81-96 \\
87-112 \\
173-128 \\
129-144 \\
145-160 \\
161-176 \\
177-192 \\
193-208 \\
209-224 \\
225-240 \\
247-256 \\
257-272 \\
273-288 \\
289-304 \\
305-320 \\
327-336 \\
337-352 \\
353-368 \\
369-384 \\
7-64 \\
65-96 \\
97-112 \\
173-144 \\
145-156 \\
i-1 v\end{array}$ & $\begin{array}{cc}\text { Jan. } & 7 \\
n & 14 \\
n & 21 \\
n & 28 \\
\text { Feb } & 7 \\
n & 14 \\
n & 21 \\
\text { " } & 28 \\
\text { Mar. } & 7 \\
\text { " } & 14 \\
n & 21 \\
\text { " } & 28 \\
\text { Apr. } & 7 \\
\text { " } & 14 \\
\text { " } & 21 \\
\text { " } & 28 \\
\text { May } & 7 \\
\text { " } & 14 \\
\text { " } & 21 \\
\text { Jun. } & 28 \\
\text { Jun. } & 7 \\
\text { " } & 14 \\
\text { " } & 21 \\
\text { " } & 28 \\
& \\
& \\
\text { Jul. ? }\end{array}$ \\
\hline \multicolumn{4}{|c|}{$\begin{array}{l}\text { 1) + fold-out } \\
\text { 2) + } 1 \text { plate (not in other vols.) }\end{array}$} \\
\hline
\end{tabular}

volume $8^{2}$ :

\begin{tabular}{|c|c|c|c|}
\hline "Lieferung" & gath. & pages & 1825 \\
\hline $\begin{array}{c}25 \\
26 \\
27 \\
28 \\
29 \\
30 \\
31 \\
32 \\
33 \\
34 \\
35 \\
36 \\
37 \\
38 \\
39 \\
40 \\
41 \\
42 \\
43 \\
44 \\
45 \\
46 \\
47 \\
48 \\
1 . B e i l a g e \\
2 . \text { Beilage } \\
3 . \text { Beilage } \\
4 . B e i l a g e \\
5 \text { Beilage } \\
{[\text { titles] }} \\
\text { Erganzungs- } \\
\text { Blatter }\end{array}$ & \begin{tabular}{r|}
$2 B^{8}$ \\
$2 C^{8}$ \\
$2 D^{8}$ \\
$2 E^{8}$ \\
$2 F^{8}$ \\
$2 G^{8}$ \\
$2 H^{8}$ \\
$2 I^{8}$ \\
$2 K^{8}$ \\
$2 L^{8}$ \\
$2 M^{8}$ \\
$2 N^{8}$ \\
$2 O^{8}$ \\
$2 P^{8}$ \\
$2 Q^{8}$ \\
$2 R^{8}$ \\
$2 S^{8}$ \\
$2 T^{8}$ \\
$2 U^{8}$ \\
$2 X^{8}$ \\
$2 Y^{8}$ \\
$2 Z^{8}$ \\
$3 A^{8}$ \\
$3 B^{8}$ \\
$1^{8}$ \\
28 \\
38 \\
$4-5^{8}$ \\
66 \\
$\pi^{2}$ \\
$A-C^{8}$
\end{tabular} & $\begin{array}{r}385-400 \\
401-416 \\
417-432 \\
433-448 \\
449-464 \\
465-480 \\
487-496 \\
487-512 \\
513-528 \\
529-544 \\
545-560 \\
561-576 \\
577-592 \\
583-608 \\
609-624 \\
625-640 \\
641-656 \\
657-672 \\
673-688 \\
689-704 \\
705-720 \\
721-736 \\
737-752 \\
753-768 \\
1-16 \\
17-32 \\
33-48 \\
49-80 \\
87-92 \\
i-i v \\
1-48\end{array}$ & 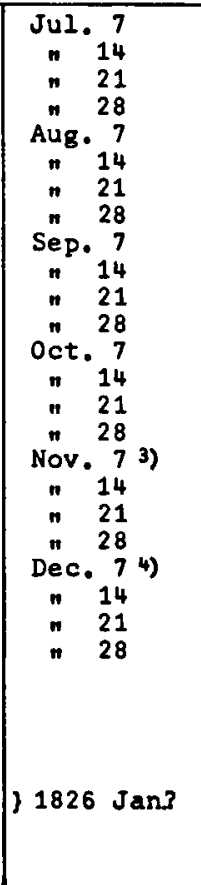 \\
\hline \multicolumn{4}{|c|}{$\begin{array}{l}\text { 3) } 646-656 \text { as '666'-'676' } \\
\text { 4) } 2 \mathrm{Y}_{8}+\text { fold-out: "Plantae lectae in } \\
\text { itinere Hispanico-Tingitano. } \\
\text { Index Fasciculi Primi." } \\
\text { + folded plate (not in other vols.) }\end{array}$} \\
\hline
\end{tabular}

Collation of vol. 9 and 10 identical with that of vol. 8, except:

volume $9^{1}$ : 1826, Jan-Jun.

\begin{tabular}{|c|c|c|}
\hline & gathering & pages \\
\hline $\begin{array}{l}\text { 1. Beilage } \\
2 . \text { Beilage } \\
\text { Auszer } \\
\text { ordentliche } \\
\text { Beilage } \\
\text { Druckfehler }\end{array}$ & $\begin{array}{c}1-6^{8} \\
7_{1}-7_{6} \\
7_{7}-7_{8} \\
x\end{array}$ & $\begin{array}{r}1-96 \\
97-108 \\
109-112 \\
113-114\end{array}$ \\
\hline
\end{tabular}

volume $10^{1}: 1827$, Jan-Jun.

\begin{tabular}{|l|r|r|}
\hline 1. Beilage & $1^{8}$ & $1-16$ \\
2. Beilage & $2^{8}$ & $17-32$ \\
3. Beilage & $3-6^{8}$ & $33-96$ \\
4. Beilage & $7^{6}$ & $97-108$ \\
\hline
\end{tabular}

volume 92: 1826, Jul-Dec.

\begin{tabular}{|l|l|l|}
\hline & gathering & pages \\
\hline Beilage & $1-6^{8} 76$ & $7-108$ \\
\hline & \\
(main text: & $\begin{array}{l}\text { page } 248 \text { as '148' } \\
\text { page 622 as ' } 922^{\prime} \text { ') }\end{array}$ \\
\hline
\end{tabular}

volume $10^{2}$ : $1827, J u l .-D e c$.

\begin{tabular}{|c|c|c|}
\hline 1. Beilage & $1-7^{8} \quad 8^{4}$ & $7-120$ \\
\hline $\begin{array}{l}\text { (no incor } \\
\text { seen in }\end{array}$ & $\begin{array}{l}\text { page nu } \\
\text { ime } 10)\end{array}$ & \\
\hline
\end{tabular}


Notes. When I began my work for Index Nusoorum I took it for granted that the dates on the fascicles were correct. Gradually I began to wonder how these weekly sheets could have been efficiently handled. I realized that I did not see traces of wear in individual fascicles, which could be expected with weekly issue. My doubts were diminished when I found in Flosa 81 (Beil.4): 139 . 1825, the statement: Flora "kann nach Belieben poettyglich, monatlich, oder quartalweice bezogen werden." This explained the immaculate library copies. Local members would have received the fascicles weekly indeed. However, I also found the following announcement on one of the fascicle wrappers of Iois (Oken), 1826, of the second quarter:

Von folgonden Werken hat der Unterzeichnete die Lieferung $2 u$

bei tehenden Preisen in Preusa. Courant tbernommen, und erlaubt sich, dieselben allen Botanikern dringend zu anempfehlen. Flora, oder botanische Zeitung, welche Recensionen, Abhendlungen, [...] die Botanik betreffend enthalt, Heraugegeben von der k8niglichen beierischen botanischen Gesellschaft in Regengburg. 8 Jahrgange oind erechienen, der neunte Jahrgeng von 1826 wird in conatlichen Lieferungen ausgegeben.

Preit eines Jahrgangs von 2 Banden 3 Thlr. Leipzig, im Aprili 1826 .

Friedrich Hofmeister.

(Translated: of the following works the undersigned has taken over the delivery at the mentioned prices in Prussian currency, and he permits himself to recommend these strongly to all botanists.

Flora, or botanical journal, which contains reviews, articles and news concerning botany. Published by the royal Bavarian botanical society at Regensburg. 8 years appeared, the ninth year of 1826 is being published in monthly instalments. Price of one year of 2 volumes 3 Thaler.) Another announcement was published in Flora 101 (Beit.2): 32. 1827 (sem.1), which stated: "... dex zehnte Jahrgang von 1827 wird in monatlichen Lieferungen ausgegebon. Preie einer Jahrgang von 2 Binden 3 Thlr. 8 Ggr." This definitely indicates monthly publication of groups of four weekly fascicles from that date. I assume that as a rule these will not have been published before the date on the last fascicle. It still is possible that each fascicle was printed before the date indicated in its head-title, and was distributed on that day to the local members of the society in Regensburg. These days, however, in some months, would all be Sundays, and other days in other months. Therefore, these days will not coincide with regular meeting days of the society, making distribution on these days unlikely as a regular occurrence. Moreover, if so, it can scarcely be taken as effective publication, available to the general public, but this possibility should be investigated more ciosely, e.g. in the archives of the society. In critical cases it may make a difference for the priority of plant names, which date is the correct one for publication, the weekly or the monthly date. of course the publication easily could have been delayed beyond the last printed date.

The numbering of the fascicles is continuous throughout the year. Therefore, in citing fascicles, I omit the semester number and give only the volume of the year and the fascicle number between parentheses: e.g. $8(3)$ or $8(48)$. For the "Beilagen" the situation is different. Firstly these are numbered anew for each semester; its number, therefore, has to be stated in the correct citation. Here it is given as a superscript, e.8.: $8^{1}$ (Beit.3), though it could be added after a comma, e.g.: 8,1 (Beil.3). Secondly, they are undated. This is a real problem for precise dating, the more so, since these supplements contain new described species and taxa of other ranks, as well as useful information for the more precise dating of the other publications, if their own dates were better known. Up to now I have not been able to find information on this point. In the light of the announcement cited it could be expected that each month with four gatherings of nomal text would also have one or two gatherings of "Beilagen". However, their number is not a multiple of 6 , for the years studied, and the hypothesis of 
a regular number of sheets per nonth does not lead to a solution. The only explanation which is likely from a bibliographical point of view is that an incomplete gathering at the end (the several gatherings in 6s) were really issued at the same time with or later than the latest fascicle, since they will have contained the title-page to the whole volume and its conjugate leaf $\left(\pi_{1}, \pi_{2}\right)$; moreover they usually contain the index.

Besides the "Beilagen" some other publications were issued together with the fasaicles of $B$ lora. In the first place this was: Sylioge plantarum novarum..., vol.1-2, [1822]-1828. This title is important and is treated separately in this thesis. Another was the Literaturblatt to Flora, of which F.G. Eschweiler (1796-1831) was the editor. I found some information in the correspondence of Ad. Brongniart (PMusBC), though this does not concern the period I want to treat. Eschweiler wrote to him on $20 \mathrm{Feb} .1828$ that he would soon (sous peu) send its first fascicle to Brongniart. In the next letter, dated $20 \mathrm{Jul}$. 1828 he announced sending it and also that the second fascicle was not yet ready: le econd cahier oera orne par vos propres reoherohes our les Rhamnés et vos déouvertes our la gankétion des vegetaux. I did not trace this further.

\section{FRIES, Elias Magnus}

Biogr. Born 1794 Aug. 15, Femsj8, Smaland, Sweden.

Died 1878 Feb. 8, Upsala, Sweden?

E.M. Fries studied in Lund from 1811, received the degree of Ph.D. in 1814 and became lecturer in botany there. In 1819 he was nominated "adjunct botanist" and in 1824 royal professor. In 1834 he was called to Upsala as professor in agricultural economics (oeconomica practica), to which botany was added in 1851 , and the direction of the botanical garden, which he improved. He retired as professor in 1859 , and as director of the garden in 1863.

His publications form a long list, and his most outstanding work was on Fungi This was recognized by the acceptance of his work Syotema mycologioum $1821-1828 \mathrm{as}$ the starting-point for the nomenclature of the majority of the Fungi. The phanerogams of his herbarium were bought by the Botanical Museum of the University at Upsala; the mosses and algae were presented to the same institution and the lichens came to his son, Thore Magnus Fries.

The following generic names were proposed in honor of E.M. Fries: Friesia Sprengel 1818, now considered a synonym of Crotonopois Michaux (Euphorbiaceae), Friesia A.P. de Candolle 1824, nom, rej. versus Ariototelia L'Héritier nom. cons. (Tiliaoeas or Elasocarpaceas), Friseia P. Wieselgren 1846, considered a synonym of Epipogium R. Brown, Eriesites P.A. Karsten 1880 (Eungi, Bydnaoeae) and Friesula Spegazini 1881, now a synonym of Skepperia Berkeley 1857 (Fungi, Thelephoraosae), and possibly also Frisea (Endlicher) Spach 1841, for Thesium L. sect. Frisea Endlicher (Theoiaoeae).

Refo.: Lefnadsteokn. Svenska Vetensk.Akad.2: 212-226. 1878-85 (with bibliogr.). Elfving, S.: Finsk Tidsokr.4: 324-326. 1878 .

Upsala Universitet 1872-1897 Anh. 64-68 (with bibliogr.).

Lloyd, C.G.: lyool. Notes 32: 413-427, 1909; 33: 480-482. 1910.

Krok, T.0.B.N.: Biblioth.Bot.suea, 199-216. 1925 (with bibliog.).

1 Stirpes agri Femsionensis...

7 parts [used as different theses]. Lund, 1825-1826.

Titles: part 1: "STIFPES | AGRI FEMSIONENSIS, | QUARUM INDICEM I CONS. AMPLISS. PHIL ORD. LUI.DENS. I PRES IDE I ELIA MAGNO ERIES, I PROF. REG. ET BOT. ADJ ORD. I REG. AL AD. SCIENT. HOLM. ETC. MEMBRO, I P. P. I MAGNUS G. WINDING, GOTHO BURGENSIS i IN ACAD. CAROL. D. XXV. MÁJI MDCCCXXV. I [long thick rule] | LONDINI GOTI.ORUM, | EX OFF ICINA BERLINGIANA; | MDCCCXXV." ; part 2 (continuation 1): same except part: "P. P. I J. G. ARRHENIUS, I VERMELANDUS, I IN ACAD. CAROL. D. XI. JUNII MDCCCXXV. I [medium long thick rule] | CONTIfiJATIO I. | [long thick rule] | LONDINI GOTHORUM, I Ex offIcINA BERLINGIANA; | MDCCCXXV."; 
part 3 (cont. 2): same except lines: "P. P. | NICOLAUS HEMMES, I SCANUS. I IN ACAD. CAROL. D. XI JUNII MDCCCXXV. | [medium long thick rule] | CONTINUATIO II." ;

part 4 (cont. 3 ): same except lines: "P. P. | SVENO LUDOV. LOVEN, I SCANUS. IN ACAD. CAROL. D. XVI JUNII MDCCCXXV. | [medium long thick rule] | CONTINUATIO III." ;

part 5 (cont. 4): same except part: "P. P. I J.P. HJELM, | SCANUS. I IN ACAD. CAROL. D. XIX MAJI MDCCCXXVII. | [mediun long thick rule] | CONTINUATIO IV. [long swelled rule] | LONDINI GOTHORUM. | EX OFF ICINA BERLIKGLANA, | MDCCCXXVII,";

part 6 (cont. 5): same except lines: "P. P. | C. P. SNOBERG, I SCANUS. I IN ACAD. CAROL. D. II JUNII MDCCCXXVII. | [medium long thick rule] | CONTINUATIO V." ;

part 7 (cont. 6): same except lines: "P. P. | C. N. AHNFELT, | SCANUS. I IN ACAD. CAROL. D. VIII DEC. MDCCCXXVII. | [long thin rule] | CONTINUATIO VI. | [fancy swelled rule]".

Collation: $8^{\circ}$ : part 1 :

part 2 (cont.1): $2-3^{4} \quad(2$ unsigned, 22 as 121$) ; \quad i-i i$ 17- 30 ;

part 3 (cont. 2$): 4-5^{4}$. ( 4 l unsigned, 42 as $\left.14^{\prime}\right) ; \quad i-i i \quad 31-44$;

part 4 (cont.3): 6-74 $\quad(61$ unsigned, 62 as 161$) ; \quad i-i i$ 45- 58;

part 5 (cont.4): $8-9^{4} \quad\left(8\right.$, unsigned, 82 as $\left.18^{\prime}\right) ; \quad i-i i \quad 59-72$;

part 6 (cont.5): 10-114 (10, unsigned)

part 7 (cont.6): $12^{2+6}$ (12, unsigned, 12 as $\left.112^{\prime}\right) ; \quad i-i i$ 87-100.

Contenta: part 1: 1 title; 8 dedication to Magnus Christian Winding and Maria Winding née Liedberg, parents of M.G. Winding; 3-10 introduction; 11-16 text, Diandria - Polyandria, Thaliotrum, with 26 footnotes (numbered 1-26); part 2 (cont.1): $i$ title; $i i$ dedication to Carolus Magnus Arrhenius "Phil. mag., suprem. in expeditione reg. secretario" and Petrus Arrhenius "camerar.

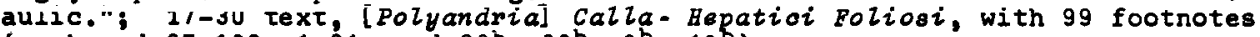
(numbered $27-100,1-21$, and $28 \mathrm{D}, 33^{\mathrm{b}}, 6 \mathrm{~b}, 19 \mathrm{~b}$ );

part 3 (cont.2): i title; ii dedication to Anders Peter Stahle, "Troman, Lagmannen och Riddaren af Kongl. Majts Nordstjerne- och Vasa-orden"; 31-44 text, [Hepatici] Erondosi - Hydrophycen Nostocina, Pulmella hyalina?[sic] with 97 footnotes (numbered 22-100,1-16, and 29b, 43b);

part 4 (cont.3): i title; ii dedication to Christianus Lovén, "Urbis Holmia consuli, equiti aurato de regio ordino Wasa", father of S.L. Lovén; 45-58 text, Chzorocoooum - Fungi, Polyporus giganteus, with 109 footnotes (numbered $17-100,1-24$, and $\left.13^{b}\right)$;

part 5 (cont.4): $i$ title; $i i \square ; 59-72$ text, [Polyporus] Sulphureus Sphasia nivea, with 92 footnotes (numbered 25-100, 1-7, 11-17, and 62b; 8-10 together one footnote);

part 6 (cont.5): i title; ii प; 73-86 text, Fungi continued, [Spharia] diatrupa - Isaria terrestria, with 88 footnotes (numbered 18-26, 28-100, 1-6); part 7 (cont.6): i title; ii $\square$; 87-92 text, list concluded, with 64 footnotes (numbered 7-70); 93 observation; 93-99 "PLANTE CULTE 9 agri

Femsionensis"; 100 additional note: the opinion of "Grewille" [=R.K.Greville] on the new moss species Gymnostomum Ahnfeltii. No RT. Language: Latin.

Paper: leaf height $180 \mathrm{~mm}$. (BMNH copy, cut); laid, chains vertical; no wm.

Printer: Berling, Lund, Sweden.

Dates: on or shortly before the dates of the theses:

part 1: 1825 May 25:

part 2 (cont.1): 1825 Jun. 11;

part 3 (cont.2): 1825 Jun. 11;

part 4 (cont.3): 1825 Jun. 16; part 5 (cont.4): part 6 (cont.5): part 7 (cont.6):
1827 May 19;

1827 Jun. 2 ;
1827 Dec. 8 . 
Reviews: parts 1-4: Arsberattelser K.Vet.Acad. 1825, 6: 98, 1826; Svea $1826^{10}(2): 223-224,1826$.

Refo.: BMNH 622

Bradl. 1: $353^{\mathbf{a}}$

Krok 201

Pr.ed.1 n.3391 (in note)

Wikstr. 77-78

Bibl.notes. According to the custom of the period, the praeses wrote the whole book and gave parts to different students for their doctor's theses. Consequently each part had a different title-page, with a separate dedication at the versa $1 \mathrm{~g}$. The folding of part 7 is inferred from Fries $n .2$ (the separate edition under Fries' name only); I did not check conjugacy here.

Bot.notes. Regional flora, with lists of Latin plant names without author's citations, only with indications of frequency. Musoi were treated on p.24-29 and some other pages, e.g. Sphagnum p.7, Bypnum species p.7. The importance lies in the critical footnotes, containing new descriptions, e.g. of taxa in the genus Lepigonum, possibly in Fungi, and of the new moss species Gymnostomum ahnfeltii, p.28. The additional remark by Greville (p.100) that this species belongs to the genus Eymenostomum has no nomenclatural consequence.

2 Stirpium agri Femeionensis index....

1 vol. Lund, 1825-1826[1827] [re-issue].

Titze: "STIRPIUM | AGRI FEMSIONENSIS | INDEX, | OBSERVATIONIBUS ILLUSTRATA, I AB EL. FRIES, | [long swelled rule] | LUNDE | IYPOGRAPHIA ACADEMICA, | 1825,1826 ,"

Colzation: $8^{\circ}: 7^{8}\left(=7_{1}\right) \quad 2-11^{4}\left(-2,-4_{1}-6,-8_{1}-10_{1}\right) \quad 12^{8}\left(-12_{8}\right) \quad\left(2,, 42,6_{2}, 8_{2}\right.$, $10_{2}, 122$ signed $\$ 1 ; 5_{1}$ unsigned); $7-3$ 4-100.

Contents: 1 title; 2 D; 3-10 introduction; 11-92 text, list of local plants with 575 footnotes, phanerogams and extensive list of cryptogams; 93 observation; 93-99 "PLANTE CULTE | agri Femsionensis"; 100 additional note concerning the opinion of "Grewille" [=R.K. Greville] on the new species Gymostomum ahnfeltii: it should be placed in the genus bymenostomum. No RT. Language: Latin.

Paper: leaf height $181 \mathrm{~mm}$. (WU copy, cut); laid, chains vertical; no wm.

Printer: printer of the Academy [Berling], Lund, Sweden.

Date: 1825-26 (t.-p.); probably after 8 Dec. 1827 (date last thesis, see Notes).

Reviewe: Bulz.Univ.sci.Hat. (Férussac) 14(5): 85. 1828 May; Linnaea Lit.Ber. 4(3): 70.1829.

Refo.: Krok 201 Pr.ed.1 n.3391, ed.2 n.3071 Wikstr. 78.

Bibl,notes. From Wikstrom (see Refs.) I derive that the title-leaf is a cancellans; if correct I overlooked this in the copy studied (WU). I regret I did not yet have an opportunity to recheck this and the conjugacy of the middle parts too. Wikström also states that some corrections were made in this issue. This is remarkable, since the two issues certainly were printed from the same type-setting, without re-imposition. The possibility that the type-formes were left standing till the days of the doctor's promotions seems very remote since the Lund University printer was so busy that arrangements for printing of theses usually had to be made a couple of months ahead of time. The only plausible explanation for corrections, therefore, is by stop-press alterations. I take it for granted that the complete issue was publisned later than the parts as doctor's theses. If so, the dates on the title-page do not give the actual year of publication of this reissue. 
FROHLICH, Josef AlOis

Biogr. Born 1766 Mar. 19, Oberstdorf, Bavaria, Germany.

Died 1841 Mar. 11, Ellwangen, Bavaria, Germany.

Frohlich was a physician at Ellwangen, with a strong interest in botany, especially

in cryptogans, and more particularly in mosses, making regularly collecting trips

to the AlPB. In 1825 he was indicated as "Medizinalrath" at Ellwangen.

He was commemorated in the generic names Froeliohia Vahl 1796 = Froehlichia

D. Dietrich 1839, now considered a synonym of Coussarea Aublet (Rosaceae).

Froeliohia Moench 1794 (Amaranthaceae), and Froeliohiella R.E. Fries 1920

(Amaranthaoeal).

Refs.: Familler, I.: Denkoohr.Bayer.Bct.Ges. 11: 12. 1913.

Dalla Torre Sarnth.: El.Tirol 1: 79. 1900.

1 [Pflansen in den an die Kuratie steoh im Lechthale angranzenden Gebirgen.]

Bothe von und fur Tirol und Vorarlberg 1825(89): 356. 1825 Nov. 7 .

Collation: $2^{\circ}$ each fascicle one gathering.

Paper: laid, chains vertical (copy Universitats-Bibliothek Innsbruck, Austria).

Date: fascicle dated 1825 Nov. 7 .

Hote. Short communication under the general heading "Naturkunde", of a list of Latin names of rare or important plants collected by Frölich, from four localities in the mountains near the upper Lech valley. One moss is mentioned from "Unter der Wand": Splachnum angustatum, and two lichens. The other plants are phanerogams.

\section{FUNCK, Heinrich Christian}

Biogr. Born 1771 Nov. 22, Wunsiedel, Bavaria, Germany.

Died $1839 \mathrm{Apr}$. 14, Gefrees near Bayreuth, Oberfranken, Germany.

When Funck was very young, his mother moved to Gefrees for a second marriage with a pharmacist. After elementary 8 chool at the nearby place Hof, he learned pharmacy in Regensburg, where his botanical interest was stimulated by Hoppe. When the latter founded the Regensburger Botanische Gesellschaft in 1790, Funck joined as "eleve". In 1793 he was in $a$ job at Salzburg, and learned to know the flora of the Alps, where he later repeatedly botanized. In 1794 he worked at Erlangen for the courtpharmacist prof. Martius, followed for a short time courses at the University of Jena and returned to Gefrees. In 1808 he took over his mother's pharmacy which he headed until 1834, selling it to devote his time to science, and to his community where he became Bürgermeister.

He was commemorated in the generic names Funokia Willdenow 1808 , a rejected synonym of Astelia R. Brown 1810, nom. oons. (Liliaceae), Funakia Sprengel 1817, the well-known name for a genus now named Hosta Trattinick 1812, nom. cons. (Liliaoeae), and Funokia Dennstedt 1818, now a synonym of Lumnitsera Willdenow (Combretaceae).

Refo.: Ascherson: AlZg.Deutsohe Biogr. 8: 196-197. 1878.

Flora 62: 97-103.1879.

Dalla Torre Sarnth.: PL.Tirol 6(4): 17-19. 1904.

1 Cryptogamische Gewalohe [besonders] des Bichtelgebirg's.

42 fascicles. "Leipzig or Hof, 1801-1838 [exsiccata].

Titzes: fasc.1: "Cryptogamische Gew y̆chse | des | Fichtelgebirg's. | [rule of spiral ending in arrows at both ends] | Gesammelt | von | Heinrich Christian Funck, | verschiedener naturforschenden Gesellschaften Mitglied. | [rule of thick spiral ending in arrows at both ends] | Erstes Heft| [long swelled rule] | Leipzig, 1801. I In Commission bey Iohann Ambrosius Barth.";

fasc.2: "Cryptogamische Gewachse | des | Fichtelgebirg's | [short thin swelled rule] i Gesammelt | von | Heinrich Christian Funck. | [short thin swelled rule] | Zweites Heft | [Long rule] | Hof, | in Commission bey Gottfried Adolph Grau | 1801."; 
fasc.3: same as fasc.2 except: " | Drittes Heft. | " and "1802."; fasc.4: "Cryptogamische Gewăchse I des | Fichtelgebirg's. I Fshort thin swelled rule] | Gesammelt | von | Heinrich Christian Funck. | Viertes Heft [long wavy rule with arrows at both ends] | 1804.";

fasc.5: "Cryptogamische Gewächse | des | Fichtelgebirg's. | [rule of spiral ending in arrows at both ends] | Gesammelt | von | Heinrich Christian Funck, | verschiedener naturforschenden Gesellschaften Mitglied. [ [short rule with double spiral in the middle] | Eanftes Heft. | [long swelled rule] | Leipzig, 1805 In Commission bey Iohann Ambrosius Barth.";

fasc.6: "Cryptogamische Gewächse | des | Fichtelgebirg's | nebst | einigen beygefügten seltenen Arten aus andern | Gegenden | von | Heinrich Christian Funck, I verschiedener naturforschenden Gesellschaften Mitglied, I [short rule] | Sechtes Heft. | [long swelled rule] | Leipzig, 1806. | In Commission bey Iohann Ambrosius Barth.";

fasc.7: same as fasc.6 except: "einigen beygefugten Arten aus I andern Gegenden |" and "Mitglied. [short double spiral between two arrows] | Siebentes Heft. | [long swelled rule] | Leipzig, 1806. | In Commission bey Iohann Ambrosius Barth.";

fasc.8: "Cryptogamische Gewächse | besonders | des | Fichtelgebirg's. [short double spiral between two arrows] | Gesammelt | von | Heinrich Christian Funck, | verschiederier naturforschenden Gesellschaften Mitglied. I [short double spiral between two arrows] | Achtes Heft.| [long swelled rule] | Leipzig, 1807. | In Commission bey Johann Ambrosius Barth.";

fasc.9: same as fasc.8 except: "Neuntes Heft | [short rule] | Leipzig, 1807."; fasc.10-19: same as fasc.9, except for the lines:

fasc.10: "Zehntes Heft." ". "Leipzig, 1808." ;

fasc.11: "Eilftes[8ic] Heft." : : "Leipzig, 1808.";

fasc.12: "Zwolftes Heft" : - "Leipzig, 1808."?

fasc.13: "Dreizehntes Heft." : : "Leipzig, 1808."?

fasc.14: "Vierzehntes Heft" : : "Leipzig, 1809.";

fasc.15: "Funfzehntes Heft.": : "Leipzig, 1809.",

fasc.16: "Sechzehntes Heft." - . "Leipzig, 1810.";

fasc.17: "Siebenzehntes Heft.": : " "Leipzig, 1810." "

fasc.18: "Achtzehntes Heft." "Leipzig, 1811.";

fasc.19: "Neunzehntes Heft. | [fuli rule of alternating thick and thin spiral ending in arrows] | Leipzig, 1811.",

fasc.20-26: same as fasc.19, except for the lines:

fasc. 20: "Zwanzigstes Heft."

fasc.21: "Ein und zwanzigstes Heft." : : "Leipzig, 1815."

fasc. 22: "Zwei und zwanzigstes Heft." . . "Leipzig, 1815.";

fasc. 23: "Drei und zwanzigstes Heft." : : "Leipzig, 1816.";

fasc. 24: "Vier und zwanzigstes Heft." . - "Leipzig. 1817.";

fasc. 25: "Fünf und zwanzigstes heft.". - "Leipzig, 1818,";

fasc.26: "Sechs und zwanzigstes Heft. | [wavy rule] | Leipzig, 1819.";

fasc. 27-42: same as fasc. 26, except for the lines:

fasc. 27: "Sieben und zwanzigstes Heft."

fasc. 28: "Acht und zwanzigstes Heft."

fasc.29: "Neun und zwanzigstes Heft."

fasc.30: "Dreisigtes [sic] Heft."

fasc.31: "Ein und dreissigtes [sic] Heft."

fasc.32: "Zwey und dreissigtes [sic] Heft."

fasc.33: "Drei und dreissigtes [sic] Heft."

fasc.34: "Vier und dreissigtes [sic] Heft."

fasc.35: "Fünf und dreisigstes [sic] Heft."

fasc.36: "Sechs und dreisigstes [sic] Heft."

fasc.37: "Sieben und dreissigstes Heft."

fasc.38: "Acht und dreissigstes Heft."

fasc.39: "Neun und dreissigstes Heft."

fasc.40: "vierzigstes Heft."

"Leipzis, 1819,";

-

-

"Leipzis, 1823 "

- - "Leipzig, 1824."

- "Leipzig, 1825.";

- "Leipzig, 1826."

- " "Leipzig, 1827."

"Leipzig, 1828." ?

"Leipzig, 1829." "

"Leipzig, 1831." :

"Leipzig, 1832," ?

"Leipzis, 1835."

"Leipzig, 1836."

"Leipzig, $1836 . "$ "

fasc. 41: "Ein und vierzigstes Heft. | (N2.826-845) | Leipzis. 1838."

fasc.42: "Zwei und vierzigstes Heft." 
Coltation: $4^{\circ}$ :

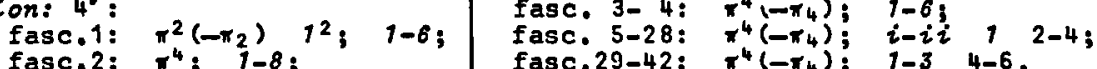

Contents: fasc.1-4: 1 title; 2 ; 3-6 list of species, with particulars: numbers, "phrases", references, habitats and localities, and month of sporulation; [fasc. 2 in addition:] $70 ; 8$ numerical list of plants of fasc.2;

fasc.5-28: $i$ title; $i i[$ [except fasc.6: notice concerning the extension of the series to include rare species from other regions (compare the additions in its title), those species marked with asterisks; signed: "Febr. 1806 / Funck." " 7-4 list of species as in fasc. 1;

[fasc. $14,20,21,25$ in addition:] 4 corrections to foregoing fascicles; fasc.29-42: 1 title; $20 ; 3-6$ list of species as in fasc.1.

Speoimens: fasc.1-5: 25 specimens per fescicle; fasc.6-42: 20 specimens per fasc.; one per leaf, with printed label (number and name only); versos $\square$.

Wrappers: rreen thin paper covers without information.

Paper (text): leaf height $189 \mathrm{~mm}$. (NYBG copy, cut); laid, chains horizontal; wm.: "[stylized eagle, $B$ on breast] $=$ I G RAHM [outline]": fasc.1 (PC copy); " [eagle] | HOF [outlinej": fasc.7-10;

" [eagle] I IAA for reverse]": fasc.12-16;

"leagle] | IHS": fasc.18;

" [coat of arms?j" (top only seen): fasc.20;

"[crowned shield with fleur-de-lis]"; fasc.24;

"[structure with paraliel top and bottom, glightly concave sides opening in one flat part, small circle outside opposite side, in double outline]": fasc.25; "C [outline]": fasc.27, 39, 42?; "JoC [?]": fasc.30;

none seen: fasc.6,11,19, 26, 28, 29, 31-38, 41 (NYBG copy); not studied: fasc,2-5, specimen-part 1-42.

Printer: no imprint.

Publisher: Funck, H.C., the author:

in consipnment with: Barth; J.A. (see Bridel n.4): fasc.1 [variant?], 5-42; and with: Grau, G.A., Hof, Germany: fasc.1 [?], 2-3.

Dates, announcements and reviows: see tahle next pare.

Bibliogr.studies: Sayre, G.: Dates of publ. 71-73, 1959; Stafleu, F.A.: Taionomio literature n,386. 1367.

Refe.: BMNH $631 \mathrm{~b}$

Brun 2: 1424 Graesse 2: 647a

Linn.Soc. 278

Milt. 277

Pr.ed.1 n.3447

Pr.ed. 2 n.3158

Bibl.notes. The collation of the printed part is remarkably uniform throughout the series, except for the first two fascicles; page numbers were introduced in fasc.5, and changed to include the title-page in fasc.29. Fasc.1 (NYBG copy) definitely has the title on another leaf than the text. This may point to a cancellans, especially since Funck in an "Anklndigung", Bot.Tasohenbuch(Hoppe) 1800: 249-252. 1800 , announced that fasc.1 was to be had from G.A. Grau in Hof, who had the collection in consignment ("Commission"). This announcement was dated Feb. 1800. Fasc.2 was indicated as to appear at the Michaelmas Fair, and lists of sfecies in both fascicles were given. From this might be inferred that a title-page with the year 1800 and Grau's name was originaliy published, and that Barth, taking it in consignment, wanted another title, which received the date of 1801 . More information is needed to decide this question; if a re-issue of 1801 really exists, its precise date is not known.

Concerning the title-pages of fasc.3-42 the consistent removal of in is strange. Possibly these leaves contained the printed labels. I have not seen an indication that title-pages of different fascicles were printed from the same type-setting. I pondered over the possibility that two different titlepages were printed conjugately, in which case some of the collations would have to be corrected, but I was not able to recheck this point thoroughly, because I no longer had the copies at hand; it would explain some discrepancies between title-page date and publication date. 
Dates, announcomente and reviews:

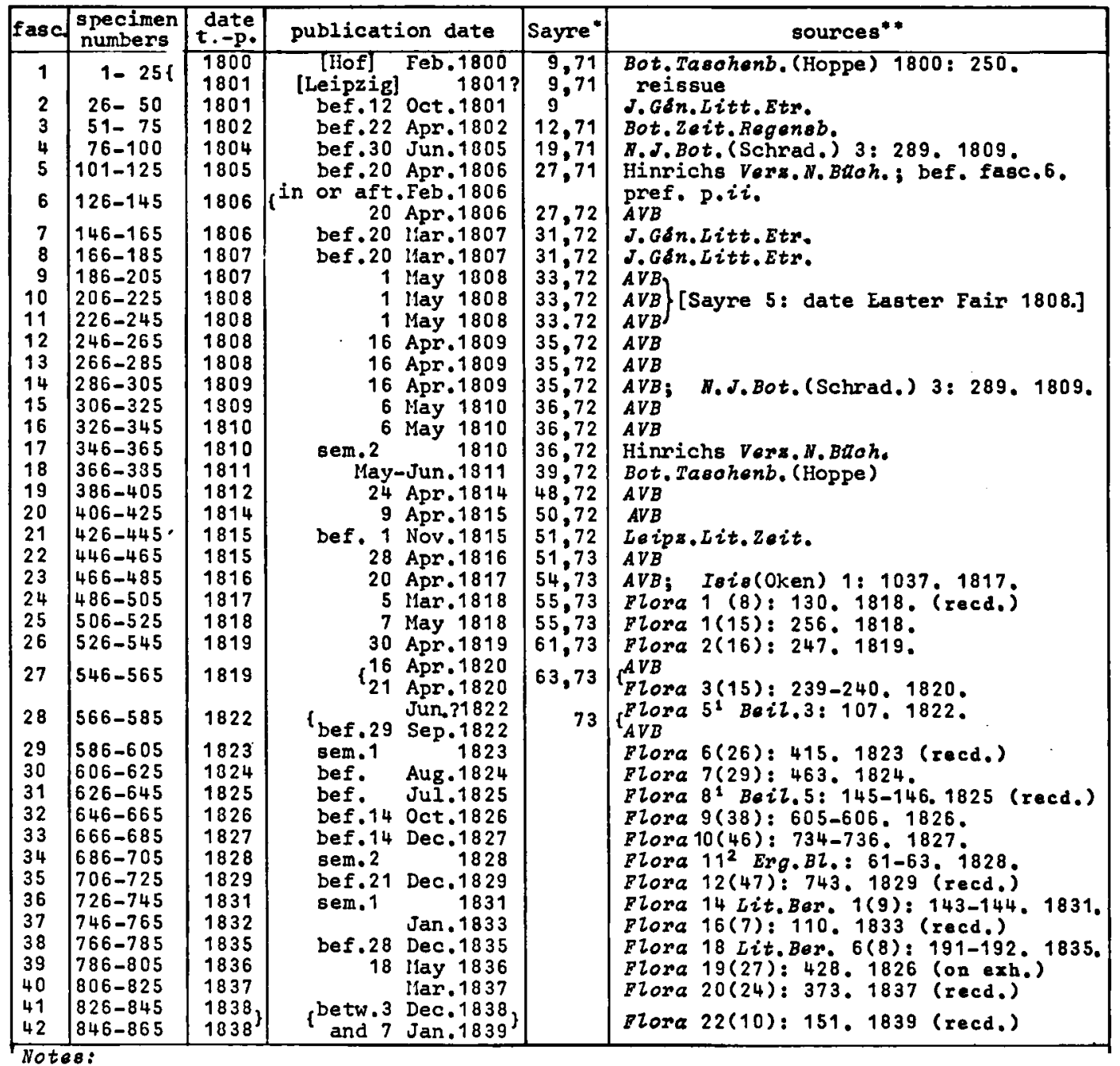

* Sayre, G.: Dates of pubtioations describing Musoi, 1801-1821. 102 p., Troy, N.Y., 1959.

* The sources without page numbers are derived from Dr. Sayre's list.

$A V B=A Z$ Igemeines Verseichniss der Bucher ... in der Frankfurter und Leipziger ... Ostermesee [... Miohaelmesse]. Leipzig.

Hinrichs Verz. H. Bttoh. = Hinrichs, J.C.: Verseiahnise neuer Blloher die vom Januar bie $J_{i} l_{i}$ [or other half year] ... [title varies]. Leipzig, 1798-1844.

N.J.Bot. (Schrad.) = Neues Journal fur die Botanik (Schrader). 
Bot,notes. This important series of exsiccata began as a series of local plants, and was developed to cover a wider area, expressed first in a change in the title of fasc.6, 1806 .

Because of the start about 1801 the moss names published have become of extra importance by the change of the starting-point of the nomenclature of mosses (Sphagnum excepted). Especially the dates of the first fascicles became critical, since the validity and priority of some names depend on it If e.g. fasc.1 was really published in 1801 , as the title implies, the nane Bryum rugosum $(n, 10)$ would compete with the name Lioranum polysetum Swartz for a species widely spread in the Northern hemisphere, often known under the now very confusing name of Diaranum undulatum. The name Bryum rugosum, however, is invalid if we accept the publication date as 1800 . Apart from this problem created later. Funck proposed a number of new species and new combinations.

2 Cryptogamisohe Gewachse des Fichtelgebirg's.

Ed.2. 5 fascicles. Leizpig, 1806 [exsiccata].

Titlee: "Cryptogamische Gewalchse | des | Fichtelgebirg's | gesammelt von Heinrich Christian Funck, | verschiedener naturforschenden Gesellschaften Mitglied. Erstes Heft [Zweytes Heft] [Drittes Heft] [Viertes Heft] [Funftes Heft] | [swelled rule] | Zweyte Ausgabe | [full swelled mule] | Leipzig, 1806.| In Commission bey Iohann Ambrosius Barth."

Collation: $4^{\circ}$ : fasc.1-5: $\pi^{4}\left(-\pi_{4}\right)$; i-ii $12-4$.

Contenta: fasc.1-5: $i$ title; $i$ 听 1-4 text, descriptions and habitat, occasionally localities, of 25 species of cryptogams.

Specimens: 25 specimens on 25 leaves, numbered:

\begin{tabular}{l|l|l} 
fasc.1: $1-25 ;$ & fasc.3: $51-75 ;$ & fasc.5: 101-125. \\
fasc.2: $26-50 ;$ & fasc.4: $76-100 ;$ &
\end{tabular}

Paper: leaf height $189 \mathrm{~mm}$. (NYBG copy, cut); laid, chains horizontal; wm.: "[double-headed eagle, perhaps as top of coat of arms?]": fasc.1-2; "[crowned eagle]": fasc.3-5.

Printer: no imprint.

Publisher: Funck, H.C., the author;

in consignment with: Barth, J.A. (see Bridel n.4).

Dates: 1806 (t.-p.), 20 Apr. (Sayre 72; Alzg.Vers.Buoh.).

Bibliogr.otudies: Sayre, G.: Dates of publ. 72. 1959;

Stafleu, F.A.: Taxonomio literature n.386. 1967.

Refo.: Brun.2: 1424 Linn.Soc. 278.

Notes. A reprint from the first edition, this being exhausted; specimens not checked, not necessarily from the same locality. According to Dr. Sayre some nomenclatural changes were included.

The NYBG copy did not have specimens with the text.

3 Deutsohlands Moose.

Bayreuth, 1820 [including exsiccata]

Titze: "Deutschlands Hoose. | [short rule] | Ein | Taschenherbarium | zum Gebrauch | auf botanischen Excursionen, | herausgegeben | von | Heinrich Christian Funck, | mehzerer naturforschenden Geselischaften Mitglied. | [very long swelled rule? | Baireuth, 1820. | Gedruckt in der ZeitungsDruckerei und | lithographirt bei F. C. Birner."

Collation: $4^{\circ}: \pi^{4} 1-9^{4} ;$ I-III IV-VI VII-VIII 1 2-70 17-72. 
Contento: I title; II quotation, a four-line poem by "Baron von der Lahe."; III-VI preface, unheaded, dated: "1 Juni 1820."; VII half-title; VIII D; 1-70 text, descriptions of genera and species, with synonyms, habitat (occasionally with a locality), and time of capsules; 71 index of generic names with two columns: page- and plate-numbers; 72 ' $\mathrm{D}$.

speoimen part: 60 lithographs, including a ti+le: "[thick-thin rectangie] | Doutsohlands Laub-Hoose. "lines in script." [swelled rule]"; the 59 other leaves with lithographed rectangles for 422 species, and narrow rectangles for the generic names above those of the species concerned; lithographed specific namen in the bottom of the spaces for the species, except on leaf 59 (4 spare spaces for Bypnum species); one rectangle provided for a variety; specimens consisting of a few stems, usually with at least one sporophyte, pasted to the paper in the rectangles concerned; about 10 species not provided (in the specimen part of the copy examined, of Mr. J. Erencken, Hilversum. Netherlands).

Paper: leaf height $195 \mathrm{~mm}$. (NYBG copy, cut); laid, chains horizontal; wm.: "[post-horn in crowned shield]' $W A$ ' I [maid with harp in crowned double "W A J [outline]": 8 ;

text of specimen part: wove; no wm.

Printers: Zeitungs-Druckerei, Bayreuth; Germany (text); Birner, F.C., Bayreuth? (lithographs).

Publisher: Funck, H.C., the author; in consignment with: Barth, J.A. (see Bridel n.4).

Date: 1820 (t.-p.); after 1 Jun. (preface), bef. 21 Dec. (Plora 3(47): 750. 1820: "Moostaschenherbariun" -... "eben erachienen").

Reviews: Allg.Repert. Neuest.In-Aus Z.Lit. 18212(4): 250-251. 1821 (57 Taf.); Plora 5(22): $349-350$. 1822 Jun. 14 (about $360-370$ specimens); Buzz.Gén.Univ.Annonces Nouv.Sci. (Férussac) 4(10): 54-55. 1823; Flora 6(18): 273-281, 6(19): 289-297. 1823 (59 Iith,); Isis (Oken) 13(7): $7 \dot{1} 3.1823$ (about 360 pasted specimens); J.Bot. (Hooker) 1: 158.1834.

Bibliogr.otudy: Sayre, 6.: Dates of publ. 72. 1959.

Refo.: BMNH $631^{\mathrm{b}}$ Brun. 1: 1424 Kew 215 Graesse 2: 647 a

Linn. Soc, 278 Milt. 277

$\begin{array}{ll}\text { Pr.ed.1 } & n .3448 \\ \text { Pr.ed.2 } & n .3157\end{array}$

Pr.ed.2 n.3157
Stafl. TL n.385.

Bibl.notes. The complete copy I studied was preserved in a green case, containing also the specimen part within a similar green oblong cover. Possibly the first copies did not have the specimens as complete as later copies had. since a different number of specimens is stated in different reviews. Flora 5(22): 349-350. 1822 stated that copies would be ready again about the end of June, with about $360-370$ species, including Cinclidium, and that material for supplements was in stock.

Bot.notes. Funck prepared this work as a handy field-guide to have all German mosses together; apparently he was unable to provide the rare species from the beginning. I did not find new names.

4 Moose aus der Umgebung von Bayreuth.

Flora 8(41): 61-62. 1825 Jan. 28 .

colzation eto.: see Flora.

Note. Notes on the moss flora of Bayreuth, 
5 Corresponders.

Flora $8(20): 313-315.1825$ llay 28.

Collation eto.: see Ilora.

Note. Discussion of a few rare mosses and new localities in connection with the preparation of fasc.31 of the Crypt. Gew. Fichtelgebirg's.

\section{Correspondens.}

Flora 10(11): 173-175. 1827 Iar. 21.

Collation itc.: see Ilora.

Note. Contains indications for the preparation of nosses for herbaria.

\section{FÜRNROHR, August Emanuel}

Biogr. Born $1804 \mathrm{Jul.27}$, Regenslurg, Bavaria, Germany. Died 1861 May 6, Regensburg.

Furnrohr received elementary education in Regensburg and also studied pharmacy there. He worked for some time in a pharmacy in München and afterwards in that of the bryologist F. Bruch in Zweibrucken. Finally he studied at the University of Erlangen, 1824-26, where he passed the examination. He stayed in Erlangen until 1833, in which year he received the degree $P h . D$. honoris causa from the University mentioned.

In the same year he became teacher of natural history, chemistry and technology at the newly founded "Kreis-Landwirthschafts- und Gewerbeschule" at Regensburg. In 1834 he became lecturer ("Docent") and in 1839 professor at the Lyceum there. After Hoppe's death, 1846, he became jirector of the botanical society of Regensburg, for which society he had been co-editor of Flora since 1830 and sole editor since 1842 .

Besides the many botenical papers he wrote a handbook of technologieal chemistry, 1842, which went through several editions, and in collaboration with others a Naturhistorischs Topographis von Regensiurg ( 3 vols., 1838-40). He was commemorated in the generic name Fuernrohria C. Koch 1842, an uncertain genus (Umbelliferae).

Refo.: v. Martius: Akad,Denkreden. Sitaungober.Akad, Hunchen 1861(182): 448-450. Flora 44: 289-297. 1861 (with list of publ.). 1861 (birthday as 27 Jun.). Ascherson: Alig.Deutsohe Biogr. 8: 2C8. 1878.

1 Verouch einer nuheren Beleuchtung der Disposition methocique ... Arnott.

$$
\text { Flora } 10^{2} \text { (Beil.1): 22-86. 1827 [1828?]. }
$$

Bead-titie: "Versuch einer naheren Beleuchtung der Dioposi-|tion methodique[sic] des especes de mouses par G. I Aalker-Arnott, $\because .$, Membre des soniétés royale et Wennerienne d'Edimbourg etc. Paris. | 1825 (4. 72 Seiten)."

Collation: $8^{\circ}: 2{ }_{3} \mathrm{v}-6 \dot{3}^{\circ}$; 22-86.

Contents: 22 head-title; $22-36$ critical review of Arnott's Disposition ...

Date: Probably Jan.1828: p.108 of Beil.1 has date 28 Dec. 1827.

Bot.notes. Very thorough and critical review of the article of Arnott (see Arnott $\mathrm{n.5}$ ), with many indefendent judgments on the value and delimitations of genera and species of rosses, differring from the opinions of Arnott. The review includes the description of a new genus Brachydontium (p.37) for Heissia triohodes, corrected to Brachyocon, probably in the same fascicle, p.112. (If this Beilage was really issued as one fascicle, the name Brachydontium is invalid, not being accepted by the author at the time of publication,) 
GAUDICHAUD-Beaupre, Charles

Biogr. Born 1789 Sep. 4, Angoulêne (now dép. Charente), Erance.

Died 1954 Jan. 16, Paris, Frarice.

Gaudichaud lost his parents in 1798, was then raised by his maternal grandfather. He became interested in natural history, especially insects, birds, and taxidermy, through a neighbor, Kérillon. Then he was 12 , his grandfather died and an uncle took care of him. ffter elementary studies at Angoulème he went to a brother-inlew at Cognac to study pharmacy. Two years later he was called back to Angoulême by ilr. Chauvin-Desroches, pharmecist, who taught him, besides pharmacy, botany and the meticulous preparation of good herbarium specimens.

After military service, Gaudichaud went to Paris in 1808 to finish his studies under able pharmacists such as J.P. Robiquet $(1780-i 840)$, who advised him to follow a scientific career. He studied at the College de Frasce, the École de Phamacie, the :luséum d'Histoire Naturelle, and the École de Hédecine. He studied botany especially under L.C. Richard $(1754-1821)$, and took part in the famous "herborisations" of A.L. de Jussieu (1748-1836).

He was also interested in arms anc in exploration, and through friends he was able to receive an appointment as "phamacien auxiliaire" with the French navy at Brest, 2 Apr. 1810. However, it was soon ruled that for this rank an examination was necessary, so he went back to Paris in September for further study. In Jul. 1811 service brought him to Antwerp where he took part in a "concours" for "pharna- : cien troisiène classe" which he obtained $15 \mathrm{Jul}$. 1813. In 1814 he was posted at Rochefort.

After the restoration the royal government planned large expeditions in the interest of science, and Gaudichaud was chosen as phamacist-botanist of the voyage around the world on the corvette "L'Uranie". The preparations, in Toulon, took nearly a year, and as part of these Gaudichaud studied the natural history of Provence.

L'Uranie sailed $17 \mathrm{Sep}$. 1817, visited Ténériffe, Rio de Janeiro, Cape of Good Hope, Réunion and Mauritius, West Australia, Timor, isiands near liew Guinea, the Harianas and Sandwich Islands, and I.E. Australia, where a group traversed the Blue Mountains. The Pacific Ocean was crossed and the Cape Horn region was visited, but a long stay was impossible. Finally the ship hit unknown rocks in the falkland Islands on $14 \mathrm{Feb} .1820$ and was lost 12 hours later on the beach. Part of the collections (herbarium specimens) was lost, and the remaining part was completely soaked in salt water. This was carefully treated in fresh water and dried again by Gaudichaud during the four ronths of camping at that place, where he also studied the local botany. The voyage was continued on the ship "La Physicienne", bought for this purpose, via Kontevideo, Rio de Janeiro, and back to France, Dec. 1820. Gaudichaud was charged to work out and publish the botanical results of the expedition. On 22 Dec.1828 he was elected "correspondant" of the "Acadénie".

3 Dec. 1830 he obtained authorisation for participating in a voyage to South America on the frigate "L'Herminie", which sailed 10 Feb. 1831. In Brasil Rio de Janeiro was visited, j.n Chile Valparaiso and Coquimho, and in Peru Lima. The ship sailed back. round Cape Horn; Rio de Janeiro was visited again, and the island S.Catherine. When the frigate was ordered back to France in 1832, Gaudichaud remained in Brasil to continue his botanical work (including anatomy), and finally he returned to France on "La Bonite", embarking 21 Jun. 1833.

The same year, 23 Dec., he was nominated professor of phamacy at Paris. He prepared a treatise on organography and physiology of plants and submitted this to the Académie to compete for a prize on experimental physiology founded by Monthyon. He shared it with another, 20 Dec. 1835.

On the same day he left Paris for Toulon, to sail with "La Bonite" around the worlc, this time to bring consular service men to different parts of the world. Sailing $6 \mathrm{Feb}$. 1836, the ship stayed not too long at the different ports: Rio de Janeiro, Nontevideo, Valparaiso, Cobija, Lima and Payta, Puna and Guyaquil (Ecuador) Owyhée and Orahau, Philippines, Macao, Canton, Tourane, Singapore, Penang and líalacca, Calcutta, Pondichéry, Mauritius, Réunion, and finally St.Helena.

In the meantime he was nominated "lembre titulaire" of the Académie, $16 \mathrm{Jan}$. 1937, in the place of A.L. de Jussieu. The rest of his life he used mainly in preparing the results of his travels for pubilcation, and in anatonical bhvsiological studies. He was commenorated in the generic name Gaudiohaudia Humboldt. Bonpland et. Kunth 1821 (Malpighiaceae). 
Ref: Pascallet, E.: llotice biographique our id. Gcudiohaud-Beaupre, membre de l'Inetitut. Ed.2. 31 p. Paris, 1844. (Extr. de la Revue gérérale tiographique, politique tittiraire, livr. d'Avril 1844).

1 Voyage autour du monde... our les oorvettes... L'Uranie et la Physioienne... Botanique.

1 vol. text $4^{\circ}, 1$ vol. plates $2^{\circ}$. Paris, $1826[-1830]$.

Titze (text-volume): "VOYAGE I AUTOUR DU HONDE, I Entrepris par Ordre du Roi, [line in gothic] | SOUS LE IIINISTERE, ET CONFORHEIENT AUX INSTRUCTIONS DE S. EXC $M$. LE VICOHTE DU BOUCHAGE, I SECRETTAIRE D'ETAT AU DÉPARTEIENT DE LA ILARINE, Excoute our leo corvettes de S. H. I'Uranie et le Physicienne, l penarit les annese 1817, 1818, 7819 et 1820 [these two lines in flowing script except "l'Uranie" and "la Physicienne" which are in erect script, the "U" resembling an "O"I | Publie sous les Auspices line in gothicj| DE S. E. M. LE COMTE CORBIERE, SECRÉTAIRE D'ÉTAT DE L'INTERIEUR, I Pour la partie Hietorique et les sciences aturelles, [line in erect script] ET DE S. E. M. LE COMTE CHABROL DE CROUZOL, SECRÉTAIRE D'ÉTAT DE LA MARINE ET DES COLONIES, POUT la pertie Wautique; [Iine in erect script] | PAR 11. LOUIS DE FREYCINET, | Capitaine de vaisseau. Chevalier de Saint-Louis et officier de la Légión d'honneur. Membre de i l'Académie royale des sciences de l'Institut de France, qc; Commandant de l'expédition. I swelled rule] | Botanique [in gothic I PAR $M$. CHARLES GAUDICHAUD, PHARMACIEN DE LA MARINE.| [swelled rule] [ two sides of medal, each indicated by three concentric circles and connected by two thick-thin lines; in left circles head of Louis XVIII and border inscription, top: "LOUIS XVIII ROI DE FRANCE ET DE NAVARRE." bottom: "GALLE F.": at right circles border inscription, top: "IIEMISPHERE AUSTRAL.", bottom: "PHYSIQUE ASTRONOIIE.", and straight I ines: "LA CORVETTE L'URANIE. |" IRLSDE FREYCINET COMNAND? | [very short swelled rule] | S.A.R.MeI LE DUC D'ANGOULEME | AMIRAL DE FRANCE. | [very short swelled rule] I MRLE VTE DU BOUCHAGE | MINISTRE DE LA MARINE. | [very short swelled rule] | 1817."] PARIS, CHEZ PILLET AfNÉ, IMPRIMEUR-LIBRAIRE, RUE DES GRANDS-AUGUSTINS, N.07: I [short rule] 1826."

Engraved title of atlas (plate-volume): "VOYAGE | AUTOUR DU MONDE | Fait par ordre du Roi, Iline in fancy gothic] our les oorvettes de $S_{n} M_{n} 1$ iuranie et la Physicionne. [script except names of ships] | pendant les années 1817, 1818, 1819 et 1820 . | [long swelled rule] | HISTOIRE NATURELLE: BOTANIQUE. | PLANCBES | Desinces et graves par A. Poiret, fils. | [short swelled rule] PARIS, I CHEZ PILLET, AINE, IMPRIMEUR-LIBRAIRE, RUE DES GRANDS AUGUSTINS No 7. 1826. [all lines in capitals are in fancy letters, except the last one; the year in fancy numerals.]" Plate-mark: $324 \times 239 \mathrm{~mm}$.

Collation: text vol.: $4^{\circ}: \pi^{4} 1-65^{4} 66^{2}\left(-66_{1}\right)$ (\$2 signed $\left.\$ *\right)$; $i-v$ vi-vii viii $12-522$ ( 515,286 as $\left.1826^{\prime}\right)$;

plate-vol.: $2^{\circ}: \pi^{2}$ (engraved title) $1-6^{2} ;$ i-ii $12-2283-84$.

Contents: text-vol.: i half-title; ii imprint; iii title; iv list of the six divisions of the complete "Voyage..."; v-vii preface, dated Mai 1826; viii ${ }^{\prime}$; 1-514 text, divided into two "libres": 1-146: general observations on the nature and the plants of each locality visited during the expedition, 147-514 classification of the herbarium (list of plants preserved); 575 contents; 516-522 index of names of genera and higher taxa. RT: book title, and in index: "TABLE DES MATIERES," Language: French, with Latin descriptions of new species and indications of habitat; plate-vol.: i engraved title; ii D; 1-22 explanation of the plates, with references to text-pages; 23-24 D. RT: chapter headings. Language: French.

Plates: 120 copper-engravings of plants, usually with details, numbered 1-120; plate-mark: $331 \times 236 \mathrm{~mm}$. (pl.1).

Artist and engraver: Poiret (fils), A., Paris, son of the well-known naturalist and botanist Jean Louis Marie Poiret (1755-1834): alj. plates (t,-p. pl.-vol.). 
Paper: text-vol.: leaf height $298 \mathrm{~mm}$. (HBL copy, cut); laid, chains horizontal; wm.: "-grapes] $=\mathrm{J} \mathrm{H}$ i in script monogram]" [or without grapes]: $\pi$ 1-15 $27-33$ 36-37; "J $\mathrm{H}$ [erect script at middle of lower sheet border]": 16-27 34-35 38-58; "8 (perpendicular to chainzine near middle of short sheet sidej": 59 61-64; none seen: 606566 (apparently of the same provenance as the foregoing); (Bibliogr. Prance gives 2 other paper states: wove paper and "papier de Chine"); plate-vol.: table of contents: leaf height $483 \mathrm{~mm}$. (HBL copy, cut); laid; no $\mathrm{km}$; engraved title and plates: wove; no wm.

Printer: Imprimerie royale, Paris.

Publisher: Pillet alné, Paris.

Collaboratore: Néraud, Jules $(1794$ Oct. 10, "19 Vendém. an IV", La Châtre, dép. Indre, France-early spring or late winter 1855, La Chatre), botanist and horticulturist who for a number of years stayed at Mauritius (Ile de France); contributed: Nouveaux renseignemente our la végetation opontané de l'Ile-de-Franoe, $\mathrm{p}, 21-30$, a list of genera in natural families of plants of Mauritius, including a number of new genera, mostly unnamed; the new names, however, were not accompanied with a description and are, therefore, invalid (see the example Egeria Neraud in the ICBN, art.32);

Dumont d'Urville, Jules Sébastien César (1790-1842): lists of plant names (Phanerogamia) from the Falkland Islands, 36 species and 1 variety with Latin descriptions in footnotes, P.121-128;

Bory de Saint-Vincent, Jean Baptiste George Maria (1780-1846): list of plant names (Cryptogamia) from the same region, with Latin descriptions for 18 species;

Schwaegrichen, Christian Friedrich (which see): supplied Latin descriptions of new species of Hepaticae, p.217-218, and of Musci, p.223-230;

Arnott, George Arnott Walker (which see): reviewed the Musci, determined by Schwaegrichen, but he did not add valid new species; the names given by him in Dieposition msthodique des mousses... (1825) were cited by Gaudichaud in the synonymy;

Gay, Jacques Etienne (1786-1864), French botanist (born in Switzerland): description of species Eryeimum maoloiranum, p.136, from the Falkland Islands.

Dates and announoemente:

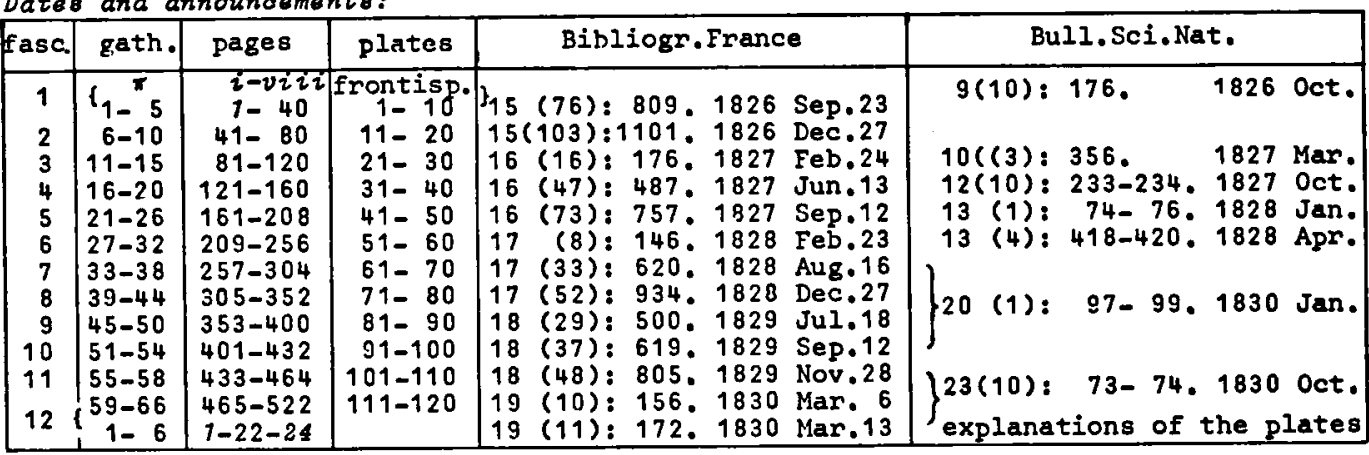

Reviewe: see BulZ,Soi. Nat. in table; mostly by R[aspail]; $I_{8 i}$ (Oken) $25(4): 362-382,1832$.

Bibliogr. atudies:

Sherborn, C.D. Woodward, B.B.: Ann,Mag.Nat.Biet, ser.8, 7: 392. 1901 (dates), and J.Bot. 39: 206. 1901. (fasc.11 erroneously as from 28 Sep.) : van Steenis-Kruseman, M.J.: Fl.Males. ser.1 vol.4(5): CLXXXIII. 1954; Stafleu, F.A.: Taxonomia iiterature n.396. 1967. 
Refo.: Arn.Arb.1: 271

337560,644

Bradl. 1: $302^{\mathrm{b}}$

Brun.2: 1392
Cat .Juss . n.1418

Graesse 3: 35

Jacks. 223

Kew 220, 723
Linn.Soc. 274

ilass. IIS-Ii 111

ilas $8,45-i l$ 1: $690 \mathrm{~b}$

2: $108 \mathrm{~b}$ liiss. n,c89

Pr.ed.1 n.3527

Pr.ed.2 n. 3234

Teyl. 585 .

Bibl.notes. The puslication in parts is fully borne out by the contemporaneous announcements. Fasc.5 and $G$ were reported to have 10 plates each in the announ. cenent in Buzl.Soi.Wat. (Férussac); I take it for cranted that all fascicles contained 10 plates. The fascicles must have been published before tie dates of t're Bibliogr. France, mentioned above. Undoubtediy t'in fascicles were issued in rappers, bearing at least the year of publication, as is evident from the announcements, but I have not seen any. The breaks between the text fascicles are in some cases confirmed by chanres in the waternark. For a remark on the date $0=1.85$ see F.A. Stafleu: Paxonomia literature n.39E. 1967.

Bot.notes. Gaudichaud sent plants of several oroups to specialists, as mentioned under Collaborators, or they studiec the herbarium specimens in Paris (as was the case with Arnott durinp his stav there). Statements elsewhere that Agarius worked uD the $A l_{g a b}$ and Persoon the Fungi, are not confirmed in the actual text; Gaudichaud simply said to follow their arrangements of the eroups in question. Of course it is quite possible that these botanists were consulted during the course of the work, but Gaudichaud certainly took the responsibility of describing the new species himself. Some new genera in phanerogams were published by him before this work. in: Ann.Soi.Wat. 3: 507-510. 1824 Dec. The text apparently was not finished, as the plates contain drawings of plants of a number of families which were not represented in the text (primarily dicotyledons). Most likely this was caused by Gaudichaud's appointment for the next voyage. The names on the plates published before the description, or for which no description followed, nevertheless are valid in nomenclature when they give analytical details.

GREVILLE, Robert Kaye

Biogr. Born 1794 Dec, 13, Bishop Auckland, Durham, Great-Britain. Died 1866 Jun. 4, Murrayfield near Edinburgh, Scotland.

Greville was early interested in plants and had carefully drawn nearly 200 British plants by the age of 18 . He was intended for the medical profession and studied four years in London and Edinburgh. Having become of independent means, he did not proceed to a degree.

In 1816 he married the daughter of Sir John Eden, of Windlestone, Durham, and settled in Edinburgh to study anatomy under Dr. Barclay. In 1819 he joined the Wernerian Natural History Society and from time to time he lectured and contributed articles for its journal. He made frequent botanical excursions to the Highlands with W.J. Hooker, Robert Graham and other botanists.

Later he published, besides the Soottioh aryptogamio fiora (which see), with W.J. Hooker: Ioones Filiaum [1827-1832]. He gave popular lectures on botany in Edinburgh, and once he hoped to be appointed to the Glasgow chair of botany. Apart from his botanical interest he was an active opponent of slavery and an advocate of temperance, publishing tracts against drunkenness. He compiled also, with Rev. T.K. Drummond, a Hymn-book (1838). He was elected Member of Parliament for Edinburgh in 1856. In his later years his private means had diminished and he executed many drawings and paintings of the Scottish Highlands for sale. He was survived by a son and three daughters.

The herbarium he amassed was especially rich in lower Fungi; he also collected other natural history objects, of which the molluscs were said. to be noteworthy. His herbarium of phanerogams came to the University of Glasgow, and was recently transferred to Edinburgh. Apparently his cryptogams are kept there too. He was commemorated in the generic names Greviliea R. Brown 1809, nom. cons. (Proteaoeae) and Kayea Wallich 1831 (Cluoiaceae).

Refo.: Balfour, J.H.: Trans.Bot.Soc.Edinb. 8: 464-476. 1866 . Boulger, G.S.: Diat.Nat L.Biogr. 23: 164-166. 1890. 
1 An account of some of the oryptogamous plants of Devonshire.

Mem. Wernerian Nat. Hist. Soc, 3: 351-370, pls. 15-16. 1821.

Head-title: "XXIV.-An aocount of oome of the Crypto-loamous Planto of Devonshire, | By RoberT KAYE GREVILLE, Esq. M. W. S. | (Read 5th Auguot 1820.)"

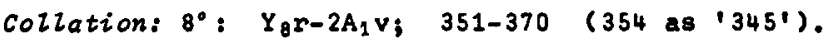

Contents: 351 head-title; 351-355 introduction, including 7 interesting phanerogamous species from the region; 355-362 list of Latin names, with localities. of Musci (355-359), Musci Eepatioi (359), Filioes (359), Fuoi (360-362). Ulvae (362); 362-370 "NOTES AND OBSERVATIONS.", discussions on a few species including the description of a variety Gymnostomum trunoatulum var. ramosum (see Bot.notes).

Plates: 2 color-printed copper-engravings of red algae, numbered: "Plate $X V . "$ and "Plate XVI."; plate-mark cut off (HBL copy).

Artiot: Greville, R.K., the author.

Engraver: Mitchell, E.: 2 pls.

Date: 1821 (t.-p. vol.), May (see Mem, Wernerian Nat. Hiot. Soa.).

Bot.notes. List of cryptogams of Devonshire, Fungi excepted, observed during a three months stay, completed with observations from others, esp. from Mrs. Griffiths, algologist. The variety Gymnootomum trunoatulum var. ramosum was named "for distinction's sake"; since Greville meant a growth-form only, it should be ranked as a modification, in modern 8 tandards.

2 Desoription of a new speoies of Potentilia, from the West coast of Greenland; with some acoount of the Arotio flora.

Mem. Wernerian Nat. Hist. Soc, 3: 416-436. pl.20. 1821.

Head-title: "XXIX.-Desoription of a llew species of Poten-ltilla, from the West Coast of Greenland; with I come Acoount of the Arotio Blora. I By ROBERT KAYE GREVILlE, Esq. M.W. S. | (Read 18th November 1820.)"

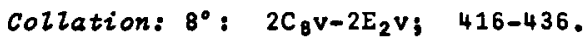

Contents: 416 head-title; 416-417 introduction; 417-419 description and discussion of a new species, Potentilza jamesoniana; 419-436 discussion of arctic plants, mainly lists of plants determined by Robert Brown, from collections of William Jameson and Captain Scoresby, to which Greville added other localities from literature, to illustrate the geographical distribution.

Plate: 1 copper-engraving, of Potantilla Jamesoniana, "Pl.XX."; plate-mark: $198 \times 113 \mathrm{~mm}$.

Artist: Greville, R.K., the author.

Engraver: Mitchell, E.

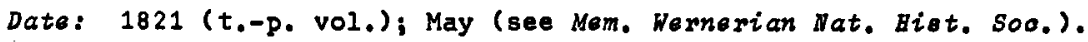

Bot.notes. Mosses are mentioned (det. Robert Brown): p.425 from Spitzbergen, coll. by Scoresby, P.432 from the West coast of Greenland, coll. by W. Jameson, and $p .436$ from Baffin's Bay region, coll. by Captain Ross. 
3 On the leaves, oapoule and root of Buxbaumia aphylla.

Mem. Wernerian Nat. Hist. Soc, 3: 442-449. pl.21. 1821.

Bead-title: "XXXI. On the Leaves, Capoule and Root of I Buxbaumia aphyzza. I By ROBERT KAYE GREVILLE, Esq. M. W. S. \&c. | (Read 2d December 1820.)"

Collation: $8^{\circ}: 2 E_{5 V}-2 F_{15} ; 442-449$

Contente: 442 head-title; $442-448$ text; 449 explanation of pl.21.

Plate: 1 copper-engraving of Buxbaumia aphylza with details, some parts magnified, numbereds "PLATE XXI", name at the top, details 1-11; plate mark cut off ( $\mathrm{HBL}$ copy).

Artiet: Greville, R.K. the author.

Engraver: Lizars, William Home (1788-1859); biogr.: Bryan, Biogr.Diot.Paint. Engr. [ed.3]: 236. 1910; Bénézit 5: 604. 1956.

Date: 1821 (t.-p. vol.); May (see Nom. Wernerian Wat. Bist. Soo.)

Bot.notes. Detailed description of Buxbaumia aphy 2 a, confinming the presence of microscopical leaves, discovered by J. Stewart (died 1820 Nov. 3 ); describing moreover a second kind of leaves, which now would be considered modified rhizoids. The "rooting" of the sporophyte is also described and figured.

4 A description of a new speoies of Grimmia, found in sootland.

Mem. Wernerian Nat. Hist. Soc. 4(1): 87-90. pl.6. 1822,

Bead-titila: "VII. A Desoription of a llew speoies of Grim-lmia, found in sootland. I By ROBERT KAYE GREVILlE, Esq. F. R. S. E. I M. W. S. \&C. I (Read 12th January 1822.) | [very short thick-thin rule]".

Collation: $8^{\circ}: \mathrm{F}_{4} \mathrm{r}-\mathrm{F}_{5} \mathrm{~V} ; 87-90$.

Contents: 87 head-title; 87-90 text, description of Grimmia Zeucophasa, with discussion; 90 explanation of pl.6.

Plate: 1 copper-engraving of Grimmia leuoophaea with details, "PLATE VI.", binomial at bottom. Plate-mark cut off (HBL copy).

Artiot: Greville, R.K., the author.

Engraver: Lizars, William Home (see Greville n.3).

Date: 1822 (t.-p. fasc.), after 18 May, bef. or in Aug. (see Nem. Wernerian - Nat. Hist. Soo.).

Bot.note. One new moss species, Grimmia Louoophaea, described, illustrated and discussed, from Kings Park, Edinburgh. 
5 Soottigh Cryptogamio Flora.

6 vols. [72 fasc.] Edinburgh, [1822-]1828.

Title: "SCOTTISH | CRYPTOGAMIC FLORA, | OR | COLOURED FIGURES AND DESCRIPTIONS OF CRYPTOGAMIC | PLANTS, BELONGING CHIEFLY TO THE ORDER RURGI; | AND | INTENDED TO SERVE AS A CONTINUATION | OF | ENGLISH BOTANY. | BY | ROBERT KAYE GREVILLE, F.R.S. \& F.A.S.E. T2-4: ROBERT K. GREVILLE, LL.D. F.R.S. * F.A.S.E.] [5-6: ROBERT KAYE GREVILLE, | LL.D. F.L.S. F.A.S.E.j | tapering set of five lines:] CORRESPONDING MEMBER OF THE NATURAL HISTORY SOCIETY OF PARIS; I MEMBER OF THE IMPERIAL ACADEMY NATURAE CURIOSORUM; OF | THE WEPNERIAN NATURAL HISTORY SOCIETY; HONORARY | MEMBER OF THE YORKSHIRE PHILOSOPHICAL SOCIETY, I do. bo. linstead of this tapering set in the other volumes sets of one long line and the remaining lines indented:] [2: MEMBER OF THE WERNERIAN NATURAL HISTORY SOCIETY OF EDINBURGH; OF THE | IMPER IAL ACADEMY NATURAE CURIOSORUM; OF THE NATURAL HISTORY SO-| CIETY OF LEIPSIC; CORRESPONDING MEMBER OF THE NATURAL HISTORY SO-|CIETY OF PARIS; OF THE ACADEMY OF NATURAL SCIENCES OF PHILADELPHIA; I HONORARY MEMBER OF THE LYCEUM OF NATURAL HISTORY AT NEW YORK; I OF THE YORKSHIRE PHILOSOPHICAL SOCIETY; AND OF THE LIVERPOOL INSTI-|TUTION, $80 . \overline{]}$ [3: MEMBER OF THE WERNERIAN NATURAL HISTORY SOCIETY OF EDINBURGH; OF THE I IMPERIAL ACADEMY NATURAE CURIOSORUM; OF THE NATURAL HISTORY SO-|CIETY OF LEIPSIC; OF THE PHYSIOGRAPHICAL SOCIETY OF LUND; CORRES-|PONDING MEMBER OF THE NATURAL HISTORY SOCIETY OF PARIS; OF THE | ACADEMY OF NATURAL SCIENCES OF PHILADELPHIA; HONORARY MEMBER OF | THE LYCEUM OF NATURAL HISTORY AT NEW YORK; OF THE YORKSHIRE PHI- | LOSOPHICAL SOCIETY; AND OF THE LIVERPOOL INSTITUTION, \&O.] [4-5: HONORARY MEMBER OF THE ROYAL IRISH ACADEMY; OF THE LYCEUM OF NATURAL HISTORY AT NEW YORK; OF THE YORKSHIRE PHILOSOPHICAL SOCIETY; AND | OF THE LIVERPOOL INSTITUTION; MEMBER OF THE WERNERIAN NATURAL | HISTORY SOCIETY OF EDINBURGH; OF THE IMPERIAL ACADEMY NATURAE CU-|RIOSORUM; OF THE NATURAL HISTORY SOCIETY OF LEIPSIC; OF THE PHY - | SIOGRAPHICAL SOCIETY OF LUND; CORRESPONDING MEMBER OF THE NATURAL । HISTORY SOCIETY OF PARIS; OF THE ACADEMY OF NATURAL SCIENCES OF PHI-| LADELPHIA, 8a. 3 [6: HONORARY MEMBER OF THE ROYAL IRISH ACADEMY; OF THE CAMBBR IDGE [sic] AND | YORKSHIRE PHILOSOPHICAL SOCIETIES ; OF THE LYCEUM OF NATURAL HISTORY । AT NEW YORK; OF THE NATURAL HISTORY SOCIETY OF MONTREAL; AND OF THE LIVERPOOL INSTITUTION; MEMBER OF THE WERNERIAN NATURAL HISTORY SO-|CIETY OF EDINBURGH; OF THE IMPER IAL ACADEMY NATURAE CURIOSORUM; OF | THE NATURAL HISTORY SOCIETY OF LEIPSIC; OF THE PHYSIOGRAPHICAL SOCIETY | OF LUND; CORRESPONDING MEMBER OF THE NATURAL HISTORY SOCIETY OF | PARIS; OF THE ACADEMY OF NATURAL SCIENCES OF PHILADELPHIA; OF THE | MEDICO-BOTANICAL SOCIETY OF LONDON, \&o. \&o.] [end of sets] |' [very long rule] | Cui bono haec omnia?-Ut cognoscamus sapientiam CREATORIS, quae in 1 minimis non minus elucet, quan in magnis plantis.-DILL. [very long rule] [rules and quotation absent in vol,4-5] | VOL. I. [2: VOL. II.] [3: VOL. III.] [4: VOL. IV.] [5: [short rule] i VOL. V. | [short rule]] [6: VOL. VI.] | EDINBURGH:| PRINTED FOR MACLACHLAN \& STEWART, EDINBURGH; t5-6: MACLACHLAN \& STEWART, EDINBURGH; I

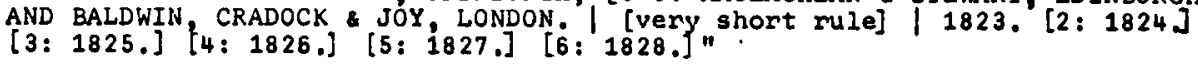

Collation: $8^{\circ}$ in 4s: vol.1: $\pi^{4} 2 \pi^{4} \quad \lambda 1-60$ ( $\lambda$-leaves signed: $1:$ 'A' 5:'C' $6:$ 'C' 8: 'A' 10:'D' 11:'E' 15:'F' 16:'F' 17:'F' 21:'I' 25:' $\mathrm{K}$ ' 26:' $M$ ' 30:' $M$ '

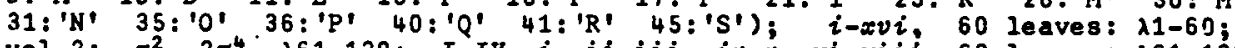
vol.2: $\pi^{2} 2 \pi^{4} \lambda 61-120 ;$ I-IV $i$ ii-iii $i v-v$ vi-viii, 60 leaves: $\lambda 61-120 ;$

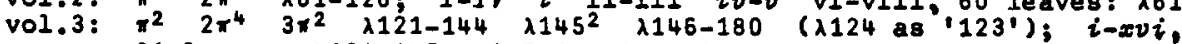
61 leaves: $\lambda 121-145 \quad \lambda 145+1 \quad \lambda 146-180$

vol.4: $\pi^{2} \lambda 181-212 \lambda(213 / 214)^{2} \lambda 215-230 \quad \lambda 231^{4} * t^{4}\left(-t_{2}\right) \quad \lambda 232-239$ $\lambda 240^{4}{ }^{4} ; i-i v, 50$ leaves: $\lambda 181-212 \quad \lambda 213 / 214 \quad \lambda 213 / 214+1$

vol.5: $\quad \lambda 215-230,7(=\lambda 231) \quad 2-1778, \quad 9$ leaves: $\lambda 232-240, I-\lambda I V ;$

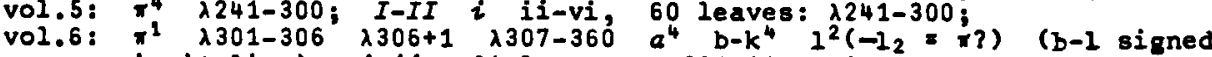
in italics); $i-i i, 61$ leaves: $\lambda 301-306{ }^{2} \lambda 306+1 \lambda 307-360$, $12-82$ ( 51 53, 65 as 175 !).

Note. For conjugacy of $i$-leaves see table under Dates. 


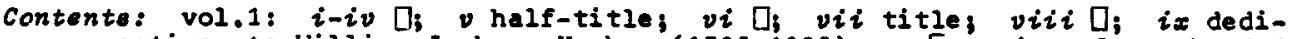
cation to William Jackson Hooker (1785-1865); $x$ [i si preface, headed: "ADVERTISEMENT.", dated: "May 1823." sii G; xiii-ziv systematic index of Latin binomials of plante figured, in natural orders; $v v$ alphabetical index of same, both lists with the new name clavaria oetifolius Grev. for the plant figured as Clavaria triohopus Grev. non Pers,; xvi alphabetical list or tnglisn plant names of plants figured; $\lambda 1-60$ text, explanations of plates, existing of: Latin binomial. English name, indication of class and order, generic character in Latin and in English, specific character in both languages, synonyms and earlier citations especially of British literature, habitat and frequency, or, for rare species, localities and collectors, elaborate description in English, discussion, explanation of details, and, only on left side of recto bottom, plate number as single identifier of text (verso $0: \lambda 5,11,29,31,32,40,49$ );

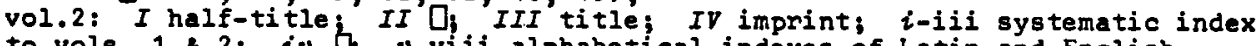
to vols. 1 2; iv $\neg$;-viii alphabetical indexes of Latin and English names; $\lambda 61-120$ text, descriptions as in vol.1 (verso $\square$ : $\lambda 63$ ); vol.3: i half-title; ii D; iii title; iv imprint; v-xii alphabetical index of Latin binomials in vols.1-3, with occasional new information added between parentheses; xiii-xvi systematic index to vols.1-3, with footnotes to additional information in the alphabetical index; $\lambda 121-180$ text, descriptions as in vol.1 (verso $\square$ : $\lambda 131$ ); vol.4: i half-title; ii D; iii title; iv imprint; $1181-240$ text, descriptions as in vol.1 (verso $\square$ : $\lambda 185,190)$; I-X alphabetical index to Latin binomials in vols.1-4; XI-XIV systematic index to vols.1-4; vol.5: I title; II imprint; $i-i v$ alphabetical list to binomials of plants figured in vol.5; v-vi systematic index of same; $\lambda 241-300$ text, descriptions as in vol.1 (verso ㄱ: $\lambda 246,275$ ); vol.6: $i$ title; ii imprint; $\lambda 301-360$ text, déscriptions as in vol.1 (verso $\square: \lambda 301,315,318,321$ ), $1-50$ synopsis of names with short descriptions of genera and species and some varieties in natural orders, all in Latin, of all plants figured; $51-52$ systematic index of the binomials of plants figured in vol.6; 53-82 general alphabetical index to the whole work, including page numbers of the synopsis, excluding names (even of an occasional new genus) mentioned in the text, and not referring to plants figured. RT only in indexes and synopsis. Language: English, with descriptions of characters (phrases) in Latin, as well as the Syropsis. Fascicle-titles: see Bibl.notes.

Plates: 360 copper-engravings, uncolored, or (more expensive 8 tate) hand-colored with a few plates, especially of red algae, printed in one color and other colors added by hand; numbered in lower left corner: "1"- "360": picturing species and rarely varieties of cryptogams, especially Bungi, with microscopical details; details again numbered with arabic numerals, except when two species are figured on the same plate, only of the same genus, in which case the two species are indicated by arabic numerals and the details by italic letters; no names on the plates; plate-marks much varying according to the size of the drawing: pl.2: $183 \times 127 \mathrm{~mm}$. , pl.270: $232 \times 146(+x) \mathrm{mm}$. pl.325: $79 \times 70 \mathrm{~mm}$; some plates placed oblong, the top towards the outer edge: pl.336: $223 \times 136 \mathrm{~mm}$.

Artiet: Greville, Robert Kaye, the author; pl.171 signed: "R. K. Greville omnea delint"; certainly all plates.

Engraver: Miller, William (1796-1882); pl.171 signed: "W. Miller omnes sculpst"; presumably all the later plates too.

Paper: leaf height $239 \mathrm{~mm}$. (copy Dublin, Trinity College Library); wove; wm.: "A.C | 1821 [outline, over 2 leaves]": vol.1 occasionally, vol.2 more frequent, vol.3 in leaves up to the pair $\lambda 143.142$;

"1823 [outline, over 2 leaves:": vol.3 in $\lambda 154.151$ to $\lambda 182$, occasionally; "1822 [outline, in one leaf]": vol.3 $\pi-3 \pi$, possibly in some high numbered leaves too; vol.4 occasionally; vol.5 very few leaves with this mark; no wm. in vol.6; (these marks in the Dublin copy; highest leaf number first indicates the direction of the mark); no wm. at all in HBL copy; 
plate paper: wove; wm. (copy Dublin, Trinity College Library):

"A C | 1821 [outline, over 2 plates]": vol.1 in 6 plates, vol.2 in 9 plates; fragments: "1 irather long cipher, outline]": vol.1, pl.60; not determined: vol.2, pI.79;

no wm. at all in HBL copy.

Printer: Neill, Patrick (1776-1851), Edinburgh; later partner of the firm Neill Co (printers and type-founders); naturalist, secretary of the Wernerian Natural History Society, and member of many other societies; author of travelogues. zoological and horticultural papers; Greville mentionad him number of times in this work as a collector of interesting plants; he was commemorated in the generic name Weillia D. Don 1825 (Rosaceae). Biogr.: J [ackson], B.D,: Diot.datz.Biogr. 40: 178-179. 1894.

Publishere: llaclachlan \& Stewart, Edinburgh; Baldwin, Cradock \& Joy, London.

Dates of fascicles with their plates and gatherings of text leaves:

\begin{tabular}{|c|c|c|c|c|c|c|c|c|c|}
\hline vol & fasc. & plates & gath. & fasc.date & vol & fasc. & plates & gath. & fasc.date \\
\hline 1 & $\begin{array}{r}1 \\
2 \\
3 \\
4 \\
5 \\
6 \\
7 \\
8 \\
9 \\
10 \\
11 \\
12 \\
\pi\end{array}$ & $\begin{array}{l}1-5 \\
6-10 \\
11-15 \\
16-20 \\
21-25 \\
26-30 \\
31-35 \\
36-40 \\
41-45 \\
46-50 \\
51-55 \\
56-60\end{array}$ & $\begin{array}{c}2+2+1 \\
2+2+1 \\
4+1 \\
4+1 \\
4+1 \\
4+1 \\
4+1 \\
4+1 \\
4+1 \\
4+1 \\
4+1 \\
4+1 \\
4+4\end{array}$ & $\begin{array}{r}\text { Jul.1822 } \\
\text { Aug. } 1822 \\
\text { Sep.1822 } \\
\text { Oct.1822 } \\
\text { Nov.1822 } \\
\text { Dec.1822 } \\
\text { Jan.1823 } \\
\text { Feb.1823 } \\
\text { Mar. } 1823 \\
\text { Apr. } 1823 \\
\text { May } 1823 \\
\text { Jun.1823 } \\
1823\end{array}$ & 4 & $\begin{array}{l}37 \\
38 \\
39 \\
40 \\
41 \\
42 \\
43 \\
44 \\
45 \\
46 \\
47 \\
48 \\
\pi\end{array}$ & $\begin{array}{l}181-185 \\
186-190 \\
191-195 \\
196-200 \\
201-205 \\
206-210 \\
211-215 \\
216-220 \\
221-225 \\
226-230 \\
231-235 \\
236-240\end{array}$ & $\begin{array}{c}4+1 \\
4+1 \\
4+1 \\
4+1 \\
4+1 \\
4+1 \\
4+1 \\
4+1 \\
4+1 \\
4+1 \\
4+4+1 \\
4+4+1 \\
2+4\end{array}$ & $\begin{array}{r}\text { Jul. } 1825 \\
\text { Aug. } 1825 \\
\text { Sep. } 1825 \\
\text { Oct. } 1825 \\
\text { Nov. } 1825 \\
\text { Dec. } 1825 \\
\text { Jan. } 1826 \\
\text { Feb. } 1826 \\
\text { Mar. } 1826 \\
\text { Apr. } 1826 \\
\text { May } 1826 \\
\text { Jun. } 1826 \\
1826\end{array}$ \\
\hline 2 & $\begin{array}{l}13 \\
14 \\
15 \\
16 \\
17 \\
18 \\
19 \\
20 \\
21 \\
22 \\
23 \\
24 \\
\pi\end{array}$ & $\begin{array}{r}61-65 \\
66-70 \\
71-75 \\
76-80 \\
81-85 \\
86-90 \\
91-95 \\
96-100 \\
101-105 \\
106-110 \\
111-115 \\
116-120\end{array}$ & $\begin{array}{l}4+1 \\
4+1 \\
4+1 \\
4+1 \\
4+1 \\
4+1 \\
4+1 \\
4+1 \\
4+1 \\
4+1 \\
4+1 \\
4+1 \\
2+4\end{array}$ & $\begin{array}{r}\text { Jul. } 1823 \\
\text { Aug.1823 } \\
\text { Sep.1823 } \\
\text { Oct.1823 } \\
\text { Nov.1823 } \\
\text { Dec. } 1823 \\
\text { Jan.1824 } \\
\text { Feb.1824 } \\
\text { Mar. } 1824 \\
\text { Apr. } 1824 \\
\text { May } 1824 \\
\text { Jun.1824 } \\
1824\end{array}$ & 5 & $\begin{array}{l}49 \\
50 \\
51 \\
52 \\
53 \\
54 \\
55 \\
56 \\
57 \\
58 \\
59 \\
60 \\
\pi\end{array}$ & $\begin{array}{l}241-245 \\
246-250 \\
251-255 \\
256-260 \\
261-265 \\
266-270 \\
271-275 \\
276-280 \\
281-285 \\
286-290 \\
291-295 \\
296-300\end{array}$ & $\begin{array}{l}4+1 \\
4+1 \\
4+1 \\
4+1 \\
4+1 \\
4+1 \\
4+1 \\
4+1 \\
4+1 \\
4+1 \\
4+1 \\
4+1 \\
4\end{array}$ & $\begin{array}{r}\text { Jul.1826 } \\
\text { Aug.1826 } \\
\text { Sep.1826 } \\
\text { Oct.1826 } \\
\text { Nov.1826 } \\
\text { Dec.1826 } \\
\text { Jan.1827 } \\
\text { Feb.1827 } \\
\text { Mar.1827 } \\
\text { Apr.1827 } \\
\text { May } 1827 \\
\text { Jun. } 1827 \\
1827\end{array}$ \\
\hline 3 & $\begin{array}{l}25 \\
26 \\
27 \\
28 \\
29 \\
30 \\
31 \\
32 \\
33 \\
34 \\
35 \\
36 \\
\end{array}$ & $\begin{array}{l}121-125 \\
126-130 \\
131-135 \\
136-140 \\
141-145 \\
146-150 \\
151-155 \\
156-160 \\
161-165 \\
166-170 \\
171-175 \\
176-180\end{array}$ & $\begin{array}{c}4+1 \\
4+1 \\
4+1 \\
4+1 \\
4+2 \\
4+1 \\
4+1 \\
4+1 \\
4+1 \\
4+1 \\
4+1 \\
4+1 \\
2+4+2\end{array}$ & $\begin{array}{r}\text { Jul.1824 } \\
\text { Aug.1824 } \\
\text { Sep.1824 } \\
\text { Oct.1824 } \\
\text { Nov.1824 } \\
\text { Dec.1824 } \\
\text { Jan.1825 } \\
\text { Feb.1825 } \\
\text { Mar.1825 } \\
\text { Apr.1825 } \\
\text { May } 1825 \\
\text { Jun.1825 } \\
1825\end{array}$ & 6 & $\begin{array}{l}61 \\
62 \\
63 \\
64 \\
65 \\
66 \\
67 \\
68 \\
69 \\
70 \\
71 \\
72 \\
7\end{array}$ & $\begin{array}{l}301-305 \\
306-310 \\
311-315 \\
316-320 \\
321-325 \\
326-330 \\
331-335 \\
336-340 \\
341-345 \\
346-350 \\
351-355 \\
356-360\end{array}$ & $\begin{array}{c}4+1 \\
4+2 \\
4+1 \\
4+1 \\
4+1 \\
4+1 \\
4+1 \\
4+1 \\
4+1 \\
4+1 \\
4+1 \\
4+1 \\
1+4+4+1\end{array}$ & $\begin{array}{r}\text { Jul. } 1827 \\
\text { Aug. } 1827 \\
\text { Sep. } 1827 \\
\text { Oct. } 1827 \\
\text { Nov. } 1827 \\
\text { Dec.1827 } \\
\text { Jan. } 1828 \\
\text { Feb. } 1828 \\
\text { Mar. } 1828 \\
\text { Apr. } 1828 \\
\text { May } 1828 \\
\text { Jun. } 1828 \\
1828\end{array}$ \\
\hline
\end{tabular}


Reviewe and announoemeris:

fasc. 1: Blaokwood's Edini.ilag.11(65): 752. $1822 \mathrm{Jun}$.;

Ann.Philos. n.ser. 4(1): $78.1822 \mathrm{Jul}$. (just published);

fasc. 1- 3: Philos.llag. J. 60: 227-229, iz22 Sep.

fasc. 4: Blackwood' Edino.ilag. 12(69): 508. 1822;

fasc. 1- 6: Elora 6(24): 371-375. 1823 Jun.28;

fasc. 1-10: AlZg.Repert. leuest.In-Ausi.Lit. 18232(1): 14-16. 1823 Apr.15;

fasc, 7-16: Flora 7(6): 89, 1824 Feb.14;

fasc.11-24: Allg.Repert.ileuest. In-Ausl.Lit. $1823^{2}(2): 34-3 j .1324$ Apr.30:

fasc.27-29: Edinb.J.Soi. 2(1): 168-169, 1द25 Jan.;

fasc.17-30: Flora 8(36): 565-569.1825 Sep.28;

fasc. 30: Edinb.J.Soi. 2(2): 355. 1825 Apr.;

fasc. 25-36: Alig.Repert.ileuest.In-Ausl.Lit. $1825^{4}(1-2):$ 105-106. 1825 0ct.i Gard. 1 ag. (Loudon) $1(1): 74.1826$;

fasc. 1-36?: Linnaea 1(1): 155. 1826 (Jan.): iseued each month without breaks, 10 fasc 1826: A $2 Z_{g}$.Repert. leuest. In- Ausi. Lit. $18272(5): 330-332.1827$;

fasc.49-72: A27g.Repert. leuest. In-Ausz.Lit. $1829^{2}(2): 92-94.1829$. .

Refe.: BMIH 733

Brun. 2: 1736

Cat.Juss, n, 2242

Graesse $3: 154$

\section{Jacks. 246}

Kew 243

Krug. 210

Lind: Libr. 180

Lirn.Soc. 314
Lownd. 943

líass. HS-H 124

Iass.HS-i1 2: $172 \mathrm{C}$

liilt. 473

Hiss. n.757
Pr.ed.1 n.3869

Pr.ed. 2 n.3550

Staf2. TL $n .442$

Teyl. 409

Un.Edinb. 2 : 162 b

Variant: the paper withoit watermarks of the HBL copy may represent a better quality paper state; I do not know of a confirmation in contemporaneous announcements.

Bibl.notes. The collation is following the lambda-method proposed by Stevenson and discussed in the introduction. For purposes of references this is the best way to collate. However, the draw-back is that it does not show the conjugacy of the leaves in the gatherings, which is important for the determination of the contents of the fascicles. Therefore I added these in a short notation in the table of the dates, $4+1$ beirg the regular make-up of ascicle, meaning one gathering in fours and a single leaf, containing the descriptions to 5 plates. The number of 5 plates per gathering is consistent throughout the 6 volumes. The number of the text-leaves, however, varies; in a few cases two or more leaves of text are devoted to one species, and in one case the text refers to two plates of the same species.

I am convinced that the text was printed in half-sheet imposition, and the preliminaries also; even where a gathering of 8 might have been possible, the checking of conjugate leaves proved that all gathenings were folded as half-sheets or smaller parts.

The fascicle titles form a peculiar problem. Though I have only seen off-sets, as in Hooker's Exotia flora, I suppose that these formed with the fifth leaf a wrap-around to protect the complete fascicle. It would be unusual to print the wrapper on the same paper as the text, but the off-sets of Hooker's book lead me to consider this as a possible situation there, and Greville's book was printed by the same printer and in a similar way and on similar paper. Differring from hooker's $\vec{E} x \circ$ tio flora the name of the month was added to the date on the fascicle titles.

Another problem is the place of the indexes. In vol.4 the first three leaves of the indexes formed one gathering with the text to flate 240 . This is indicated in the collation as $240^{4}$, whish is not the consistent lambdamethod. In some copies these three index-leaves (together with the following gathering ${ }^{*}$ ) have been removed to the front of the book, directly after the title-page. In one copy the hajf-title had been removed, which of course is not shown in the collation of the ideal copy.

The same copy (HBL copy) does not have any watermark in the text- or plate-paper, and I think this is a better quality of paper. Moreover it has guard-leaves between plates and text of a grod glossy quality. 
The fascicle dates have partly been derived from contemporaneous references. They were completed with the assumption of regular months throughout the year. From analogy with the work of hooker, ivici exotici, I presume that the publication of the fascicles was scheduled for the first of each month. The earlier fascicles probably followed this pattern, since they were reviewed soon. For fasc.47 I found evidence pointing to the contrary. The 18 pages of text concerning the red snow, protococous nivalia, of plate 231, were issued with a separate title-page. Greville sent copies of this to Ad.Brongniart on 28 May 1826 and to A.P de Candolle on 30 May 1826, as was announced in letters of these dates. This makes it very likely that this fascicle 47 of the soottish cryptogavic flora had been published late in May 1826, the month for this fascicle. In such long series delays can easily creep in, especially in the later parts, but I have up to now no indication of delay beyond the months scheduled for the fascicles.

Bot.notes. Greville beautifully illustrated this work, and the treatment is also of high quality. New species were described, and a number of new combinations proposed, which are easily traced in the indexes, except for some combinations which were made in the text and did not refer to the plates.

In the preface it was announced that the species treated would include aritish plants outside Scotland in " small number only of supplementary fassiculi". This was not realized, but English plants were occasionally included (Bryum tozeri Grev., pl.285). Nor was the project, announced in the same preface, of "a snoptical Arrangement of all British Cryptogamic vegetables" realized. It may be regretted that no more volumes were produced.

For the nomenclature of bryophytes the dates of some fascicles are important since some names compete with those in other publications, especially in Grevilie's own Flora Edinensis (which see, n, 6 ).

\section{Flora Edinensis.}

Edinburgh, 1824 .

Titze: "FLORA EDINENSIS: | OR | A DESCRIPTION OF PLANTS GROWING | NEAR EDINBURGH, | ARRANGED ACCORDING TO THE LINIEAN SYSTEI1. I WITH I A CONCISE INTRODUCTION'TO THE IHATURAL CRDERS | OF THE | CLASS CRYPTOGAMIA, I. AND ILLUSTRATIVE PLATES. | [medium short rulej | BY | ROBERT KAYE GREVILLE, F. R. S, \& F. A. S. E. I MEMBER OF THE HERNERIAN MATURAL HISTORY SOCIETY OF EDINBURGH; | OF THE IUPERIAL ACADEIYY NATURA CURIOSORU11; OF THIE NATURAL | HISTORY SOCIETY OF LEIPZIG; CORRESPONDING MEIIBER OF THE NA-| TURAL HISTORY SOCIETY OF PARIS; HONORARY MIEHBER OF THE YORK-| SHIRE PHILOSOPHICAL SOCIETY, OF THE LIVERPOOL BOTANICA.L INSTI-/TUTION, AND OF THE LYCEUM OF NATURAL HISTORY AT NEW YORK, do. | [medium short rule] | EDINBURGH: | PRINTED FOR WILLIAM BLACKWOOD, EDINBURGH; | AND T. CADELL, STRAND, LONDON. | [short rule] | MDCCCXXIV."

Colzation: $8^{\circ}: a^{4}$ b-e $e^{8} \mathrm{f}^{2}\left(-g_{2}\right) \quad A-2 G^{8}\left(-2 G_{8}\right) ; \quad i-v$ vi-1xxxi $2 x x x i i \quad 1 \quad 2-478$ (viii-ix $x x v i \quad 472-473$ ).

Contents: $i$ title; $i i$ quotation from Linnaeus, $c_{2} i t$. Bot., and imprint; $i i_{i}$ dedication to Robert Graham (1786-1845), professor of botany at the University of Edinburgh; iv $]$; $v$-vii preface, dated $7 \mathrm{Jan} .1824$; viii $[$; $i x-x \times v$ introduction to cryptogams; $x_{i}$; xxvii-xxx explanations of the plates; xxxiIxxxi arrangement of the genera j.n the Linnaean classification for phanerogams and in natural classes, mainly the method of A.L. de Jussieu, for cryptogams, with descriptions of the genera; $2 x x x i i$ [; 1-471 text, descriptions of the species; 472 ; $473-478$ index of Latin generic names, stating the number of species per genus, the page number of the specific descriptions and (in italics) the page numbers of the generic descriptions; 478 imprint. RT: preliminaries: chapter headings; text: names of classes and of the first genus on the page; incex: "INDEX." Language: English.

Plates: 4 uncolored copper-engravings illustrating different groups of cryptogams with details, numbered: "PLATE I." - "PLATE IV", species numbered on each plate, details with italic letters; no plant names on the plates; plate-mark: $211 \times 131 \mathrm{~mm}$. (pl.1). 
Artist: Greville, Robert Kaye, the author: all plates signed. Engraver: Lizars, William Home (see Greville n.3).

Paper: leaf height $222 \mathrm{~mm}$. (HBL copy, cut); wove; wm.: occasionally "1822" (HBL copy: gath. Y), mostly unmarked; plate paper: wove; unmarked.

Printer: Neill, Patrick, Edinburgh (see Greville n.5).

Publishore: Blackwood, Hilliam, Edinburgh; Cadell, T., London.

Date: $1824\left(t_{.}-p_{.}\right)$; after $7 \mathrm{Jan}$. (preface), bef, or on 22 Mar. (letter from Greville to A.P. de Candolie, accompanying the book).

Reviews: Blaokwood's Edinb.Nag. 15(87): 482. 1824 Apr.; Edinb. J. Soi. 1: 171. $1824 \mathrm{Jul}$.

Refe.: Arn.Arb.1: 300 | Brun.2: 1736 BMNH 733 Graesse 3: 154 Brad1.1: $397^{a} \mid$ Jacks. 252

Kew 243

Linn. Soc. 314

Lownd. 943

Pr.ed.1 n.3870
Pr.ed. 2 n.3551 Soulsby Add. $n .829^{a}$ Stafl. TL $n .443$ Un.Edinb.2: 162 .

Bibz.notes. Most likely the single leaf of gathering 8 had been part of 26 during printing, but I could not find definite proof for this. The watermarked gathering $Y$ in the $H B L$ copy is also in another respect different from other gatherings, since it shows deckle-edges at the bottom and the sides of the leaves. This may be chance, but it also could indicate a reset gathering.

Bot.notes. Local flora of the plants growing within 10 miles of Edinburgh, after the Linnaean classification for phanerogams and a modification of the natural classification for the cryptogams, which are moreover explained by an able introduction and four plates. Varieties are rarely mentioned, and then only by descriptions preceded by Greek letters, without varietal epithets (see e.g. Luzula campestris, p.81). Some names also appeared also in Greville's soottish oryptogamic flora; e.8. Grimmia triohophylla (pl.100) has priority from the latter work if this was really published in February 1824 , and Flora Edinenais in March 1824, as is likely. In Soottish oryptogamio flora a reference was given to Flora Edinensis, and not the reverse, for which reason Index Muscorum cited the forner. However, the proofs of this part of Flora Edinenoio were ready before fascicle 20 of the other work was prepared. The last part of Flora Edineneis was set about that time, for Aeoidium berberidis (p.446) has mutual cross-references (scott. orvpt. fi. pl.97) and even from the March fascicle two species are mutually and correctly cited (Fusidium griseum and $F$. flavo-virens, p1.102 and p.464).

7 Desoriptions of two new epeoies of ifusoi ...

Mem. Wernerian Nat. Hist. Soc. 5(2): 481-484. pl. 14. 1826 [Jani.

Head-titie: "XXVIII.-Descriptione of Two New species of I Musci, belonging to the Genera Neckera and | Hypnum. By ROBERT KAYE GREVILLE, LL.S. F.R.S.E. \&. I (Read 30 th Aprit 1825) | [short swelled rule]".

Collation and contents: $B^{\circ}: 2 \mathrm{H}_{1}-2 \mathrm{H}_{2} ; 481-484$; text, descriptions of the new species Neokera amerioana ( $\left.p_{0} 481, \mathrm{pl} .14\right)$ and $B y p n u m$ remotifolium, dated: "May 5. 1825."

Ref.: RSC 3: 12 .

Date: 1826 (t.-p. fasc.), bef, or on 2 Jan. (see Hem. Wernerian llat.Bist.Soc.)

Note. Neokera americana was proposed here as a new species, but was reduced to a synonym of $N$. minor. Schwaegr. in the same fascicle (see $n, 8$ ), and therefore the name here is invalid, unless published in a pre-publication separate, of which I have no evidence. 
8 Adiendum to Dr. Greville's article, p. 483.

Nem. Wernerian Nat. Hist. Soc. S(2): 564, 1826 [Jan.].

Head-title: "Addendum to Dr GREVILLE'B Artiole, P. 483. I [short swelled rule]".

Collation and oontents: $8^{\circ}: 2 \mathrm{~N}_{2} \mathrm{r}$; 564; head-title and text, correction to foregoing paper, reducing Neokera ameriaana to a synonym of $H$. minor Schwaegr.

Ref.: RSC 3: 12 .

Date and note: see n.7.

9 Some cooount of a colleotion of oryptogamia plante from the Ionian Iolands. Trans, Linn, Soc, London 15(2): 335-348, pl. 3, 1827.

Head-title: "XI. Some Acoount of a Collection of Cryptogamio Plante from I the Ionian Is zande. By Robert Kaye Grevizle, LL. D. B.L.S.| I.R.S.E. I Read February 7, $1826 . "$

Colzation and oontents: $4^{\circ} ; 2 X_{1}-2 Y_{3} ; 335-348$; short introduction, list of plants collected in the Ionian Islands by the Earl of Guilford (Frederick North, philhellenic, 1766-1827), with an "EXPLANATION OF TAB. III.", p.348.

Plate: 1 copper-engraving of different new species of cryptogans; in upper right corner: "Trans.Linn.Soc.Vol.XV.Tab.3.P.348."; plate-mark: $268 \times 211 \mathrm{~mm}$.

Artiet: Greville, Robert Kaye, the author.

Engraver: Fox, C.

Paper: leaf height $274 \mathrm{~mm}$. (HBL copy, cut); wove; no wm. (machine-made, seam mark seen elsewhere in the copy);

plate paper: wove; no wm. (other plates in the same copy have wm.:

"J. WhatMaN | TURKEY lílls | 1827 [outline]" (pl.4, 7), or:

"I. Whatman | 1827 [outline]" (p.15)).

Printer: Taylor, Richard, London.

Date: 1827 (t.-p. vol.), after 6 Nov. (last date in vol., p.501).

Note. Descriptions of the two new Eungi are included (though the genera actually were excluded from a restricted order of Fungi as understood by Greville at the moment of writing), one new species of Algae, and four new species of lusci: Tortula northiana, p. 342, Bryum elegans, p. 344, Bryum donianum, p. 345 and Bypnum leskea, p.347, with carefully executed drawings, as usual with Greville.

10 Description of some new mosees discovered in South America by Dr. Gillies.

Edinb. J. Nat. Geogr. Sci. 2(1): 1-4. pl. 1. 1830 Apr.

Collation eto.: not studied.

Notes. Included for the sake of completeness; the article contains four new species of liusoi, in some lists referred to as from Cheek's Journal, after one of the editors (William Ainsworth and Henry H. Cheek). 
GREILLE, Robert Kaye \& ARNOTT, George Arnott Walker

1 Tentamen methodi muecorum; or, a new arrangement of the genera of mosses... 3 memoirs. Edinburgh, 1822-1826 [pre-publication separate].

Titze: Tentamen methodi Muscorum; or, A New Arrangement of the Genera of Mosses, with Characters, and Observations on their Distribution, history, and Structure.

Collation: $8^{\circ}:$ memoir $1: \pi^{1} A^{2} B-C^{8} D-E^{2}\left(-E_{2}\right) ; \quad i-i v \quad 1 \quad 2-42$; memoir $2: F^{4} G^{6}\left(-G_{6}\right) \quad H-L^{4}\left(-H_{4}\right) \quad M^{2}\left(-M_{2}\right) ; \quad 43-45 \quad 46-92 ;$ memoir 3: $\quad \pi^{2} \mathrm{~N}^{8} \mathrm{OIO}\left(-\mathrm{O}_{10}\right) ; 93-95$ 96-127 728 [courtesy of Mr. D.S. Kalk].

Printer: Neill, Patrick (see Greville n.5).

Dates: mem.1: 1822, on or shortly bef. Apr. 22 (letter from Arnott to Ad.Brongniart); mem. 2: 1823, on or shortly bef. Dec. 18 (letter from Arnott to Ad,Brongniart); mem.3: 1826, presumably in January (earliest date for fasc, of periodical).

Ref.: Cat.Juss, n.2289.

Bibl.notes. Only after having departed from London I realized the interesting problem connected with this article. I had made superficial notes of the BMNH copy, including the title of memoir $1\left(\pi^{1}\right)$, and later asked my colleague IIr. D.S. Kalk to prepare the collation, and especially to describe the pagination, since a copy in the library of the Linnean Society, London, has the last two parts only, and these wit the original pagination of the journal. Moreover, this library has a letter from Greville to J.E. Smith, dated $19 \mathrm{Jan}$. 1824, accompanying the second memoir. Greville wrote that he had entrusted a certain person with bringing Smith a copy of the first memoir, but he feared this person had forgotten to do so; this explains the absence of this first memoir. [Information: courtesy Miss S. Raphael, Librarian Linnean Society, London.]

Apparently Greville was responsible for the separate with unchanged pagination, and it is reasonable to assume that the more expensive issue with the continuous pagination was ordered by the impulsive Annott.

I could have made a complete new entry for Greville's separates, but I have not done so because of the lack of sufficient data. It is interesting to check the first part of Greville's separate; I presume the NYBG copy represents this. When seeing it I did not prepare a complete treatment of it, so now I cannot say whether a special titie is present or not, nor did I check Arnott's separate in BMNE on traces of conjugacy of the title (I pondered on the possibility that the title was added with a later part; however, the chance of a positive answer is small).

The printing of the different separates will not have differred considerably, since they were printed from the same type, except for the page numbers.

I have to doubt the pre-publication of Arnott's form of Memoir 3 , since he was in Paris in Dec. 1825 and Jan. 1826; therefore he was proprobably unable to distribute copies before the publication of the fascicle of the periodical.

Bot.notes. Critical discussion of the structure of mosses in general, and descriptions of a number of genera and species in particular, including the new genus $D i s e 0 d o n, 3: 114$, and the new specific names Voitia hyperborea, 1: 42, Diseodon eptachnoides, $3: 121, D$. hornschuohit, 3: 121, D. frosiichianum, 3: 122, and D. ocabriestum, 3: 122 .

Hedvig's ideas on the sexual reproduction of mossas were accepted in general. However, the authors hesitated to use the words pistils and anthers for the organs in this group. 
2 A new arrangement of the genera of mosees... 1.

Mem. Hernerian Iat. Hist. Soc. 4(1): 109-150. pl. 7. 1822 [Aug.j.

Ieac-title: "IY:-A Vew Arrangement of the Genera of $\mid$ llosses, with Charaoters, and observations on I their Distribution, History, and Structure, I By R. K. GREVILLE. Isq. F.R.S.E. II. I.S. \&c., A ATD I G. A. HALKER ARHOTT, Esq. A.il. F.R.S.I. | (Read $23 d$ pebruary 182i.) | [very short swelled rule i | MEMOIR I." Collation: $3^{\circ}: \mathrm{G}_{7}-\mathrm{K}_{3}$; $109-150$.

Contents: 109 head-title; 109-123 introduction, discussion of organs of mosses, especially of the theca; 124-150 descriptions of genera and higher groups of mosses: 124 Musoi, 125 Andreaea (spelled Andraca). 130 Sphagnum, 139 Phasooidea, 140 Phasoum, 145 Voitia, and 149 the new species $V$. hyperborea.

Plate: 1 copper-engraving of the thecae and other details of the four genera, numbered: "PLATE VII.", with the generic names at the top (speliing of Andrea differring from the text); plate-mark cut off (HBL copy).

Artist: Greville, Robert Kaye, the first author.

Engraver: Lizars, ililian llome (see Greville n.3).

Ref.: RSC $3: 13$.

Date: 1822 (t.-p. fasc.); Aug. (see Mem.Hemerian Nat.Biot.Soc.).

Bibl.notes. The first of an apparently unfinished series of three articles. The different separates ordered by Greville and Arnott are discussed under n.1; they were both published earlier than the fascicle of the periodical.

3 Tentamen methodi muscorum; or, a new arrangement of the genera of mosses... 2. Mem. Wernerian Hat. Hist. Soc. 5(1): 42-89. pls, 2-3, 1824 [May].

Head-title: "IV.-TENTANEN METHODI MUSCORUM; I OR, I A New Arrangement of the Genera of Hosees, | with Charaoters, and observations on their | pistribution, History, and Structure. I BY R. K. GREVILLE, Esq. F.R.S.E. M.H.S. \&C. I AND I G. A. WALRER ARNOTT, Esq. A.M. F.R.S.E. M.H.S. I Continued from Vol. IV. p. 150.) | (Read 26 th April 1823.) | [very short swelled rule] | MEMOIR II."

Collation: $8^{\circ}: \mathrm{C}_{5} \mathrm{~V}-\mathrm{F}_{5} \mathrm{r}$; $42-89$.

Contents: 42 head-title; $42-89$ descriptions of genera and higher groups of mosses: 42 Gymnostomoidex, 43 Gymnostomum, 55 Schistostega, 61 Aniotangium,

72 Buxbaumoides, 73 Diphyocium, 79 Buxbaumia.

Plates: 2 copper-engravings of the genera treated, numbered: "PLATE II" and "PLATE III.": plate-mark cut off (HBL copy).

Artist: Greville, Robert Kaye, the first author.

Engraver: Lizars, Uilliam Home (see Greville n.3).

Date: 1824 (t.-p. fasc.); betw. 21 Mar. and 20 May (see Mem. Wernerian Mat.Hiat.Soo.).

Ref.: RSC $3: 13$.

Note. Continuation of descriptions of moss genera with ample critical discussions.

4 Tentamen methodi muscorum; or, a new arrangement of the genera of mosses... 3.

llem. Hernerian llat. Hist. Soc. 5(2): 442-474, pl. 13, 1826 [Jan.].

Head-title: "XXVI. - [same as n.3, except after Grevilie:] LL.D. F.R.S.E. M.W.S. \&c., [and after Arnott:] Esq. A.M. F.R.S.E. I (Continued from p. 89 ) i (Read 22d January 1825.) | [very short swelled rule] | MEMOIR III."

Collation: $8^{\circ}: 2 E_{5} r-2 G_{4} ; 442-474$.

Contents: 442 head-title; $442-474$ descriptions of genera and higher groups of mosses: 442 splachnoidea, 448 Splaohnum, 461 the new genus Dissodon with four species, and 470 Tayloria. Date: 1826 (t.-P. fasc.); betw. 17 Dec.1825 and 2 Jan.1826 (see Mem. Wernerian Nat.

Note. Third and last article in the unfinished series. Possibly the separate prepared for Greville, with unchanged paginaticn, was published earlier, but I do not have any proof. Arnott's separate with the pagination continuing that of the other separates of his probably was distributed later (see n.1). 
HALL, Hermanus Christiaan van

Biogr. Born 1801 Aug. 18, Amsterdam, Netherlands.

Died 1874 Jan. 12, Berg en Dal, Guelderland, Netherlands.

H.C. van Hall studied at the Athenaeum of Amsterdam, and at the University of Utrecht with J. Kops. Prizes were awarded at Leiden and Utrecht for botanical papers of his. he made a scientific tour in Germany and France.

Afterwards he received the degree of D.M., Utrecht, 11 Jun. 1823, and settled, as a physician in Amsterdam. He published on botany; e.g. for some time he was a collaborator of the Flora Batava begun by J. Kops. In 1826 he was appointed professor of botany and agronomy of the Groningen University, from which he retired in 1871. Through his Elora Belgii septentrionalis he had a good influence on the development of botany in the Netherlands, but when the Dutch Botanical Society was founded in Leiden, 1845 , he had not been invited, and for a long time there was no connection until van hall finally became a member at an advanced age, in 1873. liis herbarium then came to this society, and is now kept at the Rijksherbarium, Leiden. He was commemorated in the generic names Ballia Dumortier 1826 , based on Bonkenya Willdenow (Tiliaceae), replaced by Clappertonia Meissner, Vanhallia L. Marchand 1828 (Fungi), now considered a synonym of Chaetomium Kunze, and Vanhallia J.A. J.H. Schultes 1829 , replaced by Munniokia Reichenbach (Ariotolochiaoeae).

Refe.: Ned.Kruidk.Arah. ser.2, 2: 1, 17-19, 21. 1877.

Academia Groningana NDCXIV-LCUXIV: 392-398. 1914.

Jansen, P. Wachter, W.HF Ned,Kruidk.Arch. 49: 443. 1939; 50: 191. 1940: 51: 352,$1941 ; 53: 241,1943$,

1 Flora Belgii septentrionalis...

2 vols, in 5 parts. Ams terdam, 1825-1840 [1841].

Title: vol.1: "FLORA | BELGII SEPTENTRIONALIS, | SIVE | INDEX PLANTARUM INDIGENARUM," QUAE HUCUSQUE | IN VII PROVINCIIS FOEDERATIS REPERTAE SUNT. | VOL. I. | Plantas Phanerogamas oontineno. | [medium fancy swelled rule] | FLORA | VAN | NOORD-NEDERLAND, | OF | KORTE AANWIJZING DER IN HET WILD WASSENDE | PLANTEN, j WELKE TOT NU TOE IN DE VOOR-|MALIGE VII VEREENIGDE GEWESTEN | GEVONDEN ZIJN. I I. DEEL. I Zigtbaar bloeijende Planten. | DOOR I H. C. VAN HALL, | Lid van de " Maatschappij van Landbouw te Amsterdam, Corres-l pondent van de Sooiet. d'Bigt.t natur. te Parijs; Med. Doct. te Amsterdam. | [medium fancy swelled rule] | Te AMSTERDAl, bij | J.C. SEPP EN ZOON.|1825.";

Vol.1(1): "FLORA I BELGII SEPTEHTRIONALIS. I VOL. I. PARS I. I [short rule] | FLORA | VAN | NOORD-NEDERLAND. | I. DEEL. I. STUK.";

VO1.1(2): "FLORA | BELGII SEPTENTRIONALIS. | VOL. I. PARS II. | [short rule] | FLORA | VAN | NOORD-NEDERLAND. | I. DEEL. II. STUK, ";

VO1.1(3): "FLORA | BELGII SEPTENTRIONALIS, | SIVE | FLORAE BATAVAE COMPENDIUM. | VOL. I, PARS 3, | CONTINENS PLANTAS YHAIEROGAUICAS IN BATAVO SOLO REPER-| TAS POST PRIMI VOLUMINIS EDITIONEM ANNI 1825; | AUCTORE | H. C. VAN HALL, I Instituti Regii Batavi Socio, Botanioes et Oeconomiae Ruralis I Profeseore in Aoademia Groningana. I' [short swelled rulej I FLORA VAN NOORD-NEDERLAND, | OF | KORT BEGRIP | DER | NEDERLANDSCHE FLORA. | DEEL I, STUK 3, I BEHELZENDE I DE ZIGTBAARBLOEIJEIDE PLANTEN, WELKE IN NE-I DERLAND GEVONDEN ZIJN, NA DE UITGAVE IN | 1825 , VAN HET IE DEEL, 1 e EN 2 e STUK. | [very short rule] | TE AMSTERDAM BIJ |'J.C. SEPP EN ZOON. | 1836."; vol.2(1): "FLORA | BELGII SEPTENTRIONALIS, | SIVE | FLORAE BATAVAE COMPENDIUM. | VOL, II, | PLANTAS CRYPTOGAMICAS CONTINEIJS. | PARS I. | Equisetaceae, Filioes, ilareiliqoeae, Lyoopodiaceae, I lusoi et Hepatioae, ELABORATAE STUDIO I FRIDi. ANTi. GUILi. MIQUEL, dath. et Phil. nat. et med. cand;"I et I Mis. DASSEN, Hed. Stud. | EDIDIT EilENDAVIT ATQUE PRAEFATUS EST $\left.\right|^{\prime} H$. C. VAN HALL, I Inotituti Regii Batavi oocius, Botanioes et oeconomiae I ruralis Profesoor in Academia Groningana. | [short swelled rule] | FLORA | VAN | NOORD-NEDERLAND, | OF | KORT BEGRIP DER BATAAFSCHE FLORA. | DEEL II, STUK I. | BEDEKTBLOEIJEIIDE PLANTEN, I (Paardestaartigen, Varens, Wortelsadigen,. I Wolfoklaauwaohtigen, Bladmosen en I Levermosoen). I [medium fancy swelled rule] | Te AMSTERDAM, bij | J. C. SEPP EN ZGON. | $1832 . "$; 
vol.2(2): "FLORA | BELGII SEPTENTRIONALIS, | SIVE | FLORAE BATAVAE COMPENDIUM. | VOL. II, PARS II. | CONTINENS | LICHENES, | QUOS ELABORAVIT | H. C. VAN HALL, | EI | ALGAS, I QUAS ELABORAVIT | F. A. G. MIQUEL. I [IONg swelled rule] | FLORA | VAI | NOORD-NEDERLAND, | OF | KORT BEGRIP DER BATAAFSCHE FLORA. | DEEL II, STUK II. | BEVATTENDE DE | KORSTNOSSEIT en WIEREI. | [medium fancy swelled rule] | Te AMSTERDAM, bij |J. C. SEPP EN ZOON. | 1840."

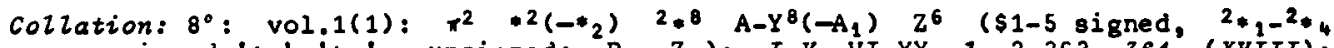
signed '*2'-'*5', unsigned: $\left.\mathrm{P}_{5} \mathrm{Z}_{5}\right) ; \quad I-V$ VI-XX $122-3633_{364}(X V I I I)$; vol.1(2): 2A-3AB; 365 366-746 i-ii (772-713 728 733 741$)$; vol.1(3): $\pi^{6} 1-788^{2}$ ( $\$ 2$ signed $\$ *$, unsigned: $\left.8_{2}\right) ; i-i i$ I-V VI-IX $x$ $747748-861,862$;

vol.2(1): $\pi^{8} 1-14^{8} 15^{4}$ (unsigned: $15_{2}$ ); I-VII VIII-XVI 1 2-227 $228-232(X I V)$;

vol.2(2): $\pi^{6} 76^{\circ} 17-31^{8}$ (unsigned: 172); I-VII VIII-XI XII $233-235$

$236-477 \quad 478-488 \quad(352-353)$.

Contente: vol.1(1): I title; II $[$; III quotation from "S. J. BRUGMANS I orat. de coour. plant. indig. notitia p. 9."; IV-XVII preface, headed: IV "PRAEFATIO." and $V$ "VOORREDE.", dated 25 Mar. 1825 (preface, as well as main text of the book printed in Latin on the left pages and in Dutch on the right pages facing the equivalent Latin version); XVIII-XX explanation of abbreviations of sources, collector's names and signs: "INDEX NOTARUM, I in hoo opere, brevitatio causa, adhibitarum." 7 part-title; $2-3$ key to the modified Linnaean classes: "CLAVIS CLASSIÚl," "SLEUTEL DER KLASSEN." 4-363 text, descriptions of Dutch plants, Linnaean classes Monandria Decandria; 364 index of classes in vol.i( 1 );

vol.1(2): 365 part-title; 366-711 text, Dodecandria - Dioeoia; $772-727$ appenalx; $7 z \Delta-132$ conspectus or vurcn plant genera arranged in Le Candolle's natural orders in Flore Frangaise, 1815; 733-740 index of Latin generic names in vol.1(1)-(2); 741-746 index of Dutch generic names in vol.1(1-2); $i$ errata; $i i$ index to classes in vol.1(2), and imprint;

vol.i(3): i-ii G; I title; II D; III quotation from vol.1(1) p.XVI; $I V-I X$ preface, dated $24 \mathrm{DeC}, 1835$, no catchwords; $X$ additional abbreviations explained; 747 part-title of vol.1(3): "FLORAE BATAVAE I COMPENDIUM. | VOL. I, PARS III. | [short swelled rule] | KORT BEGRIP | DER | NEDERLANDSCHE FLORA. I Ie DEEL, IIIe STUK."; 748-859 text additions to vol.1; 860-861 addenda (in Dutch text unheaded); 862 index of classes in vol. $1(1)-(3)$;

vol.2(1): I half-title; II $\square$; III title; IV $\square$; V quotation from Brugmans as in vol.1(1); VI-XIII preface, dated $20 \mathrm{Jun}$, 1832 , signed H.C. van Hall, no catchwords; XIV-XVI explanation of abbreviations and signs; 1 part-title; 2-227 text, Equisetaceas - Bepaticae, prepared by M. Dassen and F.A.W. Miquel and edited by van Hall; 228 index of orders; $228-230$ index of Latin generic names; 231 index of Dutch generic names; 232 ; vol.2(2): I half-title; II $\Gamma_{j}$ i III title; IV D; $\nabla$ quotation from Brugmans as in vol.1(1); VI-XI preface, dated 1 Aug. 1840, signed: "H. C. VAN HALL. F. A. W. MIQUEL.", no catchwords; XII explanation of additional abbreviations; 233 part-title; $234 \square$; 235 chapter-title Lichenes in Latin and Dutch, a quotation from [E.M.] Fries, Liohenogr. Eur. Ref. in between; 236-351 text, Lichenes; 352 ; 353 chapter-title Algae by F.A.W. Miquel, in Latin and Dutch, separated by a long swelled mule; $354-475$ text, A2gae; 476-477 addendum; 478 D; $479-481$ index of Latin generic names in vol.2(2); $482 \square ; 483-484$ index of Dutch generic names in vol.2(2); $485-486$ advertisement of botanical and zoological books published by J.C. Sepp Zoon, 187 text for 6 spine labels (vol.1(1)-(3), vol.2(1)-(3)); 488 : RT: prefaces: subject heading; vol.2(2): name of class (left) and genus (right). Languages: Latin and Dutch on opposite pages (except lists; see Bot.notes). 
Paper: leaf height $232 \mathrm{~mm}$. (copy Stafleu library, uncut); white or slightly bluish: vol.1(2): 2B-2Z; laid, chains vertical; wm. only in about half of the sheets of vol.1(1): "Igrapes with leaves. = s.....IAN. ! partly outline:".

Printer: Barteling, B., Amsterdam: vol.1(1)-(2); no imprint in other parts, other shop? (see method of signing).

Publishex: firm J.C. Sepp \& Zoon, Amsterdam, founded by Jan Christiaan Sepp (17391811), continued by his son Jan Sepp (1778-1853); biographies: Zuidema: Nieuw Uedert.Biogr.Woordenb. 5: 725,724. 1921.

Collaborators: Dassen, Michiel (1809 Apr.12, Zwolle, Netherlands - 1852 0ct.10, Zwolle), physician successively at Groningen, Hoogeveen and Zwolle (biogr.: Molhuysén: Nieuw Nedert.Biogr.Woordenb. 4: 495. 1918): part of vol.2(1); Miquel, Friedrich Anton Wilhelm (1811 0ct.24, Neuenhaus near Bentheim, Germany - 1871 Jan. 23, Utrecht, Netherlands), professor of botany at Ámsterdam, later at Utrecht, and director of the Rijksherbarium, Leiden (biogr.: Zuidema: Nieuw Nederi.Biogr. Woordenb. 4: 986-987. 1918; Stafleu: Wentia 16: 1-95.portr.1966): part of vol.2(1) (see Bot.noteo), vol.2(2):353-47i(Algae)

Dates: vol.1(1): 1825 (t.-p.), after 25 Mar. (pref.), on or about 5 April (letter from van Hall to Ad. Brongniart of this date announcing that this part would reach him in about 10 days, in PMusBC);

vol.1(2): 1826 bef. or on $24 \mathrm{Jan}$. (letter from van Hall to Ad. Brongniant vol.1(3): 1836 (t.-p.), after 44 this part was ordered to be sent);

1836 (t.-p.), after $24 \mathrm{Dec} .1835$ (pref.), $10 \mathrm{Jan.1836}$ (Stafl. TL), $1832(t .-p$.$) , after 20$ Jun. (pref.);

vol.2(2): 1840 (t.-p.), after 1 Aug. (pref.); 14 Feb.1841 (Stafl. TL).

Reviewe: vol.1(1): Linnaea 1(1): 133.1826 [Jan.] (in list of books of trim.1-3,1825); Mesa.Soi,Anto $1826(3 / 5): 46-49.1826$ Mar.-May (D[umortierl. proposed

vol.1(2): E. M[eyer]: Gott.Gel.Anx, 18272(113):1125-1127. 1827 .

Bibliogr.etudies: Stafleu, F.A.: Wentia 16: 49-50.1966, Tax.Lit. n.469. 1967.

Refo.: Arn.Arb.1: 311 b

Backer, Verkl. Woordenb. 252a BMNH 771 a
Brad1.1: $390 \mathrm{~b}$,

Kew 251 5: $\mathrm{xx}^{\mathrm{a}}$

Milt. 174
Pr.ed. $1 \mathrm{n.4058}$

Pr.ed.2 n.3079

Teyl. 431

Utr. 88 .

Bibl.notes. The plans for vol.1 probably were changed after the printing of gatherings and $A$, shifting from one volume in one part to one volume in two parts; this would explain the removal of leaf *2 (or possibly even more leaves of the original gathering *) with the text of the preface, as well as the removal of leaf $A_{1}$. This was replaced by a cancellans leaf, which I treat in the collation as $2 * 8$, since the chain-lines match those of $2 * 1$. Though I was not able to check the conjugacy completely, I am sure of the conjugacies of the other pairs of this gathering, and also of the places of the removed leaves (broad stubs in the $U$ copy). I did not see originals of the removed leaves.

Leaf $31_{8}$ of vol.2(2) had to be cut up for spine labels of all parts.

Bot.notes. Van Hall's purpose was to give a flora of the Northern Netherlands (consisting of the State of the Netherlands with the present-day boundaries minus the provinces Noord-Brabant and Limburg) according up-to-date concepts of species. Localities were given in the Dutch text only.

Van Hall only proposed a few new species, e.g. Draba boerhaavii, and a number of signed now varieties; unsigned varieties have to be checked. Some original Dutch names for cryptogamic genera were proposed. The part with the non-vascular cryptogams is in a way the first thorough list of the Netherlands. Dassen's mosses were studied and revised by $W . H$. Wachter: Neder2. Kruidk. Aroh. 51: 419-430. 1941. The year before Wachter had stated that the division of the work in vol.2(1) by Dassen and Miquel was: Miquel: Hepaticae and the genera Bypnum, Bryum, Dioranum, Didymodon, Fissidens and Leuoodon of Busoi, and Dassen: the remaining genera of Musoi and the vascular cryptogams (Neder 2 . Kruidk. Arch. 50:366.9940). According to Stafleu Miquel also prepared the Equisetaceas. 


\section{HEDHIG, Johann}

Biogr. Born $173 n$ Dec. 8, Kronstadt or Brass6 in Transylvania (Siebenbürgen). Died $1799 \mathrm{Feb}$. 7, Leipzig, Germany.

There is some uncertainty about the exact date of birth of Johann Hedwig.

Schwaegrichen, who had known him personally, stated 8 0ct. 1730; other sources mentioned $8 \mathrm{Dec}$. 1730. Gyorffy found the registration of Hedwig's baptism, which was dated $10 \mathrm{Dec} .1730$. He also quoted a spokesman who said that in that time it was a custom to baptize children the very sane day of their birth, and this was Gyorffy's reason to take the date of baptisn as the day of birth (Gyorrfy, Istuán: Rev. Bryol. 57: 161, 1930). This is open to doubt; in my opinion it is more likely that the previous statements of the 8 th day of the month were correct and that baptism took place some days later. Indeed Gyorffy's find makes it more likely that the real month of birth was December rather than October. Schwaegrichen's statement needs an explanation. It is possible that this was a misreading of the abbreviation "Xbris" (standing for Decembris) as Octobris, being now the tenth month. However, this would be more a present-day mistake than one to be expected in 1800. Possibly other documents still exist somewhere which may give a final decision.

Hedwig spent his youth in his native town, bringing plants into his father's garden, not only those with showy flowers, but also those with tiny flowers. After his father's death, he went to Pressburg, where he continued his studies at the lyceum. (1747), finishing at Zittau (1749-52).

He entered the Unj.versity at Leipzig in 1752 for the study of medicine; here he heard among others Hebenstreit (1702-1757), Ludwig (1709-1773) and Boehmer (1723-1803), names well-known in botany. They were able to help him financially by giving him jobs such as classifying and labeling plants in the botanical garden, cataloguing books of one of their libraries and making anatomical preparations. he received his bachelor's degree in 1756 and his doctor's degree in 1759. However, he was unable to settle as a practising physician in his native town Kronstadt since a law allowed only physicians with a degree from Vienna to practise there.

He then chose Chemnitz (1762), where he married Sophia Teller. His practice throve, and in free hours he botanized and studied the plants brought home. He began to include cryptogams in his researches, especially the mosses. As help he received from Schreber (1739-1810) several books and from J.G. Koehler (1745-1801, inspector of instruments in Dresden) a microscope. He became interested in reproduction of cryptogams, and carefully analyzed the tiny structures now called antheridia and archegonia. He supposed their functions, until he observed $17 \mathrm{Jan}$. 1770 the bursting of an antheridium of Grimmia pulvinata and the appearance of the spermatozoids, which he compared with the pollen of higher plants.

To record his observations correctly he learned to draw at the age of 40 , and also to engrave. The plates in his books bear witness that he learned it quite well. His observations were epoch-making, but for several. reasons he only began to publish them in 1779, one of these being the death of his wife, 1776, leaving him with a family of 6 children.

He married Clara Benedicta Sulzberger in 1777. At her instigation, for the sake of the education of the children, they noved to Leipzig in 1781 , where he published his important book Fundamentum historiae naturalis muscorum in two volumes.

In 1786 Hedwig was nominated extraordinary professor of medicine and in 1789 professor of botany. His main work is the folio work in four volumes: Desariptio et adumbratio mioroscopico-analytica muscorum frondosorum, 1787-1797, which was started in 1784 under the title Stirpes aryptogamicas novae aut dubiae ioonibus adumbratae, additaque historia analytica. Besides his very important bryological works he also published articles on the anatomy of higher plants, which did not have lasting importance. He also translated works of the Swiss philosopher Charles Bonnet. He was commemorated in the generic names Hedwigia [Ehrhart] Palisot de Beauvois 1804, nom. cons. (Nusoi, Hedwigiaceae), Hedwigia Swartz 1788, nom. rej. (Burseraceas, = Tetragastris Gaertner), Hedwigia Medikus 1790 (Commelinaceae, = Commelina L. , Hedwigidium Bruch, Schimper \& Glmbel 1846 (Uusoi, Hedwigiaoeab), and the family name Hedwigiaceae Schimper (Musoi).

The periodicals Hedwigia and Hova Hedwigia, devoted to cryptogamic botany, are named in his honor. 
Refo.: Schwaegrichen, C.F.: Hedvigii vita. In: Hedwig, J.: Speoies Ituscorum frondosorum. 301-317. 1801. Reichardt: Allg.Deutsohe Biogr, 11: 230-231. 1880. Florschutz, P.A.: Johannes Hedwig 1730-1799. In: Hedwig, J.: speoies iuscorum frondozorum. Facsimile d. V-XII. Weinheim (Germany), 1960.

\section{1 species muscorum frondosorum ...}

Leipzig, 1801 .

Title: "JOANNIS HEDWIG | MED. DOCT. AC PROFESSORIS BOTAN. EXTRAORD. IN ACAD LIPSIENSI, ACADEM. I IMPERIAL. HATVRAE CVRIOSORVM, REGIAE SCIENT, HOLI. SOCIETATISQVE | LONDIN . MEIMBRI, PHYSIOPHILOR, BEROL, TVRICENS.

MEDICO-CHIRVRG. | TVRIC., OECONOM. LIPS. ET MARCHICO-POTSDAMENSIS, MATHEMATICO-|PHYSICAE ERFORTENSIS SODALIS | SPECIES | MUSCORUM FRONDOSORUM | DESCRIPTAE ET TABULIS AENEIS LXXVII COLORATIS ILLUSTRATAE. | [swelled rule] | OPUS POSTHUMUM | EDITVM | A | FRIDERICO SCHWAEGRICHEN | MED. ET PHIL. D. SOC. BOT. RATISB. MEMB, HON. ET LINNEAN. LIPS. SOD. I copper-engraving of mountainous landscape with 2 kneeling botanizing boys, a third one standing looking through a microscope and young lady making notations] [very long swelled rule] | IIPSIAE, | SUMTU JOANNIS AMBROSII BARTHII | MDCCCI. | PARISIIS, APUD ALLALD KOENIG, QUAI DES AUGUSTINS NO. 13."

Colzation: $4^{\circ}: \pi^{4}\left(-\pi_{4}\right) \quad A-B^{4}\left( \pm B_{4}\right) \quad x^{1} \quad C-2 U^{4}\left( \pm M_{3}\right) \quad 2 X^{2}\left(-2 x_{2}\right) \quad 2 x^{4}\left(-2 x_{4}\right) \quad 3 x^{1}$; I-III IV-VI 1 2-17 78 i-ii $19-353 \quad 354$.

Contente: I title; II ; III-VI preface of the editor: "PROOEMIUM EDITORIS." ; 1-17 terminology: "TERMINORUM BOTANICORUM AD MUSCOS I APPLICATIO."; 18 ந́; $i$ folded typographical table, key of genera of mosses: "GENERA MUSCORUM FRONDOSORUM.", in Hedwig's classification; ii D; 19-300 text, descriptions of 35 genera of mosses, 362 species and 3 varieties, moreover citing 4 species from other authors not sufficiently known to be grouped in the new iHedwigian genera; 301-346 appendix, containing a biography of hedwig, a list 3 , and an evaluation of his works, written by Schwaegrichen, the editor, consisting of: 301-317 "SECTIO I. | HEDWIGII VITA.", 318-327 "SECTIO II. | OPERA HEDWIGII." 328-338 "SECTIO III. I UNIVERSA QLAEDDA DE VEGETABILIUM STRUCTURA INTERNA HED'WIGII | PLACITA."; 339-346 "SECTIO IV. | CLASSIS CRYPTOGAYICAE PLANTARUM NOTIONES HEDWIGIANAE."; 347-350 index of specific names, including Bynonyms; 351 magnifications on the plates "Lentium vitrearum efficacia."; 352 errata; 353 text addition with description of Hypnum abietinum; 3540 .

Plates: 77 hand-colored copper-engravings of moss species, with details of capsules, peristome, leaves, (magnified), numbered: "Tab. I" - "LXXVII", (indexed in Index Nuscorum); plate-marks: $169 \times 106 \mathrm{~mm}$. (pl.2) $181 \times 152 \mathrm{~mm}$. (pl.27).

Artiot: Hedwig, Johann: all plates, unsigned.

Engraver(o): not ascertained, all plates unsigned.

Paper: text: large paper state: leaf height $290 \mathrm{~mm}$. (Teyl. copy); wove; no wm.; normal paper state: leaf height $235 \mathrm{~mm} .$, sheet size different: $500 \times 396 \mathrm{~mm}$. (gath.A), $482 \times 383 \mathrm{~mm}$. (gath.H), $519 \times 391 \mathrm{~mm}$. (gath.2S) (M copy, uncut); laid, chains horizontal; $\mathrm{wm}$. (mainly CM copy):

"[fleur-de-lis] I $P=G ": \pi 2 \pi \quad A-G \quad M \quad N \quad 2 A \quad 2 B \quad 2 E-2 I \quad 2 L-2 R \quad 2 X_{1} x_{i}$

"[crowned shield with fleur-de-Iis] $\Rightarrow C$ C GREPEL": H-K O-R U-Z $2 \mathrm{C} 2 \mathrm{D} 2 x_{\text {, }}$ cancellans $M_{3}$;

"I D H [in cartouche, $H$ inferred]": $S T 2 K$;

"[crowned shield with post-hom] | SCHONST = IOSEF EOERTSCH": 2S-2U 3x;

plate paper: laid, chains horizontal; wm.: large paper state:

"[fleur-de-lis] | [coat of ams of Strasburg] | C \& I HonIG [outline]"; normal paper state: "[crowned shield with fleur-de-lis] ] PDV \& $C_{g}$ [" Pieter de Vries CO.]" or "PIETER DE VRIES": 1-40 49 51;

"X [very large in: 30 64 72-74; "[figure on globe] $\left.\left.\right|_{53}\right|_{67} ^{D} L_{70}=V_{A 1}$ RER laY [fragments on each leafj": $49-48$

"B [with appendix]": 6375 . 
Printer: no imprint.

Publisher: Barth, J.A., Leipzig (see Bridel n.4).

Editor: Schwaegrichen, Christian Eriedrich (1775-1853), botanist (which see).

Date: 1801 ( $\left.t .-p_{.}\right), 19$ Apr. (Sayre, Dates of publ. 9-10); first part of the plates would be ready at the "Jubilatemesse (fair on the 3rd Sunday after Easter) and the second part at the "Michaelis [-messe]" (29 Sep.); break possibly betw. plates 1-40 and 41-70, because of the watermark of the maker Pieter de Vries in the first set, which mark is only exceptionally found after pl.40; arbitrary date for purposes of nomenclature: $1 \mathrm{Jan} .1801$.

Reviewe and announcements:

J.Bot. (Schrader) 1800, 1(2): 433, 436, 1801;

Alig.Lit.Zeit. 4 Mar. 1801 (both announc, for Easter-fair);

$11 \mathrm{Jul} .1801$ (rev.);

J.G\&n.Litt. Etr. 20 Oct. 1801 ; idonthly Hag. 1 Jan. 1802 ;

Alig.Bot.Biblioth. (Bot.zeit.) $1802^{1}(5): 65-80.1802 \mathrm{Mar} .8$;

$1802^{1}(6): 81-82$. 1802 Mar. 22 (critical rev.).

Bibliogr.stud.: Sayse, G.: Dates of publ. 9-10. 1959;

v.d.Wijk, R.: Trans.Brit.Bryol.Soc. 2: 82. 1952 (post-publ. insert 3x);

Florschütz, P.A.: Introduction to Hedwig's Speoies Muscorum, in Hedwig, J.: speoies ijuscorum ... fasc, ed. p.V-XXII, Weinheim, 1960.

Ref..: $\mathrm{BINH} 810$

Brun.3: 77

Cat.Juss. n.2299

Heins.2: 304

Jacks 153
Kew 264
Krüg. 241

Kew 264
Krüg. 241
Pr.ed.1 n. 4262

Pr.ed.2 n.3885

Stafl. TL n.491

Teyl. 411.

Variants. From the small number of copies printed on wove paper (see J.Bot. (Schrader) $1800^{1}(2): 433$. 1801) I saw a copy in Teyler, Haarlem; the text paper is wove and the plate paper laid, however, of different quality and size than the normal paper state.

The additional leaf $3 x(p, 353)$ was not available at the time of the original publication of the book: its species was mentioned as missing in the reviews in $A$ I lg.Lit.zeit. 1801(3): 188. $1801 \mathrm{Jul} .23$ and in AlZg.Bot.Biblioth. (Bot. $\left.z_{\text {eit. }}\right) 1802^{\mathrm{i}}(6): 81-82$. $1802 \mathrm{Mar}, 22$. Therefore, this leaf is a postpublication state; it is not present in every copy, but certainly belongs to the ideal copy. I have not seen the original cancellanda and I have no indication for their reason.

Bibl.notes. The printed table $\chi$ is included in the collation, since it is an integral part of the text. Indeed the binders took some freedom to insert this folded table before or after P.17, to which it belonged as indicated in print, and either with the printed side towards the back or towards the front of the book The printing must have proceeded slowly, especially of the later part, since at least three paper supplies were used, diferring in size or watermark.

Bot.notes. Hedwig's work was proposed as the starting-point for the nomenclature of Husoi (Sphagnum excepted) by a group of 18 European bryologists for the International Botanical Congress to be held at Brussels, 1910. This proposal was duly accepted by the Congress. However, the American botanists in general did not approve of the decisions of this Congress, and the American bryologists did not accept this particilar decision. When Dr. A.J. Grout went to the next Congress, Cambridge 1930, he had the positive opinion that Linnaeus 1753 and not Hedwig should be the starting-point for mosses. Nevertheless, the European bryologists were able to convince him of the advantages they saw in accepting Hedwig's work as the starting-point, and he supported this in the Congress. After this decision, confirmed in the Amsterdam Congress, 1935, most bryologists accepted the new starting-point. The American bryologist A. LeRoy Andrews (1878-1961), however, did not agree and used the Lirnaean starting-point throughout his bryological work. 
The consequences of the change of starting-point, together with those of the type-method, introduced into the International Code at the Cambridge Congress, were only very slowly worked out, first in a paper by Dixon (Rev. Bryol.Lich. 6: 93-115. 1934), later by several workers. including L.F. Koch. and lately by the compilers of Index iluscorum for the nomenclatural changes in the period following hedwig's publication.

Still, when other books in this period are checked or rechecked, new points come to light, which have a bearing on the status of some names. This is rather unfortunate, since the nomenclatural rules should fix the nomenclature instead of causing changes.

It is not the place here to discuss all consequences of the change of the starting-point, but I agree with the view-point of Dr. Donk, insofar that it would have been much better to give only the later starting-point names a legitimate status and to retain valid names from Linnaeus, or, in other words, to let the typification begin with Linnaeus. When Hedwig or any revalidating author clearly misapplied the older name and described another plant, this usually is taken as the type under the current Code, and this is a reason for many unfortunate changes in nomenclature.

The date arbitrarily set for Hedwig's posthumous work is somewhat complicated. The Stockholm Congress, 1950, accepted a general proposal concerning the later starting-point works. Their dates should be arbitrarily fixed either as from $1 \mathrm{Jan}$, or as from $31 \mathrm{Dec}$. of the year concerned, this to be decided by the special committee for the group. The Special Committee for Musci decided for 31 Dec. 1801. This raised opposition from American bryologists, especially L.F. Koch, with the sound argument that all lists using Hedwig as starting-point had included other works from 1821 and with the statement that it had been an undemocratic decision. This, of course, should have been expressed at the Stockholm Congress, which set the procedure. The committee, in any case, was fair enough to reconsider the problem, and, after asking the opinion of all bryologists, reversed its decision to 1 Jan. 1801. In this connection Dr. Sayre investigated the real date of publication, and her conclusion was that Hedwig's book was published early enough in 1801 to precede all other important publications with names of iluaci, so that this later decision of the committee was nearer to the real situation than the former one.

Hedwig's posthumous book was edited by Schwaegrichen, and a number of descriptions, especially in the later part, are signed "S.", meaning that Schwaegrichen added something to the description he found in Hedwig's papers, or former books, a circumstance apparently necessitated by the addition of species in the meantime. A number of new species from Jamaica were included, probably received from Swartz, others from the South Sea Islands, which could include New Zealand and even Australia.

The descriptions were carefully made, and the figures were, just as Hedwig's figures in his former books, very fine, including a number of magnified details.

The typification of Hedwig's taxonomic groups has become important. It is self-evident, in my opinion, that a satisfying typification has to go back to other works of hedwig. Bartramia, in Species duscorum comprising three species, goes back to Hedwig's Descriptio, where only one species was included: Bartramia halleriana. This species, therefore, clearly is the historical type species for the genus Bartramia. Of course another type could have been chosen at the conservation of the nane, but this was done for another reason and this species is maintained as the type.

In other cases the choice is not so obvious, since a number of elements were included that are now regarded as different. Fissidens, e.g., as published for the first time by Hedwig, Deaor. 2(4): 85. pl.31 and 91. pl.32, 1789 , included two species long since excluded from the genus. The first species, $F$. polycarpus, is even treated as the conserved type of Cynodontium Bruch 'Schimper, nom, cons. 
Two different lectotypes for Fisiciens have been proposed in this century: $F$. juyoicies liedw. by lirs. Britton in 4916 , and $F$. exilis fiedw. by Grout in 1936. According to the Code the first choice of a lectotype must be followed unless this does not agree with the description. The first species certainly does; it could be questioned for the second species. This concerned the explicit choices of lectotypes, and is unambiguous. A difficulty would arise if indications of an uncertain nature were to be taken into account, as the treatments of subgenera with the name Eu-Fisaiciens, which include some other. species of the genus, but exclude the two lectotypes mentioned. This has not been considered a lectotypification in Index duscorum, since no definite species was indicated.

A difficult problem is the case where hedwig described an element which is not in accordance with his citations and with the usual concept of the group based on these citations. Eypnum ilzecebrum is an example. Hedwiz cited $H$. illeoejorum L., Spoo. PL. Ed.2: : 1594. 1763, Dillenius, Hist. Huso. 311 t. $40 \mathrm{f} .46$ and Vailiant, Botan. Paria. $137 \mathrm{t} .25 \mathrm{f.7}$. These citations all refer to European material, usually named Soleropodium illeoebrum. However, in hedwig's Speoies iuscorum other specimens were explicitly described and figured: from Lancaster, Pennsylvania. These were later reckoned to be a separate species: Hypnum josoii Schwaegrichen, Suppl. Speo. Husc. 1(2): 223. 1816, which is now treated as a member of a different genus: Cirriphyllum.

In accordance with the idea that hiedwig's specimens should be regarded as the types of the names, L.F. Koch coined the new combinations: scleropodium touretii (Eridel) L.F. Koch to include the $H$. illecebrum of Linnaeus, based on the earliest synonym included in its present-day concept, and Cirriphyllum $i$ ileaebrum (liedw.) L.F. Koch for the American specimens of liedwig and the later Hupnum boscii. I consider this sort of name-change very unfortunate for bryology since it does not serve any purpose except as far-fetched consequences of a change in the rules which was never meant to have such results. had Donk's idea of later starting-points of legitimate names only and not of valid names been applied from the beginning, this sort of changes would have been avoided; on the other hand some other changes would have had to be introduced, in connection with the consequences of the typification of Linnaean names. The chances that some stability of names at the specific level could be achieved by conservation seems remote, however useful it might be.

Another case where the established usage of all bryologists could be maintained by careful lectotypification is Hypnum plumosum. Hedwig again cited Linnaeus and Dillenius. A plate in his earlier Descriptio was cited too This plate had already been considered to picture a different species, by Hof fmann (DeutsohZ.F L. 1791): Hypnum salebrosum. In Index Huscorum Hedwig's name Hypnum plumosum was typified by his reference to Linnaeus, and not to his earlier plate. His description, it was assumed, included both, since he did not recognize Hoffmann's species as different, but this should not warrant. a change of the type from Linnaeus to a later plate.

Still another case is Bryum annotinum, for which Hedwig gave a picture in Species ifuscorum which has been identified with one of the modern segregates of this group of bulbilliferous mosses, characterized by the different forms of bulbils or gemmae. Of course it is rather a matter of chance, which of these segregates has been preserved in Linnaeus' or in Hedwig's herbaria, and it is no wonder that their "types" differ. Later, Lindberg, the first author to treat this taxon under the genus Pohlia and to make the combination, only cited Linnaeus and not hedwig. For this reason L.F. Koch made a new combination again, disturbing the nomenclature in use, and creating homonym for the already difficult problem of Pohlia annotina. Here the reasoning is: since Lindberg did not cite Hedwig, he did not include his type in the concept of the species and it must automatically be excluded. This reasoning is open to doubt; it depends on the interpretation of the rules, and it can be reasoned that Lindberg cited Linnaeus only for brevity and that Hedwig would have been included, had he given a full list, in which case Hedwig's type would have been included under Pohlia annotina too. Apparently this is the interpretation of Crum, Steere A Anderson in their recent List of North amorican ilusoi (Bryologist 68: 377-432. 1965[1966;). 
Supplements and faosimile. Schwaegrichen published a long series of supplements to hedwig's Species Muscorum, which are, botanically, complete new works, mentioning all species anew, though, of course, referring to hedwig. ihe fact that Hedwig's name is the first one on the title-page is the reason that many catalogues file the supplements under his name, but since riedwip did not contribute a word and Schwaegrichen was the sole author, the works are treated under the latter in this thesis.

A facsimile of the Species Uus corum proper was published in 1960 by: H.R. Engelman (J. Cramer), Weinheim, Germany, and wheldon biesley, Ltd., Codicote, England, and Hafner Publ. Co., New York, U.S.A. This facsimileedition has an introduction by P.A. Florschulz, Utrect.t.

\section{HOCHSTETTER, Christian Ferdinand}

Biogr. Born 1787 Feb. 16, Stuttgart, Weltemberg, Germany.

Died 1860 Feb. 20, Reutlingen (Wurtemberg? h, Germany.

Hochstetter was a town clergyman, and professor at Esslingen. He studied the Bohemian flora, wrote on the flora of Africa, and was mainly interested in phanerogamous plants, though he collected also cryptogams.

he was commemorated in the generic name Hoohstettera A.P. de Candolle 1838 (as Hochetetteria, spelling changed by Spach 1841), (Compositae).

Refe.: Verh.zool.Bot.Ges.Vien 6(Abh.): 364-365. 1856.

Ascherson \& Graebner: Syn. ifitteleur.FI. 2(2): 465 (Christian name: Christian Friedrich, not Christian Ferdinand).

Dalla Torre Sarnth.: Fl.Tirol 6(4): 19, 153. 1913.

1 Enumeratio plantarum Germaniae Helvetiaeque indigenarum ... 1826.

(See Steudel Hochstetter $\mathbf{n}, 1$. )

2 Hachtrag su den Bemerkungen aber Hrn Fleiooher'o botanisohe Reise naoh ryrol im Sommer 1825, nebst einigen Worten aber den jotanisahen Reise-Verein und die bereits angetretene Reise naoh Istrien, Krain und Kurnthen.

Flora 9(18): 273-278, 1826 May 14 .

\section{Coliation eto.: see Flora.}

Date: issue dated; article signed: "11 Marz 1826".

Ref.: RSC 3: $370 \mathrm{~b}$.

ilotes. Supplement to the remarks on a collecting trip of the pharmacist Fleischer, for a travel-society paying collectors for collecting in different regions and sharing the specimens proportionately to the contributions. In this article the Musoi had been determined by Philipp Bruch (Zweibrücken), p.275276, of whom remarks from letters are included, with a description of the new moss species Poñlia oucullata Bruch (p.276).

3 Ueber die Leistungen des botanischen Reiaevereins.

Flora 10(6): 81-92. 1827 Feb. 14 .

Collation eto.: see Flora.

Date: issue dated; see rzora.

Ref.: RSC 3: $370 \mathrm{~b}$.

ilote. Similar to foregoing paper, now including the description by Bruch of the new species Weiseia flexuosa Bruch (p.81). 
HOOKER, William Jackson

Biogr. Born 1785 Jul. 6, Norwich, Norfolk, England. Died 1865 Aug. 12, Kew, Surrey, England. W.J. Hooker was "mainly a self-educated man". He was early interested in natural history: ornithology, entomology, and botany. His first notable botanical discovery was Buxbaumia aphylla, a moss new to the British Isles, in 1805 . This find brought him into contact with J.E. Smith, Dawson Turner, and L.W. Dillwyn. he was an excellent draughtsman, beginning, with illustrations for Diliwyn's Britiah Confervae (1802-1814), and Turner's Fuoi (1808-1819); later he illustrated many of his own works, occasionally engraving the copper-plates too.

In 1806 he was elected a fellow of the Linnean Society, and he visited London, where he was introduced to Sir Joseph Banks, Robert Brown and other lotanists. In 1812 he was nominated a member of the Royal Society. Ile made several tours to the Scottish Highlands, finding interesting mosses, e.E. the new Andreasa nivalis, and a voyage to Iceland (1809), which was an adventurous one. The results were published in his Journal of a tour in Iceland, in two editions, 1811 and 1813 . He hoped to be able to visit the tropics, but a planned visit to Ceylon was canceled because of a rebellion there. In the meantime Turner offered him a partnership in and the management of a brewery at Halesworth (Suffolk), which he accepted, and he settled in Halesworth He continued his botanical trips in England and Scotland, visited Paris in 1814 , and traveled to the South of France, Switzerland, and northern Italy. Returning through Paris in 1815 he was introduced to Alexander von Humboldt, who asked him to prepare the cryptogams of his South American travels, which led to an independent publication of Hooker, beginning with the mosses. This proved a finansial failure and was abandoned; the remaining Musci and Hepatioae were included in Husoi exotici.

Hooker married Maria Sarah Turner, the oldest daughter of Dawson Turner, on 12 June 1815; they made a long wedding tour to the Lake District, Ireland, and Scotland. The brewery business brought Hooker neither satisfaction nor support for his family and his expensive, though scientifically important, publications. Through recommendation of Sir Joseph Banks, Hooker was nominated regius professor of botany in Glasgow, Feb. 1820, where he began his lectures in May. He received the degree LL.D. from Glasgow that same year. His teaching aroused enthusiasm, and the yearly excursion to the Highlands was eagerly awaited.

His life in Glasgow was full of activity; many visitors were received and correspondence was kept up with many of them, leading to enrichments of the Glasgow botanical garden and to many new species for Hooker's publications, a number of which were prepared in collaboration with other botanists. He was knighted in 1836 .

The fruitful Glasgow period ended in March 1841 when he was appointed director of the Royal Botanic Gardens at Kew, which establishment had been neglected by officials for some time. Hooker energetically developed the garden to a botanical establishment of the first order, a fact which does not need to be discussed here. From 1855 on he was helped by his son Joseph Dalton Hooker (1817-1911), a botanist in his own right, who became Assistant Director.

W.J. Hooker was commemorated in the generic names Hookeria J.E. Smith 1808, nom. cons. (liusci, Hookeriaceae), Hookeria Schwaegrichen 1816 (Musoi, a homotypic synonym of TavZoria Hooker), Hookeriopsio (Bescherelle) Jaeger 1877 (Mus0i, bookeriaceae), and the family name Hookeriaceae C. MUll. 1848 .

Refs.: de Candolle, Alph.: La vie et les éorito de W. Hooker. Genève, 1866. $8^{\circ}, 19 \mathrm{p}$. (not seen).

B [oulger], G.S.: Dict. Natl. Biogr. 27: 296-299. 1891. Hooker, J.D.: A ketch of the life and labours of Sir william Jackeon Hooker. Ann. Bot. 16(64): ix-ccxxi. 1902 Dec. (portrait, list of works, correspondents, etc.). Britten \& Boulger: BIBIB ed.2: 153. 1931. 
1 British Jungermannias...

1 vol. [in 22 fasc.] London, [1812-11816.

Titie: "BRITISH | JUNGERMANNIF : | BEING | A HISTORY AND DESCRIPTION, | UITH COLORED [sic] FIGURES, OF EACH SPECIES OF THE GEIUS, I AND I Microscopical Analyses of the Parts. [Iine in gothic] | ishort swelled rule $]_{j}$ BY WILLIAM JACKSON HOOKER, ESQ., | FELLOW OF | THE ROYAL, ANTIQUARIAN, AND LINNAEAN SOCIETIES, AND MEMBER OF THE | WERNERIAN SOCIETY OF EDINBIJRGH, | thin-thick mule] | LONDON: | PUBLISHED BY LONGMAN, HURST, REES, ORIE, AND BRÖWH; | SHERWOOD, NEELY, AND JONES: AND J. HARDING. "[short thin-thick rule] | 1816."

Colzation: $4^{\circ}$ in $2 \mathrm{~s}$ (or, in a small number of copies: $2^{\circ}$ ):
$\pi^{2} \quad A-B^{2} \quad C-K^{2} L^{2} \quad \lambda 1-4^{2} \lambda 5^{2}+1 \quad \lambda 6-15^{2} \lambda 16^{1} \lambda 17-23^{2} \quad \lambda 24^{1} \lambda 25^{2}+1$ $\lambda 26-39^{2} \quad \lambda 40^{2}+1 \quad \lambda 41-46^{2} \lambda 47^{2}+1 \quad \lambda 48-54^{2} \quad \lambda 55 / 56^{2}+1 \quad \lambda 57-58^{2} \lambda 59^{2} \lambda 60-62^{2}$

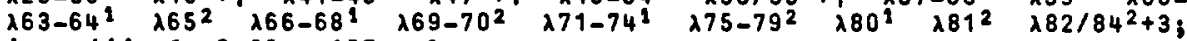 $i-x x v i i{ }_{1} 2-20,157 \lambda$-leaves.

Contente: i half-title; it $\square$; iii title; iv 0 ; $v$ dedication to Dawson Turner (1775-1858), banker and botanist; vi $\square$; vii-viii index; is-xxviii introduction; 1-6 analytical key to the British species of the genus Jungermannia $L_{\text {, }}$ including Blasia L. (Bepaticae); 7-20 synopsis of the species, with discusBions; $\lambda 1-82 / 845$ text, descriptions of Jungermannia species, with synonyms, ample discussions and explanations of plates. RT: book title in capitals, with above text the name of the species in italics between parentheses. Language: English, with Latin "phrases".

Plates: 88 hand-colored or uncolored copper-engravings of Jungermannia species,

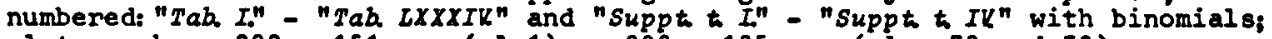
plate-marks: $200 \times 151 \mathrm{~mm}$. (pl.1), $236 \times 185 \mathrm{~mm}$. (p1s.78 and 79).

Artiet, Hooker, W.J., the author: all pls.: pl.1 signed: "W.I. . omnis[sic] delineavit". Engraver: Edwards, William H. Canden (1777-1855), Bungay, Suffolk: all pls.; pl. 1 signed: "W. B. C. Edwards omnes | ockipoit."

Paper: leaf height $294 \mathrm{~mm}$. (GH copy, cut); wove; wm. (all outline):

"1810": $\lambda 1-37$;

"RYE MILL | 1812": $\lambda 41-58$;

" 5 | BALSTOR | 1811": $\lambda 52-53$

"1812": $\quad \lambda 60-613$

"W BALsTON 1 1813": $\lambda 65, \lambda 67$;

"RYE MILI I 1813": $\lambda 69-81, A-B$ C-K $L$, (part of the edition)

"RYE MILL I 1815": (other part of the edition);

plate paper: wove; in the original edition presumably without watermarks, in later pulls with different wm.:

"RUSE \& TURNERS | TURKEY MILLS | 1815": parts 2-10;

"J WHATMAN | TURKEY MILLS | 1825": parts 1, 14-15;

"TURKEY MILLS I J WHATMAN I 1817": part 12;

"TURKEY MILLS I J WHATMAN | 1819": parts 18, 20;

"TURKEY MILLS | J WhatMaN | 1820": parts 20-21;

"J GREEN": parts 16-17 in NYBG copy;

"J WhatMan | TURKeY MILLS I 1819 [or 1820 " : pls.69 and up, including the suppl.pl8., in GH copy;

"J Whatmay | 1837": 6 copy (courtesy of Dr. C.E.B. Bonner, Geneva).

Printer: Keymer, J., Yarmouth, England.

Publichers: Longman, Hurst, Rees, Orme \& Brown, London;

Sherwood, Neeley Jones, London;

$J$. Harding, London.

Dates: issued in 22 parts, for which Gepp published the dates on which the firm of Longman etc. received the printed material from the printer (represented in table, see next page); it is assumed that in most cases the real publication date was the first of the month following within a few days, or possibly the fifteenth in some cases.. 


\begin{tabular}{|c|c|c|c|c|c|}
\hline & part & plates & $\begin{array}{r}\text { text- } \\
\text { leaves }\end{array}$ & date Gepp & $\begin{array}{l}\text { probable } \\
\text { publ.dete }\end{array}$ \\
\hline $\begin{array}{l}\text { (con- } \\
\text { tinued): }\end{array}$ & $\begin{array}{r}1 \\
2 \\
3 \\
4 \\
5 \\
6 \\
7 \\
8 \\
9 \\
10 \\
11 \\
12 \\
13 \\
14 \\
15 \\
16 \\
17 \\
18 \\
19 \\
20 \\
21 \\
22\end{array}$ & $\begin{array}{l}1-4 \\
5-8 \\
9-12 \\
13-1 b \\
17-20 \\
21-24 \\
25-28 \\
27-32 \\
33-30 \\
37-40 \\
41-44 \\
45-48 \\
49-52 \\
53-50 \\
57-60 \\
61-64 \\
65-68 \\
69-72 \\
73-76 \\
77-80 \\
81-84 \\
5.1-4\end{array}$ & $\begin{array}{r}8 \\
9 \\
8 \\
7 \\
8 \\
7 \\
9 \\
8 \\
8 \\
9 \\
8 \\
9 \\
8 \\
7 \\
7 \\
6 \\
5 \\
6 \\
6 \\
7 \\
7 \\
24\end{array}$ & $\begin{aligned} & 21 \text { Apr. } 1812 \\
& 26 \text { May } 1812 \\
& 29 \text { Jun. } 1812 \\
& 29 \text { Jul. } 1812 \\
& 29 \text { Aug. } 1812 \\
& 29 \text { Sep. } 1812 \\
& 30 \text { Oct. } 1812 \\
& 30 \text { Jiov. } 1812 \\
& 1 \text { Jan. } 1813 \\
& 1 \text { Feb. } 1813 \\
& 1 \text { Jar.1813 } \\
& 14 \text { Apr.1813 } \\
& 13 \text { Aug.1813 } \\
& 2 \text { Uct.1813 } \\
& 18 \text { Dec.1813 } \\
& 26 \text { May } 1814 \\
& 13 \text { Jul.1814 } \\
& \text { b Jul. } 1815 \\
& 4 \text { Dec.1815 } \\
& 27 \text { Mar.1816 } \\
& 1 \text { May } 1816 \\
& 14 \text { Jun.1816 }\end{aligned}$ & 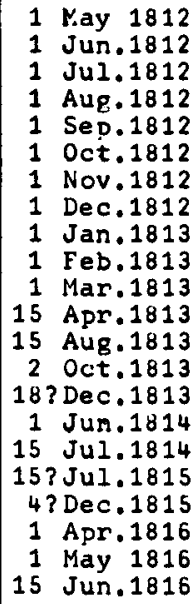 \\
\hline
\end{tabular}

\section{Announoement:}

Neues J.Bot. (Schrader)

$3(1 / 2): 251.1809$ (in preparation).

Refa.: BMNH 870

Brun. 3: 300

Cat.Juss, n.2279

Graesse 3: 344

Jacks, 241

Kew 286

$\mathrm{Krug}, 239$

Lindl. Libr. 209

Linn.Soc. 370

Lownd. 1108

Mass.HS-H 145

Mass.tiS-M 2: 249 a

Milt. 485

Niss. $n .916$

Plesch 105

Pr.ed.1 n.4646

Pr.ed. 2 n.4208

Teyl. 412

Un,Edinb. 2 : 413 (2॰ copy).

Bibliogr.studies: Pley: Biblioth. Arpad Plesoh 105. 1954 [20 copy?]; 3epp, A.: J.Bot.Brit.For. 44: 175-176, 1906; Stafleu, F. A.: Taxonomio literature n.527. 1967.

Variante: a small number of copies were prepared on better and larger paper with folio imposition, the only difference being the width of the margins; uncolored copies were also available (title not checked).

Bijl.notes. Hooker's first book already was beautifully executed, on the pattern of Dillwyn's Britioh Confervae and Turner's Fuoi, but with the plate-numbers added to the text as identifiers.

The production took a long time; preparations began already in 1808 by borrowing specimens from Linnaeus' herbarium. Publication started in 1812 and was regularly continued in monthly fascicles, promptly available on the first day of each month, until April 1813. In this month the first delay occurred, followed by more irregularities. Gepp's dates are extraordinarily wellcome, as they were derived from the files of the publisher firm, which files do not exist any more. I assume that the real date of publication of each fascicle was the first of the month concerned, except for the irregularities as noted in the table.

The watermarks in the plates represent several later pulls of the plates of parts 2-10; apparently a rather small number were printed for these fascicles at pubiication.

Each fascicle contained four plates with the corresponding text. I could not check the conjugacy of the text leaves as thoroughly as I wished since I had no opportunity to see a loosely bound copy.

Bot.noteo. This book may be called a classical treatment of the Hepatioae of GreatBritain, though restricted to one genus, which however included all leafy and a number of thallose Hepaticae, now in the genera Peilia, Blasia and Moerokia. A number of new taxa were described here for the first time. This book is included in this thesis, although it is outside the strict scope of it, because the dates are known so weIl and it set a standard for Hooker's later works, showing clearly the tendency to publish the fascicles on the first day of each month. Moreover it is Hooker's first important bryological work. 
2 líscologia Britannioa ...

London, 1818 (and ed.2, 1827) - See Hooker t Taylor n,1, n,2.

3 Husci Exotici $\ldots$

2 vols. [23 fascicles] London, 1818-1820.

Pitze: "HuBoi Exotioi; | CONTAINING | FIGURES AND DESCRIPTIONS | OF | NEW OR LITTLE KNOWN | FOREIGN MOSSES | AND OTHER | CRYPTOGANIC SUBJECTS. | BY | WILLIAM JACKSON HOOKER, F.R.A. AND L.S. SC. I [2: REGIUS PROFESSOR OF BOTANY IN THE UNIVERSITY OF GLASGOW. | $\bar{j}$ VOL. I. [2: VOL. II ] [short thick-thin rule] | "Quiv autem tale otudium, quo ad aternam omnium rerum oausam l evehimur, tamquam inutile ao contemnendum detreotare ao deprimere l ausit?"-BRIVEL. I [short thin-thick rule] | LONDON: | PRINTED BY RICHARD AND ARTLUR TAYLOR, SHOE LANE: | FOR LONGMAN, HURST, REES, ORME, AND BROWI, I PATERINOSTER-ROW. I [very short rule] | 1818. [2: 1820.j"

Collation: $8^{\circ}$ state: vol.1: $\pi^{4}$ 11-96; i-vi vii-viii, 96 leaves; vol.2: $A^{2} \lambda 97-176$ B-C $C^{8} i-i v, 80$ leaves, $72-3132$ (28-29);

$4^{\circ}$ state: same, except vol.2: $A^{2} \lambda 97-176 \quad B-E^{4}$.

Contente: vol.1: i half-tisle; ii $\square_{;}$iii title; iv $\square$; $v$ dedication to James Brodie $(1744-18 \hat{i} 4)$, Brodie, Elgin, Scotland; vi D; vii-viii index of binomials in vol.1; $\lambda 1-96$ text, descriptions of bryophytes foreign to Great. Britain, versos $\square$ (see Bibl.notes);

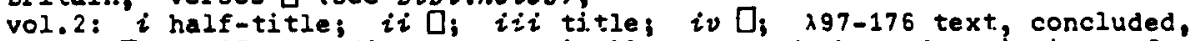
versos $\square$; 1-27 appendix, systematically arranged short descriptions of all species, with corrections and additional remarks; $2 \theta 0$; $29-31$ index of accepted binomials in vols.1-2; 32 errata. RT: book title in small capitals followed by the collector's name (adjectival form) in italics (this name omitted in a number of pages). Language: English with short Latin descriptions,

Flatea: 176 copper-engravings, hand-colored or unsolored, of bryophytes, numbered: "I $a b$. I" - "Tab. CLXXVI."; binomials at the bottom, details with aratic numerals; plate-marks: $165 \times 119 \mathrm{~mm} .(\mathrm{pl} .24), 215 \times 114 \mathrm{~mm} .(\mathrm{pl} .273)$.

Artiot: Hooker, Willian Jackson, the author,

Engravers: Edwards [possibly Sydenham Teast, 1769-1819 Feb. 8, though former engravings for Hooker were done by W.H.C. Edwards]: 146 plates, signed;

Hooker, William Jackson, the author, possibly engraved the remaining 30 unsigned'plates, though his wife could have collaborated (different styles of letters are present); unsigned: 30 plates: 137-152 154-156 158-159 168-176.

Facoiole wrappers: thin green paper wrappers: front wrapper recto with wrapper title; $4^{\circ}$ state: apparently one wrapper (or a (ew) printed for all fascicles, having only the year (no month nor day) and a space for the fascicle number which had to be filled in by hand (according to Dixon); $8^{\circ}$ state: different for each fascicle, with printed fascicle number and day and month before the year (see table); verso of the back wrapper with advertisements, e.g. on fasc. 1 an announcement of Hooker Taylor, liusoologia Britannioa (which see), and an evaluation of the present work, insluding the following statement: "This work is intanded to comprise such Exotic Cryptogamic eubject. : exclusive of the Ferns, es have not been Hoticed, or are imperfectly described, by proceding haturaliets. In those cases where the Author has been favoured by collections of conoiderable extent made by any individual Botanist, they will be distinguished from the miscellaneous collections by an additional running title, as 'Humboldtiani,' 'Wenziesiani," and with a distinct Index; o that they may be bound separately, or incorporated with the rest of the vork, eccording to the option of the possessor," 
Spine labela: spine labels with a modified title are present on HBL copy 2 (George Stabler's copy): "[thick-thin rule] | HOOKER's | MUSCOLOGIA | EXOTICA | Figures and Desoriptions | OF I FOREIGN I MOSSES. Ivery short rule] | 176 Plates | [very short rule] | Two volumES. VOL. I. [2: VOL. II.] | [very short rule] | prioe \& 4.4\%. | [thin-thick rule]", possibly copies with colored plates had other price indications.

Paper: $4^{\circ}$ state: text: leaf height $292 \mathrm{~mm}$. (U copy, cut); wove; wm. (U FH copy): "1816": up to $\lambda 30$;

"1817" and the variant "18 7": $\lambda 33-103$;

"1818": $\lambda 105-176$, B-E;

"1819": $\lambda 137$ (FH' copy);

plate paper: wove; wm.:

"RUSE \&URNERS | 1815.": fasc.3-10, 13-17 (with exceptions);

"RUSE \& TURNERS 1817.": fasc.11;

"TURKeY Mills | J Whatman | 1817": fasc.4 (U copy), fasc.5 (FH copy);

"J Whatman | 1818": fasc.12, fasc.19 (U copy);

"J Whatian | Turkey Mills | 1819 ": fasc.18, fásc.14-16,19-21(FH copy),

"J Whatman | TURKEY MILLS| 1821": pl.175 (U copy);

"J GREEN": fasc.20-21 (partly);

$8^{\circ}$ state: text: leaf height $221 \mathrm{~mm}$ ( (HBL copy 2, trimmed); wove; no wm.; plate paper: woves wm. (HBL copy 1 , presentatión copy of Dawson Turner):

"1808": fasc.1;

"J GREEN | 1814": fasc.2-5, fasc.6(partly);

"J GREEN": fasc.17-19 (partly);

"RUSE \& TURNERS | 1814": fasc.6, pl.46;

"RUSE t TURNERS | 1815": fasc.10, 12-13;

"RUSE TURNERS 1817": fasc.11;

"RUSE \& TURNERS | 1818": fasc.20;

"W TURNERS | 1815": fasc.10 (partly):

"W TuRnERs": fasc.16, 17 (partly).

Note. All watermarks are in outline symbols, and in lower half-sheet.

Printers: Taylor, Richard, and Taylor, Arthur, London.

Publishers: Longman, Hurst, Rees, Orme, and Brown, London.

Dates: vol.1, 1818 :

\begin{tabular}{|c|c|c|c|c|}
\hline fasc. & $\begin{array}{c}\text { text } \\
\text { leaves }\end{array}$ & plates & $\begin{array}{c}\text { wrapper } \\
\text { dates }\end{array}$ & $\begin{array}{l}\text { date } \\
\text { Gepp }\end{array}$ \\
\hline $\begin{array}{r}1 \\
2 \\
3 \\
4 \\
5 \\
6 \\
7 \\
8 \\
9 \\
10 \\
11 \\
12\end{array}$ & $\begin{array}{r}4 \\
8 \\
12 \\
8 \\
8 \\
8 \\
8 \\
8 \\
8 \\
8 \\
8 \\
\pi ?^{8} 8\end{array}$ & $\begin{array}{r}1-4 \\
5-12 \\
13-24 \\
25-32 \\
33-40 \\
41-48 \\
49-56 \\
57-64 \\
65-72 \\
73-80 \\
81-88 \\
89-96\end{array}$ & $\begin{array}{ll}1 & \text { Jan. } \\
1 & \text { Feb. } \\
1 & \text { Mar. } \\
1 & \text { Apr. } \\
1 & \text { May } \\
1 & \text { Jun. } \\
1 & \text { Jul. } \\
1 & \text { Aug. } \\
1 & \text { Sep. } \\
1 & \text { Oct. } \\
1 & \text { Nov. } \\
1 & \text { Dec. }\end{array}$ & $\begin{array}{ll}1 & \text { Jan. } \\
29 & \text { Jan. } \\
28 & \text { Feb. } \\
31 & \text { Mar. } \\
30 & \text { Apr. } \\
30 & \text { May } \\
29 & \text { Jun. } \\
30 & \text { Jul. } \\
29 & \text { Aug. } \\
26 & \text { Sep. } \\
31 & \text { Oct. } \\
28 & \text { Nov. }\end{array}$ \\
\hline
\end{tabular}

vol.2, $1819 \& 1820:$

\begin{tabular}{|c|c|c|c|c|}
\hline Easc. & $\begin{array}{c}\text { text } \\
\text { leaves }\end{array}$ & plates & $\begin{array}{l}\text { wrapper } \\
\text { dates }\end{array}$ & date Gepp \\
\hline $\begin{array}{l}13 \\
14 \\
15 \\
16 \\
17 \\
18 \\
19 \\
20 \\
21\end{array}$ & $\begin{array}{l}8 \\
8 \\
8 \\
8 \\
8 \\
8 \\
8 \\
8 \\
8\end{array}$ & $\begin{array}{r}97-104 \\
105-112 \\
113-120 \\
121-128 \\
129-136 \\
137-144 \\
145-152 \\
153-160 \\
161-168\end{array}$ & $\begin{aligned} 1 & \text { Jan. } \\
1 & \text { Feb. } \\
1 & \text { Mar. } \\
1 & \text { Apr. } \\
1 & \text { May } \\
1 & \text { Jul. } \\
{[1} & \text { Sep.] } \\
1 & \text { Nov. } \\
1 & \text { Dec. }\end{aligned}$ & $\begin{aligned} 1 & \text { Jan. } 1819 \\
1 & \text { Feb. } 1819 \\
27 & \text { Feb. } 1819 \\
31 & \text { Mar. } 1819 \\
1 & \text { May } 1819 \\
29 & \text { Jun. } 1819 \\
31 & \text { Aug.1819 } \\
26 & \text { Oct. } 1819 \\
30 & \text { Nov. } 1819\end{aligned}$ \\
\hline $\begin{array}{c}22 \\
{\left[\begin{array}{ll}2 & 3\end{array}\right]}\end{array}$ & $\begin{array}{c}8 \\
A-C[E]\end{array}$ & $169-176$ & {$\left[\begin{array}{ll}1 & \text { May } \\
1 & \text { May?] }\end{array}\right]$} & $\begin{array}{r}29 \text { Apr. } 1820 \\
1 \text { May } 1820\end{array}$ \\
\hline
\end{tabular}

Wrapper dates here clearly represent exact publication-dates, except, perhaps, for fasc. 23 , which might not have a special wrapper.

Reviews: vol.1: Blaokwood's Edinb. Mag. 2(10): $454.1818 \mathrm{Jan}$. (anncd.);

Brongniart, Ad.: Bull.Gen. Univ.Annono.Soi. (Férussac) $3(9): 424-425.1823 ;$

vol.2: Linnaea 2(4): 676. 1827;

Zlora $13^{2}($ Ergens. Bi.): $18-35,1830$.

Bibliogr. otudies: Gepp, A.: J.Bot.Brit.For. 44: 176-178, 1906;

Dixon, H.N.: J.Bot.Brit.For. 72: 15-17. 1934;

Sayre, G.: Dates of pubi, 56, 61. 1959 ,

Stafleu, F.A.: Taxonomio literature n.529.'1967. 
Refe.: BMNHi 870

Cat.Juss. n. 2308

Graesse 3: 344

Jacks. 153
Kew 286

Krüg. 242

Linn. Soc. 370

Lownd. 1108
Mass, HS-H 245

Mass.HS-11 2: 250

Milt. 485

Nis8. n.925
Pr.ed.1 n.4648

Pr.ed. 2 n. 4210

Teyl. 412

Un.Edinb. 2: 414.

Variante: The $4^{\circ}$ and $8^{\circ}$ states were printed with a different imposition from the same type-pages. I did not study the conjugacy of the lambda-leaves of the $4^{\circ}$ state, since I did not see an uncut copy, but the places of the wm. indicate normal $4^{\circ}$ imposition. The inner margins of this state are markedly wider than those of the $8^{\circ}$ state: about $50 \mathrm{~mm}$. in the former and $30 \mathrm{~mm}$. in the latter. The plates were colored or uncolored; I have no indication of uncolored plates in the $4^{n}$ state. A copy with no watermarks in the platepaper at all (HBL copy 2) apparently represents a later pull of the plates; it belonged to the bryologist George stabler (1839-1910) and was probably bought new at a late date.

Bijl.notes. The arrangement of the plates and text for final binding was left "to the option of the possessor". The fascicles were delivered as folded sheets with the corresponding plates. The first, easy, way was to bind the sheets in this folded position with the plates at the end of the volume. A second way was to place the plates within these sheets facing the leaves with the corresponding descriptions (lambda-leaves); this results in alternate pairs of lambda-leaves and pairs of plates, the blank sides of each pair coming together. A third way, which I saw in several copies, was to separate the leaves of the folded sheets and to place all text-leaves with the text as rectos and all plates facing the corresponding text. I consider this form to represent the ideal copy, as described in the collational formula. A fourth method was to bind the separated text leaves and the facing plates in a systematical order, e.g. that of the appendix. This was done in the copy of Stabler (HBL copy 2). A last possibility was, as indicated by the author, an arrangement of the leaves in groups of species collected by one collector; for this purpose the coljectors names were already mentioned in the running title. I have not seen a copy with this arrangement.

The distribution of text and plates over the 23 fascicles had not been worked out to the last detail by previous authors (Gepp, Dixon, Sayre).

During Dr. Sayre's research I expressed my opinion to her that the later parts had equal numbers of plates, which was a supposition only. After the bibliographical analysis I can now confirm this opinion with the following facts. (1) The text of the $8^{\circ}$ state was printed on complete sheets (except for fasc.1, a half-sheet only, and fasc.3, one sheet and a half), and a complete sheet had 8 text leaves. I carefuliy checked the edges of the slightly trimmed Stabled copy, and differences in protruding or slightly tilted leaves. In this way I am certain of complete sheets in fasc.2, 4, 7, 11-15, $19,21$. (2) The offsets of the printed text on the plates of some copies is heavy in all plates of one fascicle (copy of Dawson Turner, tiBL copy $1, \mathrm{fasc}, 6,7,21$ ) or weaker but clearly visible (fasc.5, 8, 20, and the even numbered plates of fasc.11).

(3) The signature of the engraver is consistently present on the plates of fasc.1-17, and not on those of fasc.18-19. This indicates the break between fasc.17 and 18. It is probably connected with the death of the engraver on 8 Feb. 1819 and could be explained by supposing that he had sent out the plates for fasc.17 and that his other engravings were not directly released or anyway rot used before fasc. 20 .

(4) The watermarks in the plates confirm these conclusions. Additional confirmation for the contents of fasc. 1 is that its plates are ancolored or partly colored in the Dawson Turner copy (all other plates are fuliy colored) and that the text sertainly was printed on alf-sheet.

I have no reason to doubt the regular make-up of those gatherings which I was not able to check definitely.

The dates on the wrappers were given by Dixon for most wreppers. I saw wrappers of the fascicles of vol.1 in the Rijksherbarium copy, Leiden. These dates are in a very precise way confirmed by Gepp, who stated the days on which the publisher received the material from the printer. These dates are usually a few clays before, or exactly the date printed on the wrafper. 
The date on the wrapper of fasc.19 has not been reported. In my opinion it is safe to assume regular intervals and to assign the date 1 Sep. 1819 to this fascicle. No wrapper of the final fascicle 23 is known to us, and here the date reported by Gepp is the only source. It is reliable enough, and fulfills the main requirement for effective publication of the Botanical code: cories were available for sale on that date.

It is remarkable how precise the publication of the fascicles was as to dates. This means that there must have been a considerable planning. The disturbance in the monthly sequence after fasc.17 was probably connected with the death of the engraver Edwards. Two months intervals followed until fasc.20; fasc. 21 was issued one month later, 1 Dec. 1819, and the last two fascicles, 22 and 23 , only on 1 llay 1820 .

Hooker had more material and certainly planned a third volume, but this was not realized. Apparently as a Glasgow professor his attention was taken up by other fields.

Bot.notes. Hooker thoroughly described and figured 175 species of mosses and liver. worts from different parts of the world, contributed by a number of his correspondents, e.g. Humboldt, Gardner, Menzies and R. Erown. A large number of the species were new, representing singular bryophytes, which were later segregated into several new genera. In the Appendiz (fasc.23) new names were proposed too.

The new genus Drepanophyllum was proposed in the text to pl.145. The description was marked: "Riohard in $l_{i t}$." ", a note was added that the deseription had been made from fresh specimens in its native country (French Guiana). This concerned Louis Claude Marie Richard (1754 Sep. - 1821 Jun.), as is evident from a letter from Arnott to Ad. Brongniart: Arnott wrote that he had asked Achille Richard for specimens of Drepanophyliun of Richard's father, but had not received any answer. The description and the plate characterize the genus perfectly. However, by a small detail the name is invalid in this place, according to the letter of the International Code of Botanical Nomenclature. Technically the description is a specific description only, because the genus, though monotypic, was not based on a new species, since the synonym Dioranum faloifolium was included, in turn based on $B$ isoidenu falcifolius Schwaegrichen 1816 (cited in the text to pl.82).

In the Appendix (fasc. 23) Hooker maintained the name Drepanophy $2 l_{u m}\left(p_{0} 3\right.$ ) and made for the generic description an explicit reference: "For the very imperfect character of this Genus, sea Description to TAB.CXLV." This is a good reference, but the Code requires a reference to a generic description. Therefore the genus is published invalidly in the second place too.

4 Flora scotica $\ldots$

1 vol. in 2 parts. Edinburgh \& London, 1821.

Titze: "FLORA SCOTICA; | OR | A DESCRIPTION | OF | SCOTTISH PLANTS, | ARRANGED I BOTH ACCORDING TO THE ARTIFICIAL AND NATURAL I METHODS. I IN TWO PARTS. I BY WILLIAM JACKSON HOOKER, LL.D. F.R.A. AND L.S., MEMBER OF THE WERN. SOC. OF EDINB., OF THE IMP. ACAD. I NATURE CURIOSORUM, OF THE ROYAL BOT . SOC. OF RATISBON, OF | THE HELVETIC SOC. OF NAT. HIST., ETC. | AND REGIUS PROFESSOR OF BOTANY IN THE UNIVERSITY OF GLASGOW. I [short swelled rule] | London: [in gothic] I PRINTED BY RICHARD AND ARTHUR TAYLOR, SHOF-LANE, FOR ARCHIBALD CCISTARLE AND CO., EDINBURGH; AND | HURST, ROBINSON, AND CO., CHEAPSIDE, LONDON. | [very short rule] | 1821."

Collation: $8^{\circ}: a^{4} \quad b^{2} \quad B-T^{8} \quad U-X^{2} \quad{ }^{2} A-T^{8}$ (\$1-2 signed, second alphabet in square brackets); $i-v$ vi-x $x i-x i i$ (vii) [part 1:] 1 2-292 293-296 (163) [part 2:] $1-3 \quad 4-297$ 298-304 (2: 28 as ' 8 '). 
Contento: i half-title; ii D; iii title; iv D; v-vi dedication to James [Graham, 3d] Duke of Montruse $(1755-1836)$, chancellor of the University of Glasgow, dated 10 April 1821; vii-x preface, dated 10 April 1821 ; $x i$ part-title for part 1 ; xi Di $_{\text {; }}$

part 1: 1-292 text, descriptions of genera and species of Scottish plants in the Linnaean classes 1-23 (Phanerogams) with habitats and localities; 293-296 ir.dex of the reneric names in part 1 ;

part 2: . 1 part-title for part 2; $20 ; 3-297$ text, descriptions of natural classes, orders, genera and species of Scottish plants of all groups, cryptogams with habitats and localities, phanerogans with references to part 1, ending with 3 genera "of which the situation is uncertain."; 288-303 index of generic names in part 23 304 imprint. RT: part 1: abbreviated names of Linnaean classes and orders; part 2: full names of class, order and genus. Language: English.

Paper: leaf height $228 \mathrm{~mm}$. (U copy, slightly trimned); wove; no wm. Printere: Taylor, Richard, and Taylor, Arthur, London.

Publiahere: Archibald Constable Co., Edinburgh; Hurst, Robinson Co., London.

Collaborators: Lindley, John (1799-1865), botanist and horticulturist, collaborated with Hooker in drawing uf the descriptions, "characters", of the natural orders, Aootyzedones excepted: "where no name is cited we mut be considered * wholly responible" (preface, $p, x$, foctnote);

Greville, Robert Kaye (which see): "devoted a large portion of his time to the tudy of the minuter Fungi, ...";

Brown, Robert (which see): occasional information on natural plant groups, especially a note on a particular character of Cieteae (p.284, and footnote).

Date: 1821 (t.-p.); after 10 Apr. (preface and dedication); on or bef. 10 llay (llonthl,Lit.Aciv. fide Sayre).

Reviews and arnounoemente:

J.G\&n.Litt.Etr. (Jun. 10);

Blaakwood's Edinb. Hag. o (51): 356. 1821 Jun,;

Ann.Phil. n.ser. 1(6): 471. 1821 Jun. (just publ.);

Edinb.Phil.J. 6(11): 145-156. 1822 (rev.);

Buiz.Gen.Univ.Annona. Nouv.Sai. 1823 (3) (rev.).

Bibliogr.otudies: Rogers, D.P.: Hyoologia 43: 378, 1051;

Sayre, G.: Dates of pubz. 66. 1959;

Stafleu, F.A.: Taxonomic literature n.530. 1967.

Refo.: BIIIH 871

Brad1.1: $397 a$

Brun.3: 3C1

Cat.Juss. n.1797

\begin{tabular}{|c|c|}
\hline $\begin{array}{l}\text { Graesse 3: } 344 \\
\text { Jacks } 246 \\
\text { Kek 286 } \\
\text { Lindl.Libr. } 209\end{array}$ & $\begin{array}{l}\text { Linn.Soc. } 371 \\
\text { Lownd. } 1108 \text { a } \\
\text { liass.HS-H } 145 \\
\text { lass.HS-11 2: } 249\end{array}$ \\
\hline
\end{tabular}

Mi.lt. 138

Pr.ed. $1 \mathrm{n} .4649$

Pr.ed. 2 n. 4212

Un.Edinb.2: 414 .

Bibl.notes. The make-up indicates a shift to two parts after the beginning of printing. In the first place the part-title of part 1 was printed as a part of the preliminaries at the end of the whole work. Secondly the printer had reserved the signature $A$ for the preliminaries of part 1 , and finally used the lower case "b" when a quarter-sheet was necessary. "The index of part 1 might be another indication, being printed on a separate quarter-sheat, where the text already ended with a quarter-sheet. What probably happened was that Hooker, with his knowledge of cryptogams in general and of bryophytes in particujar, wanted to shift to the natural classification when he came to elaborate the 24 th class of Linnaeus. Then, extending tinis to a treatment of the natural classification throughout, it was made a separate part with a new pagination and a new alphabet of signatures.

The preliminaries were not printed on one sheet with gathering $x$, as would seem likely; the torn edges of the $U$ copy do not match. 
Bot.notes. This book is a result of hicker's remarkable capacity for work, since he must have begun this book after or about the time of his nomination as professor of botany at the Glasgow University, 1820. In a handy form it gives a complete survey of Scotland's flora as known at the time. The treatment is clear, and the second volume with the natural arrangement certainly added to its usefulness.

The nomenclature of mosses was in accordance with that used in the ifusoologia Britanniaa by Hooker and Taylor; therefore the number of new names in $H u s o i$ is not high. The Bungi were arranged according to Persoon's Synopsis methodum Fungorum; the Liohenes according to Acharius' Synopsis methodioa Liahenum.

There were no keys, as earlier introduced in France by De Lamarck. Also lacking were author-citations for the Latin names of genera and species; the books cited only gave information about Scottish localities.

A second edition was planned: Edinb.J.Soi. 1(2): 367 . 1824 Oct., but was not realized.

5 Eungi, ... Lichenes, ... Hepatiaae, ... Musoi, ...

In: Kunth, C.S.: Synopois plantarum Equinootialium Orbis novi 1: 7-65.

Collation: $8^{\circ}: 1_{4} \mathrm{r}-5, \mathrm{r} ; 7-65$ (see Kunth n.1). Paris-Strasburg, 1822.

Contenta: 7-13 descriptions of fungi, headed: "FUNGI, PERSOON"; 14-39 descriptions of lichens, headed: "LICHEIS.S, ACHAR,"; 40-45 descriptions of hepatics, headed: "HEPATICF, JUSS."; 46-65 descriptions of mosses, headed: "MUSCI, JUSS.". Jo RT. Language: Latin.

Date: 1822 Dec. 9 (see Kunth n.1).

Bot.notes. Hooker prepared the text for the groups of South- and Central American Cryptogamae mentioned above. The majority of the mosses already were described in his lifus oi exotioi or in other publications; 10 species were new; 1 was transferred to another genus, and 2 varieties were included, which, in my opinion, do not have a description.

Exotio flora ...

3 vols. [in 38 fascicles] Edinburgh-London, [1822]1823-1827.

Titze日: "EXOTIC FLORA, | CONTAINING | FIGURES AND DESCRIPTIONS | OF | NEW, RARE, OR OTHERWISE INTERESTING | Exotic Plants, [line in gothic, except in vol.3] ESPECIALLY OF SUCH AS ARE DESERVING OF BEING | CULTIVATED IN OUR GARDENS; TOGETHER WITH | REHARKS UPON THEIR GENERIC AND SPECIFIC CHARACTERS, NATURAL | ORDERS, HISTORY, CULTURE, TIME OF FLOWERING, \&. | [ rule] ] BY | WILLIAM JACKSON HOOKER, I LL.D. F.R.A, L.S. I MEMBER OF THE IMPERIAL ACADEMY NATURE CURIOSORUM; OF THE WERNERIAN i NATURAL HISTORY SOCIETY OF EDINBURGH; OF THE GEOLOGICAL AND HORTI-|CULTURAL SOCIETIES OF LONDON; OF THE ROYAL BOTANIC SOCIETY OF RATIS-|BON; OF THE HELVETIC SOCIETY OF NATURAL HISTORY; OF THE PHYSIOGRA-|PHICAL SOCIETY OF LUND; OF THE PHILOSOPHICAL SOCIETIES OF CAMBRIDGE, | AND YORK; OF THE ACADEMY OF NATURAL SCIENCES OF PHILADELPHIA, \&o. Bo. [2-3: AND YORK; OF THE ACADEMY OF NATURAL SCIENCES OF PHILADELPHIA, HONO-|RARY IIEMBER OF THE ROYAL IRISH ACADEITY; OF THE LYCEUM OF NATURAL | HISTORY OF IEW YORK, \&o, \&o.] | AND I REGIUS PROFESSOR OF BOTANY IN THE UNIVERSITY OF GLASGOW. | [ruIe] | VOL. I. [2: VOL. II.] [3: VOL. III.] EDINBURGH: | PRINTED FOR WILLIAM BLACKWOOD, EDINBURGH; | AND T. CADELL, LONDON. I [short rule] | MDCCCXXIII. [2: MDCCCXXV. ] 3: MDCCCXXVII.]"

Colzation: $8^{\circ}$ in 48: vol.1: $\pi^{1} 2 \pi^{4}$ A-L $x^{1} \quad M-P^{4}\left(-P_{4}\right){ }^{2} A-C^{4} 2 x^{4}$ (A $A_{1}$ unsigned, $A_{3}$ as ' $A$ ', $F_{4}$ in some copies as ' $D$ ', $X_{1}$ as ' $M$ ') ' I-II i-iv v-vii viii, 76 leaves: $\lambda 1-2 \quad \lambda 3 / 4 \quad \lambda 5-40 \quad \lambda 41 / 42 \quad \lambda 43-46 \quad \lambda 47 / 48 \quad \lambda 49-79$ vol.2: $\pi-3 \pi^{2} \lambda 80-89 \lambda 90 / 91 \quad \lambda 92-150 \quad \lambda 151+1 \quad \lambda 152+1 \quad \lambda 153-154 ; \quad i-x i i$, $76 \lambda$-ieaves (see $\lambda 80-154)$; vol.3: $\pi^{4} \lambda 155 / 156+2$ i157-163 $\lambda 163^{*} \lambda 164-232 ; \quad i-i i i$ iv-viii (v), $80 \lambda$-leaves (see $\lambda 155-232$ ); (errata slip to $\lambda 75$ in HBL copy). 
Contents: vol.1: I half-title; II D; $i$ title; ii imprint; iii dedication to Charles Lyell (1767-1849), dated 1 Nov. 1823; iv $D_{;} v$-vi index of Latin plant names; vii index of English plant names; viii $D_{\text {; }} \lambda 1-79$ text, descriptions of the plants figured, and explanation of the plates, versos 0 : $\lambda 22,23,63 ;$ vol.2: "i half-title; ii 0; iii title; iv imprint; $v$-vii irdex of Latin plant names in fasc.1-21 (pls.1-154); viii 0 ; $i x-x$ index of Latin plant names in fasc.6-21 (pls.80-154), xi-xii index of English plant names in fasc.6-21; $\lambda 80-154$ text, versos $L$ : $\lambda 135,137,141,146$; vol.3: i title; ii imprint; iii-iv index of English plant names in fasc. 22-38 (pls.155-232); v-viii index of Latin plant names in vol.1-3; $\lambda 155-232$ text, versos $\square$ : $\lambda 164,165,169,172,223,231$. NO RT. Language: English, with short Latin descriptions of plants.

Plates: 233 hand-colored or uncolored copper-engravings, numbered $1-163^{163^{\text {t* }}}$ 164-232; names Latin binomials or (in the few varieties) trinomials; plate-maris: $224 \times 134 \mathrm{~mm}$. ( $\mathrm{pl} .3$ ), $321 \times 244 \mathrm{~mm}$. (pl.190) (most plates somewhat trimned in HBL copy; larger dimensions may be present); 23 plates are double (folded in the middle) and 5 are folded in another way (his copy; these numbers may vary in other copies); bound-in folded narrow stub-like strips correct the thickness of the volumes.

Artists: 1) Hooker, William Jackson, the author: probably all plates not definitely assigned to another artist, and moreover some detail figures on plates by other artists; in the text Hooker explicitly states his responsibility for some plates;

2) Colebrooke, Henry Thomas (1765-1837), Chief Judge, Bengal (biogr.: LanePoole, S.: Diot.diati.Biogr. 11: 282-286. 1887): pls.135, 136, 137, unsignec;

3) Duncombe, [Mr.], working at Bury Hill, Surrey, apparently for Robert Barclay: pls.166, 188 , unsigned;

4) Greville, Robert Kaye (which see): pls.73, 75, 79, 86, 88, 105, 118, 150, $168,195,209,210,211,216,219,222$ (except probabiy details in some pls.); all signed except pl.88;

5) Guilding, Revd. Lansdoune [Lansdown in Britten Boulger], (1797-1831), colonial chaplain, St.Vincent (biogr.: Britten Boulger, BIBIB ed.2: 133 . 1931.): pls.155, 156 and unsigned 167, "a coloured drawing was sent"; 6) Harrison, Mrs. Arnold, from Aegsburgh, Liverpool (biogr.: Britten Boulger, BIBIB ed.2: 140.1931.): pl.120, signed;

7) Lindley, John (1799-1865), botanist and horticulturist (biogr.: Boulger, G.S.: Diot.llat, Biogr. 37: 258, 1894.): pls.123, 132(except the later added leaf), 134,139 , all signed;

8) Menzies, Archibald (1754-1842), English explorer, botanist: pls.193, 194;

9) Richard (Louis Claude Marie?, 1754-1821; biogr.: Mem.Mus. Hist. Soc. Paris 11:215-229, 1824): pl.21, only the dissections of the fruj.t, "copied [by W.J. Hooker] from the beautiful drawings of Richard in Humboldt Kunth'. Hov. Gen. et Sp. Plant.",

10) Syme, Patrick (1774-1845), Scotland (biogr.: O'Donoghue, F.M.: Diot.ilat . Biogr. 19: 268. 1898.): part of pl.87, unsigned;

11) Telfair, Annabella (Mrs. Charles) (d.1832, biogr.: Britten Boulger, BIBIB ed.2: 297, 1931.): pls.192, 203, or at least plates prepared with the aid of her drawings.

Engravers: Swan, J., Glasgow, (fl, 1822-30): 234 plates, signed; Hooker, William Jackson, the author: probably the 9 unsigned plates: 20, 22-24, $26,28,38,47,48$, and additional details on other plates, e.8. the leaf on pl.132 which was added during printing of the plate, or the specific epithet on pl.37 which was changed from rigida into teliata by Hooker himself, if the text may be taken literally, possibly his wife helped him with engraving. 
Paper: leaf height $246 \mathrm{~mm}$. (HBL copy, slightly trimmed); wove; wm.: "A C | 1821 " in lower middle of half-sheet, to be found throughout all three volumes; unsarked sheets may have been used too but this is not certain since in half-sheets the wm. will show at randor; plate paper: wove; wm.: "J Whatilai | TuRkey MILl | 1822" throughout the three volumes, except for an occasional plate with the same wm. as has the text paper: "A C | 1821" (pl.14 in the copy of the University of California). Apparently much later more copies of the plates were printed, as is indicated by the wm. (hiBL copy): "J WHATiLAN | 1861", plates 39 and up: plates up to 31 have the same wm. as has the text.

All watermarks mentioned here are mainly in outline.

Faociole titles: no wrappers seen, only offsets from the fascicle-title and versos. The fascicle-titles had a frame of very thick black rules around the text, which was similar to the text of the volume-titles, but with the fascicle indication "PART" and the number in a Roman numeral; the bottom line had the printed year without month; the verso containes an announcement concerning a work planned by Hooker (some fascicles).

Printer: Neill, Patrick, Edinburgh (see Greville n.5).

Publishers: Blackwood, William (1776-1834), Edinburgh (biogr.: Espinasse, F.: Cade11. Thomas (the younger) (1773-1836), London (biogr.: Lee, S.L.: Diot. Nati.Biogr. 8: 179: 1886 .

Collaborators: descriptions of plants were furnished by: Colebrooke, Henry Thomas (see Axtisto): $\lambda 136,137,146$;

Graham, Robert (1786-1845), professor of botany, Edinburgh: $\lambda 86,168,209$, $210,211,222$ (no new species);

Lindley, John (see Artiste) $\lambda 115,123,132,139 ; 134$ (this not a new species). and the generic name Pholidota Lindley ex W.J. Hooker, but not its description: $\lambda 138$;

some plant names were cited from other collaborators, not their descriptions, e.g. Bowie, James (ca, 1789-1869): $\lambda 227$; according to the Code this name should be cited Didymooarpus raxii Bowie ex W.J. Hooker;

many other persons were duly acknowledged who had sent plants and seeds from overseas to Great-Britain, or who had put at Hooker's disposal plants from their gardens and stoves.

Dates: see table next page.

Reviews and announcements:

fasc, 1: Edinb.Phil.J. 7(14): 395-396. 1822 Oct.;

fasc. 2: Elinb.Phil.J. $8(16): 405-407$ 1823;

fasc. 3: Blackwood's Edinb.Mag. 13(75): 489-490.1823;

fasc. 4: Blackwood's Edinb.ilag. 13(76): 618. 1823 (as from May);

fasc. 5: Phiz.ifag.J. 61: 463. 1823 (facc. appeared firet of this month),

fasc.12-13: Edino.J.soi. 1(2): 365.1824 oct.;

fasc. 15: Blzarwood'e Edinb.ilag. 16(92): 355. 1824 (anncd. Sep.);

fasc. 6-15: Flora 82(Erganz.Bi.): 24-44. 1825 sem.2 (vol.1 $\pi$ with fasc.6);

fasc.14-16: Edini.J.Soi. 2(1): 167-168. $1825 \mathrm{Jan}$. (with additional note);

fasc. 17: Edini).J.Soi. 2(2): 355. 1825 Apr.i

fasc.19-20: Edinb.J.Soi. 3(2): 367. Oct.;

fasc.19-24: BulZ.Soi. Nat. 7(1):77-80.1826;

fasc. 1-29: Loudon Gard.uag. 1(1): 47: 1826 (as from "1823"-"1826");

fasc.25-34: Bulz.Sci.Nat. $10(1): 96-99.1827$ Jan.;

fasc.35-38: BulZ,Soi.ilat, 14(5): 92-93. 1828 May;

fasc.37-38: Edino.J.Soi. 6(1): 186. 1827 Jan.

Bibliogr. otudies:

Stearn \&.Steenis-Kruseman: Rl.Males, ger.1, 4(5): CLXXXVIII. 1954;

Stafleu, F.A.: Taxonomio i iterature n.532. 1967 . 
Dates and contents of fasoiolea:

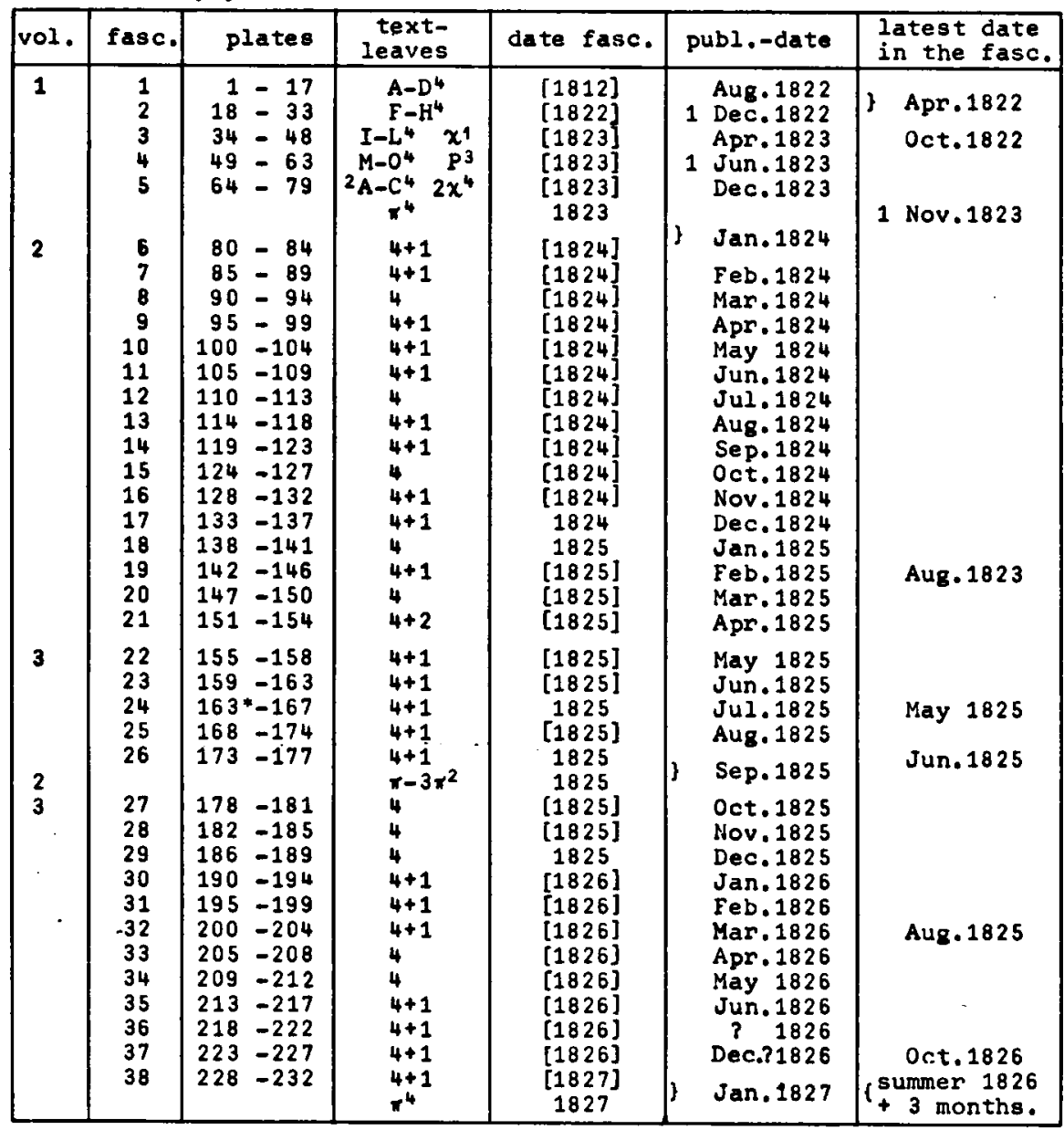

The dates on the fascicles are inferred, or derived from other sources ("1812", a misprint), when in brackets; the others I saw on offsets from fascicle-titles unless they are the dates of the volume titles ( $\pi^{\prime} s$ ). The publication dates are the intended dates, as far as I could ascertain from iiterature; the announcements in Blackwood's Edinb. Uag. are interpreted as pre-publication announcements of the publisher, unless they are the only dates available. The real publication may have been delayed beyond the dates given, especially of the later fascicles (see Reviews). The first two fascicles apparently had been delayed tco; the month August of the first fascicle has been derived from Dr. Stearn's list in van Steenis-Kruseman, Flora lualesiana; our first review is ciated Uctober. In some cases the latest dates in the fascicles have a bearing on the dates of publication, indicating that these are later. The numeral 4 in the text column indicates a gathering of 4 leaves.

Reviaws and announcemonts: see foregoing page. 
Refs.: Arn.Arb.2: 350 BMNH 871 Bradl.1: 267a Brun. 3: 302 Cat.Juss. n. 1550
Dunth. 209

E.As, Bot. 191

Graesse 3: 344

Lindl.Libr. 209
Linn. Soc. 371
Lownd. 1108
Niss. n.920
Plesch 105
Pr.ed.1 1.4651

Pr.ed. 2 n. 4215

Sitw.Blunt 60

Teyl. 359

Un.Edinb.2: 414 .

Variants. The half-sheet imposition allowed a large-paper $4^{\circ}$ state with only slight reimposition, but I have not seen any reference. Available with uncolored plates at reduced prices. Plate 132 of Chrysiphiala pauoiflora had a stoppress additional engraving of a leaf on the plant, which Hooker had received too late to include before printing; it turns up at random in different copies and is present in the HBL copy and in a copy in NYBG. The error 1812 on the wrapper of fasc.1 was possibly corrected during printing.

Bijl.notes. The three volumes were published in 38 fascicles with very unequal contents. Dr. Stearn established the distribution of plates and text over the first 17 fascicles. I was able to ascertain the contents of the remainder by studying the matching watermarks and deckle-edges of the gathering leaves of the HBL copy, and conjugate leaves in NYBG copy 1 , and by checking other copies (Univ.Calif.copy, NYBG). There has been confusion about the contents of the three volumes, since the plans had changed. The gatherings signed with the second alphabet $A-C$ in vol. 1 was destined to form the first part of vol.2, but the second I of the Roman numeral of the volume indication in the direction-line was erased; the next gathering $x$ had the correct indication of vol.1 printed without change, the text-leaf to pl.80 had "VOL. II" but the leaf to pl.81 by mistake "VOL. I". The end of vol.2 again was a source of confusion. The indexes for this volume only include names up to $\mathrm{pl} .154$. The text-leaves to pls.155-163 still have the indication "VOL. II" in the direction-line on every recto; the preliminaries, finally, were issued with fasc.26. This explains the different copies with different breaks between vol.2 and 3 ; it was a matter of chance which of these three breaks came to the attention of the binder or the person instructing him. The collation given here represents the ideal copy as finally intended by the publisher.

The unsigned leaves with indexes could be bound at the end, or in another arrangement. I am convinced that the preliminaries were printed in half-sheet imposition too. The HBL copy has an errata-slip to $\lambda 75$, which probably was issued with a later fascicle.

The offsets discussed under Fasciole titles are present in the HBL copy obviously because it was stored in sheet-form for a long time: the plates of this copy have a much later watermark, with the date 1861, indicating a very late pull of the plates. In the other copies I examined 1 either did not find these offsets so well marked, or not at all. The copy of the Univ. of California has a few offsets. They are mainly to be seen on the last page of a fascicle, and sometimes on the first leaf. I considered the possibility that the fascicle title was printed on a leaf conjugate with the last single leaf of the fascicle of 5 leaves, forming a wrap-around, though this would have been an exception to the usage of having cheaper paper for the wrappers. The preliminaries of vol.1 were issued with fasc.6 (Flora $8^{2}$ (Ergän. BZ.): 24. 1825).

Bot.notes. This important work reflects the extent of active plant introduction into Great-Britain, and Hooker's part in it. Many of the plates represent new species; some new genera and varieties are included. The English descriptions are ample and the notes give interesting details, of ten including the history of the introduction of the plants in Great-Britain. The drawings are meticulously prepared and executed. Some of the names were changed in the indexes, e.g. Alstroemeria tricolor Hooker, pl.65, into A. pulohra Sims (index vol.1: v) and Caloeolaria paralia Cavanilies, pl.75, into C. corymbora Cavanilles (already on the correction slip, probably issued with the same fascicle); the generic name Stelis is correct on the plate (185) and in the indexes, but misprinted $s$ tetis in the text.

Some mosses are mentioned incidentally as companions in the natural habitat of some species. This might be an excuse, if one is needed, to treat this interesting work here. I especially thank my colleague D.E. Kalk for letting me take over the description of this title when he was studying it and $I$ realized the problems it offered. 
HOOKER, William Jackson GREVILLE, Robert Kaye

1 Sketon of ... the genera Orthotriohum, ... Glyphomitrion, and zygodon. Edinburgh J. Sci. 1(1): 110-133. pls. 4-6. 1824 July.

Head-title: "ART.XXIII.-sketch of the Characters of the species of I Hoses belonging to the Genera orthotriohum, (inoluding | Schlotheimia, idioromitrion ana viota, GLyphomitrion, and | zygodon. By W.J.HookER, LL.D. F.R.S. \&c. \&c. Re-lgius Professor of Botany in the University of Glasgow; and $\mid R . K . G R E V I L L E, ~ L L . D$. F.R.S.E. \&c. \&c. with three Plates. I Communicated by the Authors."

Collation: $8^{\circ}$ : $\mathrm{H}_{7} \mathrm{v}-\mathrm{K}_{3} \mathrm{r}$; $110-133$.

Contents: 110 head-title; 110-111 introduction; 111-133 text, descriptions of the genera Orthotriohum (111) with 59 species, Glyphomitrion (130) with 1 species and $2 y g o d o n$ (132) with 2 species.

Plates: 3 copper-engravings of moss species, numbered: "PLATE IV." - "PLATE VI." , with 8 figures each; plate-marks cut off in copies examined (Library Trinity College, Dublin; UB Utr.).

Artists: plates unsigned.

Engraver: Swan, J., Glasgow (pls. signed).

Paper: leaf height $219 \mathrm{~mm}$. (copy UB Utr., cut); wove; no wm.

Printers: A. Balfour \& Co.. Edinburgh (t.-p. vol.).

Date: $1824 \mathrm{Jul}$. (issue dated; each gathering having date in the direction-line of the first page); after $7 \mathrm{Jun}$. (date of preface to the periodical fascicle); probably 1 Jul. 1824 (fascicle contains astronomical table for 1 Jul. - 1 0ct.)

Refo.: RSC 3: 424 Flora 8(20): 317-318, 1825 llay 28.

Nota. Monograph of a group of three related genera, with a number of new species and new combinations. Probably existing as a separate, but not seen.

2 On the genus Tortula...

Edinburgh J.Sci. 1(2): 287-302, pl. 12. 1824 oct.

Head-titie: "AR'I.XIII.-On the Genus TORTULA, of the Order MUSCI. I By W. J,HOOKER, LL.D. and F.R.S. and F.L.S.; and | R.K.GBEVILLE, LL.D., F.R.S.E. BC. Communi-l cated by the Authors."

Collation: $8^{\circ}: U_{6}-X_{5} ; 287-302$.

Contents: 287 head-title and introduction; 288-302 text, descriptions of the genus Tortula with 37 species and a number of varieties.

Plate: 1 copper-engraving of species of Tortula, numbered: "XII"; plate-mark: $213 \times$ about $133 \mathrm{~mm}$.

Artist: Greville, R.K., co-author (which see).

Engraver: Swan, J., Glasgow.

Paper: leaf height $219 \mathrm{~mm}$. (copy UB Utr., cut); wove; no wm. Printers: A. Balfour \& Co., Edinburgh.

Date: 1824 Oct. (issue dated); probably 1 Oct. 1824 (astron. table 1 0ct. -1 Jan.). Refe.: RSC $3: 424$ Flora $8(20)$ : 318.1825 May 28.

Hotes. Monograph of the genus rortula Hedwig, Huoi, in a wide concept, including Barbula Hedwig (and some modern segregates). 37 species are described, and a number of varieties, not all with varietal epithets. A considerable number of new combinations are present, insofar as they had not been made earlier by Hooker, and five new species were proposed. The text refers to plate "XI" as well as to "XII". However, all figures were united in pl.12, and pl.11 belongs to another article. The assistance of G.A. Walker Arnott (which see) concerning species of Bridel was acknowledged. Possibly a separate was prepared, but I did not find an indication. 
On the genis Hookeria of smiti ....

Edinburgh J. Sci. 2(2): 221-236. pl. 5. 1825 Apr.

Eead-titie: "ART.IX.-On the Genus Hookeria of Smith, of the or-lder Husoi. By W.J. HOOKER, LL.D. F.R.S. \&C. \&C. I Regius Professor of Botany of the University of Glasgow, $\mid$ and R.K.GREVILLE, LL.D. F.R.S.E. E. C. Com-l municated by the Authors."

Collation: $8^{\circ}: \mathrm{P}_{7}-\mathrm{Q}_{6} ; 221-236$.

Contente: 221 head-title; 221-236 text, Latin description of the genus Bookeria (221), discussion, including the remark: The wel1-known mos: Hypaum lucens is to be considered the type of the genus. (221-225), and descriptions of 35 species of Hookeria (225-236). RI: author names and title of article over two pages.

Plate: 1 copper-engraving, figuring 12 species of Hookeria (some by leaves only); plate-marks cut off in copies seen; number cut off?

Artiut: Greville, R.K., co-author (which see).

Engraver: Swan, J., Glasgow.

Paper: leaf height $219 \mathrm{~mm}$. (copy UB Utr., cut); wove; no wm.

Printe:: Stark, John, Edinburgh.

Date: 1825 Apr. (issue dated), probably 1 Apr. (astron. table for 1 Apr.-1 Jul.). Ref.: RSC 3: 424 .

Wote. Monograph of the genus Hookeria J.E.Smith, Husoi, with the description of a considerable number of new species from the tropics, and 5 dubious species, apparently not seen by the authors.

4 On the genus Hookeria of Smith of the order Musoi. Edinburgh, 1825 [separate].

Head-title: not transcribed; not essentially different from the article in the periodical, but probably reset, without the article number.

Collation: $8^{\circ}: 1^{8} ; 12-16$.

Contente: 7 head-title; 1-16 text, description of the genus ( 1 ), discussion of its history $(1-5)$, and description of 35 species $(5-16)$, of which 5 dubious (15-16). RT: author names and title of article over two pages. Language: English, with Latin descriptions (phrases).

Plate: 1 copper-engraving of 12 species of the genus Hookeria, unnumbered (at least in trimmed copy of NYBG), generic name at the top, specific names below each figure in italics; plate-mark not measured (copy cut).

Artist, engraver and printer: see periodical article.

Paper: leaf height $209 \mathrm{~mm}$. (NYBG copy, cut); wove; no wm.; plate paper: wove; no wm. (NYBG copy).

Date: 1824, about April (date of issue of periodical), possibly a pre-publication issue, if the plate number really is missing (this would prove an earlier printing of the plate, not necessarily an earlier publication).

Hote: see n.3. 
5 On the genus Calymperes of Swartz and Syrriopodon of scinwagrionen ... Edinburgh J. Sci. 3(2): 218-227. 1825 0ct.

Head-title: "ART.IV.-On the Genus Calymperes of Swartz and syrino-lpodon of Sohwaegrionen, of the order isusoi. By W.J.|HoOKER, LL.D. F.R.S. \&C. \&C. Regius Professor of Bo-ltany in the University of Glasgow, and R.K.GREVILLE, I LL.D. F.R.S.E. \&C. \&C. Communicated by the Authors."

Colzation: $8^{\circ}$ : $\mathrm{O}_{5} \mathrm{~V}-\mathrm{P}_{2} \mathrm{r} ; 218-227$.

Contents: 218 head-title; 218-221 introduction; 221-227 text, descriptions of the

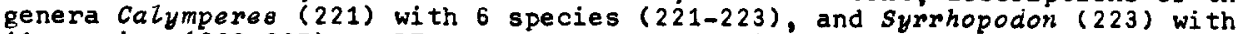
11 species (223-227). RT: author names and titie of article over two pages.

Paper: leat height $219 \mathrm{~mm}$. (copy UB Utr., cut); wove; no wm.

Printer: Stark, John, Edinburgh.

Date: 1825 0ct. (issue dated); probably 1 0ct. (astron. table for 1 oct. - 1 Jan.)

Ref.: RSC 3: 424 .

Notes. Monograph of the genera of Husci: Calymperes and Syrrhopodon, both of the warmer regions, including one new species of the first ( $c$ guildingii) and four of the second ( $S$. fascioulatus, S. rigidus, S. spioulosus, and $S$. rufescens). A separate is likely, but I have not seen one.

HOOKER, William Jackson \& TAYLOR, Thomas

1 Muocologia Britannica...

London, 1818 .

Title: "Musoologia Britannica | CONTAINING | THE l:OSSES | of Great Britain and Ireland [line in gothic] | SYSTEILATICALLY ARRANGED AIID DESCRIBED; | WITH PLATES ILLUSTRATIVE OF THE CHARACTERS OF THE | GENERA AND SPECIES. | Ishort thick-thin rule] | BY | WILLIAI JACKSON HOOKER, F.R.S. A.S.L.S. I AND MEMBER OF THE WERNERIAN SOCIETY OF EDINBURGH, I AND I THOMAS TAYLOR, M.D. M.R.I.A. \&.L.S. I AND FELLOW OF THE KING AND QUEEN'S COLLEGE OF PHYSICIANS OF | IRELAND. I [short thin-thick rule] | LONDON: | PRINTED BY RICHARD AND ARTHUR TAYLOR, SHOE LANE; | FOR LONGMAN, HURST, REES, ORME, AND BROWN, I PATERNOSTER ROW. i Vvery short rule] | $1818 . "$

Colzation: $8^{\circ}: \mathrm{a}^{2}\left( \pm \mathrm{a}_{1}\right.$ [or $\mathrm{a}_{2}$ ]) $\mathrm{b}-\mathrm{c}^{8} \mathrm{~d}^{2} \mathrm{~B}-\mathrm{K}^{8} \mathrm{~L}^{4} ; \quad I-I V$ i $i \mathrm{i}-\mathrm{xx \times V} \operatorname{xxvi}$ $12-152$ (xix $\left.x x x_{i} i \mathrm{i}\right)$.

Contente: I title; II D; III dedication to James Dalton (1764-1843), rector of Croft (Yorkshire), botanist; IV $\square$; $i-x$ introduction; xi-xiii key to genera; xiij-xxxii key to species; $x x i x_{i-x \times x v}$ sources; $x x x i$ addenda emendanda; 1-128 text, descriptions of British genera and species of ifusci; $129-136$ index; 137-152 explanation of the plates; 152 imprint with vignette of oil lamp: RT: in text generic names, elsewhere chapter headings. Language: English.

Plates: 31 copper-etchings with engraving, of mosses, usually uncolored, in a number of copies hand-colored, numbered: "Taj. I." "Tab. XXXI", the lower part of the last plate separately numbered: "SUPP.I."; pls.1-3 with the indication "GEWERA." at the top of the plate and the generic name above and the specific names below the figures; plate-mark: $189 \times 114 \mathrm{~mm}$. (pl.1).

Artiat: Hooker, William Jackson, the first author, as far as I know all plates; unsigned: pls. $1,9,12-15,18-22,30-31$.

Engravers: Edwards, W.H.C., (see Hooker n.1): pls. 2-6, 8, 10-11, 16-18, 22-29; Curtis, J. (1791-1862): pls. 2, 19-20, 30-31; Hooker, William Jackson, the first author: possibly the remaining unsigned plates 9, 12-15 (perhaps assisted by his wife). 
Paper: leaf height $210 \mathrm{~mm}$. (NYBG copy, cut); wove; no wm.; plate paper: wove (thicker than text paper); no wm.

Printere: Taylor, Richard, and Taylor, Arthur, London.

Publishere: Longman, Hurst, Rees, Orme a Brown, London.

Vate: $1818\left(t,-p_{.}\right), 1 \mathrm{Jan}$. (announced on the wrapper verso of fasc.1 of W.J. Hooker, Kusoi xotioi, 1 Jan. 1818, stating that the present work would be pubiished on the same day ( $L$ copy)).

Reviewe and announcements: Blaakwood's Edinb. Mag. $1818 \mathrm{Jan}, ;$ Peddie Waddington: Engl.Cat.Books $1818 \mathrm{Feb}$. Wonthly Lit.Adv. $1818 \mathrm{Feb}, 10$; Rev.Enoyol. 1819 Jan.-Mar. J.Sav.Paris 1818(7): 448. $1818 \mathrm{Jul}$. (states: "London, 1817"); Ann.Soi.Arte Lett. 2(2)App.: (13). 1818 .

Bitliogr.studies: Sayre, G.: Dates of publ. 56.1959, Stafleu, F.A.: Taxonomio literature n.546. 1967.

Refo.: BMNH 872

Brun. 3: 300

Graesse 3: 344

Jacks. 241

Kew 289

Kew-S 156
Krug. 242
Lindi.Libr. 210
Linn.Soc. 372
Lownd. 3 : 1107

Milt. 485

Niss. n.930

Pr.ed.1 n.4647

Pr.ed.2 n.4211

Un.Edinb.2: 414 .

Variante: title-cancellandum: see Bibl.notes; certainly issued in colored as well as in uncolored state; up to now no indication of large paper copies of the text; "The plates also publiohed separately in 4 to form, coloured in very superior menner, by Georgo Graves." (J.D. Hooker: Ann.Bot.16: xcii. 1902); a copy in Kew-S 159 is listed as from 1820; a set of the plates on large paper is in the HBL, without a title.

Bibl.notes. Probably the copy reviewed in J.Sav. (Paris) as dated 1817 concerned a copy with the title-page cancellandum, which would explain the cancellans with the date 1818, and makes the date $1 \mathrm{Jan}$. 1818 for actual publication more likely. From the prompt publication of Musci exotioi it may be inferred that this work was also effectively published on the planned date 1 Jan. 1818.

Bot.notes. Important British mossflora, the first specially devoted to the Nusai proper of all the British Islands, since Linnaeus. The treatment of genera and species is conservative, not even all genera of Hedwig were accepted, e.g. Barbula and Tortula were united, as were Fiseidens and Dioranum. A number of forms new to the British Islands were recorded here and a number of new combinations were introduced in bryology. According to modern rules of nomenclature, however, many of these, especially at variety level, are illegitimate, if epithets for varieties are present at all.

2 Muscologia Britannica...

Ed.2. London, 1827 .

Tit le: "MUSCOLOgIA BRITANNICA; | CONTAINING | THE MOSSES | OF | GREAT BRITAIN AND IRELAND, | SYSTEMATICALLY ARRANGED AND DESCRIBED; | WITH | PLATES ILLUSTRATIVE OF THE CHARACTERS | OF THE | GENERA AND SPECIES; | BY | WILLIAM JACKSON HOOKER, LL.D., F.R.A., \& L.S. I AND REGIUS PROFESSOR OF BOTANY IN THE UNIVERSITY OF GLASGOW, I AND I THOMAS TAYLOR, M.D., M.R.I.A. \& F.L.S, I FELLOW OF THE KING AND QUEEN'S COLLEGE OF PHYSICIANS OF IRELAND, AND | PROFESSOR OF NATURAL HISTORY IN THE ROYAL INSTITUTION OF CORK, i Second Edition, Corrected and Enlarged. [line in gothic] | LONDON: | PRINTED FOR LONGIIAN, REES, ORME, BROWN, \& GREN; | PATERNOSTER-ROW. | [very short rule] | $1827 . "$

Colzation: $8^{\circ}: a-b^{6} c^{4} A-R^{6}$ ( $I_{4}$ as 'I'); $i-v$ vi-xxxvii xxxviii-xi $12-272$

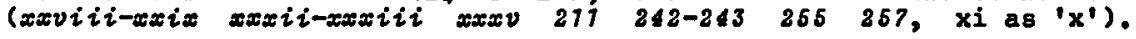


Contente: $i$ title; ii imprint; iii dedicetion to James Dalton (as in ed.1); iv $D_{i} v-x x v i i$ introduction to the second edition, undated, including a list of species found by Thomas Drumnond on his first journey in North America, up to Fort Franklin, sent by Dr. Richardson (vii); xaxviii $D_{;}$xix-xxxi key to British genera of mosses: "MUSCORUM BRITANNICORUM | GENERUM | CLAVIS ANALYTICA."; 2*xii D; $x x i i i-x \times x i v$ addenda \& corrigenda; $x x x v-x y x v i i$ sources: "AUCTORES CITATI. | LIST OF THE PRIHCIPAL AUTHORS QUOTED."; $2 x x v i i i$ D; 2xix half-title to the text: "BRI'TISH MOSSES."; 22 [j; 1-210 text, headed: "BRITISH MOSSES."; 277-241 "APPENDIX", treatinf the British hepatics; 242 D; 243-254 index to the Husoi; 255-256 index to the uepaticae; $257-272$ explanation of the plates. RT: centered: name of class or order, in capitals; inner corner: name of genus in italics. Language: English, except for key to the genera which is in Latin; no Latin descriptions in the text.

Plates: 36 copper-etchings with engraving, of mosses, uncolored or hand-colored, numbered: "Tab.I." - "IAB. XXXI" and "Supp 2. I. II." - "Suppl. T.VI." (Suppl. I as in ed.1 lower part of pl.31); pls.1-31 identical with those of ed.1; suppl.pls.2-6 only with binomials below the figures; plate-mark: $199 \times 126 \mathrm{~mm}$. (suppl.pl.6).

Artist: hooker, William Jackson, the first author: all plates.

Engravers: W.H.C. Edwards, J. Curtis, W.J. Hooker: pls.1-31 (see ed. 1); Edwards, hilliam Camden, London (see p.xxv): suppl.pls.2-5 (pls.3,5,6, signed explicitly: "W. C. Edwards Scpt").

Paper: sheet size $564 \times 461 \mathrm{~mm}$. (BMNH copy, slightly trimmed); wove; no wm.; plate paper: wove, thicker than text paper; wm. indistinct, not deciphered, possibly two lines of letters, horizontal lines present, superimposed on the wire systein, possibly from a dandy-roll of machine-made paper (HBL copy).

Printer: Glasgow University Press.

Puoliuhers: Longman, Rees, Orme, Brown Green, London.

Date: $1827\left(t,-p_{.}\right)$, probably 1 Jan. (Sayre, Dates of publ. 56, 1959 cited a letter from Arnott to Hooker, now at Kew, indicating that printing was completed in August 1826; Edinb.J.Sci. 6(1): 186. $1827 \mathrm{Jan}$. first?, of which W.J.Hooker was the collaborator for botany, stated: "just ready for publication"; the fasc. of this journal was prepared for printing in the first weeks of Dec.1826).

Pre-publioation. announoements:

Flora 6(15): 249.1823 ("necheteng"), 7(20): 317. 1824 (delayed); Ann. Philos. n.ser. 7(3): 237, 1824 (in the press), 8(1): 77. 1824 (same); Edino.J.Soi. 2(1): 185. 1826 Jan. (delayed), 6(1): 186. 1827 Jan. 1.

Refs.: BMNH 872

Brun. 3: 300

Kew 289

Graesse 3: 344

Linn.Soc, 372

Lownd. 3: 1107

Jacks. 241

Mass.HS-H 145

Mas8.HS-M 2: 250

Nis8. n.930

Pr.ed.1 n.4654

Pr.ed. 2 n.4211
Stafl. TL n.546 Teyl. 410 Un.Edinb, 2: 414.

Variante: only variant to my knowledge: hand-colored or uncolored plates, prices: "12. $116.6 d$. plein, and 3Z. 38. coloured pletes" (publisher's announcement in a folded octavo sheet of advertisements of the publisher, p.7, n.33, dated 0ct. 1827 , which is bound with copy BMNH).

Bibl.notes. There was a long delay in the publication of this edition (see prepublication announcements). This explains the numerous press figures (numbers in the direction-line, associated with individual compositors or presses): 3 (boi), 4 (QOi),. .7 (aoi Moi), 8 (Ao Boi), g (co Oi Poi Roi), 10 (D-tioi), 11 ( $\mathrm{Ci}$ ), 13 (Lo), 16 (Co Ioi $\mathrm{Li}$ ), 18 (Koij, confirming that printing proceeded very slowly io stands for outer forme, $i$ for inner forme).

Bot,noter. Revised edition, with the important appendix with Hepaticae. The literature of the period since the first edition has been cited, and occasionally answered, e.8. in the long footnote to Hypnum proliferum (171-173). The numbers of the exsiccata of Hobson, Brit. mosese and of Thomas Drummond, ilusoi scotioi, are cited. The treatment of genera and species of Musoi is in the main the same as in the first edition. 
HOPPE, David Heinrich

Biogr. Born 1760 Dec. 15, Vilsen, Hannover, Germany.

Died 1846 Aug. 1, Regensburg, Bavaria, Germany.

hoppe learned pharmacy with the court pharmacist at Celle (Hannover), and later was assistant pharmacist in Hamburg, Halle, Wolfenbuttel and Regensburg, in all these places actively botanizing; in fact he had chosen pharmacy to be able to find a living in botanical work. He acquired a good practical knowledge of the plants in the environments of the places where he worked.

In Regensburg he was instrumental in founding the Regensburger Botanische Gesellschaft (1790). He also edited Hoppe's Botanioches Taschenbuch (1790-1804; a final volume was edited by furnrohr with Hoppe's biography, Regensburg, 1849). He studied medicine and natural history at the University of Erlangen (1792-1796), received the degree of D.M., and settled as a physician in Regensburg. He taught natural history at the Lyceum in Regensburg, and made it a custom to go each summer to the Alps near Salzburg and Heiligenblut, with one of the most interesting experiences an ascent of the Gross-Glockner. He concentrated more and more on botany and prepared many collections for sale, including a number of exsiccata of alpine plants.

He married in 1795 ; his wife died in 1805 . He was survived by a daughter. His name was commemorated in the generic names Hoppea Willdenow 1801 (Gentianaceae), Hoppea Reichenbach 1824, considered a synonym of Senecio L. (Compositae), and Hoppia Nees 1842 (Cypercosae).

Refo.: Hoppe, D.H. Fünnohr, A.E.: Selbatbiographie, ergänzt von A,E, Fürnrohr. Hoppe's Bot. Taschenb. 23: 1-352, 1849.

Rleichardt?: AZlg. Deutsohe Biogr. 13: 113-114. 1881.

1 Bemerkungen uber einige Pflansen Deutsohlands, nach Anleitung von steudel und Hochstetter Enumeratio Plantarum Germ. Helv. indigenarum.

Flora 10(32): 497-511. 1827 Aug. 28;

(33): $524-528,1827$ Sep. 7 ;

(36): 561-573. 1827 Sep. 28;

(41): 647-656.1827 Nov. 7 .

Colzation eto.: see Flora.

Refe.: RSC 3: 430 .

Wote. Contains on p.654-656 critical remarks on the mosses, mostly additional lccalities or species.

HORNEMANN, Jens Wilken

Biogr. Born 1770 Mar. 6, Marstal, island Aerø, Denmark. Died 1841 Jul. 30, Copenhagen, Denmark.

Hornemann was home-educated, and at the age of 14 he went to the island Fyn, and later to Copenhagen, where he entered the university in 1788 , receiving a prize for a botanical paper. After traveling in. Europe he was a supervisor of forests on Falster late in 1800. He became successively editor of the Flora Danica (Ioones Florae Danioas) in 1803, extraordinary professor of botany at the University of Copenhagen on $23 \mathrm{Apr}, 1808$ and ordinary professor on 18 Ju1. 1817. He was rector of the University in 1830-31 and became $\mathrm{Ph}$. D. honoris causa in 1836. He married Marie Judithe Horneman on 9 Oct. 1801 ; she died 14 May 1830. He was commemorated in the generic names Bornemannia Wilidenow 1809 , now a synonym of Mazus Loureiro (Scrophulariaceas) and Bornemannia Vahl 1810, included by some authors in Thibaudia Ruiz \& Pavon 1802 (Vaociniaasas).

Refe.: Flora 25(9): 141-147. 1842 .

Bot.Tidsekr, 12:88-92, 1880 .

Erslew, T.H.: Almindeligt Forfatter-Lexioon Konger. Danmark 1814-1858. 
1 Womenezatura florae Daricae...

hiafnia [Copenhagen], 1827.

Zit le: "liOMENCLATURA | FLORE | DANICAE | EMENDATA | CUM INDICE SYSTE:LATICO F. | ALPHABETICO. | [short ruie] | AUCTORE | J.W. HCRIEWAWW, | PROFESS. BOTAHICES ORDIN. EQVITE AURAT. ORDIN. DANIJEBROG. I Ifuli thick-thin rule] HAFNIE. | TYPIS HARTV. PRID. POPFII, | [very short rule] | MDCCCXXVII." (see Variant).

collation: $8^{\circ}: \pi^{2} \quad *(2 * 1) \quad 2 * 6( \pm 2 * 5) \quad 1-13^{8} \quad 142 \quad x^{2}\left(-x_{2}=\right.$ cancellans $\left.* 1\right)$ ( $\$ 2$ signed $\$$ ); $i-i i$ I-III IV-XXVIII $12-214$ (XXVII 100 160 208, 208 as $(108$ ').

Contents: i title; ii D; I dedication to the King IFrederic VI of Denmark (1768$1839)$ ] II D; III-XXVI preface, undated; XXVII-XXVIII abbreviations of author's names; $1-99$ romenclature of Deder, Ioones florae Danicae [2", known as Elora Danica, not to be confused with Oeder, Flora Danica, $8^{\circ}$ ! which has only text], in numerical sequence, listing the original nanes and the equivalents accepted by hornemann, grouped according to fascicles, of which the authors are stated; 100-159 systematical index in the Linnaean classification of the names accepted by Liornemann; 160-208 alphabetical index of all binomials; $208-214$ corrections and additions. RT: chapter headings, or in the part with numerical sequence fascicle-numbers and their editors. Language: Latin.

Paper: leaf height $184 \mathrm{~mm}$. (HBL copy, cut); laid, chains vertical; wr.: "[fleurde-lis] $=\mathrm{C}$ H HonIG"

Printer: Popp, Harty. Frid., Copenhagen.

Date: 1827 (t.-p.), late (see Variant).

Refs.: Arn.Arb.1: 352

BMNH 876

Bradl.1: 353 a

Brun.1: $338\left(1828^{\prime}\right)$

Graesse 3: $371($ ('1828')

Heins.8(1): $370 \mathrm{~b}$

Kew 290

$\mathrm{Kra}_{\mathrm{B}} \cdot 126\left(1829^{\prime}\right)$
Linn. Soc. 374 Pr.ed.1 n.4702 Pr.ed.2 n. 4268 Teyl. $434 \mathrm{n}, 49$.

Variant. A variant with the title-page date 1828 is recorded in several of the references; no copy seen. See the Bibl.notes, where the cancels are also discussed.

Bitz.notes. The title-page is a single leaf. It is likely that it formed with its discarded conjugate leaf a quarter-sheet above the quarter-6heet 14; the watermarks I checked do not contradist this supposition. The dedication, cancellans 1 , is in several copies (inclujing the HBL copy) still conjugate with the correction leaf $x$. The cancellans $2{ }^{*}$ might have been part of $a$ half-sheet with the pair $x_{1} .1$, but not the title $\pi$. Pcssibly the cancellandum * was ar. original title, even with the date 1828 , which was replaced at the explicit wish of the author when it appeared that the book could be brought oit in 1827 , but this is conjecture end does not explain the situation completely.

Bot.noted. hornemann gave in this bock the nomenclature of all plants of the plates of the important series Ioones fiorae Janicad, which work itself is not incluced in this thesis partly because there are no new combinations for mosses in the pericd, though some plates of mosses were included in tize fascicles of these years. However, I had not the time to treat this long series in a sufficient way. A much leter review of the nomenclature was given by Lange, J.M.C.: iromenclator "Florae Danicae" sive Inüex systematious et alphajetious operis ... Havnia, 1887. No new combinations seen in tornemann's nomenclature. 
HORNSCHUCH, Christian Friedrich

biogr. Born 1793 Aug. 21, Rodach, Sachsen-Coburg, Germany.

Died 1850 Dec. 29, Greifswald, Vor-Pomern, Germany.

hornschuch was already interested in natural history during his elementary school period in his native town. After the death of his father (a pharmacist) he became a pupil at the court pharmacy at Bartenstein (hildburghausen). He went to Regensburp in 1813 as an assistant in a pharmacy, and there he botanized with Hoppe (which see). Hornschuch then came in the same position in the pharmacy of Funck (which see) at Gefrees, where bryology became his favorite study. With Hoppe he traveled through the Alps to the Adriatic Sea, 1816, and to Tyrol and Carinthia, 1817. They also founded the periodical Flora in 1818 . Hornschuch was nominated "demonstrator botanices" at the University of Greifswald on $28 \mathrm{Jan}$. 1817 as the successor of Ledebour; he started his lectures in April. On 7 April 1819 he was nominated supervisor of the natural history museum and of the botanical garden at Greifswald. In 1819 he was for three months in Berlin, studying the mosses of Willdenow's herbarium. After this he traveled to Sweden where he visited C.A. Agardh, and returned via Copenhagen.

In Apr. 1820 Hornschuch was nominated extraordinary professor of natural history and botany and director of the botanical garden in Greifswald. On 26 Feb. 1827 he was nominated Professor ordinarius. He received the degree Dr. med. hon. causa. In 1836 he became rector magnificus of the University of Greifswald for the term of a year. He made several other travels, e.g. in 1823 to Switzerland and Paris, returning via holland and hamburg, and in 1826 to the Alps in Tyrol. He went to Sweden for important meetings, e.g. the festivals of the Swedish Academy of Sciences in Jul. 1842 .

rornschuch was an eminent bryologist, publishing several articles on mosses, and co-author of the Bryologia Germanioa. His views on the development of organisms were strongly influenced by the "Naturphilosophie" of Schelling and others; algae, lichens and mosses could, in his opinion, grow out of the "Priestleyan green matter" by the influence of light, air, and the formative vegetabilic principle. Similar ideas were proposed by Cassebeer (which see).

The valuable herbarium of Hornschuch came after his death to Laurer (which see), and finally to the Botanische Staatssammlung at Berlin, where it was destroyed during World War II.

Hornschuch was commemorated in the generic names Hornochuchia C.G. Nees von Esenbeck 1821 (Annonaceae), Hornochuchia Sprengel 1822 (incertae cedis), and Hornsohuohia Blume 1823 (=Cratoxylon Blume, Hyperioaoeas).

Refs.: Flora 34: 62-63. 1851 .

Häckermann: $A l \mathrm{lg}$. Deutoche Biogr, 13: 158, 1881.

Dittrich, Mauritz: Christian Briedrich Hornschuch (1793 bis 1850) al.

Botaniker (ein Beitrag zu seiner Biographie). Festoohr. 500-Jahrfeier Univ. Greifswald 2: 540-547. 1956 (with portr. as rector of the university, list of publications, and two reproductions from his works).

1 Ptyohostomum novum muscorum frondosorum genus.

Sylloge plantarum novarum 1: 62-64. 1824 [1822].

Head-title: "Ptyohoetomum novum musoorum frondo-loorum genus. Conetituit et aescripsit Dr. | Hornsohuch."

Collation: $8^{\circ}: D_{7} v-D_{8} v ; 62-64$.

Contents: 62 head-title; 62-64 text, description of the new moss genus Ptyohostomum with three species.

Date: 1824 (t.-p.); 1822 (see sylzoge plantarum novarum).

Bot.note. Hornschuch proposed a new genus on a pecularity of the Deristome. The group is now usually treated as a subgenus of Bryum. 
2 Bryologia germanica. $1823-1831$.

See Nees von Esenbeck, C.G., Hornschuch, C.F. S Sturm, J. n.1.

3 Diagnosen neuer Laubmoose und andere iie iooskunde betreffencie jotizen. Flora 8(5): 77-80, $1825 \mathrm{Feb}, 7$.

Coliation eto.: see Flora.

Contenta: 77 head-title; 77-80 text, descriptions of 5 new species of mosses, a number of new localities of rare species, and new variety. Language: German, with Latin descriptions.

ivotea. Descriptions of the new species Tayloria aouminata, byprum frouchenianum and Dicranum moerkianum (p.78), Gymnostomum globosum, G. confertum (p.79), and of the new variety $G$. ovatum $c$ muoronulatum, (p.80). Horeover the localities of several rare species are reported.

4 Beitrag sur Gesohiohte der Fortoohritte in der kenntnise cier loose, naoh den

Sohriften der altern Botanikern bis auf unsere zeit.

Flora 8(14): 209-223. 1825 Apr. 14; (15): 225-240. 1825 Apr. 21 .

Colzation eto.: see Flora.

Ref.: RSC 3: 439 .

Note. Interesting discussion of the history of bryology.

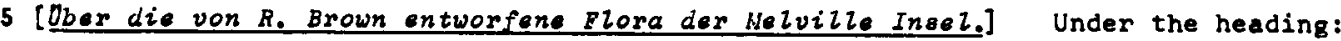
"Correspondens".

Flora 8(16): 249-254. 1825 Apr. 28 .

Colzation etc.: see Blora.

Wote. Discussion of the merits of $R$. Brown's article, and a comparison of the arctic vegetation of Melville Island and the alpine vegetation of the GrossGlockner, in which a pair of moss species are mentioned.

6 Musoi. In:Presl, K.B.: Keliquiae Haenkeanae ... vol.1(1): 13. 1825. Head-titze: "MUSCI. JUSSIEU. | F. hornschuh[sic], M. D. Prof, Gryph.". Collation eto.: see Presl n.1.

Note. Hornschuch published the determination of 2 moss species from the collections of T. Haenke: Hnium palustre from Nootka-Sound, N.Am, and Kypnum epiniforme from Peruvia, S.Am.

7 [Review of Schwaegrichen: Species Uusoorum Supplementum 2 vol.1(1).]

Flora $8^{2}($ Ergänz.B1.): 1-23, 1825 .

Head-titie: full title of the reviewed book (see Schwaegrichen n.1) in italics. Collation eto.: see Flora.

Date: 1825 , sem.2 (title of half vol:), probably late (if early, it would most likely have been included in "Beilage"), or 1826, early (not later than Beil.5, since its contents listed the articles of this Ergänsungsbiatt).

Wotes. This detailed review of the fascicle of Schwaegrichen's large work praised it in general. The circumscriptions and characters of several genera, however, were discussed or criticized, as were those of some species. Two new cener, were proposed: Bruchia Hornsch. p.10, based on Pterogonium tenue (look.) Schwaegr., and Walkeria tiornsch., p.21, based on Triahos tomum leucoloma Schwaegr. 
8 Beriontigung.

Flora $10^{2}$ (Beil.1): 98. 1827 [1828?].

Collation eto.: see Flora.

ilote. Correction to Nees, Hornschuch \& Sturm, Bryologia Germanioa (which see), concerning the names on pl.20, Gximmia donniana and $G$. oudetica; these must be interchanged.

9 [Review of Bridel: Bryologia universa.]

Jahrbücher fur wissenschaftliche Kritik $1828^{1}(55 / 56)$ : $442-448$;

(57/58): 448-464; (59/60): 465-472. 1828 Mar.

Beaa-titles: col.442: "XX. I Samuel EZ. a Bridel-Brideri a consiliis oe-loretio legationes Saxo-Gothanae eto. Bryologia l univeroa oeu systematioa ad novam methodum | dispositio, historia et desoriptio omnium musoo-|rum frondosorum huousque oognitorum oum | oynonymia ex auotoribus probatiseimis. Acoe-|dunt tabulae aeneae tredecim. V. I. II. Lipsiae, I apud Barth. 1826-27. XLVI. 856 et $848 . "$; col.448: same, except: "oognitorum eto. I (Fortsetzung.)"; col.465: same, except: "oognitorum to. | (Beschluss.)".

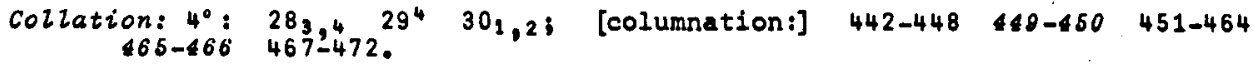

Contento: $442,442,465$ head-titles; $442-472$ text, ample review of Bridel, Bryologia univerea (which see), with many opinions on the circumscriptions and characters of genera and species and three generic names. RT: name of reviewed book. Language: German.

Paper: leaf-height $266 \mathrm{~mm}$. (copy UB Leiden, cut); laid, chains horizontal; wm. not studied (probably some outline capitals).

Printer: no imprint.

Publisher: Societat für wissenschaftliche Kritik, Berlin, in collaboration with J.G. Cotta, Stuttgart Iubingen.

Date: 1828 Mar. (head-title of fascicles as well as wrapper-title of the group of 5 fascicles concerned).

Notes. Important review of Bridel, Bryologia univerea, 1826-27, praising the thoroughness of the work and supporting in general the many generic segregations and the efforts to achieve a natural classification. Hornschuch's two new genera are Expodium (raised from subgeneric rank, col.450 \& 466) and Braunia (based on Neckera subg. Distichia, col.467); he proposed the new generic name Vlophy $I_{u m}(\operatorname{col} .458)$ for the illegitimate homonym Brachypodium Brid. In detail Hornschuch expressed many different circumscriptions of taxa or stressed other characters, or gave the result of recent research, $2 . \varepsilon_{\text {. the }}$ genus bollia Sieber was stated to represent Dionemon calyoinus Schwaegr. (col. 467), as checked by reliable bryologists. Together with the new generic name these independent opinions warrant the treatment of this review as an article here.

[Review of Arnott: Dieposition methodique des eopdoes de mousese.]

Jahrb. Wiss. Krit. 18281(69/70): 557-560; (71/72): 561-569. 1828 Apr.

Heaa-title: col.557: "Disposition methodique des espeses de mousese par I G. A. Walker-Arnott, A. M. Paris 1825. 4. 72.".

Collation: $4^{\circ}: 35_{4} 36_{1,2,3 i}$ [columnation:] 557-560 561-562 563-569.

Contents: 557, 567 head-titles; 557-569 text, critical review, sharply rebuking the lumping of Annott as superficial. RT: title of reviewed work. Language: German.

Paper publisher: see Hornschuch n.8. Date: 1828 Apr. (head-titles of fascicles as well as wrapper-title of group of
5 fascicles). 
Wotes. Review of one of the main articles treated in this thesis (Arwot $n, 5$ ) $p$ stating that a copy was sent to Hornschuch by the author from Paris (apparently before Feb.1826, see discussion under Arnott), mentioning the two forms of the article in the periodicals and their relative order, and indicating, erroneously, that the $4^{\circ}$ separate was published later than the two forms in the periodicals, and that is was available in the book-trade. Hornschuch replied firmly to the criticisms of Arnott on the splitting of new species and genera of the German authors, and gave an interesting discussion of the problem of lumping and splitting. He ended the review with the mildy ironical sentence: we ask the Author to use in future with nis determinations the compound microscope, from which he will realize his own mistakes, and his disdain for the works of the Germans will change into esteem, and in this conviction we pardon him already now for all injustices ("Unbill") against us.

ISIS (Oken).

Jena (later Leipzig), 1816-1848.

Colzation: $4^{\circ}$; in monthly fascicles with (often discarded) fascicle wrappers which had information on books fust received, or advertisements of plant collections etc; the earlier volumes were accompanied by Literatur-Anaeiger and Beylagen. Details not studied.

Dates: The first 3 fascicles were published in 1816; the remaining 12 fascicles of vol.1, of which the numbers 11 and 12 were combined into one $(11 / 12)$, were dated 1817; up to 182717 fascicles were produced each year, arranged into 2 volumes; in 1827 and 1828 small number of combined fascicles were published, and the volumes contained the fascicles of the whole year. Occasionally the publication had a few weeks delav. e.r. fasc.3(12) of 1818 (December) cited Flora $2(2)$ of 14 Tan. 1819.

wctes. Though it was outside my field to prepare collations of this periodical, I had to study apfroximate dates of the fascicles in connection with the dates of other works. In the above survey I combined the notes made by $\mathrm{Mr}$. $\mathrm{F}$. Schütz from the copy of the Leiden University with my own observations on a limited number of volumes of the Ptiladelphia Academy of Sciences. These had the original wrappers and moreover some numbers hac an interestirg advertisement journal of the publisher Brockhaus, Inteliigenabiatt, bound in. My impression is that delays of publication were not serious.

\section{KITTEL, Balduin Martin}

Biogr. Born 1798 Jan, 4, Aschaffenburg, N.W. Bavaria, Germany. Died 1885 Jul. 23 , Aschaffenburg.

No biographical account avalalile to me. Kittel was for some time in Paris, where he became a member of the Société Linnéenne de Paris. In 1826 he attended its meetings and contributed a Memoire our les pucerons (memoir on aphids), and the report to Annott's Nouvelle disposition, which report was read in the meeting of 23 Feb. 1.826 (in which the suggestion of Kittel, that Arnott be admitted as a corresponding member, was unanimously accepted). On the separate he is indicated as "docteur". Later he was back in Aschaffenburg, and became director of the "Gewerbeschule", the technical school there. He wrote pocket flora of Germany which had several editions, but this did not include mosses. UF to now $I$ have found only one indication that after his stay in Paris he still studied mosses. This is the sentence in a report of the meeting of the Sociéte Linnéenne de Paris, held on 22 Feb. 1827: "4. bittel annonce la découverte d'un nouvel Hypnum", MÉm,Soo.Linn.Pario 6 (BuZi.Linn.1): 32. 1827. I do not know of a detailed publication of this discovery.

Kittel was commemorated in the generic names Kittelia Reichenbach $1837, a$ homotypic synonym of Cyanea Gaudichaud 1828 (Campanulaceae), and Xittelocharis Alefeld 1863 , a superfluous synonym of Reinwardtia Dumortier 1822 (Linaceae).

Refo.: Bot. Notis. 1886: 39. 1886 .

Backer, C.A.: Verki. Woordienb. 303. 1936. 
1 Rapport sur la Nouvelie disposition méthodique des especes de mouses ... par H. G. - A. Halker Arnott.... l'ém. Soc, Linn. Paris 5(3): 205-324, $1826 \mathrm{Jul.}$

Head-title and oollation: see Arnott n.7.

Contents: 205 head-title; $205-214$ text of Kittel's report on Arnott's article with a short historical introduction to bryology; $214-323$ text of the article of Arnott $(n .7)$, interspersed with observations by Kittel printed in larger type, and two names of "tribu": Andreaeoideae [spelled Andraeoideae], p.214, and Sphagnoideae [spelled Spagnoideae]. p.215, both with descriptions in the observations; $323-324$ concluding remarks by Kittel: "Conclusions."

Paper: leaf height $215 \mathrm{~mm}$. (HBL copy of re-issue of periodical, uncut; see Saumaises n.1); laid, chains vertical; $\mathrm{wm} .:$ "L [partiy outline] = Chapelle [erect script in center of lower quarter-sheet ]".

Date: $1826 \mathrm{Jul}$. (date fasc.); bef. 9 Aug.? (earlier than separate?);

bef. 27 Sep.? (see MEm.Soo.Linn.Paria);

bef. 30 Sep. (Bibliogr.Eranae 1826(78): 834. 1826).

Fef.: RSC 3: 667 .

Notes: see Arnott n.7, Kittel $\mathrm{n.2}$, and Saumaises n.1.

2 Mémoires d'histoire naturelle.

Paris, 1826 [separate].

Wrapper-title: "[frame: thick rule and two thin rules enclosing at each corner three rosettes] | liÉMOIRES | D'HISTOIRE NATURELLE; | PAR M. le docteur B,-M. KITTEL, | Correspondant de la Société Linnéenne de Paris, etc. | [vignette: Minerva bust with inscription in 'pedestal': "ARTS.", and surrounded by a laurel wreath and several tools and symbols as globe, scroll, telescope, etc.] | PARIS, | DECOURCILANT et GALLAY, IMPRIMEUR ET LIBRAIRE, | RUE D'ERFURTH, No I. | 1826."

Collation: $8^{\circ}: 1^{8} 2^{4} 3_{-98} 9^{8} 0^{4}$ ( $\$ 2$ signed $\$ \cdot, 9_{1}$ as $18^{\prime}, 9_{2}$ as $\left.8^{\prime}\right)_{3}$ $12-144\left(25,121-136\right.$ as $\left.1105^{\prime}-1201\right)$.

Contents: 1-24 text of zoological article by Kittel: Nemoire our les pucerons (Memoir on the aphids); $25-34 \mathrm{Kittel's}$ report on Annott's article, with headtitle: "Ifull navy rulej| RAPPORT | SUR IA NOUVELLE DISPOSITION DES MOUSSES, | PRÉSEMTEE PAR M. WALKER-ARIOTT; | SUIVI | DE NOTES CRITIQUES ET D'ADDITIONS NUI COIPLETENT CE TRAVATL I ET LE METTEIT A LA HAUTEUR DES CONNAISSANCES ACTUELLES. [ [short swelled rule, partly open]"; 34-143 text of the article of Annott $(n .8)$, interspersed with observations by Kittel etc. (see $n .1$ ); 143-144 concluding remarks by Kittel: "CoNCLUSIONS."; 144 footnote concerning the erroneous signature and page numbers of gathering 9 .

Wrapper: thin paper wrapper; front recto: wrapper title, front verso: indication of the source, and imprint: "[full rulej I Extrait du ve vol. des Memoireo de la Société Linnéenne de Pario. I [fulI rule] | [at bottom:] PARIS, IMPRIMERIE DE DECOURCIIANT, I SUCCESSEUR DE LEBEL."; back wrapper recto $\square$, back verso: "[frame as on front recto, with central vignette only]".

Paper: leaf height $194 \mathrm{~mm}$. (HBL copy, cut); laid, chains vertical; wm.: "L [partly outline] = Chapelie [erect script in center of lower quarter-sheet]".

Printer: Decourchant, Paris.

Publisher: Gallay, Paris.

Date: 1826 (title); bef.9 Aug. (Bibliogr,France 15(6.3): 691. 1826)

Ref.: B!NH 987 .

$B i b$ l.note. This "mémoire" of articjes with the wrapper title and the changed headtitle of the report on Arnott's article clearly indicates the influence of Kittel; it is evident that he ordered the separates (see also Arnott $n, 8$ ).

Bot.note. Ilot an important separate, unless it could be proved that it was published before the periodical fascicle. 
KNEIFF, Friedrich Gotthard

Biogr. Born 1785 or 1786 .

Died 1832 Sep. 7, Strasburg.

No biography avallable to me. He was commemorated in the generic names $X_{n e i f f i a}$ Spach 1835 (Onagraceae) and Xneiffia E.M. Fries 1838 (Pungi), and in the sjecific name Amblyotegium kneiffii Bruch, Schimper Gumbel (jusoi, Amblyetegiaceae).

1 Den Stanciort des zygodon oonoideum Hook. bei Straseburg betreffend.

Flora 8(37): 590-591. 1825 oct. 7 .

Collation etc.: see Flora.

Date: 1825 oct. 7 (fasc. dated).

Bot.note. Description of the locality and the peculiar habitat of the rare moss species zugodon oonoideus of which the sporophytes were collected in the past years after regularly watering a reservoir in the hole of the tree trunk on which it grew, providing sufficient moisture.

KNEIFF, Friedrich Gotthard 4 MARKER [Maercker?], $\mathrm{Ch}, \mathrm{Ph}$.

1 Musoi frondoei quas in Alsatia variague Helvetiae et Germanibus partibus colzegerunt E. G. Kneiff et Ch. Ph. warker.

10 parts. Strasburs, 1825-1832. [exsiccataj.

Collation to.: no copy seen.

Dater: fasc.1: 1825; fasc.7: 1827; fasc.9-10: 1832 .

Refe. and reviews: fasc.1-7: Krol, .112 ;

fasc.9-10: Arohives de botanique 1:566-567. 1833.

wote. Mentioned for the sake of completeness. No indication of new names or combinations. Fascicles 1-7 contained 150 specimens.

KUNTH, Carl Sigismund

Biogr. Born 1788- Jun, 14, Leipzig, Germany. Died 1850 Mar. 22, Berlin, Germany.

Kunth had since childhood a strong interest in the study of natural sciences. When his father, teacher of English, died in 1806, he was without resources. He went to an uncle in Berlin, who was able to procure him a job at the office of a commercial organization. He did his work conscientiously, and in his leisure hours he studied chemistry and botany. he followed lectures of Willdenow and soon became his pupil. he published a flora of Berlin using the Linnaean ciassification.

Kunth's uncle had been an instructor to the von lumboldt family, and so kunth himself met Alexander von lumboldt. Since the latter needed skilled collaborators for studying, the collections brought from his American travels, he charged Kunth with the determination of the botanical collections and called him to Paris in 1813 . i.cre he became the pupil of A.L. de Jussieu, Desfontaines and above all of Louis Claude Richard, who had a personal knowledge of the South-American flora. There was a mutual collaboration; several of the plates of the first volumes of wova genera et peoies plantarum (humboldt, Bonpland Kunth) were drawn by Richard. A very large number of plates were drawn and signed by Turpin, but Adr. de Jussieu stated that Kunth drew all analytical as well as other details. It is self-evident that Kunth hecame a student of the natural families; he described his genera with much detail to decide the family affinity.

he led quiet life, living in the house of $A$, von humboldt, describing the plants, regularly visiting the museums, cabinets and jibraries of his learned friends and the botanical garden, as well as taking part in the famous "herborisations" of the de Jussieus. He was nominated "correspondant" of the Institut de France. 
When the German publisher Cotta asked Kunth to prepare a new edition of the $s_{i n o p a i z}$ of Persoon, the plan was to follow the original closely. Kunth soon wanted to replace the Linnaean classes by the natural families; this was accented by the putlisher, so the ¿irumeratio plantarum iucusque cognitarum became a new work, which bepan with the monocotyledons, differring in this respect from the Prociromu of $A . P$. de Cancolle.

In 1629 Kunth was rominated professor at Berlin, and he moved to this olace just a few months after his marriape. In Berlin he apain lived quietly, devoting his time mainly to his work and his family. Though he had no children, he had taken care of two nieces. During his lectures Kunth demonstrated the parts of plants on living specimens, the students having specimens too (Adr. de Jussieu described this as somethinp new, which had been introduced by L. C. Richard). Kunth also led "herborisations" in the neighborhood of Berlin. 11 Jan. 1830 he was nominated a member of the Akademie der Wissenschaften at Berlin; he also helped to supervise the botanical garden, under Link.

In 1839 he had a fall in the botanical garden with serious consequences; a dislocation in the shoulder was not recognized by the doctors and this was the beginning of a moral depression. Afterwards he became deaf. In 1845 he tried to travel to Salzburg alone, but he fell ill at Munich, from which place his wife had to bring him back to Berlin. his health declined and in 1849 a deep melancholy was the result. The end was a suicide.

he was commemorated in the generic names Kunthia Humboldt, Bonpland \&unth 1813 ( $P a$ lmaceae), considered a synonym of Chamaedorea Willdenow, and Kunthia Dennstedt 1818 , a superfluous synonym of Garuga Roxburgh (Burseraceae).

Reje.: Bot.zeit. 9: 427-432, 1850.

de Jussieu, Adr.: Hotice sur la vie et les ouvrages de Charles-Sigisnond linth. Professeur de botanique, a Derlin. Ann.Sci. Wat.Bot. ser.5, 14: $76-106.1850$.

1 synopsis plantarum aequinoctialium orbis novi.

4 vols. Paris strasburp, 1822-1824.

Titles: "SYNOPSIS | PLANTARUM, | QUAS | IN ITINERE AD PLAGAM FEQUINOCT IALEM | ORBIS HOVI, | COLLEGERUNT | AL. DE KUMBOLDT ET AM. BONPLAND. | [double ruIej | AUCTÓRE | CAROLO SIGISM. KUNTH, | PROF. REG.; ACAD, BEROL., INSTIT. GALI., SOCILTT. PHILOM. I ET HIST. NAT. PARIS. [last two lines replaced in vol. $3^{\circ}$ by: PROF. REg,; ACAD. BEROL. ET CES. LEOP. HAT. CURIOS,, INSTIT, GALl, Societt. Philom, et Hist, Nat. Paris, Hort, Cult, Berol, | PuYsiogr. LULDENS. NAT. SCRUTAT. LIPS., CET.] [same two lines replaced in vol.4 by: PHILOS. DOCT., PROF. REg., CRD, AQUILE RUBRE EQUITE; ACAD, BEROL, I ET CES. LEOP. CAROL. NAT. CURIOS., IHSTIT. GALL, SOCIETT. PHILOM, I ET HIST. HAT. PARIS., WERNERIAIVE EDIHB, HORT, CULT, BEROL., I PHYSIOGR, LUNDENS, NAT. SCRUTAT. BEROL, ET LIPS, LINN, CADOM., TE C. [sicj] | [short rule] 'TOMUS PRIIUS. [2: TOMUS SECUNDUS.] [3: TOMUS TERT IUS.] [4: TOMUS QUARTUS.] [ [short rule] I PARISIIS, Apud F.G.LevRault, bibliopolam, via dicta $M$. ie Prince, $n .0^{\circ}$, I atque ÁRgentoRATI, via dicta des Juifs, $n .033 . \mid 1822$. [2: 1823.] [3: 1824.] [4: 1825.]";

series titles: "VOYAGE I DE HUMBOLDT ET BONPLAND. I SIXIEME PARTIE: BOTANIQUE, | SYNOPSIS | PLANTARUM EQUINOCTIALIUM | ORBIS NOVI. | [short rule] 1 TOMUS PRIMUS. [2: TOMUS SECUNDUS.] [3: TOMUS TERTIUS.] [4: TOMUS QUARTUS.] I] A PARIS, | Chez F.G.LEvraulT, rue des Fossés M. le Prince, n.0 31, | et rue des Juifs, n. $0^{\circ} 3$, à StRASBOURG. | 1822 . [2: 1823.] [3: 1824.] [4: 1825.]"

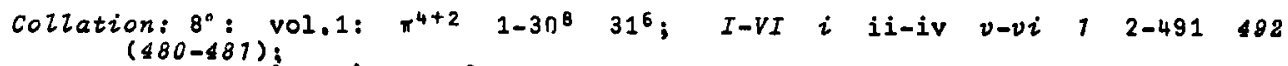

vol.2: $\quad \pi^{2} \quad 2 \pi^{1} \quad 1-33^{8}\left(-33_{7}=22 \pi_{1}\right) ; \quad I-V I \quad 7 \quad 2-526 \quad$ (517);

vol.3: $\pi^{2} 2 \pi^{1} 1-31^{8} ; I-V I ; 2-496(485-486)$;

vol.4: $\pi^{4}$ 1-338; I-VIII 7 2-528 (783-194 $277-275 \quad 373-375 \quad 339-341$ $397-399 \quad 445-447 \quad 463-465 \quad 517-513 \quad 522-523)$. 
Contents: vol.1: I half-title; II imprint; III title; IV $\bar{G} V$ dedication to Robert Brown (which see), signed: "AL. DE HUMBOLDT. C. KUNTH, AM. BONPLAND.", $V I D_{1}$ i-iv preface: "PRFFATIO.", dated: "Kal. Oct, HDCCCXXII."; v seriestitle; $v i$ Di 1-479 text, descriptions of genera and species of the plants collected by von Humboldt and Bonpland in South- and Central America, Algae $(7-6)$ by C.A. Agardh, Fungi (7-13), Hepatioae (40-45), Musoi (46-65) al1 by W.J. Hooker, the remaining families by Kunth; 180 Ji 187-491 index of generic names: $182 \mathrm{D}$;

vol.2: I half-title; II imprint; III title; IV [i V series-title; VI ]; 1-516 text, continued; 517-526 index of generic names in vol.2;

vol.3: I half-title; II imprint; III title; IV D; $V$ series-title; VI O; 1-485 text, continued 486 G; $487-496$ index of generic names in vol.3; vol.4: I half-title; II imprint; III series-title; IV D; V-VI corrigenda to vol.1-4; VII title; VIII तi 1-192 text, concluded; 183 part-title: "SUPPLENDA." $184 \square_{3} 195-270$ text of supplenda, additional descriptions; 271 section-title: "DISTRIBUTIO | GEOGRAPHICA | PLANTARUM EEQUINOCTIALIUM | ORBIS NOVI, | quas in latitudine boreali 210 usque ad altitudinem 2850 hexap. collegerunt | AL. DE HUMBOLDT ET AM, BONPLAND, | DESCRIPSIT HOC OPERE |
CAROL. SIGISM. KUNTH,"; 272 ; 273 part-title: "FLORA | PROVINCIARUM NOVE ANDALUSIE; | VENEZUELF, NEC NON PLANITIEI | BARCINONENSIS." i 274 D; 275-312 text, short description of the region and lists of species per natural family, Hepaticee (279), Musoi (280); 313 part-title: "FLORA NOVO-GRANATENSIS."; 340 D; 347-396 text, Bepatioae (346), Nusoi (346-347),

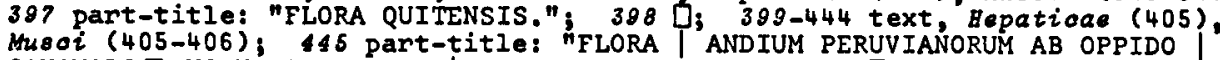
CAXAMARCE USQUE AD LITTUS | OCEANI PACIFICI."; 446 ; $447-510$ text; 571 part-title: "FLORA CUBA INSULE."; 572 ; $573-521$ text; 522 ; $523-528$ index of generic names in the descriptive parts of vol.4.

Paper: leaf height $202 \mathrm{~mm}$. (U copy, cut); laid, chains vertical; wm. not studied, fragments of outline letters present.

Printer: Levrault, F.G., Strasburg.

Publisher: Levrault, F.G., Paris Strasburg.

Collaboratore: Agardh, C.A. (1785-1859): algae;

Hooker, W.J. (which see): other cellular cryptogams (see Hooker n.5).

Datee:

\begin{tabular}{|c|c|c|c|c|c|c|c|c|c|}
\hline vol. & date $t_{0 .}-p$. & recd. Ac & ad. Sci & - Paris & \multicolumn{5}{|c|}{ Bibliogr.France } \\
\hline $\begin{array}{l}1 \\
2 \\
3 \\
4\end{array}$ & $\begin{array}{l}1822 \\
1823 \\
1824 \\
1825\end{array}$ & $\begin{array}{l}1822 \\
1823 \\
1824 \\
1826\end{array}$ & $\begin{array}{l}\text { Dec. } \\
\text { Mar. } \\
\text { Feb. } \\
\text { Jan. }\end{array}$ & $\begin{array}{l}9 \\
31 \\
28 \\
16 \\
\end{array}$ & $\begin{array}{l}11(50): \\
12(16): \\
13(10): \\
15(10):\end{array}$ & $\begin{array}{l}748 . \\
243 . \\
148 . \\
108 .\end{array}$ & $\begin{array}{l}1822 \\
1823 \\
1824 \\
1826\end{array}$ & & $\begin{array}{lr}\text { ec. } & 14 \\
\text { pr. } & 19 \\
\text { ar. } & 6 \\
\text { eb. } & 4\end{array}$ \\
\hline
\end{tabular}

Bibliogr.study: Stafleu, F.A.: Taxonomic literature n.620. 1967. Reviews Linnaea 1(2): 294. 1826 Apr.

Bot.notes. Important work for the flora of South America, bringing together the descriptions published in the large work of Humboldt, Bonpland \& Kunth. The mosses were described by W.J. Hooker in vol.1, including a number of new species. In vol.4 the species, cryptogams included, were recapitulated per region; for this reason I include this work in my thesis since I want to treat all publications with mosses in the years 1825-1827. Of real importance for bryology, of course, is vol.1.

\section{LAMOUROUX, Jean Pierre Péthion [or Justin Pierre]}

Biogr. Born 1797 Feb, 11, Agen, dép. Lot-et-Garonne, France. Died. 1866 Jan. 17, Paris, France.

No biography available to me. He apparently had the degree M.D. from Paris and was a phsician there. He was married (see Artiat). His Christian names are sometimes stated as Justin $P_{\text {. }}$, the Barnhart file gives the names mentioned above, derived from Andrieu, Bibl.Gen.Agen 2: 43-44 (not seen). The names Lamourousia Agardh 1817 (Algae) and Lamourouxia H.B.K. 1827 (Sorophulariaceae) commemorate his brother Jean Félix Vincent lamouroux (1779-1825), a student of marine plants and animals. 
1 Rlsumb complet de botanique.

\section{2 vols. Paris, 1826.}

Titze: "RESUIE | COIPLET | DE BOTANIQUE. | TOme Premier [vol.2: Tome Second][1ines in gothicj | ORGANOGRAPHIE ET TAXONOLIE, | contenant l'ANATOMIE vEGETALE et la GLOSSOLOGIE ou la / description de tous les organes et de leurs modifications, et la TAXONOHIE ou I'exposé des systemes et des méthodes de classification; précédés d'une Introduotion historique; [vo1.2: PHYSIQUE VEGETALE, I contenant la PHYSIOLOGIE et la PATHOLOGIE VEGÉTALE, ou l'e-/tude de l'organisation, des fonctions et des maladies des plantes, et la GEOGRAPBIE BOTANIQUE. Terminé par la Biogra-lphie des botanistes, une Bibliographie et un Vooabulaire.] | ORNE DE PLANCHES. | PAR J.-P. LAMOUROUX, D. M. P. I [Vo].2; extra lines: | ET POUR LA PARTIE PHYSIOLOgIQUE ET PATHOLOgIQUE, | PAR C. BAILLY DE IIERLIEUX.] | La nature n'emploie jamais d'instrumens | inutiles .... fvol.2: Et Flore, en souriant, $\mathrm{m}^{\prime}$ appelle a ses mystères. I P. RADBL, Myst. de Flore. Trad.] [ publisher's emblem, monogram $C B$ in laurel and oak wreathil Paris, Iin gothicj, AUX BUREAUX DE L'ENCYCIOPEDIE PORTATIVE, | Rue du Jardinet-St.-André-des-Arts, no 8 , | Et rue Taitbout, no 6. Et chez BACHELIER, lib., quai des Augustins, no 55 . | [short swelled rule] | 1826."

Collation: $32^{\circ}$ in 88 :

vol.1: $\pi^{6} 1-178 \quad 18^{2} ; \quad I-I V \quad i$ il-viii 1 2-275 276 (35 64-65 243); vol.2: $A^{4} 1-17^{8} 18^{4}$ (A3 signed 'A', $A_{4}$ signed 'A*'); I-IV $i$ ii-iv

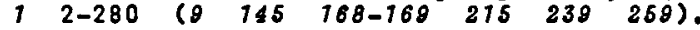

Contenta: vol.1: I general title of the Enoyolopedie portative; II imprint: "IISPRIMERIE | DE | Pochard [in gothic] | RUE DU POT-DE-FER, No 14."; III title; IV J; i-iv contents; v-viii preface, headed: "AVERTISSEIENT"; 1-275 text, headed: "RÉSUIÉ|| DE BOTANIQUE.": 1-34 historical introduction, 35-63 "IOTIONS FRÉLIHINAIRES", 64 D, 65-242 "Premiere Partie [line in gothic] | ORGANOGRAPHIE, | OO ANATOHIE ET GLOSSOLOGIE | VÉGÉTALES.", 243-275 "DeuXième Partie [line in gothic] | TAXONOMIE."; 276 errata and notes, announcing that vol. 2 would appear before the middle of June 1826, and two other volumes on special botany during the course of the year;

vol.2: I general title of the Enoyolopédie portative; II imprint as in vol.1 with addition to the last line: "A PARIS."; III title; IV D; i-iv contents; 1-280 text, headed: "RÉSUIE | DE BOTANIQUE | [very short rule] | Troisième Partie [line in gothic] | PHYSIQUE VÉGÉTALE." : 7-8 "CONSIDÉRATIONS GENERALES.", 9-144 "Première Division 'Iine in gothic] | PHYSIOLOGIE VÉGÉTALE." $745-167$ "Deuxième Division [line in gothic] | GEOGRAPHIE BOTANIQUE." $168^{\circ} \square$, 168-214 not studied, 215-238 "BIOGRAPHIES | DES BOTANISTES LES PLUS CELEBRES | ANCIENS ET MODERNES.", 239-258 "BIBLIOGRAPHIE | BOTANIQUE | OU CATALOGUE RAISONNÉ | DES IIEILLEURS OUVRAGES ÉCRITS SUR LA | BOTANIQUE." 259-280 "VOCABULAIRE | DES MOTS TECHNIQUES | DE | LA BOTANIQUE." including botanical terms of vols.1 and 2 , the last with the indication: "(T.2)"; 280 errata. RT: usually left division, right subject. Language: French.

Plate: 2 lithographed frontispieces illustrating the mottos: vol.1: "Dano Z'itude des fleurs il trouva le repos", and vol.2: (folded) "Ce mouvement oudain de peine on plaisir | D'en ohercher les reseorte, fait naitre le desiz".", both signed: "Feugere d. f. inv. C. Girardet o." and at bottom: "Lith. de Uartoux"; 3 copper-engravings illustrating plant morphology (pls.1 and 2 in vol.1) and physiology and pathology (pl.3 in vol.2); signed: "S. Lamouroux dez. Ambroise Tardieu soulpt."; plate-mark only seen at top of pl.1; probably printed originally together or with other plates from one block.

Artistr: Feugere: frontispjece vol.1-2;

Lamouroux, S. [Mrs. J.P.]: plates.

Engravers: Girardet, $C .:$ frontispiece vol.1-2; Tardieu, Ambroise: plates.

Paper: leaf height $116 \mathrm{~mm}$. (PBN copy, cut); wove; no $\mathrm{mm}$. seen; plate paper: wove; no wm. seen. 
Printere: Pochard, Paris (text); Mantoux [Paris?] (Iithographs).

Publishere: Bureau de l'Encyclopédie portative (Bailly de Merlieux), Paris; Bachelier, Paris.

Collaborator: Bailly de Merlieux, Charles François: "partie physiologique et pathologique".

Dates: vol.1: 1826 (t.-p.), bef. 28 Jun. (Bibliogr.France 15 (51): 565. 1826): vol.2: 1826 (t.-P.), bef. 30 Aug. (Bibliogr.Franoe 15 (69): 741.1826$)$.

Reviews: vol, 1: BulL,Sci,Nat, 8(8): 433-434, 1826; vol.2: Buli.Soi.Nat. 9(18): 181-182. 1826 sep.

Refe.: BMNH 1052 Bradl. 1: $86^{\mathrm{a}}$

Krüg. 54

liilt. 47
Pr.ed.1 n.5521

Pr.ed.2 n.5027.

Bibl.notes: The format is stated to be "grand $32^{\circ} n$ by contemporary reviewers and I have no reason to doubt this, though later references give it as "small $16^{\circ}$ ". I was unable to check the format exactly because of the absence of chainlines, watermarks or deckle-edges. The volumes were part of a larger series, the Enoyolopdice portative. Vol.1 formed "livraison" 12 of this series, and vol. 2 "Iivraison" 13.

Bot.notes. Popular introduction to botany, mentioning mosses in a general treatment Some later botanical works by Lamouroux followed, but are not treated here.

\section{LAURER, Johann Friedrich}

Biogr. Born 1789 Sep. 28, Bindlach near Bayreuth, Germany. Died 1873 Nov. 23 , Greifswald, Germany.

Laurer attended the gymnasium at Bayreuth, learned pharmacy with Funck (Gefrees) and traveled with Hoppe in the Salzburg Alps. At the instigation of Hornschuch he began the study of medicine at the University in Greifswald. Here he became "prosector" in anatomy early in 1827 (staying this for 24 years), and received his 11.D. degree 30 Oct. 1830. In 1830 he was admitted "Privatdozent" for anatomy and physiology; on 15 Jan. 1849 he was nominated extraordinary professor of pharmacology and on 1 Apr. 1863 ordinary professor of "materia medica".

Laurer had a strong botanical interest and especially studied lichens. He was very modest and many results of his studies were published in works by others. He issued a hardbook of pharmacology as a second edition of Seiffert, Bandbuch der Araneimittellehre, though it was virtually useful new book. This modesty brought him some grief by lack of recognition. He married the printer's widow Koch nse Krey on 18 Aug, 1852 and lost her by death in 1858, childless. They founded stipendia for students of the University. His herbarium, enriched by that of Hornschuch, was willed to the Bot. Museum at Berlin. Laurer was commemorated in the generic names Laureria v.Schlechtendal 1833

(Sozanaocae) and Laurera Reichenbach 1841 (based on Meioneria Fée non A.P. de Candolle), and in the specific name Trichootomum laureri Schultz (Musoi).

Refo.: Flora 10(8): 127 Feb.28; Minks, A.: Flora 56(34): 529-536. 1873.

Bot.2eit. 24: 65.1874.

Bedwigia 13: 16,1874 .

Melnter: Nitt.Naturw.Ver, Neu-Vorpommern u. Rttgen 7: 129-134. 1875 (not seen). Häckermann: AlZg.Deutsche Biogr. 18:66-68. 1883 . Wunschmann: Alig.Deutsche Biogr. 51: 604-605. 1906.

Wels, Paul: Pharmakologisches Institut. Festsohr. 500-Jahrfeier Univ. Greifowe zd 2: 337-357. 1956.

1 Beitrage sur kryptogamischen Flor der Insel Rügen.

Flora 10(19): 289-299. 1827 May 21 .

Bead-title: "Beiträge sur kruptogamisohen Flow der Insel Rilgen; I von Hrn. Prosector Laurer in Greif swalde."

Colzation: 8*: $\mathrm{T}_{1}-\mathrm{T}_{6} \mathrm{r} ; 288$ 290-299 (see Flora). 
Contente: 289 head-title; 289-290 introduction; 290-299 1ist of cryptogamic plants of the island Ragen with author citations, localities and descriptions of new species: Filices (290), Musoi frondosi (290-294), Musoi hepatici (295), Lichenes (296-298), Algae (298) and Fungi (298-299). No RT. Language: German, with Latin descriptions.

Paper to.: see Flora.

Date: 1827 May 21 (fasc. dated).

Bot.notes. Article with the result of collecting cryptogams in the island Rugen (Germany, in the Baltic Sea). The new moss species Mnium rugioum (294) was described. An extensive footnote (293-295) was devoted to the moss genus Timmia, describing the known species and adding new one, T. alpina (294), though including the name $T$, salioburgenoio Hoppe (295) as a variety.

\section{LESTIBOUDOIS, [Gaspard] Themistocle}

Biogr. Born 1797 Aug. 12, Lille, dép. du Nord, France.

Died 1876 Nov. 22, Paris, France.

Themistocle Lestiboudois was the son of François Joseph, and the grandson of JeanBaptiste Lestiboudois, botanists in Lille. During the period he studied medicine in Paris his father died (1815); his father's place of professor of botany in Lille was temporarily filled by a friend of the family (Aime Fauvel), and after his death by another, until the son was ready to occupy this position.

He was indeed nominated $8 \mathrm{Apr}$. 1819, shortly after he had received his doctor's degree. He gave the courses at least up to 1848 , and had the supervision of the botanical garden. He was also a practizing physician, and took part in the town administration of Lille, being nominated to the council in 1830 , and later in several other functions. Finally he came to Paris and was charged in 1848 with the course in plant anatomy and physiology at the "Faculte des Sciences". In 1849 he became a member of the "Assemblée legislative". In 1845 he already had been nominated a corresponding member of the Institut, Académie des Sciences, botanical section. He married 12 Aug. 1829 Christine Thérèse Juliette Richebé (1772-1848). The generic name Lestibudesia Thouars 1806 (now considered a synonym of Celosia L., Amaranthaceae) is certainly named after his father, grandfather, or both; also probably Lestibudaea Jussieu 1823, an altered spelling of Lestibodea Necker 1790 (now considered a synonym of Dimorphotheoa Moench, nom.cons.).

Ref.: Leclair, Edm.: Les Lestiboudois ... botanistes 1illois. BuLZ,Soc.Etud.Divero Prov. Cambrai 12: 39-90. 1908 .

1 Botanographie belgique...

2 vols. Paris, Lille, 1827.

Title: Botanographie Belgique, ou flore du nord de la France, et de la Belgique proprement dite; ouvrage disposé selon la méthode naturelle, contenant les tableaux analytiques de François-Joseph Lestiboudois, la description des plantes qui croissent spontanément ou que l'on cultive généralement dans I'ancienne province Belgique, leurs localités, leurs propriétés, I'indication du temps de leur floraison, la citation de leurs figures ... par Th. Lestiboudois :... Paris, Roret, et Lille, Vanackère pêre, Grand'Place, $n^{\circ} 7$, et Vanackère fils, place du Théatre, no10, 1827.

Collation: $8^{\circ}$ in 4s: part 1: $\pi^{2} a-b^{4} \quad c^{2}\left(-c_{2}\right) \quad d-e^{4} \quad \lambda 1-17^{1} \quad 1-39^{4} \quad 40^{2}\left(-40_{2}\right)$ (a-e signed in italics); $I-I V \quad i$ ii-xxxiv, 17 leaves: $\lambda 1-17,12-314$ (306); part 2: $\pi^{2} 1-62^{4} 63^{2}\left(-63_{2}\right) ; i-i v 172-498$ (475).

Contents: part 1: I half-title: "Botanographie I II I I.re partie Cryptogamie."; II list of booksellers, and imprint; III title; IV signature stamp of the author under notice of the publisher; $i$-xviii "DISCOURS PRÉLIMINAIRE."; xviii catchword "TABLEAUX."; xix-xxxiv introduction, discussing organisms with plant as well as animal characters, moreover listing and describing those which were considered doubtful in the Plant kingdom, since they have movement, as Diatoma and osoillaria [0ocillatoriaj, or free swimming swarm spores or other stages reminding of the Animal kingdom, e.g. "Anthophysis", zygnema, and "Salmaois" [Spirogyra]; $\lambda 1-17$ lists of genera in 17 classes with 
reference to the numbers on the plates and the new numbers in the text, and occasionally added keys for later segregated genera which were not present on the engraved tables; verso $\square: \lambda 1 \lambda 3-6 \lambda 11-13$; 1-304 text, containing the cryptogams $305-314$ index of names of genera and groups of higher rank;

part 2: I half-title: "Botanographie | II | II.e partie Phanerogamie." ii list of booksellers and printer's imprints iti titles iv signature stamp of the author under notice of the publisher, 1-474 text, containing the phanerogams (473-474 addenda); 175-495 index of names of genera and groups of higher rank; 496 errata; $497-498$ signs and abbreviations. Language: French.

Platee and tables: 17 folded copper-engravings ("CLASSE I" - "CLASSE XVII") and 6 folded typographical tables ("MÉTHODE ANALYTIQUE." "CLASSE XVIII" - "CLASSE $\left.X X I I^{\prime \prime}\right)$, containing keys to the genera, the engraved plates in graphic form with sketches illustrating genera, placed between preliminaries and text, and facing the corresponding $\lambda$-leaf; plate-mark: $188 \times 396 \mathrm{~mm} .(\mathrm{Cl} . \mathrm{XI}$ ).

Artiet: Chotard: probably all engraved plates; unsigned: plates of classes $6,13,16$ (or signatures worn).

Engraver: Durieux: $\mathrm{Cl} .4$ (signed: "Durieux. imp."); other plates unsigned.

Paper: leaf height $204 \mathrm{~mm}$. (HBL copy, cut), laid, chains vertical; wm.: "ROU[BI?]LIIOA" in the middle of the sheet parallel to the chain ines; plate paper: Dutch; laid; wm.: "J KOOL=[rampant lion with Bwordj" (Cl.8, HBL copy).

Printer: Vanackère fils, Lille, France.

Publiohers: Vanackère père, Lille, France; Vanackere fils, Lille;

Roret, Paris.

Date: 1827 (t.-p.); bef. or on 21 May (recd. Acad.Sci.Paris; see Stafl. TL); bef. 6 Jun. (Bibliogr.Franae 16 (45): 466. 1827).

Review: Linnaea Lit.Bar. 3(2): 67. 1828 ,

Refe.: Arn.Arb. 1: 424 BMNH 1097 Bradl.1: 392 a

\author{
Jacks . 271 \\ Kew 357 \\ Linn. Soc. 445
}

Pr.ed. $1 \mathrm{n} .5804$

Pr.ed. 2 n.5242

Stafl. TL n.675.

Notes. This book, constituting a new edition of the Botanographie belgique of the father. François-Joseph, was entirely rewritten. From the engraved plates of the earlier editions 17 were used, the engraved page-numbers on the copper plates being eliminated; the references to the new page-numbers were printed separately on adjoining leaves, where necessary augmented with additional keys for genera segregated later. The keys for "Graminees" (Gramineae + Cyperaoeae) and cryptogams (ferns, mosses, algae + hepatics, and fungi) were rewritten and typographically printed on folded tables.

In the text the classification of Lamarck, used in the former editions and on the plates, was dropped and replaced largely by that of A.P. de Candolle, in turn based on that of A.L. de Jussieu. The nomenclature also followed largely de Candolle, although in some groups considerable deviations occurred (e.g. Algae).

A few new names were proposed, e.g. Girodia (Algae), substitute name for the genus Butohineia Agardh non R. Brown in Aiton. Ho new names or combinations were proposed in the Bryophyta. In other groups new combinations might be present which are not indicated as such. Especially sections and varieties may appear to have-new combinations, and some treatments are even inconsistent with the trend of the whole work, e.g. under Pyrus L. three sections are listed, "MALUs", "** PYRU S" and "***CYDONIA". The species of the first and last sections, however, are indicated by sectional initials, contrary to the usual procedure in the book. This could be treated as an oversight in preparing the text for this edition, since it occurs only on these pages (vol.2: 406-407). Varieties were indicated in different ways, without a name, with a name in italics, or with a name cited in brackets, with a generic initial.

The original copper plates were presented to the municipality of Lille on 5 oct. 1857 , to be placed in one of the museums. 
LOREY, FEIIX \& DURET, L.

Biogr. Of the first author I did not yet find any biographical reference, except the indication on the title-page: "D. M." (doctor medicinae). He was commemorated in the generic name Loreya A.P. de Candolle 1828 (Melastomataceae).

of the second author, with the same title, I found only a reference to a notice: Buli.Soc.Bot.France 21(1): 8. 1874, which gave the date and place of his death: $1874 \mathrm{Jan} .7$, Nuits (Cote d'Or), France. Ile was comnemorated in the generic name Duretia Gaudichaud 1830 (Urtioaceae).

1 Catalogue des plantes... de la Cote-d'or ... Dijon, 1825 .

Titze: "CATALOGUE I des Plantes qui aroiseent naturelzement dane le | Département de la Cote-d'or, et des especes I les plus généralement cultivées, I OBSERVÉES JUSQU'AUJOURD'HUI | PAR MM. LOREY ET DURET, DD. MM.".

Colzation: $8^{\circ}: 1^{8} \quad 2-3^{8} x^{2} ; 1-3 \quad 4-47 \quad 48-50$.

Contents: 1 title; 2 ]; 3-18 preface: "AVERTISSEMENT"; $19-46$ text, alphabetical list of Latin names of plants without author citations nor any other indication; 47 supplement, adding 3 names, and the explanation that names in italics represent cultivated plants; $\$ 8$ imprint and date; 49 errata; 500.

Printer: Frantin, Dijon, France.

Date: 1825 (p.18), Jan.?, bef. 6 Aug. (Bibliogr.Prance 14 (32): 527. 1825). Announoement: MSm.Soo.Linn.Pari, 4(6): LII, CXXIX.1826 (offered to the soc. during Refo.: Arn.Arb.3: $186 \mathrm{a}$ Bradl.1: $407^{\mathrm{a}}$ Cat.Juss. n.1657

Linn.Soc. 485 Milt. 131
Pr.ed.1 n.6270

Pr.ed. 2 n.5616

Stafl. TL n.782.

rote. Local flora, list of names only, with a number of not too important mosses.

MÄRKER, Ch. Ph. No biography available to me. (See: Kneiff Marker $n, 1$ ). MARTINOV, Ivan [Martuinov, Ivan Ivanovich in BMNH cat.]

F1. 1820-1826. No biography available to me.

1 slovar' rodov'ioh' imen' rastinit...

S. Petersburg, 1826 .

Titze [in Russian, transcribed]: [SLOVAR' | RODOV'ICH' IMEN' | RASTÉNII. | S' PEREVODOM' NA RUSSIISKII JAZ 'IK', OSNATSHENIEM' ICH ' PROIS'CHOZDENIJA, KLASSA, I K' KOEMU KAZHD'II ROD' PRINADLEZHIT' I I TSHISLA IZVESTN 'ICH' POROD' KAZHDAGO | RASTÉNIJA, PO POKAZANIJAM' PERSONA I | SHTEUDELUA, | SOSTAVLENN'II | IVANOM' MART'INOV'IM' | [full swelled ryle] | SANKTPETERBURG' | ${ }^{\prime}$ TIPOGRAPHII DEPARTAMENTA NARODNAGO | PROSVESHCHENIJA. | 1826.1

Colzation: $8^{\circ}: \pi^{8} 1-22^{8}(-27) \quad 23^{4} x^{2}$ I-III IV-XVI 1 2-362 (317).

Contents: I title; II imprint: [Izdago on Departamenta Narodnago Pro-I

svéshchenija.]; III-XVI preface, headed: [SREDISLOVIE.], undated; 1-316 text, headed: "GENERA PLANTARUM. | [ROD'I RASTÉNIİ.]", alphabetical list of Latin names of plant genera, followed by the Russian names, the derivation of the Latin names, and in the case of names derived from personal names some of the works published by those authors, and finally an abbreviation indicating the class or other group in the modified Linnaean classification ( 22 classes); 377-362 index of Russian generic names with their Latin equivalents. No RT. Language: Russian, except latin plant names and an occasional head-title part. 
Paper: laid, chains vertical; wm. "(crowned figure, probably eagle," 3, 4 (PBII copy); indistinct marks at borders of other sheets.

Printer: :Iational Department of Education, St. Petersburg.

Date: 1826 (variant 1825?).

Reviewe: BuZZ.Soi.Nat. 17(4): 81. 1829 (cited date "1825"); Trautvetter, E.R.: Florae Rossicae fontes. Petropoli, 1880.

Refe.: Bradl.1: 77a Jacks.9 Krtg. 67 ("1825") Pr.ed.2 n.5863.

Variant: the date 1825 in some references may concern a title-page variant.

Notea. A list of generic names of plants for Russian use, following Persoon and Steudel. Cryptogams are treated as class 22 , the names are in the alphabetical list with phanerogans. No new names traced in Husoi.

ME HOIRES dU HUSÉUH d'BISTOIRE NATURELLE ... [PaYi:.

20 vols. Paris, 1815-1832.

Titze (Vol.12-15): "MEMOIRES | DU :YUSEUNA I D'HISTOIRE NATURLLLE, I PAR I LES PROFESSEURS DE CET ETABLISSEIIENT. | [short rule] | OUVRAGE ORNE DE GRAVURES. DEDIÉ AU ROI, I short rule] I, TOIE DOUZIENE. 113: TOIE TREIZIEIE.: [14: TO:IE QUATORZIEME.] [15: TOLE QUINZIElE.] | [monogram of swash script letters:] $A B$ A PARIS, I CIIEZ A. BELIN, IIIPRIIEUR-LIBRAIRE, I RUE DES UATHURIIS S. -J., HOTEL DE CLUNY, | 1825, [13: 1825.j [14: 1827.] i15: 1827. "

Colzation: $4^{\circ}$; see table next page.

Plates: usually engravings, a fev hand-colored; some plates lithographed.

Paper: leaf height $254 \mathrm{~mm}$. (Teyl. copy); laid, chains vertical; wm. (Teyl. copy, all letters in outline, in countermark the letter $L$ larger than the others): "C [diamond] $B=L^{n:}$ vol.12, $\pi, 1,2,4-10,14,16,18-22,30,33-37,39$, 42, 43, 49,50,52 ( $\mathrm{L}$ missing, ar $B$ and $L$ missing and diamond misformed in a number of sheets):

"P V [right top corner]": vol.12: 12, 23-28, 51, 53,58,59;

"P V I I [right top corner] ": vol.12: 47;

"I P [left top corner]": vol.12:60,64; vol.12: 21-36, 38-41;

"J G [left top corner]": vol.12:61,63, vol.13: 3,6;9;

"J G [right botton corner]": vol.12: 70; vol.13:

"S [diamond] $V=L$ ": vol.12: 62,66-69 (V missing: 69); vol.13: $\pi, 1-2$, 5. $11=19$;

"J [diamond] $F=L$ ": vol.13: 7,8;

$n G=L "[?]:$ vol.13: $G, 8$;

"J [diamond] B $\mathrm{B}$ ": vol.13: 42-59 (B missing: 43, 57; L missing: 55, 51, 56) vol. 14: $1,3-7,9-10$;

"A [triangle] T": vol.14: 12-51 (not all gatherings checked since the mark is only $14 \mathrm{~mm}$. high and therefore often not visible in the spine), and table facing p.366;

"T [triangle] D": vol.14; 54-62; vol.15; 1-4, 33-60 (50 uncertain);

"B P": vol.15: 10:

"P [diamond] L": vol.15: 11,

"M [liamond] $T$ [left top conner]": vol.15: 12-32 (diawond in at least one mould compressed to a narrow erect triangle);

plate paper: mainly laid, usually chains vertical, occasionally horizontal,

wm.: " $A$ F [eft top corner]": vol.12: pls.3,23,26, 27;

or "J D [left top corner]": vol.13: pls.1,4:

a few plates on wove paper: vol.14: pls, 1, 2, 3/5, 19.

Printer: Belin, A., Paris.

Publishers: Huseun d'Fistoire Naturelle, Paris: Bélin, H.: Paris. 
coliation, dates and anrounoements:

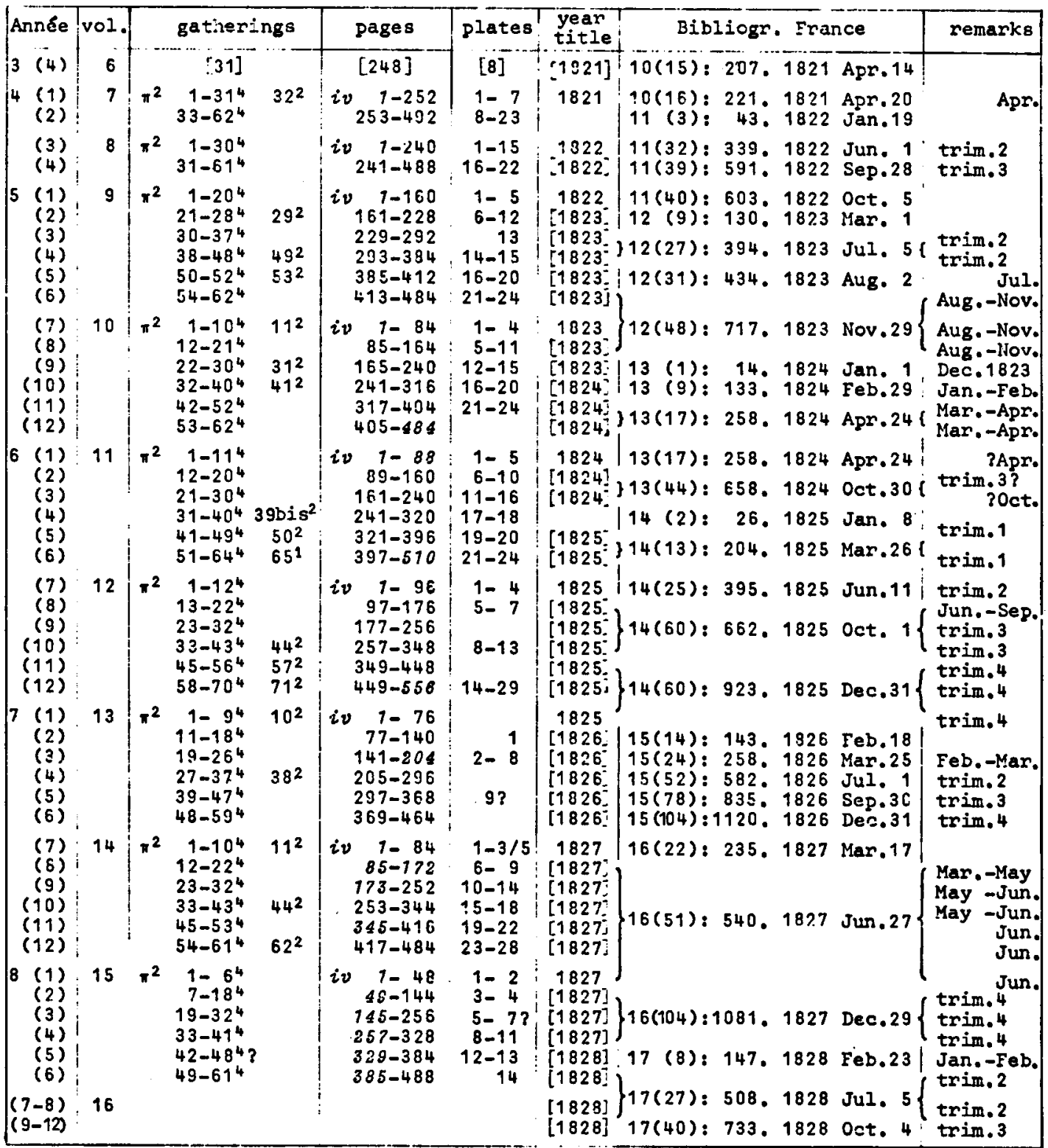


Bib2.notes. The distribution of the text over the fascicles as giver in the table is based on the following criterions:

1) an incomplete gathering is definitely the last cne of a fascicle;

2) fascicles begin, as a rule, with an article;

3 ) the plates, where bound in the middle of ar article, jindicate the end of a fascicle (the article by Cambessedes, vol.14, extends over two fascicles, and pls.10-14 are bound in after gath.32 in the Teyl. ccpy);

4) references to continuation of articles in later fascicles ("caniers");

5) watermarks.

The preliminaries $(\pi)$ were issued with the first fascicle of the volume,

The date of the title-page, therefore, is often too early for the other fascicles of the same volume.

The wrapper titles did not have the volume indication, since only the years (années) and the corresponding fascicle numbers were stated in Bibliographie de la Franoe. I did not see a copy in wrappers. This would have enabled me to settle some of the breaks between the fascicles, where the criteria mentioned did not lead to a conclusion. In these cases I selected the break which gave a better distribution of gatherings over the fascicles. Only the announcements in Bibliographic de la Brance were studied for collateral evidence. This journal appeared regularly each week or, in 1826 and 1827, twice a week. Books published in Paris will, as a rule, have been announced within 10 or 7 days of their publication. Journals, however, were only treated in full the first time a fascicle was announced in any years later fascicles in the same year were announced in a quarterly list of "Subscriptions" only, without a statement of the number of sheets or plates.

\section{MÉMOIRES de La SOCIETE' d'BISTOIRE RATURELLE de PARIS.}

Paris, vol, an VII, [1799], vol, 1-5, 1823-1834

22t2e [only studied one wrapper-title]: vol.2(2): "[frame: thick-thin rule I border of stylized floral ornaments with fancy ornamented circles in the corners and two circles in the bottom center | rule] | MÉMOIRES | DE LA SOCIÉTÉ | D'HISTOIRE NATURELLE | De Paris. [in gothic, the capitals swash decorated] I TOME SECOND. I [short double rule] I II PARTIE. I [short double rule] | Paris [in thick-thin gothic] | CHEZ LES EDITEURS DU DICTIONNAIRE CLASSIQUE D'HISTOIRE NATURELLE, | BAUDOUIN FRËES, LIBRAIRES-ÉDITEURS, | RUE DE VAUGIRARD, No 17, | REY ET GRAVIER, QUAI DES AUGUSTINS, N9 55. i [short wavy rule] AVRIL'1826. | [below frame in right corner:] IMPRIMERIE DE J. TASTU, RUE DE VAUGIRARD, $\mathrm{N}^{\circ} 36 . "$

Colzation: $4^{\circ}$, see table.

Printer: Tastu, J., Paris.

Publisher Baudouin frères, Paris; Rey Gravier, Paris.

Dates :

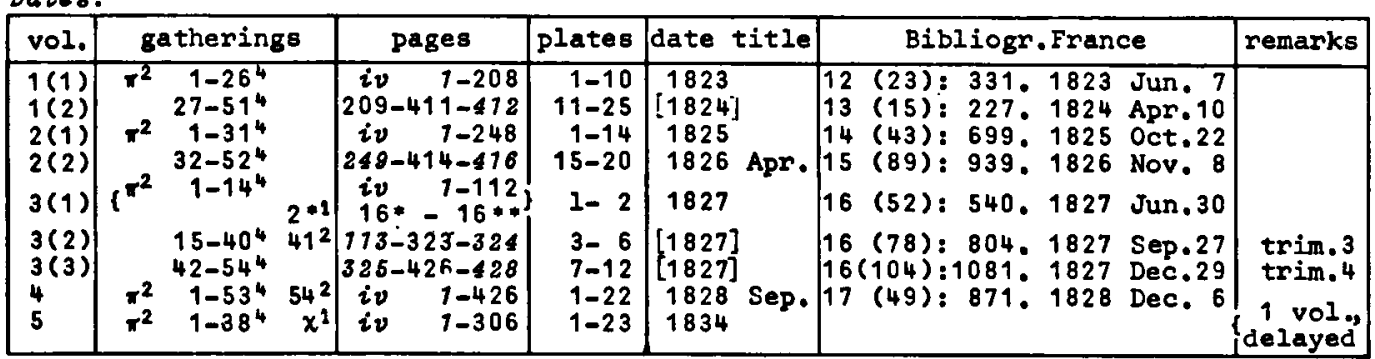

Dotes. The contents of the fascicles are derived from the indication of the numbers of sheets and plates in Bibliographie de la Franoe, except for vol. 3 , in which the paper color and the place of the plates in the Teyler copy were the guides.

For bryological articles see Annott $n .2$ and $n .6$. 
MEYHOTRES de Za SOCTETE LINNEENRE de PARIS

\author{
Vol. 1, 3-5, 6(1)-(5). Paris, 1822 [1823]-1827.
}

Titzes: vol.1: "MEMOIRES | DE LA | SOCIETE LINNEEINNE | DE PARIS, | PRECEDES DE SON HISTOIRE, | DEPUIS 1788 , EPOQUE DE SA FONDATION, JUSQUES | ET COMPRIS L'ANISEE 1822. [wavy mule] | TOME PREHIER. | [wavy rule] | PARIS, I AU SECRÉTARIAT DE LA SOCIETE LINNEEINNE, | Rue des Saints-Pères, no. 46 , en face la rue Taranne. | CHEZ AUDOT

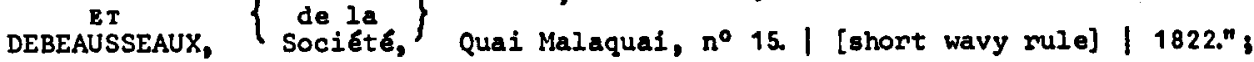
plate-part of vol.1: "FASCICULE | DE | QUATORZE PLANCHES | FAISANT PARTIE | DU PREIIIER VOLUME DES MÉMOIRES | DE LA | SOCIÉTE LIINÉENNE DE PARIS. [vignette of palm with snake] | A PARIS, | AU SECRETARIAT DE LA SOCIETEE LINNEENNE, RUE DES SAIIISS-PERES, I N similar to the imprint on the title of vol.1, in another type-setting] ", Vol.3-5: "MEMOIRES | DE LA | SOCIÉTE LINNEENNE | DE PARIS, | PRECEDES DE SON HISTOIRE, I PENDAITT LES ANNEES 1823 ET 1824. [4: PENDANT L ANNEE 1825;] [5: PENDANT L'AINSEE 1826;] | [Wavy mule ] | TOME TROISIEME. [4: TOME QUATRIEME.] [5: TOME CINQLIEME.] | [wavy rule] | PARIS, | AU SECRÉTARIAT DE LA SOCIÉTÉ LINIEENNE, I Rue des Saints-Péres, no 46 , en face la rue Taranne, [5: last part of line: pres la me Taranne,] | ET CHEZ DESBEAUSSEAUX, LIBRAIRE, QUAI MAIAQUAI, n० 15 | [short wavy rule] | 1825. [4: 1826.] [5: 1827:; ";

fascicle-titles (wrapper-titles) of vol.6(2)-(3): "[frame of thickthin rule, rows of stylized flowers, and circles at the corners, slot in the bottom row, and double thin rule within] / ANNALES I DE LA SOCIÉTÉ LINRÉENNE DE PARIS. I [short swelled mule] [ VIE VOLUME DES MÉMOIRES. I [very short rule] II [III - LIVRAISON DE LA IVE ANNEE DE SOUSCRIPTION. [fancy swelled rule] | Mai 1827 [Juilzet 1827] [Iines in large flowing soript] I [fancy swelled rule] | L'abonnement de 1827 a commencé avec le mois de mars dernier. | Ceux qui sont en retard pour renouveler leur souscription doivent | le faire de suite, s'ils veulent recevoir exactement les cahiers a me-l sure de leur publication. Pour les conditions, voyes la 3 e page. I PARIS, I AU SECRÉTARIAT DE LA SOCIETTÉ LINNÉENIE, | RUEE DES SAINTS-PEERES, NO 46.| $1827 \mid$ [in slot:] PARIS, DE L'IMPRIMERIE DE E. POCHARD. | rue du Pot-de-Fer, no 14."

Collation: see next page.

Contents and plates: see individual articles by Arnott, Desvaux and Palisot de Beauvois. At least two plates were engraved on one copper block (seen in copy of Saumaises, re-issue); probably other pairs were treated the same way.

Paper: leaf height $215 \mathrm{~mm}$. (HBL copy of re-issue Saumaises, uncut); laid, chains vertical (except for some plates with horizontal chains); wm. in vol.5: "L [partly outline] = Chapelle [erect script, in lower half sheet]".

Printers: D'Hautel, Paris: vol.1; Lebel, Paris: vol.3, 4(i), possibly more fascicles of vol.4; Decourchant (successor of Lebel), Paris: vol.4(6)-6(5), probably more fascicles of vol. 4 .

Publishers: Société Linnéenne de Paris; Audot, Paris; Debeausseaux [Desbeausseaux?], Paris.

Editor: Thiébaut de Berneaud, J.B.M.A.Arsenne, "secrétaire perpétuel" of the society.

Dates: vol.1: 1823, after 7 Dec. (last date in vol., in article of A. Richard: vol.2: never published?; vol.3-6: see table next page. 
Colzation: $8^{\circ}$ (except plate-vol. to vol.1: $4^{\circ}$ ); vol. 1: [fagin.:] $i-v i, 72-741742$ fother unnumbered pages omitted: plate-vol. to vol.1: $1^{4} 2-4^{4}, 32$ unnumbered leaves; vol.2: [pagin.:] I II-CXLI CXLII i-ii, $2-256$; vol. 3-6 $(5)$ :

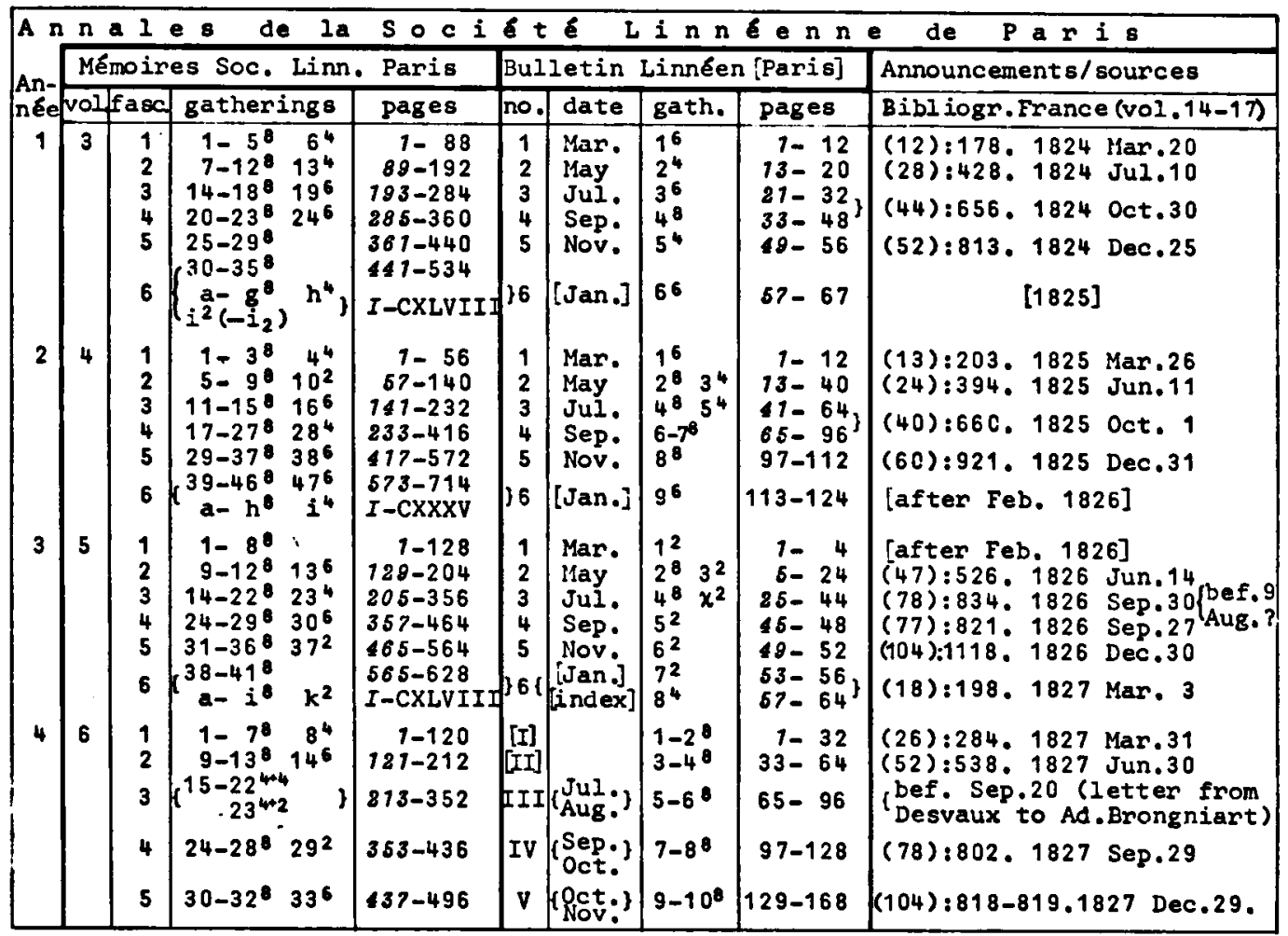

Note: unnumbered pages in the middle or at the end are omitted.

Re-issue. A remarkable re-issue of a number of sheets in the disguise of a completely new title was found: Saumaises, Auguste: Cours d'agrioulture, de botanique t d'histoire naturelie. 2 vols. Paris, 1837 (which see).

Bibl.notes. The fascicle contents of this periodical had to be worked out (see tabie) in connection with the articles of Arnott (n.7), Kittel (n.1) and Desvaux ( $n, 1,2)$. The two fascicle-wrappers I studied were helpful for their information, including the contents of these fascicles. The contents of the other fascicles have been worked out by the bibliographical method. It is clear that all incomplete gatherings (of less than 8 leaves) mark the end of a fascicle. In this way only the end of two fascicles remained uncertain: vol. $3(5)$ and $5(1)$. For these I took it for granted that the beginning of a new fascicle also was the beginning of a new article (consistently the case for the other fascicles with one exception: the break between $6(2)$ and $6(3)$ in the article of Desvaux $n .2$ ); still, this left some uncertainty, since in both volumes another break was possible, with these criterions. 
For fasc.5(2), however, we find that the announcement in Bibliogr. France indicates the number of sheets in the fascicle: 5 . This explicitly included the Bulletin Linnsen. My collation indicates 6 sheets, since this is in better agreement with the statement mentioned than any other arrangement. For fasc.3(5) I inferred the break at a point where the numbers of sheets in the two fascicles were not too unequal; the other possibility is a break between $\mathrm{p} .424$ and $\mathrm{p} .425$.

The dating of the volumes and fascicles formed another problem. The volume- and fascicle-dates cannot be trusted; there were considerable delays. Vol.1 was probably published late in Dec. 1823, in time before the yearly meeting at the end of December, I suppose.

Vol. 2 was, as far as I know, never published in the bibliographical sense, that is, put for sale. This is clear from the wrappers of fasc.6(2) and $6(3)$, stating that vol.2 was not yet published because it was "retardé par la gravure t quelques sutres auteurs absens, 14 planches et portrait de Tournefort." Since after fasc.6(5) no more of the journal was published, it is unlikely that vol.2 was published at all. The copy in PMusBC therefore probably came in some other way to the Museum. In how far it was distributed to botanists, fulfilling a requirement of the ICBN, I am unable to say.

The fascicles of the volumes 2-6 were published with new wrapper-titles: Annales de la socist Linnénne de Paris, counting the years from 1823 onwards; they contained the Memoires and the Bulletin Linnsen, and were scheduled to appear each two months; the wrappers consisted of thin colored paper.

The dates can be seen from the table of the collation, where the announcements in Bibliographie de la Franoe are added. This journal appeared twice a week; the announcements under the heading "Subscriptions" of the periodicals published in Paris indicate publication with a margin of three months. Only occasionally an announcement will have been published later, e.g. When a copy was not delivered correctly.

This may be the explanation for the remarkable fact that fasc.5(3) was announced later than fasc. 5(4), just one installment later. Probably fasc. $5(3)$ and 5(4) were published together, shortly before 27 Sep. 1826 , as it is also likely that fasc, $4(3)$ and $4(4)$ were published together. Possibly the secretary tried to bring out the summer fascicles before the sessions of the society were resumed in October.

I did not find any announcement for the sixth fascicle of the years 1824-1825, which contained the last gatherings of the Memoirse and the Bultetin Linnsen and also the preliminaries of the complete volume of the Memoires and the reports of the society over the year concerned; the title bears the year number of the publication year, not of the year of the fascicles $1-5$. The 6 th fascicles were scheduled for January, but I doubt that they were published already in this month; for vol.4 I am sure it was not even yet published in February because of the reference to the fact that Arnott was a "correspondant" (see Arnott n.5).

Another indication is the announcement of a prospectus for the Ann. Soo. Linn. Paris in Bibliographie de $2 a$ Franoe 1825(12): 185, 1825 Mar. 19. This announcement indicates the size of the prospectus $\left(8^{\circ}\right.$, il sheet), the price and the printer of the periodical, and then quotes with two italicized words: "1. anné finira avec le moie de janvier 1825, 10 $2^{\circ}$ anne a commenof avec le mois de mare 1825 et finira avec le mois de fanvier 1826." This italicizing apparently is from the editor of Bibliogr. Pranoe, indicating that he had not seen the fascicles concerned. In the same journal it is indicated (Bibliog*. France 1826(47): 526. Jun. 14) that only 5 fascicles of 1824 and 5 of 1825 were been. 
8 vols. Edinburgh, 1811-1839.

Titze (vol.5(1)): "MEMOIRS | OF THE | WERNERIAN | NATURAL HISTORY SOCIETY. | VOL. V. FOR THE YEARS 1823-24. | [short rule] | PART I. | [short rule] | WITR SEVED BNGRAVINGS.| [very short swelled rule] | EDINBURGH; PRINTED FOR I ADAM BLACK, NORTH BRIDGE, EDINBURGH | AND LONGMAN, HURST, REES, ORME, BROWN, I'LONDON. I [very short rule] | $1824 . "$

Dates and announoementa:

\begin{tabular}{|c|c|c|c|c|c|c|c|}
\hline vol. & pages & $\begin{array}{l}\text { Pls. \& } \\
\text { maps }\end{array}$ & $\begin{array}{l}\text { date } \\
t .-p .\end{array}$ & $\begin{array}{l}\text { last } \\
\text { date }\end{array}$ & $\begin{array}{l}\text { on } \\
\mathrm{p}_{2}\end{array}$ & publ.-date & source \\
\hline 1 & $\begin{array}{l}i-x \times i v \\
1-632\end{array}$ & $\begin{array}{c}15 \\
2 \text { tables }\end{array}$ & 1811 & $\begin{array}{c}1810 \\
\text { Nov } 24\end{array}$ & 609 & $\begin{array}{l}1811 \text { Jan-Jun, } \\
1811 \text { Jun. } 6 \\
1811 \text { Oct. }\end{array}$ & $\begin{array}{l}\text { Edinb.Rev.18:286.1811(between } \ldots) \\
\text { Monthi.Lit.Adv.1811(74):43.1811. } \\
\text { Sherborn,Ind.Animak.1807-60:xlvii.1922 }\end{array}$ \\
\hline $2(1)$ & $1-260$ & 19 & . & $\begin{array}{c}1814 \\
E \in b .12\end{array}$ & 252 & $\begin{array}{ll}1814 & \text { May } \\
1814 & \text { Nov. } 7\end{array}$ & $\begin{array}{l}\text { Sherborn 1.c. } \\
\text { Trans.R.Soo.Edinb.9:531.1823(recd.) }\end{array}$ \\
\hline $2(2)$ & $\begin{array}{c}i-x v i \\
261-700\end{array} \mid$ & 9 & 1818 & $\begin{array}{c}1817 \\
\text { Dec. } 20\end{array}$ & 666 & $\begin{array}{ll}1818 & \text { Jan. } \\
1818 & \text { Feb. } 2\end{array}$ & $\begin{array}{l}\text { Blaokw.Edinb.Mag. } 2(10): 379.1818 . \\
\text { Trans.R. Soo.Edinb. } 9: 533.1823 \text { (recd.) }\end{array}$ \\
\hline 3 & $\begin{array}{l}i-x i i \\
1-560\end{array}$ & 25 & 1821 & $\begin{array}{c}1821 \\
\operatorname{Mar} .10\end{array}$ & 539 & $\begin{array}{ll}1821 & \text { May } \\
1821 & \text { Jun.20 }\end{array}$ & $\begin{array}{l}\text { Blaokw.Edinb.Mag.May } 1821 \text { (Sayre p.66) } \\
\text { J.Gen.Litt.Etrang. (Sayre P.66). }\end{array}$ \\
\hline $4(1)$ & $\begin{array}{l}i-v i i i \\
1-252\end{array}$ & 10 & 1822 & $\begin{array}{c}1822 \\
\text { May } 18\end{array}$ & 237 & $\begin{array}{ll}1822 & \text { May } \\
1822 & \text { Aug. } \\
1823 & \text { Apr. } 5\end{array}$ & $\begin{array}{l}\text { Sherborn 1.c. (doubtful). } \\
\text { Blaokw.Edinb.Mag.12(67):243.1822, } \\
\text { Linn. Soc.Lond. (recd.) }\end{array}$ \\
\hline $4(2)$ & $\begin{array}{r}{[v i i i]} \\
253-604\end{array}$ & 7 & 1823 & $\begin{array}{l}1823 \\
\text { May } 31\end{array}$ & 588 & $\begin{array}{ll}1823 & \text { May } \\
1823 & \text { JuI. }\end{array}$ & $\begin{array}{l}\text { Sherborn 1.c. (not comect) } \\
\text { Blaokw. Edinb, Nag.14(78):112.1823. }\end{array}$ \\
\hline $5(1)$ & $\begin{array}{l}i-v i i i \\
1-288\end{array}$ & 7 & 1824 & $\begin{array}{c}1824 \\
\operatorname{Mar} .21\end{array}$ & 287 & $\begin{array}{ll}1824 & \text { May } 20 \\
1824 & \text { Jun } .14\end{array}$ & $\begin{array}{l}\text { letter Arnott to Brongniart } 20 \text { May } \\
\text { Linn. Soc. Lond. (reed.) }\end{array}$ \\
\hline $5(2)$ & $\begin{array}{r}i-v i i i \\
289-600\end{array}$ & 10 & 1826 & $\begin{array}{c}1825 \\
\text { Dec. } 3\end{array}$ & 580 & $\begin{array}{ll}1826 & \text { Jan. } 2 \\
1826 & \text { Jun. } 20\end{array}$ & $\begin{array}{l}\text { Trane.R. Soo.Edinb.10:423.1826(recd.) } \\
\text { Linn. Soc. Lond. (recd.) }\end{array}$ \\
\hline 6 & $\begin{array}{l}i-v i \\
1-591\end{array}$ & 6 & 1832 & $\begin{array}{c}1831 \\
\text { Apr.16 }\end{array}$ & 581 & $\begin{array}{ll}1832 & \text { Jan. } 1 \\
1832 & \text { Feb. } 1\end{array}$ & $\begin{array}{l}\text { Trans.R.Soc.Edinb. } 12: 570.1834 \text { (recd.) } \\
\text { Linn. Scc. Lond. (recd.) }\end{array}$ \\
\hline 7 & $\begin{array}{l}i-i v \\
1-520\end{array}$ & 45 & 1838 & $\begin{array}{c}1838 \\
\text { Aus. } 11\end{array}$ & 510 & $1839 \mathrm{Jan} .7$ & Trans.R.Soc.Edinb. 14 (2).1841(recd.) \\
\hline $8(1)$ & $\begin{array}{l}i-i v \\
1-164\end{array}$ & 5 & 1839 & & & $\begin{array}{l}\text { after } \\
1839 \mathrm{Jul} .\end{array}$ & Sherborn 1.c. \\
\hline
\end{tabular}

Printer: Neill, Patrick, Edinburgh (see Greville n.5).

Hoter. This list gives some refinements compared with earlier lists (Sherborn Stearn in v.Steenis-Kruseman: Flora Males. ser.1, 4(5): CCI. 1954). As was already known for the articles of $R$. Brown and D.Don, separates from this journal were published before its fascicles; I could prove the same for the articles of Greville and Arnott. The position of the printer, being the secretary of the society, makes this understandable.

The dates given by Sherborn are not completely reliable, and he did not give any documentation. The other dates given are the dates of the fasc. of the periodicals with the announcement or review, and the dates of receipt of the book by the organization, indicated: (recd.); obviously the actual date of publication was usually earlier. 
MOUGEOT, Jean Baptiste

Biogr. Born 1776 Sep. 25, Bruyères, now dép. Vosges, France. Died 1858 Dec. 5, Bruyères.

After education at home he studied at the school of the gray friars at Alt-Breisach, later at the universities of Freiburg im Breisgau, and Basle, where he studied philosophy: Being placed on the list of "émigrés", he could not come back into France until 1795. In this year he botanized for the first time on the mountain Hohneck in the Vosges, where he returned nearly every year. He found many alpine plants in these mountains which before were considered to be confined to Switzerland. He was sent to the medical school at Strasburg as national pupil for the district of Bruyeres. Here he heard botany from Jean Hermann (1738-1800), and met Nestler as a fellow-student. He left the school 1 ventose an VII (19 Feb: 1799), was called to arms to the field hospitals, went into Germany, where he studied natural history whenever possible, and made acquaintances with other botanists. After the peace of Luneville (1801) he went to Paris for further study, where he received his doctor's degree 26 germinal an XI (18 Apr. 1803).

He settled as a physician at Bruyeres for the remainder of his life, soon having charge of the hospital and helping the poor and the sick at every opportunity. llevertheless he found time for a very fruitful scientific exploration of the Vosges mountains, not only botanical, but also geological. He was mentioned in 1810 by A.P. de Candolle as one of the botanists who had contributed most to the study of the French flora.

The exsiccata series, which he published together with Nestler, and after the death of the latter with W.P. Schimper, is discussed below. He also helped to prepare a geological map of the Vosges and was a founder of the Museum at Epinal (the capital of the department Vosges), gave a choice collection of minerals and contributed yearly to it.

He was mayor of Bruyères for a considerable time, and was also elected a member of the general council of the departement in 1833 and was reelected every time. In 1836 he was nominated chevalier de la Legion d'honneur. His son, [J.] Antoine,
(1815-1889) (1815-1889) became a well-known mycologist. A collection of letters of Jean Baptiste is preserved at the Bibliotheque of the Muséum d'Histoire Naturelle de Paris. He was commemorated in the generic name Mougeotia C.A. Agardh 1824 nom.cons. (Chlorophyta, zygnemataoeae), and Mougeotia Humboldt, Bonpland \& Kunth 1821 (sterouliaceae), and the specific name Amphidium mougeotii (B.S.E.) Schimper (Musoi).

Refe.: Jaubert: Bulz.So0.Bot.Prance 5: 562-565. 1859.

Annales Soo.E'mul. Vosges 10(1). 1858 (extract 20 p.).

MOUGEOT, J.B. \& NESTLER, C.G. [fasc.12-15:]

\& SCHIMPER; W.P.

1 Stixpes aryptogamae Vogeso-Rhenanae ...

15 fasc., 1 index-vol. Bruyères, 1810-1860 [exsiccata].

Tit te: fasc.1: "STIRPES CRYPTOGAIAE | VOGESO-RHENANAE; | Quas in Rheni superioribus inferiorisque, nec non Vogesorum praefecturus | collegerunt | J. B. Mougeot (Bruyeriensis M. D.) et C. Nestler, Argentinensis Pharm. I Fasc. 1, Bruyerii Vogesorum typis 11 . Vivot, 1810.",

fasc.2-11: slightly altered tities, especially as to printer

fasc.12-14: added after the authors: W, P. Schimper;

fasc.15: J.-B. et J.-A. Mougeot, C. Nestler, et W. P. Schimper;

index-vol.: "INDEX ALPHABETICUS | GENERUM, SPECIERUM ET SYNONYMORUM | IN |

J. B. Mougeot, C. Nestler et W. P. Schimper Stirpibus I Cryptogamis VogesoRhenanis a fascizulo prino ad duodecimum usque enumeratorum. [ [short swelled rule with pearls] | Bruyerii vogesorum 1843."

Collation: $4^{\circ}$ :

fasc.1: $\pi^{4}, \quad i-v i i t ;$

fasc, 2-15: "not studied, usually 2 leaves, unnumbered;

index-vol.: 13 leaves; pagin.: $1-4$ 5-25 26 . 
Contente: fasc.1: $i-i i \mathrm{O}$; iit title; iv $\mathrm{O}$; $v$ dedication to Dominique villars (1745-1814), professor of botany at strasburg; vi $D$; vii-viii alphabetical index to the species with their serial number;

fasc.2-15: not studied in detail, usually only title and list of species, fasc.12 with a preface, dated Oct. 1842 , sjgned: "J.B. Mougeot W.P. Schimper."; fasc.15 with a preface, dated 1 Jun. 1860 , written by the son of J.B. llougeot, [J.] -Antoine Mougeot (1815-1889) who prepared this fascicle after his father's decease.

Plate: frontispiece in fasc.15: portrait of J.B. llougeot.

Specimens: pasted to the rectos of quarto leaves, one species per Ieaf, sometimes two specimens from different localities, occasionally of a different variety on the same leaf: gatherings quired of 8 or 10 leaves ( 2 or $2 \frac{1}{2}$ sheets), in sufficient amount to make 100 leaves; printed labels pasted on rectos of the specimen-leaves, with the following information (in general): a) consecutive number, b) Latin name with author's citation, c) usually a synonym, d) habitat, month of the sporophyte, and general indication of occurrence, e.g. "ubique", rarely a special locality, e.g. "12 Gymnos tomum Bedwigia Schrank" had an extra specimen marked "a" on the leaf, on the label referred to as "a. Varietes mejor, frequene circa Gerardmex."

Printer: fasc.1-...: Vivot, Bruyères, dép, Vosges, France; he died circa 1815 ; his widow continued the press for a time and then moved to saint Die, déf. Vosges, where the remaining parts were printed. She married there another printer, I did not investigate whether he continued printing this series.

Publiaher: apparently Mougeot sert out the copies.

Dates and contents of fascioles:

\begin{tabular}{|c|c|c|c|c|}
\hline fasc & $\begin{array}{l}\text { specimen } \\
\text { numbers }\end{array}$ & $\begin{array}{c}\text { Musci } \\
\text { numbers }\end{array}$ & $\begin{array}{l}\text { date } \\
t .-p .\end{array}$ & publication date and source \\
\hline $\begin{array}{l}1 \\
2 \\
3 \\
4\end{array}$ & $\begin{array}{r}1-100 \\
101=200 \\
201-300 \\
301-400\end{array}$ & $\begin{array}{l}112-146 \\
209-238 \\
307-335\end{array}$ & $\begin{array}{l}1810 \\
1811 \\
1812 \\
1813\end{array}$ & after 1 Sep.i 1810 or 1811 (Sayre 37). \\
\hline 5 & $\begin{array}{l}401-500 \\
501-600\end{array}$ & $\begin{array}{l}405=430 \\
505-526\end{array}$ & $\begin{array}{l}1815 \\
1818\end{array}$ & 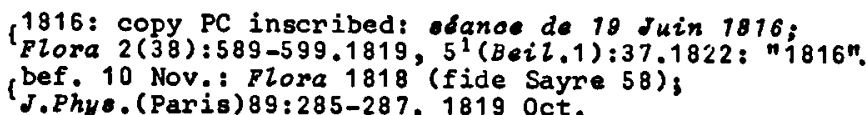 \\
\hline $\begin{array}{r}7 \\
8 \\
9 \\
10\end{array}$ & $\begin{array}{l}601-700 \\
701-800 \\
801-900 \\
901-1000\end{array}$ & $\begin{array}{l}605-628 \\
703-732 \\
802-835 \\
902-934\end{array}$ & $\begin{array}{l}1820 \\
1823 \\
1826 \\
1833\end{array}$ & $\begin{array}{l}\text { in or bef. Mar.1824: Bul2.Soi. Nat.1(3):252-253.1824, } \\
\text { after Jan. (later than Arnott n.5); Ca. Apr.? (see } \mathrm{P} .67 \text { ). } \\
\text { after } 1 \text { May (pref.); bef. or in Apr.1834: } \\
\text { Ann.So.Mat. ser.2: } 1: 251-252.1834: 11834^{\prime \prime} ;\end{array}$ \\
\hline $\begin{array}{l}11 \\
12 \\
13 \\
14 \\
15\end{array}$ & $\begin{array}{l}1001-1100 \\
1101-1200 \\
1201-1300 \\
1301-1400 \\
1401-1500\end{array}$ & $\begin{array}{l}1002-1036 \\
1102-1134 \\
1204-1231 \\
1304-1322 \\
1403-1416\end{array}$ & $\begin{array}{l}1840 \\
1843 \\
1850 \\
1854 \\
1860\end{array}$ & $\begin{array}{l}\text { aft. } 100 t .1842 \text { (pref.); bef. } 11 \mathrm{Mar} .1845: \text { PC copy(recd.) } \\
\text { after } 1 \mathrm{Jun} \text {. (pref.). }\end{array}$ \\
\hline
\end{tabular}

Review (other than already in the above list):

de Candolle, A.P.: Biblioth. Univ.Soi. (sect. Soi.) 44(7): 261-262. 1830 Jul.

Refe.: index 1843: BMNH 1361

Cat.Juss. n.2148

exsiccata fasc.: $\mathrm{Kew}_{\mathrm{Krug}}, 110(1-12)$

Pr.ed.1 n. 7248

Milt. $279(1-5)$. 
Notes. Important series of exsiccata, serving as a model for many others. The dates of the fascicles $1-7$ have been reviewed by Dr. Sayre. I was unable to find any more precise date for fasc.9, with the title-date 1826 . Possibly in some letters of Mougeot information is to be found, but the file I glanced through at the Bibliotheque du Museum d'Histoire Naturelle, Paris, did not give me any answer on this year. I had especially hoped to find letters of S.E. Bridel, who had sent information of his Bryologia universa to lougeot: "n.832 Bryum erythrocarpon Brid. Bryol.Univ. p.654 (ex Brid. in Litt.)". The only certain point, up to now, is that this fascicle was published later than Arnott's Dioposition m\&thodique .... (the $4^{\bar{\prime}}$ prepublication), since it is cited after $n .813$ in the synonymy.

A number of new names were proposed in the series, but usually no descriptions were printed, and only if some reference to a name with $a$ published description was given, the name is valid. Unfortunately this is the case with Buxbaumia indusiata Brid., as a species universally recognized under this name, without any exception as far as our work for Index Muscorum showed, but which name is antedated by "Buxbaumia viridis Brid. in Litt.". with the valid reference to "B, aphylla b. viridis De Candolle Fl. Fr. Suppl. p.227 [1815] ", in fasc.8, n.724. 1823.

\section{NEES von ESENBECK, Christian Gottfried [Daniel]}

Biogr. Born 1776 Feb. 14, Reichenberg (castle) near Erbach, Odenwald, Germany. Died 1858 Mar. 16, Breslau, Germany.

C.G. Nees von Esenbeck attended the gymnasium of Darmstadt, 1792-1796, and at the University of Jena he studied medicine, and natural history under A.G.J.C. Batsch (1761-i802), and philosophy under F.W.J. Schelling (1775-1854), having also contacts with Goethe in Veimar. He received his degree Dr.Med. in Giessen in 1800.

He then practized as a physician in his native region, but gave this up since it badly influenced his health. He retired to the estate Sickershausen near kitzingen an Main which he had inherited from his wife who his died after one year of marriage. Here he devoted his time to the study of languages and to the formation of collections of animals (especially birds and insects), and of plants. His animal collection later came to the University of Bonn, after he had published on some insect groups. His articles on plants are numerous, and of different contents, advocating the "Naturphilosophie" of Schelling, or treating different groups of crypto gamous as well as phanerogamous plants systematically.

He became a member of the Acadenia Caesarea Leopoldino-Carolina in 1816, its president on 3 Aug. 1818, and edited its Nova Aota for many years. When the returns from his estate diminished considerably he needed a position; he was nominated professor of botany at Erlangen in 1817, and at the new University of Bonn in 1818. Here he worked fruitfully, publishing also together with his brother Theodor Friedrich Ludwig (which see). The botanical garden was energetically supported by him. In 1830 he exchanged his position in Bonn with the similar one of Treviranus in Breslau, in connection with the interests of the Academia Caesarea LeopoldinoCarolina. In Breslau he gradually became more involved in political and social organizations advocating freedom, which finally led to dismissal from all his functions He had to sell all his collections and ended in a rather poor condition, but he did not renounce the ideals he had lived for.

His collection of Bepatiaae is preserved in the Institut de Botanique de la

Faculte des Sciences of the University at Strasburg.

He and his brother are commemorated in the generic names Esenbeokia Humboldt, Bonpland \&unth 1825 (Rutaceas), Esenbeokia Blume 1825 ENeesia Blume 1825 , Esenbeokia Brid. 1827 , replaced by Garovaglia Endlicher 1836 (Musai, Pterobryaceae), Neesia Sprengel 1818 , nom.ref., a superfluous synonym of Otanthus Hoffmannsegs Link (Compositae), Neesia Blume 1825, nom.oons. (Bombacaceae), and Neesielia Schiffner 1893 (Bepatioas, Marohantiaies).

Refo.: Hooker, W.J.: Kew J. Bot. 4: 28-29. 1852 .

Kieser: Nova Acta Phys. Med. Aoad. Caso. Leop.-Car. 27: 1xxxv-xcvii. 1860. Wunschmann, E.: Alig. Deutsohe Biogx. 23: 368-376. 1886 .

1 Spirideno... 1823.

See: Reinwardt \& Nees, n.1. 
2 Naohochrift [to: Breutel: Beitrag su der Noosgattung Sphagnum].

Flora 7(28): 441-442, 1824 Jul. 28 .

Collation to.: see Flora.

Bot.note. Supplement to the article of Breutel ( $n .2$ ) on sphagnum, giving comparison of the parallel series of Sphagnum species with "exserted" and with "immersed" (sessile) sporophytes, the latter except one proposed by Breutel.

NEES von ESENBECK, Chr. HORNSCHUCH, Fr. \& STURM, Jacob

1 Bryologia Germanioa...

2 vols. in 3 parts. Nurnberg Leipzig, 1823-1831.

Titze (not transcribed): Bryologia Germanica, oder Beschreibung der in Deutschland und in der Schweiz wachsenden Laubmoose, von ... C.G. Nees von Esenbeck.... $F$. Hornschuch und $J$. Sturm, ... Narnberg, J. Sturm ... Leipzig ... Fleischer.

Colzation: $8^{\circ}$ : vol.1: $\pi^{6}(-\pi 3.6, \pi 8) 2 \pi^{2}(=\pi 3.6)$ a-i $k^{4} x$ (quarter-sheet folded table) $A-B^{8} 2 x$ (folded table) $C^{8}\left(-C_{1.0}=2 x\right)$ D-N $i-x v i$ I II-CLIII CLIV $12-206$ (CXXII as 'CXII', 203 as '206', CLIII folded table, recto of $x$, verso unnumbered, $33-34$ : folded table $2 x$ ), vol.2(1): $\pi^{1} A-E^{8}\left(E_{6}+x^{i}\right) F-L^{8} M^{6} i-i i, 2-76$ [unnumbered folded table] 77-182 183-188; vol.2(2): $A-N^{8} x^{1}: 1-3 \quad 4-208 \quad 209-270$.

Contente: vol.1: $i$ title; if $\square_{3}$ ii dedication to Karl Freiherr Stein von Altenstein $(1770-1840)$; iv $\square ;$ p-viii text of the dedication, signed: "Bonn und Greifswald, | den 1. May 1822. | [...] | Dr. Nees von Esenbeck | Dr. Hornschuch.": $i x-x i i$ thanks to the friends of German muscology: "Den Freunden | der deutschen Mooskunde", signed: "Die Verfasser." xiit notice of the authors: "Zur Nachricht." signed: "Die Herausgeber." and dated 14 Feb. 1823 ; $x i v \square ; x v-x v i$ corrections in the introduction; I-III introduction, dated: "Bonn und Greifswalde am Christfest 1821.", signed: "Dr. C.G.Nees von Esenbeck. | Dr. Fr. Hornschuch."; IV-CLII introduction to bryology in general and that of Germany in particular, including (CXLIV-CLII) a list of sources; CLIII folded table of genera of mosses of Germany, headed: "Einleitung. IX. Conspectus generum Muscorum Germaniae." CLIV D; 1 -206 text, headed: "DEUTSCHLANDS MOOSE.", descriptions of Geman moss genera, species and (in some sdecies a large number of varieties, Sphagnum - Aymenostomum, including the folded table 33-34; vol.2(1): $i$ title; it $0 ; 1-180$ text, continued, Tetraphis - Grimmia; 181-182 corrections; $783-786$ list of works published by Jacob Sturm, dated 1827, including his Deuteohlands Flora 1-17; $187-188$ offer of a 1 inited number of complete sets of his Deutochlando Blora and Deutoohlands Fauna at a reduced price; vol.2(2): 7 title; 8 [; 3-208 text, continued, Braohyodus - Trematodon; 208-270 list of works published by Jacob Sturm, including his Deutoohlands Flora, Abt.2 Cryptoganen 1-20, which was also offered with illustrations on wove paper at a higher price. RT: mostly German names of systematic groups and the Latin generic name, o.g.: "Gipfelfruchtige. MUndungslose. Voitia. | Fam. 2 Scheidige. Vaginulati. Voitia." Language: German.

Plates: 43 hand-colored or uncolored copper-engravings, in vol.2(2) (colored state) partly printed in color (Brachyodus $\mathrm{pl} .25$ ), illustrating moss species and varieties, numbered: vol.1: I-XII, vol.2(i): XIII-XXXIV, vol.2(2): XXV-XLII; , generic names above, specific epithets below the figures concenned, species also with a numeral (in each genus new numbering), varieties marked with one or more (up to 4) asterisks, plate-mark: $189 \times 117 \mathrm{~mm}$. (pl.1).

Artiet and engraver: Sturm, Jacob (which see)

Paper: leaf height $221 \mathrm{~mm}$. (NYBG copy 1); laid, chains vertical; wm.: "N $8=W$ [swash script letters]" (at least 2 different moulds, with larger or amaller 8 ): vol.1, 2(1): most sheets; 2(2): all sheets except $E-N$ (no wm. seen in $E-N$ ): plate paper: wove; wm. "J T [outline] ": pl.1-2; "L OR [outline]": pl.4 67 ,

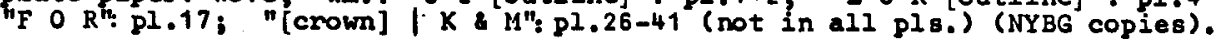


Printer: no imprint.

Publishers: vol.1: Sturm, Jacob, Julnnberg, Germany (which see); vol.2(1): Fleischer, Friedrich, Leipzig;

vol.2(2): Sturm and Fleischer (? notes insufficient).

Dates: vol.1: 1923 (t.-p.); after $14 \mathrm{Feb},\left(p_{i} x_{i i}\right)$;

Feb. (Hess.Soi.Arte Gand $1823(2): 88.1823$ Jun., not completely reliable);

bef. 15 Apr. (Ailg.Repert. Neuest. In-Aus Z.Lit. $1823^{2}$ (1): 11-14.1823 Apr. 15)

sem.2 (Flora 6(26): 414. 1823 Jul.14: recd. for library opring 1823 ):

vol.2(1): 1827 (t.-p.); circa Apr. (Linnaea 2(4): 676. 1827);

vol.2(2): 1831 (t.-p.); in or bef, Oct.(Flora 15(8):119.1832: recd, for 1 ibrary).

Reviews (other than mentioned under Dates):

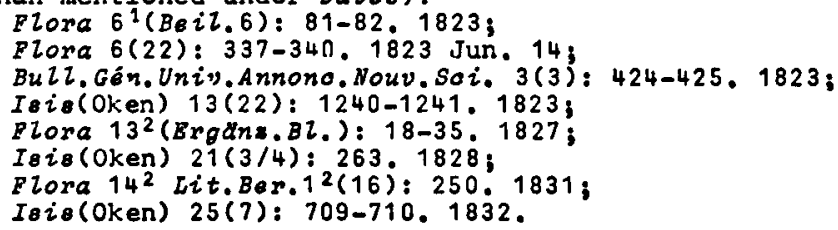

Refs.: BMNH $287,1408,2043$

Brun. 4: 32

Graesse 4: 655

Jacks. 296

Krelg. 242

Lindl. Libr. 324

Linn.Soc. $374,562,740$

Kew 291, 448, 594
Milt. 485

Niss. n.1439

Pr.ed. 1 n. 7452

Pr.ed. 2 n.6649.

Bibl.notes. The $x^{\prime}$ s and $x^{\prime}$ s in vol.1 deserve mention. The gathering $2 \pi$ consists of the conjugate pair of leaves $\pi_{3.6}$ taken out and inserted after the other leaves of $\pi$; the WU copy had this pair folded together with the other leaves which interrupts the dedication. Another collation is: $\pi^{6} 2 \pi^{2}$, but the one here is preferred to show its position.

$x$ and $2 x$ are folded tables, but they are included in the pagination and therefore treated as part of the collation. $2 x$ could also be designated $C_{1}$, but $2 X$ is preferred since it in fact is $C_{1.8}$ inserted as a folded table. Likewise $x$ may have been part of the sheet on which $k$ was printed, but this has not been checked thoroughly.

The folded table in vol.2(1) is for consistency also treated in the text-collation, though this leaf is unnumbered. In the notice on $2 \pi_{1} r(p . x i i i)$ a "synopsis" to the plates is mentioned, to be used for quick finding and determining. I have found no other reference. Since the work is unfinished, this part too will never have been published.

Bot.notes. A thorough treatment of the German mosses, illustrated by careful drawings of the species and varieties.

The authors of the text were Nees and Hornschuch; Sturm was the artist. Nevertheless, in my opinion, the new names should be cited with the three names as authority, since they are all on the title-page. In some bryological works this set of names has been abbreviated to N.H.S.: in some earlier works only Bryol.Germ. was used.

The preparations of the work took a long time. An early announcement is in Flora 2(7): 107-111. $1819 \mathrm{Feb}$. 21. In Oct. 1821 it was expected that vol.1 would be ready at the Easter Fair 1822 ; vol.2 was planned for Easter 1824, see Flora 6(28): 447. 1823 Jul.; in the same journal, $9(15): 236.1826$ Apr. 21 it was mentioned as follows: "... wird nichstans in neuer Band ercheinen; die Manuekipte dazu ind chon ln sturms Blnden, und dieser iet unaufhorlich mit dem Stich der Kupfer beschaftigt." Apparently this took some time, together with the printing.

The treatment of the species goes deeply into details, with sometimes long discussions. An unusual number of varieties was proposed, which in many cases were only modifications in the modern concept; probably they were not meant to be more. The work was never completed, since it was not a financial success. Possibly it went into too much detail. 
MFES von ESEIJBECK, Theodor Friedrich Ludwig

Biogr. Born 1787 Jul. 26, Reichenberg (castle) near Erbach, Mdenwald, Germany. Died 1837 Dec. 12, Hyères, dép. Var, France.

T.F.L. Hees von Esenbeck attended school at Erbach, and after that he had to help his father in the management of an estats in litzingen an llain, but he preferred to accompany his brother Christian Gottfried on trips for collecting plants and insects. He chose pharmacy, but first he followed a course in botany with his brother. In 1805 he became a pupil of Martius, court-pharmacist in Erlangen, and interested one of the sons in botany (the later famous Carl F.P. von Martius, 1794-1868). In 1811 he went to the pharmacy of Bernoulli in Basle, where he stayed until 1816 , making many botanical excursions in the Swiss mountains.

For health reasons he was home in 1816 and after that he assisted in a pharmacy in Hanau. Ilere he made the acquaintance of H. Kuhl (1796-1821) who han an assignment from the Dutch government to make a scientific journey in the island of Java and was taking leave of his relations in Fanau. Back in Leiden Kuhl recommended Nees to S.J. Brugmans $(1763-1819)$, the director of the botanical garden, which led to his appointment as inspector of this garden in 1817. He reorganized the garden in a systematical arrangement of the plants, made an inventory of the plants, and made many connectiors for the establishment.

Observations on the gemmae of the moss Bryum annotinum found in the dunes near the Dutch coast was the subject for his doctor's thesis, Erlangen 1818, including his view on the development of the cryptogams. He also made the acquaintance of C.L. Blume (1796-1862), who vas preparing for a voyage to Java too.

In the sumner of 1819 his brother Christian Gottfried called hin to the University of Bonn, as inspector of the botanical garden and Repetent of Botany, where he helped to develop the new botanical garden to an important establishment, together with the gardener W. Sinning $(1794-1874)$.

In Sep. 1919 he becane "Privatdocent" at the University, and he lectured on pharmaceutical botany and preparative pharmacy, with real material for observation. In 1822 he became extraordinary professor and in 1827 ordinary professor of pharmacy and the director of the new pharmaceutical laboratory, founded largely by his efforts,

In 1833 he became co-director of the botanical garden.

He published many phamaceutical-chemical papers; he especially worked on the botanical identifications of many foreign dmigs. In 1834 he was a founder of a botanical society of the middle- and lower Rhine area. His health was not too good. and when it strongly deteriorated in the sumer of 1837 , he hoped to recover in the milder climate of Southern France, but he died there.

For commemoration in generic names, see Christian Gottfried.

Refo.: Nees von Esenbeck, C.G.: Theodop Friedrich Ludwig dees von Eeenbeok, sur Erinnexung... Breslau, 1838, p. 32-40 (not seen).

Wunschmann, E.: Ailg. Deutsohe Biogr. 23: 376-380. 1886 .

1 De muscorum propagatione oommentatio...

Bonn, 1820 .

Titie: "THEOD. FRID. LUD, NEES AB ESENBECK I PHILOSOPHIAE DOCTOR I REG. SOC. BOT. RATISBOH. SOC. PHARH. BAVAR. MEMBR. HON, | DE I IUSCORUM PROPAGATIONE. COMIENATIO. | Cum tabuja aenea picta. | [very long swelled mule] | BONNAE | apud Adolphum Marcun | 1820."

Collation: $4^{\circ}$ : identical with the 1818 thesis, with cancellans title-leaf

Paper: laid, chains horizontal;

plate paper: laid; wm.: "[two circles around inscription:] PATRIA EIUSQUE LIBFRT ... [narrower circle within, enclosing Dutch lion on pedestal with inscription:] VRIJHEID".

Publioker: "Marcus, Adolphus", Bonr, Germany.

Note: title-page issue of the thesis of 1818 . 
2 Beobachtungen thber die Entwioklung der Laubmoosen aus ihren Xeimkornern.

[Bonn, 1824] [separate].

Titie: "BEOBACHTUIIGEN | ÜBER DIE | ENTWICKLUNG DER LAUBMOOSE | AUS IHREN KE NIKÖRNERH | VON | DR. TH. FR. LUDW. INEES V. ESENBECK, | M. d. A. d K. | Mit 2 Kupfertafeln." Collation: $4^{\circ}: \pi^{1} 22-23^{4}\left(-23_{3,4}\right) ; \quad 167-168$ 169-180.

Contents: 167 title; $168 \mathrm{~J} ; 169-179$ text, discussing observations on the development of mosses from gemmae; 179-180 "Nachtrag", discussion of Cassebeer n.2; 180 observations and correction.

Plates: 2 copper-engravings, color-printed (green) with additional hand-coloring; numbered: "XIII", "XIV" (in period.) of moss protonema; plate-mark: $243 \times 206 \mathrm{~mm}$.

Artiat: Wild, T., Germany.

Engraver: Engels, W., Germany.

Paper: leaf height $255 \mathrm{~mm}$. (UB Utr, copy of period., cut); wove.

Date: $1824\left(t,-p_{.}\right)$; early 1825 (period. p. V: list of new members: Nusque ad tinem anni

Review: Flora 8(25): 397-400. 1828 Jul. 7; (26): 401-408. 1828 Jul. 14. $\left.1824^{\prime \prime}\right)$.

Bibl.note. Separate consisting of sheets of Nova Asta Phys.Med.Acad.Caes.Leop. -Car. $12(1): 167-180$. 1824, without change. No pre-publication notice seen.

Bot.note. The "Keinkorner" (gemmae) of this article included spores from the sporophyte; careful observations, with a supplement, doubting Cassebeer's explanations of the "generatio originaria" and giving his own argument to treat the spores of mosses as "Keimkorner" and not as seeds.

INESTLER, Chrêtien Geofroy [Christian Gottfried, in German]

Biogr. Born 1778 ilar. 1, Strasburg, France.

Died 1832 Oct. 2, Strasburg.

C.G. Hestler was the son of a pharmacist and began to study pharmacy at the age of 16 under the direction of his father. When he later studied under Jean Hermann (al so spelled Johann flerrmann, 1738-1800) he became interested in botany, as "passion dominante", so that his father had to take him away from his herbarium for the pharmaceutical preparations. He followed also medical courses.

In Jan. 1802 he was nominated honorary member of the Regensburger Bot. Gesellschaft. In 1803 he visited Paris where he met such botanists as Richard, admiring their collections. As a pharmacist of the ammy he was in Prussia and Austria, and visited Hungary. Salzburg and parts of Switzerland.

He was nominated professor of pharmacy (obviously, more correctly "professeuradjointe a l'école de pharmacie" of Strasburg [documents in Archives Departementales, Bas-Rhin, Strasbourg], in 1811, and lectured for the professor of botany, Dominique Villars (1745-1814) as "suppleant" when the latter was ill.

After Villars' death he applied for this position and was nominated after a

"concours" (on which I only saw a few documents in the Archives aforementioned), 20

liar. 1817. He was very well versed in the botany of his region, made improvements in the botanical garden and sent many observations on plants to de Candolle. He did not publish much, apart from the exsiccata series with lougeot (iougeot \& Nestler n.1) He was working on a flora of Alsace, when death overtook him. One of the candidates for his chair was F.F. Chevallier (which see).

Nestler's Christian names were checked in a "copie" of his "Acte de naissance"

in the Arch. Dép. Bas-Rhin, Strasburg. Usually they are given in German (see above). He was commemorated. In the generic names destzera Sprengel 1818 (Compositae),

nest lera Willdenow ex Steudel 1841, a synonym of Bouteloua Lagasca (Gramineae), and

Hestlera E. Meyer ex Walpers 1852, a synonym of Leuoosidea Ecklon \& Zeyher (Rosaceae)

Refo.: Caillot: Notice lue a la Faoutte de medeoine de Straobourg, le 27 d\&o. 1832. Sitzmann, F.E.: Diotionnaire de biographie des hommes oeldbree de l'Aleace.... 2: 363, ig10 (Rixheim, Alsace).

1 Stixpes oryptogamae Vogeso-Rhenanae.... 1810-1860.

See Mougeot \&estler n.1. 
NOLTE, Ernst Ferdinand

Biogr. Born 1791 Dec. 24, Hamburg, Germany.

Nolte received private education at home until at the age of 18 he came to the court physician Dr. Sachse in Schwerin, who taught him the classical languages and natural sciences; this brought him to botany. He fled the French army and finally settled in Goslar, where he became a pupil of the pharmacist Braunholz. He left after half a year and went in Sep. 1813 to the University of Gottingen, studying medicine, and not forgetting botany.

He became $\mathrm{Dr}$. med. in 1817 and continued his studies in a hospital in Berlin. He botanized in the Berlin region with Schlechtendal. After meeting J.W. Hornemann he became a collaborator of the Ioones florae Danicae. He traveled from 1821-1823 in Lauenburg and the neighboring region, in 1824 he settled in Copenhagen, making botanical trips all over Denmark.

In the summer of 1826 he became professor of botany and director of the botanical garden at Kiel, where he had among his pupils the later famous Ferdinand [von] Muller, the outstanding Australian botanist. After the death of his wife (1860) his health deteriorated, but he bore his sufferings with resignation. He was pensioned in 1873 .

He was comnemorated in the generic names Noltia Schumacher ex Thonning 1827 [or 1828?] EDiospyros L. sect. Noitia (Thonning) Hiern (Ebenaceae) and Nolteo Reichenbach 1828 (Rhamnaceas).

Ref.: Wunschmann, E.: Allg. Deutsche Biogr. 23: 760-762. 1886.

\section{$1 \frac{\text { Novitias florae Holsatioae }}{\text { Kiel, } 1826}$}

Titze: "NOVITIAE | FLORAE HOLSATICAE | SIVE SUPPLEMENTUM ALTERUM | PRIMITIARUM FLORAE HOLSATICAE | G. H. WEBERI | AUCTORE | ERNESTO FERDINANDO NOLTE, M. D. $|[\ldots]|[$ thickthin rule] | KILONII. | PROSTAT IN LIBRARIA ACADEMICA | [very short thin rule] | 1826 ."

Collation: $\left.8^{\circ}: \pi^{*} \quad 1-5^{6} 6^{2}(-6)_{1}\right)$; I-V VI-XXIV 1 2-82.

Contento: I title; II quotation from Seneca; III dedication to G.H. Weber (17521828), IV D; V-XXIV preface, headed: "Praemonita.", dated: "Junio anni 1826.", containing a concise history of botany in Holsatia and discussing the floral elements, in which some Musoi (and other cryptogams) are mentioned, e.g. P.XXX: Cincilidium tygium, Meesia uliginosa, dealbata, Longiseta and splaohnum ampulzaceum; 1-82 text, list of 500 Holsatian phanerogams not mentioned in G.H. Weber/F.H.Wiggers: Primit. Fl. HoZs., occasionally with descriptions 82 corrections and imprint: "HAVNIAS | EX OFFICINA HARTV. FRID. POPP." No RT. Language: Latir.

Paper: leaf height $182 \mathrm{~mm}$. ( $W$ copy); laid; no wm.

Printer: Popp, Hartv. Frid., Copenhagen, Denmark.

Publisher: Libraria Academica, Kiel (see also Variant).

Date: 1826 (t:-p.); after Jun. (pref.).

Reviews: Linnaea 2(1): 88-89. $1827 \mathrm{Jan} . ;$ Flora 11(39): $610-618.1828$.

\begin{tabular}{l|l|l|l|l} 
Refs.: BMNII 1441 & Cat.Juss. n.1777 & Jacks. 305 & Linn,Soc. 570
\end{tabular} \begin{tabular}{l|l|l|l} 
Brun.-S 2: 32 & Heins.7(2): 131 & Kew 453 & Pr.ed.2 $\mathrm{n.6735}$
\end{tabular}

Variant: Pritzel (see $R \dot{e} f \cdot$.) indicates a variant title-page: "Hamburg, Perthes und Besser. 1828", whish probably is a cancellans title (not seen) of a re-issue.

Bot.notes. Nolte collected in this book all new species discovered for his region since the publication of the Primitiae floras Holsaticae by Weber and Wiggers

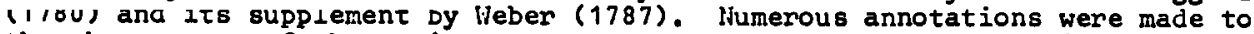
the phanerogams of the region; cryptogams were only shortly mentioned in the introduction. They were studied by Nolte in more detail, which remained in manuscript at the University of Kiel (according to Prahl, Schriften Naturw. Ver. Sohleswig-Bolatein 10: 153-155. 1895). 
Biogr. Born 1779 Aug. 1, Bohlsbach near Offenburg, Baden, Germany. Died 1851 Aug. 11, Züich, Switzerland.

Lorenz Okenfuss studied at the Franciscan gymnasium of Offenburg (1793-1796), in Stadt Baden (1799-1800) and at the University at Freiburg im Breisgau (autumn 1800 ). Here he studied medicine, but he was more interested in philosophy and natural sciences. In summer 1804 he received his degree of Dr. med.

He published in 1802 Grundriss des Syotems der Haturphizosophie under the name Oken which he retained through his life; he was registered under this name when he entered the University of Wirzburg. In 1805 he went to the Gottingen University, where he made one of his few original researches, namely on the development of the intestinal tract of the embryo. In July 1807 he was nominated extraordinary professor of medicine at the University of Jena, where he developed his "Naturphilosophie" in general, and the theory of the derivation of the skull bones from vertebrae in particular, which later became a prime controversy with Goethe. In 1816 he received the degree Dr. Philos. honoris causa.

In this year he began the journal Isis which he maintained up to 1848 . It was open to every scientific opinion, and Oken expressed his own opinions freely too which led to much opposition and the change of the place of publication from Jena to Leipzig. His lectures were successful, but in May 1819 he was forced to choose between stopping the publication of $I_{8 i}$ and giving up his professorship. Isis remained. He lectured in Kiel, but was not noninated. He organized the first meeting of German natural scientists and physicians, after the example of the Swiss meetings. From 1822 to spring 1827 he had no appointment, only publishing Isis. In 1827 he went to MUnchen, where he was nominated professor of physiology at the University. Here his personality again raised opposition; he handed in his resignation in 1832 . The next year he was nominated at the new University at Zllrich, Switzerland, and he became its first rector.

He had married Louise Stark in 1814; she survived him. They had a son and a daughter: the son died before him.

His "Naturphilosophie" had a otrongly deductive character: from a few principles he derived many conclusions and he pressed facts in a sort of bed of Procrustes. Nevertheless he must be considered a pioneer of the cell theory, having expressed the basic idea clearly. He advocated de Jussieu's natural classification of plants and considered as the real higher classification the philosophical one, which takes into account the development or genetical system, but he explicitly excluded the idea of evolution from these terms.

He was commemorated in the generic plant names okenia F.G. Dietrich 1819, a homotypic synonym of the conserved name Adenandra Willdenow (Rutaoeae), and okenia Schlechtendal \& Chamis8o 1830 (Nyotaginaoeae).

Ref.: Lang, A.: Alig. Deuteohe Biogr. 24: 216-226. 1887,

\section{Lehrbuoh der Naturgeschichte.}

3 vols. in 5 parts (not completed). Leipzig or Jena, 1813-1826.

Tities [in gothic]: "Okens I Lehrbuch I der | Naturgeschichte. | [short swelled rule] Erster Theil | Mineralogie | [long rule] | Mit achtzehn Kupfertafeln | (Preis: dex Bogen 2 Groschen, die Kupfertafeln nichts) | [1ong swelled mle] I Leipzig ( bej. Carl Heinrich Reclam. | $1813^{\text {"i }}$ vol.2(1): not published; vol.2(21;: same as vol.1, except: "Zweyter Theil. I Botanik. | [short mule] Zweyter Abtheilung erste Hulfte. | Mark- und Stamm-Pflanzen. [long thin rule] | (Preis: 4 Thaler Cond. M.) | [long swelled rule]| Jena, | bey August Schmid. | $1825 . "$; vol.2(22): same, except: "Zweyter Theil. | Botanik. | [short mule] | Zweyter Abtheilung zweyte Halfte. I Blathen und Frucht=Pfianzen. I [long thin rule] f. (Laden-preis: 5 Thaler Cond. M.) | [long swelled mile] | Jena, | bey vol.3(1): same, except: "Dritter Theil | Zoologie. I Mit vierzig Kupfertafeln. [short mule] I Erste Abtheilung | Fieischlose Thiere. I [long thin rule] | (Preig: 4 Thaler) | [long swelled rule] | Jena, | bei August Schmid und Comp. | (Ausgegeben 1815)" 
vol.3(2): same, except: "Dritter Theil | Zoologie. | [... ?] I Zweite Abtheilung | Fieischtiere. [Iong thin rule] (Preis: 2 Thaler) | [ong swelled rule] | Leipzig, bei C. H. Reclan. | 1816."

Coliation: $8^{\circ}$ : [all letters in signatures in gothic]:
vol.1: $\pi^{8} \mathrm{~A}-2 I^{8} 2 \mathrm{~K}^{4} ; \quad I-I I I$ IV-XVI 1 2-519 520

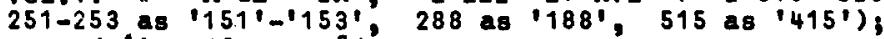
vol.2(21): 18 A-3Y $\left(* 2 \mathrm{G}_{1,2}=2 \mathrm{R}_{1}=3 \mathrm{C}_{1}-3 \mathrm{G}_{7,8}-3 \mathrm{~T}_{7,8}\right) ;$ I-III IV-XV XVI
$12-10771078-1080(2274601053,569$ as 5661,592 in right corner, 761 as $(661$ '):
Vol.2(22): $\pi^{8} \quad A-2 Y^{8}\left(* 2 \mathrm{M}_{8} \pm 2 \mathrm{X}_{1}\right) \quad x^{1} \quad 2 \mathrm{Z}-4 \mathrm{U}^{8}\left(* 4 \mathrm{~K}_{6,7}\right) \quad 4 \mathrm{X}^{2} \quad 2 \mathrm{X}^{2} ; \quad I-I I I$ IV $-\mathrm{XV}$
$X V I \quad 1 \quad 2-720$ i-ii $721-1428$ 1429-7430 (641 $\mathrm{as} 1661^{\prime}, 644^{\prime}$ as '664',
$645 \mathrm{as} ' 665^{\prime}, 648 \mathrm{as} 1668^{\prime}, 649 \mathrm{as}$ ' $669^{\prime}, 652 \mathrm{as} 1672^{\prime}, 653 \mathrm{as}, 673^{\prime}$,
656 as ' 676 '? 1382 ):
vol.3(1): $\pi^{2} * 82^{8}(-2 * 7,8) \quad A-3 F^{8} 3 G^{6}\left(-3 G_{6}\right) 1^{8} x^{1} ;$ [pagin. not studied];
vol.3(2): collation not studied, only totals of pages: iv XVI 1270 .

Contente: vol.1: I title; II 口; III-XVI index to chapters, headed: "Rahren zur Irdlehre"; 1-494 text of mineralogy; 495-510 explanation of plates; 511-519 alphabetical register; 519 corrections; 520 ;

vol.2( $\left.2^{1}\right)$ : I title; II O; III-XIII Oken's classification of plants, on the principles explained in his Naturphilosophie, vol.2, Jena, Fromann 1810; XIV older classification; XV Linnaean classification; XVI note for the binder concerning cancels; 1-1052 text: 1-8 the piant, 9-220 classification and description of what now are considered Fungi, $227-227$ introduction to "Aderpflanzen, Venaria", 228-350 Algas, 351-393 Lichenes, 394-459 Musci, 160-468 introduction to "Drosselpflanzen, Trachearia", $469-487$ Hepatiaae, 488-550 Filices, 550-1052 Monocotyledones; 1053-1077 alphabetical index; 1078 corrections; $1078-1080 \mathrm{D}$;

vol.2(22): I title; II-III $\square$; IV-XIII Oken's classification, printed over sets of 2 pages; XIV-XV older classification over 2 pages; XVI note for the binder concerning cancels; 1-720 text, Dicotyledones partiy, "Blüten=Pflanze" in Oken's concept; i optional part-title, repeating the titie for vol.2( $\left.2^{2}\right)$, the price excepted and a line changed: "Frucht=Pflanzen (S.721)."; ii $\square$; 721-1381 text, Dicotyledones concluded as: "Frucht=Pflanzen"; 1382-1428"alpnabeticat register including vernacular (German) names of vol.2( $\left.2^{2}\right) ; 1429$ corrections; $1430 \square$;

vol.3(1): I title; II D; III dedication to: "Pallas I dem Auferstandenen Schrank, Jacquin, Blumenbach | den Wiesterbenden | ben [sic for den] greisen, weisen | ersten | Naturforschern | Deutschlands | gewidmet | aus |

Anerkennung"; IV D; [contents not fully studied, classifications and text]; vol.3(2): not studied.

Plates: 18 folded copper-engravings in vol.1, crystal forms only; 40 in vol.3(1), invertebrata only; [vol.3(2) not studied]; no botanical plates.

Engraver: Schnorr, C., Jena, Germany.

Paper: leaf height $204 \mathrm{~mm}$. (copy Osterr. Natl. Bibl., Vienna); laid, chains vertical; no wm.

Printer: no imprint.

Publishers: Reclam. Carl Heinrich, Leipzig: vol.1 and $3(2)$, Schmid, August, Jena: vol.2(2); possibly also original of vol, 3(1); August Schnid \&. Comp., Jena: vol.3(1) [cancel?].

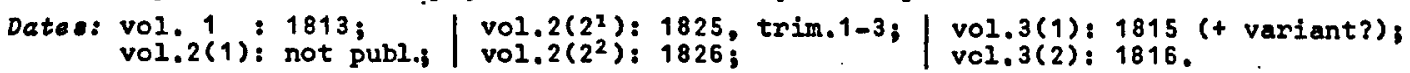

Reviews: vol:2(21): Linnaea 1(1): 103. $1826 \mathrm{Jan}$ (publ, trim.1-3, 1825); vol. $2\left(2^{2}\right)$ : Linnaea $2(3): 487: 1827$ (Aug.-Oct.) Isis (Oken) 22(2): 157-181, 1829.

Refs.: BMNH 1466 Bradl. 1: 255a.

Graesse $5: 16 \quad\left(N_{1} 1912-1826^{\prime \prime)}\right.$

Heins.7(1): $138\left(\right.$ (1825-1827m $^{\prime}$

Jacks. 37

Pr.ed.1 n.7618 $5: x^{a}$

Teyl. 144. 
Variants: the title-page of vol.3(1) probably was a new title because of the change of publisher. The reasons for the other dates in some references have not been investigated.

Bibl.notea. The cancels were mentioned ir the indications for the binder. of vol. $2\left(2^{1}\right)$ the leaves $G_{7}$ and $G_{8}$ were cancelled and replaced by the new leaves $3 \mathrm{II}_{2}$ and $3 \mathrm{H}_{2}$ of the following gathering; the copy in the lational Bibliothek, Vienna, had the cancellanda intact and consequently its page-numbers 845-848 were twice present. I did not check the conjugacy of pairs of cancellantia.

Bot.notes. Oken published in these volumes his classification of nature according to his principles, based on the age-old "elements" earth, water, fire and air. These "elements" he certainly did not conceive as the modern chemical elements but as general concepts, not existing as individuals; the mineral, plant and animal kingdoms, on the other hand, in his conception, do exist as individuals; with the combinations of his 4 "elements" he built his whole classification. Ife used a natural classification and made divisions into three or four groups nearly everywhere. This from a modern viewpoint artificial division was changed by oken during his work, as is clear from the cancels, and also from comparison of his classification schene in vol.3(1), 1815, with that in vol.2( $\left.2^{1}\right), 1826$. In the first he applied a division in three groups throughout the plant kingdom, taking the root - stem - leaf division as the main criterion; in the latter he had divisions into four groups mainly: marrow trunk - flower - fruit, each subdivised: marrow: cell - vene - trachea; trunk: root - stem - leaf; flower: seed - capsula - corolla; fruit: nut drupe - berry - apple. On this system all plant species were given new Eerman names by oken, consisting of a rather arbitrary generic name with prefixes derived from all parts of these subdivisions. Musoi were named by him in German: "IV. Ordnung Frucht=Aderer. Moose."; the simple genus Phasoum: "Zellen=Teisch", and the nanes of its species had prefixes before this word. His Latin names for the plants were the traditional ones; he took into account the recent publications of schwaegrichen and Bridel for the mosses, though I found no reference to a work published in 1826.

His treatment of species in subgenera is not clear; sonetimes he cited

the Latin species name with the initial of the subgeneric name, sometimes with the initial of the larger genus. Nevertheless no new combinations have been traced up to now, in the Musci. Oken apparently planned a first section of his botany part, possibly treating general botany and physiology, but this never appeared.

\section{OPIZ, Philipp Maximilian}

Biogr. Born 1787 Jun, 5, Czaslau, now Czechoslovakia.
Died 1858 May 20, Prague, Czechoslovakia.

Born into a family of administrators, P.H. Opiz became in 1805 "Cameralbeamter", succeeding his father, in his native town. He was transferred in 1808 to Pordubitz and in 1814 to Pragise, where he became "Forstamtsconcipist" in the same year, from which he was finally pensioned.

He was early interested in botany, publj.shing more than 400 articles, the first in 1800, and founded the first society for exchange of botany (and natural history) specimens and objects. He was commenorated in the generic names Opiaia J. C. Presl 1830 (Gramineae), and opisia Rafinesque 1836, a synonym of Capseila Moench (Cruciferae).

Refo.: Wunschmann, E.: Alig. Deutsohe Biogr. 24: 378-380, 1887 .

Klastersky, I.: Philipp Maximilian Opiz. 1958 (not seen).

1 Nachtrag su Boheime phanerogrmiechen und aryptogamiochen Gewächoe.

Flora 82 (Beil. 4): 52-59. 1825 .

Collation eto.: see Flora

Date: 1825 ; sem.2, probably late, Dec., or Jan. 1826.

Note. List of binomials with author citations localities, including 4 Muei (p. 54). 
PALISOT de BEAUVOIS, Ambroise-Marie-François-Joseph [Baron de Beauvois]

Biogx. Born 1752 Jul. 27, Arras, now dép. du Nord, France. Died 1820 Jan. 21, Paris, France.

Palisot de Beauvois studied at the college of Harcourt, served as a nusketeer, studied law, and became "receveur général des domaines et bois" in liorthern France after the death of his father and his elder brother. He studied botany with J.-B. Lestiboudois in the meantime. In 1777 his function of "receveur" was suppressed. He lived in Paris afterwards, studying botany with and attending herborisations of de Jussieu. He became "Correspondant" of the "Académie des Sciences", 1781 or 1782. In 1784 he sailed for West Africa with a group to settle a French trading post in Benin, and he collected there and also in Oware. Some shipments were sent to de Jussieu. Many of his companions died from tropical diseases and in 1788 he was obliged to go on board a ship because of a renewed attack of yellow fever, taking only his notes with him. This ship happened to go to S. Domingue (ilarti); the collections he left behind were destroyed during an English attack in 1791. The voyage to $S$. Domingue took 5 months, during which he suffered from scurvy and a dangerous inflamation.

Arriving 28 June in Cap-Français in bad condition, he finally recovered while staying with an uncle. He envisaged seliing his French properties to settj.e in the colony. He began collecting again, and discovered new medicinal plant. In 1790 he was nominated to the superior town council of Cap-Français, which council had been abolished for some years by the French government, but was maintained by the "colons" because of the threat of llegro uprisings. In 1791 he was sent to philadelphia to obtain financial and other help against this threat, and also acainst a threatening famine.

In 1793 he came back to Cap-Français three days after a large fire following the hottest fighting of an uprising which destroyed the tow, including all the new collections and the old and new manuscripts. Horcover he was imprisoned for having taken part in the death sentence of a mulatto, but he was released at the instigation of a mulatto woman who had served with his uncle. He was deported from the Island on condition that he not come back until peace was established. The ship with his belongings from the Philadelphia trip had left the island already and had been taken by the British; moreover his om ship was teken too and the only possessions which were left him were a small trunk, a freenason "diplome" and 10 francs.

Thus he came back to Philadelphia as a fugitive and had to earn his living as a street musician, of which the worst part for him was that people threw dirty things at him when he played Haydn, shouting for popular tunes such as Marlborough. A Quaker physician, Caspar Wistar (1761-1818), interested in natural history, provided him with the job of arranging a cabinet of curiosities of the painter Charles W. Peale (1741-1827), which enabled Palisot to study natural history objects again. He was able to travel Southwest to the Creek and Cherokee Indians and to make collections. These collections afterwards were for the larger part lost in shipweck. In 1798 he was finally permitted to return to France and he arrived in Bordeaux August 1798 , learning that his properties had been confiscated during the Revolution. Afterwards he lived only for natural history, publishing on his collections, the small parts which had been sent to de Jussieu and therefore had been saved, and on mosses, clubmosses and grasses. He was opposed to lledwig's views of the sexuality of mosses and advocated another idea.

In 1806 he was appointed "membre" of the "Académie" in Adanson's place.

His final herbarium came to Delessert (1773-1847), in which the mosses were studied by Arnott. This herbarium is now in the Conservatoire botanique, Geneve. Palisot de Beauvois was commemorated in the generic nanes Belvisia flurbel ex Massey 1804 (Filioales, Polypodiaaeas), Belvioia Desvaux 1814, replaced by napoleona P. Beauvois (Barringtoniaceas), Palieota Reichenbach 1828, nom oone. (Commelinaoeae).

Refe.: Cuvier, G.: Bloge historique. in: Recueil des Eloges historiques ... 1827 Reoueiz des Eloges higtoriques... ed.2, 2: 165-196, 1861.

Thiebaut de Berneaud, A.: Eloge histöique. 81 p., portrait. 8.. Paris, 1821. Biogr. Univ. Ano. Nod. ed.2, 14: 319-320.1343-47.

Boatner, C.H.: Noirio 1: 173-183. 1936.

Ewan, J. (in): Lee botanicteo Franfai en Amerique du Nord avant 1850 (in:) Colloquee Internat, Centre Nat. Rech. Soi. 63: 23, 37. 1947.

Camus, Aimé: same publication 63: 109-111. 1947.

Stafleu, F.A.: Taxonomic. Ziterature 344.1967. 
Husoologie, ou traits eur les monsese.

liem. Soc. Linn. Paris 1: 388-472, (Fascic. Planch.) pl. 1-11. 1822[1823].

bead-titie: "[full wavy rule] I luSCOLOGIE, | ou Traite our les Mousese, par feu PALISOT | DE BEAUvoIs, de Z'Inatitut de Exanoe, eta: | [short rule]".

Coliation: text volume: $8^{\circ}: 252 x-304 \times 388-472$; plate volume: $4^{\circ}: 7_{3}-7_{4}, 2-3^{4} 4,3$ il leaves $(\lambda 1-11)$.

Contents: text volume: 388 head-titles 388-472 text, including: 388-392 introduction (untitled); 392-431 six morphological chapters, ending with a discussion of different systems and (431) a key with descriptions of the system of the author; $432-472$ descriptions of the 45 genera accepted by the author. with a derivation of the names, synonyms, and a selection of the species in the genera, often only indicated by basionyms; 472 additional note, " $B . B . "$, signed: "(A. T. D. B.S", apparently Arsenne Thiébaut de Berneaud, drawing the attention to the publication of Palisot de Beauvois: Prodrome de $l^{\prime a e t h d o g a m i e, ~}$ Paris, 1805, which gives a very complete synonymy; ; an alphabetical list of generic names in this article is given on $\mathrm{P} .738$ in the index of the volume of the periodicalj:

plate volume: $\lambda 1-11$ explanation of the plates. No RT. Language: French.

Plates: 11 copper-engravings, pl. I-XI, of mosses, illustrating the author's ideas of important generic characteristics; no names on the plates; species indicated by arabic numerals per plate, details by italic letters per species; plate-mark: $248 \times 191 \mathrm{~mm}$. (pl.1).

Artist: Pretre, Jean Gabriel, Paris: 11 plates, all signed.

Engraver: Plé, [François B.?]. Paris: 11 plates, all signed.

Note: François B. Plée is the only Plée in the membership lists of the volume $(p, 7 \xi)$ and for this reason I suppose he was the engraver.

Paper: text vol.: leaf height $199 \mathrm{~mm}$. (Teyl. copy, cut); laid, chains vertical; wm.: "D D S [swash script]",

plate vol.: leaf height $294 \mathrm{~mm}$. (Teyl. copy, cut): laid, chains horizontal, wm. absent (or hidden in the spine);

plate paper: laid, chains horizontal; wm. usually: "I V D [outline]".

Printer: D'Hautel, Paris.

Publisher: Societe Linnéenne de Paris,

and for sale with Audot, Paris, and Debeausseaux [Desbeausseaux?], Paris.

Date: 1822 (t.-p.); after 7 Dec. (see NSm,Soo.Linn.Paris).

Review: Buzl.Gen.Announa.Bouv.Soi. 1(2): 244-245. 1823.

Refo.: Pr.ed.1 n.7711 Pr.ed.2 n.6901 RSC 4:743.

Bibi.notes. The anticle was given to the societe linnéenne de Paris by the widow of Palisot de Beauvois (Mśm.Linn.Soo.Pario 1: 25. 1822), it was edited by its secretary. A. Thiébaut de Berneaud.

Bot.notes. In this work Palisot de Beauvois maintained his negative opinion on the theory of Hedwig concerning the sexulity of mosses, and stated his reasons for doing so, including another explanation for experiments on germination of spores. Instead, he considered the spores to be the fertilizing agents and the columella to be the receptive organ.

The taxonomic part contains the description of 45 genera, amanged in the 5 sections distinguished by the author. One new genus was proposed in the text: Codriophorus, P.445, pl.3 f.2-3, with the specific combinations only in the plate-volume. New generic names used in the plate-volume but not in the text, were: Aorooarpum, Fusloonia and Perioiphorue. These 3 names are invalid since they do not have a description and were not based on a new species, as is clear from the text. The name Bryum eolerodon is valid (pl.5 f.4). the species clearly does not belons to the genus Bryum in its modern circumscription, and has not been taken up afterwands.

The plates are well executed and give good figures with many details. 
2 Husoologie ou traits our tes mousece.

Paris, 1822[1823] [8eparate].

Titze: "MUSCOLOGIE | OU | TRAITE SUR LES MOUSSES, | PAR FEU PALISOT DE BEAUVOIS, | IIEMBRE DE L'INSTITUT DE FRANCE, etc. | [Iong rule] | J'invite les botanistes à Étudier et à répéter mes obser-lvations sans les isoler: leur réunion et leur ensemble for-lment la base du système que je leur soumets. (pag. 9) | [long rule] | PARIS, | DE L'IMPRIMERIE DE D'HAUTEL, | RUE DE IA IIARPE, NO, 80. | [very short wavy rule] | $1822, n$

Colzation: i text part: $8^{\circ}: 7^{\circ} 2-5^{\circ} 6^{4} ; \quad 7-56-88$; plate part: $4^{\circ}: 11$ leaves $(\lambda 1-11)$.

Contente: text part: 1 half-title; 2 D; 3 title; 4 source, between two long rules: "Extrait du 1 er. volume des Mémoires de la / Société Linnéenne de Paris.", 6-88 text, essentially similar to that of the article in the periodical; plate part: $\quad$ 1-11 explanation of the plates. No RT. Language: French.

Platee: 11 copper-engravings, pl. I-XI, identical with those in the periodical article, up to the inscription at the left top: "MÉm. de la soo. Linnéenne.", above the middle: "Mousses." and at the right top: "Tom.I. PI.I." [to PI.XI.]; plate-mark: $246 \times 191 \mathrm{~mm}$.

Artist: Pretre, Jean Gabriel (see n.1).

Engraver: Plée, [François B.?] (see n.1).

Paper: text part: leaf height $206 \mathrm{~mm}$. (BMNH copy, cut); laid, chains vertical; wm.: "D D S [swash script] ";

plate part: leaf height $294 \mathrm{~mm}$. laid, chains horizontal; no wm.;

plate paper: laid, chains horizontals wm.: "J", traces in some leaves.

Printer: D'Hautel, Paris.

Date: 1822 (t.-p.); (see $\mathrm{n.1}$ and Mim.Soc.Linn.Paris).

Refo.: Milt. 485 Pr.ed.1 n.7711 Pr.ed.2 n.6901.

Bibl.notes. This separate was printed from the same type-setting as the article in the periodical, probably with another distribution of the lines over the pages to fit an even number of pages (I did not study the separate at the same time as the reprint). The title leaves, being part of a gathering with text, also point to a re-imposition. These two points make it likely that the separate was printed after the sheets for the periodical had been finished. It may in turn be an indication that the separates were also published later. This may have been a general policy of this society, of which I have not yet seen any pre-publication separate.

Nevertheless, more information on the exact date is very welcome, since the journal appeared late in 1823 and the separate might have been available earlier (the finished sheets of the incomplete second volume were held in stock up to 1827 ).

Bot.noter. See n.1.

PERLEB, Karl Julius

Biogr. Born 1794 Jun. 20, Constanz, Wartemberg, Germany. Died 1845 Jun. 11, Freiburg im Breisgau, Baden, Germany.

No biography available to me. Perleb was Dr. Med. and professor of natural history at the University of Freiburg in Breisgau.

He was commemorated in the generic names Pexlebia Martius 1828 (Caesalpiniaceae/Leguminosa) and Perlebia A.P. De Candolle 1829, replaced by Prangoe Lindley (Umbelliferae).

Refs.: Bot.Notie. 1845: 220. 1845 (states day of death 8 Jun.). Pr.ed.2: 243. 1872 (day of death 8 Jun.). Barnhart, John Hendley: Biogx, notes botanists. Boston, 1965. 
Conepeotus methodi plantarum naturalis...

\author{
Freiburg in Breisgau, 1822 .
}

Title: "COHSPECTUS | IIETHODI PLANTARUM NATURALIS | [medium short swelled rule] | IN USUI AUDITORUII | TYPIS EXSCRIBI CURAVIT | DR. C. J. PERLEB. [short swelled rule] | [long swelled rule] | FRIBURGI BRISGOVIAE, | EXCUD. Fr. Xav. WAMGLER $1822 . "$

Collation: $4^{\circ}: 7^{4} \quad 2-5^{4} 6^{2}\left(-6_{2}\right) ; \quad 7-3 \quad 4-42$.

Contents: 1 title; 2 motto from Linnaeus, Gen. PL. Praes.; 3 Linnaeus' Fragmenti Methodi Naturalis, 1771 (list of "orders") 4-5 classification of A.L. de Jussieu, list of his orders ("Ordo"); 6-8 classification of A.P. de Candolle: 8-42 Perleb's own classification: "ORDINUN GENERUMQUE PLANTARUM | DISPOSITIO AB AUCTORE PROPOSITA."; 42 emendanda. Language: Latin.

Paper: leaf height $245 \mathrm{~mm}$. (BMNH copy); laid, chains horizontal, chains and wires coarse; no wm. seen.

Printer: Wangler, Fr. Xav., Freiburg im Breisgau, Germany.

Date: $1822\left(t .-p_{.}\right)$.

Ref.: BlaNH 1548 .

Bot.notes. This work contains an account of Perleb's classification, preceded by the outlines of the natural methods of Linnaeus, A.L. de Jussieu, and A.P. de Candolle. Lists only of names of orders or families, followed, in Perleb's rethod, by the names of genera in the groups, arranged in four columns. No descriptions; in some groups indications in which groups of the older authors the genera concerned were included. New names of genera, if present, invalid; names of other ranks probably invalid too. Example: p.10: "HOMALOPHYLLAE. | (ALgar. Gen. Linn. Bepatiaar. Gen. Eohreb. Juse. DC.) Riccia. Blasia. Sphaerocarpus. | HEPATICAE. | (Algar. Gen. Linn.) | Targionia ... Andreaea. | MUSCI. | [56 genera]".

2 Lehrbuch der Naturgeschichte des Pflansenreichs.

Freiburg im Breisgau, 1826.

Titze [in gothic?: "Lehrbuch | der | Jaturgeschichte | des | Pflanzenreichs | von Karl Julius Perleb, I Doctor der Philosophie und Medicin, ordent. Bffentl. Professor der Natur-/geschichte ar der groszherzogl. Badischen Universitat zu Freiburg, Mitglied I der Gesellschaft fur Beforderung der Naturwissenschaften daselbst, der natur-|forschenden Gesellschaft zu Halle, der Senckenbergischen naturforschenden Gesell-|schaft zu Frankfurt und der botanischen Geselischaft zu Regensburg, Ehren=|mitglied der mineralogischen Societzt zu Jena und des Apotheker=|Vereins im Groszherzogthume Baden. | [short swelled rule] | [full thick-thin rule] | Freiburg im Breisgau, | Druck und Verlag von Friedrich Wagner. I [very short rulej | $1826 . "$

colzation: $8^{\circ}: \pi^{8}\left(-\pi_{8}=26_{1}\right) \quad 1-25^{8} 26^{2}\left(-26_{2}\right) \quad 27-29^{4} \quad\left(32\right.$ signed $\left.14^{* 1}\right)$; I-III IV-XII XIII-XIV 7 2-422 $423-426$ (VII 403 ).

Contents: I title; II G; III-VI preface: "Vorrede [in gothic]"; VII-XII index; $X I I I$ printing errors; XIV $\square$; 7-7 introduction, including list of books on general botany; $8-46$ text, first section, properties of plants in general, including a discussion of classifications; 47-382 text, second section, Perleb's natural classification of the plant kingdom with descriptions of classes, orders between classes and families ("Ordnungen"), families and genera, some species in genera mentioned; 383-402 text, thirf section, plant geography; $403-422$ index of German and Latin plant nanes, including names of plant products; 423-424 printing errors, including those of XIII; 425-426 publisher's advertisement, list of books available. Language: German.

Paper: leaf height $201 \mathrm{~mm}$. (HBL copy, cut); laid, chains vertical; wm.: "[doubleheaded eagle with broad cross on breast-plate] = [letters, only fragments seen]". 
Printer and publisher: Hagner, Friedrich, Freiburg in Breisgau, Germany.

Date: $132 \mathrm{C}$ (t.-p.); bef. 28 Oct. (Flora 9(40): 640.182C).

Reviewe: Flora 9(40): 640.1826; 9(42):671-672.1826; Linnaea 1(4): 614-615. 1826.

\begin{tabular}{l|l|l|l|l} 
Refe.: BMNH 1548 & Bradl.1: 86a & Kräg. 54 & Pr.ed.1 n.7876
\end{tabular}

Bibl.notes. Leaf $\pi$ is removed in sone copies since its infornation is repeated on 293. $26_{1}$ in the HBL copy fits with the watermark of $\pi_{1}$; this makes it practically certain that they were originally conjugate. The work was part of Perleb's Lehrbuch der Naturgesohichte, which had an independent title.

Bot.notes. Perleb stressed "llatural IIstory" as a "historical descriptive doctrine" as different from the school of nature philosophy ("llaturphilosophie") with the systems of Oken (which see), J.B. Wilbrand, and G.V.F. Wenderoth (p.60). He claimed to have instituted the order ("Ordnung") as a separate rank between class and family. An example is (p.86-88): "klasse II iluscosae. I. Ordnung Hepaticae. 1. Familie Entoaarpae [with description] (syn.: Iromalophyllae Willd.). Genera: Riccia, Ricciella, :p.87:; Targionia. 2. Familie Valvatae (syn.: Ilepaticae Villd. Spr.) - Eigentliche Lebermoose; Genera: Anthoceros, [p.88: Marchantia, [p.89:] Jungermannia [ 4 species described], II. Ordnung llusci frondosi, Laubmoose. [with description] [p.90:] Genera: Sphagnum, Fontinalis, Polytrichum, !each with one species mentioned] [p.91:] Hypnum [no species mentioned]."

PERHITZSCH, Heinrich

No biography available to me. Apparently he was a forester in "Heidelbach".

1 Flora von Deutsohlands Waldern ... Leipzig, 1825 .

Title: Flora von Deutschlands Wäldern mit besonderer Rllcksicht auf praktische Forstwissenschaft. Leipzig, 1825 in der Baumgätnerschen Buchhandlung.

Collation: $8^{\circ}: \pi^{4} \quad 1-21^{\circ}\left(-21_{\theta}\right) ; \quad I-I I I$ IV-VI (in italics) VII-VIII $1 \quad 2-332$ $333-334$ (3 18 47 85-86 88-91 146 155-157 329).

Contento: I title; II C; III-VI prefase, dated: "Forsthaus Heidelbach, | im Mărz 1825.", signed: "Heinrich Pernitzsch.", VII index; VIII O; 7-2 introduction; 3-328 text: 3-17 morphology of plants, 18-46 alphabetical Iist of morphological terms and their explanation, 47-88 systematics, 89 part-title, $90 \mathrm{D}, \quad 97-154$ descriptions of 341 genera, 165 part-title, $1560,157-328$ descriptions of species in alphabetical arrangenent, cryptogams included, Latin names without author names, nor habitat nor locality, uses indicated; 329-332 index; 333 corrections; 334 . No RT. Language: German.

Table: folded typographical table, after $10_{5}(\mathrm{p} .154)$, table of the genera in Linnaeus' classification; verso $\square$.

Paper: leaf height $207 \mathrm{~mm}$. (copy Vatl. Bibl., Vienna); laid; no wm.

Publioher: Baumgartner, Leipzig, Germany.

Date: 1825 ( $\left.t .-p_{.}\right)$, in or after March (pref.).

Refe.: Arn.Arb.1: 549 \begin{tabular}{l|l|l|l} 
BMNH 1549 & Heins.7(2): 153 & Pr.ed.1 n.7880 \\
Bradl.1:377b & Milt. 146.418 & Pr.ed.2
\end{tabular}

Notes. Unpretentious list of plants occurring in German forests and their uses. The natural system of A.L. de Jussieu as well as the Linnaean classification are discussed. I did not trace new combinations in Nusei. 


\section{PRESL, Karel Boriwog (Carl)}

Biogr. Born 1794 Feb. $14, \ldots$

Died 1852 ... Prague, Bohemia, now Czechoslovakia.

K.B. Presl was professor of natural history and technology at Prague and custodian of the museum there. ilo biography available to me.

Ref.: Weitenweber: Abh. Boehm. Ges. Wise. ser.5,B(Anh.): 24-26. 1854 (not seen).

1 Reliquiae Baenkeanae...

2 vols. [6 fasc,; unfinished]. Prague, 1825-1835

Titles: vol.1: "RELIQUIAE | HAENKEANAE | SEU | DESCRIPTIONES ET ICONES PLANTARUM, | QUAS IN AMERICA HERIDIONALI ET BOREALI, IN INSULIS | PHILIPPINIS ET MARIANIS COLLEGIT | THADDAEUS HAEINKE, | PHILOSOPHIAE DOCTOR, PHYTOGRAPHUS REGIS HISPAIIAE, | REDEGIT ET IN ÓRDINEI1 DIGESSIT | CAROLUS BOR. PRESL | MEDICINAE DOCTOR, III IUSEO BOH. CUSTOS, BOTAN. PROF, EXTRAORD. | CURA IUUSEI BOHEMICI | TOMUS PRIMUS. | PRAGAE, | APUD J. G. CALVE, BIBLIOPOLAM. | M. DCCC. XXX." ; vol.2(1) [wrapper-title] : "frame: thick-thin rule / row of elliptic typographical ornaments with round ornaments. at the corners I rule of simple typographical signs | thick-thin rule] | RELIQUIAE HAENKEANAE; I SEU | DESCRIPTIONES ET ICONES PLANTARUII, | QUAS IN AMERICA MERIDIONALI ET BOREALI. IN IIISULIS | PHILIPPINIS ET MARIANIS COLLEGIT | THADDAEUS HAENKE, | PHILOSOPIIIAE DOCTOR, PHYTOGRAPHUS REGIS HISPANIAE. | REDEGIT ET IN ORDINEM DIGESSIT | CAROLUS BOR. PRESL, | MEDICINAE DOCTOR, IN MUSEO BOH. CUSTOS, BOT. PROF. EXTRAORD. | CURA IUSEI BOHEMICI, | TOMI SECUNDI FASCICULUS PRIMUS.' CUM TABULIS XII AERI INCISIS. | PRAGAE, | APUD J. G. CALVE, BIBLIOPOLAM. 11. DCCC. XXXI."

Collation: $2^{\circ}$ : vol.1(1): $1-4^{2}[-1$, in bound copies] ( $\$ 2$ signed '\$*', 42 unsigned) vol.1(2): $\quad x^{2} K^{2+2} L^{2}$ (\$2 signed); I-III IV-XV XVI 1 2-84;

vol.1(3): $2 x^{2} \quad U^{2}+2 \quad V-W^{2}+2 \quad r-2 A^{2} ; 2\left(-2 A_{4}\right) ; \quad 149-206 ;$

vol.1 $1(4 / 5): \pi^{2} 2 B-2 U^{2}+2\left(-2 U_{4}\right) ; \quad i-i v \quad 207-256$

vol. $2(1): A-G^{2+2} ; 12-56$

vol.2(2): $\mathrm{H}-\mathrm{T}^{2+2} ; 57-152$.

Contents: vol.1(1): I [title of fasc.1, not seen]; II [possibly imprint]; III-XV preface: "PRAEFATIO", dated: "Pragae die 12 Junii 1825 " signed: "Caoparus Comes de Sternberg I Praeses Nusei Bohemioi." and containing a biography of Thaddaeus Haenke (1761-1817); XVI $\square$; 1-84 text, descriptions of genera and species of plants collected by $T$. Haenke, arranged in natural families, each family beginning on a new page, the family in the head-title usually followed by the name of the author (where absent, K. B. Presl apparently was the author. since in such cases always the last previous family with a name was prepared by him; for other authors see the list of collaborators); vol.1(2)-(3): 85-206 text, continued;

vol.1(4/5): $i$ half-title; $i i$ imprint, iii title vol.1; iv 0 ; $207-349$ text, continued; 350-351 addenda \& corrigenda, including the new generic name Nowodworekya (P.351) for Raopailia; 352 list of the plates $1-48$ and the names of the plants pictured; 353-356 index of names of genera and families in voli; vol.2(1)-(2): 1-152 text, continued.

Plates: 72 copper-engravings of plants, numbered I-LXXII, no plant names; plate-marks: $277 \times 207 \mathrm{~mm}$. (pl.1); $259 \times 425 \mathrm{~mm}$. (pl.61, the only double plate).

Artiets: Both, Franz: $17 \mathrm{pls}$. $\left(\begin{array}{llll}1-15 & 19 & 19) ;\end{array}\right.$

Fieber. F.X.: 52 pls, (16 17 20-56 60-72, the majority only signed: "F. Fieber del." )

Longer, J.: 3 pls. (57-59, 8igned: "Longer del."). 
Lingravere: Jotin, Franz: $19 \mathrm{pls} .(1-15$ 17-19 21); Skala, Jos.: 51 pls. (1C 20 22-56 59-72, several signed: "J. Skala sc."); Zeliska, W.: 1 pl. (57).

Fasoicie wrappers: only seen front-rmapper of vol.2(1) (see $z i t z e s$ ), and traces of otler imappers (see $B i b i$, notes).

Paper: leaf height $408 \mathrm{~mm}$. (U copy, cut); woves wm.: "E [outline, in lower right corner of sheet]": vol.1: $x$ II-H $X_{1.2 ;}$ all other sheets unnarked (possibly machine-made in vol.2)

plate paper: wove; w.: "E [as in text paper]": pls. 13-33 in about one third of the plates (U copy; a statistical analysis of more copies should result in cne half of the plates with the raternark);

paper of wrappers: wove; gray-brown thick paper; no wo.

Printer: Spurny, Joannes [Jan?], [Praguej.

Publisher: Calye, J.G., Prague.

Editor: Presl, C.B., the author of the majority of the families.

Colzaboratore: Agardh, Carl Adolf
Bartling, Friedrich Gottlieb

Floerke, Heinrich Gustav

(1785-1859): Algae 1(1):

8- 12. 1825

(1789-1875): Paronychicae 2(1): 5- 10:1831;

Meyer, Ernst Heinrich Friedrich (1791-1858): Juncaceae

Opiz, Philipp llaximilian

(which see): Piperaceae

$1(1): \quad 3-7.1825$;

1(1): 13.1825 ;

1(2): 141-146, 1827;

Presl, Jan Swatopluk

(1791-1849) $\begin{cases}\text { Tacoaceas } 1(3): & 149.1828,\end{cases}$

Sternberg, Caspar Count von

Gramineae 1(4/5): 207-351: 1830; III $=\mathrm{XV}: 1825$.

Dates:

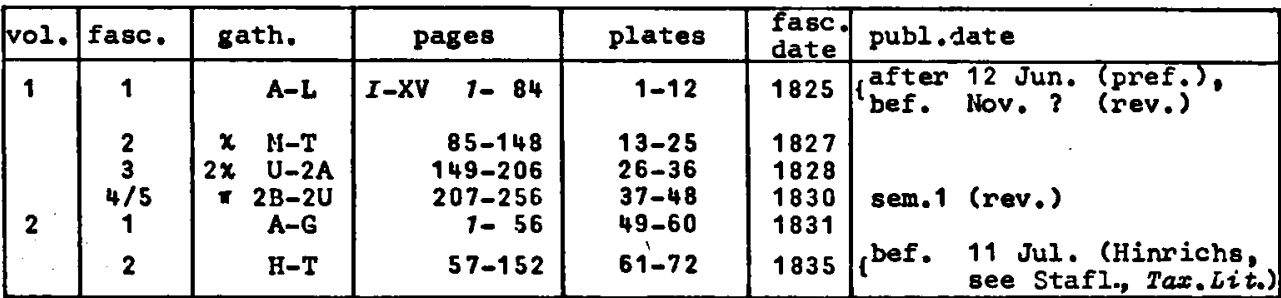

Reviews: vol.1(1): Flora $8^{2}(B e i 2.3): 35.1825$ sem.2 (Oct.?); Linnaca 1(2): 259-262. 1826 ;

vol.1(4/5): Flora 131(Beiz.5): $41.1830 \mathrm{sem} .1$;

vol. $2(2)$ : Leipx. Repert.Lit. (Gersdorf) 1835 Aug. 30 (cited from Stafl, Tax. $[i t$. )

Bibliogr.otudies: Kuntze, $0 .:$ Rev.Gen, 3(2): 160,1898 ;

Stearn, W.T.: J.Soo.Bibliogr. Nat.Bist. 1: 153-154, 1938, 3: 14. 1954:

van Steenis-Kruseman, M.J.: Fl.Males. ser.1, vol.4(5): CCVI. 1954;

Stafleu, F.A.: Taxonomio itterature n.994. 1967.

Refe.: Heins. 7 : 318 ,

$8(2): 153$

Niss. $n .1564$

Pr.ed.2 n.7394

Sitw.Blunt 71.

Bib2.notes. An unusual bibliographic feature of this book is the way of signing the gatherings. The "gatherings" of four leaves have leaves 1 and 2 signed and 3 and 4 unsigned. This is normal for quarto gatherings. However, in this case the first two leaves are conjugate as are the last two. I did not check every single pair in this respect, because the copy I studied was rather tightly bound, but I sampled every fascicle and did not find any exception. Still, this might have been a quarto format with an unusual folding of the sheets. I was able to exclude this possibility by the study of the watermark in fasc.2 and 3 of vol.1. The place of the watermark is at ranjom in the top corner or the bottom corner of the printed leaf (not of the complete sheet) in the first pair as well as in the second pair. In the case of quarto the place in the leaf would have been at the botton corner only; the book, therefore, is definitely of the folio format, with every second gathering unsigned. 
Because of this way of signing the other unusual feature is possible: in two cases the breaks between fascicles are in the middle of a "signature". The older indications of fascicle contents did not satisfy me, but they are fully confirmed by the traces of the gray fascicle wrappers which I observed near the spine in the leaves concerned, p.85 and p.149.

In the collation I indicate these features, the first one by the superscript notation $2+2$, the other one by the notation $x$ and $2 x$ for the unsigned leaf pairs in the beginning of the fascicles. These $x^{\prime} s$ would not be necessary in the collation of a complete copy in which the fascicle contents are not reported.

Fascicles 1,3 and $4 / 5$ prohably had fascicle titles on normal paper; that of fasc. 1 was cancelled for the volume title, and those of fasc. 3 and 4/5 explain the number of sheets as stated in Heinsius, being $\frac{1}{2}$ sheet more than in the collation given here. Probably the other fascicles only had printed titles on gray wrapper paper; usually one of these is preserved in vol.2 since this remained unfinished.

Bot.notes. K.B. Presl was the editor of this work. He distributed plant families to specialists for study. However, the treatments of the majority of the families were written by hin and therefore I list the book under his name. For the bryological contribution see Hornschuch $\mathrm{n} .6$; he did not propose new names.

RAMOND de CARBONNIÈRES, Louis François Elizabeth [baron]

Biogr. Born 1753 Jan. 4, Strasburg, France. Died 1827 May 14, Paris.

Ramond studied law and medicine and acquired the title Dr. in both. He traveled, made connections easily, and wrote "with taste". Because of his liberal ideas he was chosen in the Assemblée Législative in 1791; he became known for his eloquence and moderation. In Aug. 1792 Ramond went to the Pyrenees to avoid the Terreur, but was imprisoned there for some time. In 1796 he became "professeur" of natural history in the dép. HautesPyrénés. In 1802 he was nominated a member of the Institut. After the restauration he had important political posts, finally honorary councillor of state.

He was commemorated in the generic names Ramonda L.C. Richard ex Persoon 1805, nom.oone, (Gesneriaceae) and Ramondia Mirbel in A.P. de Candolle 1801 (Sohizaeaoeae).

Ref.: Houv. Biogr. Gen, 41:555-557. 1862 .

\section{1 État de la végétation au sommet du Pio du Nidi de Bagnères.}

Mém. Mus, Hist. lat. Paris 13(10): 217-281, 1825 [1826].

Head-titzo: "[full thick-thin mle] | ÉTAT DE LA VÉGÉTATION I AU SOMMET DU PIC DU MIDI DE BAGNERES. | Mémoire lu a I'Académie des Sciences, en sa séance de 16 janvier 1826. | PAR M. LE BON. RAMOND. | [rule]"

Collation: $4^{*}: 28_{3,4} \quad 29-35^{4} \quad 36_{1,2.3}$ \& 217-281 282.

Contente: 217 head-title; .217-243 introduction, description of the locality and general discussions of the plants collected; $244-277$ list of 133 species and varieties with names, references, synonyms, exact localities and discussions, headed: "Enumération des Plantes qui aroissent au oommet I du pio du Midi.", including Lichenes $(211-252)$, Bepatioae (252; 1 species), Musoi (252-253, 6 species), ferns and phanerogams; 278 recapitulation, number of species (and varieties) per family; 279-281 appendix: "APPENDICE. I Espèces observées sur les sommets qui excèdent en hauteur| le Pic du Midi.", list of species observed on higher mountains in the Pyrenees; 281 errata; 282 . RT: short title. Language: French. 
Paper; leaf height $252 \mathrm{~mm}$. (Teyl. copy, cut); laid, chains horizontal; wm.: "JP [outline, in left top corner of sheet]".

Printer: BElin, A., Paris.

Date: 1825 (t.-p. vol.) 1826 trim.2 (see Nim.Nuo.Hiet.Nat.Paris).

Ref.: RSC $5: 89$.

Bibl.notes. According to a review In Edinb.J.Sot. 4(2): 380-381. 1826 Apr. 1, this paper already appeared in $L \circ a 20 b \cdot 3: 62.1826 \mathrm{Jan}, 19$, which I did not see. Neither did I check Ann.Sot. Dat. 8: 96 . 1826, which has an article with the same title, according to Linnaea 1(4): 615. 1826. See also RSC.

Bot.noted. Interesting account of the plants (Fungi and Algae excepted) from the higher peaks of the Pyrenees, with descriptions of a considerable number of new species of lichens and of a few new species of phanerogame (Galium oespitosum, F.266 and Cerastium equalidum, p.268).

In a note following the few moss species the author stated his surprise about the lack of sporophytes of many species of mosses in the Pyrenees.

RE, Giovanni Francesco

Biogx. Born 1773 Sep. 27, Condove, near Susa, Italy. Died 1833 Nov. 2: Turin, Italy.

G.F. Re studied at the University of Turin where he received the degree $M . D$. He became a physician at Susa, studied philosophy and taught mathematics at the college of Carignan. Finally he became professor of botany, chemistry and physics at the royal veterinary chool at Turin and a member of the Academy of Scierces there. His herbarium came to the botanical. garden in Sasso (Sardinie).

He was commemorated in the generic name Rea Bertero ex Decaisne 1830. now considered - synonym of Dandroseris D. Don (Compositae).

Refe.s Iouv.Biogr.Gen. 41, 787, 1862 . Caso, B. in: Re, 6 F, Floxa Seguoieneie [reprint], 1881 (not seen). Barraja, E.' Mattirolo, O., Negri, G., Cassano, G., a Couvert, C.G.: II' botanioo Giovanni Brancesoo'Re. 127 p. Torino, 1909 (not seen).

\section{Plora Forinese.}

2 vols. in 3 parts. Turin, 1825-1827.

Titlea: VO1.1: "FLORA TORINESE | DEL DOTTORE IN MEDICINA | GIOANHI FRANCESCO RE | PROFESSORE DI BOTANICA, DI CHIMICA, E DI IIATERIE IIEDICA | NELLA R. SCUOLA VETERINARIA, SOCIO CORRISPONDENTE DELLA | R. ACCADEMIA DELLE SCIENZE DI TORINO, E DELLA SOCIETA' | LINNEANA DI PARIGI, MEMBRO DELLA | R. SOCIETA' AGRARIA EC. | 'short wavy rule]| VOLUKE I. | [short wavy mule] | TORINO DALLA TIPOGRAFIA BIANCO | $1825 . "$;

vol.2(1): same, except: "SOCIETA' | LINNEANA DI PARIGI DI LIONE, E DELLA I. E R. ACCADEMIA | DELLA SCIEHZE DEI FISIOCRITICI DI SIEN, MEMBRO DELLA | R. SOCIETA' AGRARIA ECC. I [8hort wavy rule] I FOL. II. TASC. I. I [short wavy rule] | COLPIMENTO DELLE PIANTE FANEROGAME. | TORINO | DALLA TIPOGRAFIA BIAIICO | $1826 . " 3$

vol.2(2): same, except: "DELIA R. SCUOLA VETERINARIA, SOCIO CORRISPONDEITE DELLA | SOCIETA LINNEANA DI PARIGI, DI LIONE, E DELLA I, E R. | ACCADEMIA DELLE SCIENZE DEI FISIOCRITICI DI SIENA, MEMBRO I DELLA R. SOCIETA' AGRARIA DI TORINO, E DELIA R. ACCADEMIA DELLE SCIENZE ECC. | [ short wavy rule] VOL. II. EASC. II. ! [short thin wavy rule] I ETEOGAYIA I COMPIIENTE DELIA ELORA TORINESE. | TORINO | DALLA TIPOGRAFIA BIANCO | 1827."

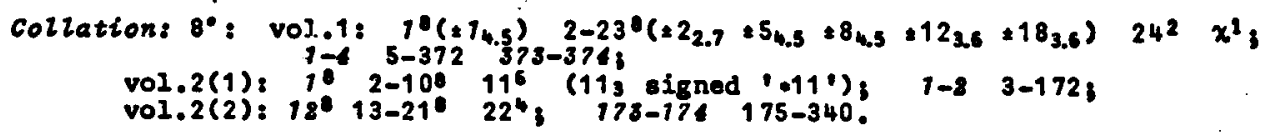


Contents: vol.1: 1 title; 2 D; 3 dedication to Sebastiano Ferrari; 1 ; $5-18$ preface, headed: "ALLIEVI AlATISSIMI", signed: "Venaria 15 gennajo 1825.", 19-23 characters of the Linnaean classes; 24-358 text, descriptions of genera and species, Monandria - Monadelphia Polyandria; 359-365 added observations and species; $366-372$ index of Latin generic names of vol.1; 372 imprimatur, undated; 373 corrections; 374 D;

vol.2(1): 1 title; 2 ; 3-159 text, descriptions continued, Diade lphia Polygamia; 160-164 additional or substituted plants (vol.1); $100-100$ additional plants (vol.2 fasc.1); $167-169$ index of Latin generic names in vol.2(1); 170 index of Latin generic names in the addenda to vol. 1 in this fasc. and imprimatur, dated: "11. febbrajo 1826."; 171-172 corrections to vol.1: "CORRECTIONES I. VOL. | ADDENDAE INDICI JAM TYPIS EDITO | pag. 373."; 172 corrections to vol.2(1);

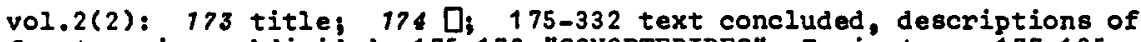
Cryptogamia, subdivided: 175-176 "GOHOPTERIDES", Equisetum, 177-185 "STACHYOPTERIDES", 186-213 "IUSCOLOGIA." "seu Muøci Prondosi." , 213-218 Bepatiaae, 218-220 Algae, 220-255 "LICHENES,", 255-332 "DE FUNGIS."; 333-335 index of Latin generic names in vol.2(2); $336-339$ additions to vol.1; 340 corrections to vol.2(1)-(2), and imprimatur, undated. No RT. Language: preface and characters of classes: Italian; descriptions of genera and species: Latin; French generic names added.

Paper: leaf height $175 \mathrm{~mm}$. (BIIJH copy); laid or wove: laid: vol.1 gath.2-10 except cancellantia, gath.1 cancellantia only, and $x_{;}$wove: vol.2, vol.1 gath. 11-24, cancellantia in gath.2-10, and gath. 1 except cancellantia; wm.: in the laid paper: "BRIGIURASIO" or "BIRGINRASIO"; in the wove paper: "F A [large script]": vol.1 gath.12; "A M [large outline script monogram]": the rest of the wove paper, except vol.2 gath.11 121516 , in which no wm. was seen, perhaps because of the thickness of the paper (BMNH copy).

Printer: Bianco, Turin, Italy.

Datas: vol.1: 1825 (t.-p.); aft. $15 \mathrm{Jan}$. (pref.),

vol.2(1): 1826 (t.-p.), bef. 28 Dec. (Mém.Soo.Linn.Parie 4(6): LII. 1826);

vol.2(2): 1827 (t..-p.); aft. 11 Feb. (imprimatur):

Reviews and announcemente: Iinnaea 1(2): 331.1826 ;

Huove Giornale de Letterati 1825 (fide Linnaea);

Mim.Soo.Linn.Parie 4(6): LII. 1826.

Refe: BlarH 1675 Bradl.1: $426 \mathrm{a}$ Milt. $184 \quad$ Pr.ed.1 n.8402, ed.2 n.4744.

Bibl.notes. Volume 1 of this work is again one of those having at the same time laid and wove paper. Its cancellantia were easily detected because of the paper difference. Moreover those on laid paper were signed with an asterisk on their first page. If there have been more cancellantia, of the same paper type as the rest of the gathering as well as unmarked, they would be very difficult to detect since they also would consist of conjugate pairs. I can not explain the laid paper cancellans in vol.1 gath.1; it is possible that the 6 other leaves on wove paper in reality were the cancellantia and the pair of the fourth and fifth leaf the only remaining part of the original gathering, set before the main body of the text. This, however, seems unlikely, since it would have been easien to reprint the whole gathering; moreover. the preliminaries were usually set after the setting of the text had been finished.

Bot.notes. A regional flora, with the Linnaean classification, and a more modern division in the cryptogams. The habitat for the species was given, and the locality only for rare species. The descriptions were printed in italics, as well as the discussions. A number of varieties were treated, but they were numbered only (per species) and no varietal epithets have been noted. In the Musoi, p.186-205, I did not find new names or combinations. 
2 Ad floxam pedemontanam appendix altera.

Memorie R. Accad. Scienze Torino 31: 189-224. 1827.

Head-title: "DOCTORIS JOANNIS FRANCISCI RE | R. ACAD. SCIFNT. SOCII CORRESPOLIEITIS I IN REGIA SCHOLA VETERINARIA BOTANICES PROTESSORIS ETC. I AD FLOPA:I PEDEMONTANAM | APPENDIX ALTERA | Zeota die 20 funii 1824. | !short swelled rule !".

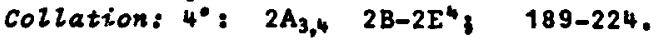

Contente: 189 head-title; 199-190 introduction; 190-224 text, enumeration of additional information on species already mentioned for the region, or descriptions of species new to the region, in Linnaean classes (descriptions omitted when already in Linnaeus or Willdenow), included are 2 species of Husci (p.20 and a considerable number of Lichenes (p.206-214) and of Fungi (p.214-224). Language: Latin.

Paper: leaf height $266 \mathrm{~mm}$. (copy separate in U, cut); wove; wm.: "Jne Avondo [erect script]" .

Date: 1827 (t.-p. vol.).

Ref.: RSC 5: 113 .

Bot.note. Additional information on the flora of Piedmont, Italy, including two species of mosses new for the region: Phasoum ourvicollum and Polytrichum arotioum.

\section{REINTARDT, Caspar Georg Carl}

Biogx. Born 1773 Jun. 5, Luttringshausen near Remscheid, Rheinprovinz, Germany. Died 1854 Mar. 6, Leiden, Netherlands.

Reinwardt studied at home, until his father died, then at the gymnasium at Lennep. In 1787 his elder brother acquired a pharmacy in Amsterdam and soon Caspar came there as a pharmacy pupil. Though he was devoted to botany, he studied medicine at the Athenaeum of Amsterdam (now the University of Amsterdam).

At the age of 27 he was nominated professor of natural history at the University of Harderwijk, at the same time receiving the degree of Dr. Med. \& Nat. Hist. honoris causa there. In 1803 he was rector of the University.

In 1808 he was nominated by King Louis Napoleon of Iloliand director of the "Menagerie", a botanical and zoological garden and a natural history museum, which was moved from Soestdijk to Haarlem and then to Amsterdam. In 1810 he was nominated professor extraord. of chemistry and pharmacy, and ordin, of natural history at the Athenaeum at Amsterdar; he held his oration 5 Nov. 1810.

In 1815 te became Director of Agriculture, Arts and Sciences for the Island of Java and adjacent regions (the present-day Indonesia except Sumatra). In spring 1816 he sailed for Java with a draughtsman and a taxidermist. During his 6 year stay he reorganized the school system and the health service, introduced new plants for agriculture, founded the Botanical Garden at Buitenzorg (Bogor), and traveled much for natural history reconnaissance. The first three shipments of the objects collected were lost in shjpweck, but the others came to Leiden.

He was nominated in 1820 professcr of natural history at Leider, but before sailing to Hollard he again made a collecting trip. In Oct. 1822 he embarked, and 3 May 1823 he held his oration. In 1832 he was rector of the University.

He was commersorated in the generic names Reinwardtia Dumcrtier 1822 (Linaceas). Reinwardtia Blume ex Nees 1824, a synonym of Saurauia billdenow (Dilleniaoeae), Reinwardtic Sprencel 1825, a synonym of Breweria R. Brown (Convolvulaceae), Reinwardtia Korthals 1842, a synonym of Ternotroemia liutis (Theaceae), and Reinvardtiodendron Koorders 1898 (Heliaceas).

Refo.: Meyer, A.B.: Allg. Deutsche Biogr. 28: 111-113, 1889. van Steenis-Kruseman, M.J.: Fl. Maleo. ser.1, 1: 429-431. 1951. 
REINUARDT, Caspar Georg Carl \& HORNSCHUCH, Christian Friedrich

1 Husoi frondasi Javanici.

Nova Acta Phys. Med. Acad. Caes. Leop.-Car. 14(2): 697-732, p1. 39-41. 1829.

Tit $z_{e}:$ "HUSCI FRONDOSI IAVANICI, | REDDIDI CONIUNCTIS STUDIIS ET OPERA | REILHARDTII Dr., ET HORNSCIUUCHII Dr. | A. C. N. C.SS. | Cum tabulis tribus, aeri

insculptis. | [short rule] | Academiae trad. d. XXIII. Maii a. MDCCCXXVI."

Colzation: $4^{\circ}: 883,489-92^{4} ; 687-698$ 700-732.

Contents: 697 title; 698 D; 698-732 text, list of 50 Javanese mosses with

localities, the description of the new genus Traohypus (, 708 ), and of 28 new species, and discussions on some others. RT: "REINWARDT ET HORNSCHUCH Husoi frondosi Iavanioi,", combined on p.732. Language: Latin.

Plates: 3 copper-engravings, numbered: "XXXIX" - "XLI" in upper right corner; in upper left corner all with: "Vol.14. P. 2", moss species indicated by italic letters, details by arabic numbers; at bottom Latin binomials; plate-mark: $253 \times 204 \mathrm{~mm}$. (p1.40).

Artiet and engraver: Sturm, Jacob (which see): all plates, signed.

Paper: leaf height $270 \mathrm{~mm}$. (HBL copy, cut), wove; wm.:

"VAN DER MEULEN \& COMP [outline, except \&]" at border of the leaf (HBL copy); plate paper: wove.

Date: 1829 (fasc. title).

Ref.: RSC 4: 153 (states: "1828")

Bibl.notes. I include this article since the date of its lecture at the academy is 23 May 1826. However, there is little doubt that the periodical containing the printed article indeed appeared in 1829 , though $I$ have not investigated this as $I$ would have liked to do. No indication of the separate as an earlier publication has been found, though its existence is likely.

Bot.notes. Important article on the Javanese mosses collected by Reinwardt. A number of new species were signed by Hornschuch only, a number of new species and new combinations were signed by both authors. The new genus Trachypus and its species T. bioolor were also signed by both authors. The plates are of a good quality.

REINIARDT, Caspar Georg Carl \& NEES von ESENBECK, Christian Gottfried

1 spiridens, novum muscorum diploperistomiorum genus.

Nova Acta Phys. Med. Acad. Caes, Leop.-Car. 11(1): 141-146. pl. 17. 1823.

Titze: "SPIRIDENS, | HOVUM MUSCORUM DIPLOPERISTOMIORUM GENUS. | DETEXIT | Dr. C. G. C. REINWARDT, A.C.N.C.S., | DESCRIPSIT | Dr. C. G. NEES ab ESENBECK, Acad. h. t. Praeses. | (Cum Tabula aenea picta)".

Collation: $4^{\circ}: 18_{3,4} 19_{1} ; 147-142$ 143-146.

Contente: 147 title; $142 \square$; $143-145$ text, description of the new genus Spiridene and its only species $S$. reinwardtii; 146 explanation of the plate. RT: "C.G.C. REINWARDT, I Spiridens, Musat genue,", combined on p. 146. Language: Latin.

Plate: hand-colored copper-engraving, numbered "XVII", of the noss, with details, and of 1 hepatic.

Artiot: Wild, T., Germany. 
Engraver: Engels, W., Germany.

Paper: leaf height $262 \mathrm{~mm}$. (HBL copy, cut), wove; wm.: "[outline script letters or monogram along long side of sheet]", plate paper: wove; thicker than that of text; no nm. (HBL copy).

Date: $1823\left(t_{.}-p_{.}\right)$, probably sem.1.

Review: Ann.sai, Hat. 1: 335-336. 1824 .

Ref.: RSC 4: 153 .

Bibl.notes. Probably a separate had been prepared without change of pagination, and consisting of the same leaves, detached. No copy studied; and no indication of earlier publication found.

Bot.notes. Description of a new conspicuous genus of mosses, found by Reinwardt and described by Nees. The name could be assigned to both authors, although the title-page ascribed the description to Nees; a narrow interpretation of the rules would assign the name to Nees only. In the explanation of the olate the description of Jungermannia indioa "nob," is added.

REYGER, Gottfried

Biogr. Born 1704 Nov. 4, Danzig, Germany, Died 1788 Oct. 29, Danzig.

No biography available to me.

Refe.: Pr.ed.2: 262 .

Festochr. Naturf. Ges. Dansig 81. 1893 (not seen)

1 Die um Dansig wizdwaohsenden Pflansen ...

Ed. 2. 2 vols, Danzig, 1825-1826:

Title: "Die | um Danzig | wildwachsenden Pflanzen | nach | ihren Geschlechtstheilen | geordnet und beschrieben | von | Gottfried Reyger. | [short rule] | Neue ganz umgearbeitete und vermehrte Auflage. [full stop missing in vol.2] I von Johann Gottfried Weiss, | der Königl. Baierischen botanischen Gesellschaft zu Regensburg, I so wie mehreren gelehrten Gesellschaften ordentliches | Mitglied und ausübender Apotheker hieselbst. I [short swelled rulej | Erster Theil. [long swelled rule] | Danzig, 1825. I Im Verlag in der S. Anhutschen Buchhandlung. | [short rule] | Gedruckt in der Wedelschen Hof buchdruckerei." vol.2: same, except: "Zweiter Theil | Die Kryptogamie enthaltend. | [short rule] | Mit 3 Kupfertafeln.| [long swelled rule] | Danzig, 1826. | In Verlag der $S$. Anhutschen Buchhandlung."

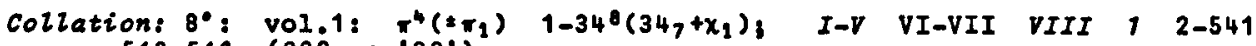
542-546 (290 as $(90$, vol.2: $\pi^{2} 1-27^{6} 21^{2} 7^{4} 28^{2} *{ }^{4}, i-i v \quad 1 \quad 2-432$ I II-LXVIII $L I X-I X V I I I_{4}$ (XXXVIII LVII).

Contente: vol.1: I title; II D; III dedication to Eduard Ferdinand Geiseler, "Kơn. Medicinalrath", IV O; V-VII preface, headed: "Vorbericht.", signed: "Danzig, in Februar 1825."; VIII the region in the Linnaean classes 1-23, species numbered 1-2029; 542 D; 543 correction; $544-546 \square$; vol.2: $i$ titles $i i \square_{\text {; }}$ iii-iv explanation of plates; 1-432 text, descriptions of cryptogams of the region; I-XXXVII index of Latin names referring to the species numbers; $X X X V I I I-L V I$ register of German names of vol.1; LVII-LX register of German names of vol.2; LXI-LXIII additions to vol.1; LXIII-LXVII additions to vol.2, LXVIII corrections. No RT. Language: German.

Plate: : copper-etchings, probably with some engraving, folded, numbered: "T.I" "T.III", details in arabic ciphers on each plate anew, figuring details of moss species.

Artiot and engraver: plates unsigned. 
Paper: leaf height $179 \mathrm{~mm}$. (copy Bibl. Senckenbergiana, Frankfurt a.K.); Iaid; wm. not checked.

Printer: Wedel, Danzig, Gernany.

Publisher: Anhuth, S., Danzig, Germany.

Editor: Veiss, Johann Cottfried (d. 1832 llay 24), Danzig, Germany; pharmacist (biogr.: Linnaea 9: 735. 1835; Festechr.Naturf.Ges.Dansig 92. 1893, not seenl

Dates: vol.1: 1825 (t.-p.); after Feb. (pref.); bef. 21 Sep. (see Reviews: Flora); vol.2: 1826 (t.-p.); bef. Apr. (see Reviews: Linnaea).

Revisws: vol.1: Fiora 8(35): 553-555. 1825 Sep. 21; Linnaea 1(1): 108. 1826; vo1.2: Linnaea 1(2): 276. $1826 \mathrm{Apr}$. (sharp criticism).

\begin{tabular}{c|l|l|l|l|l|l} 
Refs.: BMH 1692, & Bradl.1: 373b & Heins.7(2): 211 (vol.1) & Pr.ed.1 n.8535 \\
\hline 2289 & Cat.Juss. n.1772 & Ililt. 153
\end{tabular}

llotes. The second edition of a regional flora of 1768 , following the Linnaean classification; in the second volume the cryptogams, containing 3 plates with details of lusci. I did not find a new taxon nor a new combination in this group. The work was severely criticized; Pritzel quoted (from Linnaea?): "Ein ganz neues, v811ig werthloses Buch. Der zweyte Theil ist aus von Sohleohtendal's Flora Derolinensis fast voliig w8rtich uberetzt."

ROFFAVIER, Georges Biogr. Lorn 1775 Sep. 17, Lyon, France.

A merchant who had studied botany under Gilibert (1741-1814), Roffavier botanized often in the Lyon region, and cultivated critical plants at his country-seat at Saint-Genis-Laval. He was a founder of the Société Linnéenne de Lyon in 1822 and interim director of the Botanical Garden at Lyon for a very short period in 1830. He discovered many plants new to the Lyon region; some species were named after him (Hieraoium, Rosa).

Ref.: Magnin, Ant.: Bist. Botanist. Lyonn. 79-80. Lyon, 1906.

1 Bupplément d la flore Lyonnaise...

[anonymous] Lyon, 1835 .

Titze: "SUPPLÉMENT | A LA I FLORE LYONNAISE, | PUBLIÉE | PAR LE DOCTEUR J. B. BALBIS | EIT 1827 ET 1828; | OU | DESCRIPTION DES PLANTES | PHANEROGAMES ET CRYPTOGANIES DÉCOUUVRTES DEPUIS | LA PUBLICATION DE CET OUVRAGE; | SUIVI | D'UI TABLEAU GÉIJÉRAL CONTENAIT LA NOMENCLATURE | MÉTHODIQUE DES ESPẺCES AGALIES DECRITES DAIS LA FLORE LYONNAISE, | CONJOINTEMENT AVEC CELLES QUI ONT ÉTE TROUVEES DEPUIS LA HÊIIE ÉPOQUE | DAIS LES ENVIRONS DE LYON. | [rosette] LYOIf. I IMPRIMERIE TYPOGRAPHIQUE ET LITHOGRAPHIQUE | DE LOUIS PERRIN, | rue d'Amboise, 6. | 1835."

Collation: $8^{\circ}$ in $48: 1^{4} 2-11^{4} \quad 12^{2} ; 1-5 \quad 6-91$ 92 (7 60-61 88-89).

Contents: 7 half-title; 2 [; 3 title; 4 ; 5-6 preface: "AVERTISSEMENT", dated: "Lyon, février 1835"; 7-59 text, descriptions of phanerogams, ferns and bryophytes (under the restricted name cryptogames) new to the flora of Lyon; 60 ; 61-62 index to the foregoing part; 63-87 complete list of lower cryptogams, lichens, fungi and algae of the region, without descriptions, with comparison of the nomenclature of Duby and Baibis: "TABLEAU GElvÉRAL" COMPREIIANT | JES PLAITES AGAIIES DE LA FLORE LYONIAISE | ET CELLES NOUVELLEMENT DÉCOUVERTES, DISPOSE SUIVAIST LA CLASSIFICATION DU BOTANICON GALLICUM DE DUBY. | (L'asterisque désigne les plantes nouvelles.)"; 88 two short lists of plants found in the region of Lyon, but outside the area of the flora (Vienne 3 species, Crémien $4 \mathrm{sp}$.$) ; 89-91$ index of generic names of the lover cryptog,ans, including synonyms; $92 \mathrm{D}$. RT: names of plant groups. Language: French. 
Plate: 1 plate indicated (see Bibl.notes); missing in IIBL copy.

Paper: leaf height $218 \mathrm{~mm}$. (HBL copy, uncut); laid, chains vertical; wm.: "[shell] A II D G [partly outlinej", usualiy in the middle of the upper quarter-sheets, occasionally in those of the same half-sheet, showing both marks in one half-sheet, and none in another.

Printer: Perrin, Louis, Lyon, France.

Collaborators:

Rollet, Marc Antoine (1803-1882), Lyon: contributed a number of indications; Seringe, Nicolas Charles (1776-1858): contributed some indications (both according to Marnin: Bist.Botanist.Lyonn. 89-90, 102. 1906).

Date: $1835\left(t,-p_{.}\right)$) Apr. (see Bibl.notes);

bef. 12 Sep. (Bibliogr. Franoe 24(37): 557. 1835).

Review: Repert.Gesammt. Deutsoh. Lit. (Gersdorf) 6(5) Lit.1liso.: 37,1835 l!ov. 30. Refo.: Bradl.1: $408 \mathrm{a}$ Brun.6: 5074 Graesse 1: 279 Pr.ed.1 n.431, ed.2 n.368.

Bibl.notes. A printed letter accompanies the HBL copy (and possibly other copies) with the following text:

"Moneieur, | J'ai l'honneur de vous adreseer un exemplaire | du oupplement a la Flore Lyonnaise publiée par | Mr Balbio. Ce petit travail qui est le résultat | des reoherohes de plusiours Botanistes de cette ville, I contient que lques espèce asess rares, entre autre | le Trifolium legopus dont on a donne une figure, le Carex nutans et plusieurs plantes l agames, nouvelies pour la Franoe. I Agrés, Monsieur, l'aseurance de ma I considération diotinguée, | Roffavier. I Lyon, le Avriz, 1835."

This letter, in flowing script, with the botanical names in erect script, probably was Iithographed. It can be inferred from this letter that Roffavier was the main author of this anonymous supplement.

Bot.notes. This supplement contains additional information to Balbis' Flore Lyonnaise, mainly new localities and species, also some corrected determinations. The list of Fungi (without descriptions) was considerably enlarged

SAUIIAISES, Auguste [editor]

No biography available to me.

1 Cours d'agrioulture, de botanique et d'hiotoire naturelle; ... 2 vols. Paris, 1837.

Title: not studied.

Collation: $8^{\circ}$ :

vol.1: $\pi^{2} \quad 1-12^{8} \quad 13^{6} \quad 14-22^{8} \quad 23^{4} \quad 24-29^{8} \quad 30^{6} \quad 31-36^{8} \quad 37^{2} \quad 39-47^{8}\left(* 47_{8}\right) ;$

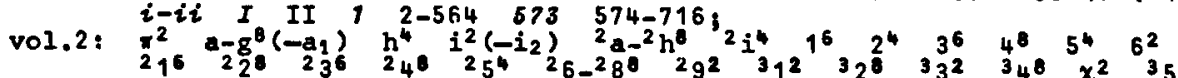

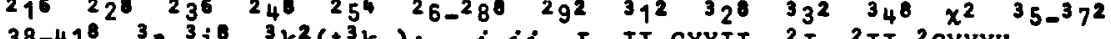
$38-41^{3}{ }^{3} \mathrm{a}^{3} \mathrm{i}^{3}{ }^{3} \mathrm{k}^{2}\left( \pm^{3} \mathrm{k}_{2}\right) ; i-i i$ I II-CXXII ${ }^{2} I{ }^{2} \mathrm{II}-{ }^{2} \mathrm{CXXXV}$

Note: For brevity the numerous unnumbered pages are not recorded here.

Contents (by collational reference):

vol.1: $\pi_{1}$ title, $v$ imprint; $\pi_{2}$ new text, headed: "COURS | D'AGRICULTURE", new chapter, headed: "ARROSELEIST,"; $1,-37_{2}$ re-issue of sheets of Usmoires de la Société Linnéenne de Paris 5(1)-(5): 1-564. 1826 (including the article of Arnott n.7 \& 11, with the report and annotations by Kittel); $399_{1}-47$, re-issue of sheets of the same journal 4(6): $573-716$. [1826?; 478 cancellans, new chapter on destructive insects; 
vol.2: $\pi_{1}$ title, $v$ imprint; $\pi_{2}$ rv text, headed: "COURS | D'AGRICULTURE.", new chapter, titled: "CULTURE DE L'AIIANDIER."; $\pi_{2} v$ reprint of a part of the same periodical, P.1-2, titled: "Discours prononcé par $M$. le docteur Descourtilz, président de la Société | Linnéenne, à la séance publique du 28 décembre 1824 , jour anniver-|saire de la mort de Tournefort."; $a_{2-i_{1}}$ reissue of sheets of the same journal 3(6): III-CXXII. [1825]: history of the society concerned during the year $1824 ;{ }^{2} a_{1}-{ }^{2} i_{4}$ re-issue of sheets of the same journal 4(6): I-CXXXV. [1826. : history of the society during 1825; $11_{1}-6$ re-issue of the Bulletin Linnsen $1824(1)-(6) ; 21_{1}-29_{2}$ re-issue of the same bulletin $1825(1)-(6) ; 3_{1}-37_{2}$ re-issue of sheets of the same bulletin $1826(1)-(6) ; \quad 381-41$, re-issue of sheets of the MÉm. Soo. Linn. Paris $5(6)$ : 573-714. [1826]; ${ }^{3} a_{1}-3 k_{1}$ re-issue of sheets of the same journal $5(6)$ : I-CXLVI. [1827: : history of the society during $1826 ;{ }^{3} \mathrm{k}_{2} \mathrm{r}$ reprint of $\mathrm{p}$. CXLVII of the foregoing history, continuing the list of books received during 1826 up to "Société d'agricuiture de Vesoul ..."; ${ }^{3} \mathrm{k}_{2} \mathrm{rv}$ new final chapter of Cours d'agriculture, headed: "CULTURE DÜ CHANVRE." (culture of hemp). No RT. Language: French, with Latin descriptions.

Plates: 16 copper-engravings, reissued from vols.4 and 5 of the journal, representing plants, animals, fossils and minerals, and a map showing the result of an anti-hail device; some plates folded, a $f e w$ still in the pairs as printed from one copper-plate (frontispiece vol. 2 consists of Pl.XIV and XII together, dated 1826, with engraved dividing line); plate-marks not measured.

Artiots (of botanical plates):

Billotti, L.: pl.II of 1825 (vol.2);

Brondeau, L. de: pl.VI of 1826 (vol.1);

Iescourtilz, Théodore, naturalist: pl.I of 1825 (vol.2);

Desmazières, J.B.H.J. (which see): pl.IV of 1826 (vol.1);

Léveillé, J.H. (1796-1870), botanist: pls.XIV, XX of 1825 (vol.2):

Libert, Ifelle Anne (1782-1865), Belgian botanist (biogr.: Bull.Soc.Bot.Belg. 4: 403-411. 1865): Pl.V of 1826 (vol.1);

Machado née Berthelot, Marg. (sister of Sabin Berthelot): pl.VII of 1826 (vol.1); Roubieu: pl.XII of 1826 (vol.2 frontispiece);

Zippelius: pl.XIII of 1826 (vol.1 frontispiece).

Engravers (of botanical plates): Desève: pls.V-VI of 1826, pl.XII of 1825; Lanvin: pl.XIII of 1826 ; Tourcaty: Pls.I, II, XIV, XX of 1825.

Paper: leaf height $215 \mathrm{~mm}$. (HBL copy, uncut); laid, chains vertical (except in some plates with horizontal chains); wm. new leaves: not studied; old leaves: see N\&m.Soo,Linn, Pario.

Printers: A. Le Boyer \& Comp., Lagny, France: the few new leaves; Lebel, Paris: the re-issued sheets of vol.3 of periodical; Decourchant, Paris: the re-issued sheets of vol.4-5 of the periodical.

Publisher and editor: Saumaises, Auguste, Paris.

Date: 1837 (t.-p.) (not traced in Bibliogr. Franoe)

Reviewe and references: none traced.

Bibl.notes. Remarkable re-issue, with a few newly printed leaves to cover the manipulation, of the sheets of the M\&moires de la sooidts Linneenne de Paris of 1824-26. The printer's stock possibly came into other hands, with more material, since vol.2 (HBL copy) has the green wrapper pasted to the rectos of a title-page and a half-title of another book printed by Decourchant: Histoire de France, vol.8, by Le Comte de Segue, Paris, 1829 (publisher: Alexis Eymery, Paris). The contents of the journal are not recorded here, since the bryological articles are recorded at their appropriate places.

Bot.notes. The nomenclatural consequence of this re-issue for the names in the article of Annott are discussed under Arnott n.11; there is a possibility that a similar situation is present for articles treating fungi, in connection with the different dates of the starting-point of nomenclature of this group; I did not check this possibility. 


\section{SAUTER, Anton F.Ieutherius}

Biogr. Born 1800 Apr. 10, Grossarl, Herzogthum Salzburg, Austria.

Died 1881 Apr. 6, Salzburg, Austria.

Sauter entered the gymasium at Salzburg in 1809 and the Collegium Rupertinum there in 1812. In 1814 he began learning plants with the help of the Salzburgioohe Fiora published by F.A. von Braune in 1797, and later with the author himself. He studied philosophy in Graz in 1819 and medicine in Vienna in 1820, where he finished with his doctor's thesis in 1826 (treated below).

In the autumn of 1826 he became second physician in the St. Johns Hospital in Salzburs, where he stayed $1 \frac{1}{2}$ year. From 1828-1848 he held official medical positions in different places in Austria consecutively: Kitzbächl [Kitzbuhel?], Bregenz, Zell am See, Ried (Oberosterreich) and Steyr. Finally he became "Kreisarzt" in Salzburg, a position from which he retired in 1871.

He made many trips in the neighborhood of the places whese he worked, studying the local floras thoroughly. Hot neglecting possible new species, Sauter paid special attention to cryptogams, earning the epithet: "nestor of the Austrian cryptogamology".

He corresponded with many other botanists and was visited by several of them, e.8. W.P. Schimper was with him in Steyr in 1844. After his retirement Sauter diligentiy studied the fungus flora of Salzburg. A botanist of the old school, he never used a microscope.

He was commenorated in the generic name Sauteria C.G. Hees von Esenbeck 1838 (Bepatioae, Narchantiaoeae).

Ref.: Schiedermayr, Karl: Oestewr. Bot. Zeitoohr. 27(1): 1-6. $1877 \mathrm{Jan}$.

1 Dissertatio inauguralis geographico-botanioa de territorio Vindobonensi;

Versuoh einer geographisch-botanisohen sohizderung der Umgebung Wiene.

Vienna, 1826 .

Latin title: "DISSERTATIO | INAUGURALIS GEOGRAPHICO-30TANICA | DE | TERRITORIO | VINDOBOIENSI." ...... (not further transcribed);

German title: "VERSUCH | EINER | GEOGRAPHISCH-BOTANISCIIEI SCIILDERUNG | DER | UMGEBUNG VIENS. | [swelled rule] | VON | ANTON ELEUTH. SAUTER, I DER REGENSBURGER BOTAN. GESELLSCIAFT MITGLIED. | [ swelled rule] | WIEN 1826. | GEDRUCKT BEY ANTON $V$. HAYKUL." (typography not studied).

Collation: $8^{\circ}: 7^{8} \quad 2-3^{\circ} x^{1} ; \quad I-V I I$ VIII-X $11 \quad 12-48 \quad 49-50$.

Contente: I Latin title; II G; III German title; IV $\square$; $\dot{V}$ dedication to "Joseph Franz Freiherrn von Jacquin" (1766-1339); VI D; VII-X preface, dated: "Vien, am 26. July 1826."; 11-48 text: 11-23 physical geography of Vienna, 24-48, flora of Vienna in natural families; 48 list of abbreviations; 49 "Theses"; so correction. llo RT. Language: German.

Paper: not studied.

Printer: Haykul, Anton von, Vienna, Austria.

Date: $1826\left(t_{.}-p_{.}\right)$; after $26 \mathrm{Jul}$. (pref.).

Refo.: BIHJH 1812 Bradl.1: 439b Pr.ed.1 n.9008, ed.2 n.8053.

Bot.notes. An important study on the plant geography and ecology of the flora of the Vienna region, however, not treating the cellular cryptogans except for a short mention in the introduction; e.g. one paragraph devoted to Musi, in which one species is mentioned: Anaoamptodon oplachnoides. 
SAVI, Gaetano

Biogr. Born 1769 Jun. 13, Florence, Italy.

Died 1844 Apr. 28, Pisa, Italy.

G. Savi was professor of botany and director of the botanical garden in Pisa;

he was author of many botanical works, e.E. a flora of Pisa.

Ile was commemorated in the generic names Savia Villdenow 1805 (Euphorbiaceae) and Savia Rafinesque 1909, a synonym of Amphioarpaea S. Elliott corr. A.P. de Candolle (Leguminosae).

Ref.: Huov. Giorn. Bot. Ital, 4: 177-208, 1872.

1 Botanioon Etrusoum ...

4 vols., $1808-1825$.

Titze: "CAJETANI SAVI | MED. DOCT. | IN IHPER. PISAYO ATHENEO | BOTANICES PROFESSORIS | ACAD. GEORGOPHIL. FLOREIT, SOC. | BOTANICON ETRUSCUM | SISTENS | PLANTAS | IN | ETRURIA SPONTE CRESCENTES | [medium rule] | VOLUMEN I. [Vol.2: VOLUMEN II.] [Vol.3: VOLUMEN III,] [Vol.4: VOLUMEN IV.I | [medium rule] | PISIS I TYPIS RAYIERII PROSPERI ] 1808. [vol.2: 1815.] [vol.3: 1818.]

Collation: $8^{\circ}$ : vol.1: $7^{8} 2-12^{8} \quad 13^{4} ; \quad 1-5 \quad 6-200 \quad(8-9 \quad 123)$; vol.2: $\quad \pi^{2} 1-16^{8} 17^{6} ; \quad i-i v 2^{2} \quad 268$; vol.3: $1-11^{8} 12^{4} ; 7-3 \quad 4-184$;

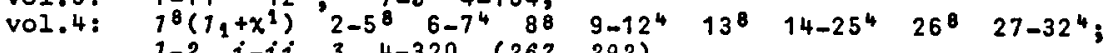

Contonte: vol.1: 1 title; 2 C; 3 dedication to Octaviano Targioni Tozzetti; 4 [; 5-7 preface; 80 ; $9-192$ text, descriptions of plant species: "[1.] Veronica spicata." - "248. Vallisneria spiralis."; 193-199 index; 200 addenda and emendanda;

vol.2: i title; ii $\square$; iii-iv preface; 1-258 text: "249. Ligustrum vulgare" - "711. Hippoorepio multisiliquosa."; $259-268$ index of vol.2;

vol.3: 7 title; 2 ; 3-177 text:" 711 [sic for 712]. Equisetum sylvaticum." - "1000. Evonymus latifolius."; 178-184 index of vol.3;

vol.4: 1 title; 20 ; $i-i i$ preface; 3-266 text: "1001. Corydalis lutea." "1509. Bysous aurantiaca."; 267-291 alphabetical index to vols.1-4; 292-319 systenatical index to vols,1-4; 320 addenda and emendanda. No RT. Language: Latin.

Paper: laid, chains vertical; wm.:

"[croumed shield with post-horn] I C \& I HonIG = I V": vol.1, vol.2: 11-17;

"[crowned shield with fleur-de-lis] | $1806=$ [monogram in script with C]": vol.2: $1-10$, vol.3: 1-11;

" [crowned shield with post-horn]'। L G [...] E C": vol.3: 12;

"[crowned shield with post-horn] | G B A \& M": vol.4.

Printer: Prosper, Rayner, Pisa, Italy.

Dates: vol.1: 1808 (t.-p.); bef. 20 Jun. (J.Gén.Litt.Étrang., Sayre 59), Sep.-Oct. (Nuov.Giorn.Lett.Pisa ser.2, 9(26): 260-261.1808);

vol.2: 1815 (t.-p.); bef. 20 lov. 1816 (J.G8n.Litt.Etrang, Sayre 59);

vol.3: 1818 (t.-p.); Apr. (Biblioth,Ital. 10(4): 139-140.1818);

vol.4: 1825 (t.-p.); Jun. (Antologia Firenze 19(56): 145-146. 1825 Aug.).

Reviews: vol.1: J.Bot. (Desvaux) 2: 111-114. 1809;

vol.2: Flora $3^{1}($ Beiz.2): 27. 1820;

vol.3: Biblioth.Ital. 10(4): 139-140.1818;

vol.4: Nuov.Giorn.Lett.Piaa ser.3, 10(21): $245-246,1825$;

vol.1-4: Linnaea 1(2): 330.1826 [from Buiz.Soi. Nat. ser.2, 1825 Nov.].

Bibliogr.otudy: Sayre, G.: Dated of publ. 58-59. 1959.

Refe.: Arn.Arb.1: 626 BMNH 1815

Brad. 1: $425^{\mathrm{a}}$
Brun. 6: 5101 Kew 549
Linn. Sos. 679

Milt. 185
Pr.ed. 1 n.9017

Pr.ed. 2 n.8062

Un.Edinb.3: 475 . 
Notes. Savi, apparently not content with his Flora Pisano of 1793, published in this book his accumulated knowledge of the flora of his region. He acknowledged the consultation of the manuscripts of Pier' Antonio IIicheli (1679-1737). The arrangement of the plants and the nomenclature are in essence Linnaean; the Linnaean arrangement was for convenience not followed throughout the book, but at the end a systematical index was added.

A number of new species were proposed, or new conbinations (Eromus hispiäus), for phanerogams listed in Index Kewenois. Cryptogams were included, except Algae (and the Hepatioae, included in $A Z_{g a b}$ by Linnaeus). This work is often cited for Fontinalio juliana Savi (3: 107); however, this name was already published by A.P. de Candolie in Lamarck De Candolle, El. Frang. ed.3, 6: 236. 1815, and both were antedated by skitophyllum fontanum De la Pylaie which was cited by Savi as a synonym.

2 Soelta di generi di piante...

Pisa, 1826 .

Title: "SCELTA | DI GENERI DI PIANTE | CON I LORO RESPETTIVI CARATTERI | DISPOSTI SECONDO IL SISTEMA SESSUALE | E IL METODO IIATURA.LE | PER USO | DELLI STLDEIFTI DI BOTANICA | DI GAETANO SAVI | PROFESSORE DI BOTAIICA E DIRETTORE DEL GIARDINO | DELLA I. E R. UNIVERSITA DI PISA | SOCIO CORRISPONDENTE DELLA R. ACCADEMIA DEI GEORGOFILI I DI FIRENZE, DELL' ACCADEIIA VALDARIESE DEL POGGIO, I DELL' ACCADEMIA LABRONICA, DELLA R. ACCADEIIIA DELLE I SCIEIVE DI STOCKOL1, DELLA R. ACCADEMIA DELLE SCIENZE | DI TURIHO, DEL LICEO DI STORIA NATURALE DI NEV-YORK, | DELIA SOCIETA' ORTICULTURAIE DI LONDRA, DELLA SOCIETA' | ELVETICA DI STORIA NATURALE EC. EC. EC. | PISA | PRESSO SEBASTIAHO IIISTRI | IIDCCCXXVI."

collation: $8^{\circ}: \pi^{4}\left(\pi_{2}+2 \pi^{2}\right)$ $7^{8} \quad 2-19^{8} ;$ I-III IV-XII 1-3 4-302 303-304 $\begin{array}{lllllllllllllll}\text { (VII } & 7 & 72 & 85 & 88 & 84 & 102 & 172 & 119 & 124 & 135 & 151 & 154 & 773 & 186\end{array}$ 208-211 $216227 \quad 291$ ).

Contents: I title; II Di III-VI preface: "PREFAZIONE"; VII-XII systematical list of genera in natural families (Itaijan names); 7 part-title: "PARTE PRIMA | (short double rule] | GENERI DI PIANTE | DISPOSTI | SECONDO IL SISTEIIA SESSUALE | COLLE CORRISPOINDIIZE | ALLE FAMIGLIE IIATURALI"; 2 G; 3-207 text, descriptions of plant genera in the Linnaean classification with marginal references to the natural families; $208 \mathrm{G}$; 208 part-title: "PARTE SICOIJDA I [short double rule] | GENERA DI PIANTE | DEPOSTI SECOIIDO LE FAMIGLIE NATURALI | COLLE CORRISPONDEINE | AL SISTE!IA SF.SSUALE"; 210 D; 211-290 text, descriptions of natural families with lists of genera in the families and their numbers in the first part; 281-302 index of names of genera and families, page-numbers and consecutive numbers; 303 corrections; $304 \square$. RT: absent in $\pi$; Latin names of Linnaean classes and their subdivisions in part 1, Italian names of natural classes in part 2. Ianguage: Italian.

Paper: leaf height $199 \mathrm{~mm}$. (BHNH copy, cut); laid, chains vertical; wm.:

"[five-pointed star] | La Stelia $=$ G \& C Cini [large outline script]": $2 \pi \quad 2-13$ 19;

"[cromed shield with post-horn] I G B A \&" I" 14-15;

"[crowned shield with post-horn] | [monogram ll or CA?]": 16; not identified: 17,18 (BMNH copy).

Printer: Nistri, Sebastiano, Pisa, Italy.

Date: $1826(t,-p$.$) .$

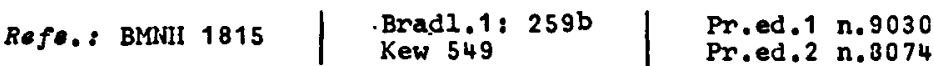

Solilsb. n.831a

Un. Edinb. $3: 475$.

Bibl.note. The part $2 \pi$ in the gathering 1 could have been part of one gathering $\pi^{6}$ but the wm. and the paper color ( $\pi$ more browned than $2 \pi$ indicate otherwise, possibly a cancel.

Bot.note. Arrangement of the genera of plants in the Linnaean and natural classifications. Musoi were treated on P.VII: "Le Muscoidee", P.189-194 with special references to Savi: Botanioon Etrusaum and its numbers; p.213 exactly the same arrangement. 


\section{SCEULTZ, Carl Friedrich}

Biogr. Born 1765 ... , Stargard, Mecklenburg, Germany.

Died 1837 Jun. 27, Neubrandenburg, Mecklenburg, Germany.

C.F. Schultz was a physician at Neubrandenburg. He received the title "Grossherzoglich Mecklenburgisch-Strelitzischen Hofrath" and he was a member of the Academia Caes. Leopoldina-Carolina. He was a bryologist. His herbarium came to the Botanical Institute of the University of Rostock. The first half-year volume of the periodical Flora was dedicated to him. He was commemorated in the generic name Sohulsia Sprengel 1813, nom.cons. (Umbelliferae). Ref.: Boll, E.: Fiora von Neaklenburg 161-163. 1860 (not seen).

1 species nonnullas novas e Barbularum generi.

Sylloge plantarum novarum 1: 34-37. 1824 [1822].

Collation: $8^{\circ}: C_{1} r_{-} C_{3} r_{;}$34-37.

Date: 1824 (t.-p.); 1822 (see Sylloge plantarum novarum).

Bot.note. Descriptions of new species of Barbula (Musci), e.g. B. hornsahuchiana (35), usually overlooked (title date 1824 is later than that of Schultz n.22

2 Recensio Generum Barbulas et Syntriohiae.

Nova Acta Phys. Med. Acad. Caes, Leop.-Car. 11(1): 191-232. p1.32-34. 1823.

Titze: "RECENSIO | GENERUM BARBULAE $\mathrm{z} T$ SYNTRICHIAE | AUCTORE | C. F. SCHULTZ, M. D., Ac. C. N. C. S. | (Cum tabulis 3 aeneis pictis.) | [short mile]".

Collation: $4^{\circ}$ : $24_{4} \quad 25-29^{4}$; 181-182 193-232.

Contents: 191 title; 182 G; $193-195$ introduction; 196-232 text, descriptions of species of the moss genera Barbula and syntrichia; 232 note for explanation of plates, referring to p.196, and errata.

Plates: 3 hand-colored copper-engravings of mosses with details, numbered: "XXXII." - "XXXIV.", name of species below the figures, details with italic letters; plate-mark: $233 \times 190 \mathrm{~mm}$. $(\mathrm{pl} .34)$.

Artist and engraver: Sturm, Jacob (which see): all plates, signed.

Paper: leaf height $262 \mathrm{~mm}$. (HBL copy, cut); wove; wm. (periodical): "[outline script letters or monogram along long side of sheet]"; plate paper: wove; no $\mathrm{wm}$. seen.

Date: 1823 (fasc. title); probably sem.1.

Ref.: RSC 5 : 566 .

Bot.note. Important monograph of the moss genus Barbula and the related genus Syntriahia, including the species of Tortula.

Trichostomum Laureri Schults, eine neue Laubmoosart.

Flora 10(11): 161-164. 1827 Mar. 21.

Fitla: "Trichostomum Laureri Schultz, eine neue Laub-|moosart; aufgestellt von Herrn Hofrath Dr. I Schultz in Neubrandenburg."

Collation and date: see Flora.

Ref.: RSC 5: 566 .

Note. Latin description of a new species of Musol, p.163, with a German introduction. A correction to the description was published in glora $10^{2}$ (Beil.): 112. 1827 (probably Jan. 1828). 
4 Observationes bryologioas.

Sylloge plantarum novarum 2: 119-154, 177-217. !1827?;, 1828 .

Collation: $8^{\circ}$, see sylloge plantarum novarum.

Date: 1828 (t.-p.); after 7 Mar. 1826 (see Announcement);

at least partly after 12 Dec. 1826 (second part dated, p.217); probably 1827 (see Sylloge plantarum novarum).

Announcement: "particula prima" was announced in Flora 9(9): 142. 1826 Mar. 7: "wird in der Porteetzung der sylloge plantarum einverleibt verden" (will be incorporated in the continuation of the $S y 2 z, p Z$.nov.).

Bibi.notes. It is quite well possible that the first part or at least some gatherings already appeared during 1826 , but $I$ did not find other indications than the pre-piblication announcement referred to. It is very likely that the whole article was published before 1828 , but again $I$ do not have any certainty.

Bot.notes. The new names in these bryological discussions were entered in Index huscorum under the year 1828, taken from the title.

SCHWAEGRICHEN, Christian Friedrich

Biogr. Born 1775 Sep. 16, Leipzig, Germany.

Died 1853 May 2, Leipzig.

C.F. Schwaegrichen, from a merchant family, studied in Leipzig and became Dr. Med.

in 1799. In 1802 he was appointed professor extraordinarius in natural history, and in 1806, after the death of R.A. Hedwig (1772-1806, son of Johann Hedwig), proressor extraordinarius of botany and director of the botanical garden there. In 1815 he became professor ordinarius. He visited Great Britain in $1822 / 23$ and afterwards becane a foreign member of the Linnean Society. In 1837 he consigned the directorate of the botanical garden to G. Kunze (1793-1851). In 1852 he resigned as professor and was awarded the order "Pour le Mérite". He died from a fall. Schwaegrichen was an outstanding bryologist, a worthy pupil of Johann Hedwig (which see), whose herbarium he afterwards acquired. The combined herbarium hedwigSchwaegrichen is now kept in the Conservatoire et Jandin Botanique de Geneve. Schwaegrichen edited the posthumous work Species Huscorum of Johann Hedwig, refraining from adding material not contributed by Hedwig. Additionally he published his om material modestly as Supplements to Hedwig's work, although it is clear from the title-page that Schwaegrichen wrote it. He also was the author of the part treating the mosses in Willdenow's edition of Linnaeus' speoies Plantarum, which was not completed.

Moreover he published papers in periodicals, added parts on mosses to scme travel accounts and published independently on hepatics, on plants and insects around Leipzig, and a text-book on natural history for schools. He had a well-known collection of insects and birds.

He was commemorated in the generic names sohwagrichenia Sprengel 1817, probably a synonym of Anigosanthus Labillardière (Amarylizidaoeae), and Sohwaegriohenia Reichenbach, a superfluous name for Tetragastris J. Gaertner (Buresraceae). and in some specific names of kusci.

Refo.: Wunschmann, E.: Allg.Deutsohe Biogr. 33: 175. 1891; Florschutz, P.A.: Chrietian Priedrich Schwaegrichen (1775-1853) in: Hedwig, J.: Species Muscorum frondosorum. Facsimile ed. P.XIII-XIV. Weinhein, 1960. 
1 species muscorum ... supplementum.
4 supplements in 7 volumes
[11 parts].
Leipzig,
$1811-1842$.

Titles: suppl.1: vol.] 1: "IOANNIS HEDWIG | IIED. DOCT. AC PROFESSORIS BOTANICES IN ACAD. LIPSIEISI, ACADEH, IYPERIAL, I NATVRAE CVRIOSORVM, REG. SCIENT. HOLH. SOCIETATISQVE LONDIHENS. MELHBRI, I PHYSTOPHILOR. BEROL. TVRICENS., MEDICOCHIRVRG. TVRIC., OECOIOI. LIPS. ET | MARCHICO-POTSDAIEISIS, MATHEMATICOPIYSICAE ERFORDIEISIS SODALIS | SPECIES | IYSCORVM FRONDOSORVM | DESCRIPTAE ET TABVLIS AENEIS COLORATIS ILLVSTRATAE I OPVS POSTVMVM. | SVPPLEIIENTVM PRIMVM | SCRIPTVM | A | FRIDERICO SCHIAEGRICHIEN | MED. ET PHILOS. DOCT., BOTANICES ET HISTORIAE NATVRALIS PROFESSORE IN ACA-|DEMIA LIPSIENSI, SOCIETATT. REG. PHYSIC. GOETTINGENS. MEMBR., REG. MOILACENS. | CORRESP., PHYTOGRAPHIC. YOSCVENS., BOTANIC, RATISB., PIYSIOGRAPHIC. WETTERA-|VIENS., IIEIDLLBERGENS. OECON. 'LIPS. SODAL. I [copper-engraving of mountainous landscape with two botanizing boys, a third one standing locking through a microscope and a young lady making notations j | SFCTIO PRIIA I TABVLIS AENEIS COLORATIS L. ILLVSTRATA. [ [Very long swelled rule] | LIPSIAE | SVMTV IOANNIS AIBROSII BARTH | MDCCCXI. | PARISIIS APUD TREVTTEL ET WURZ, RVE DE LILLE NO. 17.";

suppl.1 [Vol.j 2: "IOANNIS HEDWIG | MED. DOCT. AC PROFESSORIS BOTANICES IN ACAD. LIPSIENSI, ACADEM. IMPERIAL, | NATURAE CURIOSORUM, REG. SCIENT, HOLM. SOCIETATISQUE LONDINENS. MEMBRI, I PHYSIOPHILOR. BEROL. TVRICENS. MEDICOCHIRURS. FIRIC., OECONOH. LIPS. ET | MARCIICO-POTSDAMENSIS, MATHEMATICOPHYSICAE ERFORDIENSIS SODALIS | SPECIES | MUSCORUM FRONDOSORUM | DESCRIPTAE ET TABVLIS AENEIS COLORATIS ILLVSTRATAE | OPUS POSTUMUM. | SUPPLEMENTUM PRIMUM I SCRIPTUM A I FRIDERICO SCHWAEGRICHEN I MED. ET PHILOS. DOCT., BOTANICES ET HISTORIAE NATURALIS PROFESSORE IN ACA-|DEMIA LIPSIENSI, SOCIETATT. REG. PHYSIC. GOETTINGENS. MEMBR. REG. MONACENS. HARLEMENS. PHYTOGRAPHIC. MOSCUENS , BOTANIC. RATISB. "PHYSIOGRAPHIC. WETTERA-|VIENS.", HEIDELBERGENS. IElJENS. OECON. LIPS. SODAL' | [copper-engraving, identical with that in suppl.1 [vol.] 1] I SECTIO POSTERIOR I TABULIS AENEIS COLORATIS LI. ILLUSTRATA. I [very long swelled rule] | LIPSIAE | SUMTU IOANNIS AIBROSII BARTII | MCCCXVI. | PARISIIS APUD TREVTTEL ET WURZ, RUE BOURBON HO. 17."; suppl.2 voli1(1): "IOAIIIIS HEDIIIG | IED. DOCT. AC PROFESSORIS BOTANICES IN ACAD. LIPSIEISI, ACADEM. IHPERIAL, IIATURAE CURIOSORUM, REG. SCIENT. HOLM. SOCIETATISQUE LOIDIIEIS. MEIBRI, | PHYSIOPHILOR. BEROL. TVRICENS., V1EDICO-

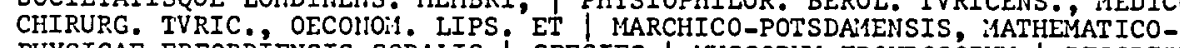
PIIYSICAE ERFORDIEIISIS SODALIS | SPECIES | IIUSCORU. FROIDOSORUM | DESCRIPTAE ET TABULIS AEIJIS COLORATIS ILLUSTRATAE I OPUS POSTIIUIUH. I SUPPLEYENTUM SECUNDUH | SCRIPTUII | A I FRIDERICO SCIWAEGRICHEN | MED. ET PHILOS. DOCT., HISTORIAE NATURALIS ET BOTANICES PROFESSORE IN ACADEMIA I LIPSIENSI, SOCIETAT. HIST. IIAT. LIPS, DIRECTORE, SOCIETT. IIPER. LEOPOLDIIO-CAROLIIIAE, IOSCOVIENSIS, REGIAE GOETTINGENS. MONACENS, "LIIIEANAE PARISIENS., PIYYSICÓIED. I ERLAIIGENS. , DRESDANAE, IIAT' SCRUT. HALENS., HARLËIEIS . HEIDELBERG. , IIARBURG. I VETTERAV., OSTERLAND. RATISBON, PIIYTOGRAPH, HOSCOVIENS., IIINERALOG. DRESDEISS ', I IEINENS., OECONOM. LLARCHIAE POTSDANENS. ET LIPS. ALIARU:QUE SODALI. ' [copper-engraving, identical with that in suppl.1 [Vol.j 1] | TABULIS AEISIS L. ILLUSTRATA. [ [very long swelled rule] | LIPSIAE SUMTU IOANIIS AHBROSII BARTH | IIDCCCXXIII. | PARISIIS RUE BOURBON NO. 17. APUD TREUTTEL ET UURTZ | LOIIDINI SOHO SQUARE 30. APUD TREUTTEL ET WURTZ, TREUTTEL FILIUS ET RICHTER.";

suppl.2 [vol.]1(2): "IOANHIS HEDHIG | MED. DOCT. AC PROFESSORIS BOTANICES IN ACAD. LIPSIENSI, ACADEM. IMPERIAL; WATURAE CURIOSORUM, REG, SCIENT, HOLM. SOCIETATISOUE LONDINEIS. MEMBRI, I PHYSIOPHILOR. BEROL. TURICENS., MEDICOCHIRURG, TURIC. OECONOA. LIPS. ET | IIARCHICO-POTSDAIEISIS, MATHEMÁTICO-
PHYSICAE ERFORDIEISIS SODALIS | SPECIES I MUSCORUM FRONDOSORUM | DESCRIPTAE ET TABULIS AENEIS COLORATIS ILLUSTRATAE I OPUS POSTHUMUM. I SUPPLEMEITTM SECUNDUM | SCRIPTUM | A | FRIDERICO SCHWAEGRICHEI | MED. PHILOS. ET CHIRURG. DOCT. HIST. NATURALIS ET BOTANIC. PROFESS. ET FACUL-ITATIS NED. ASSESS. IN ACADEMIA LIPSIENSI, SOCIETATIS IIAT. SCRUT. LIPS. DIRECTORE, I SOCIETT. IIPER. LEOPOLDIIO-CAROLIN. ET MOSCOVIENSIS, REGIAE HARLEIENS. "MONA-I CENS. LINNEANAE LONDIN. ET PARISIN., PHYSICO-NED. ERLANGENS.'ET DRESD., INÁT. 1. 
CURIOS. ALTENBURG, BEROLINEIS, , FRAITCOFURTAIIAE SENKEIBERGEIS , GOETTIN-|GEIS., IIALENS., HEIDELBERG., HARBURG., OSTERLAID., RATISBOII., IJETTERAV̆. | PHYTOGRAPH.

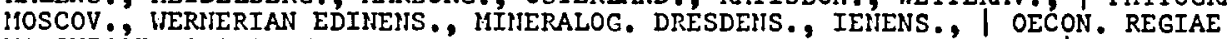
MARCHICÁE POTSDAMEIS., DRESD. ET LIPS., SOC. PILARIACEUT, GERMANI. I BOR. ETC. SODALI. | [copper-engraving, identical' with that in suppl.1 [vol.] 1] |TABULIS AENEIS L. ILLUSTRATUM. | [very long swelled rulej | LIPSIAE | SUITU IOAINIS AIBROSII BARTH. | MDCCCXXIV. PARISIIS RUE BOURBON No. 17. APUD TREUTTEL ET WÜTZ. | LONDINI SOHO SQUARE 30. APUD TREUTTEL ET WÜRTZ, TREUTTEL EILIUM ET RICHTER." ;

suppl.2 vol.2(1): "IOANNIS HEDHIG | MED. DOCT. AC PROFESSORIS BOTANICES IN ACAD. LIPSIENST. ACADEM. IMPERIAL; I NATURAE CURIOSORUM, REG. SCIENT. HOLM. SOCIETATISQUE LONDINENS. MEMBRI. | PHYSIOPIILOR. BEROL., TURICENS., MEDICOCHIRURG. TURIC, OECONOM. LIPS, ET | ILARCHICO-POTSDAIEISIS, IIATHEMÁTICOPHYSICAE ERFORDIENSIS SODALIS | SPECIES | MUSCORUI FRONDOSORUM | DESCRIPTAE ET TABULIS COLORATIS ILLUSTRATAE | OPUS POSTHUMUM | SUPPLEMENTUM SECUNDUM | SCRIPTUM | A | FRIDERICO SCHWAEGRICHEN | MED. PHILOS. ET CHIRURG. DOCT., HIST. NATURALIS ET BOTAIIC. PROFESS, ET FACUL-| TATIS MED. ASSESS. IN ACADEMIA LIPSIENSI, SOCIETATIS NAT. SCRUT. LIPS. DIRECTORE, | SOCIETT. IMPER. LEOPOLDINOCAROLIN. ET MOSCOVIENSIS, REGIAE HARLEMENS, MONA-| CENS., LINIEANAE LONDIN. ET PARISII., PHYSICO-MED. ERLANGENS. ET DRESD, NAT.| CURIOS. ALTENBURG., BEROLINENS., FRANCOFURTANAE SENKENBERGENS., GOETTIN- GENS., HALENS., HEIDELBERG., MARBURG., OSTERLAND., RATISBON., WETTERAV., I PHYTOGRAPH. MOSCOV., WERNERIAN EDINENS., MINERALOG. DRESDENS., JENENS., I OECON, REGIAE MARCHICAE' POTSDAMENS., DRESD: ET LIPS., SOC. PHARMACEUT. GERMA]l. I BOR. ETC. SODAL. I [copper-engraving, identical with that of suppl.1 [vol.11] | vOLUMEN SECUIDUM. | TABULIS AENEIS L. ILLUSTRATUM. | [very long swelled rule] | LIPSIAE | SUMTU JOANNIS AMBROSII BARTH. I MCCCXXVI. PARISIIS RUE BOURBON NO, 17. APUD TREUTTEL ET WÜTZ, LONDINI SOHO SQUARE 30. APUD TREUTTEL ET WURTZ, TREUTTEL FILIUM ET RICHTER.";

suppl.2 vol.2(2): "IOANNIS HEDHIG I MED. DOCT. AC PROFESSORIS BOTAIIICES IN ACAD. LIPSIENSI, ACADEM. IITPERIAL, I NATURAE CURIOSORUM, REG. SCIENT. HOLM. SOCIETATISQUE LONDINENS, MEMBRI, | PHYSIOPHILOR, BEROL. TURICENS, MEDICOCHIRURG. TURIC., OECON. IIPS. ET'| MARCHICO-POTSDAMENSIS, MATHEMATICO-PHYSICAE ERFORDIENSIS SODALIS i SPECIES | MUSCORUM FRONDOSORUM | DESCRIPTAE ET TABULIS AENEIS COLORATIS ILLUSTRATAE | OPUS POSTHUMUM | SUPPLEMEINTUM SECUNDUM | SCRIPTUM | A | FRIDERICO SCHWAEGRICHEN | MED. PHILOS. ET CHIRURG. DOCT., HIST. NATURALIS ET BOTANIC. PROFESS. ET FACUL-I TATIS MED. ASSESS. IN ACADEMIA LIPSIENSI, SOCIETATIS NAT. SCRUT, LIPS. DIRECTORE, | SOCIETT. IMPER. LEOPOLDINO-CAROLIN. ET MOSCOVIENSIS, REGIAE HARLEMENS., MONA-| CENS., LINNEANAE LONDIN. ET PARISIN., PHYSICO-IED. ERLANGENS. ET DRESD., NAT. I CURIOS. ALTENBURG., BEROLINENS., FRANCOFURTANAE SENKENBERGENS, GOETTING-। GENS., HALENS., HEIDELBERG., MARBURG., OSTERLAND., RATISBON., WETTERAV., I PHYTOGRAPH. MOSCOV., WERIJERIAN EDINENS., MINERALOG.' DRESDENS. JENENS., | ÓECON. REGIAE MARCHICAE POTSDAMENS., DRESD. ET LIPS., SOC. PHARIACEUT. GERM I BOR. ETC. SODAL.] [ copper-engraving, identical with that of suppl.1 [vol.] 1] | VOLUMEN SECUNDU1. I TABULIS AENEIS L. ILLUSTRATUM. | [very long swelled rule] | LIPSIAE | SUMTU IOANNIS AMBROSII BARTH. | MDCCCXXVII. | PARISIIS RUE BOURBON NO, 17. APUD TREUTTEL ET WÜRTZ. LONDINI SOHO SQUARE 30. APUD TREUTTEL ET WÜRT, TREUTTEL FILIUM ET RICHTER."; suPPI.3 vol.1(1)-2(2): "IOANIIS HEDWIG | SPECIES | MUSCORUM FRONDOSORUM | DESCRIPTAE ET TABULIS AENEIS COLORATIS ILLUSTRATAE | OPUS POSTHUMUM | SUPPLEIENTUM TERTIUM | SCRIPTUM | A | FRIDERICO SCHIAEGRICHEN | PROF. LIPSIENSI. [Vol.2(1)-(2): PROF. HIST. NAT. LIPSIENSI]| VOLULIEII PRIMUH. [VOI.2(1)-(2): VOLURIEN SECUNDUM] | TABULIS AENEIS L. ILLUSTRATUM. | [full swelled mule] [vol.1(2) vol.2(1)-(2): very long swelled rule] LIPSIAE SUMTU IOANIIS AMBROSII BARTH. I MDCCCXXVII [Vol.1(2): IDCCCXXVIII.] [vol.2(1): MIDCCXXIX.] [vol.2(2): MDCCCXXX.] | PARISIIS RUE BOURBON No. 17. APUD TREUTTEL ET WÜTZ. LONDINI SOHO SQUARE 30. APUD TREUTTEL ET WÖRT,, TREUTTEL FILIUM ET RICHTER.", supp 1.4(1): "IOANNIS HEDHIG | SPECIES | MUSCORUM FROHDOSORUM | DESCRIPTAE ET TABULIS AENEIS COLORATIS ILLUSTRATAE | OPUS POSTHUMUM | SUPPLEIENTUM QUARTUM | SCRIPTUM | A I FRIDERICO SCHUAEGRICHEN | PROF. HIST. NAT LIPSIENSI II IfUII swelled mile] | LIPSIAE | SUMTU IOANNIS AMBROSII BARTH. | MDCCCXLII. | PARISIIS RUE DE LILLE NO. 17. APUD TREUTTEL ET WÜRTZ. | LONDINI PATERNOSTER ROV NO. 39. APUD LONGMAN, BROHN, REES AND LONGMANS " " 
Collation: $4^{\circ}[\lambda$-numbers may refer to more than 1 leaf (see Bibl,notes) suppl.1 [vol.] 1: *4 2*4 $A-2 A^{4} 2 B^{2}$ ( $\$ 1$ signed, inferred);

suppl.1 [vold 2: $I=V$ VI-XVI $12-196 \quad(X V)$ $\pi^{1} 2 \pi^{2} A-2 U^{4}\left( \pm Y_{3} \pm 2 C_{1}\right) \quad 2 X^{2} \quad 2 Y-2 Z^{4} \quad 3 A^{2} \quad X^{1}$ $I-V$ VI 1 2-348 $363 \quad 354-373$. [ $=369] \quad 374[=370]$ (VI as 'VII', 369 as' 379 ');

suppl.2 [Vol.] 1(1): $\pi^{4}\left(-\pi_{4}=H_{1}\right.$ ? $) A-K^{4}$ L-H $H^{2}\left(-M_{2}\right) ; \quad I-V$ VI $1 \quad 2-86$; suppl.2 [vol.] 1(2): $\pi^{2} \mathrm{~N}-Z^{4} 2 \mathrm{~A}^{2} x^{1} 2 \mathrm{~B}^{4}\left(2 \mathrm{~B}_{2}\right.$ signed $\mathrm{Bb}, 2 \mathrm{~B}_{1}$ unsigned); suppl.2 vol. $2(1): \begin{array}{lllll}i-i v & 87 & 88-186 & 187-188 & (180 \\ \pi^{2} A-K^{4} & i-i v & 1 & 2-79 & 80\end{array}$ suppl. 2 vol. $2(2): x^{2} \quad \mathrm{~L}-2 \mathrm{C}^{4} \quad 2 D^{2}\left(-2 \mathrm{D}_{1}\right) ; \quad i-i v \quad 81-210 \quad(173 \quad 176-177)$; suppl.3 vol. $1(1): \pi^{2} 1^{4} 2-4^{2} 5^{4} 6-82\left(-8_{2}^{2}\right) 9^{4} 70^{2} 77^{4} 12-15^{2}\left(-14_{2}\right)$ $16^{4} 77-78^{2} ; 46$ leaves (inferred indicators: $i-i v \lambda 201-275$ except $\left(1^{2}\right): 1,2-4,\left(\theta^{4}\right):{ }^{2}, 22-28$, and $\left.\left(77^{4}\right): 3_{1}{ }^{3} 2-38\right)$; suppl.3 vol. $1(2): \pi^{2} 79-27^{2} 22^{4}(-224) 23-25^{2}\left(-25_{2}\right) 26^{4} 27-40^{2}\left(-29_{2}-34_{2}\right.$ suppl, 3 vo $\left.-362-382-39_{2}\right)$; 43 leaves (inferred: $i-i v \quad \lambda 226-250$ ): suppl.3 vol. 2(1): $\pi^{2} 7-10^{2} 77^{4} \quad 72-17^{1} \quad 18-27^{2} ; 40$ leaves (inferred: suppl.3 vol. $2(2): \pi^{2} 22-42^{2}\left( \pm 26_{2}\right) ; 44$ leaves (inferred: $\left.i-i v \lambda 276-300 v-x\right)$; suppl.4 (1): $\pi^{2} 2 \pi^{2} 1-17^{4} 72^{2}$; 50 leaves (inferred: $i-v i i i$ $\lambda 301-325 \quad i x-x)$.

suppl.1 [vol.]1: I title; II I] III dedication to C.P. Thunberg (1743-1822) and 0 . Swartz (1760-1818), botanists; IV $\square ; V-X I V$ text of the dedications; $X V$-XVI preface: "EDITIOIIS RATIO.", dated: "Calendis Juniis MDCCCXI."; $1-196$ text, descriptions of genera, species and some varieties of Musoi, Phasoum Iioranum;

suppl.1 [vol.]2: I title; II [; III dedication to H.A. Schrader (1767-1836) and C. Sprengel (1766-1833) IV $\square$; V-VI preface: "PROOEMIUM.", dated: "Decembri HDCCCXV."; 1-348 text, descriptions of mosses concluded, Leuoodon - Weissia, including Bypnum and Neokera; 353-373 index to the binomials in Hedwig: Speo. Musc. and Suppl.1, with references to pages and plates; 374 errata or addenda;

suppl.2 [vol.]1(1): I title; II D; III part-title: "SECTIO PRIOR. I [short rule] | TITULUS ET PRAEFAT. I - VI. | TEXTUS PAG. $1-86$. | TABULAE CI - CXXV. | [short swelled rule]"; IV G; V-VI preface, dated: "Hamburgi, die octavo Novembris JDCCCXXII."; 7-86 text, Phasoum - Drepanophyllum,

suppl.2 [vol.]1(2): i volume-title; ii li $_{\text {i }}$ i part-title: "SECTIO POSTERIOR. I short rule] | TEXTUS PAG. $87-179$ | TABUIAE CXXVI - CL. | [short swelled rule]"; iv $\square$ [in NYBG copy with a slip with printed binders instructions: "NB. Di. Benitzer von Hedwig species suppl. II. Sect. Ima werden gebeten. | beim Zusamenbinden beider Sectionen ich des Titels zu sect. IIdal al des richtigen Hauttitelo des genzen Supplem. IIdi zu bedienen."]; $87-179$ text, Voitia - Dawoonia; 780 , $187-186$ index to suppl.23 186 one comrection; 187-188 announcement of the publisher of the whole work, including Hedwig: Speaies Musorum, giving some details, and also mentioning Hedwig: Theoria generationis ...;

suppl. 2 vol. $2 \nmid i j:$ "i volume-title 1826 ; ii ; iii part-title: "SECTIO PRIOR. $\mid$ [short rule] | TEXTUS PAG. 1-79. | TABULAE CLI-CLXXV. | [short rule] | (Ab auctore finita d. XXVIII. Aprilis MDCCCXXVI.)"; iv Di 1-7g text, Polytriohum - Gymnos tomum tortula; 80 G;

suppl.2 vol.2(2): i volume-title 1827; ii Di iii part-title: "SECTIO SECUIDA. | [short rule] | TEXTUS PAG. 81-210: | TABULAE CLXXVI-CC. | [short mule]) (Ab awotore finita calendie Aprilio MDCCCXXVII.)"; iv $\square ; 81-172$ text, Gymnostomum involutum - Hypnum leptooarpon; 173-175 epilogue, dated: "calendis Aprilis MDCCCXXVII."; 776 D; 177-210 index to Hedwig: Speo. Muso. and Suppl.1-2, with references to pages and plates; suppl.3 vol.1(1): i volume-title 1827 ; ii D; iii part-title: "SECTIO PRIMA. | [short rule] | TABULAE CCI-CCXXV, cum descriptionibus per eosdem | numeros distinctis. [short rule] (Ab auotore finita oalendis novembris

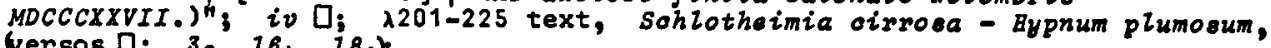
versos $\left.0: 3_{2} 16_{4} \quad 3_{1}\right)_{3}$ 
suppl.3 vol.1(2): $i$ part-title: "SECTIO SECUNDA | [short rule] I TABULAE CCXXVI-CCL, cum descriptionibus per eosdem! numeros distinctis. | [short rule] | (Ab auotore finita calendis Aprilio MDCCCXXVIII.)", ii $\square_{\text {; }}$ iii volume-title 1828; iv $D$; 2226-250 text, Hypnum ripaiense - Peromnium radioulosum, (versos O: $25_{2} 27_{2} \quad 30_{2} \quad 7_{2}$ ) : suppl.3 vol.2(1): i part-title: "SECTIO PRIriA | [8hort mule] | TABULAE CCLICCLXXV, cum descriptionibus per eosdem | numeris distinctis." volume-title 1829; iv $\square_{3}$;251-275 text, Diaranum dicarpon - Bookeria incurva, (versos O: $113,18_{2}$ ); $v$ addendum and errata (already effected in print in the copies I checked on this point); vi Di suppl.3 yol.2(2): i volume-title 1830; ii G; ii part-title: "SECTIO SECUNDA | [short rule]| TABULAE CCLXXV́I-CCC, cum descriptionibus per eosdem | numeros distinctis."; iv D; $2276-300$ text, Hookeria swartsi - Bypnum

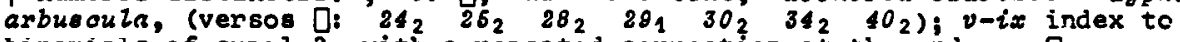
binomials of suppl.3, with a repeated correction at the end $x$; suppl.4(1): $i$ part-title: "SECTIO PRIMA | [short rule] I Tábulae cCCI CCCXXV, cum descriptionibus per eosdem I numeros distinctis."; ii [; iii volume-title; iv ఏ; v-viii preface: "PROOEMIUM." - ubulata - Diphysaium Zongifolium, (versos $0: 7_{3} 1_{4} 2_{1} 2_{4} 3_{3} 4_{2} 4_{3} 5_{2}$

Plates: 326 hand-colored copper-engravings of mosses with details, numbered: suppl.1 [vol.] 1: "I"-"III" "III*" "IV"-"XLIX" [vol.] 2: " $L "-" C "$ suppl.2 [vol.] 1(1): "CI"_"CXXV" vol. 2(1): "CLI"_"CLXXV"— vol. 2(2): "CLXXVI" "CC" suppl.3 vol. 1(1): "CCI"-"CCXXV"— vol. 1(2): "CCXXVI"-"CCL" suppl.4 vol. 2(1): "CCLI"_"CCLXXV"— vol. 2(2): "CCLXXVI" ( $s$ me numbers corrected by hand in all copies checked); binomials below figures of species concerned; plate-mark: $167 \times 131 \mathrm{~mm}$. (pl.1).

Artists: Fricke, Friedrich August (...1858), Germany (biogr.: Bénézit ed.3, $4: 86$. 1956): pis.137 148155-157 (Stafl, Tax.Lit. n.1209 states: pls.151-175); Ludwig, C., Germany: pls.1-49 5154 56-100 122125 ;

Strauch, C., Germany: pl.140 (in reviews he is indicated for more plates); unsigned: remaining, plates.

Engravers: Fricke, Friedrich August (see above): Pls. 137 148 155-157; Strauch, C!: pls.1-3 3*4-49 51 56-100 102-105 107-111 $113-123 \quad 125$ 142145146 ; up to pl.47 a number of pls. are signed: "C. Strauch oc. \& col."; unsigned: remaining, plates.

Paper: Ordinary paper state: leaf height $266 \mathrm{~mm}$. (U copy, uncut); laid (suppl.1-2), chains horizontal, or wove (suppl.3-4); wm.:

"[cromed shield with fleur-de-lis] | $4=$ I F B [out].ine]": suppl.1 [vol.]1, [Vol.] 2: 2C-2M 20;

"[post-horn] = R": suppl.1 [vol.]1: R (CM copy), [vol.]2: 2N 2P-2U[this set bluish paper] $2 Y_{\text {; }}$

"[crowned shield vith post-horn] = VAN LER LEY": suppI.1.[vol.] 2: $\pi$ A-2B;

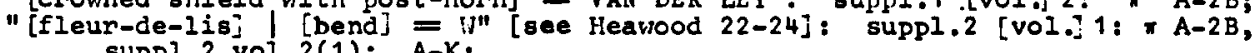
suppl.2 vol.2(1): $A-K$

"[large crowned shield with post-horn] | $4=$ G J F [outline]": suppl.2 vol. $2(2): \quad L-2 A$;

"[same mark with G J F [outline], also below shield and 4]": suppl.2 vol.2(2): $\pi \quad 2 \mathrm{~B}-2 \mathrm{C} \quad \mathrm{Y}_{4}$ cancellans;

"J WhatMan ] LONDON [Outline along long side of sheet, possibly twice per sheet]": suppl.3 vol.1 (majority);

"F B \& C loutline, in, lower right corner of sheet]", suppl.4;

expensive paper state: leaf height $255 \mathrm{~mm}$. (NYBG copy); wove; wm.: "M de Tor \&?] I. A. HUBER [outline]": suppi.1 [vol.] 1, [vol.] 2: A-2C; "H:OSER.SUPER. FEIN.GROSS. I MEDIAN.POST. [outline, along long side of sheet]", suppl.1 [ Vol.] 2: 2D-2U;

"[part of eagle with star?] '[letters] BASEL": suppl.1 [vol.] 2: $\mathrm{Y}_{3}$ cancellans, $2 \mathrm{G}_{1}$ cancellans;

"F [or E] 'at long side of sheet]": suppl.2 vol.2(2); 
plate paper: ordinary paper state: laid; wm.:

"[figure on globe] | O I V VAN DER I.EY [ín another mold with capital $C$ in the globe] ": 1-49, majority of suppl.2 [vol.]1;

"[fleur-de-lis] = II F T": $50-98$;

"[Pro Patria] = T [script]" (chains vertical): 99-100;

individual plates on quarter-sheets only showing a part of the wm:

wove: suppl.2 vol.2 - suppl.4; $\mathrm{m}$. (mostly from Cli copy):

"J WIIATMAN | TURKEY MILL": 177 191 201-243 251-300;

"J WHATMAN [in full over quarter-sheet]": 244-250;

"J WHATMAN | 1840": suppl.4;

expensive paper state: wove; thinner and smoother than text paper (of the same state); w.: absent in suppl.1-2;

"J WhatMAN | TURKEY MILL 1826": suppl.3; | see Bibl.notea.

Printer: no imprint in suppl.1-3; Reclam Jr., Ph.: suppl.4.

Publisher: Barth, Johann Ambrosius, Leipzig (see Bridel n.4).

Dates and announosments [supplement (S), volume (V), part (P)]:

\begin{tabular}{|c|c|c|c|c|c|c|c|}
\hline S V & $\mathbf{P}$ & $\begin{array}{c}\text { number } \\
\text { of pages }\end{array}$ & plates & $\begin{array}{l}\text { date } \\
t .-p \text {. }\end{array}$ & last date & publ, date & source \\
\hline$f \begin{array}{lll}1 & 1 \\
1 & 2\end{array}$ & & $\begin{array}{r}76+196 \\
6+370\end{array}$ & $\begin{array}{r}1-493 \\
50-100\end{array}$ & $\begin{array}{l}1811 \\
1816\end{array}$ & $\begin{array}{l}1 \text { Jun } \\
\text { Dec. } 1815\end{array}$ & $\begin{array}{c}\text { Jul.1811 } \\
\text { bef.9 May } 1816\end{array}$ & $\begin{array}{l}\text { Mag.Enoyol, (see Reviewa) } \\
\text { Leips.Lit.zeit. (Sayre 53) }\end{array}$ \\
\hline $2: 1$ & 1 & $6+86$ & $101-125$ & 1823 & $\left\{\begin{array}{c}8 \mathrm{Nov} \\
1822\end{array}\right\}$ & 1823, trim.1-3 & $\begin{array}{r}\text { letter from Arnott to Brongn, } \\
(21 \text { Nov.1823) }\end{array}$ \\
\hline 1 & 2 & $4+102$ & $126-150$ & 1824 & - & 1824 & t. $-\mathrm{p}$. \\
\hline 2 & 1 & $4+80$ & $151-175$ & 1826 & 28 Apr. & & $\begin{array}{l}\text { Alig.Repert. (see Reviews) } \\
\text { Linnaea } 1(3): 469.1826 .\end{array}$ \\
\hline 2 & 2 & $\$+130$ & $176-200$ & 1827 & 1 Apr. & Mas & AIIg. Repert. (see Reviews) \\
\hline 1 & 1 & 92 & $201-225$ & 1827 & 1 Nov. & & $\begin{array}{l}\text { Stafl. TL } n_{1} 1209 . \\
\text { Linnaea } 3(2) \text { Lit. Ber, }: 51,1828 .\end{array}$ \\
\hline $\begin{array}{ll}3 & 1 \\
3 & 2 \\
3 & 2 \\
4 & 2\end{array}$ & $\begin{array}{l}2 \\
1 \\
2 \\
1\end{array}$ & $\begin{array}{r}86 \\
80 \\
88 \\
100\end{array}$ & $\begin{array}{l}226-250 \\
251-275 \\
276-300 \\
301-325\end{array}$ & $\begin{array}{l}1828 \\
1829 \\
1830 \\
1842\end{array}$ & $\begin{array}{l}1 \text { Apr. } \\
- \\
- \\
-\end{array}$ & $\begin{array}{c}\text { bef. Dec. } 1828 \\
\text { Jan. } 1829 \\
1830 \\
15-18 \text { Jun. }\end{array}$ & $\begin{array}{l}\text { Linnaca } 3(4) \text { Lit. Ber. } 175.1828 \\
\text { Isis(Oken) } 22(1): 66-68.1829 . \\
\text { t.-p. } \\
\text { Stafl. TL n.1209. }\end{array}$ \\
\hline
\end{tabular}

Reviewe and announoements:

suppl.1 [vol.]1: Mag.Enoyol.18114(7):161-162.1811 Jul. "paroitra dene un mois"; Leipz.Lit.Zeit. 1812 Apr.22 (fide Sayre);

suppl. 2 [vol.]1(1): Flora $8^{2}$ (Ergans, Bl.): 1-23. 1825 Jul.;

Isio(Oken) 16(6): 655-660. 1825 May?;

suppl. 2 vol. 2(1): Alig.Repert. Neuest. In-Ausi.Lit.18262 (3):161-162.1826 May 15 ? Bui2.Soi.Nat. 14(5): 98-99. 1828;

suppl.2 vol. 2(2): Alig.Repert.Neuest. In-Ausi.Lit.18272(4):247-249.1827 Jun.17; Isis(Oken) 20(12): 1043-1053. 1827; 21(3/4): 264.1828; Flore 11(4): 63. 1828 ;

supp1.1-2:

Linnaea 2(4): 681,1827 Dec.

Flora $11^{2}$ (Ergans.BZ.): 1-39.1828 Feb.:

suppl. 3 vol. $1(1)\}$ Jahresber, K. Sahwed,Akad.Wise.Fortsohr.Bot.1826 \& 1827:25,1839;

suppl.3 vol.1(1-2): Isis(Oken) $22(1), 66-68,1829 \mathrm{Jan}$. ;

Flora $13^{2}$ (Ergans. Bl. ): 1-18, 1830;

Muller, C.: Bot.Zeit. 1:601-604. 1843 Sep.1.

Bibliogr.otudies: Sayre, G.: Dates of pubi. 38, 41, 53, 59. 1959;

Stafleu, F.A.: Taxonomio literature n.1209. 1967.

Refo.: BMNH 810,1874

Brun, $3: 77$

Cat.Juss, n.2299

E.As.Bot. 65,441

Graesse 3: 229
Heins.7(1): 334

Jacks. 153

Kew 264, 565

Krieg 1: 306
$\mathrm{Krag} \cdot 241$

Linn.Soc. 346,694

Milt. 484,486

Niss. n.831
Pr.ed.1 n.4262

Pr.ed. 2 n.3885

Teyl. 411

Un.Edinb. 2: 296 
Bibl,notes. Of this important work 11 parts were published, each with a title-page. However, the titles of the first parts of all volumes of Suppl.2 and 3 were to be replaced by the titles of the second parts; the latter titles were meant to serve as volume-titles. I sav only a fen copies in which the original titles of the first parts were preserved (one copy in PC). For the purpose of dating and of checking the contents of the parts these titles are valuable. Their dates have to be accepted in nomenclature as long as proof of another date is absent.

I definitely want to include such title-leaves in the concept of the iceal copy for the purpose of botanical bibliography; it was an integral part of the book as long as the second part had not yet appeared, in the same way as the title of the first part of Suppl.4 still belongs to the ideal copy in the concept of descriptive bibliography anyway, although it might have been canceled if a second part had been published.

Bibliographically this work is also interesting for the shift from laid to wove paper. Suppl.1 and 2 of the normal state are printed on laid paper, Suppl.3 and 4 on wove paper; the plate paper shifted earlier. I have not been able to study sufficiently the difference between the paper of the expensive paper state and the normal state after the shift; apparently the source of the plate paper did not differ (compare the watermarks in the plate paper), but the size and perhaps the quality too probably were different.

The collation of Suppl.3 is complicated, because signatures as well as page numbers are absent. The text pages can be identified by the plate numbers only, stated in the head-title and repeated in the direction-line (except for the treatment of some genera, which have short series of page-numbers and the references to the plate-numbers in the text only). This suggests a lambda-treatment. However, I preferred the collation with inferred signatures throughout to show the conjugacy of the leaves, which would make a lambdatreatment very complicated.

Another difficulty is that on many plates two species are figured, in the text differentiated by an additional letter a or b to the plate-number. On the other hand I did use the plate-numbers preceded by the $\operatorname{sign} \lambda$ in the place of page-numbers, since the former have to be used in references to the text. I did not work out these references to the same detail as I did for other works; instead a statement of the correct sum-total of unnumbered leaves precedes the $\lambda$-numbers.

In the collation of these inferred signatures $I$ used another unorthodox feature by reporting in Suppl.3 vol.2(1) the signatures $12-17$ with one leaf only. Hy reason for this is that they were planned this way: a single leaf was printed as soon as a plate was ready, which I found indicated in a publishers announcement. It is even possible that they were printed in a quarter-sheet imposition. Anyway a collation with the second leaves ail reported as missing is more cumbersome.

Cancels are very difficult to detect in this method of printing. In one case I have inferred a cancel on rather weak indications and more cancels may have been present since the changes indicated on the page with addendum and errata in Suppl.3 vol.2(1) are corrected in print in the copies I examined.

The plates have a number of changes. Some numbers were changed in ink by hand, or by orasures: 186 from 187,260 from 261,262 from 253 or a similar number, 263 from 262,264 from 261 (the ink line extends beyond the plate-mark). The text still refers to pl.187 instead of the new number $186 ;$ the text references to pls.195 and 196 are interchanged.

A number of names originally engraved on the plates were changed; a cancellans slip of paper with another (engraved?) name was pasted over the name concerned: pl.178 splachnum "Adameianue" was pasted over "paradoxum"; pl.214 Bryum "celiziare" over "vesioulare"; pl.216 "Aulacomnion" over "AuLaoomitrion"; 21.224 "Bruum" (paradoxum) over "Bypnum" a few names were changed by hand from the original engraving: pl.259 Hypnum "oxypoma" and B. "loxense", here I was unable to decipher the original version. 
Bot.notes. llajor work of bryology, treating in Suppl.1 all species anew which were present in Hedwig's Speoies musoorum. Though Schwaegrichen maintained Hedwig's name on all title-pages, the work can be considered a new work mitten by Schwaegrichen, for which reason I prefer to have the main entry under $h$ is nane, instead of under Iledvig's name.

lany new and rare species were described and figured in this work, and Schwaegrichen was able to found a number of new genera, as well for European mosses (Aulaoomium) as for tropical mosses. Hedwig's high standards of giving microscopical. details of the peristome were maintained; for many species leaves were figured with an indication of leaf cells, which later played a more significant role in bryotaxonomy.

Schwaegrichen did not propose changes in the lledwigian classification which he followed; he treated the genera without any indication of groups or higher ranks, as Arnott and Bridel and Chevallier were doing in this period.

\section{SORIERFELT, Soren Christian [Lat.: Severin Christianus]}

Biogr. Born 1794 Apr. 9, Sukkestad, distr. Toten near Akershus, Christiansamt, Morway. Died 1838 Dec.29, Ringebo, Horway.

S.C. Sommerfelt studied theology in Copenhagen from 1812, achieved the degree Cand. theol. in Christiania (now Oslo) 1817, became minister in Saltdal 1818, and finally in Ringebo (Gudbrandsdal) in 1827 . He botanized often in his region and published a number of botanical articles and the exsiccata treated below.

Ile was commemorated in the generic names sommerfeltia Lessing 1832, ncm.oons.

(Compositae), Sommerfeltia Floerke 1827 , nom.rej., possibly a synonym of Solorina Acharius (Lichenes), and Sommerfeldtia Schumacher 1827, replaced by Drepanooarpus G.F.H. Heyer (Leguminosa).

Refo.: Bot. Notis. 1839: 9-12, 1839 .

Krok: Biblioth. Bot. Suso. 660.1925.

1 Centuriae glantarum aryptogamarum norvegicarum.

2 fasc. Christiania [now 08lo], 1826-1827 [exsiccata].

Titze: Centuriae plantamum cryptogamarum norvegj.carum, quas collegit et edidit S. Chn. Somerfelt. Centuria I. Christiania 1826 [Centuria II. Lips. 1827].

Colzation etc.: $4^{\circ}$; no copy seen.

Specimens: 100 specimens per fascicle.

Printer: Grondahl, Chr., Christiania [now 0slo], Norway.

Publishers: the author; and the printer?

Dates: fasc.I: 1826 ; fasc.II: 1827.

Reviews: Sommerfelt, S.C.: Anmeldelse; [in:] Mag.Naturvid.7(1): 158-161. 1826. (complete list of species); ijkström: Arsber.Framet.Bot.Ar is26: 256.1827.

Refa.: Krtig. 211 (I. Lips, 1827) Milt. 473 (II. Lips, 1827).

Hote. Cryptogamic exsiccata, in fasc.1 containing 6 Filioes, 26 Musoi frondooi, 9 lusci hepatioi, 35 Algae Lichenosae, 9 Algae aquatioae, and 15 Fungi. According to Wikstrom $(1826)$ the specinens were carefully chosen and provided nith a name-label.

2 Supplemantum florae Lapponioae... Christiania [now Oslo], 1826.

Title: "Supplementum | Florae Lapponicae | qvam edidit | Dr. Georgius Vahlenbers I auctore | Sev. Christiano Somerfelt | Sacri verbi ministro| reg soc. scient. llidrosiensis sodali | [thin mle] | cum tabulis coloratis III | [long thick and thin rules] | Christianie. | Typis Borgianis et Grondahlianis. | 1826." 
Coltation: $8^{*}: \pi^{\circ} 1-19^{\circ}(* 1, * 57) 20^{4} 21^{2} 22^{\circ} ;$ i-iv I II-XII $12-331 \quad 338$ ( 305 as $\left.307^{\prime}, 317-319\right)$.

Contenta: i title; ii $\mathrm{Ci}_{3}$ ii dedication to Christian Sommerfelt, the author's father: iv D; I-XII preface, dated: "XII llartii a. MDCCCXXVI."; 1-316 text, descriptions of plant species not mentioned by Uahlenberg: Flora Lapponica, for Lapland, inciuding a number of new species, especialiy in cryptogans; 317 addendum; 318 ; 319-331 index of accepted generic and specific names and of selected synonyms 332 corrections. RT: in text: names of Linnaean groups of plants, e.g.: "54 CRYPTOGAYIA. I MUSCI 55". Language: Latin.

Plates: 3 copper-engravings, possibly with stipple-engraving, a number of partial figures in different colors ( $a$ la poupée), surfaces hand-coiored; numbered: "Tab. I" - "Tab. III", illustrating cryptogans, including details; two or three species per plate, Latin binomial at bottom: pl.1: Weissia longipes, Orthotriahum eubrepeno; Fl.2: Leskea norvegioa, Hypnum arotioum; pl.3: Jungermannia soutata (uncolored), Leoanora limbata and Hitruia giobora; plate-mark: $167 \times 109 \mathrm{~mm}$. (pl.2).

Artiet: Boeck, $C$.

Engraver: Bagge.

Paper: not studied.

Printers: Borg and Grondahl, Christiania [now 0slo], liorway.

Pubiieher: Grondahl, the printer (see Mag.Naturvid.7(1): 184. 1826).

Date: 1826 (t.-p.); after 12 Mar. (pref.).

Reviews and announoemente:

Mag.Naturvid.7(1): 184.1826 (has been printed) : 8(1): 163-170.1828;

R[aspail]: Bull.soi.Nat.12(10): 238, 1827 ;

Wikström: Arsberatt.Framst.Bot.Ar 1826: 251-256. 1827;

Danske Litteraturtid. 1827 (6).

Refo.: Arn.Arb.1: 659

BlQNH 1970,2249

Bradl. 1: $353^{\mathrm{a}}$

Brun.5: 1399

Graesse 7: 409
Kew 646
Krok 743, 660
Krdg. 123, 124

Linn. Soc. 720,798

llass. HS-H 295,326

Mass.HS-M 3: 380,594

Niss. n. 2092

Bibl.notes. This book has the plates delicately drawn and beautifully printed in color, and the coloring finished by hand. It represents the first complete color-printing of mosses which came to my attention, though the process of color-printing came into use much earlier (see T.F.G. Nees n.2 for colorprints of germinating mosses).

The cancellanda were clearly visible in the uncut PC copy.

The author is Sommerfelt, as clearly stated on the tit]e-page, but in many references the book will be found under the name of Wahlenberg.

Bot.notes. Extensive lists of additions to the Lapland flora, compared with Wahlenberg's book; occasionally new species were proposed, particularly in the cryptogams.

Bemaerkninger ved Supplementum Florae Lapponioae.

Mag. Naturvidensk, 8(1): 153-166, 1827 .

Title, oollation to.: no copy seen.

Date: vol.-title: 1828 ; fascicle probably 1827 .

Review: Hikstróm: X.Vet.Aoad.Bot.Areber. 1828: 264-265. 1829

Refo.: Pr.ed.1 n.9743, ed.2 n.8767 RSC 5: 748 .

Hotes. The indications in Wikstrom: Conop. 239. 1831, are puzzling. The pages of the fascicle are indicated as dissertatio, as from "Aargang" 1827; the title only as from 1828. This obviously refers to a separate, but the date 1828 mokes it questionable whether the fascicle of the periodical already appeared in 1827 . 
SPrEIC:EL, Curt Polycarp Joachim

Biogr. Born 17E6 AUE. 3, Boldekov near Anklam. Pomerania, Germany. Died 1833 lar. 15, llalle, Germany.

C.P.T. Sprengel learned other languages early and easily; he began the study of theology in 1785, changed soon to medicine, and received his doctor's degree in 1787 tie published on botany and on medicine, especially historical studies. After having practized as a physician for a couple of years, he became in 1789 professor extraordinarius at halle and in 1795 ordinarius; in this position he could stop practizing In 1797 he also lectured botany and he directed the botanical garden. He wrote on plant anatomy, of which study some ideas could stand the test of time.

In 1820 Sprengel published Grundzltge des wissenochaftiliahen Pflanaenkunde, for which he had translated large parts of A.P. de Candolle's Thérie élémentaire de la botanique, 1813. Out of recognition Sprengel published his German work under joint authorship, placing the nane of de Candolle first. A.P. de Candolle strongly resented this since he did not want to be responsible for some important views expressed by Sprengel. After a long period of silence Sprengel again began correspondence collection of letters in the Conservatoire Botanique, Geneve] and apparently the bad feelings of de Candolle were not permanent, since more letters of Sprengel followed.

Sprengel's herbarium came after his death to his son Anton; after the latter died in 1851, the herbarium was divided and sold in several parts. An important part came to the bryologist Carl lïller of llalle (1818-1899); this collection was bought by the Bot. Iuseum at Berlin in 1890 and was lost in Vorld :Var II. For the location of the other parts, see Stafleu, Taxonomio Ziterature (1967).

He was commemorated in the generic names Sprengelia J.E. Smith 1794 (Epaoridaceae), Sprengelia J.A. Schultes 1809 (Sterouleaceab/Byttneriaceae) and Curtia Chamisso \&chlechtendal 1826 (Sorophulariaoeae/Gentianaceae).

Refe.: Sprengel, C.: Opuscula Academioa 7-12. 1844 (not seen). Seemann: J. Bot. 1: 352. 1863 (herb.).

Hunschmann, E.: Alig. Deutsohe Biogr. 35: 296-298, 1893. Stafleu, F.A.: Taxonomio literature 455. 1967.

\section{Syetema vegetabilium.}

5 vols. in 6 parts. Gottingen, $1825-1828$.

Titzes: "CAROLI LINNAEI, | EOUITIS STELLAE POLARIS, ARCHIATRI REGII, PROF. MED. ET | REI HERB. IN UNIVERS, UPSAL. | SYSTEMA | VEGETABILIUM. | EDITIO DECIMA SEXTA, $\mid$ CURANTE | CURTIO SPRENGEL, I EOUITE STELIAE POLARIS ET AQUILAE RUBRAE, PROF, IIED. ET REI HERB. IN UNIVERS. HAL. [vol.5: last 2 lines replaced by: EQUITE STELLAE POLARIS, AQUILAE RUBRAE ET LEONIS BELGICI, I PROF. MED. ET REI HERB. Ill UIIVERS. HAL.] | [long rule] | VOLUIEN I. | CLASSIS 1-5 [Vol.2: VOLUMEN II. | CLASSIS 6-15.j [Vol.3: VOLUIEN III.| CLASSIS 16-23.] [vol.4(1): VOLUHINIS IV. PARS I. | CLASSIS 24.] [VOI.4(2): VOLUMINIS IV. PARS II. | CURAE POSTERIORES.] [VOI.5: VOLUNEN V. | SISTENS | INDICEM | GENERUM, SPECIERUM ET SYIONYMORUI, | AUCTORE | ANTONIO SPRENGEL | PH.D., LL.AA.M.] | [full sweIled rule] GOTTINGAE, | SUMTIBUS LIBRARIAE DIETERICHIANAE. | 1825. [vol.3: 1826.] [Vol.4(1)-(2): 1827.] [vol.5: 1828.]"

Collation: $8^{*}$ :

vol.1: $\pi^{2} \quad 2 \pi^{2} \quad A-30^{8}\left( \pm A_{4} \neq 2 E_{5} \neq 2 L_{3} \neq 2 S_{4} \pm 2 T_{7}\right) \quad 3 P^{6} \quad 3 Q^{8} \quad 3 R^{2} \quad(\$ 1-2$ signed); $I-V$ VI $7-3 \quad 4-992\left(7 \theta^{-3} 2430 \quad 125139365376 \quad 507 \quad 636 \quad 873\right)$;

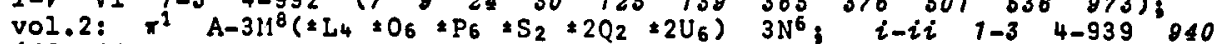

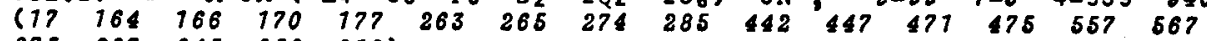
$675687 \quad 845 \quad 850 \quad 979)$

vol.3: $\pi^{2} A-311^{8}\left(=F_{7} \pm 2 \mathrm{~B}_{5} \neq 2 \mathrm{G}_{5} \neq 2 \mathrm{H}_{3} \pm 2 \mathrm{I}_{4}\right) \quad 3 \mathrm{~N}^{4} ; \quad i-i v \quad 1-3 \quad 4-936 \quad(14 \quad 149$ $\begin{array}{lllllllllllll}757 & 330 & 332 & 353 & 369 & 675 & 684 & 756 & 765 & 892 & 897 & 973-874 & 820):\end{array}$ vol.4(1): $\pi^{2} \quad A-2 N^{8}\left( \pm N_{2}: Z_{7}\right) \quad 20^{6} \quad 2 P^{2} ; \quad i-i v \quad 7-3 \quad 4-592$ (8 735 140 $\begin{array}{lllllll}237 & 239 & 371 & 315 & 376 & 383 & 587) ;\end{array}$ vol, 4(2): $\pi^{1} \quad A-2 B^{8}\left( \pm A_{6,7} \neq B_{8} \pm H_{1} \pm K_{2} \neq L_{1} \pm M_{6} \pm Q_{1} * R_{8}\right) \quad 2 C^{6}\left(-2 C_{1}\right) \quad\left(2 C_{2}-2 C_{3}\right.$

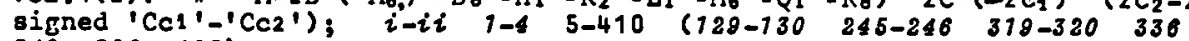

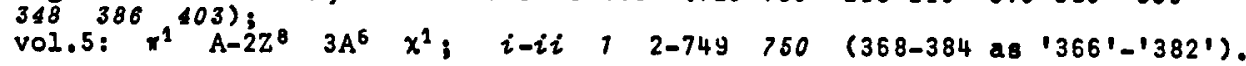


Contenta: vol.1: I title; II $\square_{3}$ III-IV dedication to Grand Duke Carl August von Sachsen-Weimar etc.: V-VI preface; VI corrigenda; 1 half-title; $2 \Pi$ 3-972 text, descriptions of genera and species in Linnaean classes, Monandria - Pentandria; 073-992 index of generic names; 992 imprint; vol.2: $i$ title; ii $D_{3}, 1$ half-title; 2 ; $3-918$ text, classes Bexandria Tetradynamia: $818-939$ index; 840 imprint;

vol.3: i title; ii $\square_{3}$ iti dedication to Alexander von Humboldt, explorer and scientist; iv $\square$; 1 half-title; 2 ; 3-919 text, classes Monadelohia Polygamia; 920-936 index; 936 imprint;

vol.4(1): i title; it $\square$; iii announcement concerning part 2; iv $\square$; 1 half-title; 2 : 3-580 text, class Cruptogamia, including Musoi frondosi (735-216) and Musoi hepatioi (218-236); 587-592 index; 592 imprint;

vol.4(2): i title; ii D; 1 half-title: "CURAE POSTERIORES | IN | SYSTEMA VEGETABILIUM."; 2 ; 3 section-title: " AD | VOLUMEN I."; 4-128 additions to vol.1; 129 section-title: "AD I VOLUMEN II.", 130-244 additions to vol.2; 245 section-title: "AD | VOLUMEN III,"; $246-318$ additions to vol.3; 310 section-title: "AD I VOLUMEN IV." $320-335$ additions to vol.4(1), including Musai (321-324) and Bepatioae (324-326); 336-347 additions to vol.1-3; 348-385 authors cited, with biographical notes and titles of publications; 386-402 index of generic names; 403-410 appendix, headed: "APPENDIX. I [short mule] | HENRICI SCHOTT FASCICULUS PLANTARUM BRASILIENSTUM", introductory note ( 403 ) and descriptions of 77 new species in the classes 1-22, by $H$. Schott: 410 imprint:

vol.5: $i$ titles ii $D_{3}$ 1-749 index of names of genera and species in vol.1-4; 750 addenda and corrigenda, and imprint.

Paper: leaf height $196 \mathrm{~mm}$. (U copy, cut); laid, chains vertical.

Printer: Gebauer, Halle, Germany.

Publisher: Dieterich, Gottingen, Germany.

Colzaboratore:

Schott, Heinrich (1794-1865): Basoioulus plantarum Brasitiensium: 4(2): 103-410; Sprengel, Anton (1803-1851), son of the author: compiled the index, vol.5.

Dates:

\begin{tabular}{|c|c|c|c|}
\hline vol. & $\begin{array}{l}\text { title- } \\
\text { date }\end{array}$ & publ.-date & source \\
\hline 1 & 1825 & $\begin{array}{l}\text { late } 1824 \\
\text { bef. } 28 \mathrm{Feb} .\end{array}$ & 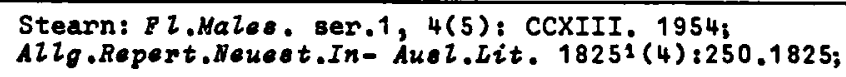 \\
\hline 2 & 1825 & ( Jan.-May & $\begin{array}{l}\text { Stafleu: } T L \mathrm{n} \cdot 1266,1967 ; \\
\text { Gott.GeZ.Ans. } 1825^{2}(\mathrm{~B}): 875-877\end{array}$ \\
\hline 3 & 1826 & Jan, -Feb. & $\left\{\begin{array}{l}\text { Linnaca } 1(2): 274: 1826 \text { Apr.; } \\
\text { Ioie (Oken) } 20(2): 133.1826 \text { (Feb.?); }\end{array}\right.$ \\
\hline $4(1)$ & 1827 & bef. $7 \mathrm{Jan}$. & PLoxa 10(1): 14-15, 1827 Jan. 7; \\
\hline $4(2)$ & 1827 & $\left\{\begin{array}{l}\text { bef. } 15 \text { May? } \\
\text { trin.2 } \\
\text { bef. Sep. }\end{array}\right.$ & $\begin{array}{l}\text { Al2g.Repert. Heuest.In-Auel.Lit. } 1827^{2}(5): 329.1827 \text {, } \\
\text { Linnaea 2(3): } 486.1827 \text { Jul.; } \\
\text { presented to the Linnean Society, London; }\end{array}$ \\
\hline 5 & $1828^{\circ}$ & $\left\{\begin{array}{l}\text { Jul. -Aug. } \\
\operatorname{sem} \cdot 2\end{array}\right.$ & 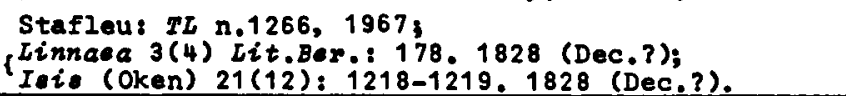 \\
\hline
\end{tabular}

Bibliogr.otudiea:

Stearn, W.T. in: M.J. van Steenis-Kruseman: Fl.MaZee. ser.1, 4(5): CCXIII.1954

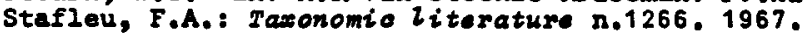


Reviews: vol.1: Alzg.Repert.lleueot.In-Ausl.Lit. $1825^{1}$ (4): 250-253. 1825 Feb.28; Ioio (Oken) 16(2): 207-210. 1825 (Feb.?); Flora $8(17)$ : $269-271$. 1825 :Lay 7 ;

vol. i-2: Gott.Gel.Ans. 18252(88): 875-377, $1825 \mathrm{Jul} .2$; Flore 2(41): 649-654 '1669'-1674i]. 1825 liov.7, Linnaea 1(1): 102, 1826 (book publ. 1825 sem.1-3); Loudon Gard.Hag. 1(2): 155-161, 1826 ;

vol. 2: Ioie (Oken) 17(9): 1029-1031.1825 (Sep.?);

vol. 3: Isis (Oken) 20(2): 133. 1827:

vol.4(1): Isia (Oken) 20(10): 835-836.1827,

Fora $10(1): 14-15,1827 \mathrm{Jan} .7$;

Bulz.Soi. Wat. 17(4): 74-80.1829;

vol.4(2): Isis (Oken) 21(3-4): 263-264.1828:

vol.2-4(2): Alig.Repert. Neueat. In-Augl.Lit. 18272(5): 329-330. 1827 llay 15-31; vol. 5: Ioie (Oken) 21(12): 1218-1219. 1828 (DeC.?);

vol. 1-5: Hed.-Chir.zeit. 18294(88): 161-167:1829;

\begin{tabular}{l|l|l|l|l} 
Refo.: \begin{tabular}{l|l} 
BlMiH 1995 \\
Jacks. 111
\end{tabular} & Krok 430 & Pr.ed.2 n.5430, 8879 & Teyl. 141 n.69 \\
Pr.ed n.6009 & Soulsb. n.616 & Utr. n.1334.
\end{tabular}

Shpplement: Anton Sprengel published a supplement: mentamen skpplementi ad syotematio vegetabilium..., $8^{\circ}$, iv, 35, 1 , p., Gottingen, 1828. This thesis, defended on $20 \mathrm{Sep} .1828$, is not treated here since it does not contain bryophytes (see Stafleu: Tax.Lit, n.1255).

Bibl.notes. This 16 th edition of Linnaeus is treated here under the name of Sprengel for simplicity just as the full citation of new names or combinations can be shortened from Sprengel in Linnaeus, Syot.Veg. ed.16 to Sprengel, Syst.Veg. The numerous cancels were studied in the uncut HBL copy, which has both cancellanda and cancellantia preserved. As stressed in some of the reviews, the work must have been compiled hastily, which explains the numerous cancels.

Bot.notes. This work is an important compilation of all species known to and accepted by Sprengel, treated with a conservative concept of generic and specific limits, that is, without recognizing many of the segregates proposed or adopted by many of his contemporaries. ilany new combinations are present; the additions in the second part of vol.4 should be consulted too. The index was prepared by the author's son Anton Sprengel.

As expressed by Stafleu, this book marks the end of the Linnaean era, in which the Linnaean classification was considered to be sufficient for plant taxonomy (Stafleu, F.A.: The great prodromus, in: A.P. de Candolle: Prodromus Systematie Naturalie Regni Vegetabilis vol.1-8, reprint, Lehre 1966, p.1.1).

\section{STEUDEL, Ernst Gottlieb}

Biogr. Born 1783 lay 30, Esslingen near Stuttgart, Wurttemberg, Germany. Died 1856 lay 12, Esslingen.

After education at his home town Steudel studied medicine and natural history at the University of Tubingen; he received his doctor's degree $25 \mathrm{Sep}$. 1805. After some traveling he settled as a physician in his home town, where he first became "Oberamts-Thierarzt" and in 1828 "Oberamts-Arzt".

He devoted much of his spare time to botany, compiling the Nomenalatos, and with Hochstetter, the Enumeratio (see below), moreover he wrote articles on the

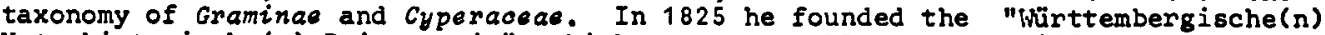
Naturhistorische $(n)$ Reiseverein", which sent out collectors to different parts of Europe and later also outside of Europe, to collect natural history specimens which were distributed among the members in proportion to their shares.

He was commemorated in the generic names Steudelago 0 . Kuntze 1891, a synonym of Exostema L.C. Richard (Rubiaceae), Steudelia Sprengel 1822, considered a synonyr of Erythroxyzon L. (Erythroxy Laceae), Staudelia Martius 1827, considered a synonym of Leonia Ruiz Pavon (Violaoeae), Steudelia C. Presl 1829, a homotypic synonym of Adenogramma Reichenbach (Phytolaooaceae), and Steudelelia Honda 1930 (Rubiaceae).

Ref.: Uunschmann, E.: Alig. Deuteche Biogr. 36: 151-152. 1893. 
1 Nomenalator botanious ...

\section{[Ed.1j 2 parts. Stuttgart \& Tubingen, 1821-1824.}

Title: "NOIENCLATOR | BOTANICUS | EIJUIERAIS ORDINE ALPHABETICO | HOIIIIA ATQUE SYIOHY:LA I TUM GENERICA TUM SPECIFICA ET A LINHAEO ET RECENTIORIBUS DE RE BOTAIICA I SCRIPTORIBUS I PLANTIS PHAIIEROGAIIS I Part 2: PLALTIS CRYPTOGAUIS] | IIIPOSITA. | [short swelled rule] | AUCTORE | ERNESTO STEUDEL, | 'IED. DR. | [full swelled rule] | STUTTGARDTIAE ET TUBIIIGAE. | SUMTIBUS I. G. COTIAE. IDCCCXXI. Ppart 2: SUMTIBUS J. G. COTTAE. MDCCCXXIV.:"

Collation: $8^{\circ}:$ part 1: $\pi^{1} 2 \pi^{6} 3 \pi^{2} x^{4}$ A-2F $2 x^{9} \quad 2 G-3 K^{8} \quad 3 L^{4} \quad(\$ 1,2$ signed, $\mathrm{A2}$ signed 'A*') I-III IV-XVII XVIII-XX $72-464$ XXI-XXII $465-900$ $901-904$ (53 as'ES'; $X-X I \quad 88 \quad 130 \quad 261 \quad 288 \quad 332 \quad 349 \quad 387 \quad 424 \quad 455 \quad 459$ $\begin{array}{llllllllllllll}503 & 548 & 559 & 587 & 672 & 676 & 712 & 823 & 867 & 867 & 897 & 884 & 887) \text {; }\end{array}$ part 2: $* 8 \quad 2 * 2(-2 * 2) \quad A-2 \mathrm{E}^{B} \quad 2 \mathrm{~F}^{2}\left(-2 \mathrm{~F}_{2}=2 * 1 ?\right)_{3}$ I-III IV-XVIII 1 2-450 (V VII $\left.159 \begin{array}{lllllllllll} & 182 & 185 & 223 & 230 & 284 & 307 & 363 & 107 & 443 & 448\end{array}\right)$.

Contento: part 1: I titles II imprint; III-IX preface: "Praefatio.", dated Nov. 1820; X explanation of signs and abbreviations; XI-XVII names of cited authors; $X V I I I D ; X I X-X X$ folded table of the pages and numbers of genera of the Linnaean classes in Roemer \& Schultes, Persoon, Villdenow (Species \& Enumeratio); 1-464 text, listing names of genera and species of phanerogans, 1 - Laeiospermum $X X I$ section title: "NOMENCLATOR | BOTANICUS.| [short thin mule] | Sectio II. I L - Z."; XXII [; 465-900 text, phanerogams concluded; 901-903 corrigendas 2040 ;

part 2: I title; II imprint; III-IV preface, dated Sept. 1824 ; V-VI names of authors cited, followed by abbreviations used in part 2 [this 1 ist not present in HBL copy]; VII-:iVIII systematic enumeration of cryptogamic genera and subdivisions in natural classification, presenting the systems of Nees von Esenbeck, of Fries, and of Persoon, for Funai. of Agardh (Speoies Algarum rite oognitae) for Algae, of Acharius (Synopsio methodioe Lichenum 1814), Fries (K.Vetensk.Aoad.Handi. 1821(2): 520 etc.) and Agardh (Aphorismi botanioi 8, 1322) for Liahenes, of Bridel (Methodus nova muscorum, Lipsiae 1822) for Muei Frondosi, no explicit source mentioned for Bepatioae (Musai Hepatioi) and Filioes (Pteroideae), but including uncommon generic names of Willdenow for Bepatioae, and citing Villdenow and Sprengel for Filices and allies; 1-450 text, enumeration of names of genera and species of cryptogams.

Papex: leaf height $226 \mathrm{~mm}$. (HBL copy, cut); partly laid, partly wove; lajd paper: chains vertical, except folded table $x$ which has chains horizontal; wm.: "I B loutline]": part 1, part 2: A-L, Q; wove paper: wh.:

"Beck[script]" in lower left or right corner of sheet: part 2: *2* M-0 2A-2F. Printer: Hopfer de l'orme.

Publisher: Cotta, J.G., Stuttgart \& Tubingen, Germany.

Dates: part 1: $1821\left(t .-p_{1}\right)$, bef.28 Jun. (F Zora 4(24): 377.1821$)$;

part 2: 1824 (t.-p.), in or aft.Sep.(pref.); bef.28 Oct.(P 2ora 7(40):639-640.

Reviewe: part 1: AlZg.Repert.Neuest.In-Aus I.Lit.18213(1):2-5. 1821 Jul.15; 1824). Aizg.HaZi. Lit.Zeit. $1821(252)$

Flora 4(48): 749-754. 1821 Dec.28;

Sprengel: Neue Entdeok.Pflansenk. 3: 293.1822;

Gott.Gel.Ans. $1823^{3}(175): 1750-1751$. 1823;

Iois(Oken) 15(9):965.1824(reply of Steudel: Isis(Oken)16(1):124-128.

part 1-2: Ioio(Oken) 20(2): 132. 1827.

$1825)$;

Refs.: Arn.Arb.1: 688 BINNH 2018

BINHH-S 1274

Bradl.1: $77 \mathrm{a}$

Cat.Juss. n.553
E.As.Bot, 472 Heins.7(2): 346 Jacks. 15 Kew 590
Krdg . 67

Lindj. Libr. 415

Linn.Soc. 732

list. 405
Pr.ed.1 n.9925

Pr.ed.2 n.8965

Soulsb. n.35, 922

Stafl. TL n.1271.

Bibl,notes. This work is interesting for the nixture of laid and wove faper. The HBL copy has in part 1 a section-title 'L-Z' still conjugate with the title for the phaneroganous part [1], this suggests that another section-title for the section 1, letters A-Lasiospermum, had been present, which was discarded in the copies I saw. The break between these sections is uncertain, since 
the letter $L$ does not begin on a new gathering; the beginning of the next gathering is taken as the break. I did not find evidence for different dates of publication of these two sections, though the section-title would be an indication. Each direction-line gives the numbersof (accepted?) genera as well as species up to that line. The total numbers are: Phanerogamae: 3376 genera and 39,684 species; Cryptogamae: 557 genera and 10,965 species. In part 2 a stop-press addition on "3v apparently was made, which $I$ saw in the $M$ copy and which is absent in the HBL copy.

Bot.notes. Compilation of botanical names of plants, with the drawback that the original places in books or periodicals, where the names were published, were not stated. Taxonomic opinion evaluations are given without any notivation, which easily could be criticized. Nevertheless, for its time it was very useful, and for some groups even until recently a help for tracing names to a certain period. A second edition was published 1840-41, in which no cellular cryptogams were listed. Therefore, the 2 nd edition is not treated here. The precise dates are listed by Stafleu, Tax.Lit. n. 1271. 1967.

STEUDEL, Ernst Gottlieb \& HOCHSTETTER, Christian Ferdinand

1 Envmeratio plantarum Germaniae Belvetiaeque indigenarum....

Stuttgart \& Tubingen, 1826 .

Titza: "ENUIERATIO | PLANTARUM | GERMIANIAE HELVETIAEQUE | INDIGENARUM, SEU | PRODROMUS, | QUEII | SYNOPSIS PLANTARUM GERMANIAE HELVE-I TIAEQUE EDITURI BOTAINOPHILISQUE ADJU-|VANDAY COIMENDANTES | SCRIPSERUNT | E. STEUDEL, MED. DR. $|E T| C B$. F BOCHSTETTER, PROF.| [short swelled rule] [very long swelled rule] | STUTTGARDTIAE ET TUBINGAE. | SUMTIBUS J. G. COTTAE. MDCCCXXVI."

Colzation: $8^{\circ}: \pi^{4} 1-21^{8} 22-23^{4}$ (\$2 signed $\$ *$ ): I-III IV-VIII $12-352$ (93 as '95', 275 [in some copies, $W]$ as '27', 316 as '816', 332341 ).

Contente: I title; II C; III-VIII preface: "Praefatio.", dated: "mense Julii 1826"; 1-331 text, enumeration of German and Swiss plant species (and some varieties) in the modified Linnaean classification, names with author citations, lifeform, flowering time and habitat, rarely with indication of the region where the plant occurs; $332-340$ additions and corrections; 341-352 index of generic names. No RT. Language: Latin.

Paper: leaf height $219 \mathrm{~mm}$ ( (HBL copy, cut); laid, chains vertical; wm.: "N[script] 01 [outline]" in the center of the sheet, or "No" 2".

Printer: no imprint.

Publieher: Cotta, J.G., Stuttgart \& Tubingen, Germany.

Date: 1826 (t.-p.); in or aft.Jul.(pref.); bef.7 Dec.(Flora 9(45):719-720.1826).

Reviewe: Flora 9(45): 719-720,1826; 11(7)-(8):97-109.1828; Linnaea 2(1): 87.1827 (Jan,); Jen,AILg,Lit.zeit. 1827(104): 350.1827; \}(cited from Miltitz).

Refo.: Arn.Arb. 668 BINH 2018 Bradl. $1: 377^{b}$

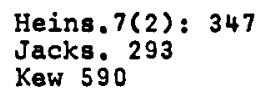

Kew 590

$\mathrm{Krag}_{\mathrm{g}} 138$

Linn. Soc. 732

Milt. 180

Pr.ed.1 n.9923

Pr.ed.2 n.8963.

Notes. Checklist of the names of plants occurring naturally in Germany and Switzerland, without citation of literature. A number of footnotes give extra information on species reduced to varieties by certain authors, or dubious species of some authors. Mosses are treated on p.149-174, in the footnotes numerous names were cited from Schleicher, without descriptions or references to descriptions; a number of names of new species of Orthotrichum of $P$ Bruch are included in a footnote to $\mathrm{P} .1 \overline{6} \overline{8}$, with the remark that these are not mentioned in Brid. Bryol. Univ. [vol.1], these also not described [they appeared in the Supplement to vol.1 of Bryol. Univ., 1827]. (See for remarks by Hoppe: P.20.) 


\section{STURM, Jacob}

Biogr. Born 1771 lar. 21, Nurnbers, Bavaria, Gernany. Died 1848 l!ov. 28 , Numbers.

Jacob Sturm was trained by his father as a copper-enrraver, and concentrated on enEraving natural history objects after having made a new flate of insects from specimens when a first plate by his father had not met approval. lie began an insert collection which became an inportant one and which he used for many encravings, and of which he prepared a catalorue, which had several editions.

In 1796 he began his important work: Deutschiands plora, which was divided in three Abtheilungen: I Phaneropamas, II Cryptogamae except $F$ ungi, III 5 ungi; only Abth.II is treated below. In 1797 Deutschlands Fauna followed. He illustrated nany other natural history books and papers, from which llees, ilornschuch ard Sturn, Bryologia Germanica is treated in its proper place in this thesis, and the other articles of C.G. Hees von Esenbeck. He was his own publisher, and he must have been very busy with all these occupations. In 1346 he received the degres of Dr. Phil. hon.causa from the University of Breslau. In the last part of his life he was helped by two sons, who continued his work after his death, e.g. Deutsolizands $F$ Lora.

He was commemorated in the seneric names Sturmia lloppe 1799, a synonym of

Mibora Adanson (Gramineae), Sturmia Rejchenbach 1328, a homotypic synonym of Lipario L.C. Richard 1818 (Orchidaceae), and Sturmia C.F. Gaertner 1806, a synonym of Antirrhaea Jussieu (Rubiaceae).

Fofo.: Hilpert: Zum Andenken an Dr. Jacob Sturm. Nürnberg, 1849 (not seen) Wurschmann, E.: Alig. Deuteohe Biogr. 37: 20-21. 1894.

1 Deutsohiande Blora... Abtheilung II. Cryptogamen.

[8] vols. in 31 fasc. [not completed]. Nürnberg, [1798] 1801-1839.

Titzes (not transcribed): J. Sturm. Deutschlands Flora in Abbildungen nach der Natur, mit Beschreibungen. II. Abtheilung Cryptogamen, Iurnberg, gedruckt auf Kosten des Verfassers. [dates see table]; fasc.19/20,22/23 and 26/27 with part-titles [all in gothicj: "Deutschlands Jungermannien | monographisch bearbeitet | von A. J. C. Corda. I [very short rule] I 1. und 2. Heft [fasc.22/23: 3. und 4. Heft] [fasc:26/27; 5. und 5 . Heft] | ifull swelled rule] Nürnberg, 1830 fasc.22/23: 1832] [fasc.26/27: 1835] [transcription from part of wrapper-title of fasc. $22 / 23$ and inferred for the other wrapper-titles, no wrapper seen of fasc.19/20]; fasc.24, $28 / 29$ with part-tities: Laurer Die Flechten. 1.Heft [fasc.28/29: 2.Heft]; 1832 [fasc.28/29: 1835]; fasc.30/31 with part-title: Deutschlands Algen, von A. C.J. Corda. 1. und 2. Heft.

Collation and datee: see table next page.

Contente: vol.1: i title; ii $\mathrm{D}_{\text {; }}$ iii dedication to the "botanischen Gesellschaft in I Regensburg"; iv text of the dedication; v-vi index in 2 columns; fasc.1-4: $4 \times 16$ leaves text, descriptions of the species pictured;

vol.2: i title; ii $\square_{\text {; }}$ iii-iv index; fasc.5-8: $4 \times 16$ leaves text;

vol.3: $i$ title; ii index [?j; fasc.9-12: $4 \times 16$ leaves text:

vol.4: i title; ii ${ }^{\prime}$ i ii-iv index (2 columns); fasc.13-16: $4 \times 16$ leaves text; vol.5: i title; ii ${ }_{1}$ i ii-iv index; fasc,17, 18, 21, 25: $4 \times 16$ +6 leaves text; vol.6: $1-5$ introduction, including the ciassification of corda; 6 transverseIy printed table of genera, dated: "Prag im Dezember 1829" ? 7-6? tovt: descriptions of Hepatioae by A.C.J.Corda: Gymnomitrion - Pellia, and of Sphagnum and Andreaca; I-II (48) announcement of books published by J.Sturm; dated 1830; 63-184 text, descriptions of Hepaticae continued; 185-186 supplementary remarks, criticisms of Hibener: Eepat. Germ.; vol.7: [not studied in detail] descriptions of Liohenes by J.F. Laurer: vol.[8]: ffasc.30/31]: [not studied in detail] descriptions of izgae by A.C.J. Corda.

Plates: 146 hand-colored copper-engravings of Gernan species of cryptogans, Fungi excepted, unnumbered, except vol.6-8: vol.6: "I." - "XLVIII.", vol.7: 1-32, vol not measured, parts cut off in the copy examined; possibly 4 together engraved on one copper plate (see Bibl.notes). 


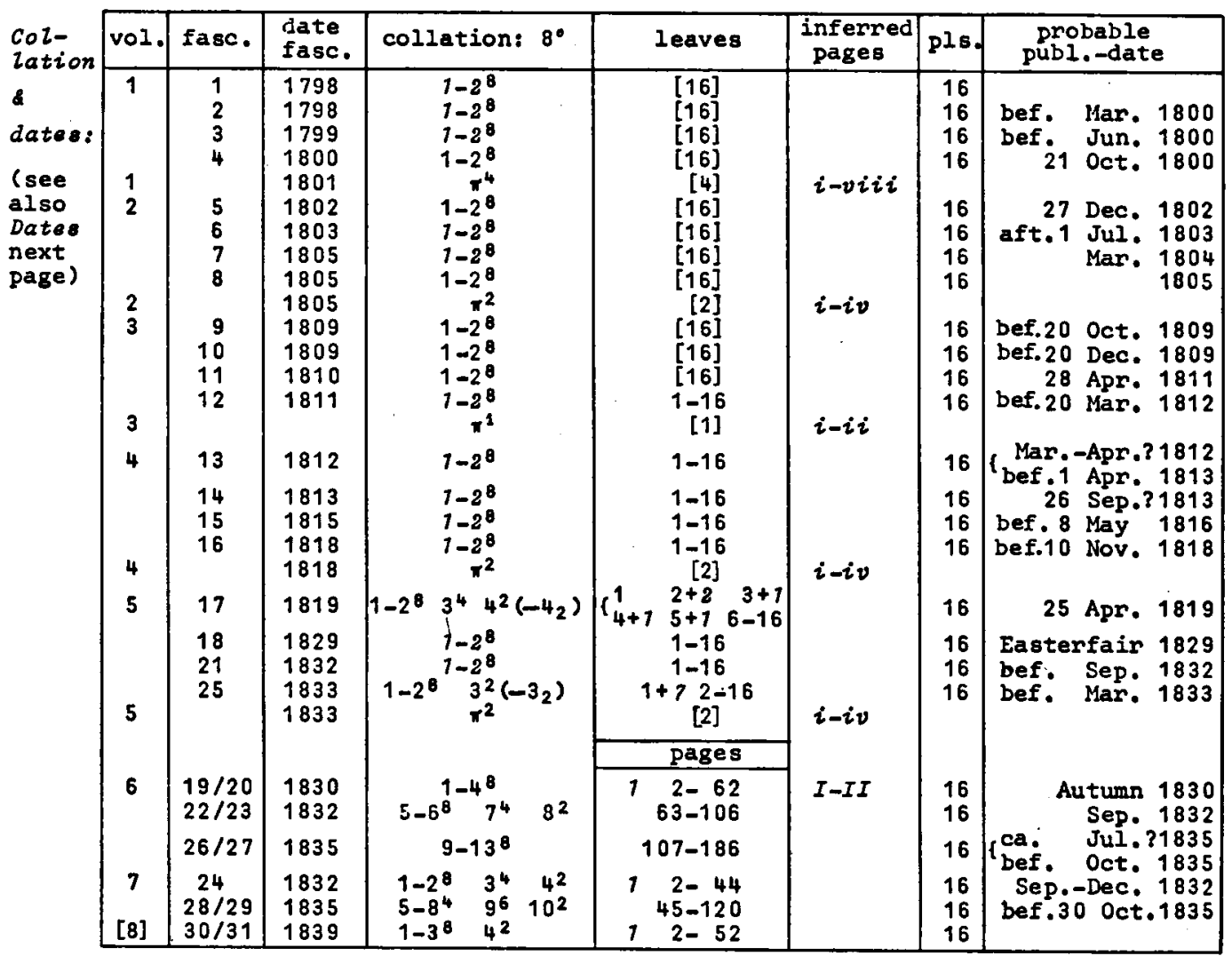

Antiste: Corda, A.C.J. (1809-1849): fasc.18; all $16 \mathrm{pls.,}$ vol.6: all 48 pls., and probably fasc, $30 / 31$ [not checked];

Kaulfuss, Georg Friedrich (1786-1830): fasc.15: pl.[1]-[6] and possibly all, fasc.16: all 16 pls.;

Laurer, Joh. Friedrich (1798-1873): vol.7: all 32 pls.;

Sturm, Jacob, author of the first fascicles: all remaining plates.

Engraver: Sturm, Jacob; last fascicles by his sons $\mathfrak{J}_{\mathrm{J}}$. H.C. Wilhelm $(1808-1865)$.

Wrappers: All wrappers seen ( $2 \mathrm{HH}$ copy) except for fasc,19/20; front wrapper recto with title, verso blank or with an announcement: fasc.2: "Nachricht"; fasc.3: "Nachricht", dated: "im Juny 1799.", announcing that more than one species of the same genus would be treated in one fascicle; fasc.4: "Berichtigung", correction concerning Bryum contortum Wulf., which would appear under the name Encalypta grandio as a completely new species; fasc.9: announcement, continued over recto of back wrapper (the cryptogamic part is continued after an interruption and the new collaborator is Otto Christian Blandow from Waren (Mecklenburg), who contributed complete specimens and descriptions) dated: "Marz 1.809"; fasc.12: "Nachricht". "a list for correct binding in systematical order of plates and text of fasc.9-12, two columns of names, 1-44, going over to recto of back wrapper, 45-64, fasc.30/31: "Nachricht", concerning the part Algen Deutsohlands by Corda, which would be continued in the next fascicles, accompanied by a preface [nothing more appeared]; back wrappers with index on verso, making these wrappers valuable, being the only means to establish the order of the species as published rectos blank, except those on which the text of the verso front wrappers was continued, and fasc.26/27: errata. 
Papar: laid, chains vertical; $\mathrm{km} .:$

"[post-horn] G F C V [outline] = [17th century ship]": fasc.1-4 (except fasc.2 gath.2) 7-10 12 13 17-19/20, vol.1, 2, 4: gatherings $\pi ;$ "[crowned shield around post-horn] | GF M $=$ R. B. S. WOLFGANG": fasc.2 (gath.8) 5611 13(* only) 14-16 21-30/31; plate paper: laid with "fils de soie", chains vertical; wn.: the 2nd mark above-mentioned: all pls. (possibly in the fascicles where text and plates have paper with the same mark a selection on thickness had been made, the slightly thicker paper reserved for the pls.); it was also offered with the plates on wove paper (not seen; announced in Bryol.Germ. vol.2(2), which see); wrapper paper: pink-colored; laid; wh.:

" [crowned snake serpentining before a rod with two stalked flowers at the top and at bottom a decorated shield with letters C C I N in outline]": fasc.1-17 [not all wrappers of the copy checked did show the mark, but there is little doubt that it is all the same paper type]

"[rod ending in clover leaf pattern with at both sides feather-like side branches tapering in length towards the point of the rod]": fasc.18;

"[broad ornated arc with rosette below center?": fasc.21 and 24 [?]; no traces of chains in the wrappers of fasc.25 and $30 / 31$, perhaps because the paper is too thick in fasc.25, the color of the last wrapper is definitely much deeper pink than of all others, and the "fils de soie" are more numerous.

Printer: no imprint.

Publieher: Sturm, Jacob, the author.

Colzaboratore: Blandow, Otto Christian (1778-1810), Waren (Mecklenburg): fasc.9-10, all descriptions signed; fasc.11: descriotions of Trichostomum coiuroides and Veokera complanata;

Corda, August Carl Joseph (1809-1849): vol.6 (see Tities), and fasc.30/31;

Funck, Heinrich Christian (1771-1839): fasc, 17, all descriptions signed except those of Amphidium pulvinatum and Sphagnum oubseoundum;

Hoppe, David Heinrich (1760-1846): fasc.4-6, many descriptions signed;

Kaulfuss, Georg Friedrich (1796-1830): fasc.15-16, some new names signed;

Laurer, Johann Friedrich (1798-1873): vol.7;

Nees vón Esenbeck, Christian Gottfried (1776-i858): fasc.17: Amphidium pulvinatum and Sphagnum subsecundum, names signed;

Voit, Johann Gottlieb Wilhelm (1776-1813), physician at Schweinfurth: fasc.11-13, nearly all descriptions signed.

Dates: the dates of publication up to 1822 are derived from Sayre, Dates of publ. 1959, with one addition from an announcement, listed below together with other announcements; the latest dates in the volumes or wrappers have not been listed in the table because they are generally too early to be of help in the dating problems (see foregoing page).

Reviews and announcemente:

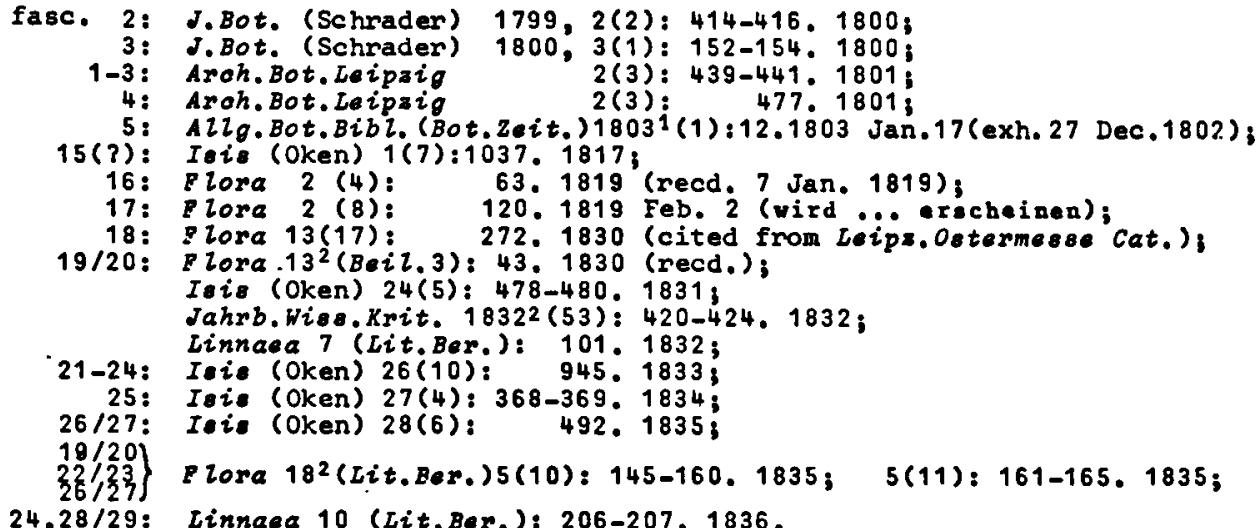

24,28/29: Linnaea 10 (Lit.Ben.): 206-207. 1836. 
Bibliogr.studies:

Sayre, G.: Dates of publ. $17($ fasc.2-7), 36, 42, 43, 46, 53, 55, 59, 63, 71-73. Stafleu, F.A.: Taxonomic literature n.1275. 1967.

Refe.: Arn.Arb.1: 672

BNiNH 2043

Brad1.1: $375^{a}$

Brun.5: 573

\author{
Cat.Juss. n.1741 \\ Graesse 6: 516 \\ Jacks. 293 \\ Kew 594
}

\author{
$\mathrm{KrOg} \cdot 148$ \\ Mass.HS-H 303 \\ Mass.HS-l1 3: 413 \\ Nilt. 144
}

Bibi.notes. The section described here is part of the complete set, which is indicated as having appeared up to 1861 (Bradley) and in 163 fascicles (Jackson). The collation is complicated in most copies, because the plates and their descriptions were delivered (as far as I could ascertain) in loose cut leaves, to facilitate systematical arrangement by the owners; in fact, the finished volumes j.ndicated another arrangement than the original one in the fascicles. of the section 2 I studied a copy in original wappers in the Gray Herbarium library, llarvard University, of which only the wrapper of fasc.19/20 was missing. These wrappers had important additional information, besides the year, especially the index on the back.

The format is another point on which diverse opinions are stated in the reference works. The small size would indeed bring the volumes in the range of $16^{\circ}$, or $24^{\circ}$, as is often stated, but scarcely in that of $12^{\circ}$, which also is indicated several times. The relation in size class may depend on the special criteria of the cataloguers, but the bibliographical format is with very little doubt $8^{\circ}$. This is indicated by the chain-lines as well as by the watermarks, which are exactly centered in the inner top corner of the leaves of the text; the wr.parts in the cut leaves of the same gathering do match. The only doubt, though small, was left because I did not see any deckle edges, so I could not reconstruct the actual sheet size. If the watermarks really were in the center of the half-sheets the bibliographical format is octavo. The sheet size must have been unusually small, the paper being supplied by one or a few paper-makers only, as is clear fron the long period in which the same watermark appeared; in the plates the same mark was found throughout, and in the text only two marks, which is very unusual, in view of the disturbed political situation in Europe during the period. The wrappers show more variation; the small amount needed perhaps did not warrant maintenance of the type. The gatherings were occasionaliy signed in the first fascicles, 1-2 in each fascicle anew. Later the signatures were dropped and leaf-numbers instead were inserted in the direction-lines of the rectos (fasc.12 and up): in fasc.17 numbers were used to indicate the text to the plates, though the plates remained unnumbered. In the parts with a special title (vols.6-8), finally, the pages were numbered. The volumes also had some irregularities: vol.5 deviated insofar as the constituent fascicles were not consecutive; vol.6, Corda's Jungermanniaoeae, consisted of 3 sets of 16 plates, and much more text than usual: 3 combined fascicles; vol.7, Laurer's Lichenes, did not come to more than 2 fascicles; and what supposedly would have formed vol.8 only had 1 fascicle: Corda's Deutsohlands Algen; these parts remained unfinished, and therefore without volume-titles.

The plates apparently were engraved on much larger copper-plates than the final leaf size, probably the drawings of 4 leaves to one copper-plate. This is indicated by the dividing lines, which were engraved between the partial plates and are still visible on some plates. The absence of deckle-edges again made it impossible to determine the sheet-or copper-plate size. The place of the watermarks in the leaves of the plates might have been of help in mapping out the place of the partial plates on the copper-plate. However, apparently for the coloring, the leaves with the different species had been separated before being collected for individual copies of the book, and the resulting watermark fragments are more or less at random in one copy. Astatis tical analysis of a large number of copies would most likely give an idea of this distribution, but this was not possible to me. 
Bot.notes. I included this title because of the peculiar problems it has for the botanical bibliographer, though it was not in the restricted period, but beyond it at both ends. Doubtless it was an important publication, if not alone for the number of new species proposed, or species illustrated for the first time. The plates were carefuliy executed, as can be expected from an engraver devoting ali his time to natural history engraving.

The descriptions vary in their thoroughness, and later collaborators sometimes criticized their predecessors, even gave new treatments of the same species. The new species and new names have been inserted in Index Nuscorum, except for a name in Corda's part on hepatics, where no mosses would be expected, but where nevertheless sphagnum and Andreaea were included, the first with a new subgenus sphagnelia, P.17.

\section{SYLLOGE PLANTARUM NOVARUM ...}

2 vols. Regensburg, [1822-]1828.

Tit les: "SYLLOGE | PLANTARUM NOVARUIM | ITEMQUE | MINUS COGNITARUM I A I PRAESTANTISSIIIS BOTANICIS | ADHUC VIVEITIBUS COLLECTA | ET | A SOCIETATE REGIA BOTANICA I RATISBONENSI | EDITA; | CUM TABULA AENEA. [2: TOMUS SECUINDUS | CUM TABULA LITHOGRAPHICA] | RATISBONAE, | TYPIS VIDUAE C. E. BRENCK. | 1824. [2: 1828.]"

\begin{tabular}{|c|c|c|c|c|c|c|}
\hline Col- & vol. & gath. & pages & & date & sources \\
\hline $\begin{array}{l}\text { Lation } \\
8^{\circ} \\
\text { dater: }\end{array}$ & 1 & $\begin{array}{r}A^{8} \\
B^{8} \\
C-E^{8} \\
F-P^{8} \\
Q^{2}\end{array}$ & $\begin{array}{r}1-16 \\
17-32 \\
33-80 \\
81-240 \\
241-244 \\
I-X I I\end{array}$ & $\begin{array}{l}1822 \\
1822 \\
1822 \\
1823 \\
1824 \\
1824\end{array}$ & $\begin{array}{l}\text { Jan. } 28 \\
\text { bef.Apr. } 7 \\
\text { or } 1824 \\
\text { ? }\end{array}$ & $\begin{array}{l}\text { Plora } 5(4): 64.1822 \text { Jan.28 } \\
\text { F lora } 5(13): 208.1822 \text { (corrections) } \\
\text { GRO copy bound with F lora vol.5 } \\
\text { t. }- \text { p. }\end{array}$ \\
\hline & 2 & $\begin{array}{r}A^{8} \\
B^{8} \\
C^{8} \\
D-G^{8} \\
H-P^{8} \\
Q^{8} \\
\pi^{4}\end{array}$ & $\begin{array}{r}1-16 \\
17-32 \\
33-48 \\
49-112 \\
113-240 \\
241-256 \\
I-V I I I\end{array}$ & $\begin{array}{l}1825 \\
1825 \\
1826 \\
1826 \\
1827 \\
1828 \\
1828\end{array}$ & $\begin{array}{l}\text { bef.Nov.or Dec. } \\
\text { late } \\
\text { Jan.or Feb. } \\
\text { after Feb. } \\
\text { or } 1828 \\
\text { J. }\end{array}$ & $\begin{array}{l}\text { I Lora } 8^{2}(\text { Beiz. 3): } 47,1825 \\
\text { v. Hall: Bifdr. Natuurk. Wet. 1(2):211. } \\
\text { v. Steenis (see below). } \\
\text { t. -p. }\end{array}$ \\
\hline
\end{tabular}

Paper: leaf height $175 \mathrm{~mm}$. (U copy, cut); laid, chains vertical; wa.: vol.1: "L $=R$ [outline]",

vol.2: "[two keys in double circle with inscription REGENSPURG and omall fleurs-de-lis between circles] = LoschGE" (U copy: sheets C-G, $M-0$ ).

Printer: Brenck, Widow C.E., Regensburg, Germany.

Publisher: Kön. Regensburger Botanischer Verein.

Bibliogr.tudies: Steenis, C.G.G.J.van: Fl.Malee.Bul2, 1(4): 97-99. 1948 Sep.1 Stafleu, F.A.: Taxonomia literature n.552. 1967.

Bibl.note. The decision to publish this title periodically was made in a session of the Regensburg botanical society on 10 Nov. 1821 (pref, vol.1). The first sheet was announced in the $B$ lora fascicle of $28 \mathrm{Jan}$. 1822 , as being issued with this fascicle. Data for the issue of other sheets are scarce most probably the individual sheets were issued at irregular times with fascicles of lopa. The fact that in the GRO cOpy the first 5 sheets were bound with vol.5 of flora makes it certain that these were issued with fascicles of this volume This indicates the year 1822 for these 5 gatherings, except for the slight possibility that the last one of these 5 was issued with the last part of Fora 5 and actually appeared in 1923 , as may be expected for the part with the full subject index to the completed volume of Fiora. Possibly gatherings of vol. 2 were issued in groups (see the 2 parts of the article of schultz n.4). 
I found a confirmation of my supposition of irregular publication in a let ter from F.G. Eschweiler to Ad. Brongniart (PIYusBC), dated 11 Dec.1828, in which he wrote that he would send ndeux volumes de sylloge plenterum rariorum aut minus cognitarum, qui ont été publié a fur et mesure avec la gazette [Flora] pendant les dernieres annés." Another confirmation can be read from the next letter, dated 2 Jan.1829; it announced the shipment promised in the former let ter, with an excuse for one gathering of the syzloge which was lacking: "manque ... la feuille $N$ du premier volume du sylloge, que dans ce moment on n'e pu trouver, mais que je ne doute pas de pouvoir envoyer plus tard." In my opinion this is good evidence that the sheet $N$ was published separately.

Another point is the fact that in the direction-line of gathering $L$ of vol.1 the word Sylloge appeared for the first time. This indicates a different printing time for the two gatherings $K$ and $L$.

$I$ compared the watermarks in the volumes of Flora with those in the sylloge in the hope that some changes in watermark coinciding in the two periodicals might give more clues to dates. This hope was not realized; sylioge vol.1 had the same watermark as the corresponding volumes of $F$ lora throughout and vol.2 had a different watermark, not observed in Flora at all.

I trust that continued research will make more data available on this problem. The archives of the society mentioned probably contain valuable material.

Bot.note. This periodical contains many articles important for nomenclature; for bryological articles see Hornschuch $n, 1$ and Schultz $n .1$ \&.4.

\section{TAYLOR, Thomas}

Biogx. Born [date unknown], in India.

Died 1848 Feb. (early), Dunkerrion, Co. Kerry, Ireland.

Thomas Taylor was the son of Colonel Joseph Irwin Taylor. Up to his seventh year he spoke mainly Hindustani; after coming to Ireland in a vessel where nothing but Portuguese was spoken, he was sent to a school at Cork where French was the only language used. He studied at Trinity College, Dublin, and received the degree M.D. in 1814 . In the same year he became a Fellow of the Linnean Society, London. He was professor of botany and natural history in the Royal Cork Scientific Institution. He became a honorary member of the Royal Irish Academy. Splachnaceae).

He was commemorated in the generic name Tay zoria W.J. Hooker 1818 (Nusoi,

Refo.: Boulger, G.S.: Thomat Taylor (d. 1848). In: Diot. Natl.Biogr. 55: 470-471. 1898. Hooker, J.D.: Ann.Bot. 16: xxi-xxii. i902.

1 Muscologia Britannica. 1818, 1827.

See Hooker \& Taylor n.1\& n.2.

\section{WAHLEINBERG, Georg [from 1804: G8ran]}

Biogr. Born 1780 0ct, 1, Skarphyttan, Varmland, Sweden.

Died 1851 lar. 22, Uppsala, Sweden.

Wahlenberg studied medicine and botany at the University of Uppsala from 1792, and received the degree of $\mathrm{Dr}$. Med. there in 1806. In this year he became botanical demonstrator in the same University. He traveled in different parts of Europe, as a result writing important floras, such as a flora of the Carpathian Hountains, of Lapland, and finally of Sweden. Receiving the title of professor in 1826 , he became professor of medicine and botany in 1829 (in the place of Thunberg).

He was commemorated in the generj.c names Wahienbergia Schrader 1821, nom.aons. (Campanulaceae), Wahlenbargia Blume 1823 , a synonym of Tarenna Gaertner (Rubiaceae). Wahionbergia Schumacher 1827, a synonym of Enhydra Loureiro (Compositae), and Wahlenbergia R. Brown 1831, a synonym of Dichapetalum Thouars (Chailietiaceae).

Refs.: Bot. Notis. 1851 (3): [insert]. 1851 (death notice in the index referred to as on $p .64$, however, the HBL copy has the death announcement in a black frame at one side of an unnumbered leaf).

Krok: Biblioth. Bot. Suec. 741. 1925. 
1 Elora sueoioa $\ldots$

\author{
[Ed.1.] 2 parts. Uppsala, 1824 [1825?]-1826.
}

Tit les: "FLORA SVECICA | ENUMERANS | PLANTAS SVECIEE INDIGENAS | CUM SYNOPSI CLASSIURI ORDINUMQUE, CHARACTERIBUS | GENERUM, DIFFERENTIIS SPECIERUM, SYNONYMIS CITATIONIBUSQUE | SELECTIS, LOCIS REGIONIBUSQUE NATALIBUS, DESCRIPTIONIBUS | HABITUALIBUS NOMINA INCOLARUM ET QUALITATES PLANTARUM | ILLUSTRANTIBUS | POST LINNAUIA EDITA I A I GEORGIO WAHLENBERG | BOTANICES DEMONSTRATORE UPSALIENSI. [short rule] | PARS PRIOR [2: PARS POSTERIOR] [ [short rule]| [fuli rule] UPSALIAE, | SUIS IMPENSIS EXCUDEBANT PALMBLAD \& C, | [ following 5 lines in two columns; column 1:] ARGENTORATI apud TREUTTEL i \& WRTZ. | CHRISTIANIE apUd HARTMAN. | HAFNIF apUd GYLDENDAL. | LIPSIF apUd BROCKHAUS, column 2:? LONDINI ap. TREUTTEL \& WURTZ, | TREUTTEL filium \& RICHTER. | PARISIIS ap. TREÚTTEL \& WURTZ. | TIGURI (ZURICH) apud ORELL, | FUESSLI \& c:o. [end of columns] |short rule] | MDCCCXXIV. [2: MDCCCXXVI.]";

volume-title: "FLORA SVECICA | ENUMERANS | PLANTAS SVECIAE INDIGENAS | POST LINNEUM EDITA | A | GEORGIO WAHLENBERG | [short rule] | IN DUAS PARTES DISPERTITA. | [short rule] | [full swelled rule] | UPSALIE | SUIS IMPENSIS EXCUDEBANT PALMBLAD \& C. | [very short rule] | 1826."

Colzation: $8^{\circ}:$ part 2:

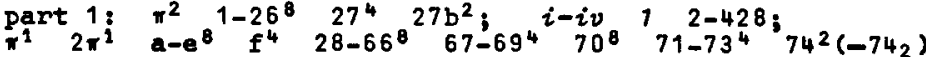

$$
\begin{aligned}
& \text { ( } \$ 1 \text { signed, a-f signed in italics, gatherings in } 48 \text { signed } \$ \frac{1}{2} \text {, } \\
& 74 \text { signed }\left(74 \frac{1}{8}\right) \text {; } i-i v I \text { II-LXXXVIII 429-1117 } 1178 \\
& \text { (XXV } 1043787810851103,550 \text { in inner conner). }
\end{aligned}
$$

Contente: part 1: $i$ part-title; $i$ i ${ }_{\text {; }}$ iii-iv preface, dated: "Calendis Octobribus MDCCCXXIV."; 7-428 text, descriptions of Swedish plant genera, species and varieties, in the Linnaean classification, with keys to the genera within the orders, species and varieties with citations, habitats and distributions in Sweden, often with localities, classes Monandria - Tetradynamia;

part 2: i title; ii D; iii part-titles iv D; I-XXIV preface: "RATIO OPERIS.", dated: "mense Febmarii 1826."; XXV-LXXX introduction, concise description of Sweden and its vegetation, headed: "CONSPECTUS | REGNI ET VEGETATIONIS." including an enumeration of the groups and their genera in the natural classification: LXVIII-LXXX, headed: "DESIGNATI METHODI NATURALIS."; LXXXI key to the Linnaean classes; LXXXII-LXXXVIII list of the genera of which some species belong to other Linnaean classes or orders than the majority, with the number before the generic name, and where necessary the numbers of the species after this name; $429-1042$ text concluded, classes Monadelphia - Cryptogamia (class 24); 1043-1076 additions, emendations and corrections, including descriptions of occasional new species (varieties), e.g. Boletus bensoinus: 1077 latest additions: "Addenda ulteriora | post impressionem primae plagulae addendorum | accepta."; $1078-1084$ list of adventitious, dubious or too imperfectly known plants, not included in the text; $1085-1102$ index of Swedish plant names; 1103-1117 index of Latin names of genera; $1118 \mathrm{Q}$. RT: text: names of Linnaean class (left page) and order (right page) in italic capitals; introduction and addenda etc.: chapter heading in capitals, except vol.1: $\pi$, vol.2: $f$, and indexes, which do not have a RT. Language: Latin.

Table: 1 folded table, numbered: "ad pag. LXVIII.", with printed table of numbers of species of Phanerogamia in different natural plant families for Scania and Lapponica sylyatica.

Paper: leaf height $208 \mathrm{~mm}$; wove; no $\mathrm{km}$.

printer: no imprint.

Publisher: Palmblad \& Co., Uppsala, Sweden.

Dates: part 1: 1824 (t.-p.); after 1 0ct. (pref.); offered for sale in Stockholm the first days of May 1825 (Mêm. Soo.Linn. Pario 4(3): 52, 1826); part 2: 1826 (t.-p.); in or after Feb. (pref.); after or about 28 Jun. 1826 ( $F$ lora $9(24)$ : 377 . 1826: ready, but not yet published). 
Reviews: part 1: G[uiilemin: BuzL.Soi. Nat. S(6): 237-241. 1825;

Svenak Litt. Tidn. 1824(82): 654-656. (1824 or early 1825?); 1 )

Iikstrom: Arober. Iramat.Bot. 1824: 519-522. 1825;

fart 1-2: Linnaea 1(4): 642-643.1826;

Fries: Svea Tilskr. Het.Konst, 1827(11): 66-83, 1827; 1)

part 2: Wikströn: Arsber.Framst.Eot. 1826: 175.1827; Stookholms-Posten 1830(49), (50), i \& 2 iar. 1830, is

1) derived from Vikstrom: Consp. litt. bot. Sucoia... Stockholm, 1833

Refs.: Arn.Ark. 1: 727

BiliH 2249

Brad1. $1: 353 \mathrm{a}$

Brun.5: 1399

Cat.Juss. $n .1804$
Graesse 7: 409

Krug. 122

Lindi. Libr. 260

Linn. Soc. 798

llilt. 178
Pr.ed.1 n.10890

Pr.ed. 2 n. 9916

Soulsb.Add. $829 \mathrm{C}$

Un,Edinh, 3: 1100

Wikstr. 278-280.

Bibl.notes. The part-title of part 2 apparently was printed from standing type of the title of part 1 (broken letters identical). From the three title-pages often one or two have been discarded, in connection with the binding of the book in two volumes or in one. In the latter case the introduction was bound before part 1 , in the first case sometimes too.

A prospectus for the work was issued in 1823 , see Iois(Oken) 1823(10), Lit.Anz.14, 1823. I have not yet seen a copy; according to the review the work was planned to have 40 sheets (actually 76 appeared). In July 1824 it was still expected that the work could be published in the summer of 1824: F loje 7(28): 443.1824 Jul. 28 .

A second edition appeared in 1831-33 with page-numbers up to XCVIII and 1134 , being corrected and augmented.

Bot.notes. A thorough Swedish flora in the traditional Linnaean classification, nevertheless made more useful by the presence of keys to the genera; in the introduction the reasons for retaining the Linnaean classification are explained.

A few new species and a number of new varieties were proposed by Wahlen-

berg in this flora, and also a number of new combinations were introduced. Musci are treated on p.695-795 (including Bepatioas) and p.1073-1075

(one doubtful species of Hepatioae on $p .1084$ ). Accoraing to Wukstrom, Consp. 279. 1831, a medal of the Swedish Royal Academy of Sciences was awarded to Hahlenberg for this book on 31 Mar. 1827.

ZENKER, Jonathan Carl Biogr. Born 1799 Mar. 1, Sundremda, Sachsen-Weimar, Germany.

Zenker received the first lessons from his father, a minister. In 1813 he studied at the symasium, Heimar, and he entered the University at Jena in autumn 1818 to study theology. This did not satisfy him; he was more interested in natural history. After a long hesitation he decided to change to natural history and medicine. In 1823 he went as a mentor of a young Hamburger to Dresden, where he continued his studies at the medico-surgical school. After going back to Jena, he received the degree of Dr. Phil, and soon after of Dr. Med. In the same year he qualified for "Privatdocent" in natural history at the University. He soon published his first zoological books, which later were followed by palaeontological publications. He was nominated extraordinarius professor at the philosophical "Facultat" of the University in 1828, and ordinarius professor at the medical "Facultat" in 1836. He became a member of the Academia Caesarea Leopoldino-Carolina in 1833. He was commemorated in the generic names Zenkeria Trinius 1837 (Gramineae). 2enkeria Annott 1838, a synonym of Apuleia Martius, nom.cons. (Leguminosae), and Zenkeria Reichenbach 1841, a homotypic synonym of Parmentiera A.P. de Candolle (Bignoniaceae).

Refs.: Flora 21(1): $16.1838 \mathrm{Jan} .7$. Hess, H.: Ailg. Deutsohe Biogr, 45: 62, 1900 . 
ZEINKER, Jonathan Carl \& DIETRICH, Friedrich Eavid

Nueci Thuringioi.

4 fasc. Jena, 1821-1825 [exsiccata].

Title: fasc.1: "Muoci Thuringici. | ishort swelled rule" I Fasc. I. I ilano swollod ruiej Jenae, | apud Auguat Sohmid. | 1821.".

fasc.2: Husci Thuringici vivis exemplaribus exhibuerant et illustraverant

I. C. Zenker et F. D. Dietrich, Jenae apud Schmid, fasciculus 2dus. 1822

(cited from Ioia(Oken) 1822(6): 663-665. 1822);

fasc.3-4: no indication.

Collation: $8^{\circ}$ : fasc.1: $\pi^{1} *^{4}$ i-ii 1-8; fasc.2-4: not seen.

Contents: $i$ engraved title; ii $]_{i}$ 1-2 preface, unheaded, signed: "Jenae mense Augusto | IDCCCXXI."; 3-8 text, descriptions of 25 species of mosses and hepatics; fasc.2-4 not seen. Language: Latin.

Speoimene: 25 specinens per fascicle, in total numbered 1-100;

fasc.1: 25 specimens pasted to rectos of 20 Jeaves, with printed labels pasted on the same leaf, with only information: number, binomial and author, e.g.: "4. Fontinal.j. antipyretica. L." icapital L $3 \mathrm{~mm}$. high?.

Wrappere: fasc.1: front wrapper: recto: title within frame, verso: Latin quotation back wrapper: same decorated frame as front, with a floral center-piece.

Paper: fasc.1: leaf height $203 \mathrm{~mm}$. (NYBG copy, cut); wove; wm.: "J WhatMaN | 1820 [outline]": fragment in text part

wrapper paper: outside pink-colored, thini laid, chains vertical.

Publisher: Schmid, August, Jena, Germany.

Dates: fasc.1: $1821\left(t_{0}-p_{0}\right)$; after Aug. (pref.);

bef. 15 liov. (Alig.Repert.Heueat.In-Ausl.Lit. 18214,

(3): 171-172, 1821):

fasc.2: 1822 (t.-p.)\} about Jun. (Ioig(Oken) 10(6): 663-665. 1822)\}

sem.2 (Hinrichs: Verseichn. Neuer Buch, from Sayre 67);

bef. 20 Dec. (J.Gén.Litt.Étrang., from Sayre 67);

fasc.3: 1823 (t.-p.); bef. $15 \mathrm{Jul}$. (Ailg.Repert.Neuest.In-Ausi.Lit. 1823?,

(1): 14. 1823);

fasc.4: 1825 (reported by Krager and Heinsius; no other information).

Reviews :

fasc.1: AlZg.Repert.Neuest.In-Ausl.Lit. 18214(3): 171-172. 1821;

Isis (Oken) $10(2): 211-212.1822$ (list and sample of 1 description);

fasc.2: Isis (Oken) 10(6): 663-664. 1822 (ca.Jun.);

fasc.3: Allg.Repert. Neuest.In-Ausi.Lit. $1823^{3}(1)$ : 14.1823 (Iist),

Isis (Oken) $14(3): 338-339.1824$ (ca. Mar.).

Refs.: Heins.7(2): 111

Kew 681 (fasc.1 only)

Krüg. 111

Milt. 282 (fasc.1-3).

Bibl.notes. Exsiccata in book form, with descriptions in text part, and not much information on the labels; specimens interspersed in herbaria without annotations as to source will be difficult to identify. The text part was worth being preserved and will be found in some botanical libraries.

Bot.notes. Exsiccata with an occasional new species or new name: Sphagnum praemorsum (fasc.1 n.18, p.6), with a valid description and the locality indication: "in ericetis elatioribus prope Bollwerk (Jen,) primum 4 Aug. 1821 fructiferum collegimus." Bypnum scalare (fasc.2 n.26) is a new name for Bypnum oriata-castrensis [L.l Hedwig, hence illegitimate, but blocking the later use of the name for another species. 


\begin{abstract}
ARNOTT $\mathrm{n} .2, \mathrm{p} .42$ :
Date: bef. 10 Apr. 1824 (see M\&m. Soa, Bist, Nat, Paris, p. 180)

Note. After sending the part with the treatments of Arnott's publications to the printer. I ascertained from Bibliogr. Exanoe the dates on which the journal was announced, which is much later than I expected from the correspondence between Arnott and Ad.Brongniart. Probably the separate of the article in the Memoirs of the Nernerian Natural Bistory Sooiety will have priority over this article.
\end{abstract}

ARNOTT $n .6, \quad$ p.46:

Date: bef. 9 Nov. 1826 (see Mdm. Soo. Bist. Nat. Paris, p. 180).

Note. Announcement in Bibliogr.Franoe much later than the date of the wrapper. I do not know the reason for this delay.

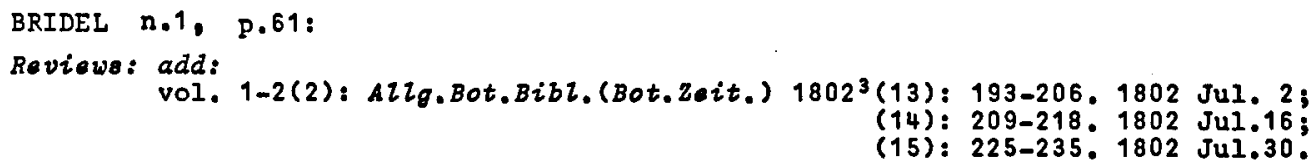

BRIDEL n.5, P.67:

Bibl.notes. Add after line 77 :

The publication of vol. 1 in 1826, at least before 7 Dec., and without

its supplement, is confirmed by the remark in Steudel \& Hochstetter, Enum. PI. Germ. Belvet., P.168, footnote, stating that the Orthotriahum-species of Bruch are missing.

DIETRICH, F.G. n.1, P.94:

Dates: add:

vol. 1: before 29 0ct. 1802 (Allg. Bot. Bibl. (Bot.Zett.) 18024(21): 325.

FUNCK $\mathrm{n} .1, \mathrm{p}, 117$ :

Dates: correot:

fasc. 26: 1 Apr. 1819 (FLora 2(16): 247-248. 1819 states that a copy was shown in a meeting on that day). 
In my work for the Index Musoorum it became apparent that dating problems existed for publications of the years 1825-1827, which were important for the nomenclature of Nusoi. The article by Annott, Nouvelite dieposition msthodique des espdaes de mousee, was indicated from 1825 in some sources, but the copy of the periodical consulted had the title-date 1827 and the fascicle conderned probably was issued in 1826. Bridel, Bryologia universa, had the internal date 16 Dec. 1826 in the preface, usually bound with vol.1; the year 1826 for this volume, therefore, could be doubted. Moreover a supplement to the same volume was apparently published later than the main text, but the date 1827, assigned to this part in the preparation of Index Musoorum, was not fully confirmed. Some of the 11 parts of Schwaegrichen, Speoies Musoorum ... supplementum, had to be dated with more precision, in connection with other works, than was possible during the work for the Index Muscorum.

Within the framework of the project Bibliographia Buntiana of the Hunt Botanical Library, Pittsburgh, Pa, it was possible to select a chapter of botanical bibliography, and the bryological pubilcations of these three years were chosen with the literature related thereto. An effort was made to trace every book containing names of Musi. Articles in periodicals were not checked as thoroughly as the books. To bridge the gap between 1825 and 1821, the last year studied by Dr. Sayre in her Dates of publioations treating Nusoi ... . bryological publications of the years 1822-1824 were studied too, but no effort was made to treat this period exhaustively.

The publications included in this thesis are described according to the method of descriptive bibliography, as developed by $W . W$. Greg, F. Bowers, and for botanical books by Allan Stevenson. This method is adapted to the problems of the books of the period, by omitting the description of some features (binding, type-font) and by using page references in the descriptions of the contents instead of signature references. Some refinements in the method are proposed and applied. A new key for determination of books of handmade paper, especially laid paper, is included.

Information concerning the dates of publication was derived from the references to reviews and announcements in contemporaneous periodicals, collected by a team of workers of the Hunt Botanical Library, I checked the original sources in many cases which might be critical. Moreover I studied several manuscript collections in botanical libraries and in archives. Completeness in these two fields, reviews and manuscripts, of course, is impossible, but some important sources remained untapped because of time restrictions.

The result is the first analytical bibliography of all publications on a plant group of a certain period, at least to my knowledge. A considerable number of dates of publication are given with more precision than was the case up to now. Some of the important solutions to special problems or new points which came to light are enumerated below.

1. The article of Arnott was published in no less than 5 variants. The first one certainly is the quarto separate, which has the title-date 1825 . My research made it probable that this was issued in January 1826 . The later variants may be of importance because of indirect references to Schwaegrichen and Gaudichaud.

2. The two volumes of Bridel: Bryologia universa, were indeed published in 7826 and 1827 , as the titles indicate; however, the supplement to vol.1 and the preliminaries were published together with vol.2.

3. The several parts of Schwaegrichen's supplements are placed in the chronological order with the other important publications. For some parts, however, more
accurate dates would be welcome.

4. The relative dates of Greville: Flora Edinenois, and the relevant fascicle of his scottioh oxyptogamio flora were better established than those used in the Index Muscorum.

5. The contents. of the fascicles of a number of books and periodicals were determined, mainly with the help of internal bibliographical evidence. These were in several cases not known to the last details, e.g. Hooker: Musoi exotioi and Exotio floxa. Off-sets of fascicle-titles in a particular copy of the latter work were helpful in establishing the breaks and dates of some fascicles.

6. Some publications were found, of which the new names of Musai were overlooked in the bryological literature (Canbessèdes, Chevallier).

7. The first color prints of mosses, to my knowledge, are indicated: of protonema in T.F.L. Nees von Esenbeck, 1824, and of complete plants in Somnerfelt, 1826, and Chevallier, 1826. 
8. Of several books cancellantia are described which were not yet indicated before, including some in the starting-point book, Hedwig: Speoies Muscorum frondosomm

9. Wove paper, originally used for expensive paper states of books, apparently became available in larger quantities and at relatively lower prices in the period treated, since several books show a shift from laid to wove paper. Machine-made paper was not yet often used for books; I only saw this paper type with certainty in the Transactions of the Linnean Society [London] of 1827 (see Greville $n .9$ ).

As a general result of this research I can discuss the development of bryology in the first three decades of the 19 th century, stressing the application of the natural classification to bryophytes, and the diverse opinions on the life cycle of mosses.

\section{A CKNOWLEDGEMENTS}

In the first place I acknowledge my gratitude to Dr. G.H.M. Lawrence, director of the Hunt Botanical Library, for the opportunities he gave me of working in his institution, for the time and facilities which he put at my disposal, and for his consent to prepare this thesis in the framework of Bibliographia Buntiana. Without this it would have been impossible to prepare this publication. I hope that my work may help to crystallize the method for the large project. I also want to express my warm gratitude for his personal interest and for the way he left me free to work out the chosen problems in my own way.

I also thank Prof. Dr. F.A. Stafleu for his interest in the start of the work and his advice on sources of new information, and for his help in the final stages of the publication. I regret that I was unable to check some of the references he suggested to me, and also that I was unable to put my information at his disposal for his publication Taxonomio literature.

I am very grateful to Prof. Dr. R. van der Wijk, editor-in-chief of the Indea Muscorum, for the opportunity he gave me to work for this index, which realized an old wish, and for his kindness to read the manuscript of this thesis and to criticize it. I hope he will be satisfied that some problems which arose during the preparation of the index now are solved.

I cordially thank Mr. I. MacPhail for introducing me into the method of descriptive and analytical bibliography, for his friendly help in many bibliographical difficulties, and for his willingness to read the first draft of my manuscript in a period in which he was loaded with work, and especially for his constructive criticisms I thank the following persons for their help with advice, literature, introductions etc. during my research in institutions in the United States and in Europe: Mme V. Allorge, Laboratoire de Cryptogamie, Muséum d'Histoire Naturelle, Paris, Dr. C.E.B. Bonner, Conservatoire Botanique, Genève;

Mr. R. Brown, Library, Botanical Garden, Edinburgh;

Mr. J.G. dé Bruyn, Library, Teylers Stichting, Haarlem;

Dr. Cohnert, Senckenberg Institut, Frankfurt am Main;

Mr. A.C. Crundwell, Botanical Institute, Glasgows

Dr. F. Demaret, Jardin Botanique de l'Etat, Bruxelles;

Mme G. Duprat, Bibliothèque Centrale, Muséum d'Histoire Naturelle, Paris;

Miss P.I. Edwards, Library. Botany Department, British Museum (Natural History), London; Dr. H. Gams, Botanisches Institut, Universitat, Innsbruck:

Dr. R. Heim, Muséun d'Histoire Naturelle, Paris;

Mme Jovet-Ast, Laboratoire de Cryptogamie, Muséum d'Histoire Naturelle, Paris;

Miss S. Raphael, Library, Linnean Society, London;

Dr. K. Rechirger, Naturhistorisches Museum, Wien;

Iirs. L. Schwarten, Gray Herbarium, Harvard University, Cambridge, Mass.

Dr. William C. Steere, New York Botanical Garden, Bronx, New York;

Dr. F. Verdoorn, Biohistorisch Instituut, Rijksuniversiteit, Utrecht;

Miss $\dot{H}$. de Wilde, Library, Instituut voor Systematische Plantkunde, Rijksuniversiteit, Utrecht.

I especially thank the team of workers of the Hunt Botanical Library excerpting periodicals of the Bibliographia Buntiana period: Dr. Claude Weber, Geneve (now Ithac N.Y.), Roman languages, IIiss I.H. Vegter, Utrecht, English ianguage, and Mn. F. Schüt, Utrecht, Germanic languages. I also thank my other colleagues of the Hunt Botanical Library for their help in several respects. 
The publications treated in this thesis journals excetect, are listed here is. chronologica? order. The dates on which pulijication was a prover or probabie fact are tal-en as the rain criterion; the dates of the last fre-publication. announcemert

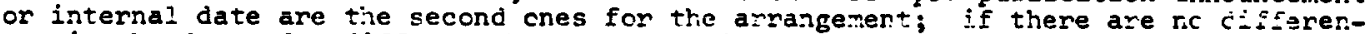
ces in the dates for different hooks or fascicles, the arrangement is aiphalietica:.

The following signs are usec in this list:

- indicates that publication was effective before this date;

* indicates that a small variation (hefore, after) is jossibie;

! indicates an exact day of publication;

? indicates coubt about the iate mentioned.

\begin{tabular}{|c|c|c|c|c|}
\hline $\begin{array}{l}1797 \\
1798\end{array}$ & $\begin{array}{l}\text { Jan. -Dec. } \\
\text { Jan.-Dec. } \\
\text { Jan.-Dec. } \\
\text { Jan.-Dec. }\end{array}$ & $\begin{array}{l}\text { Bride } 1 \\
\text { Bridel } \\
\text { Sturm } \\
\text { Sturm }\end{array}$ & $\begin{array}{l}n .1 \\
n .1 \\
n .1 \\
n .1\end{array}$ & 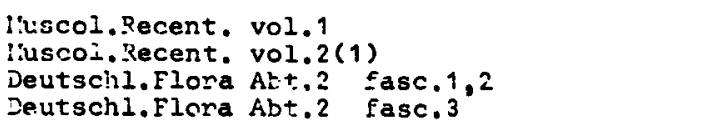 \\
\hline 1800 & $\begin{array}{l}\text { Feb. } \\
<\text { Oct.21 }\end{array}$ & $\begin{array}{l}\text { Funck } \\
\text { Sturm }\end{array}$ & $\begin{array}{l}n .1 \\
n .1\end{array}$ & $\begin{array}{l}\text { Crypt.Gew.Fichtelgeb. fasc. } 1 \text {, "Hof" } \\
\text { Deutschl.Flora Abt.2 fasc.4 }\end{array}$ \\
\hline 1801 & $\begin{array}{l}\text { Jan. } 1 ! \\
\text { May } 9 ! \\
\text { <Oct. } 12 \\
\text { Jan.-Dec. } \\
\text { Jan.-Dec. }\end{array}$ & $\begin{array}{l}\text { Hednis } \\
\text { Bridel } \\
\text { Funck } \\
\text { Eunck } \\
\text { Sturm }\end{array}$ & $\begin{array}{l}n \cdot 1 \\
n \cdot 1 \\
n \cdot 1 \\
n \cdot ? \\
n .1\end{array}$ & 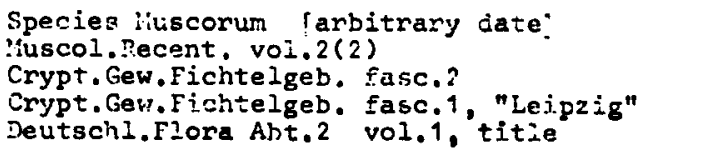 \\
\hline 1802 & $\begin{array}{l}<\text { Apr. } 22 \\
\text { Dec. } 27 \text { ! } \\
<\text { Oct.29 }\end{array}$ & $\begin{array}{l}\text { Funck } \\
\text { Sturm } \\
\text { Dietrich, F.G. }\end{array}$ & $\begin{array}{l}n .1 \\
\text { n.1 } \\
\text { r. } 1\end{array}$ & $\begin{array}{l}\text { Crypt.Gew.Fichtelgeb, fasc.3 } \\
\text { Deutschl.Flora Abt.2 Easc,5 } \\
\text { Vollst.Lexic.Gart., Rot. vol.1 }\end{array}$ \\
\hline 1803 & $\begin{array}{l}\text { Jan. -Har. } \\
\text { Sep. } 25: \\
\text { Jul.-Dec. }\end{array}$ & $\begin{array}{l}\text { Dietrich, F.G. } \\
\text { Bridel } \\
\text { Sturm }\end{array}$ & $\begin{array}{l}n \cdot 1 \\
n .1 \\
n .1\end{array}$ & $\begin{array}{l}\text { Yollst. Lexic.Gartn. Bot, vol. } 2 \\
\text { Muscol. Recent. voi.2( } 3 \text { ) } \\
\text { Deutschl.Flora Alt. } 2 \text { fasc. } 6\end{array}$ \\
\hline 1804 & $\begin{array}{l}\text { Mar. } \\
\text { Jul.-Sep. } \\
\text { Oct.-Dec. }\end{array}$ & $\begin{array}{l}\text { Sturm } \\
\text { Ejetrich, F. G. } \\
\text { Dietrich, F.G. }\end{array}$ & $\begin{array}{l}n \cdot 1 \\
n \cdot 1 \\
n \cdot 1\end{array}$ & $\begin{array}{l}\text { Deutschl.Fiora Abt. } 2 \text { fasc. } 7 \\
\text { Vollst.Lexic. Gartn. 3ot, vol.3 } \\
\text { Vollst.Lexic.3artn. Bot. vol. } 4\end{array}$ \\
\hline 1805 & $\begin{array}{l}\quad<\text { Jun. } 30 \\
\text { Apr.-Jun. } \\
\text { Jan.-Dec. }\end{array}$ & $\begin{array}{l}\text { Funck } \\
\text { Dietrich, F. G. } \\
\text { Sturm }\end{array}$ & $\begin{array}{l}n \cdot 1 \\
n \cdot 1 \\
n \cdot 1\end{array}$ & $\begin{array}{l}\text { Crypt. Sew.Fichtelgeb. Easc. } 4 \\
\text { Volist. Lexic.Gartn.Bot. vol.5 } \\
\text { Deutschl.Flora Abt.2 fasc.3; vol.2, title }\end{array}$ \\
\hline 1806 & $\begin{array}{l}<\text { Apr. } 1 \\
<\text { Apr. } 1 \\
<\text { Apr.20 } \\
\text { Apr.20! } \\
\text { Apr.20? } \\
\text { Apr.20? } \\
\text { Oct. -Dec. }\end{array}$ & $\begin{array}{l}\text { Balbis } \\
\text { Balbis } \\
\text { Funck } \\
\text { Bridel } \\
\text { Funck } \\
\text { Eunck } \\
\text { Dietrich, F. G. }\end{array}$ & $\begin{array}{l}n .1 \\
n \cdot 2 \\
n .1 \\
n .2 \\
n .1 \\
n .2 \\
n .1\end{array}$ & $\begin{array}{l}\text { Enum.Pl. Off. } \\
\text { Fl.Taurin. } \\
\text { Crypt.Gew.Fichtelgeb. fasc, } 5 \\
\text { iluscol. Recent.Suppl. part } 1 \\
\text { Crypt.Gew.Fichtelgeb. fasc. } 6 \\
\text { Crypt.Gew.Fichteleeb. ed.2, fasc.1-5 } \\
\text { Volist. Lexic.Gärtn. Bot. vol.E }\end{array}$ \\
\hline 1807 & $\begin{array}{l}\text { <iar. } 20 \\
\text { Jan.-Dec. }\end{array}$ & $\begin{array}{l}\text { Funck } \\
\text { Dietrich, F, G. }\end{array}$ & $\begin{array}{l}n .1 \\
n .1\end{array}$ & $\begin{array}{l}\text { Crypt.Gew.Fichtelgeb, fasn. } 7,3 \\
\text { Volist.jexic.Gartn.Bot. vo:.7 }\end{array}$ \\
\hline 1808 & $\begin{array}{l}<\operatorname{May} 1 \\
\text { <Jun. } 20 \\
\text { Jen.-Dec. }\end{array}$ & $\begin{array}{l}\text { Funck } \\
\text { Savi. } \\
\text { Dietrich, F, G. }\end{array}$ & $\begin{array}{l}n \cdot 1 \\
n \cdot 1 \\
n \cdot 1\end{array}$ & $\begin{array}{l}\text { Crypt.Gev.Fichtelgeb. fasc. } 9,10,11 \\
\text { Rot.Ftrusc, vol.1 } \\
\text { Volist.Lexic.Garsn. Bot. vol. } 8\end{array}$ \\
\hline 1809 & $\begin{array}{l}<\text { Apr.16 } \\
\text { Apr.16? } \\
<\text { Det. } 20 \\
\text { <Dec. } 20 \\
\text { Jan. - Dec. }\end{array}$ & $\begin{array}{l}\text { Funck } \\
\text { Funcl } \\
\text { Sturt: } \\
\text { Sturm } \\
\text { nietrich, F. G. }\end{array}$ & $\begin{array}{l}n \cdot 1 \\
n \cdot 1 \\
n \cdot 1 \\
n \cdot 1 \\
n \cdot 1\end{array}$ & $\begin{array}{l}\text { Crypt.Gew.Fichtelgeb. fasc.12, } 13 \\
\text { Crypt.Gew.Fichtelgeb. fasc.14 } \\
\text { Deutschl.Fiora Abt.2 fasc.9 } \\
\text { Deutsch. .Flora Abt.2 fasc.10 } \\
\text { Vollst.Lexic.Gartn.3ot. vol.9 }\end{array}$ \\
\hline 1810 & $\begin{array}{l}\text { <May } 6 \\
\text { May } 6 ? \\
\text { Jul.-Dec. } \\
\text { Ser.-Dec. } \\
\text { Sep.-Dec. }\end{array}$ & $\begin{array}{l}\text { Funck } \\
\text { Funck } \\
\text { Funck } \\
\text { :'ougeot \& Hestl } \\
\text { iietrich, F. G. }\end{array}$ & $\begin{array}{l}n \cdot 1 \\
n \cdot 1 \\
n \cdot 1 \\
. n \cdot 1 \\
n .1\end{array}$ & 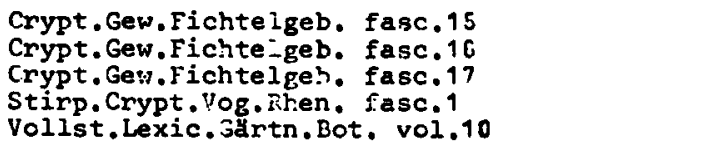 \\
\hline
\end{tabular}




\begin{tabular}{|c|c|c|c|c|}
\hline 1811 & $\begin{array}{l}\text { Apr. } 28 \\
\text { Iay -Jun. } \\
\text { Eul. } \\
\text { Jan.-Dec. } \\
\text { Jan.-Dec. }\end{array}$ & $\begin{array}{l}\text { Sturm } \\
\text { Funck } \\
\text { Schwaegrichen } \\
\text { Dietrich, F.G. } \\
\text { llougeot \& Negti. }\end{array}$ & $\begin{array}{l}n \cdot 1 \\
n \cdot 1 \\
n \cdot 1 \\
n \cdot 1 \\
n \cdot 1\end{array}$ & $\begin{array}{l}\text { Deutschl.Flora Abt.2 fasc.11 } \\
\text { Crypt.Gew.Fichtelgeb. fasc.18 } \\
\text { Spec.Husc.Suppl.1 Ivol.] } 1 \\
\text { Vollst.Lexic.Gärt. Bot. Gen.Reg. } \\
\text { Stirp.Crypt.Vog.Rhen. fasc.2 }\end{array}$ \\
\hline 1812 & $\begin{array}{l}\text { Sar. 20 } \\
\text { Iay 1! } \\
\text { Jun. 1! } \\
\text { Jul. 1! } \\
\text { A1s. 1! } \\
\text { Sep. 1! } \\
\text { Sep. 27? } \\
\text { Oct. 1! } \\
\text { Nov. 1! } \\
\text { Dec. 1! } \\
\text { Jan.-Dac. }\end{array}$ & $\begin{array}{l}\text { Sturm } \\
\text { Hooker } \\
\text { Hooker } \\
\text { Hooker } \\
\text { Hooker } \\
\text { Hooker } \\
\text { Bridel } \\
\text { Hooker } \\
\text { Hooker } \\
\text { Hooker } \\
\text { Mougeot \& Nestl. }\end{array}$ & $\begin{array}{l}n \cdot 1 \\
n \cdot 1 \\
n \cdot 1 \\
n \cdot 1 \\
n \cdot 1 \\
n \cdot 1 \\
n \cdot 2 \\
n \cdot 1 \\
n \cdot 1 \\
n \cdot 1 \\
n .1\end{array}$ & $\begin{array}{l}\text { Deutschl.Flora Abt. } 2 \text { fasc. } 12 \\
\text { Rrit.Jungerm. fasc. } 1 \\
\text { Brit.Jungerm. fasc.2 } \\
\text { Brit.Jungerm. fasc.3 } \\
\text { Brit.Jungerm. fasc. } 4 \\
\text { Brit.Jungerm. fasc.5 } \\
\text { Muscol.Recent. Suppl. part } 2 \\
\text { Brit.Jungerm. fasc.6 } \\
\text { Brit.Jungerm. fasc.7 } \\
\text { Rrit.Jungerm. fasc.8 } \\
\text { Stirp.Crypt.Vog.Rhen. fasc.3 }\end{array}$ \\
\hline 1813 & $\begin{array}{l}\text { Jan. } 1 ! \\
\text { Feb. 1! } \\
\text { Kar. 1! } \\
\text { <Apr. 1 } \\
\text { Apr.15! } \\
\text { Aug.15! } \\
\text { Sep.26? } \\
\text { Oct. } 2 ! \\
\text { Dec.18! } \\
\text { Jan.-Dec. } \\
\text { Jan.-Dec. }\end{array}$ & $\begin{array}{l}\text { Hooker } \\
\text { Hooker } \\
\text { Hooker } \\
\text { Sturn } \\
\text { Hooker } \\
\text { Hooker } \\
\text { Sturm } \\
\text { Hooker } \\
\text { Hooker } \\
\text { Mougeot Nestl. } \\
\text { Oken }\end{array}$ & $\begin{array}{l}n \cdot 1 \\
n \cdot 1 \\
n \cdot 1 \\
n \cdot 1 \\
n \cdot 1 \\
n \cdot 1 \\
n \cdot 1 \\
n \cdot 1 \\
n \cdot 1 \\
n \cdot 1 \\
n .1\end{array}$ & $\begin{array}{l}\text { Brit.Jungerm. fasc.9 } \\
\text { Brit.Jungerm. fasc.10 } \\
\text { Brit.Jungerm, fasc.11 } \\
\text { Deutschl.Flora Abt.2 fasc.13 } \\
\text { Brit.Jungerm. fasc.12 } \\
\text { Brit.Jungerm. fasc.13 } \\
\text { Deutschl.Flora Abt.2 fasc.14 } \\
\text { Brit.Jungerm. fasc.14 } \\
\text { Brit.Jungerm. fasc.15 } \\
\text { Stirp.Crypt.Vog. Rhen. fasc.4 } \\
\text { Lehrb.Naturgesch. vol.1 }\end{array}$ \\
\hline 1814 & $\begin{array}{l}\text { Apr. 24? } \\
\text { Jin. 1! } \\
\text { JuI.15! } \\
\text { Jan.-Dec. }\end{array}$ & $\begin{array}{l}\text { Funck } \\
\text { Hooker } \\
\text { Hooker } \\
\text { Cassebeer }\end{array}$ & $\begin{array}{l}n \cdot 1 \\
n \cdot 1 \\
n \cdot 1 \\
n \cdot 1\end{array}$ & $\begin{array}{l}\text { Crypt.Gew.Fichtelgeb, fasc.19 } \\
\text { Brit.Jungerm. fasc.16 } \\
\text { Brit.Jungerm. fasc.17 } \\
\text { Wetterauische Laubm. Decurie } 1\end{array}$ \\
\hline 1815 & $\begin{array}{l}\text { Apr. } 9 ? \\
\text { Jul: } 6-15 \\
\text { <Nov. } 1 \\
\text { Dec. } 4 \text { ! } \\
\text { Jan.-Dec. } \\
\text { Oct.-Dec. }\end{array}$ & $\begin{array}{l}\text { Funck } \\
\text { Hooker } \\
\text { Funck } \\
\text { Hooker } \\
\text { Oken } \\
\text { Dietrich, F.G. }\end{array}$ & $\begin{array}{l}n \cdot 1 \\
n \cdot 1 \\
n \cdot 1 \\
n \cdot 1 \\
n \cdot 1\end{array}$ & $\begin{array}{l}\text { Crypt.Gew.Fichtelgeb. fasc. } 20 \\
\text { Brit.Jungerm, fasc.18 } \\
\text { Crypt.Gew.Fichtelgeb. fasc. } 21 \\
\text { Brit.Jungerm. fasc.19 } \\
\text { Lehrb.Naturgesch, vol.3(1) } \\
\text { Nachtr.Vollst,Lexic.Gurtn,Bot, vol.1 }\end{array}$ \\
\hline 1816 & $\begin{array}{l}\text { Apr. 1! } \\
\text { Apr.28? } \\
\text { llay 1! } \\
<\text { May } 8 \\
<\text { llay } 9 \\
\text { Jun.15! } \\
\text { <Jun.19 } \\
\text { Nov.20 } \\
\text { Jan.-Dec. } \\
\text { Jan.-Dec. }\end{array}$ & $\begin{array}{l}\text { Hooker } \\
\text { Funck } \\
\text { Hooker } \\
\text { Sturm. } \\
\text { Schwae grichen } \\
\text { Hooker } \\
\text { Mougeot \& Nestl. } \\
\text { Savi } \\
\text { Dieirich, F.G. } \\
\text { Oken }\end{array}$ & $\begin{array}{l}n \cdot 1 \\
n \cdot 1 \\
n \cdot 1 \\
n \cdot 1 \\
n \cdot 1 \\
n \cdot 1 \\
n \cdot 1 \\
n \cdot 1 \\
n \cdot 3 \\
n \cdot 1\end{array}$ & $\begin{array}{l}\text { Brit.Jungerm. fasc. } 20 \\
\text { Crypt.Gew.Fichtelgeb. fasc.22 } \\
\text { Brit.Jungerm. fasc.21 } \\
\text { Deutschl.Flora Abt.2 fass.15 } \\
\text { Spec.1.usc.Suppl.1 [vol.]2 } \\
\text { Brit.Jungerm. fasc.22 } \\
\text { Stirp.Crypt.Vog.Rhen. fasc.5 } \\
\text { Bot.Etmusc. vol.2 } \\
\text { Nachtr.Volist.Lexic.Gärtn.Bot. vol.2 } \\
\text { Lehrb.Naturgesch. vol.3(2) }\end{array}$ \\
\hline 1817 & $\begin{array}{l}\text { Apr.20? } \\
\text { 20 Apr. - Jun.16 } \\
\text { Jun.18-31 } \\
\text { Sep.28 }\end{array}$ & $\begin{array}{l}\text { Dietrich } \\
\text { Funck } \\
\text { Eaton } \\
\text { Bridel }\end{array}$ & $\begin{array}{l}n .3 \\
n \cdot 1 \\
n .1 \\
n .2\end{array}$ & $\begin{array}{l}\text { llachtr.Vollst.Lexic,Gartn.Bot., vol.3 } \\
\text { Crypt.Gew.Fichtelgeb. fasc.2.3 } \\
\text { Mar.Bot. } \\
\text { Muscol.Recent.Sugpl. part } 3\end{array}$ \\
\hline 1818 & $\begin{array}{l}\text { Jar. 1! } \\
\text { Jan. 1! } \\
\text { Feb. 1! } \\
\text { Mar. 1! } \\
<\text { Mar. } 5 \text { Apr. 1! } \\
\text { Apr. } 1 ! \\
\text { May 1! }\end{array}$ & $\begin{array}{l}\text { Hooker } \\
\text { Hooker \& Taylor } \\
\text { Hooker } \\
\text { Hooker } \\
\text { Funck. } \\
\text { Hooker } \\
\text { Savi } \\
\text { Hooker } \\
\text { Funck }\end{array}$ & $\begin{array}{l}n \cdot 3 \\
n \cdot 1 \\
n \cdot 3 \\
n \cdot 3 \\
n \cdot 3 \\
n \cdot 1 \\
n \cdot 3 \\
n \cdot 1\end{array}$ & $\begin{array}{l}\text { Husci Exot. fasc.1 } \\
\text { Muscol. Brit. } \\
\text { Musci Exot. fasc. } 2 \\
\text { Musci Exot, fasc.3 } \\
\text { Crypt.Gew.FichteIgeb. fasc. } 24 \\
\text { Musci Exot. fasc. } 4 \\
\text { Bot.Etrusc. vol.3 } \\
\text { lissi Exot. fasc.5 } \\
\text { Crypt.Gew.Fichtelgeb. fasc. } 25\end{array}$ \\
\hline
\end{tabular}




\begin{tabular}{|c|c|c|c|c|}
\hline 1818 & 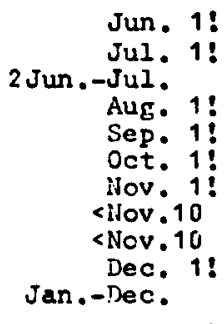 & $\begin{array}{l}\text { Hooker } \\
\text { Hooker } \\
\text { Faton } \\
\text { Hooker } \\
\text { Hooker } \\
\text { Hooker } \\
\text { Hooker } \\
\text { Hougeot \& Nestl. } \\
\text { Sturn } \\
\text { Hooker } \\
\text { Dietrich, F.G. }\end{array}$ & $\begin{array}{l}n \cdot 3 \\
n \cdot 3 \\
n \cdot 2 \\
n \cdot 3 \\
n \cdot 3 \\
n \cdot 3 \\
n \cdot 3 \\
n=1 \\
n \cdot 1 \\
n \cdot 3 \\
n \cdot 3\end{array}$ & 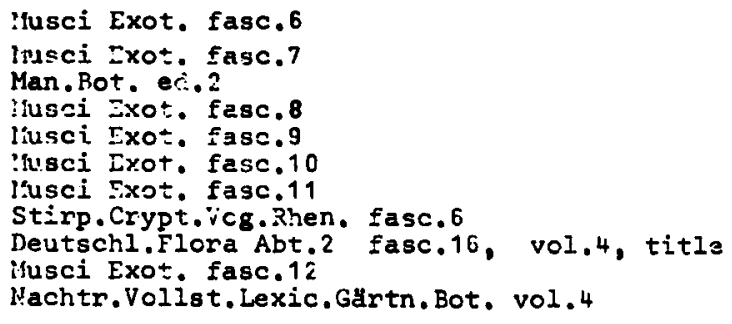 \\
\hline 1819 & 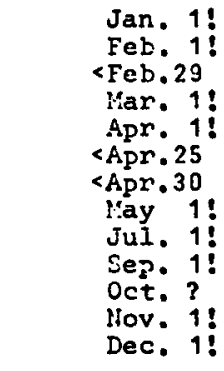 & $\begin{array}{l}\text { Hooker } \\
\text { Hcoker } \\
\text { Bridisl } \\
\text { Hooker } \\
\text { Hooker } \\
\text { Stumm } \\
\text { Funck } \\
\text { Hooker } \\
\text { Hooker } \\
\text { Hooker } \\
\text { Dietrich, F.G. } \\
\text { Hooker } \\
\text { Hooker }\end{array}$ & $\begin{array}{l}n \cdot 3 \\
n \cdot 3 \\
n \cdot 3 \\
n \cdot 3 \\
n \cdot 3 \\
n \cdot 1 \\
n \cdot 1 \\
n \cdot 3 \\
n \cdot 3 \\
n \cdot 3 \\
n \cdot 3 \\
n \cdot 3 \\
n \cdot 3\end{array}$ & 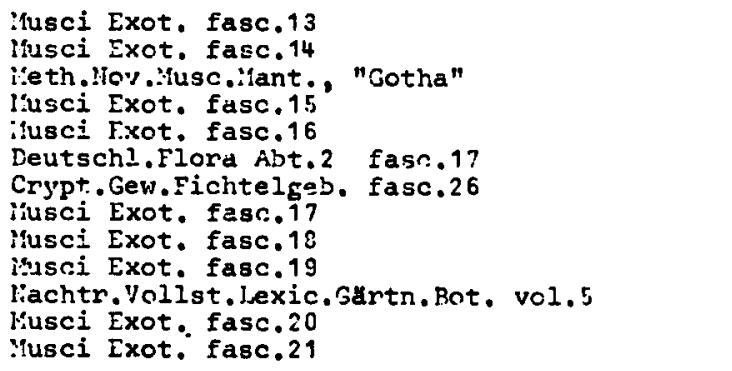 \\
\hline 1820 & $\begin{array}{l}\text { Apr. } 16 ! \\
\text { May 1! } \\
\text { <Oct.15 } \\
\text { <Nov. } \\
\text { < Dec. } 21 \\
\text { Jan. - Dec. } \\
\text { Jan. - Dec. }\end{array}$ & $\begin{array}{l}\text { Funcl. } \\
\text { Hocker } \\
\text { Dietrich, F.G. } \\
\text { Dietrich, F.G. } \\
\text { Funck } \\
\text { Hougeot Ilestl. } \\
\text { Nees, T. E. I. }\end{array}$ & $\begin{array}{l}n \cdot 1 \\
n \cdot 3 \\
n \cdot 2 \\
n \cdot 3 \\
n \cdot 3 \\
n \cdot 1 \\
n .1\end{array}$ & 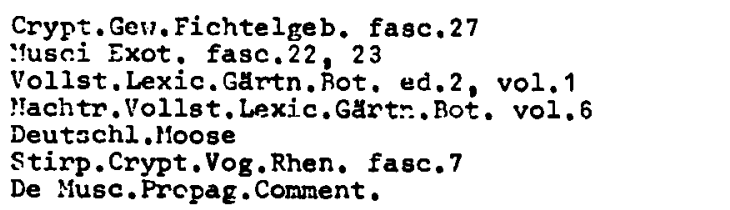 \\
\hline 1821 & $\begin{array}{r}<\text { Hay } 10 \\
\text { May } \\
<J u n .28 \\
<J u 1.15 \\
\text { Aug. - Nov. } 15\end{array}$ & $\begin{array}{l}\text { Hooker } \\
\text { Greville } \\
\text { Steudel } \\
\text { Dietrich, F.G. } \\
\text { Zenker \& Dietr. }\end{array}$ & $\begin{array}{l}n \cdot 4 \\
\text { r. 1-3 } \\
\text { n.1 } \\
\text { n.3 } \\
\text { n. } 1\end{array}$ & $\begin{array}{l}\text { Fl.Scotica } \\
\text { [in] Uemnins Wernerian Wat. Hist.Soc. } \\
\text { Nomencl.Bot. part } 1 \\
\text { Nachtr.Yolist. Lexic.Gartn. Bot. vol. } 7 \\
\text { Musci Thuring. fasc.1 }\end{array}$ \\
\hline 1822 & $\begin{array}{c}\text { Jan.? } \\
\text { Mar. 23 } \\
\text { <Apr. 22 } \\
\text { <May ? } \\
\text { Jun. } \\
\text { Jun. } \\
\text { Jul. [1] } \\
\text { Aug. [1] } \\
\text { Aug. [1] } \\
\text { AuE. } \\
\text { Aug. } \\
\text { Sep. [1] } \\
\text { Jun.-Sep. 29 } \\
\text { Dct. [1] } \\
\text { Nov. [1] } \\
\text { Dec. [1] } \\
\text { Dec. 1! } \\
\text { <Dec. 10 } \\
\text { Jan.-Dec. } \\
\text { Jan.-Dec. } \\
\text { Jan.-Dec. } \\
\text { Jan.-Dec. }\end{array}$ & $\begin{array}{l}\text { Bridel } \\
\text { Eaton } \\
\text { Grev. \& Arnott } \\
\text { Cassebeer } \\
\text { Dietrich, F.G. } \\
\text { Zenker \& Dietr. } \\
\text { Greville } \\
\text { Greville } \\
\text { Hooker } \\
\text { Greville } \\
\text { Grev, Arnott } \\
\text { Greville } \\
\text { Funck } \\
\text { Greville } \\
\text { Greville } \\
\text { Greville } \\
\text { Hooker } \\
\text { Kunth } \\
\text { Gooker } \\
\text { Breutel } \\
\text { Hornschuch } \\
\text { Perleb } \\
\text { Schultz, C.F. }\end{array}$ & 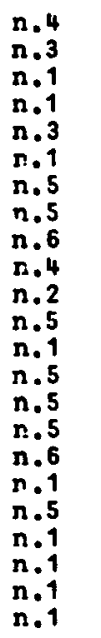 & 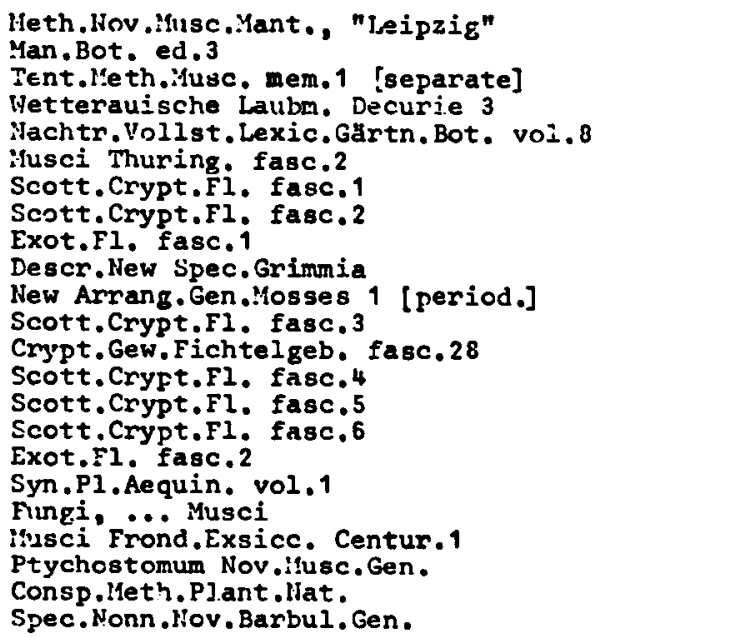 \\
\hline
\end{tabular}




\section{$\operatorname{Jan}: 19$ \\ Teb. $1=$ \\ Apr. 1 - \\ Apr. 1 - \\ Apr. 1 :}

SApr. 15

May [1.

Jun. 1!

Jun. 1 :

<Jul. 1

Jul. 1:

<Jul. 1 ?

<Jul. 1 ?

<Jul. 15

Aug. [1]

AAug. 15

Sep.:1:

<Sep. 23

Jan.-Sep.

Oct. [1]

Nov. 11$]$

SNov. 30

Dec. [1]

Dec.! 1 ?

<Dec 18

Hov,-Dec.

Dec.

May $\rightarrow$ Dec.

1824
Greville

Greville

Greville

Kunth

Greville

Hooker

(llees, C. G., Horn-

schuch Sturm

Greville

Hooker

Greville

Funck

Greville

Reinwardt

C.G.Nees

Schultz, C.F.

Zenker \& Dietr. $n$.

Greville

Dietrich, F.G.

Greville

Baron

Schwaegrichen

Greville

Greville

Cassebeer

Greville

Hooker

Grev. \& Arnott

Arnott

Pal. Beauv.

Brown, $R$.

Greville

Hooker

Arnott

Greville

Hooker

Kunth

Mougeot \& Nestl. $n$.

Hooker

Greville

Greville

Hooker

Greville

Hooker

Arnott

Grev. \& Arnott

Greville

Hooker

Greville

Hooker

Hooker \& Grev.

Desvaux

Breutel

Nees, C.G.

Funck

Greville

Hooker

Dietrich, F.G.

Greville

Hooker n.5 Scott.Crypt.Fl. fasc.7

n.5 Scott.Crypt.Fl. fasc. 9

n.5 Scott.Crypt.Fl. fasc.9

n.1 Syn.Pl.Aequin. vol. 2

n.5 Scott.Crypt.Fl, fasc. 10

n.6 Exot.Fl. fasc.3

Bryol.Germ, vol.1

Scott.Crypt.Fl. fasc.11

Exot.Fl. fasc. 4

Scott.Crypt.Fl. fasc.12

Crypt.Gew.Fichtelgeb. fasc.29

Scott.Crypt.Fl, fasc.13

Spiridens, Nov.Husc. ... Gen.

Recensio Gen.Barbul.Syntrich.

Musci Thuring. fasc. 3

Scott.Crypt.FI. fasc. 14

Nachtr.Vollst. Lexic.Gärtn.Bot, vol.9

Scott.Crypt.FI. fasc. 15

F1.DÉp.Mérid. France

Spec.Musc. Suppl.2 [vol.] 1(1)

scott.Crypt.FI. fasc.16

Scott.Crypt.Fl. fasc. 17

Ueb. Entw. Laubr.

Scott.Crypt.Fl, fasc.18

Exot.Fl. fasc. 5

Tent.Meth.Musc. mem.2 [separate]

Sur quelque mousses de Rio de Janeiro

n.1,2 Muscologie

n.1 Chloris Melvill.

n.5 Scott.Crypt.Fl, fasc. 19

n.6 Exot.Fl. fasc.6, vol.1, title

n.3 Notice Journ.Voyage Rio Jan. Peru [separate]

n.5 Scott.Crypt.Fl, fasc. 20

n.6 Exot.Fl. fasc. 7

Syn.Pl.Aequin, vol.3

Stirp, Crypt.Vog.Rhen. fasc. 8

Scott.Crypt.Fl. fasc. 21

Exot.Fl. fasc. 8

Fl.Edinens.

Scott.Crypt.Fl, fasc. 22

Exot.Fl. fasc.9

Scott.Crypt.FI, fasc. 23

Exot.Fl. fasc. 10

Notice Journ.Voyage Rio Jan. Peru [period.]

Tent.Meth.Musc. 2 period.

Scott.Crypt.Fl. fasc. 24

Exot.Fl. fasc.11

Scott.Crypt.Fl. fasc. 25

Exot.Fl. fasc. 12

Sketch ... Orthotrichum [period.]

Expos.Meth.Genr.Mouss.

Beitr.lloosg. Sphagnum

Nachschr. Breut. Beitr.Moosg. Sphagnum

Crypt.Gew.Fichtelgeb. fasc.30

Scott.Crypt.FI, fasc. 26

Exot.Fl. fasc.13

Bericht. Bemerk. Inh. Vollst, Lexic.

Scott.Crypt,Fl. fasc. 27

Exot.Fl. fasc.14 


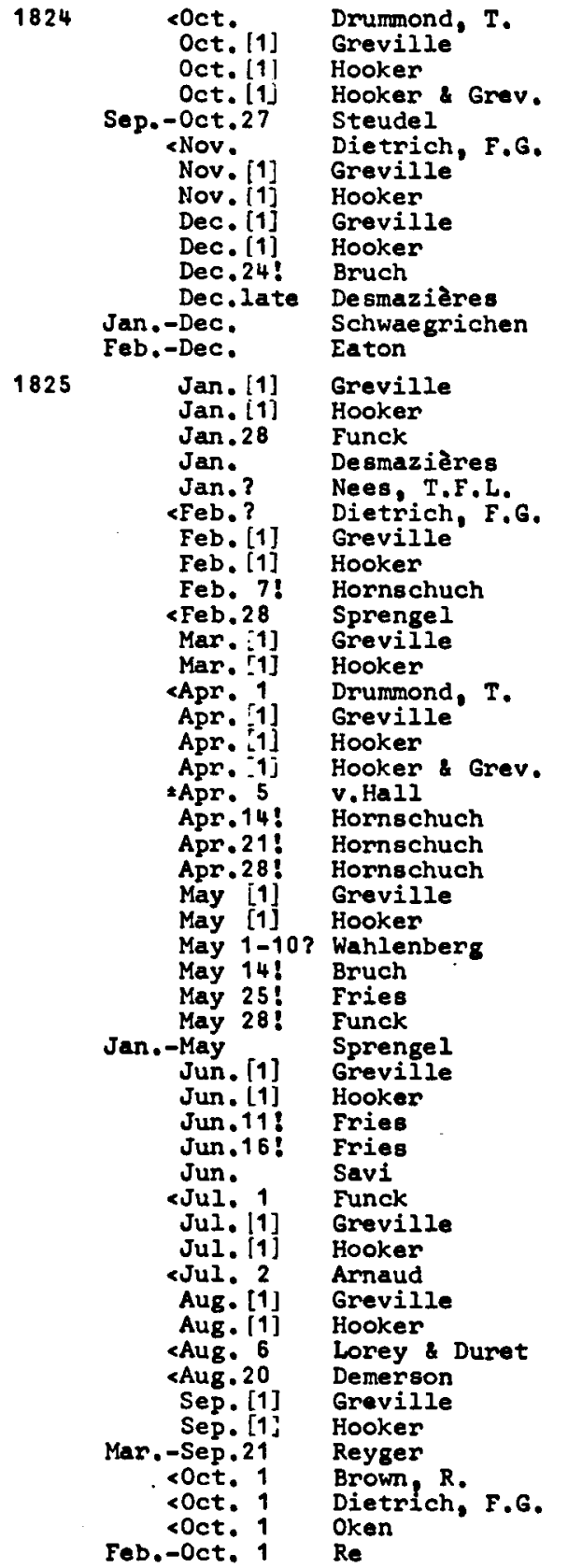

n.1 llusci Scot. vol.1

n.5 Scott.Crypt.Fl, fasc. 28

n.6 Exot.Fl. Fasc. 15

n.2 On Genus Tortula

n.1 Nomencl.Bot. part 2

n.2 Vollst,Lexic.Gärtn.Bot, ed.2, vol.2

n.5 Scott.Crypt.Fl. fasc.29

n.6 Exot.Fl. fasc.16

n.5 Scott.Crypt.Fl. fasc. 30

n.6 Exot.Fl. fasc. 17

n.1 Verz,Laubm.Zweibruck.

n.1 Pl.Crypt.Nord France [pref.]

n.1 Spec.Musc.Suppl.2 vol.1(2)

n.4 Man.Bot. ed. 4

n.5 Scott.Crypt.Fl. fasc.31

n.6 Exot.Fl. fasc. 18

n. 4 Moose Ungebung Bayreuth

n.1 P1.Crypt.Nord France fasc.1

n.2 Beobacht.Entw, Laubm.

n.3 Nachr.Vollst.Lexic.Gurtn.Bot, vol, 10

n.5 Scott.Crypt.Fl, fasc. 32

n.6 Exot.Fl. fasc.19

n.3 Diagn, Heuer Laubm.

n.1 Syst.Veg. vol.1

n.5 Scott. Crypt.Fl. fasc. 33

n.6 Exot.Fl. fasc. 20

n.1 Musci Scot. vol.2

n.5 Scott.Crypt.Fl. fasc. 34

n.6 Exot,Fl, fasc.21

n.3,4 On Genus Hookeria [period., separate]

n.1 F1.Belg. Septentr. vol.1(1)

n.4 Beitr.Gesch.Fortschr.Kenntn.Moose [1]

n.4 Beitr.Gesch, Fortschr, Kenntn.Moose [2]

n.5 Corresp. [Ober Brown Fl, Melv. Insel]

n.5 Scott.Crypt.Fl. fasc.35

n.6 Exot.Fl. fasc. 22

n.1 Fl. Suec, part 1

n.2 Bemerk.Phascum altern., subul., globif.

n.1 Stirp.Agri Fems. [1]

n.5 Corresp.

n.1 Syst.Veg. vol. 2

n.5 Scott.Crypt.Fl, fasc.36

n.6 Exot.Fl. fasc. 23

n.1 Stirp.Agri Fems. [2, 3 I

n.1 Stirp.Agri Fems. [4]

n.1 Bot.Etrusc. vol.4

n.1 Crypt.Gew.Fichtelgeb. fasc.31

n.5 Scott.Crypt.Fl. fasc. 37

n.6 Exot.Fl. fasc. 24

n.1 Fl.Dép.Haute-Loire

n.5 Scott,Crypt.Fl, fasc,38

n.6 Exot.F1. fasc. 25

n.1 Cat.Pl.Cote-d'-Or

n.1 Bot.Enseign.22 Lecons

n.5 Scott.Crypt.Fl. fasc. 39

n.6 Exot.Fl. fasc.26, vol.2, title

n.1 Um Danzig Wildw.Pfl, ed.2, vol.1 [ed, Weiss]

n.2 Vermischte Bot.Schrift. vol.1

n.5 Neuer Nachtr.Vollst.Lexic. vol.1

n.1 Lehrb.Naturgesch, vol.2(2i)

n.1 Fl.Torin. vol.1 


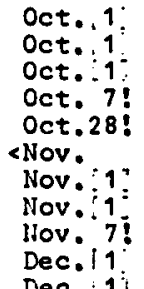

Oct. 1

Oct. 1

Oct. 1 :

0ct. 7 !

0ct.28!

<Nov.

Nov : 1 :

Nov : 1 :

llov. 7 !

Dec. 11 :

Jan -Dec.

Dec.

Jan.-Dec.

Har.-Dec.

Mar.-Dec.

28 May -Dec.

Jul.-Dec.

1826

Jan. [1]
Jan. 1!
<Jan. 3
<Jan. 3
<Jan.16
<Jan. 25
Jan. ?
Jan. ?
Feb. 1 j
Feb. [ 1$]$

Jan.-Feb. 5

Feb. 14

Jan - Feb.

Mar. [1]

Mar. [1]

Mar.21!

Apr.

<Apr.

AApr. 1

<Apr.

Apr. [1]

Apr. 11

Apr.14!

$<$ Apr. 22

May :1:

May 14 !

$<$ May 15

$<$ May 28

May ?

Jan.-May ?

<Jun.

Jun. i1]

< Jun. 28

Apr.-Jun.

$28 \mathrm{Jul}$.-Jul.?

Jul.

$<$ Aug. 5

<Aug. 9

<AUE. 9 ?

Aug. 30

Aug.

Aug.
Greville

Hooker

Hooker Grev.

Kneiff

Bruch

Presl, K.B.

Greville

Hooker

Fröhlich

Greville

Hooker

Baxter

Kneiff larker n

Zenker \& Dietr. $n$.

Desmazières

Pernitzsch

Buch

Hornschuch

Greville

Hooker

Greville

Grev. Arnott

Kunth

v.Hall

Grev. \& Arnott

Opiz

Greville

Hooker

Arnott

Breutel

Sprengel

Greville

Hooker

Bruch

Bridel

Brown, $R$.

Demerson

Reyger

Greville

llooker

Bruch

Buch

Hooker

Hochstetter

Schwaegrichen

Greville

Cassebeer

Mougeot \& Nestl.n.

Desmazières

Hooker

Lamouroux

Ramond

Wahlenberg

Greville

Chevallier

Arnott

Kitte l

Arnott

Lamouroux

Arnott

Greville n.5 Scott.Crypt.Fl, fasc. 40

n.6 Exot.F1. Fasc. 27

On Genus Calymperes

Standort Zygodon conoid.

Ueber Sphagna

Reliq.Haenkean. fasc. 1

Scott.Crypt,Fl. fasc. 41

Exot.Fl. fasc. 28

Pfl. .... Stech in Lechthale ... Gebirg

Scott.Crypt.Fl. fasc. 42

Exot.Fl. fasc. 29

Stirp. Crypt.0xon, fasc. 1

Musci Frond.Alsat. fasc. 1

Musci Thuring. fasc. 4

P1.Crypt,Nord France fasc. 2

Fl. Deutschl. Wald.

Phys.Beschr.Canar. Inseln (except pls.)

[Rev.Schwaegr.Suppl.2 [vol.]1(1)]

Scott,Crypt, Fl, fasc, 43

Exot.Fl, fasc. 30

Descr. 2 New Musci

Descr. 2 New Musci, Addendum

Tent.Meth.Musc. 3 [period.]

Syn. P1,Aequin. vol. 4

Fl. Belg.Septentr. vol.1(2)

Tent.leth.Musc, memoir 3 [separate]

Hachtr. Bohs. Phan . Krypt. Gew.

Scott. Crypt.Fl, fasc. 44

Exot.Fl. fasc. 31

Disp.Méth.Esp.Mousses $4^{\circ}$ [separate]

Einige Vergl.Bemerk.Phascum, Gymnostomum

Syst.Veg. vol.3

Scott.Crypt.Fl. fasc. 45

Exot.Fl. fasc, 32

Bryol. Beobacht.

Bryol.Univ. vol.1 (without pref, or suppl.)

Vermischte Bot.Schrift, vol.2

Bot.Enseign. 22 Lecons ed.2

Um Danzig Wildw.Pf1. ed.2, vol.2 (ed.Weiss)

Scott.Crypt.Fl. fasc. 46

Exot.Fl. fasc.33

Corresp.

Phys.Beschr.Canar. Inseln pls,3-13

Exot.Fl. Fasc, 34

Nachtr.Bemerk.Fleisch.Bot.Reise Tyrol

Spec.Musc.Suppl. 2 vol. 2 (1)

Scott. Crypt.Fi. fasc. 47

Ueb.die leichteste Meth. ...

Stirp.Crypt.Vog.Rhen, fasc, 9

P1.Crypt.Nord France fasc. 3

Exot.FI. fasc, 35

Résumé Compl.Bot. vol.1

Etat Vég.Pic du Midi

Fl. Suec. part 2

Scott.Crypt.Fl. fasc.49

Fl.Gén.Envir.Paris vol.1, pls.1-18

Nouv.Disp.Méth.Esp.Mouss, $8^{\circ}$ separate

Mémoires Hist.Nat.

Nouv.Disp.Méth.Esp.Mcuss. 8" period.

Rapport Nouv.Disp. Amott $8^{\circ}$ period.

n.1 Résumé Compl.Bot. vol.2

n.9, 10 Tour S. France Pyren. [1]

n.5 Scott.Crypt.Fl. fasc. 50 


\begin{tabular}{|c|c|c|c|c|}
\hline $\begin{array}{r}\text { Jan. } \\
\text { Jan. } \\
\text { Jan. } \\
\text { Jan. } \\
\text { Jan. } \\
12 \text { Feb. } \\
13 \text { Mar. } \\
\text { May } \\
27 \text { JuI. } \\
\text { Jul. }\end{array}$ & $\begin{array}{l}\text { Sep. } 23 \\
\text { Sep. } \\
\text {-Oct. } 1 \\
\text { <Oct.14 } \\
\text { <Oct. } 28 \\
\text {-Oct. } \\
\text { Oct. } \\
\text { Oct. } \\
\text {-Nov. } 8 \\
\text {-Nov. } \\
\text { Nov. } \\
\text { <Dec. } 7 \\
\text { <Dec. } 9 \\
\text { <Dec. } 27 \\
\text {-Dec. } \\
\text {-Dec. } \\
\text {-Dec. } \\
\text {-Dec. } \\
\text {-Dec. } \\
\text {-Dec. } \\
\text {-Dec. } \\
\text {-Dec. } \\
\text {-Dec. } \\
\text {-Dec. } \\
\text { Dec. } \\
\text { Dec. }\end{array}$ & $\begin{array}{l}\text { Gaudichald } \\
\text { Greville } \\
\text { Drummond, J.L. } \\
\text { Funck } \\
\text { Perleb } \\
\text { Demerson } \\
\text { Arnott } \\
\text { Greville } \\
\text { Arnott } \\
\text { Hooker } \\
\text { Greville } \\
\text { Steudel Hochst. } \\
\text { Brébisson } \\
\text { Gaudichaud } \\
\text { Dietrich, F.G. } \\
\text { Savi } \\
\text { Sommerfelt } \\
\text { Martinov } \\
\text { Oken } \\
\text { Re } \\
\text { Somnerfelt } \\
\text { Desmazières } \\
\text { Sauter } \\
\text { Nolte } \\
\text { Greville } \\
\text { Hooker }\end{array}$ & $\begin{array}{l}n \cdot 1 \\
n \cdot 5 \\
n \cdot 1 \\
n \cdot 1 \\
n \cdot 1 \\
n \cdot 4 \\
n \cdot 9 \\
n \cdot 5 \\
n \cdot 6 \\
n \cdot 6 \\
n \cdot 5 \\
n \cdot 1 \\
n \cdot 1 \\
n \cdot 1 \\
n \cdot 5 \\
n \cdot 2 \\
n \cdot 1 \\
n \cdot 1 \\
n \cdot 1 \\
n \cdot 1 \\
n \cdot 2 \\
n \cdot 1 \\
n \cdot 1 \\
n \cdot 1 \\
n \cdot 5 \\
n \cdot 5\end{array}$ & 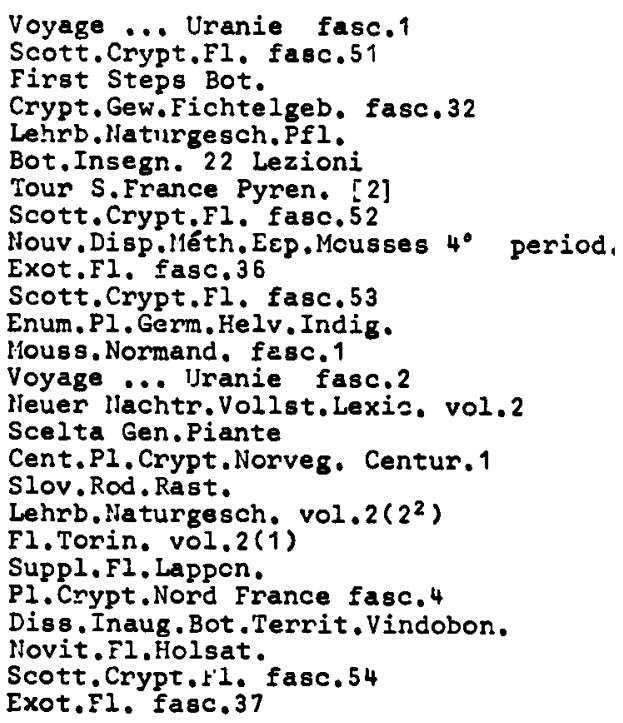 \\
\hline May & 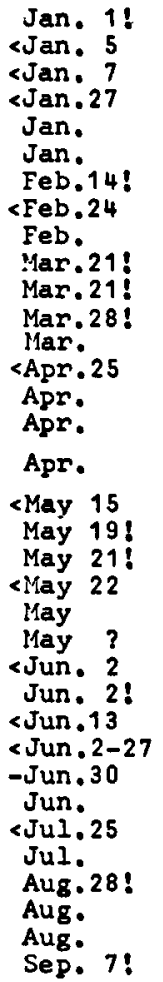 & $\begin{array}{l}\text { Hooker Taylor } \\
\text { Chevallier } \\
\text { Sprengel } \\
\text { Behere } \\
\text { Greville } \\
\text { Hooker } \\
\text { Hochstetter } \\
\text { Gaudichaud } \\
\text { Greville } \\
\text { Funck } \\
\text { Schultz, C.F. } \\
\text { Bruch } \\
\text { Greville } \\
\text { de Candolle,A.P. } \\
\text { Arnott } \\
\text { Greville } \\
\text { Nees, C.G., Horn- } \\
\text { schuch : Sturm } \\
\text { Sprengel } \\
\text { Fries } \\
\text { Laurer } \\
\text { Lestiboudois } \\
\text { Greville } \\
\text { Schwaegrichen } \\
\text { Cambessedes } \\
\text { Fries } \\
\text { Gaudichaud } \\
\text { Cambessddes } \\
\text { Desvaux } \\
\text { Greville } \\
\text { Demerscn } \\
\text { Greville } \\
\text { Hoppe } \\
\text { Arnott } \\
\text { Greville } \\
\text { Hoppe }\end{array}$ & $\begin{array}{l}n .2 \\
n \cdot 1 \\
n \cdot 1 \\
n .1,2 \\
n .5 \\
n .6 \\
n \cdot 3 \\
n .1 \\
n .5 \\
n .6 \\
n \cdot 3 \\
n \cdot 6 \\
n \cdot 5 \\
n \cdot 1 \\
n \cdot 9,10 \\
n \cdot 5\end{array}$ & 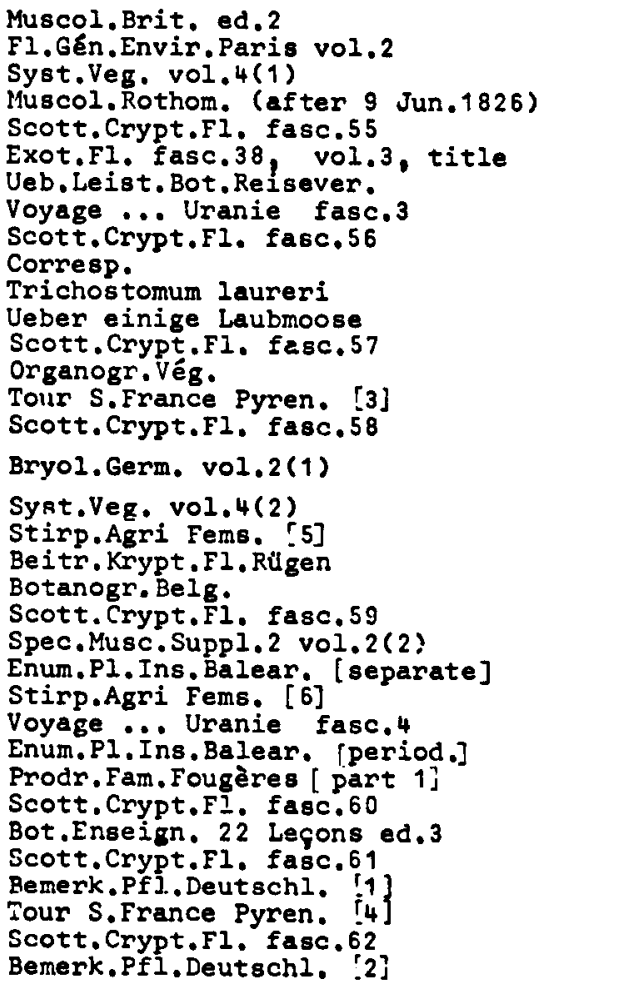 \\
\hline
\end{tabular}




\begin{tabular}{|c|c|c|}
\hline 1827 & 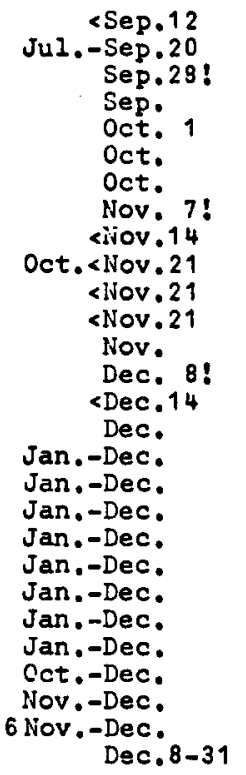 & $\begin{array}{l}\text { Gaudichaud } \\
\text { Desvaux } \\
\text { Hoppe } \\
\text { Greville } \\
\text { Brown, R. } \\
\text { Arnott } \\
\text { Greville } \\
\text { Hoppe } \\
\text { Eecker } \\
\text { Balbis } \\
\text { Balbis } \\
\text { Bridel } \\
\text { Greville } \\
\text { Fries } \\
\text { Funck } \\
\text { Greville } \\
\text { Desmazières } \\
\text { Kneiff \& Märker } \\
\text { Presl, K. B. } \\
\text { Re } \\
\text { Re } \\
\text { Schultz, C.F. } \\
\text { Sommerfelt } \\
\text { Somnerfelt } \\
\text { Hornemann } \\
\text { Schwaegrichen } \\
\text { Grevilie } \\
\text { Fries }\end{array}$ \\
\hline 1828 & $\begin{array}{c}\text { Jan. } \\
\text { Jan. } \\
\text { Jan. ? } \\
\text { Jan. } \\
\text { <Feb.23 } \\
\text { Feb. } \\
\text { Mar. } \\
\text { Mar. } \\
\text { Apr. } \\
\text { Apr. } \\
\text { Apr. } \\
\text { Jay } \\
\text { Jun. } \\
\text { May -Jul. } 5 \\
\text { Jun.-Jul. } \\
\text { <Aug.16 } \\
\text { JuI.-Aug. } \\
\text { <Sep.27 } \\
\text { Oct. } \\
\text { <Dec. } \\
\text { Dec. } 27 \\
\text { Jan.-Dec. } \\
\text { Jan.-Dec. } \\
\text { Jan.-Dec. } \\
\text { Jan.-Dec. } \\
\text { Jul.-Dec. } \\
\text { Sep.-Dec. }\end{array}$ & $\begin{array}{l}\text { Arnott } \\
\text { Greville } \\
\text { Furnrohr } \\
\text { Hornschuch } \\
\text { Gaudichaud } \\
\text { Greville } \\
\text { Greville } \\
\text { Hornschuch } \\
\text { Arnott } \\
\text { Greville } \\
\text { Hornschuch } \\
\text { Greville } \\
\text { Greville } \\
\text { Balbis } \\
\text { de Candolle, A, P. } \\
\text { Gaudichaud } \\
\text { Sprengel } \\
\text { Brébisson } \\
\text { Arnott } \\
\text { Schwaegrichen } \\
\text { Gaudichaud } \\
\text { Baxter } \\
\text { Desmazières } \\
\text { Drummond, T. } \\
\text { Presl, K. B. } \\
\text { Funck. } \\
\text { Becker }\end{array}$ \\
\hline 1829 & $\begin{array}{c}\text { Jan. } \\
\text { <Apr.18 } \\
\text { Apr. } \\
\text { Easterfair } \\
\text { <Jul.18 }\end{array}$ & $\begin{array}{l}\text { Schwaegrichen } \\
\text { Brébisson } \\
\text { Arnott } \\
\text { Sturm } \\
\text { Gaudichaud }\end{array}$ \\
\hline
\end{tabular}

n.1 Voyage ... Uranie fasc.5

n.2 Prodr.Fam.Fougères part 2

n.1 Bemerk.Pfl.Deutschl. ij

n.5 Scott.Crypt.Fl. fasc.63

n.2 Vermischte Bot.Schrift. vol.3

n.9,10 Tour S. France Pyren. [5]

n. 5 Scott.Crypt.Fl. fasc. 64

n.1 Bemerk.Pfl.Deutschl. : 7 ?

n.1 Fl.Geg.Frankf.a.M. sect.1

n.3 Fl. Lyonn, vol.1(1)

n.3 Fl.tyonn. vol.1(2)

n.5 Bryol.Univ, vol.1 (pref., suppl.), vol.2

n.5 Scott.Crypt.Fl. fasc.65

n.1 Stirp.Agri Fems. [7]

n.1 Crypt.Gew.Fichtelgeb. fasc.33

n. 5 Scott.Crypt.Fl. fasc. 66

n.1 Pl.Crypt. Nord France fasc.5, 6

n.1 Musci Frond,Alsat, fasc, 7

n.1 Feliq.Haenkean. vol.1(2)

n.1 Fl.Torin. vol.2(2)

n.2 Ad Fl.Pedemont.Append.Alt.

n.4 Observ. Bryol.

n.1 Cent.Pl.Crypt.Norveg. Centur.2

n.3 Bemaerkn.Suppl.Fl.Lappon.

n.1 Nomencl.El.Dan

n.1 Spec.lusc.Suppl.3 vol.1(1)

n.9 Some Acc.Crypt.Pl.Ionian Isls.

n.2 Stirp.Agri Fens. Index [re-issue]

n.9,10 Tour S.France Pyren. [6]

n.5 Scott.Crypt.FI. fasc. 67

n.1 Versuch Beleucht.Disp.Meth.

n.8 Berichtigung

n.1 Voyage ... Uranie fasc. 6

n.5 Scott.Crypt.Fl. fasc.68

n.5 Scott.Crypt.Fl. fasc.69

n.9 [Rev.Brid.Bryol. Univ.?

n.9,10 Tour S.France Pyren. [7]

n.5 Scott.Crypt.Fl. fasc. 70

n.10 [Rev.Annott Disp.Meth.]

n.5 Scott.Crypt.F1. fasc.71

n.5 Scott.Crypt.Fl. fasc. 72

n.3 Fl. Lyonn, vol.2

n.3 Organogr.Gewăchse

n.t Voyage .... Uranie fasc. 7

л.1 Syst.Veg. vol. 5

n.1 Mouss. Normand, fasc. 2

n.9, 10 Tour S.France Pyren. [8]

n.1 Spec.Musc.Suppl.3 vol.1(2)

n.1 Voyage... Uranie fasc. 8

n.1 Stirp.Crypt.0xon. fasc.2

n.1 Pl.Crypt. Nord France fasc.7

n.2 Musci Americ. Exsicc.

n.1 Reliq.Haenkean, vol.1(3)

n.1 Crypt.Gew.Fichtelgeb. fasc. 34

n.1 Fl.Geg.Frankf.a.M. sect.2

n.1 Spec.Musc.Suppl.3 vol.2(1)

n.1 Mouss. Normand. fasc. 3

n.9, 10 Tour S.France Pyren. [9]

n.1 Deutschl.El. Abt. 2 fasc.18

n.1 Voyage ... Uranie fasc.9 


\begin{tabular}{|c|c|c|c|c|}
\hline 1829 & $\begin{aligned} &< \text { Sep. } 12 \\
&<\text { Sep. } 25 \\
&<H o v .28 \\
&<\text { Des. } 21 \\
& \text { Jan. - Dec. } \\
& \text { Jan. - Dec. }\end{aligned}$ & $\begin{array}{l}\text { Gaudichaud } \\
\text { Eaton } \\
\text { Gaudichaud } \\
\text { Funck } \\
\text { Desmazieres } \\
\text { Reinwardt } \\
\text { Hornschuch }\end{array}$ & $\begin{array}{l}n \cdot 1 \\
n \cdot 5 \\
n \cdot 1 \\
n \cdot 1 \\
n \cdot 1\end{array}$ & $\begin{array}{l}\text { Voyage ... Uranie fasc. } 10 \\
\text { Yan.Bot. ed.5 } \\
\text { Voyage.... Uranie fasc.11 } \\
\text { Crypt.Gew.Fichtelgeb. fasc. } 35 \\
\text { Pl.Crypt.IIord France fasc.8 } \\
\text { Iusci Frond.Javanici }\end{array}$ \\
\hline 1830 & $\begin{array}{l}\text { <Mar. } 6 \\
\text { <Mar.13 } \\
\text { <Apr.10 } \\
\text { Apr. } \\
\text { <Jul. } 1 \\
\text { Oct.-Nov.? } \\
\text { Jan.-Dec. } \\
\text { Jan.-Dec. } \\
\text { Jan.-Dec. }\end{array}$ & $\begin{array}{l}\text { Gaudichaud } \\
\text { Gaudichaud } \\
\text { Brébisson } \\
\text { Grevilie } \\
\text { Presl, K. B. } \\
\text { Sturm } \\
\text { Brown, R. } \\
\text { Desmazières } \\
\text { Schwaegrichen }\end{array}$ & $\begin{array}{l}n \cdot 1 \\
n \cdot 1 \\
n \cdot 1 \\
n \cdot 10 \\
n \cdot 1 \\
n=1 \\
n=2 \\
n \cdot 1 \\
n=1\end{array}$ & 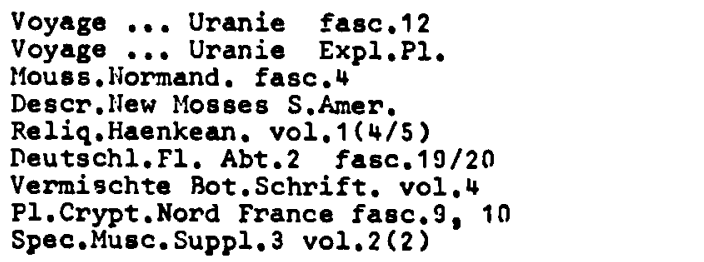 \\
\hline 1831 & $\begin{array}{l}\text { Jan.-Jun. } \\
\text { <Nov. } 1 \\
\text { Jan.-Dec. } \\
\text { Jan.-Dec. } \\
\text { Jan.-Dec. } \\
\text { Jan.-Dec. }\end{array}$ & $\begin{array}{l}\text { Funck } \\
\text { Nees,C.G., Horn- } \\
\text { schuch \& Sturm } \\
\text { Brébisson } \\
\text { Buch } \\
\text { Desmazieres } \\
\text { Presl. K. B. }\end{array}$ & $\begin{array}{l}n \cdot 1 \\
n \cdot 1 \\
n \cdot 1 \\
n \cdot 1 \\
n \cdot 1 \\
n \cdot 1\end{array}$ & $\begin{array}{l}\text { Crypt.Gew.Finhtelgeb. fasc.36 } \\
\text { Bryol.Germ, vol.2(2) } \\
\text { Mouss.Nomand, fasc.5 } \\
\text { Phys.Beschreib.Canar. Inseln pl.1 } \\
\text { Pl.Crypt.Nord France fasc.11 } \\
\text { Reliq.Haenkean. vol.2(1) }\end{array}$ \\
\hline 1832 & $\begin{array}{l}\text {-Sep. } \\
\text { Sep. } \\
\text { Jan.-Dec. } \\
\text { Jan.-Dec. } \\
\text { Jun.-Dec. } \\
\text { Sep.-Dec. }\end{array}$ & $\begin{array}{l}\text { Sturm } \\
\text { Sturm } \\
\text { Desmazières } \\
\text { Kneiff \& Marker } \\
\text { V.Hall } \\
\text { Sturm }\end{array}$ & $\begin{array}{l}n \cdot 1 \\
n \cdot 1 \\
n \cdot 1 \\
n \cdot 1 \\
n \cdot 1\end{array}$ & $\begin{array}{l}\text { Deutachl.Fl. Abt.2 fasc.21 } \\
\text { Deutschl.Fl. Abt.2 Easc.22/23 } \\
\text { Pl.Crypt.Nord France fasc.12 } \\
\text { lisci Frond.Alsat. fasc.9, } 10 \\
\text { El.Belg. Septentr. vol.2(1) } \\
\text { Deutschl.Fl. Abt.2 fasc.24 }\end{array}$ \\
\hline 1833 & $\begin{array}{l}\text { Jan. } \\
\text { <Mar. } \\
\text { <Mar. } 2 \\
2 \text { May -Jun. } 3 \\
\text { Jan. -Des. }\end{array}$ & $\begin{array}{l}\text { Funck } \\
\text { Sturm: } \\
\text { Brébisson } \\
\text { Eaton } \\
\text { Desmazières }\end{array}$ & $\begin{array}{l}n \cdot 1 \\
n \cdot 1 \\
n \cdot 6 \\
n \cdot 1\end{array}$ & $\begin{array}{l}\text { Crypt.Gew.Fichtelgeb. fasc.37 } \\
\text { Deutschl.Fl. Abt. } 2 \text { fasc. } 25 \text {, vol.5, titlo } \\
\text { Mousses Normand. fasc.6 } \\
\text { Man.Bot. ed.6 } \\
\text { Pl.Crypt. Nord France fasc. } 13\end{array}$ \\
\hline & $\begin{array}{l}15 \text { Jan. - Mar. } 12 \\
\text { <May } 1 \\
\text { Ian. -Dec. } \\
\text { Jan.-Des. }\end{array}$ & $\begin{array}{l}\text { Dietrich, F.G. } \\
\text { Mougeot Nestl. } \\
\text { Brown, R. } \\
\text { Desmazières }\end{array}$ & $\begin{array}{l}n \cdot 5 \\
. n \cdot 1 \\
n \cdot 2 \\
n \cdot 1\end{array}$ & $\begin{array}{l}\text { Heuer Nachtr, Vollst. Lexic, vol.3 } \\
\text { Stirp. Crypt. Vog, Phen, fasc.10 } \\
\text { Vermischte Bot. Schriften vol.5 } \\
\text { Pl.Crypt. Nord Franco fasc.14, } 15\end{array}$ \\
\hline 1835 & $\begin{array}{l}\text { Apr. } \\
\text { <Jul.11 } \\
\text { Jul. -Sep. } \\
\text { <Oct.30 } \\
\text { <Dec. } 28 \\
\text { Jan.-Dec. } \\
\text { 4 Nov. -Des. }\end{array}$ & $\begin{array}{l}\text { Roffavier } \\
\text { Pres?, K.B. } \\
\text { Sturm } \\
\text { Sturm } \\
\text { Funck } \\
\text { Brébisson } \\
\text { Dietrich, F.G. }\end{array}$ & $\begin{array}{l}n \cdot 1 \\
n \cdot 1 \\
n \cdot 1 \\
n \cdot 1 \\
n \cdot 1 \\
n=1 \\
n=5\end{array}$ & $\begin{array}{l}\text { Suppl.Fl.Lyonn. Balbis } \\
\text { Reliq.Heenkean. vol.2(2) } \\
\text { Deutschl.Fl. Abt.2 fasc.26/27 } \\
\text { Deutschl.Fl. Abt.2 fasc.28/29 } \\
\text { Crypt. Gew.Fichtelgeb. fasc.38 } \\
\text { Mouss. Normand, fasc.7 } \\
\text { Neuer Nachtr.Vollst.Lexic. vol.4 }\end{array}$ \\
\hline 1836 & 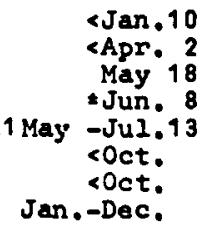 & $\begin{array}{l}\text { v.Hall } \\
\text { Chevallier } \\
\text { Funck } \\
\text { Eaton } \\
\text { Dietrich, F. G. } \\
\text { Desmazières } \\
\text { Desmazières } \\
\text { Desmazières }\end{array}$ & $\begin{array}{l}n \cdot 1 \\
n \cdot 2 \\
n \cdot 1 \\
n \cdot 7 \\
n .5 \\
n \cdot 1 \\
n \cdot 1 \\
n .2\end{array}$ & $\begin{array}{l}\text { Fl. Belg. Septentr. vol.1(3) } \\
\text { Fl.Gen.Envir. Paris ed.2 } \\
\text { Crypt.Gew.Fichtelgeb. fase.39 } \\
\text { Man.Bot. ed.7 } \\
\text { Neuer Nachtr.Vollst.Lexic. vol.5 } \\
\text { Pl.Crypt.Nord France fasc.16 } \\
\text { Pl. Crypt. France fasc.17 } \\
\text { Pl.Crypt.France [ed.2] fasc.1 }\end{array}$ \\
\hline 1837 & $\begin{array}{l}\text { Jan. -Mar. } \\
\text { Jan. -Dec. } \\
\text { Jan,-Dec. } \\
\text { Jan.-Dec. }\end{array}$ & $\begin{array}{l}\text { Dietrich, F.G. } \\
\text { Funck } \\
\text { Arnott } \\
\text { Desmazieres } \\
\text { Saumaises }\end{array}$ & $\begin{array}{l}n \cdot 5 \\
n \cdot 1 \\
n \cdot 11 \\
n \cdot 1 \\
n \cdot 1\end{array}$ & $\begin{array}{l}\text { Neuer Nachtr.Vollst.Lexic, vol.6 } \\
\text { Crypt.Gew.Fichtelgeb. fasc. } 40 \\
\text { Nouv.Disp,Weth.Esp.Houss. (re-issue Saumaises) } \\
\text { Pl.Crypt. France fasc.18 } \\
\text { Cours Agric.Bct.Hiet.liat. }\end{array}$ \\
\hline
\end{tabular}




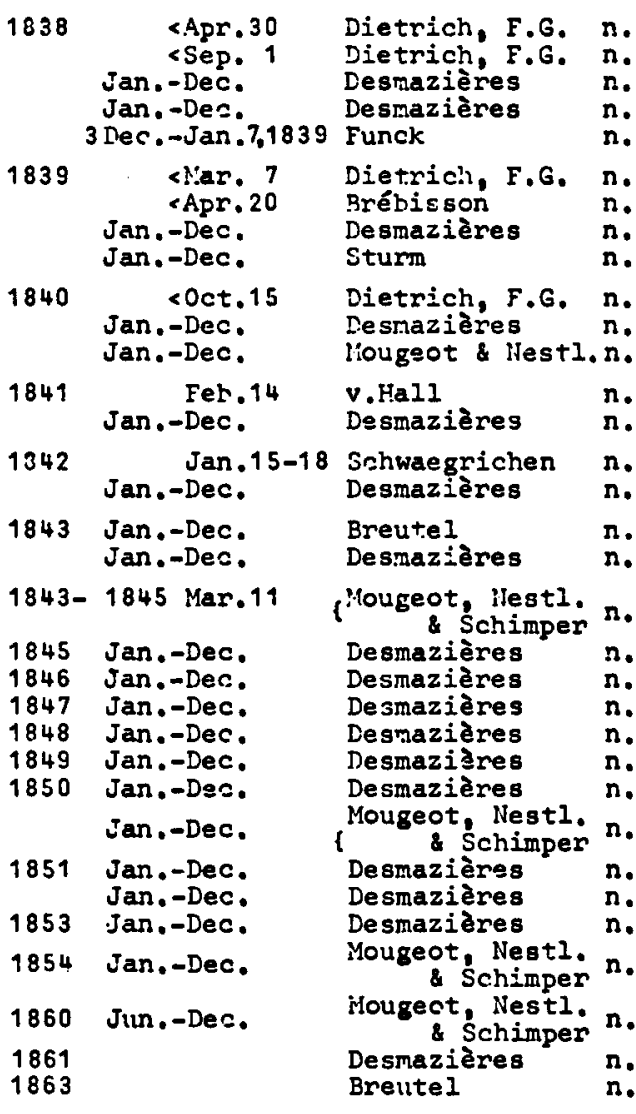

Neuer Hachtr. Vollst. Lexic, vol. 7 Neuer Nachtr. Vollst. Iexic, vol. 8 P1.Crypt. France fasc. 19

Pl. Crypt. France [ed.2 : fasc. 6 Crypt. Gew. Fichteigeb. fasc. 41,42

Neuer Nachtr. Vollst.Lexic, vol. 9 Mouss. Normand, fasc.8

P1. Crypt. France fasc. 20,21

Deutechl.Fl. Aht. 2 fasc.30/31

Neuer Nashtr.Vollst. Lexic, vol, 10

P1.Crypt. France fasc. 22

Stirp.Crypt.Vog.Rhen. fasc.11

Fl.Belg. Septentr. vol.2(2)

Pl. Crypt. France fasc. 23

Spec.Musc.Suppl.4(1)

n.1 P1.Crypt. Erance fasc. 24,25

n.1 Musci Frond.Exsicc. Centur. 2

n.1 P1.Crypt. France fasc. 26, 27

Stirp.Crypt.Vog.Rhen. fasc. 12

P1.Crypt. France fasc.28, 29

PI. Crypt : France fasc. 30,31

P1.Crypt.France fasc. 32,33

P1.Crypt. France fasc. 34,35

PI. Crypt. France fasc. 36, 37, 38, 39

P1.Crypt. France fasc. 49,41

Stirp.Crypt.Vog. Rhen, fasc.13

P1.Crypt. France fasc.42, 43, 44, index-vol. Pl. Crypt.France [ed.2] fasc.37

PI.Crypt.France [ed.3] fasc.1

Stirp.Crypt.Vog.Rhen, fasc. 14

St.ipp.Crypt. Vog, Rhen, fasc. 15

P1. Crypt.France red.3: fasc.16

Musci Frond.Exsice. Centur. 5 


\section{J. II D E X O F P I A II T II A II E S}

llot listed are synonyms of comnemorative names not belonging to Bryophyta.

Names of classes or other groups which occur very frequently are omitted, for instance ilusoi, Algae, Cryptogamae.

Acotyledones Juss .

Acrocarpi Brid.

Acrocarpum Pal. Beauv. 197

Aecidium berberidis $\quad 132$

Alstroemeria pulchra Sins 157

A. tricolor Hook. 157

Amphidium mougeotii $(B, S, G$,$) Schimp.$

A. pulvinatum Nees 232

Anacamptodon Brid. 185

232
64

A. eplachnoides (Brid.) Brid. 212

Andraeoideae Kittel 47,169

Andreaea Hedw. $135,230,234$

A. nivalis Hook. 145

Andreaeoideae Kittel 47,169

Anictangium Hedw. 135

Anodontium Brid. 63

Anomodon Hook \& Tayl. III

Anthoceros L: 200

Anthophysis (=Zygnema) 175

Antitrichia Brid. 64

Aplodon R.Brown

Archidium Brid.

Arnottia A.Richard

Aulacomnium Schwae 222,223

A. androgynum (Hedw.) Schwaegr.

Balbisia Cavanilles

Balbisia Willd.

Baxbula Hedw. III, 158,161,215

B. hornschuchiana C.F.Schultz 215

Bartramia Hedw. 142

B. halleriana Hedw. 142

Baxtera H.G.L.Reichenb. 53

Baxteria R. Brown ex Hook. 53

Bazzania S.F.Gray corr. Carrington III

Beckera Fresenius

Beckeropsis Figaria \& 54

Belvisia Desvaux 196

Belvisia Mirbel 196

Biscutella L. (key) 48

Blasia L. III, 146,147

Boletus benzoinus

B. hispidus DC.

$B$. sulfureus DC.

Brachydontium Furnr.

Brachyodon Fürnr.

Brachyodus Fürnr.

Brachypodium Brid.

120

188

167
Brassica balearica

$\begin{array}{lr}\text { Camb. (pl.) } & 74 \\ \text { Braunia Hornsch. } & 167\end{array}$

Brebissonia Grunow 57

Brebissonia Spach

Breutelia B.S.G.

Bridelia Willd.

Briedelia Willd.

Bromus hispidus Savi 214

Bruchia Hornsch. 70,166

Bruchia Schwaegr.

Brunonia J.E.Smith

Bryum L. ex Hedw.

B. subg. Ptychostomum

(Hornsch.) Amann 165

B. annotinum $L$.

(ex Hedw.?) 143,190

B. bryoides (R,Brown) v.d.Wijk \& Margadant

B. cellulare Hook.

B. demissun (Hornsch.) Hook 37

B. donianum Grev. 133

B. elegans Grev. 133

B. erythrocarpon Brid. 187

B. gaudichaudii Arnott 45

B. paradoxum Schwaegr. 222

B. rugosum Funck 118

B. sclerodon Pal. Beauv. 197

B. tozeri Grev. 131

B. vesiculare Schwaegr. 222

Buchia v.Humb.

71

Buxbaumia Hedw. 79,135

(leaves) 79,126

B. aphylla Hedw. 126,145

B. a. var. viridis DC. 187

$B$. indusiate Brid. 187

B. viridis "Brid. in Litt."187

Buxbaumoideae 126,135

Calceolaria corymbosa 157

C. paralia Cavanilles 157

Calymperes Swartz (monoga) 160

C. guildingii Hook. \& 160

Calyptrochaete Desvaux 91

Cambessedea Kunth 73

Cambessedesia DC. 73

Campylopus Brid.

Candollea Labiliard.1805 77

Candollea Labillard.1806 77

Candollea Mirbel

Candollea Raddi
Carex L. (species cited from Dewey)

Cassebeeria Dennst. ex 0. Kuntze
Catoscopium Brid.

Ceramium (monogr.

Cerastium squalidum

Ceratodon Brid. Ramond 67

Chatephora (Chaeto- 64, 91
phora) Brid.

Chaetophora Agardh 64

Chevaliera Gaud. 82

Crysiphiala pauciflora (stop-press add.to pl) 157

Cinclidium Swartz 66,119

C. stygium Swartz 192

Cirriphyllum illecebrum 143 (Hedw.) L.F.Koch

Cisteae 152

Clavaria setifolius Grev.128

C. trichopus Grev. non Pers. 128

Codonophorus Desvaux 91

Codrionophorus Pal. Beauv. 91

Codriophorus Pal.Beauv. 197

Coniferae

Conocephalun Wiggers II

Conostomum Swartz 63 Cucurbitaria cinnabarina 54
Grev.

Curtia Cham, \& Schlecht.225

Cycadae 68

Cynclidium Swartz $\quad 66$

Cynodontium Brid. 63

Cynodontium Schimp. $\quad 142$

Cynontodium Hedw. 63

Decandolia Bagtard $\quad 77$

Desmarzeria Dum. 87

Desmatodon Brid. $\quad 64$

Desmazeria Dum. 87

Desmazeriella Libert $\quad 87$

Desmazieria Mont. 87

Desvauxia R. Brown 91

Desvauxia Pal.Beauv. 91

Diatoma 175

Dicnemon calycinus 167

Dicranodon Béheré gr • 57

Dicranum Hedw. III, 57,161

D. falcifolium

(Schwaegr.) Hook. 151

D. filiforme Pal. Beauv. 37,44

D. flexuosum Hedw. 37

D. moerkianum Hornsch. 166

D. polysetum Swartz 118

D. undulatum 118

Didymocarpus rexii

Bowie ex Hook. 
Didymodon benthamii

3. megalocarpus Arnott 48

D. subulatus Camb. 74-75

Dietrichia Trattinick 93

Diospyros L.

192

Diphascum Eaton 101,103

Diphysciur llohr 101,103,135

Disandra africana

$$
\text { Camb. (pl.) }
$$

Dissodon Grev.

Arnott III,134,135

D. froelichianum (Hedw.) Grev. \& Arnott 134

D. hornschuchii Grev. Arnott 134

D. scabrisetum (Hook.) Grev. \& Arnott 134

D. splachnoides Grev. \& Arnott 134

Draba boerhaavii v.Hall 136 Drepanophyllum II 37,151 Drummondia Hook. Drummondita Harvey

Duretia Gaud.

\section{Eatonia Rafinesque}

Egeria Néraud

Entocarpae Perleb(fam.) 200

Erpodium (Brid.) Brid., 167 Hornsch.

Erysimum macloiranum Gay 123

Esenbeckia Blume $\quad 187$

Esenbeckia Brid. $\quad 187$

Esenbeckia H.B.K.

Fissidens Hedw. (type) III, 166 (leaves) $142-143$ 79

F. subg. Eu-Fissidens 143

F. bryoides HedW.

F. b. giganteus

F. exilis Hedw.

F. falcicolius Schwaegr.

F. polycarpus Hedw.

143

73
143

Fontinalis Hedw.

F. disticha Spreng. III, 151

142

200

F. juliana Savi

Friesia DC.

Friesia Spreng.

Friesia P.Wieselgren

Friesites P.A.Karsten

Friesula Spegazzini

Frisea (Endl.) Spach

Froehlichia D.Dietrich

Froelichia Moench

Froelichia Vahl

Froelichiella

Fuernrohria C.Koch

111

111

111

114

114

114
120
Funckia Dennstedt

Funckia Spreng.

Funckia lilidd.

Fusiconia Pal.Beauv.

Fusidium flavo-virens

F. griseum

Galium cespitosum Ramond 204

Garovaglia Endlicher 187

Gaudichaudia H.B.K. 121

Genista lucida Camb.

74

Girodia T.Lestiboudois (Algae) 176

Glyphomitrium Brid. (monogr.) 64,158

Grevillea R.Broun

124

Grimmia Ehrh. ex Hedw.44,59

G. donniana J.E.Smith 167

G. Eracilis lichx non leb. \& Hohr

G. Leucophaea Greville 126

G. michauxii Torrey 103

G. nigricans DC.

G. pulvinata (Hedw.)

G. spiralis

J.E.Smith

G. sudetica

G. trichophylla Grev.

Gymogramme boryi Desvaux (unpubl.)

G. thiebautii Thiébaut 92,93

Gymostomoideae Grev. \& 135 Annott

Gymnostomum Hedw. III, 59,135

G. ahnfeltii Fries 112-113

G. confertum Hornsch. 166

G. Elobosum Hornsch. 166

G. hedwigia Schrank 186

G. ovatum Hedw var. mucronulatim Hornsch. 166

G. serratum Bréb

G. sphaericum Hedw.

G. trunculatum var. ramosum Grev.

Hallia Dum.

Hedwiria Pal.Beauv. 139

Hedwigia Medikus 139

Hedwigia Swartz 139

Hedwigiaceae Schimp. 139

Hedwigidium B.S.G. 139

111 Helianthemum serrae Camb. 74

\section{Helichrysum fontanesii 74}

H. lamarckii Camb. Camb. 74

Hepaticae

Hochstettera DC.

Hollia Sieber

Hookeria Schwaegr.

Hookeria J.E. Smith (monogr.)
147,162

144

167

145

64,145 159
Hookeriaceae C.Iüll. 145 Hookeriopsis (Besch.) Jaeg.145 Hoppea Reichenb. 163 Hoppea Willd. 163

Hoppia Nees 163

Hornemannia Vahl 163

Hornemannia Willd. 163

Hornschuchia Blume 165

Hornschuchia Nees 165

Hornschuchia Spreng. 165

Hutchirsia Agardh 176

Hymenostomum R. Brown III, 113

Hypnum L. ex Hedw. IV, 200

$\mathrm{H}$. abietinum Hedw. 140 H. a. var, scitum (Pai.Beauv.) Dum. 99

H. arcticum Sommerf. 224

H. boscii Schwaegr. 143

H. coolianum Spreng. 105,106

H. crispifolium Hook. 67

H. crista-castrens is Hedw.238

H. curvisetum Brid. 48

H. cyparioides Hook. 45

H. flagellare Dicks.? 37

H. freuchenianum Hornch. 166

H. illecebrum L. $\quad 143$

H. illecebrum Hedw. 143

H. laxifolium Brid. 67

H. leskea Grev. 133

H. loxense Hook. 222

$\mathrm{H}$. Iucens Hedw. 159

H. lutescens Hedw. 67

H. oxypoma Schwaegr. 222

H. paradoxum Schwaegr. 222 (unpubl.)

H. plumosum LnHedw. (type) 143

H. proliferum L. 162

H. remotifolium Grev. 132

H. salebrosum Hoffm. ex 143 Web. Mohr

H. scabrisetum Arnott 45

H. scalare Zenk. \& Dietr. 238

H. spiniforme Hedw. 166

H. starkii Brid. 67

H. torreyanum Spreng. 103

Hyophila Brid. 67

Hypopterygium Brid. 67

Isoetes $\mathrm{L}$.

Isothecium Brid.

Jungermannia L. III,1 46-147,200 J. indica Reinw. Nees 208 J. scutata 224

Kayea Wallich

Kittelia Reichenb. 168

Kittelocharis Alefeld 168

Kunthia Dennstedt 171

Kunthia H.B.K. 
Lamourouxia Agardh

Lamourouxia H.B.K.

Laurera Reichenb.

Laureri vochlechtend.

Laurus foetens

L. foetidus

Lebidiera Baillon

Lecanora limbata

Lepigonum

Leptotheca gaudichaudi Schwaegr.

Leskea norvegica Sommerf. 224

Lestibodea Necker 175

Lestibudaea Jussieu 175

Lestibudesia Thouars 175

Leucoloma Brid.

Loreya DC.

Lotus tetraphyllus L.f. 74

Luzula campestris [var.] 132

Lycopodium L.

$r, 42$

Macrodon Arnott

III, 45

Macromitrium Brid.

M. piliferum Schwaegr.

Marchantia L.

Meesia Hedw.

M. dealbata Hedw.

M. Iongiseta Hedw.

M. uliginosa Hedw.

Micromitrion

Mitrula globosa

Minium Dill.

Mnium Hedw.

M. androgynum Dill. ex $e^{I, 158}$

J.E.Smith

M. palustre

M. rugicum Laurer 175

Moerckia

Mougeotia Agardh

Mougeotia H.B.K.

Myelomycetes [=Pyrenomycetes]

Naphar (error for Nuphar) 102 Neckera subg.Distichia 167 $N$. americana Grev. 132,133

N. complanata Bland. 232

$N$. minor Schwaegr. 132,133

$N$. pumila Hedw. 54

Neesia Blume

Neesia Spreng.

187

Neesiella Schiffner 187

Neillia D.Don

129

Nestlera $E$. Meyer ex.

Nestlera Spreng. 191

Walpers 191

Noltea Reichenb. 192

Noltia Schumacher ex

Thonn. 192

Nowodworskya C.B.Presl 201 Nuphar
Oedipodium Schwaegr.

Okenia F,G.Dietrich 193

Okenia v.Schlechtend. 193

Opizia J. \& C.PresI

195

Opizia Rafinesque

195

Orthotrichieae

Orthotrichum Hedw. monogr. new specific 70,229

0. crispulum Bruch

0. lanceolatum Arnott 45

0. microstomum Hook

0. piliferum Grev. 45

0. subrepens Sommerf. ${ }^{45,47}$

Oscillaria

(Oscillatoria)

82,175

Palisota Reichenb.

\section{6}

Paludella Ehrh.

63

Pellia

147

Perisiphoms Pal.Beauv. 197

Perlebia DC.

Perlebia Martius

198

Phascoidea Grev.

198

Arnott

135

Phascum Hedw. $59,70,135$

P. alternifolium Dicks. 70

P. curvicollum Hedw. 206

P. globiferum Bruch 70

P. eubulatum Schreber 70

Philonotis Brid.

Pholidota Lindl. ex Hook. 155

Physcomitrium (Brid.)

Plagiochila Dum. Brid.

Platygyrium B.S.G.

Pleuridium Brid.

Pleurocarpi Brid.

Pohlia annotina Lindb.

(type)

P. cucullata Bruch

Polyaetnium (error)

Polytaenium Desvaux

Polytrichum L., Hedw.

$P$. arcticum

P. commune var.

P. gracile var. scopularium Bréb. longisetum Bréb.

Porella Dill, ex L.

Potentilla jamesoniana Greville

Protococcus nivalis

Pterigophyllus. Brid.

Pterogonium terue (Hook.) Schwaegr.

Ptychostomum Hornsch.

Pyramidula Brid.

Pyrenomycetes

Pyrus L. (sections)

67

77

70

64

67

206

59

59

125

131
Racomitrium Brid. 64

Radula Dum. 77

Ramonda L,C.M.Rjchard 203

Ramondia Mirbel 203

Raspailia Presl 201

Rea Bertero ex Decaisne 204

Reinwardtia Blume ex Nees 206

Reinwardtia Dumortier 206

Reinwardtia Korthals 206

Reinwardtia Spreng. 206

Reir.wardtiodendron Koorders 206

Rhizogonium Brid. 67

Riccardia S.F. Gray corr. III

Riccia L. 199,200

Ricciella 200

Salmacis

175

Sauteria Nees 212

Savia Rafinesque 213

Savia Willd. 213

Schistidium Brid. 64

Schistostega Mohr 135

Schlotheimia Brid. 63,158

Schulzia Spreng. 219

Schwaegrichenia Reichenb.

Schwaegrichenia Spreng.

143,216

Scleropodium illecebmm 143

S. touretii (Brid.)

L.F. Koch 181

Silene disticha Willd. 74

S. villosa var, nana Camb.74

Skitophyllum fontanum

Solidago arguta La Pyl. 214

S. rauta (error)

Sommerfeldtia Schumach. 223

Sommerfeltia Floerke 223

Sommerfeltia Lessing 223

Sphagnoideae Kittel 47,169

- Sphagnum L. $\quad 59,70,135,188$,

S. subg. Sphagnella Corda 234

S. molluscum Bruch

S. praemorsum Zenk. \&

S. subsecundum

Dietr. 238

Spiridens Reinw,

232

Spirogyra

Nees 207-208

Splachnoideae Grev. 17

Splachnum Hedw. Arnott

135

(stomata in capsules) 78

S. subg. Aplodon R. Brown 69

S. adansianum Hornsch. 222

S. ampullaceum Hedw. 192

S. angustatum Hedw. 114

Sprengeli.a J.A.Schultes 225

|Sprengelia J.E.Smith 225 
Steis

157

Stetis (error for Stelis) 157

Steudelago 0.Kuntze 227

Steudelella Honda 227

Steudelia liartius 227

Steudelia C.Presl · 227

Steudelia Spreng. 227

Sturnia C.F.Gaertn. $\quad 230$

Sturmia lioppe

Sturmia Reichenb.

Subularia

Syntrichia Brid. (monogr.)

S. ruralis var. laevipila (Brid.)

Syrrhopodon Schwaegr.

s. fasciculatus Hook. \& 160 Grev.

S. rigidus Hook. \& Grev, 160

S. rufescens Hook \&

S. spiculosus Hook. \& Grev.
Grev
Synarthrophytae

0

\section{Thit}

$\begin{array}{lr}\text { Targionia L. } & 200 \\ \text { Tayloriatbok. III,135, } 145,235\end{array}$ $\because$ acuminata 166 Tetraphis browniana 70 I. ovata

Tetrodontiun brownianum

Thes anomitrium richardi Schwaegr.

Thesium L. sect. Frisea Endlicher

Tilia maderensis Lam.

Timmia

T. alpina

T. salisburgensis Hoppe 175

Tortula Hedw. III,161,215 (monogr.) 158

T. northiana Grev. 133

Trachypus Reinw. \& Hornsch, 207

T. bicolor Reinw. \& Hornsch. 207

Trichostomum laureri.

T. sciuroides Schultz 174,215

Trifolium lagopus 210

Ulophyllum Ilornsch. $\quad 167$

vlota Brid. 64.158

\section{A R T I S S}

Bauer, F.A.

Billoti, L.

Boeck, C.

Bonner, G.i.

Both, G.

Bridel, S.E.

Brondeau, Io de

Brondeau, Le de 211

Chotard Alph.L.P.P.de 178

Clauder, $C$.

Colebrooke, H.T. 176

Corda, A.J: 231

Descourtilz, T. 211

Desmazières, J.B.H.J. 211

Drummond, J.L. 98

Duménil, P.C.R.C. 82

Duncombe

\begin{tabular}{|c|c|}
\hline 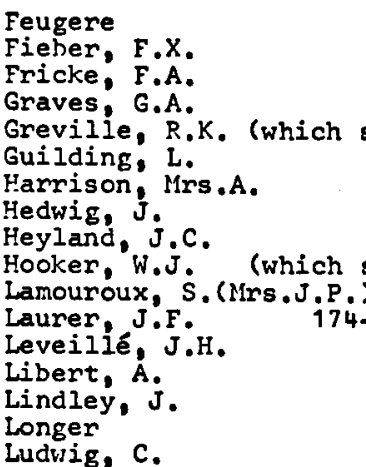 & $\begin{array}{r}173 \\
201 \\
220 \\
161 \\
\text { see) } \\
154 \\
154 \\
140 \\
78 \\
\text { see) } \\
\text { ) } 173 \\
4-175 \\
211 \\
211 \\
154 \\
201 \\
220\end{array}$ \\
\hline
\end{tabular}

Valvatae 200

Vanhallia L.Marchand 136

Vanhallia J.A. \& 136

Voitia

J.H.Schultes $\begin{array}{r}136 \\ 135\end{array}$

V. hyperborea Grev. 134,135

\& Arnott 134,135

Vahlenbergia Blume 235

Wahlenbergia R,Brown 235

Wahlenbergia Schrader 235

Nahlenbergia Schumach. 235

Walkeria Hornsch. 166

Weissia flexuosa Bruch 144

H. longipes 224

U. trichodes Weber 120

Zenkeria Arnott 238

Zenkeria Reichenb. 238

Zenkeria Tririus 238

Zygnema 175

Zygodon Hook. \& Tayl. III,158 (monogr.) 158

Z. conoideus (Dicks.) 37 Hook. \& Tayl.

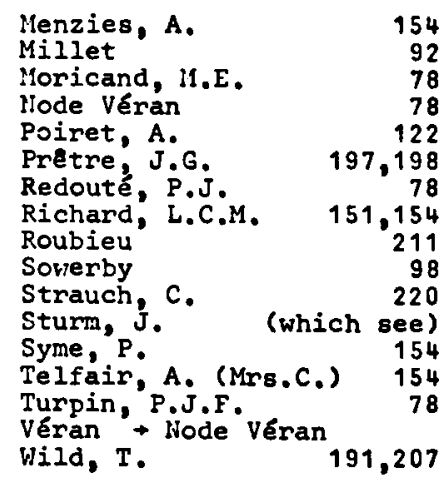

E N G R V E R S

$\begin{array}{lr}\text { Bagge } & 224 \\ \text { Bohme, J.C. } & 66 \\ \text { Bonner, G.W. } & 98 \\ \text { Bonnet } & 85 \\ \text { Both, F. } & 202 \\ \text { Curtis, J. } & 69,160,162 \\ \text { Desève } & 211 \\ \text { Dien, IC.:.F.?: } & 82 \\ \text { Durieux } & 176 \\ \text { Edwards, [S.T.?. } & 148 \\ \text { Edwards, H.C. } & 162 \\ \text { Edwards, H.H.C. } 146,150,162 \\ \text { Engels, W. }\end{array}$

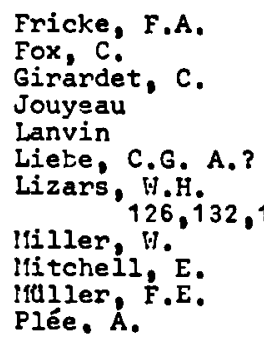

$\begin{array}{lr}\text { Plé, f., F. } & 78 \\ \text { Plé, F.B. } & 197,198 \\ \text { Plé, père } & 78 \\ \text { Plée veuve } & 82 \\ \text { Schnorr, C. } & 194 \\ \text { Schrbter, J.F. } & 61 \\ \text { Skala, J. } & 202 \\ \text { Strauch, C. } & 220 \\ \text { Swan, J. } & 154,158,159 \\ \text { Tardieu, A. } & 173 \\ \text { Tardieu, P. } & 72 \\ \text { Tourcaty } & 211 \\ \text { Zeliska, W. } & 202\end{array}$


B 0 T A N I S T S

NAMES OF AUTHORS TREATED IN THE SPECIAL BIBLIOGRAPHY

Mames of other botanists

Names of oolleotore

+cross-references

Acharius, E.

Adanson, $M$.

Agardh, C.A.

Ahnfelt, C.N.

Aikin, W.E.A. 105

Allioni, $C$.

50

Anderson, L.C.

Andrews, A.L.

ARNAUD, J.A.M.

ARNOTT, G.A.Walker III, $36-49,120,123,134-135$, $151,158,162,167-168$

Arrhenius, J.G. 111

Arrhenius, J.P. 23

Bailly de Merlieux, C,F. $173-174$

BALBIS, G.B. 50-51,209-210

Balfour, J.H. 41

Banks, Sir Joseph 67,145

BARON, P.A.

$52-53$

Bartling, F.G.

202

187

Bauer, F.A.

69

BAXTER, $W$. II, 53-54

Beauvols + Palisot

Beck, L.C. de Beauvols

BECKER, J. $54-55$

BeecheV, B.W.. Capt. 40

BEHERE, J.B.B. 56-57

Bentham, 6 . 39-40,48

Bergius; J.P.

$39-40,48$

Berneaud $\rightarrow$ Thiébaut

Blandow C.O de Berneaud

Blume, C.L. 190

Blumenbach $\quad 194$

Boehmer 139

Bonnet, C. 139

Bonpland, A.J.A. 170-172

Bory de Saint-Vincent. J.B.G.M. 123

Bowie, J.

Braune, F.A. V.

212

BREBISSON, L.A. de 41,57-59

BREUTEL, J.C.

BRIDEL, S.E.

59,70 $60-67,167,187$

BRIDEL-BRIDERI, S.E.de (von)

Erodie, $J .+$ BKIDEL

Brongniart, Ad, IV 36-38, $92,111,131,138,182,235$

Brotherus, V.F.

Broussonet, P.M.A.
BROWI, R. $\begin{array}{r}68-69,71-73,79 \\ 125,145,157,166\end{array}$

BRUCH, $P$. IV.

Brugmans, S.J.

229

BUCH, L. $v$.

190

CAMEESSEDES $J$, 73-75

Candolle, Alph.L.P.P. de

77-78

CANDOLIF, Aug.P. de IV,

$37,39,48,51,58,72,76-79$
$131,171,176,185,199,225$
CASSEBEER, J.H, IV, $80-81$

Chauvin-Desroches

121

CHEVALLIER, F,F.

Choisy, J.D.

IV $, 82-83,191$

Cleghorn, $\mathrm{H}$.

Corda, A.C.J.

Crouan fràres

Crum, H.A.

Dalton, J.

Dassen, $M$.

De BREBISSON + BREBISSON

De CANDOLLE + CANDOLLE

De JUSSIEU $\rightarrow$ JUSSIEU

Delessert, J.P.B.36,38, 196

DEMERSON, L. $\quad 23,84-86$

Desfontaines, R.L. 76,170

Deshayes, P.M.

12

DESMAZIERES, J,B.H.J.

$87-90,211$

Dewey, C.A. IV

Dierbach, J.H. 13

DIETRICH D.N.G. 93,237

DIETRICH，F.D. 237

DIETRICH, F.G. 93-97

Dietrich, J.C.G.? 93

Dillenius, J.J. $\quad 145,146$

Dixon, H.N.

DRUMMND, J.L. 97-98

DRUMMOND, T. 99,162

Duby, J.E. 209

Dumont d'Urville, J.S.C.

$\begin{array}{ll}\text { DURET, L. } & 123 \\ & 177\end{array}$

D'Urvilie + Dumont

EATON, A.

d'Urville

Eaton, D.C.

100-107

Eaton, H.H.

100

105

Fauve1, $A$.

175

Fischer, F.E.L. v. 40

Fleischer. M.
Floerke, H.G. 202

Florschütz, P.A. 144

$\begin{array}{lr}\text { FRIES, E.M: } & 111-113,228 \\ \text { FROHLICH, J.A. } & 114\end{array}$

FUNCK, H.C.

$114-120,165,174,232$

FURNROHR, A.E. IV, 120

Gardner, $G$. 151

Gatereau 53

GAUDICHAUD-BEAUPRE, $C$.

Gay, J.E. $\quad 38,121-124$

Gérand, J. 27

Gilibert, J.E. 209

Gilliee 168

Goethe, W. v. 93,193

Graham, R. $\quad 131,155$

Gray, S.F. III

GREVILLE, R.K. III,

$36,54,124-135,154,158,160^{\circ}$

Griffith, Mrs. 125

Grout, A.J. 141

Guilford, Earl of 133

Haenke, T. 201

HALL, H.C. van 136-138

Hall, J. 106,107

Halsey

Hanin, $L$. 104

Harrison, Mrs.A. 154

Hebenstreit, J.E. $\quad 139$

HEDWIG, J. II

Hedwig, R.A. $\begin{array}{r}60,139-144,216 \\ 216\end{array}$

Héritier, C.L. L' 76

Hermann, $J$. 185,191

Hobson, $E$. 162

HOCHSTETTER, C.F. 229

Hoffmann, G.F. 143

Holzinger, J. 59

Hooker, J.D. V, 36,145

HOOKER, W.J. III

$36,38,107,124,128,145-162$

HOPPE, D.H. $114,163,166,232$

HORNEMANN, J.W. 163-164,192

HORNSCHUCH, C.F.

$36-37,165-168,188-189,207$

Hosack, $D$. 100

Humboldt, A. $v, 145,170-172$

Ives, $E$. 100

Jacquemont, $V$. 73

Jacquin, N.J. v. 194

Jameoon, $W$. $36,42-43$

Jussieu, Adr. de 36

Jussieu, Ant.L. de II

Jussieu, Bern. de $36,61,121,170,196$ 


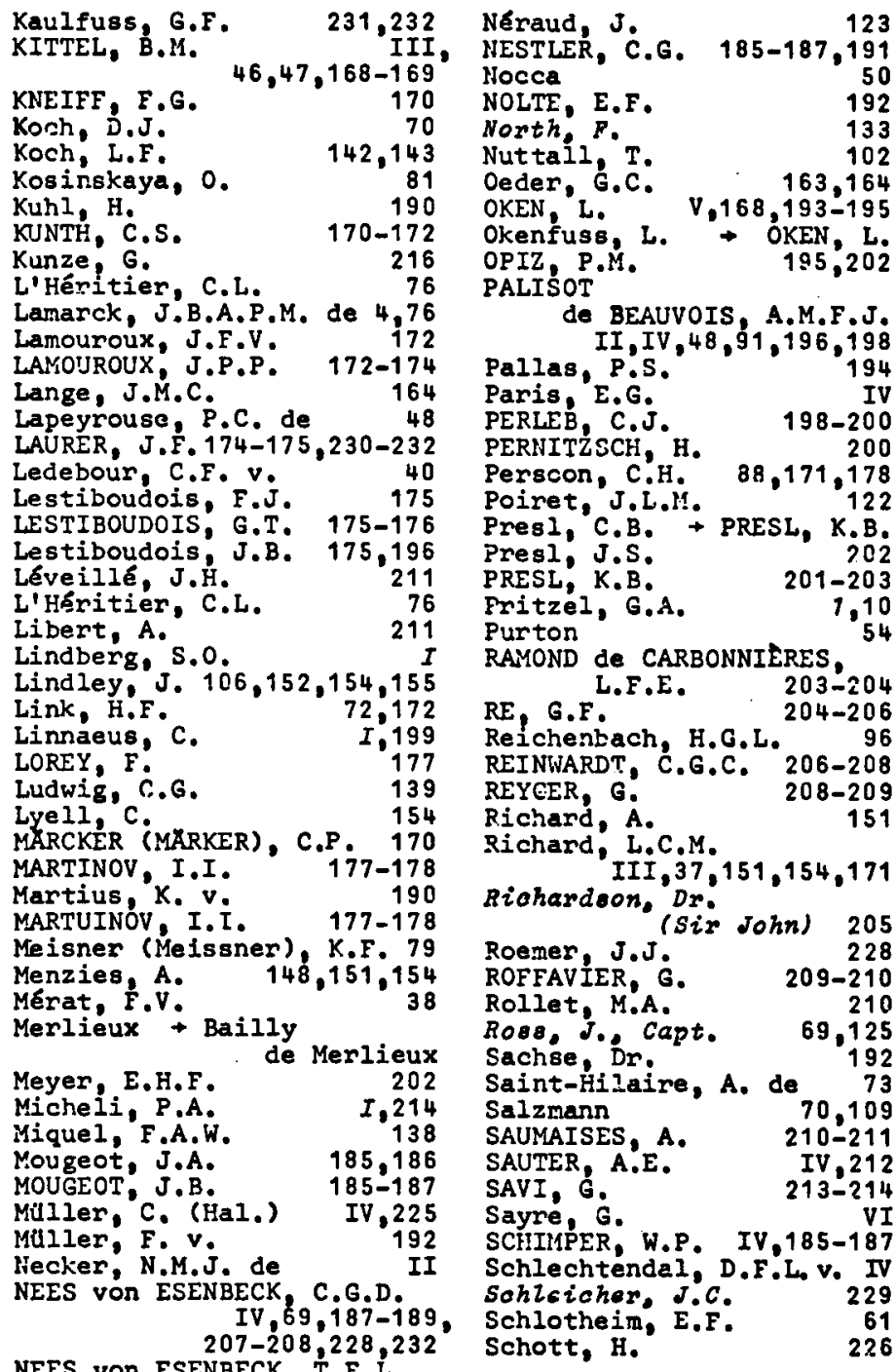

Schrader, H.A. 219

Schrank, F. V. Paula v. 194

Schreher, J.C.D. 139

Schultes, J.A. 228

SCHULIZ, C.F. $215-216$

SCHWAEGRICHEN, C.H. $I, I I, 38,45,123,216-223$

sooreoby. Capt.

Scouler, J.

Seringe, N.C.

Sinning: $W$.

Smith, C.

Smith, J.E.

226-227

SPRENGEL, C.P.J. 219,225-227

Steerc, W.C. 143

STEUDEL, E.G. 178,227-229

Stewart, J. II, 26,126

STURM, J. $188-189,207,215,230-234$

Swartz, 0 . 219

Targioni-Tozzetti, 0,213

TAYLOR, T. 160-162,235 Thiébaut

de Berneaud, J.B.M.A. $44,46,188,197$

Thunbers, C.P. 219,235

Torrey, J. 100,103-106

Treviranus 187

Turner, D. 145-145

Turpin, P.J.F. 78

Urville - Dumont d'Urville. J.S.C.

Van Hall + Hall, H.C. van

Vaucher, J.P.E. 76

Villars, $D_{\text {. }} \quad 186,191$

Voit, J.G.W. 232

Wachter, W.H. 138

WAHLENBERG, G. 235-237

Walker, Prof. 68

Weber, G.H. 192

WEISS, J.G. 208-209

Wiggers, F.H. 192

Wight, $R$. 36,40

Wilidenow, C.L. . 216

Williams, S.W. 106

Wilson, W. 99

Wistar, C. 196

Wright, J.

ZENKER, J.C. 
P R INTERS

\begin{tabular}{|c|c|c|c|c|}
\hline $\begin{array}{l}\text { Adancourt, F. } \\
\text { Ayné, D.L. } \\
\text { Balfour, A., Co } \\
\text { Barteling, B. } \\
\text { Baudry, F, } \\
\text { Bélin, A. } \\
\text { Berling } \\
\text { Bianco } \\
\text { Birner, F,C. } \\
\text { Borg \& Gröndahl } \\
\text { Boyer, A. Le \& Co. } \\
\text { Bredl, C.L., arne } \\
\text { Bré, de, I'a, } \\
\text { Brenck, widow, C.F. } \\
\text { Casimir, W. } \\
\text { Clowes, W. } \\
\text { Coque, C. } \\
\text { Crosilhes, J.P.P. } \\
\text { Crusen, G.C.J. } \\
\text { Decourchant } 46,83 \\
\text { D'Hautel }\end{array}$ & $\begin{array}{r}131 \\
51 \\
158 \times \\
138 \\
56,57 \\
178,204 \\
112,113 \\
205 \\
119 \\
224 \\
211 \\
55 \\
58 \\
234 \\
85 \\
69 \\
51 \\
53 \\
63\end{array}$ & $\begin{array}{l}\text { Frantin } \\
\text { Froebel } \\
\text { Gebauer } \\
\text { Grondahl, } \\
\text { Hautel, } \\
\text { Haykul1, } \\
\text { Hoffmann, } \\
\text { Hopfer de } \\
\text { Keymer, } \\
\text { Kittsteir } \\
\text { Lajugie, } \\
\text { Le Boyer, } \\
\text { Lebel } \\
\text { Leleux } \\
\text { Levrault, } \\
\text { Marcus, } \\
\text { Mantoux } \\
\text { Moesssard, } \\
\text { Neill }\end{array}$ & $\begin{array}{l}\text { C. } \\
\text { C.G. } \\
\text { I. Orme } \\
\text { r. J.G. } \\
\text { A. } \quad \text { Co. } \\
\text { F.G. } \\
\text { A. } 42,43 \\
132,134,\end{array}$ & $\begin{array}{r}226 \\
223 \\
197,198 \\
212 \\
63 \\
228 \\
146 \\
80 \\
35 \\
211 \\
181,211 \\
89 \\
172 \\
174 \\
174 \\
78 \\
48,129\end{array}$ \\
\hline
\end{tabular}

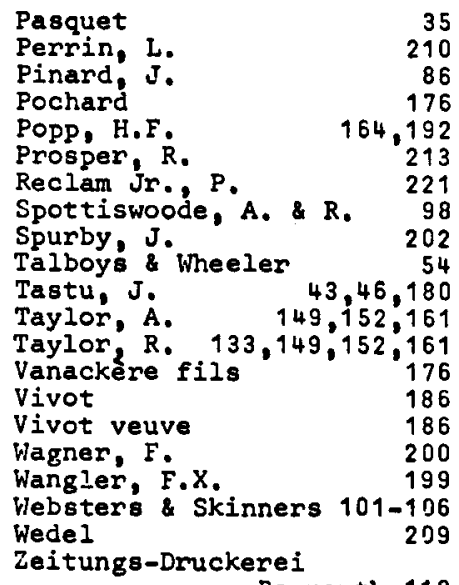

P U B L I S H E R S

(Names of societies are,excluded)

\begin{tabular}{|c|c|}
\hline $\begin{array}{l}\text { Anhuth, S. } \\
\text { Audin } \\
\text { Audot } \\
\text { Bachelier } \\
\text { Bailly de } \\
\text { Baldwin, Cr } \\
\text { Barrois Jr } \\
\text { Barth, A.A } \\
\text { Barth, J,A } \\
65,56,11 \\
\text { Baudouin fr } \\
\text { Baumgurtner } \\
\text { Belin, A. } \\
\text { Black, A. } \\
\text { Blackwood, } \\
\text { Bré, de, } \\
\text { Cadeli, T. } \\
\text { Cadell, T. } \\
\text { Calve, J.G. } \\
\text { Constable } \\
\text { Cotta, J.G. } \\
\text { Crosilhes, } \\
\text { Debeausseal } \\
\text { Desbeaussed }\end{array}$ & 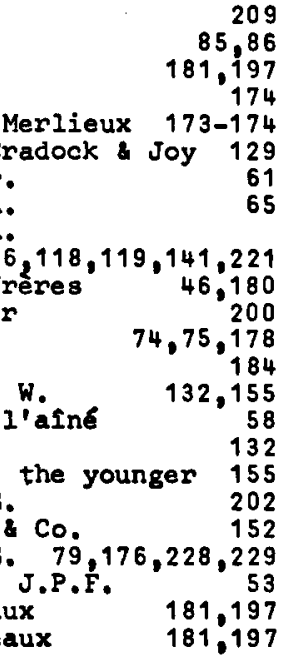 \\
\hline
\end{tabular}

Deterville

Dieterich

Dufour

Ebner, J.

Ettinger, C.W.

Ferra

Ferra jeune

Fleischer, $F$.

Funck, H.C.

Gadicke, Gebr.

Gallay

Gaury

Grau, G.A.

Grindahl, $C$.

Harding, $\mathrm{J}$.

Hermannsche Buchhandlung

Hofmeister, F.

Hurst, Robinson C Co. 152

Koenig, A.

Levrault, F.G.

Longman, Hurst, Orme \& Brown $142,146,184,162$

Ion gman, Rees, Orme, Brown \& Green 98,163
Maclachlan \& Stewart 129 Mancel 58 Meilhac 58

Palmblad \& Co. 235

Persan \& Co. 85

Perthes Besser 192

Pillet alné 123,124

Reclam, C.H. 194

Reinherz

Rey \& Gravier $\quad 46,180$

Roret 176

Schmid, A. \& Co, 194,238

Sepp, J.C. \& $\mathrm{Zn}$. 138

Sherwood, Neeley \& Jones 164

Steele, o. 106,107

Stewart, C.

Sturm, J. $\quad 189,232$

Talboys, D.A. 54

Uckert [Ukert], A. 64

Vanackère fils $\quad 176$

Vanackere père 176

Wagner, F. 200

Websters Skinners 100-106

Wheeler 54 
SUB JEC T I N D E

\author{
including: \\ CHAPTER MAIES \\ NAMES OF AUTHORS TREATED IN THE SPECIAL BIBLIOGRAPHY \\ NALIES OF PERIODICALS TREATED IN THE SPECIAL BIBLIOGRAPHY \\ Tities of books and artiales treated in the opeaial bibliography \\ Titles of other booke and articles \\ Names of other persons \\ $\rightarrow$ cross-references \\ Key-words
}

ABBREVIATIONS, jist of

$30-32$

Academa Caesarea Leopoldina-Carolina 187

Acadérie des Sciences, Paris

- de Candolle, sought membership

- Gaudichaud, member

- Palisot Reauvois, member

Account of some of the Cryptogamoue

plants of Devonshire GREV. n.3

Acharius, E.:

Synopsis methodica lichenum

ACKNONLEDGEMENTS

Ad floram Pedemontanam appendix

Adancourt, F., printer altera RE $n$.

Adanson, A.: La maison de campagne

Adanson, M.: Familjes des plantes

Aldendum to Dr. Grevilie's artiale

Agardh, C.A. GREV. n.8

- Aphorismi botanici

- collaborator of Kunth

- collaborator of PresI

- Species Algarum

- supposed algae to change int

- visit of Hornschuch

Ahnfelt, C.N., respondens

Aikin, W.E.A.: collaborator of Eaton 105

Ainsworth, $W$.

IV,

alphabets in signatures

ALLGEMEINE BOTARISCHE ZEITUNG

$\rightarrow$ FLORA

Allioni, C., teacher of Bathis

Alsace. exsiccata of Mugoi

- planned flora

ampersand

analytical bibliography

Anderson, L.C., bryologist

Andrews, A. Leroy, hryologist

Anhuth, $S$., publisher

AUNALES de Za SOCIETE LINNEENNE

ANNOUNCEMENTS

de PARIS

antheridia

archegonia

Archives Départementales

- Bas-Rhin (Strasbourg)

- Haute-Loire (Le Puy)

- Lot (Cahors)

- Nord (Lille)

- Tarn-et-Garonne (Montauban)

Archives Nationales, Paris

241

206

$108-111$

170

191

10

$1-29$

143

149

209

$182-183$

\section{9}

Arlary, estate op Arnott

ARIIAUD, Jean Andre Michel

- Flore du departement de za BauteLoire

ARNOTT, George Annott Walker

$$
\text { III, 36-49,134-135 }
$$

- collaborator of Gaudichaud

40

35

35

- Disposition méthodique des especs de moures (n.5)

- - review by Furnrohr

$39,43-45$

- - review by Hornschuch

- herbarium

- letters to Ad.Brongniart

167-168

- letter to Hooker

- Muscologia (planned)

$36-38,151$ Rio de Janeiro to the ooast of Peru (n.3. eeparate) (n.4, period.)

- Notice on Schwaegrichen's 2d Suppt. volume (unpubl. manuscript)

- Houvelie disposition msthodique des espers de mourseo

- (n.5, 4\% separate)

- $\left(\pi .6,4^{\circ}\right.$ period.)

- (n.7, 8. period.)

- $\left(n .8,8^{\circ}\right.$ separate)

- $\left(n .11,8^{\circ}\right.$ re-issue)

- preface of Wight \& Annott: Prodromus forae peninsulae Indiae Orientalis 40

- Selection from testimonial in favour of ...

- Sur cuezquen mousero de Rio de Janeiro $(n .2)$

$45-46,239$ $46-47$

- - history of its publication

42,238

- Synopsis Muscorum (planned)

- Tentamen methodi Musoorum (GREVILLE : ARNOTT n.1, 3-4) 134-135

- Tour to the South of Franos and the Pyrenees in 1825 (n.9, separate) 47-48

(n.10, period.) 49

- visit to A.P. de Candolle 39

- voyage to Russia

Arrhenius, J.G., respondens

Arrhenius: J.P.: Monographia Ruborum

ARTISTS, index of Sueciae (collation) 23

asterisks in signatures

Audin, publisher

Audit, publisher

Ayné, D.L., printer 
Bachelier, publisher

Baffin's Bay, mosses

Bagge, engraver

Bailly de Merlieux, C.F.

colilaborator of J.P. Lamouroux 173-174

- editor of Encyclopedie Portative 173-174

BALBIS, Giovanni Battista

- Enumeratio p lantarum offioinalium (n.1)

$50-51$

- Flora Taurinenoie (n.2)

50

- Flora Ticineae (Nocca B.)

- Flore Lyonnaige (n.3)

- Supplement (ROFFAVIER)

Baldwin. Cradock Joy, publishers

Balearic Islands, plants

Balfour, A. \& Co, printers

Balfour, J.H., botanist

- letters from Annott

Banks, Sir Joseph

Barclay. Dr.. anatomist

Barclay, Mr. (to Pussia with Arnott) 40

Barclay, Mary Hay (married Annott) 40

Barolo, F.

BARON, P. Alexis

- Flore des departemeno méridionaus

Barrois, Ir.. publisher

$$
\text { de ia France 52-53 }
$$

Barteling, B., printer

Barting, F.G., botanist

collaborator of K.B. Presl

Barth, A.A. pubjisher

Barth, J.A., publisher

$$
65,66,116,118,119,141,221
$$

- biography

Bas Languedoc, catalogue of plents 39,40

Batsch, A.G.J.C., teacher of C.G. Nees 187

Baudouin frères, publishers 46,180

Raudry, F., printer

Bauer, F.A. artist

$56-57$

69

200

Baungärtner, publisher

BAYTEP. Wilizam

II. 53-54

$\begin{array}{lr}\text { - Stirper cryptogamas Oxonianeer r } & 53-54 \\ \text { Bayreuth (Bavaria) mosses } & 119-120\end{array}$

Beaupré + Gaudichaud-Beaupré

Beauvois - Palisot de Beauvois

Beck, L.C., collaborator of Eaton 104

- Natural yntem of the plante of the tetes North of Virginia 106

BECKER, Johannes 54-55

- Flora der Gegend um Frankfurt

Beechey, F.W. Captain, collections studied by Hooker Amott

BÉHERE, Jean Baptiعte Joseph

- Musoologia Rothomagenois

$$
\text { (n.1, period.) }
$$

(n.2, seperate)
Beitrag su dar Hoosgattung Sphagnum

Beitrag sur Geiohiohte der Fort in der Kenntnise der Moose (HORHSCHUCH $n .4$ )

Beitrage sur kryptogamieohen fior der Inoel Rügen (LAURER n.1)
Belgium, flora

BElin, A., printer publisher $74,75,178,204$
$74,75,178$

Bemaerkringer ved supplementum Bzorae LAPponioum (SOMMERFE:T n.1)

Bemerkungen ther einige Pflansen Deutsohtand (HOPPE $n .1$ )

Bemerkungen tber Phasoum alternifolium Dioke.; Ph. subulatum Sahreb. und $P h$. globiferum Bruoh (BRUCH $n, 2$ )

Benin (travel of Pal. Beauv.)

Bentham, $G$.

Catalogue des plantes indigines des Pyrznese et du Bas Languedoc $39-40$

- criticized Lapeyrouse 48

- companjon of Arnott in S. France 39-40

- sent mcsses to Arnott 40

Beobaohtungen aber di.e Entwioklung der Laubmoosen aus ihren Keimkornern

(T.F.L. NEES n.2) 191

Bergius, P.J., responcens

Beriohtigung (HORNSCHUCII n.8) Inhalt der Gertnerei und Botanik

(DIETRICH, F.G. $\mathrm{n.4}$ ) 95

Berlin, "herborisations" by Kunth 171

Berling, printer

Bernoulli, pharmacist 112,113

Berneaud - Thiébaut de Berneaud

Berthelot, Sabin

Besser, publisher (Perthes B.) 192

Bianco, printer

Bibliographia Huntiana, project

BIBLIOGRAPHICAL FORMAT

bibliography

Bibliotec. Italiana (quired gathering) 10

Billoti, L., artist

binary system of nomenclature

BINDING

Birner, F.C., printer Iithogr.

Black, A., pusj.isher

Blackwood, W.: publisher

Blanc, P. le

Les drbut de l'imprimerie au Puy 35

Blandow, 0.C. collahorator of Sturm 232

Blume, C.L. botanist 190

Blumenbach, botanist, dedication to 194

Boeck, C., artist

Boehmer, teacher of Hedwig 139

Bogen (German for sheet or gatherjing) 10

Boheims phanerogamischen und cryptogamischen Gewllchse, Naohtrag (OPIZ n.1) 195

Bohemia, supplement to flora 195

Bohme, J.C., engraver

bolted leaves, bolts

Bonite, La (ship)

Bonn, botanical garden

Bonner, G.W. artist, engraver

Bonnet, engraver

Bonnet; C. Swiss philosopher works translated by Hedwig

174 Bonpland, A.J.A., botanist

5

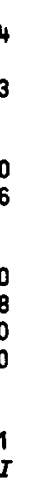

7


book binding

book description

book making

Borg \& Gröndahl, printers

Bory de Saint-Vincent, J.B.G.M. collaborator of Gaudichaud

Botanioa insegnata in ventidue

Zezioni (DEMERSON n.4)

Botanicon Etruscum (SAVI n.1)

Botanique enseigné en vingt-deux legons (DEMERSON $\mathrm{n} .1$ )

- ed.2 (DEMERSON n.2)

- ed.3 (DEMERSON n, 3)

Botanische Gesellschaft in Regensburg dedication to

Botanisches Taschenbuch (Hoppe)

Botanographie Belgique

Both, F., artist

$$
\text { (LESTIBOUDOIS } n .1 \text { ) 175-176 }
$$

engraver

201

202

$1-27$

Bowers, F., bibliographer

155

211

Boyer. A. Le, \& Co, printers

Braune, F.A. von: Salzburgische Flora 212

BREBISSON, [Louis] Alphonse de 57-59

- diatoms studied by Arnott

- letter to A.P. de Candolle

- Mouraes de la Normandie

- visit of Arnott

Bredl, C.L., printer

Brée, de, I'ainé, printer, publisher 58

BREUTEL, Johann Christian 234

- Beitrag zu der Moosgattung Sphagnum $(n, 2)$

- Einige vergleichende Bemerkungen aus den Gattungen Phasoum. Gymnostomum und Grimmia (n.3)

- Musci frondosi exeicoata (n.1)

remarks by Bruch on the Bemerkungen 70

BRIDEL, Samuel Élisée VI,60-67

- artist

$61,64 ?$

- Bryologia universa (n.5) VI,65-67,238

- - review by Hornschuch

167

- classification of mosses, new 64,67

- Mantisea generum speoierumque Muscorum frondosorum universa

$$
(n, 3)
$$

- - re-issue $(n .4)$

$63-64$

- Nethodus nova Muscorum (n.3)

65

- - re-issue (n.4)

$63-65$

- Muscologia recentionum (n.1) 60-62,239

- Supplementum 1-3 (n.2)

- - Supplementum 4 (n.3)

- - re-issue (n.4)

- sent information to Mougeot

- Specieo Huscorum (n.2)

BRIDEL-BRIDERI, S.E. de $\rightarrow$ BRIDEL

Britieh Jungermanniae (HOOKER n.1) 146-147

broadsheet, broadside 6,12,16

Brockhaus: Intelligenzblatt 168

- Li terarischer Anzeiger

Brodie, J., dedication to

broken letters

Brondeau, L, de, artist

$62-63$

$63-64$

65

187

$62-63$

148

211
Brongniart, Adolphe

- Histoire IV,36-38

- letters from Amott

- letters from Desvaux

- letters from Eschweiler

- letter from Greville

- letters from van Hall

- prospectus sent to Arnott

Brotherus, V.F., bryologist

Broussonet, P.M.A., botanist

BROWN, Robert

- arctic plants, lists in GREV.n.2

- Brownian movement

- Chloria Melvilizana (n.1)

- - review by Hornschuch

- collaborator of Hooker

- Hooker introduced to

- Madeira plants, list in Buch

- observations on the leaves of Buxbaumia and Fisoidens

$36-38,151$

92,182

111,235

131

138

38

67

76

$68-69$

125

68

$68-69$

166

157

145

71-73

Brownian movement

BRUCH, Philipp IV, 70

- Bemerkungen uber phasaum alternifolium Dioks.; Ph. oubulatum Sohreb. und $P h$. globiferum Bruch (n.2)

- Bryologioche Beobachtungen (n.4) 70

- collaborator of Hochstetter 144

- Correpondena

- described Weiseia flesuosa

- described Pohlia ououlzata

- Orthotrichum species listed and described in Brid.: Bryol.Univ. $\quad 70$

- Orthotrichum names listed by Steudel \& Hochstetter

- Veber einige Laubmoose (n.6)

- Ueber sphagna, nebet Bemerkungen zu ... Breutel ... (n.3)

teacher of Fürnrohr

70

von Zwe ibruto und Umise Laubmoose von zweibruoken

Bruch, P., Schimper, W.P.

\& Gümbel, W.T.: Bryologia EuropaeaIV,70

Brugmans, S.J. director bot, garden Leiden

Bryologia Europeea (Bruch, Schimper \& Gumbel)

Bryologia Germanioa (NEES, C.G. HORNSCHUCH \& STURM n.1)

Bryologia univerea (BRIDEL n.5)

$V I, 65-67,239$

Bryologisohe Beobaohtungen (BRUCH n.4) 70

bryology, history

$\mathrm{BUCH}$, Christian Leopold von

- Aligemeine Jebersicht der Flora auf den Canarischen Inseln, 1816 73

- Nachtrag, 1819

- Coup d'oeil ur la flore des Iles

- Physicalisohe Beschreibung der

190

$I V, 70$

$87-188$ Canarischen Inoe $l_{n}$ ( $\left.\mathrm{n}, 1\right)$

bulle (French paper quality

BULLETIN LINNEEN [PARISJ 
Cade11. T. publisher

Cadel1, T. the younger, publisher 155

Calve J.G., publisher

202

CAMBESSEDES, Jacques

$73-75$

- Enumeratio plantarum quas in inoulie Balearibus oollegit (n,1, separate) 74 - (n.2. period.)

Canary Islands, description, Buch 73-75

cancellandum, cancellanda

cancellans, cancellantia

Candolle, Alphonse L.P.P.de

- artist

$\begin{array}{lr}\text { CANDOLLE, Augustin-Pyramus de IV,76-79 } \\ \text { - appreciated Mougeot } & 185\end{array}$

- artist

$5,23,26$

$5,10,23,26$

78

78

- classific. adopted by Lestiboudois 176

- reproduced by Perleb

- Coure de botanique (n.1)

199

- criticized Lapeyrouse

- descriptions in BUCH n.1

$77-79$

48

- Encyclopédie mfthodique (prepared some articles)

- Flore Prancaise (ed.3, Lamarck \& DCJ

- Flora Iyonaise, presented

- herbarium, seen by Arnott

- Bistoire des plantes grases

- letter from de Brébisson

- letter from Greville

- letters from Sprengel

- natural classification in F1. Franc. IV

- Organographie der Gewdohse (n.2) 79

- Organographie vegetale (n.1) 77-78

- Prodromus oystematis naturalis regni vegetabilis 77

- - Kunth's Enum.P1. a complement 171

- Regni vegetabilis systema naturale 76

- Synopeis planterum in Flora Gallica descriptarum (Lamarck \& DC.) 37,76

- Theorie élementaire de le botanique 76,225

- visit of Annott

- Vorlesungen uber die Botanik (n.2) 79 capitals

Certe botenique de la mbthode nature1-

le (Deshayes, Pierre Marie), format 12

Casimir, printer

CASSEBEER, Johann Heinrich IV,80-81

- Veber die Entwickelung der

$$
\text { Laubmoose (n.2) 80-81 }
$$

- Veber die Leiohteote Methode aus der reifen-Hooobulohse die Conferve darmutelien (n.3)

- Hetterauische Laubmoose (n.1)

Catalogue des plantes ... de la Cote-d'Or (Lorey \& Duret)

catchword

Catskill Botanical School

cell theory

Central America, cryptogams

Centurias plantarum eryptoganarum

norvegicarum (SOMMERFELT $\mathrm{n.1}$ )

chain of being

chains, chain-lines

Chauvin-Desroches, teacher of

Cheek, H.M. Gaudichaud

\section{1}

80

177

4

100

193

153

223

I

2
CHEVALLIER, François Fulgis IV, 82-83

- candidate for Nestler's chair

- Flore generale des environa de Paris $(n, 1)$

$-2.2(\pi .2)$

$82-83$

- Notice $2(\pi .2)$

$83-84$

travaux acientifique* 82

Chloris Helvilliana (R.BROWN n.1) 68-69

Choiey, J.D., descriptions in BUCH $n .172$

Chotard, artist

CHRONOLCGY of publications 242-251

Clauder, C., artist

$\begin{array}{ll}\text { Clauder, C. artist } & 66 \\ \text { Cleghorn. } H . \text { substitute for Arnott } & 41\end{array}$

Clowes, $W$. printer

Cobbett, $W_{\text {. }}:$ The Americen Gardener

Colebrooke, H.T. artist

- collaborator of Hooker

COLLATIONAL FORMULA

collectors

color prints of mosses

- of moss protonema

columnation, column numbering

compartment

compositor

CONCEPT OF DESCRIPTIVE AND ANALYTICAL BIBLIOGRAPHY

confugate leaves, conjugacy

- definition

Conopeotus methodi plantarum

naturalis ... (PERLEB n.2)

Constable, A., \& Co, publishers

CONTENTS (description of)

- references to pages

Coque, C., printer

176

69

3

154

155

$22-25$

Corda, Algust Carl Joseph, artist

- Deutschland Algen (in STURM n1) 23

- Deutschlad

"corner-leaves" 15

CORRECTIONS \& ADDITIONS

comections, stop-press

corrector

Correspondens (BRUCH n.5)

Correspondens (FUNCK $\mathrm{n} .5,6$ )

Correspondens (HORNSCHUCH n.5)

188,224

191

26

4

C8te-d'or (France), plant catalogue 177

Cotta, J.G., publisher $79,176,228,229$

countermark

- in half-sheet imposition

Courchant + Decourchant

Coure d'agrioulture, de botanique at

d'hiotoire naturelize...

(SAUMAISES $n .1) \quad 210-211$

Coure de botanique (CANDOLLE n.1) 77-78

Cradock + Baldwin, Cradock \& Joy

Crosilhes, L.P.F., publisher 53

Crosilhes, L.P.P., printer 53

Crouan frères: Observation aur les

tetraspores des Algues(in DESMAZ,n.1) 88

Crum, Steere \& Anderson, list of

N. Amer. mosses 143

Crusen, G.C.J.. printer 63

Cryptogamische Gewlohse [besonders]

des Fichtelgebirg's (FUNCK n.1) 114-118

- - ed.2 (FUNCK n.2)

cuadernillo (Spanish for gathering) 10

Curtis, J.. engraver 69,160,[162]

cut copies 
Dalton, J., dedication to

dandy-rolis

Danzig, flora of

Dasser, M.: Arsoi (partly) in

Bl.Belg.Septentr. (v.HALL $n, 1$ )

- mosses revised by Wachter

date on title-page

dates in watermarks

DATES OF PUBLICATION

- necessicity of exact dating

De BREBISSON $\rightarrow$ BREBISSON

De BREE l'aIne + BREE

De CANDOLLE + CANDOLLE

De JUSSIEU - JUSSIEU

De Nuocomum propagatione oommentatio... (T.F.L. NEES n.1) i9o

Debeausseaux, publisher 181,197

deckle-edges

211

Decourchant, printer $46,83,169,181,211$

Delessert, J.P.B., botanist

- acquired herbarium Pal.Beauv.

- herbarium studied by Arnott

36,38

DEMERSON, L.

- Celendrier Francais (collation)

$84-86$

- La botanica ineegnata in ventidue lesioni ... (n.4)

- La botanique eneaignce en vingtdeux legone... $(n, 1)$

- ed.2 (n.2)

- ed.3(n.4)

- peeudonym of L.Hanin?

Desbeausseaux - Debeausseaux

Descourtilz, T., artist

Desave, engraver

Desoription of a new opecies of Grimmia ... (GREVILLE n.4)

Description of a new opecies of Potentilia ... (GREVILLE n.2)

Desoription of some new moses discovered in South America by Dr. Gilizes (GREVILLE n.10)

23

86

$84-85$

85

86

84

214

211

126

125

Description des mousses trouvees par H. Gaud i chaud (Schwaegrichen, unpubI.) 45

Descriptione of two new opeoies of Musoi ... (GREVILLE n.7)

descriptions of watermarks

DESCRIPTIVE BIBLIOGRAPHY APPLIED

Desfontaines, $R, L$. TO BOTANY teacher of A.P. de Candolle

- teacher of Kunth

Deshayes, Pierre Marie: Carte botenique de la methode naturelle (format) 12

DESMAZIERES, Jean Baptiste Henri

- artist Joseph 87-90

- Plantes cryptogames [du Nord] de la France $(\mathrm{n}, 1)$

- - ed.2 (n.2)

211

$87-89$

- - ed. [3] ed.2,ser.2 (n.3)

90

DESVAUX, Nicaise Auguste

- Exposition mdthodique des genres de la famille des mousses ... (n.1)

- Prodrome de la familio dea fougeres (n.2)

Déterville, publisher
Deuteohlande Algen (Corda, in STURY) 230-234

Deutsohlands Flora... Abt. II.

Cruptogamen. (STURM n, 1)

$230-234$

Deutsohrande Jungermannien

(Corda, in STURM) 230-234

Deutsohlands Moose (FUNCK n.3) 118-119

Deutschlands Waldern, Flora of 200

Devonshire, cryptogams 125

Dewey. C.

- Carex Bpecies cited by Eaton 107

- dedication to

D'Hautel, printer

102

agnosen neuer Laubmoose und andere Notisen (HORNSCHUCH $n, 3$ )

Dien, [C.M.F.?], engraver

Dierbach, J.H.

Plore Heidelbergeneis (format) 13

Dieterich, publisher 226

DIETRICH, David Nathaniel Friedrich 93

- Musoi Thuringioi (Zenker \&.) 237

Dietrich, Friedrich David $\rightarrow$ Dietrich, DNF.

DIETRICH, Friedrich Gottlieb 93-97

- Beriohtigungen und Bemerkungen ... Inhalt ... voliständigen Lexicon $(n .4) 95$

- Naohtrag sum vollotandigen Lexioon der Gdrtnerei und Botanik (n.3) 94-95

- Nou entdeokto PfLansen ... (n.5) 95-97

- Neuer Naohtrag sum volistandigen Lexioon ... (n.5)

- Vollotandiges Lexioon der Gdrtnerei und Botanik ( $n .1)$

- ed.2 (n.2)

Dietrich, J.C.G.?

$95-97$

94,239

94

Dilienius, J,J.: Hiteroris Muscorum

- Appendix, Cat. Pl. ... Gionam

Diliwyn, L.W.

Britieh Confervee illustrated by Hooker 145,146

direction-line

Dieposition methodique deo espeos de mousees (ARNOTT n.5)

Disertatio inauguralis geographioobotanioa de territorio Vindobonensi (SAUTER n.1)

212

Dixon, H.N., revised names by Hedwig 142

DRUMMOND, James Lawson 97-98

- artist

- Firat etape to botany, ed.2 (n.1) 98

Drummond, Rev. T.K. 124

DRUMMOND, Thomas 99

- Musai Amerioani exoiooati ...(n.2) 99

- Musai Sootiai ...(n.1) 99

- species collected on his first

journey in North America 162

drying in paper making

Duby, J.E.

nomencleture used by Roffavier 209

Dufour, publisher 91

Dumas, M. general 73

Duménil, P.C.R.C., artist 82

Dumont d'Urvilie, J.S.C. collaborator of Gaudichaud 123

Duncombe, artist

duodecimo (format)

154

DURET - LOREY \& DURET

78 Durieux, engraver

D'Urvilie + Dumont d'Urville
$10,12-13$

176 
EATON, Amos

- A botanical dictionary

- Botanical excercises

- A botanical grammar

- Botanical orammar and dictionary

- letter from John Torrey

- letters to 0. Steele

- letters to John Torrey

- Manual of Botany (n.1)

- ed.2 (n.2)

- ed.3 (n.3)

- $-0.4(n .4)$

- ed.5 (n.5)

- ed.6(n.6)

- ed.7 (n.7)

- \&right, J North American Botany 100

Eaton, Amos Beebe 100

Eaton, D.C., botanist

Eaton, H.H.

collaborator of Amos Eaton, ed.5 105

Ebner. J., publisher

Eden, Sir John, father-in-law of Greville

Edinburgh Botanical Garden

Edinburgh, regional flora

EDITION, ISSUE AND STATE

edition, definition of Bowers

Edwards, [S.T.?], engraver

Edwards, W.C., engraver

Edwards, W.H.C., engraver $146,160,162$

effective publication

Einige vergleiohende Bemerkungen aus den Gattungen Phasoum, Gymnostomum und Grimmia (BREUTEL n.3)

elements, philosophical

empty rectangle

cyclopedie mothodique botanique 76

Encyclopedie portative

Engels, W., engraver

English plants in Soottish oryptogamio flora (GREV. n.5)

engravers, ENGRAVERS (index of)

engravings

Enumeratio plantarum Germanias Helvetiaeque indigenarum ... (STEUDEL \& HOCHSTETTER $\mathrm{n} .1$ )

Enumeratio plantarum offioinalium horti botanioi Taurinensis

$$
\text { (BALBIS } n .1 \text { ) }
$$

Enumeratio plantarum quas in insulis Balearibus collegit

(CAMBESSEDES $n .1$ separate)

Epinal (France). museum

$$
\text { (n.2 period.) }
$$

etchings

Etruria, regional flora

Ettinger, C.W., publisher

etymologies of plant names

evolution, excluded by Oken

Exotio flora (HOOKER n.6)

EXSICCATA

191,208

131

25,255

24,28

185

24,28

$213-214$

61,63

106

193

$153-157$

277
Falkland islands

list of plants by Dumont d'Urville 123

fascicles of booke and periodicals

Fasciculue plantarum Brasilienaium (Schott in SPRENGEL n.1)

Fauvel, A., taught botany temporarily for T,Lestiboudois 175

felt fibres, impression in paper

Femsjo (Sweden), flora

Ferra, publisher

Ferra jeune, publisher

Ferrari, S., dedication to

Feugere, artist

feuille (French for sheet)

Fieber, F.X., artist

Fichtelgebirge, crypt exsicc.

fin (French paper quality)

Firot otepe to botany, ed.2

(DRUMMOND, J.L. n.1) 98

Fischer, F.E.L. V., Russian botanist visited by Arnott

Plechten. Die (Laurer in STURM $n, 1$ ) 40

Fleischer, pharmacist, collector for exchange society 144

Fleischer, F., publisher

Fleischer, M., bryologist

Flinders, "H.A.: A voyage to Terra

Australis; Appendix N. III (by R. Brown) 68

Floerke, H.G., collaborator of C. B. Presl 202

FLORA (periodical) 108-111

Plora Andium Peruvianorum (KUNTH n.1) 172

Flora Batava, $v$. Hall editor

Flora Belgii septentrionalis (v. HALL $n, 1$ )

Flora Cubae Inoulae (KUNTH $n .1$ )

$136-138$

Flora Danica (Oeder, $8^{\circ}$ )

Flora Danica (Oeder, $2^{\circ}$ )

- Nomenolatura Florae Danicae (HORNEMANN $\mathrm{n} .1$ ) 164

Flora dex Gegend um Frankfurt am Main (BECKER $n, 1$ )

Flora. Deutsoh Zande (STURM n.1) 230-234

Flora Edinensio (GREV. n.1) 131-132

Flora . Frankfurt am Main 55

Flora Gallica, Synopsi.

229 Flore Lapponica (Wahlenberg) 224,235

- Supp Zementum (SOMMERFELT n.2) 223,224

Flora Wovo-Granatensio (KUNTH n.1) 172

FLORA ODER ALLGEMEINE

BOTANISCBE 2EITUNG (periodical) 108-111

Flora Pedemontana (Allioni)

- Appendis altera (RE n.2)

rlora provinaiarum Novae Andaluoiae.

Veneauelae nea non Planitiei

Baroinonensia (KUNTH n. 1)

Fiora scotioa (HOOKER n.4)

206
Flora Suecica (WAHLENBERG n.1) 236-237

Flora Taurineneio (BALBIS n.2)

Flora Ticinese (Nocca Balbis)

Flora Torinese (RE $n .1$ )

Flora von Deutsohlando Waldern

(PERNITZSCH n.1)

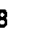

4

7


Flore des departemens méridionaus de la Franoe ... (BARON n.1)

Flore du departement de la Baute-Loire (ARNAUD n.1)

Plore Française (Lam. \& DC., ed.3)

Flore Francoite (Lamarck)

Flove Lyonnaise (BALBIS n.3)

- Supplément (ROFFAVIER n.1)

Florke $\rightarrow$ Floerke

Florschutz, P.A.: introduction to facsimile ed. of Hedw. Spec.Musc. 144 foliation (leaf numbering)

folio (format)

font-size description

FORMAT, BIBLIOGRAPHICAL

FORMATS, KEY TO

forme

inner forme

outer forme

FORMULA, COLLATIONAL

fossil leaves, nervation

fossil woods

Fouquier, F.F., dedication to

Fox, $C$. engraver

frame (in title description)

France, bryology in

- flora of

- flora of Northern France

- flora of Southern Erance

Frankfurt an Main, flora

Frantin, printer

$10,12,16$

12

$10-14$

15-21

4

4

4
25

$22-25$

71
68

82

133

IV

76

175-176

$35,52-53$

55

177

French Revolution, influence on science II

Freycinet, Louis de: Voyage autour du monde ... our lea oorvettes ...

I'Uranie et Ia Physioienne ...

- Botanique (GAUDICHAUD n.1)

Fricke, F.A., artist, engraver

$122-124$

220

FRIES, Elias MAgnus

$111-113$

- Stirper agri Femoionenoio (n.1)111-113

- Stirpium agri Femoioneneis (n.2) 113

- system of Fungi enumerated 228

- Systema mycologicum

Froebel printer

FRÓHLICH, Josef Aloi:

- CPflansen in den an die Kurathie Stech im Leahthale angransenden Gebirgen) (n.1)

FUERNROHR $\rightarrow$ FURNROKR

full rule

FUNCK, Heinrich Christian

- collaborator of Sturm

- connection with Hornschuch

- Correspondens $(n, 5,6)$ - Cryptogamische Gewdohse besonders

- ed.2 (n.2)

111

96

114

- Deutsahlands Hoose (n.3)

118-119

- Moose aus der Umgebung von Bayreuth 119

- Hoos taschenherbarium

- publisher

- teacher of Laurer

119

ungi ... Liohenes ... Hepatioae ... Nus $i$... (HOOKER $\mathrm{n} .5$ )

FURNROHR, August Emanuel

- Verouoh ciner naheren Bezeuohtung der Disposition methodique... Arnott $(n, 1)$
Gldicke, Gebr. (Broths.), publishers 97

Gallay, publisher 169

Gallia, flora, synopsis (Lam. \& DC.) 37,76

Gardner, G., botanist

Gatereaus Description des plantes ... environe de Monteuben

gathering

53

GAUDICHAUDD-BEAUPRE, Charles

- collections

- herbarium, mosses studied by Annott 38

- Voyage autour du monde ... our les oorvettes ... Z'Uranie et Za Physioienne...

- Botanique $(n, 1)$

$122-124$

Gaury, publisher

Gay, J.E., collaborator of Gaudichaud 123

Gebauer, printer

Geiseler, E.F., dedication to

gemmae, supposed to be seeds

generatio aequivoca

generatio spontanea

Gerard, L.: Flora Galloprovincialis (plate units)

226

208

German plant names of Oken

Germany, bryology in

- bryology of

- cryptogamic flora

- hepaticology (Corda)

- plant checklist

germination of moss spores

- Cassebeer

- T.F.L. Nees

IV, 81

Gillies, collected new mosses in

Girardet, C., engraver South America

Glasgow chair of botany

Glasgow University Library

Glasgow University Press

Goethe, W. v.

- contact with C.G. Nees

$88-189$

$230-234$

$230-234$

229

- controversy with Oken

travel companion of F.G. Dietriah

gothic (type, "black letter")

Graham, J., duke of Montrose, dedication to

Graham, R. botanist

- collaborator of Hooker

155

- companion of Grevilie

124.156

- dedication to

131

Grau, G.A.

Graves, G., artist (colored $4^{\circ}$ ed. Of pls, of HCOK, \& TAYL. Musoot, Brit.) 161

Gravier (Rey Gravier), publisher 46,180

Gray. S.F.I A natural arrangement of

Great Britain, Bepatioae plant $\because$ i61-162

- Jungermannia

- moss flora

Greek letters in collational

$$
\text { formulas }
$$

$146-147$

$160-162$

Greenland. West Coast mosses

GREVILLE, Robert Kaye III, 124-135,158-160

- An acoount of some of the cxyptogamous plante of Devonshire (n.1)

- Addendum to Dr. Greville'e artiole

(n.8)

\section{7}

53

1

1

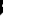


GREVILLE continued

- artist 125-126,128,132,133,154,158,159

- collaborator of Hooker 152

- A description of a new speaies of Grimmia in Scotzand (n.4)

- Description of a new epecies of Potentilza ... (n.2)

- Description of some new moseas discovered in South America by Dr. Gillies (n.10)

- Desoriptions of two new speaies of Musci (n.7)

126 125

- Plova Edinensis (n.6)

- classification used by Baxter 54

- introduced Arnott to Hooker

- On the leaves, capoule and root of Buxbaumia aphyzia (n.3)

- Scottioh Gymnostomum ahnfeltiz112,113

- Some acoount of a colleotion of oryptogamia plants from the Ionian Is lands (n.9)

- synoptical arrangement of all British cryptogams (planned)

GREVILLE \& ARNOTT

- A new arrangement of the genera of mosses (n.2)

- Tentamen methodi luscorum

- memoir 1-3 (n.1, separate)

- memoir 2 (n.3, period.)

- memoir 3 (n.4, period.)

Greg, Sir Walter H., bibliographer

Griffith, Mrs., algologist

Grimm, J.F.K., dedication to

Grondahl (Borg \& Grondahl), printer

Grondahl, C., publisher

Gross Glockner, plants

Grout, A.J., bryologist

guide fossils, importance stressed by Buch

Guilding, L., artist

Guilford, Earl of (F.North), collector 133

Haenke, T., botanist

Haiti, stay of Pal. Beauv.

half-sheet

half-sheet imposition

half-title

HALL, Hermanus Christiaan van

$136-138$

- Flora Belgii Septentrionalis

131

$134-135$

135

134

135

135

125

61

224

224

166

141

71

154

letters to Ad. Brongniart $(n, 1)$ 136-138

Hall.

Halsey, additions from, in Eaton 104

handmade paper . . 1,2

Hanin, Louis (Demerson a pseudonym?) 84

Harding, J., publisher

Harrison, Mrs. A., artist

Haute-Loire (France), flora

Hautel, d', printer

Haykuli, A. V., printer

head-line

Hebenstreit, J.E., teacher of lyedwig $139^{4}$
HEDWIG, Johann

- artist

II, $139-144$

- dedicational poem to

- Descriptio et adumbratio... Muscorum frondosorum...

founder of bryology

- Fundementum historise naturalie Muscorum

- Speoies Muscorum frondosorum

- - facsimile (n.1)

$I I, 140-144$

- Supplementum 1-4 (SCIWAEGR.) 217-223

- Stirpes cryptogamicae novae... 139

- teacher of Schwaegrichen 216

Hedwig, R.A., son of J.Hedwig 216

Hedwigia (periodical) 139

Heidelbach (Germany), Pernitzsch 200

Hemmes, N., respondens

Héritier, C.L. L',

herbarium studied by A,P.de Candolle 76

Hermann, J. teacher of Hougeot 185

- teacher of llestler 191

Hermannsche Buchhandlung, publisher 80

Herminie, L' (ship) 121

Heyland, J.C., artist 78

Hjelm, J.P., respondens, 112

Hobson, $\bar{L}_{0}:$ 'Britioh mossen (exsicc.) names cited

HOCHSTETTER, Christian Ferdinand

- Enumeratio plantarum Germaniae He lvetiaeque incigenarum ... (STEUDEL \& HOCHSTETTER n. 1 )

- Naohtrag au den Bemerkungen Uber Hrn Fleisoher's botanisohe Reise naoh Tyroz ... (n.2)

- Veber die Leistungen deo botanisohen Reiesvereins $(n .3)$

Hoffmann, C.G., printer

Hofmeis, G.F.: Deutschl.Flora 143

Holland, ficra of

Holstein, history of botany

Holzinger, J., edited exsircata

Hooker, J.D.

HOOKER, Wiliian Jackson

- artist 145,146,148,154,160

$136-138$

-138
192

59

$V, 36,945$

- British Jungermanniae (n.1) 146-147

- contact with Arnott

- contast with Greville

- dedication to

- engraver

- Exotio flora (n.6)

- generic concept

- Flora Borali Americani

- Flara scotioa (n.4) .. Hepaticae ...

- Journal of a tour in Iceland 153

- letter from Arnott

- Musoi exotici (n.3)

- Auscologia Britanniaa (HOOKER \& TAYLOR n.1)

$148-151$

- - ed.2 (HOOKER \& TAYLOR n.2)

$160-161$ 161-162 
HOOKEP continued

- Husoologia exotica (n.3)

- Species plantarum (planned)

HOOKER, H.J. \& GREVIILE, R.K.

- Icones Filicum (1327-1832)

- On the genus Calymperes of Swarts and Syrrhopodon of Schwaegriohen

$$
(n .5)
$$

- On the genue Hookerix of smith (n.3, period.) (n.4. Eeparate)

- On the genus Tortula ... (n, 2)

- sketch of ... the genera Orthotrichum,... Glyphomitrion, and Zugodon (n.1)

HOOKER, W.J. \& TAYLOR, T.

- Mrscologia Britannica (n.1)

- - ed. 2 (n.2)

Hopfer de l'orme, printer

HOPPE, David Heinrich

- Bemerkungen uber einige Pflansen Deutsohlands ... (n.1)

- collahorator of Sturm

- connection with Funck

- connection with Hornschuch

Horneman $M . J$ married J HoHomemann 16 HORNEMANN, Jens Wilken

- contact with Nolte

$163-164$

- Icones plorae Danica

163

- Nomenozatura izorae Danioas

HORNSCHUCH, Christian Friedrich IV $, 165-168,188-189,207$

- Beitrag sur Gesohichte der portochritte in der Kenntnies dor Laubmoose (n.4)

- Beriohtigung (n.8)

- Bryologia Germanioa (C.G. NEES, HORNSCHIJCH \& STURM

- criticized by Arnott

- connection with Funck

- connection with Hoppe

- Correapondenz (n.5)

- Diagnosen neuex Laubmoose (n.3) 166

- Mueai. in: PRESL: ReZiquiae

- Haenkeanae (n,6) $16 \mathrm{E}$

- Ptychostomum novum Musoorum ...

genus $(n .1)$... 165

- [Reviaw Arnott Disp.Meth.] (n,10) 167

- [Review Brid. Bryol. Univ.] (n.9)167-168

- [Reviaw Brown, $R_{0}: F i$. Melvo](n,5) 166

- Review Sohwaegr. Supp 2.2 voi. $7(1)] 16$

- Uber die von R.Broun entworfene Flora der Melvilize Inoel $(n, 5) \quad 166$

Hosack, D., botanist

166

167

8 -189

367
165

165

166

66

$6 \varepsilon$

Ja

\section{Jamer}

Jo

Jor

Johnson. T. Typographi
Jones (Shemood Neeley

Iceland, tour of Hooker 145

Icones Flora Danicae (Oeder) 164,192

ideal copy, definition of Bowers 7

Ile de France (Mauritius), vegetation 123

imposition

- schemes of Johnson

$10-21$

Imprimerie Royale, Paris, printer 5,123

imprints (printers)

in twelves

Index Kewensis

Index Muscorum

INDEX OF PLANT INAMES

INDEX OF BOTAYISTS

inferred page-numbers

inferred signatures

infusoria studied by Adanson

inner forme

inserted leaves

inserted tables

Institut de France,

Intelifgenzblatt (Brockhaus)

International Botanical Congress 1954 VI

International Code of Botanical

Nomenclature (ICBN) v

INTRIII

Ionian Islands, cryptogams

133

Ireland

- moss flora of Great Britain and 160-162

- hepatics

ISIS (Oken) (periodical)

ISSUE

161-162

ISTE

168

$6-12$

italic signatures

Italy, flora

Ives, E, teacher of Eaton

$214-215$

Jacquemont, $\mathrm{V} \cdot$, collections studied by Gaudichaud

Jacquin, N.J. v., dedication to

Jamaica mosses in Speciee Muscorum 142

Jameson, R., mineralogist 36,49

Jameson, W. collector

Journal of a voyage from Rio de Janeiro to the Coast of Peru (in ARNOTT $n .3,4$ )

$42-43$

207

Jones (Sherwood, Neeley \& Jones),

Joyeau, engraver publisher 129

Jussieu, Adr. de, "herborisation" attended by Arnott $\mathbf{3 6}$

-translated article of Buch

Jussieu, Ant.L.de, dedication to

73

- "herborisation" attended by Arnott 36

- - by Gaudichaud 121

- - by Kunth

- - by Palisot de Beauvois

170

- connection with Kunth 170-172

- Bonpland: Voyage, 6e. Partie. Botanique (KUNTH n.1) 170-172

Hurst, Robinson Co., publishers 152

hybridize, experiment of de Necker II

hyphen, in collational formula
- Genera planterum

- natural classification (which see)

- succeeded by Gaudichaud in Académie 121

- teacher of Kunth

Jussieu, Bern. de 
katern (Dutch for gathering)
Kaulfuss, G.F., botanist, artist

10

- collaborator of Sturm

Kellogg, E., dedication to

Kew, Royal Botanjc Gardens

"Kew-mule"

KEY TO BIBLIOGRAPHICAL FORMATS

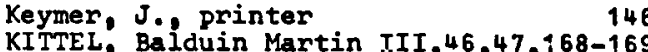

- Nomoire our les pucerons (n,2) 169

- Bypnum species discovered by 168

- Mbmoires d'histoire naturelze (n.2) (see Arnott n, B)

- Rapport aur la Nouvelte disposition methodique des espdoes de mousese ... Axnott (n.1)

Kittsteiner, J.G. printer

KNEIFF, Friedriech Gotthard, botanist

- Den Standort des zygodon conoideum Book. ... (n.1)

KNEIFF MÄRKER

170

Kuosi frondosi quas in 1zaatia(n,1) 170 Koch, D.J., donated herbarium to Bruch 70 Koch, L.F.. bryologist

Koehler, J.G., donated microscope to Hedwig

142,143

Koenig. A. publisher

K8n.Akademie Wissenschaften Berlin 71-73

Kön, Regensburger Botanischer Verein 234

Kuhl, H., contact with T,F,G. Nees 190

KUNTH, Carl Sikismund 170-172

- artist

170

- Enumeratio planterun 172

- "herborisations" near Berlin 171

- Synopsio plantamm aequinootialium orbie novi (n.1) 37,171-172

Kunze, G. succeeded Schwaegrichen 216

L'Héritier, C. L.

Labarre, paper expert

laid paper

Lajugie, L., printer

lake district (Fngland) toum Hooker

Lamarck, J.B.A.P.M. de, naturalist 76

- Encyciopedie methodique. Botenique 76

- Flore Francaise ed.3 (Lam. \&C.) 76

- Plore Francoise (type font)

lambda treatment of plate-books

Lemouroux, J.F.V. algologist

LAMOUROIJX: Jean Pierre Péthion (or Justin Piemre)

172-174

- REsum complet de botanique (n.1) 173-174

Lamouroux, S. (Mrs. J,P.), artist 173

Lange, J. M. Callomencletor F lor Danicee 164

Lanvin, engraver 82,211

Lapeyrouse, P.C., flora criticized 48

lapland, flora 223-224

"larvae of moss"

LAURER, Johann Friedrich 174-175,230-232

- artist

234

- collaborator of Sturm

- Di* Flechten (in STUR! n.1)

- Beitrage urr kryptogamiochen Flor der Inoel Rugen $(n .1)$

leaf height.

Le Boyer, A. C Co, printers

Lebel, printer
Ledebour, C.F.v., contact with Arnott 40

Lehmus, revised etymologies in Eaton 106 Lehrbuah der Naturgesohiohte

- (PERLEB n.2)

(OKEN n.1)

$193-195$

- deo Pflansenreicho (PERLEB n.2) 199-200

Leiden, botanical garden 190

- Rijksherbarium 150

Leleux, printer

150
89

Lestiboudois, F.J., botanist 175

LESTIBOUDOIS [Gaspard] Thémistocle 175-176

- Botanographie Eelgique (n.1) 175-176

Lestiboudois. J.-B., fellow-gtudent of Pal. Beauv.

letters for dating purposes

- specific letters - individual botanists

Leveille, J.H., botanist artist 211

Levrault, F.G.: printer (Strasburg) 172

- publisher (Paris \& Strasburg)

Lexicon dor Gdrtnerei und Botanik. volietandiges (F,G.DIETRICH n.1-5) 95-97

L'Heritier, C.L., herbarium studied

Libert, A., artist by A.P. de Candolle 76

Libraria Academia, Kiel, publisher 192

Liebe, C.G.[A.?], engraver 61

life history of mosses

Lindbers, S.O.

Lindley, J., antist

$I$ (note)

- collaborator of Hooker

- Introduction to the natural eystan of plant. (ed. by Torrey)

Link, F.F. deecriftions in BUCH $n$

- botanical garden in Berlin 72

Linnaean classification ( 24 classes) III $51-53,55,98,112,137,152,164,171,194$ $199,200,205,206,209,214,227,228,236$

- modified ( 22 classes)

Linnaean herbarium. $35,101-107,131,177,228,229$

Jungermannias studied by Hooker 147

Linnaeus, C.

- Hortua cliffortianus, sex of mosses I

- Fragmenta methodi naturalis $I, 199$

Linnean Society [London] $44,54,134,145$

Linnceke Samfundet Eandinger, format 13

Literariecher Anzeiger (Brockhaus) 65

Literaturblate ( $F L O R A$ ) 111

lithographs 28

Lizars, $\mathrm{H}_{0} \mathrm{H}_{0,}$ engraver $126^{2 x}, 132,135^{2 x}, 166,170$

long twelves 11,13

long twenty-fours

Longer, artist

11

Longman, Hurst, Rees, Orme Brown, publishers $146,149,161,184$ Longman, Rees, Orme, Brown \& Green.

LOREY. Féílix

LOREY \& DURET

98,162

- Catelogue des plante.... de la

177
177

Lyell, $C .$. dedication to 154
232
$230-232$

$174-175$

$10-11$

211 Cote-d.0\% (n.1)

Lovén, S.L., respondens

Ludwig, C., artist

Lyon (France), botanical garden 50

- flora of the region 50-51,209-210

177

112

220

54

$91,181,211$ 
HeKerrow, bibliographer

Machado, Marg. artist

Maclachian Stewart, publishers

MacPhail. I.

Maceira, plant list, R.Brown in Buch 71,73

Mancel, publisher

Mantigaa Musoorum (BRTDEL $\Omega_{03}$ )

- re-issue (BRIDEL $\mathrm{n} .4$ )

Mantoux, printer

Manual of botany for

North Ambrica (EATON n.5-6) 105-107

- the Northern ana middie otates of America (EATON n.2-4) 102-104

- the Northern otates (EATON n.1) 101

- ed.2 (EATON n.2) 102

- ed.3 (EATON n.3)

- ed.4 (EATON $n .4$ )

- ed.5 (EATON n.5)

- ed.6 (EATON n.6)

- ed.7 (EATON n.7)

- - ed.8 (Ezton \& Wright)

WARCKER (MARKER), C.P.

Marcus, A. printer

margins, wide; watermarks may shift because of

MARKER (MARCKER), C.P.

MARTINOV, Ivan Ivanovich

- slovar' rodov'ioh imen' rastenit

(n.1) 177-178

Martius, court pharmacist 114,190

Martius, K. v. botanist

MARTUINOV, Ivan Ivanovich

190

Meuritius, vegetation

Mckerrow, bibliogr.

measurements of plate-marks

Meilhac, publisher

(Meissner), K.F., botanist 79

Melville Island, flora 68-69,166

Mémoires d'histoive naturelle

(KITTEL $\pi .2$ )

MEMOIRES de ta SOCIETE d'BISTOIRE NATURELLE PARIS

MEMOIRES de Za SOCIETE LINNEENNE de PARIS

MEMOIRES dU MUSEUN A'BISTOIRE NATURELLE (PARIS)

HEMOIRS Of the WERNERIAN NATURAL BISTORY SOCIETY (EDINBURGH)

Menzies, A., botanist, coll, artist 37,184

'írat, F.V' herb. seen by Amott 154

Mérilion, influenced Gaudichaud 121

Merlieux + Bailly de Merlieux

121

methods of bibliography

$1-29$

Methodus nova Musoorum (BRIDEL n.3)63-64

- re-issue 1822 (BRIDEL n.4)

65

Meyer, E.H.F., sollaborator of Presl 202

Micheli, P.A.

$I, 214$

microscope, availability after $1814^{I,}$ II

- used in bryology

- used in German bryology

$I, I I$

- used in teaching by J.Stewart

- presented to Hedwig

Milier. W. engraver

Millet, artist

minus-sign for removed leaf
Miquel, F,A.W., botanist

- Hepeticee, Mueci (pantly), Algee

138

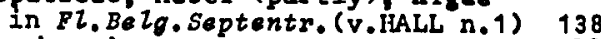

misnumbered pages

misprints in title

missignings

mistakes in watermarks

Mitchell, E. engraver

Mitchell: S.L. $125^{2 \times}$

Molssard, A. printer

Monthyon prize for Gaudichaud

Montpellier, herb. of Cambessedes

- stay of A.P. de Candolle

Nontrose, duke of dedication to

Hoore, Z,S., dedication to

Moose aus der Umgebung von Bayreuth

Moricand, M.E., artist (FUNCK n.1)

Mougeot, J.A.

MOUGEOT, Jean Baptiste

- fellow-student of Nestler

MOUGEOT \& NESTLER

- Stirper oryptogamae Vogeso-Rhenanae

(n.1, fasc.1-11) 185-187

MOUGEOT, NESTLER \& SCHIMPER

- Stirpes orvptogamae Vogeso-Rhenanae

(n, 1 fasc, 12-15) 185-187

Nourses de la Normandie (BRÉB. n.1) 58-59 moveable type

moyen (French paper quality)

Muller, C. (Halensis), bryologist

- wide generic concept

- acquired herbarium of Sprengel

185,186

$185-187$

185

$185-187$

Muller. Ferd. v., pupil of Nolte 192

Muller, F, E, engraver

Musoi in Reitquiae Haenkeanae

(HORNSCHUCH $\mathrm{n}, 6$ ) 166

theoi Americani exsicaati (T.DRUMM.n.2) 99

- ser. 2

Musoi exotioi (HOOKER n.3)

99

Musoi frondosi axsiooati (BREUTEL n.1) 59

Musoi frondoei Javanioi

(REINWARDT \& HORNSCHUCH $n .1$ )

thooi frondoei quas in Alaatia ...

(KNEIFF \& MARKER n.1)

207

Uusoi Sootioi (T.DRUMMOND $n .1$ )

170

Muocologia Britannioa

(HOOKER \& TAYLOR n.1)

- ed.2 (HOOKER \& TAYLOR n.2)

$160-161$

TAYLOR $n$.2) 161-162

Ituocologia exotica (HOOKER n.3) 148-151

Huscologia recentiorum (BRID.n.1) 60-62,239

- Suppiementum 1-3 (BRIDEL n.2) 62-63

- Supplementum 4 (BRIDEL n.3) 63-64 re-issue 1822 (BRIDEL n.4) 65

Mucologia Rothomagenais

(BEHERE n.1, period.)

(BEHERE n.2: separate)

56

Musoologie, ou traits des mouses

(PALISOT de BEAUVOIS $n .1$, period,) 197

(PALISOT de BEAUVOIS n.2; separate) 198

Muséum d'Histoire Naturelle, Paris

- Cambessedes: aide-naturaliste

- herbarium studied by Annott

- MENOIRES 
Rechoohrift ... (C.G. NEES n.2)

Haohtrag in Böheime phanerogamioohen und aryptoganisohen Gewahse

(OPIZ n.1)

Wachtrag $x u$ den Bemerkungen aber $B \times n$ Fleischex' botanische Reise naoh Tyrol ... (HOCHSTETTER n.2)

Baohtrag sum vollatandigen Lexioon der Gartnerei und Botanik (F.G.DIETRICH n.5) 94-95

Napoleonic pause

narrow book formats

National Department of Education, St. Petersburg, printer

natural classification I, III,35,68,76,83,98,102-107,131, - Eaton's philippic against natural families proposed by Adanson $I$ Naturphilosophie.

- of Oken

- of Schelling

- of Wenderoth

- of Wilbrand

- Perleb's criticism

Necker. N.[M.] J, de

- date of birth and baptism

Neeley (Sherwood, Neeley \& Jones)

publisher

$v, 193,200$

187

200

200

200

II

II(note)

146

NEES von ESENBECK Christian Gottfried [Daniel] IV,187-189,207-20s.

- collaborator of Sturm

- editor of R.Brown: Vemieohte botanische sohriften

- Nachochrift [to Breutel: Beitx. Sphagnum] (n,2) - Spiridens, novum Nusoorum ... genu॰

232

- system of Fungi presented by Steudel 207-208

NEES von ESENBECK, C.G.D. HORNSCHUCH STURM

- Bryologia Germanioa (n.1)

$188-189$

NEES von ESENBECK, Theodor Friedrich Ludwig IV,122,190-191

- Beobaahtungen uber die Entwiaklung der Laubmoosen aus ihren Keinkornern $(n, 2)$

- De lluecorum propagatione commentatio (n.1)

Neill, Patrick, printer

- naturalist $42,43,129,132,134,155,184$

- secretary Wernerian Nat.Hist.Soc 184

Neptunist school in geology (Wemer) 71

Néraud, J.

- Nouveaux reneeignemente sur 1 a

vegetation ... de l'Ile-de-

France. (in GAUDICHAUD n.1)
NESTLER, Chrétien Géfroy 191

- fellow-student of Mougect

- Stirpee aryptogamae Vogeso-Rhenanae (MOUGFOT NESTLER n.1) 185-187

Netherlands, flore of 136-138

Neu entdeckte Pfianxen ... (F.G.DIETRICH n.5)

$95-97$

Heuer Naohtrag sum vollotandigen Lexicon der Gartnerei una Botanik (F.G.DTETRICH n.5)

Iew arrangement of the genera of

95-97 mosaes (GREVILLE \& ARNOTT $n .1$ ) 135

- 2-3 - Tentamen methodi lusoorum 135-136

Nistri, S.p printer 214

Nocca Balbis: Flore Ticinee 50

Node Vóran, artist 78

Nogier de Solignac, M.A., married Arnaud 35

NOLTE, Ernst Ferdinand

- collaborator of Icones Flora

- Novitiae florae Holeatioar

192

Domenolator botanious (STEUDEL $\mathrm{n} .1$ ) 228-229

Homenolaturae florae vanioae (HORIVEMANN $\mathrm{n.1}$ ) 164

nomenclature of theoi, stawting-point 141-143

Nord de la France, flore 175

- cryptogamic exsiccata 87-89

Normandy, moss exsiccata $58-59$

North, F. Earl of Guilford 133

North Amerj.ca, manual of botany 101-107

- moss exsiccata 99

North American boteny (Eaton \& Wright) 100

Norway, moss exsiccata 223

Hotice of a journal of a voyage from Rio de Janeiro to ... Peru (ARNOTT n.3, separate) (ARNOTT n.4, period.)

Nouveaux reneeignemente our la vfge tation ... de l'J.1e-de-France (Néraud in GAUDIClLAUD $n .1$ )

Houvelie disposition methodique deo eopdces de mousces

- 4* separate (ARNOTT n.5)

- 4. period. (ARNOT: n.6)

- 8. perjod. (ARNOTT n.7)

- 8. separate (ARNOTT n.8)

- 8. re-issue (ARNOTT $n .11$ ) $43-45$ $45-46,238$ $46-47$

Wova Acta Physico-Medica Academice Leopoldina-Caroline $13(1)$ reci. 182744 Nova Hedwigia (periodical)

Hovitiae florae Holaatiaae (NOLTE $n .1$ )

nucleus of the cell, discovered by $R$. Brown

Nutta1l, T.: The genera of North American plante 
oblong formats

Obeervationes bryologisae (C.F.SCHULEZ $n, 4$ )

Ohesrvatione eur les tetrasporeo des aloues (Crouan frères)

cctavo (format)

octo-decimo (format)

Ceder, G.C.:

- I cones fiorae Danicae

- Flora Danice $2^{\circ}$

- Flora Danica $8^{\circ}$

off-set of fascicle-titles

OKEN, Lorenz

- elements (principles of his classifications)

- Grundriso des Systems der Naturphilosophie

- ISIS (periodical)

- Lshrhuch der Naturgeschichto

- Naturphilosophie

- criticized by Perleb $(n .1)$

Okenfuss + OKEN

On the genus Calymperes of Swarts and syrrhopodon of Sohwagriohen (HOOKER \& GREVILIE $\mathrm{n.5}$ )

On the genus Hookeria

(HOOKER \& GREV TLLF, n.3, period.) 159

(HOOKER \& GREVILLE n.4, separate) 159

On the genue Tortula

(IIOOKER \& GREVILLF $\mathrm{n.2}$ )

On the leaves, capoule and root of Buxbaumia aphylia (GREVILLE n.3)

OPIZ, Philipp llaximilian

- collaborator of Presl

- Nachtrag au Boheimo phanerogamischen und oryptogamischen Gewdohe (n.1)

- society for the exchange of botanical (natural history) objects

Organographis der Gewtahse

organographie vegetale

$$
\text { (CANDOLIE n.2) }
$$

Orme, Hopfer de $I^{\prime}$, printer

outer forme

Oware, visited by Pal.BEauv.

Oxford, cryptogamic exsiccata

Oxford botanic garden

page-numbers

$25-26$

26-27

fage-references

PAGINATION

PALISOT de BEAUVOIS, Ambroise-

$25-26$

Marie-François-Joseph II,IV, 196-198

- ... complement au travail de feu Palisot de Beaurois

(in DESVAUX $n, 1$ )

- herbarium, kept by Delessert and studied by Arnott

- Nusoologie, ou traité our les mousere (n.1, period.) (n.2: separate)
PALISOT de BEAUVOIS continued

- Prodrome de 1'metheogamie

- sexuality of mosses, opinion

Pallas, P.S., dedication to

197

II, IV

194

Palmblad Co. publishers

236

PAPER

raper color

PAPER DESCRIPTION

paper-machines

paper names

paper sizes

Paris, J.E.G.N.

Parry, W.L.: A supplement to the eppendix of Captain Parry's voyage for the discovery of a North-West

passage in the years 1819-20

Pasquet, père et fils, printers

1-3

3

28

Pasquet, $P$., printer

patois, plant names in

Peale, C.W., painter, patron of Pai. Beauv.

PERIEB, Car] Julius

- classification of

- Conopeotis methodi plantarum naturalis (n.1)

- critjcized "Naturphilosophie" 199

- Lehrbuah der Naturgeschiohte (n.1) 200

- Lehrbuch der Naturgesohiohte des Pflanzenreiche (n.1) V,199-200

PERNITZSCH, Heinrich 200

- Flora von Deutsohlando Waldern(n.1) 200

Perrin, L., printer

Persan \& Co. publishers

Persoon, C.H. dedication to

- classification of Fungi followed by Gaudichaud

210
85

88

by Hooker

- genera adopted by Martinov

- Synopsis plantarum (new edition to be prepared by Kunth)

Perthes \& Besser, publishers 192

[Pfiansen in den an die Kurathie steah im Leohthale angransenden Gebirgen] (FROHLICH $\mathrm{n} .1$ )

Physiadisohe Besohreibung der Canarischen Inoein (BIJCH $\mathrm{n} .1)$

Pillet aine, publisher 123

Pinard, J., Printer

Pisa, botany in

Plenta lectee in itin.

Plantes oryptoganes France (DESMAZIERES $n .1$ )

- ed.2 (DESMAZIERES n.2)

- [ed.3], ed.2, ser.2 (DESlAAZIERES n.3) 90

plate-books, lambda treatment 24

plate-mark, measurement 28

plates (excluded from the collation) 24

PLATES 27-28

Plé, [Aug.?], engraver 78

Plee, fil., F., engraver 78

Plé, F.B., engraver 197,198

$\begin{array}{llr}197 & \text { Plée, père, engraver } & 78 \\ 198 & \text { Plée, veuve, angraver } & 82\end{array}$ 
Plutoniat school in geology

Pochard, printer

Poiret, fils, A. artist, engraver 122

Poiret, J.L.M., botanist 122

Popp, H.F., printer

post-publication announcement

post-publication issue

post-publication tate

poupée (French, inkball)

- colored "a la poupée"

praface

preliminaries ("prelims")

preprint

pre-publication announcement

pre-publication issue

pre-publication separate

pre-publication state

pre-separate

PRESL, C.B. - PRESL, K.B.

Presl, J.S., collaborator of

PRESL, Karel Boriwog K.B. Presl

- Reliquiae Haenkeanae (n.1)

press-figures

Pretre, J.G., artist

"Priestleyan green matter"

PRINTERS, index of

PRINTING

164,192

VI

9

8,9

28

28

5

5

8

VI

9

9

PRIORITY IN BOTANICAL NOMENCIATURE V-VII Pritzel, G.A.:

Thesarus Iiteraturae botanicae 1,10 prix Desmazières

prize lonthyon for Gaudichaud

Prodrome de la Familize des fougdres (DESVAUX $\mathrm{n} .2$ )

Prodromu florae Reningulae Indiae Orientali. (Wight Amott;

Arnott rewrote preface)

proof in typography

Prosper. R., printer

protonema

- color prints of

publication

- dates of

- effective

- valjd

PUBLISHERS, index of

Purton, Midland flora

Puy, Le

Pyrenees, tour of Amott

- catalogue of plants

- plants of higher peaks

- sporophytes lacking in mosses of the peaks

$$
I V, V, B 0 \quad \begin{array}{r}
213 \\
191 \\
191
\end{array}
$$

$28-29$

V.VIII

VIII

258

54

35

$39-40,47-48$

39,40

203-204

204

quaderno (Italian for gathering)

quarto (format)

quarto-imposition

quasi-facsimile of the title

quaternion

quire

quired sheets raisin (French paper name and

watermark)

RAMOND de CARBONNIERES, Louis

Francois Elizabeth

- Etat de ia vegetation au oommet du Pio du Hidi de Bagneres

$$
(n, 1)
$$

Rapeort oun la louveile disposition mdthodique... par... Arnott

RE, Gicvanni Francesco

(KITTEL $n, 1$ )

169

- AC floram Pedemontanam appendix altera $(n .1)$

- Flora Torineos (n.2)

Réaunur, R.A.F, de

Reoeneio gererum Barbulae et

syntriotiae (SCHULIZ n.2)

Reclan, C.I., publisher

Reclam Jr., P.: printer

recto

Redoute, J.P., artist 78

REFERENCES 29

references to pages 26-27

Regensburger Botanische Gesellschaft founded

regularly alternating gatherings 16,23

Rehder's Bradley bibliography 10

Reichenbach, H.G.L., classification 96

re-impression

Reinherz, L., publisher

RIINWARDT, Caspar Georg Carl 206-208

REINWARDT \& HORNSCHUCH 207

- Musci frondooi Javaniai (n.1) 207

RETINARDT \& C.G.NIEES von ESENBECK 207-208

- Spiridens, novum luocorum.ï genus (n.i) 207-208

re-issue

Reliquiae Haenkeanae (PRESL n.1) 201-203

- Mueoi (HORNSCHUCH n.6) 166

Rensselaer school 100

removed leaves

reprint

Refoum acmplet de botanique

(J.P. LAMOIIROUX $n .1$ ) 173-174

[Review Arnott Diep.Meth.]

(FURNROHR n.1) 120

[Review Bri.d. Bryol.Univ.]

(HORNSCHUCII $\mathrm{n.9}$ ) 167-168

[Review Brown, $\left.R_{0} \quad F L_{,} M_{\theta} l_{v_{0}}\right]$ (HORNSCHUCH n.5) 166

[Review sohwaegr. Supp 2,2 vot. 1(1)] (HORNSCIUCH $\mathrm{n.7}$ ) 166

REVIEWS

29

Rey Gravier, publishers 46,180

REYGER, Gottfried 208-209

- Di. um Dansig wildwacheenden

Pflansen ed.2 (n.1)208-209

Richard, A., botanist

- Arnott asked sporophytes of

Drepanophy $z$ zum 
Richard, L.C.M., botanist,

- artist

- described Drepanophy IZum

- living plants for pupils

- medical properties of plants

Richardson, Dr. (Sir John), sent Drummond 8 specimens to Hooker

Richebe, C.T., married $T$. Lestiboudois

Rio de Janeiro mosses

- collected by $W$. Jarieson

- described by Amott

Robinson (Hurst, Robinson $\mathrm{CO}_{.}$), publisher

Robiquet, J.P., pharmacist, teacher of Gaudichaud

Roemer \& Schultes. Linnaean classes cited from

ROFFAVIER, Georges

- Société Linnéenne de Lyon

$$
151,154
$$

III

171

37

205

175

$42-43$

$42-43$

152

121

228

209-210

209

- Supplement a la Flore Lyonnaise -.. Balbie (n.1)

Rollet, M.A., collaborator of Roffavier

Roret, publisher

Ross, J., Captain, collector

Roubieu, artist

Rouen, moss flora

Royal Cork Scientific Institution

$209-210$

Royal Irish

Royal Society [London]

Royal Society of Edinburgh

$68,69,145$

210

176

69,125

211

56-57

235

Rugen, isl. cryptogamic flora $174-175$

rules, in titles

rules, of nomenclature

running title

Russian generic names

Sachse, Dr., teacher of Nolte

Sachsen-Weimar, Carl August von, dedication to 226

Saint-Hilaire, A. de

- Plora Brasiliae meridionali.

Salzburg, activities of Sauter

Salzmann, collector in Spain and North Africa

- Plantar lectee in itinere Hispanico-Tingitano index fac.

$\begin{array}{lr}\text { SAUMAISES, Auguste } & 109 \\ \text { - Coure diogrioulture, de botanique } & 210-211\end{array}$ et d'hiatoire naturelie... (n. 1)

SAUTER, Anton Eleutherius

$210-211$

- Diseertatio inauguralis geographioo-botanioa de territorio Vindobonenoi .... (n.1)

- Versuch einer geographisohbotanisohen schilderung der Umgebung Wiens $(n .1)$

SAVI, Gaetano

$$
(\pi, 1)
$$

- Botanicon Etrusoum .... (n.1)

- Scelta di generi di piante ...

$$
(n .2)
$$

Sayre, G.: Dates of publications describing lusci, $180 \mid-1821$

soelta $d i$ generi di piante... (SAVI n.2)

Schelling, F.W.J." "Naturphilosoph" 187

- teacher of C.G. Nees V. Esenbeck 187

SCHIMPER, Wilhelm Philipp IV,185-187

- main author of Bryol.Europeca

- Stirpes oryptogamae Vogeso-Rhenanae fasc.12-15 (MOUGEOT, NESTLER \& SCHIMPER, n.1)

Schlechtendal, D.F.L. von,

- editor of Iinneea, probably reviewer of Brid. Bryol.Univ. IV

- contact with Nolte 192

- Flora Berolinenei. 209

Schleicher, J.C., collector 229

Schlotheim, E.F. dedication to 61

Schmid, A., publisher 194,238

Schmid, A. \& Co., publishers 194

Schnorr, C, engraver 194

Schott, Heinrich, botanist 226

- Fasciculus plantarum Brasilieneium (in SPRENGEL $n .1$ ) 226

Schrader. H.A., dedication to. 219

Schrank, $F$, von Paula von, dedication to 194

Schreber. J.C.D. teacher of Hedwig 139

Schroter, engraver

Schultes: J.A. * Roemer \& Schultes

SCHULTZ, Carl Friedrich 215-216

- Obeervationes bryologioae (n,4) 216

- Reaeneio generum Barbulae et Syntrichiae $(n, 2) \quad 215$

- Species nonnulas novas Barbularum generi $(n, 1) \quad 215$

- Triahostomum laureri schults, eine neue Laubmoosart (n,3)

Schltz, C.F, amassed references 215

SCHWAEGRICHEN, Christian Heinrich

- AuZacomnium proposed $I, I I, I V, V I, 216-223$

- collaborator of Gaudichaud $\quad 123$

- criticism of Arnott 38

- Descriptiona des mousese trouvese pax $M$. Gaudichaud (not published) 45

- Musci in Willdenow: Species Plant. 216

- Speoies Muscorum frondosorum. Supplementum 1-3 (n.1) VI,217-223

Scoolar, Mr. (=Scouler, J,) 37

Scoresby, Capt., collector 125

Scotland, flora

151-153

- cryptogamic flora

$127-131$

- moss exsiccata

- new Grimmia species

soottish oryptogamio flora

Scottish Highlands (GREVILLE n.5)

127-131

Scouler, J. botanist, traveler $36,124,145$

scance pubilque de la socisté libre d'Emulation de Rouen, 1826 (see BEHERE $n, 1$ )

Seiffert: Hendbuch der Arzneimittellehre, ed.2, edited by Laurer 
Selection from testimonials in favour of G,A. Walker Arnott ... Senckent. Walker Arnote... 41 separate

Sepp, J. (Bon), publisher

Sepp, J.C., publisher

Sepp, J.C. \& Zn. publishers Seringe, N.C., collaborator of

- host to Annott

sexto (format)

sexto-decimo (format)

Sherwood, Neeley Jones, publishers 146 shift from laid to wove peper 205,222

signature, bibliographical 4,10,22

- alphabets in signatures

- method of signing gatherings

- SIGNS used in the special bibliography

Silliman, B., teacher of Eaton

Silusia (=Schleusingen), Germany

Sinning, W., developed botanical

garden in Bonn with T.F.L. Nees 190

size classes of books

aize of book leaves

Skala, J., engraver

sketoh of ... the genera orthotriohum. Glyphomitrion, and zygodon

(HOOKER \& GREVILLE n.1)

Skinners (Websters Skinners),

$$
\text { printer }
$$

publisher

slot, in frame or compartment

slovar' rodov'ioh imen' rasetnit

(MARTINOV $\mathrm{n} .1$ ) 177-178

small capitals in titles

Smith, Christian, Danish traveler, biogr. in BUCH n, $\begin{array}{r}73 \\ 145\end{array}$

Sinith, J.E., botanist

Snoberg, C.P.' respondeng

112

Societet fur wissenschaftliche

Kritik, Berlin, publisher

Societe d'Agriculture, Sciences, Arts et Commerce du Puy, publisher

Societe d'Emulation de Rouen

Societé d'Histoire Naturelle, Paris

- MÉNOIRES

- publisher

Societé Linnéenne de Lyon

Société Linnéenne de Paris

- Amott "correspondant"

- dates of library accessions not

- MENOIRES trus tworthy

$$
43,46,180
$$

180
209

- publisher \& natural history objects

some acoount of a colleation of oryptogamio piants from the Ionian Is lands (GREVILLE n.9)

SOMMEREELT, Søren Christian

- Bemaerkninger ved oupplementum flowas tapponioas (n.3)

$223-224$

$181-183$

1,181

195

133

224
SOMAERFELT continued

- Centurias plantarum oryptogamarum Norvegicarum (n.1)

- publisher

223

- Supplementum Florae Lapponiaae $(n .2)$

$223-224$

sources of descriptive bibliography $33-34$ sources (of introduction and of

history of bryology)

South America, cryptogams

VII-VIII

- flora

- some new mosses

South of France and Pyrenees, tour of Annott $39,47-49$

Sowerby, artist

Speoies Muscorum (Hedwis)

$\rightarrow$ Speoiss Muscorum frondosorum

speoies Muscorum ... (BRIDEL n.2) 62-63 speciee Muscorum frondosorum

- facsimile ed.

(HEDWIG n.1) 140-144

speoies Muscorum frondosorum ... Supp lementum 1-4

(SCHWAEGRICHEN $n \cdot 1$ ) 217-223

spermatozoa of mosses

spine-labels

- printed on spare leaf of book

spiridens, novum Muscorum diploperiotomiorum genus

(REINWARDT \& C.G. NEES n.1) 207

Spitsbergen, mosses 125

Spottiswoode, A. \& R., printers 98

SPRENGEL, Anton 226-227

- Systema vegetabilium vol.5, Index 226

- Tentamen supplamenti ad yotematis vegetabilium ...

SPRENGEL, Curt Polycarp Joachin 225-227

- contact with A.P. de Candolle 225

- dedication to 219

- Filices cited from

228

- Gruadzige der wiseenechaftliche Pf 1 angenkunde

- letters to A.P. de Candolle

- recognition for A.P. de Candolle 225

- Syotema vegetabilium (n.1) 225-227

Spurny. J. printer

square book formats

square duodecimo (format)

standing type

Standort des Zygodon conoideum Hook.

Stark, J., printer (KNEIFF n.1) 170

Stark, L., married Oken

starting-points of nomenclature

of Musoi II, V, 141-142

- definition of Bowers

$6-9$

Stech im Lechthale, some plants 114

Steele, 0.s publisher 106,107

Steenis-Kruseman, M.J. v.: Detes of publications, in flora Maleciana VI

Steere, W.C., bryologist 143

Sternberg, Count, C. von: pref, of Reliquiae Haenkeanae 
Stein von Altenstein, $K$. dedication to 188

STEUDEL, Ernst Gottlieb

- genera adopted by Martinov

178

228-229

- Württembergischer Naturhistorischer Reiseverein

STEUDEL \& HOCHSTETTER

227

229

- Enumeratio plantarum GermanioaeHelvetiaeque ... (n.1)

- - observations of Hoppe

229

163

Stevenson, Allan, bibliographer 23,24-26

Stewart (Maclachlan \& Stewart). publisher

Stewart, C., publisher

Stewart, J., teacher of Arnott

- teacher of Greville

- discovered leaves of Buxbaumia

- possibly edited Dillenius

Stippes agri Femsionensis reprint II (note)

$$
\text { (FRIES } n .1 \text { ) }
$$

$111-113$

Stixpes oryptogamae Oxonienses

$$
\text { (BAXTER n.1) }
$$

$53-54$

Stirpes oryptogamae Vogeso-

Rhenanae (MOUGEOT \& NESTLER n. 1) 185-187

Stixpium agri Femoioneneis Index (FRIES n.2)

stomata in moss capsules

$78-79$

stop-press corrections

Strauch, C., artist, engraver

$188-189,230-234$

STURM, Jacob

$188,207,215,230-234$

- artist

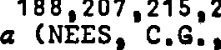
HORNSCHUCH \& STURM n.1)

- Deutochtando Iryptogamen (n.1)

$188-189$

announcements

$230-234$

- engraver

- list of publications

- publisher

SUBJECT-INDEX

Sulzberger, C.B., married Hedwig

SUMMARY

Supplement a la Flore Lyonnaise de Balbie (ROFFAVIER $n .1$ )

Supplementum Florae Lapponioae (SOMMERFELT $\mathrm{n}, 2$ )

188,230

$188,207,215,231$

189,232

$259-277$

$240-241$

209-210

$223-224$

Supplementum ... Bedwig speoiee Musoorum frondosorum

(SCHWAEGRICHEN n.1) 217-223

Sur quelques mousees de Rio de Janeiso (ARNOTT n.2)

Swan, J., engraver

Swartz, O., dedication to

$154,158^{42}, 159$

Sweden, flora

219

Switzerland, checklist of plants 229

SILLOGE PLARTARUM HOVARUM

Syme, P. artist

Synopois plantarum Aequinootialium (KUNTH $n .1$ )

111

154

Synopsis Muscorum (planned by Arnott) 36 tables, engraved

28

- typographical

Talboys \& Wheeler, printers

24.27

54

Talboys, D.A., printer

Tardieu, A., engraver

Tardieu, $P$., engraver

Targioni-Tozzetti, 0, , botanist dedication to

Tarn-et-Garonne, regional flora

Tastu, J., printer

taxon

Taylor, A., printer

Taylor, $R$. printer

TAYLOR, Thomas

Muscologia Britannica

(HOOKER \& TAYLOR $n .2$ ) 160-162

Telfair, A. (Mrs,C.)., artist

213

52

$43,46,180$

$149,152,161$

$133,149,152,161$

$160-162,253$

Teller, S., married Hedwig

Ientamen methodi muscoxum

memoir 1-3, GREV \& ARN, n.1, separate134 memoir 2 , GREV. \& ARN. $n .3$, period. 135 memoir 3: GREK \& ARN. n.4, period. 135 text figures

text-books of botany $\rightarrow$ CANDOLLE $n .1-4$

+ J.L.DRUMMOND n. 1

+ LAMOUROUX $\mathrm{n} \cdot 1$

Thiébaut de Berneaud, J.B.M.A. $44,46,197$

- editor Mem.Soc.linn.Pari. 181

Thunberg, C.P. dedication to 219

- succeeded by Wahlenberg 235

Thuringia, moss exsiccata 237-238

Tilly, French minister in Piedmont 50

TITHE-DESCRIPTION

title-page

title-page transcription

Torrey, J., botanist

- editor of Lindley: Introduction to the netural eystem of botany (opinion of Eaton)

- Flora of the Northern and Middle States of America

- letter to Eaton

104

- letter to G.W. Clinton

103

- letters from Eaton Pyrences in 7825

(ARNOTT n.9, separate) 47-48

(ARNOTT n.10, period.) 49

Tourcaty, engraver 92,211

transposition

Treviranus, changed position with C.G. Nees

Irichostomum Laureri Sohults, eine

neue Laubmoosart (C.F.SCHULTZ n.3) 215

trigesimo-duo (format)

Turin, botanical garden

- flora

$50,204-205$

Turner, D., connection with Hooker 145-146

- dedication to

- Fuci, illustrated by W.J.Hooker 145

Turner, M.S., married W.J.Hooker 145 
Turpin, P.J.F. botanist, artist

Tuttle, N.: printer

twelvemo (format)

twelves, in (format)

type, in typography

- in botanical nomenclature

type-ornaments

type-setting

typification of Hedwigian genera 142-143

typification of Mnium Dill.

typification of starting-point names $V$

typographical tables 27,36

aber + ueber

Uckert, A., publisher

Veber die Entwiokelung dex Laubmoose (CASSEBEER $\mathrm{n} .2$ ) 80-81

Ueber die Leiohteate Methode aue dex reifen Moosbllohe die Conferve daraustelien (CASSEBEER n.3)

[Ueber die von R.Brown entworfene Flora der Melvilie Insel]

$$
\text { (HORNSCHUCH n.5) }
$$

Ueber einige Laubmoose (BRUCH n.6)

Ueber Sphagna, nebot Bemerkungen su ... Breutel ... (BRUCH $n_{0}$ )

Ukert (Uckert), A., publisher

Um Dansig wildwahsenden Pfiansen. [Die] ed.2 (REYGER n.1)

uncut copies

unnumbered pages of a book

unopened copies

unsigned gatherings

unsigned leaves

unsigned preliminaries

Uranie, $1^{f}$ (ship)

Urville, J.S.C. Dumont d'

208-209

valid publication

van Hall, H.C. $\rightarrow$ Hall, H,C, $\operatorname{van} 136-138$

Vanackère fils, printer, publisher 176

Vanackère père, publisher 176

variants, bibliographical

variants and state

vat, vatman

Vaucher, J.P.E., teacher of Candolle $7 \dot{6}$

vegetative reproduction

Vegter, Miss I.H., anassed references VII

véran, Node, artist

vernacular names
Vermiooht botanische sohriften (R.BROWN n.2)

verso

$$
\text { (R.BROWN } n, 2 \text { ) }
$$

Verouch einer geographisch-botanisohen Schilderung der Umgebung Wiene (SAUTER $n .1$ )

Verouch einer naheren Beleuchtung der Disposition methodique... Arnott (FURNROHR n.ij)

Verseiohnise Laubmoose von zweibrüoken und Umgebung (BRUCH $n, 1$ ) vicesimo-quarto (format)

14

Vienna, geographical-botanical sketch of the surroundings

Villars, D.

- connection with Nestler 191

- dedication to 186

Vivot, printer

Vivot veuve, printer

Voit, J.G.W. collaborator of STURM, Deutsohl. Flora Abth.II

Vollatendigea Lexicon der Gartnerei und Botanik (F.G.DIETRICH n.1) 94,239

- ed.2 (F.G.DIETRICH n.2) 94

- Beriohtigungen und Bemerkungen ... (F.G.DIETRICH $\mathrm{n.4}$ ) 95

- Maohtrag ...(F.G.DIETRICH n.3) 94-95

- Neuer Naohtrag ... (F.G.DIETRICH n.5) 95-96

Von: see under surname

Vorlesungen uber die Botanik (CANDOLLE $n .2$ )

Vosges, cryptogamic exsiccata

Voyage autour du lee corvettes... l'Uranie et la Phyoicienne ... Botanique

(GAUDICHAUD n. 1)
oyage de tumboldt et Bonpland 6e. partie, Botanique (KUNTH n.1)

$170-172$

Wachter, W.H. studied mosses of Dassen

Hagne, F., printer, publisher

WAHLENBERG, Georg (Gorran)

- Flora Lapponica

- Supplement (SOMERFELT n.2)

$223-224$

- Flora Suecioa (n.1)

235-237

- medal awarded

Walker, Prof. advised R. Brown

Walker Arnott + Arnott

Wangler, F.X., printer

watermarks

- dates in

- descriptions

- in books in half-sheet imposition

- in hand-made paper

- in laid paper

- in machine-made paper

- in wove paper

- mistakes

- two in one sheet of laid paper

Weber, Claude, amassed references

Weber, G.H. dedication to

- in Wiggers, Primitia florae Holsaticae

- - Supplement (NOLTE n,1)

Wedel, printer publishers 102-106

WEISS, J.G. editor: Die um Dansig wildwachsenden Pflansen 
Wenderoth G.W.F., "Naturphilosoph"

Werner, G.A., mineralogist, founder of "Geognosie", defender of

Neptunism

Wernerian Natural History Society Edinburgh

- MEMOIRS

Wetterauische Gesellschaft fur die gesammte Naturkunde

Wetterauisohe Laubmoose, exsiccata (CASSEBEER n.1)

Whatman, J., papermaker, developed wove paper

Wheeler (Talboys \& Wheeler), printer

Wiggers, F.H.: Primitiat florae

- Supplementum (NOLTE n.1)

Wight, R. school fellow of Arnott

- \& Arnott: Prodromus florme Paninsulee Indine Orientalie

- preface rewritten by Arnott

Wilbrand, J.B., "Naturphilosoph"

Wild, $T$, artist

Willdenow, C.L., + modified

Linnaean classification

- Species plantarum vol.5(2): - Schwaegrichen 216

Williams, S.W., collaborator of

Eaton
Elliams, S.W., collaborato

200

\section{1}

24,184 184

54

80

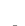

2

54

192

192

36

40

40

200

191,207
Wilson, W. W.J.Hooker: Musci Americani Bxsiccati (ser.2)

Winding, M.G., respondens

wire-lines in paper

wires in paper mold

Wistar, C., Quaker physician

wood-cuts

wood, paper from

wove paper

wrap-around

wrappers

Wright, J.: North Americen botany (Eaton \& Wright)

Wurttembergischer Naturhistorischer Reiseverein

99
$111-112$

112

2

196

27

1
2

130

6

100

227

years in watermarks

2

years in title-pages

ZEITUNO, ALLGEMEINE BOTANISCBE

Zeitungs-Druckerei (FLORA)

$108-111$ printer

Zeliska, $W$. engraver

ZENKER, Jonathan Carl

ZENKER \& DIETRICH, F.D.

Musoi Thuringioi (n. 1)

Zippelius, artist

106 Zweibrlaken, regional moss flora

$237-238$

211
BAXTER: Stirp. Crypt. Oxon.

BREBISSON: Mouse. Normand.

BREUTEL: Musoi Prond. Exsico.

CASSEBEER: Hetterauisohe Laubmoose

DESMAZIÈRES: PZ, Crupt. [Nord] Franoe

DRUMMOND, T.: Musci Sootioi

DRUMMOND, T.: Mueci Amer. Exaico.

Drummond, T.: Nusci Boreali Amer.
53-54 FUNCK: Crypt. Gew. FiohteZgeb, 114-118,238

58-59 FUNCK: Deuteohlande Moose 118-119

59 Hobson: Britieh moses 162

80 KNEIFF \& MARKER:

Muoai frondooi quas in Alsatia ... 170 MOUGEOT \& NESTLER:

Stixp. Crypt. Vogeso-Rhenanae 185-187

ZENKER \& DIETRICH: Mueoi Thuring. 238-239 